Civic Improvement:

Chautauqua and Progressive Era Aesthetic Reform

\title{
Avrom Posner
}

Charlottesville, Virginia

B.A., New York University, 1972

M.ArH., University of Virginia, 2004

A Dissertation presented to the Graduate Faculty of the University of Virginia in Candidacy for the Degree of

Doctor of Philosophy

Department of Art and Architectural History

University of Virginia

May 2012

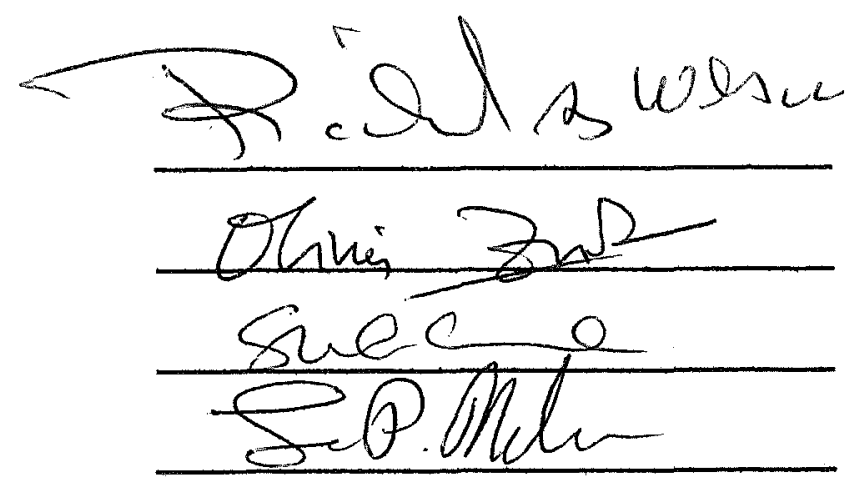




$$
\begin{aligned}
& \text { F.A. } \\
& \text { Diss. } \\
& \text { Arohtlist } \\
& 2.012 \\
& \text { P67 }
\end{aligned}
$$

$\because$ 
(C) Copyright by

Avrom Posner

All Rights Reserved

May 2012 


\begin{abstract}
Progressive Era Reformers (the 1890s - 1920s) shared a common ideology, seeking to foster positive societal change through the aesthetic manipulation of the decorative and built environment. The theme of Civic Improvement united the different aesthetic activities in which they engaged, just as their various projects drew on a wide range of styles.
\end{abstract}

Despite the many facets of Civic Improvement - or perhaps because of them most scholarship does not address the breadth of its manifestations, preferring to select one or several to explore. Architectural historians separate these efforts into discrete classifications, while classic political or economic historians at best make brief mention of aesthetic reform. An examination of the American League for Civic Improvement and its influence on the built environment of the Chautauqua Institution and the reformers' year-round communities demonstrates, however, that the reform activities, although complex and sometimes contradictory, belong to a continuum. The turn-of-the-century grounds of Chautauqua, were conceived as a Model Summer City of Improvement and should be read as an example of varied but complementary styles coming together as an integrated whole to improve the quality of life.

Chautauqua offers an ideal lens through which to view the aesthetic activities and attitudes of the Progressive Era for two reasons. First, the Chautauqua summer season was an important, highly visible venue for the dissemination of a relatively complete spectrum of reform ideals and issues; these in turn prepared the ground for the 
commissioning of a master plan to position Chautauqua as a "Model Summer City." The subsequent building campaign, with its array of styles, scales, and functions, was the built representation of these ideals. Second, Chautauqua's reformers were typically summer residents who were active during the majority of the year in their home communities throughout the country. The best approach to facilitating an exploration of the multiple aspects that comprise Civic Improvement is to examine their lives using the methodology of collective biography. This ancillary examination of the breadth of the year-round activities of some of these reformers provides a useful gauge of the many pursuits that should be viewed under the rubric of Civic Improvement. 


\section{Table of Contents}

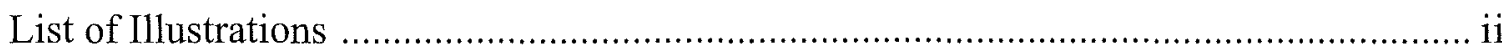

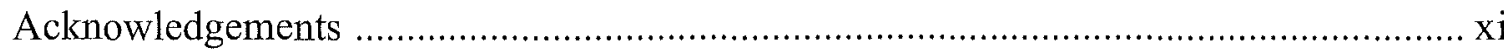

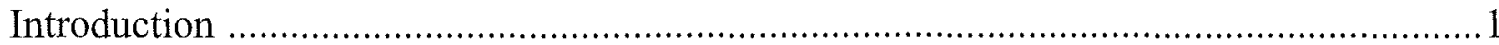

Chapter 1: The Foundation and Development of Chautauqua, 1874-1902 ..................14

Chapter 2: Chautauqua's Second Generation: The Influence of the American League for

Civic Improvement ................................................................................... 33

Chapter 3: Public Beauty: Chautauqua Embraces the Ideals of Civic Improvement ........62

Chapter 4: Chautauqua's Trustees: Clement Studebaker, Wilson M. Day, Frank Wayland

Higgins, and Charles A. Sweet at Chautauqua and on the National Stage

Chapter 5: Chautauqua's Master Planners: Albert Kelsey, J. Massey Rhind, and Warren

Manning

Chapter 6: The Evolution of the Model Summer City, 1903-1917 ..............................152

Conclusion: Successors — J. Horace McFarland and Clement Studebaker, Jr. .............172

Appendix 1: Chautauqua Presidents .............................................................. 184

Appendix 2: The New Terms of Civic Improvement ........................................... 185

Appendix 3: Sculptors of the Pan American Exposition, Buffalo New York 1901 .......187

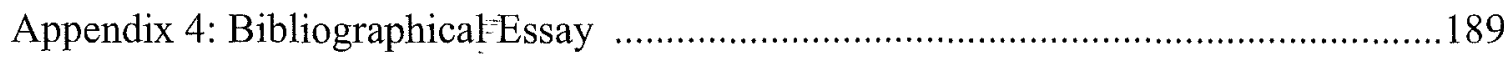

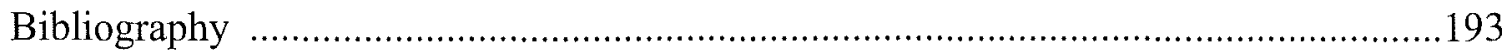

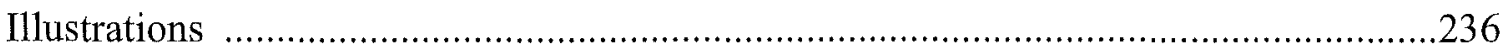




\section{List of Illustrations}

\section{Introduction}

Figure i.1 Chautauqua Institution map, 1902.

(Courtesy of Chautauqua Institution Archives.)

i.2 Chautauqua Lake region.

(Rand McNally: New York State Map.)

\section{Chapter 1: The Foundation and Development of Chautauqua 1874-1902}

Figure 1.1 Topography of Chautauqua Institution.

(Courtesy of Urban Design Associates.)

1.2 Chautauqua Lake.

(Jeffrey Simpson. Chautauqua, An American Utopia, 124.)

1.3 "Auditorium," (Miller Park), 1875.

(Courtesy of Chautauqua Institution Archives.)

1.4 Lewis Miller and Bishop John Heyl Vincent.

(Courtesy of Chautauqua Institution Archives.)

1.5 Chautauqua Lake Camp Meeting map, 1874.

(Courtesy of Chautauqua Institution Archives.)

1.6 "Test Questions: For the Final Examination at the Sunday School Assembly, Chautauqua Lake, August, 1874."

(Joseph E. Gould. The Chautauqua Movement: An Episode in the Continuing American Revolution, n. pag.)

1.7 Lewis Miller. Miller cottage, 1875, c. 1876.

(Courtesy of Chautauqua Institution Archives.)

1.8 Twenty-fifth C. L. S. C. Anniversary.

(The Chautauqua Assembly Herald 11 July 1903: 7.)

1.9 The College, "Moorish Barn," 1887, postcard.

(Courtesy of Chautauqua Institution Archives.)

1.10 Bishop John Heyl Vincent. Hall of Philosophy, 1879.

(Courtesy Chautauqua Institution Archives.)

1.11 Chapel of Good Shepherd, c. 1894 (view from Hall of Christ).

(Author's photograph, 2002.)

1.12 Pioneer Hall, 1885. Octagon Building, 1886.

(Author's photograph, 2000.)

1.13 Ellis G. Hall. Alumni Hall, 1892.

(Courtesy of Chautauqua Institution Archives.)

1.14 Amphitheater, 1879.

(Courtesy of Chautauqua Institution Archives.)

1.15 Normal Hall, 1885.

(Courtesy of Chautauqua Institution Archives.) 
1.16 Kellogg Hall, 1889.

(Courtesy of Chautauqua Institution Archives.)

1.17 Assembly Herald Building, 1889.

(Courtesy of Chautauqua Institution Archives.)

1.18 Chautauqua Literary and Scientific Circle (CLSC) Building, 1890.

(Courtesy of Chautauqua Institution Archives.)

1.19 Newton Hall, 1881.

(Courtesy of Chautauqua Institution Archives.)

1.20 Children's Temple, 1878.

(Courtesy of Chautauqua Institution Archives.)

1.21 Shops along Vincent, c. 1900.

(Courtesy of Chautauqua Institution Archives.)

1.22 Cheops Pyramid, c. 1900.

(Courtesy of Chautauqua Institution Archives.)

\section{Chapter 2: Chautauqua's Second Generation: The Influence of the American League for Civic Improvement}

Figure 2.1 William Rainey Harper.

(University of Chicago, Department of Astronomy and Astrophysics. Web.)

2.2 Henry Ives Cobb. Study for University of Chicago.

(Edward W. Wolner. Henry Ives Cobb's Chicago: Architecture, Institutions, and the Making of a Modern Metropolis, 192.)

2.3 George Edgar Vincent.

(American Sociological Association. Web.)

2.4 "Chautauqua: The Largest Institution for Higher Education in the World."

(The Chautauquan. July 1902.)

2.5 Richard Theodore Ely (1854-1943).

(Wikipedia. Web.)

2.6 Home and Flowers. Nov. 1900, title page.

2.7 Charles Zueblin (1886-1924).

("The National League of Improvement Clubs." Home and Flowers Nov. 1900:9.)

2.8 Pond and Pond. Northwestern University Settlement House. (Irving Kane Pond, "The Life of Architecture." Architectural Record 1905: 150.)

2.9 Edwin L. Shuey (1857-1924).

("The National League of Improvement Clubs." Home and Flowers Nov. 1900: 9.)

2.10 Frank Mills Andrews. N. C. R. Buildings from Main Street, posteard.

2.11 John Charles Olmsted (1852-1920). NCR Grounds. 
(Samuel Crowther. John H. Patterson, Pioneer in Industrial Welfare: opposite 183.)

\section{Chapter 3: Public Beauty: Chautauqua Embraces the Ideals of Civic Improvement}

3.1 Anna J. Pennybacker (1861-1938). (Courtesy of Chautauqua Institution Archives.)

3.2 Fred R. Gieseckie. Carnegie Public Library, 1902, Bryan, Texas. (Wikipedia. Web.)

3.3 Raphael. Sistine Madonna (1513-1514). (Wikipedia. Web.)

3.4 Dodson and Scott. Girl's Industrial School (1902). (Jay C. Henry. Architecture in Texas, 1895-1945, 98.)

3.5 Charles Rohlfs (1853-1956). Furniture. (Wikipedia. Web.)

3.6 Henry Turner Bailey (1865-1931). (Courtesy of Chautauqua Institution Archives.)

3.7 The School Arts Book, cover page, Henry Turner Bailey, ed. Vol. 7, Sept. 1907 to June 1908.

(Special Collection, New York Public Library.)

3.8 Henry Turner Bailey, "Acceptable Plant Drawing." The School Arts Book, Vol. 7, Sept. 1907 to June 1908: 21.

(Special Collection, New York Public Library.)

3.9 Henry Turner Bailey. The Beauty Lover's Creed. (Courtesy of Chautauqua Institution Archives.)

3.10 Studebaker/Carlisle Cottage, 1902. 34 South Lake Drive, Chautauqua, NY.

(Author's Photograph, 2011)

3.11 Howard Van Doren Shaw (1869-1926). O. W. Norton Cottage, 1900, 49 North Lake Drive, Chautauqua, NY.

(Courtesy Chautauqua Institution Archives.)

3.12 G. A. Mang. C. C. Taylor House, 1909, O. S. Lang, builder, 7 McClintock Ave., Chautauqua, NY.

(Courtesy of Chautauqua Institution Archives.)

3.13 20 Hurst Ave., 1914, Chautauqua, NY.

(Author's Photograph, 2010.)

Chapter 4: Chautauqua's Trustees: Clement Studebaker, Wilson M. Day, Frank Wayland Higgins, and Charles A. Sweet at Chautauqua and on the National Scene

Figure 4.1 Clement Studebaker (1831-1901).

(Tippecanoe Place Restaurant. Web.) 
4.2 Henry Ives Cobb. Tippecanoe Place, 1889.

(Tippecanoe Place Restaurant. Web.)

4.3 Sidney R. Badgley. Pilgrim Congregational Church, 1893-1894.

(Eric Johannesen. Cleveland Architecture, 1878-1976, 52.)

4.4 Sidney R. Badgley. Jones Home for Friendless Children, 1902. (Eric Johannesen. Cleveland Architecture, 1878-1976, 56.)

4.5 Sidney R. Badgley. Saint Paul's Methodist Church, South Bend, IN, 1901-1903.

(Courtesy of Saint Paul's Methodist Church.)

4.6 Saint Paul Preaching From Mars Hill in Athens. Saint Paul's

Methodist Church, South Bend, IN, 1901-1903.

(Courtesy Saint Paul's Methodist Church.)

4.7 Wilson M. Day (1850-1929).

("The World's" History of Cleveland, Commemorating the City's

Centennial Anniversary, 1896, n. pag.)

4.8 Sidney R. Badgley. Epworth Memorial Methodist Church, 1893.

(Eric Johannesen. Cleveland Architecture, 1878-1976, 53.)

4.9 Cleveland Centennial Log Cabin, 1896.

(Album of the Western Reserve Centennial.)

4.10 Cleveland Centennial Arch, 1896.

(Album of the Western Reserve Centennial.)

4.11 Frank Wayland Higgins (1856-1907).

(Courtesy of Olean Historical and Preservation Society.)

4.12 Higgins Cottage, 42 South Lake Drive, Chautauqua, NY.

(Courtesy of Chautauqua Institution Archives.)

4.13 Higgins Hall, 1895, Chautauqua, NY., postcard.

(Courtesy of Chautauqua Institution Archives.)

4.14 E. B. Green, Sr. Higgins Home, 1897, Olean, NY.

(Courtesy of Olean Historical and Preservation Society.)

4.15 The Third National Bank, Buffalo, NY.

(A History of the City of Buffalo, 63.)

4.16 E. B. Green, Sr. George V. Forman House, 1895, 824 Delaware Ave., Buffalo, NY.

(Buffalo as an Architectural Museum. Web.)

4.17 E. B. Green,, Sr. George B. Matthews House, 1901, 830 Delaware Ave., Buffalo, NY.

(Buffalo as an Architectural Museum. Web.)

4.18 E. B. Green, Sr. Charles W. Goodyear House, 1902, 888 Delaware Ave., Buffalo, NY.

(Buffalo as an Architectural Museum. Web.)

4.19 Raphael Beck. Great Seal of Pan-American Exposition, 1901.

("Doing the Pan..." Pan-American Exposition, Buffalo, 1901. Web.)

4.20 E. B. Green, Sr. Machinery and Transportation Building, PanAmerican Exposition, Buffalo, 1901. 
(Kerry S. Grant. The Rainbow City, Celebrating Light, Color, and Architecture at the Pan-American Exposition, Buffalo, 1901, 57.)

4.21 E. B. Green, Sr. Electricity Building, Pan-American Exposition, 1901. (Kerry S. Grant. The Rainbow City, Celebrating Light, Color, and Architecture at the Pan-American Exposition, Buffalo, 1901, 72.)

4.22 Pan-American Exposition at Night, 1901. John Galen Howard, Electric Tower, left; George Cary, Ethnology Building, right.

(Kerry S. Grant. The Rainbow City, Celebrating Light, Color, and Architecture at the Pan-American Exposition, Buffalo, 1901, 111.)

4.23 George Cary. New York State Building, Pan-American Exposition, 1901.

(Kerry S. Grant. The Rainbow City, Celebrating Light, Color, and Architecture at the Pan-American Exposition, Buffalo, 1901, 22.)

4.24 E. B. Green, Sr. Albright Art Gallery, 1902, Buffalo, NY. (Albright Knox Art Gallery. Web.)

4.25 E. B. Green, Sr. Art Building, 1901, Pan-American Exposition, Buffalo, NY.

(The Buffalonian. Web.)

4.26 E. B. Green, Sr. Art Building Plan, 1901, Pan-American Exposition, Buffalo, NY.

("Doing the Pan..." Pan-American Exposition Buffalo, 1901. Web.)

4.27 Augustus Saint-Gaudens. William Tecumseh Sherman.

(New York City Department of Parks \& Recreation. Web.)

4.28 Richard Morris Hunt, Karl Bitter. Administration Building, World's Columbian Exposition, 1893, Chicago, IL.

(James M. Dennis. Karl Bitter, Architectural Sculptor, 1867-1915, 43.)

4.29 John M. Carrère, Karl Bitter. Triumphal Causeway.

(James M. Dennis. Karl Bitter, Architectural Sculptor, 1867-1915, 108.)

4.30 Karl Bitter. Standard Bearer: Power, Pan-American Exposition, 1901. (Ferdinand Schevill. Karl Bitter: A Biography. Pic. 11.)

\section{Chapter 5: Chautauqua's Master Planners: Albert Kelsey, J. Massey Rhind, and Warren H. Manning}

Figure 5.1 Albert Kelsey. (Courtesy of Chautauqua Institution Archives.)

5.2 Warren H. Manning. (Robin Karson. The Muses of Gwinn: Art and Nature in a Garden Designed by Warren H. Manning, Charles A Platt, \& Ellen Biddle Shipman, 22.)

5.3 J. Massey Rhind (1860-1932).

(Go Antiques. Web.)

5.4 Paul Philippe Cret, Albert Kelsey. Pan American Union Building, 1908-1910, Washington, D.C. 
(archINFORM. Web.)

5.5 Albert Kelsey. The Park Road Project, 1902.

(Albert Kelsey. The Proposed Parkway for Philadelphia, A Direct

Thoroughfare From the Public Buildings to the Green Street Entrance

to Fairmount Park: containing a review of the various movements for a diagonal boulevard and the original argument in favor of a plaza before the northern facade of the City Hall, 16.)

5.6 Albert Kelsey. The Park Road Project, 1902.

(Albert Kelsey. The Proposed Parkway for Philadelphia, A Direct Thoroughfare From the Public Buildings to the Green Street Entrance to Fairmount Park: containing a review of the various movements for a diagonal boulevard and the original argument in favor of a plaza before the northern facade of the City Hall, 18.)

5.7 Albert Kelsey. The Park Road Project, 1902. (Albert Kelsey. The Proposed Parkway for Philadelphia, A Direct Thoroughfare From the Public Buildings to the Green Street Entrance to Fairmount Park: containing a review of the various movements for a diagonal boulevard and the original argument in favor of a plaza before the northern facade of the City Hall, 17.)

5.8 Albert Kelsey. The Colonnade, 1906. (Courtesy of Chautauqua Institution Archives.)

5.9 Albert Kelsey. Haddington Branch of the Free Library of Philadelphia, 1912.

(Philadelphia Speaks. Web.)

5.10 Albert Kelsey. Haddington Branch of the Free Library of Philadelphia, 1912, entry detail.

(Philadelphia Speaks. Web.)

5.11 Albert Kelsey. Carson College for Orphan Girls, 1912, Flourtown, PA. (Ebay. Web.)

5.12 J. Massey Rhind. The Expulsion of Adam and Eve, 1890.

(N. MacDonald, "A Genius of the Chisel." Munsey's, vol. 14: 673.)

5.13 J. Massey Rhind. The King Memorial Fountain, 1893, postcard. (Ebay. Web.)

5.14 J. Massey Rhind. The King Memorial Fountain, Childhood, 1893. (Washingtön Park Conservancy. Web.)

5.15 J. Massey-Rhind. The King Memorial Fountain, Youth, 1893. (Washington Park Conservancy. Web.)

5.16 J. Massey Rhind. The King Memorial Fountain, Manhood, 1893. (Washington Park Conservancy. Web.)

5.17 J. Massey Rhind. The King Memorial Fountain, Old Age, 1893. (Washington Park Conservancy. Web.)

5.18 Bruce Price (1845-1903). American Surety Building (1894-1896), New York, NY.

(Office Museum. Web.) 
5.19 Bruce Price, J. Massey Rhind. Portico of the American Surety Building, 1894.

(N. MacDonald, "A Genius of the Chisel." Munsey's, vol. 14: 672.

5.20 J. Massey Rhind. Peace, The American Surety Building, 1894.

(N. MacDonald, “A Genius of the Chisel.” Munsey's, vol. 14: 671.)

5.21 Robert Henderson Robertson. The Park Row Building, 1896-1899. (Wikipedia. Web.)

5.22 J. Massey Rhind. Four Maidens, Park Row Building, 1899. (Dianne Durante, Forgotten Delights. Web.)

5.23 John and Arthur Scott \& Co. Wayne County Courthouse, c 1905. (National Park Service. Web.)

5.24 J. Massey Rhind. Progress, 1899. (Dennis Alan Nawrocki. Art in Detroit Public Places, 25.)

5.25 Warren Manning. Ferns and rhododendron, wild garden, Gwinn estate, Cleveland, OH, c. 1930.

(Robin Karson. A Genius For Place: American Landscapes of the Country Place Era, 45.)

5.26 Warren Manning. Elon Hooker estate, Greenwich, CT, designed 1909-14.

(Robin Karson. A Genius For Place: American Landscapes of the Country Place Era, 39.)

5.27 Warren Manning. Ravello and overlook, Walden (Cyrus McCormick Jr. estate), Lake Forest, IL, designed 1896.

(Robin Karson. A Genius For Place: American Landscapes of the Country Place Era, 35.)

\section{Chapter 6: The Evolution of Modern Chautauqua, 1903-1917}

Figure 6.1 Chautauqua density, c. 1890.

(Courtesy of Chautauqua Institution Archives.)

6.2 Albert Kelsey. General Plan for the Reorganizing and Rebuilding of the Chautauqua Institution, 1903.

(Courtesy of Chautauqua Institution Archives.)

6.3 Albert Kelsey. Bird's-Eye View of the Chautauqua of the Future, 1903. (Courtesy of Chautauqua Institution Archives.)

6.4 Albert Kelsey. Bird's-Eye View of Arts and Crafts Village, 1903. (Courtesy of Chautauqua Institution Archives.)

6.5 Chautauqua Pier, c. 1890.

(Courtesy of Chautauqua Institution Archives.)

6.6 Albert Kelsey. Proposal for Chautauqua Pier Replacement, 1903. (Courtesy of Chautauqua Institution Archives.)

6.7 Albert Kelsey. Proposed Water Approach to the Hall of Philosophy. (Courtesy of Chautauqua Institution Archives.) 
6.8 E. B. Green, Sr. Miller Park, Tower and Boat Landing, 1911, postcard. (Courtesy of Chautauqua Institution Archives.)

6.9 Albert Kelsey. The Arnold, 1906.

(Courtesy of Chautauqua Institution Archives.)

6.10 Edward B. Green, Sr.

(Buffalo as an Architectural Museum. Web.)

6.11 Edward B. Green, Sr. The Pergola, 1908, postcard, c. 1915. (Courtesy collection of John Cofield.)

6.12 Edward B. Green, Sr. New Post Office, 1909, postcard, c. 1910. (Courtesy collection of John Cofield.)

6.13 St. Elmo Hotel, postcard, c. 1910. (Courtesy collection of John Cofield.)

6.14 Arts and Crafts Course Listing. (Chautauqua Assembly Herald 18 August 1902: 1.)

6.15 Arts and Crafts Village, c. 1902. (Frank Chapin Bray. A Reading Journey Through Chautauqua, 39.)

6.16 Frank G. Sanford. Suggestion for Architectural Style for an Arts and Crafts Village at Chautauqua.

(Chautauqua Assembly Herald 20 Aug. 1902: 1.)

6.17 Edward B. Green, Sr. Arts and Crafts Quadrangle, 1909, original section.

(Courtesy of Chautauqua Institution Archives.)

6.18 Edward B. Green, Sr. Arts and Crafts Quadrangle, 1909-1917. (Author's photograph, 2000.)

6.19 Edward B. Green, Sr. Arts and Crafts Quadrangle, 1909-1917, colonnade detail.

(Author's photograph, 2000.)

6.20 Edward B. Green, Sr. Arts and Crafts Quadrangle, c. 1917, pavilion detail.

(Author's photograph, 2000.)

6.21 Thomas Jefferson. The Lawn, University of Virginia, 1817-1826, colonnade detail.

(Author's photograph, 2000.)

6.22 Edward B. Green, Sr. Arts and Crafts Quadrangle, 1909-1917, colonnade detail.

(Author's photograph, 2000.)

6.23 Paul Pelz. Aula Christi (Hall of Christ), 1909, postcard. (Courtesy collection of John Cofield.)

6.24 Paul Pelz. Randall Hall, University of Virginia, 1899. (Courtesy of University of Virginia slide library.)

6.25 Paul Pelz. Medical School, University of Virginia, 1901-04. (Courtesy of University of Virginia slide library.)

6.26 Paul Pelz. "Nazareth," Hall of Christ, 1909. (Author's photograph, 2000.) 
6.27 Paul Pelz. “Jerusalem," Hall of Christ, 1909.

(Author's photograph, 2000.)

6.28 Paul Pelz. Hall of Christ, 1909, interior.

(Author's photograph, 2000.)

\section{Conclusion: Successors - J. Horace McFarland and Clement Studebaker, Jr.}

Figure c.1 J. Horace McFarland (1859-1948).

(Ernest Morrison. J. Horace McFarland, A Thorn for Beauty, n. pag.)

c.2 Mira Lloyd Dock (1853-1945).

(Ernest Morrison. J. Horace McFarland, A Thorn for Beauty, n. pag.)

c.3 Warren Manning. Plan for Harrisburg, PA, 1903.

(Robin Karson. A Genius For Place: American Landscapes of the

Country Place Era, 37.)

c.4 Clement Studebaker, Jr. Cottage. 39 North Lake Drive, Chautauqua, NY.

(Courtesy Chautauqua Institution Archives.)

c.5 Clement Studebaker, Jr. Cottage, interior: living room. 39 North Lake Drive, Chautauqua, NY.

(Author's Photograph, 2011.)

c.6 Clement Studebaker, Jr. Cottage, interior: dining room. 39 North Lake Drive, Chautauqua, NY.

(Author's Photograph, 2011.)

c.7 Clement Studebaker, Jr. Cottage, interior: view from dining room. 39 North Lake Drive, Chautauqua, NY.

(Author's Photograph, 2011.) 


\section{Acknowledgements}

Sixteen years ago I had the good fortune to meet Professor Richard Guy Wilson. Graciously permitting me to pursue a study of architectural history part-time, he has allowed me the rare privilege to spend part of every day thinking about issues related to the built environment. I have thoroughly enjoyed the years of classes, reading assignments, papers, presentations, and even the exams. I want to thank him for being kind enough to let me start this journey and for his unwavering encouragement along the way.

I especially value the wonderfully talented and dedicated people I have met. In addition to Professor Wilson, I would like to thank the other faculty I have studied with over the years: Sheila Crane, Yunengsheng Huang, John Maciuika, Maurie McInnis, Kevin Murphy, Louis Nelson, Ruben Rainey, Lisa Reilly, Scott Schweigert, Dell Upton, Heather Warren, and Olivier Zunz. Each brought his or her subject to life through a combination of expertise and enthusiasm.

I also feel very grateful to have had the pleasure of getting to know many of my fellow students over the years and would particularly like to thank Elizabeth Milnarik, Amy Finstein, Lydia Brandt,-and Burak Erdim for their special friendship, guidance, and support for this project.

Many of my research projects have included information about Chautauqua, which remains a very important place in my life, and the research could not have been 
possible without the tireless and creative preservation efforts of the first archivist Alfreda Irwin (deceased) and the current archivist Jon Schmitz.

I have also relied on the inspired guidance of Becky Thomas, a dear friend and gifted editor who patiently waded through multiple iterations of this project as well as my thesis.

And through it all, I have been truly blessed to have the love and support of my family - my children, David and Nora, who have grown up with Dad in graduate school, and my best friend and life's partner, my wife Janet. This project is dedicated to you. 


\section{Introduction}

I believe in Beauty as the manifestation of triumphant life. ${ }^{1}$

Henry Turner Bailey, ca. 1903

The Chautauqua ideals seem to me to be interwoven with civic improvement. ${ }^{2}$ J. Horace McFarland, 1904

This summer, indeed every summer since 1874, thousands of people from around the country will gather in a small, picturesque, lakeside community — the Chautauqua Institution - in southwestern New York State to participate in a series of programs whose overarching purpose is to promote social betterment (figs. i.1, i.2). They will do so in a remarkable setting. The grounds of Chautauqua are very dense with carefully tended gardens, well considered green spaces, a cherished canopy of mature trees, and over one hundred public buildings interspersed with twelve hundred private cottages, hotels, and rooming houses, and nearly twelve miles of narrow streets packed into fewer than 400 acres. While it is tempting to view Chautauqua as a homogeneous community, as many of the private homes have been built in a small-scale, Victorian style, it is best understood as a planned Model Summer City of Improvement. At the heart of the plan is a carefully orchestrated sequence of substantial venues for the presentation of the

\footnotetext{
${ }^{1}$ Henry Turner Bailey, "The Beauty Lover's Creed." ca. 1903. (Courtesy of Chautauqua Institution Archives.) Bailey was the editor of the influential journal The School Arts Book (1903-1917) and director of Chautauqua's Arts and Crafts programs (1906-1917).

2 "Message of Civic Improvement. Practical Address by Mr. J. Horace McFarland Yesterday Morning." The Chautauqua Assembly Herald 14 July 1904: 6.
} 
season's programs. These permanent facilities embody a wide range of styles (from formal to rustic) and materials (from stone columns to wood shingles). Most of these buildings date to a master plan proposed at the turn of the twentieth century and demonstrate Chautauqua's privileged role as a unique distillation of the national reform impulse known as Civic Improvement.

Reformers of the Progressive Era (the 1890s to the 1920s) shared a common ideology as they sought to foster positive societal change through the aesthetic manipulation of the decorative and built environment. The theme of Civic Improvement united the many different types of aesthetic activities in which they engaged throughout their careers, just as the various projects themselves drew on a wide range of styles. Chautauqua added buildings as stylistically distinct as the classical Colonnade Building and the rustic Arts and Crafts Quadrangle to improve quality of life. Despite the many facets of Civic Improvement - or perhaps because of them - most scholarship does not address the breadth of its manifestations, preferring to select one (or several) to explore. Classic political or economic historians, who tend to ignore the physical environment, typically make brief mention of aesthetic reform, and architectural historians separate these efforts into discrete classifications, including the City Beautiful and the Arts and Crafts. An examination of the American League for Civic Improvement and its influence on the built environment of the Chautauqua Institution and the year-round communities of the reformers demonstrates, however, that the reform activities, although complex and sometimes contradictory, belong to a continuum. The grounds of Chautauqua were 
conceived as a Model Summer City of Improvement and should be read as an example of varied but complementary styles coming together as an integrated whole.

Chautauqua offers an ideal lens through which to view the aesthetic activities and attitudes of the Progressive Era for two reasons. First, at the turn of the century, the Chautauqua summer season was an important, highly visible venue for the dissemination of a relatively complete spectrum of reform ideals and issues; these in turn prepared the ground for the commissioning of a master plan to position Chautauqua as a "Model Summer City." The subsequent building campaign, with its array of styles, scales, and functions, was the built representation of these ideals. Second, Chautauqua's reformers were typically summer residents who were active during the majority of the year in their home communities throughout the country. The best approach to facilitating an exploration of the multiple aspects that comprise Civic Improvement is to examine their lives using the methodology of collective biography. A study of the breadth of the yearround activities of some of these reformers is a useful gauge of the many pursuits that should be viewed as part of Civic Improvement. ${ }^{3}$

As urban planning historian William Wilson has written, improvement - "a marvelously elastic word" - encapsulates the wide range of aesthetic activities pursued and promoted by progressivereformers. ${ }^{4}$ Other words used interchangeably at the time included betterment, progress, and beautification. To fully appreciate the variety of stylistic pursuits within the improvement paradigm, we must accept their broad scope.

\footnotetext{
${ }^{3}$ Most of the reformers mentioned participated in the Chautauqua program. If not indicated, their visits to the Chautauqua grounds, while entirely possible, have not been recorded.

${ }^{4}$ William H. Wilson, The City Beautiful Movement (Baltimore: Johns Hopkins UP, 1989) 42.
} 
Civic Improvement activities could be on an intimate or small scale: the creation or appreciation of fine art, handicrafts, or home decoration, for example. They also included larger-scale endeavors such as home building, the design of college campuses, and city planning. Their wide range embraced activities as different as participation in dance and theatrical productions and improving the landscape around one's home or in public spaces. Frequently the built environment included a sculptural program - the reformers believed that a beautiful sculpture, either freestanding or incorporated in a façade as a bas-relief, communicated an allegorical narrative most effectively. To Civic Improvement reformers, aesthetic awareness was enhanced through education; they believed that societal change was effected through both the product created and the process of creation. Their definition of beauty encompassed harmony, craftsmanship, truthfulness, and originality. They believed that aesthetic improvement would help to solve many of society's problems.

To Civic Improvement reformers, many towns and cities in turn-of-the-century America seemed ugly, dirty, sinful, and dangerous. Most streets were unpaved, and very few cities had significant park acreage. In lower-income areas of large cities like New York, overcrowded tenements constituted the predominant housing type. Reformers came to believe that improved urban design would alleviate societal ills; a beautiful setting would contribute to an ideal society. A series of national expositions — the 1893 World's Columbian Exposition in Chicago, the 1901 Pan American Exposition in Buffalo, and the 1904 Louisiana Purchase Exposition in St. Louis - gave form to the new vision for the urban fabric. Each exposition featured a tantalizing display of a 
spectacular, but temporary, model city. To many of the reformers, these model cities' beauty "would reflect in the souls of the city's inhabitants, inducing order, calm, and propriety therein." heavenly city, a "City Beautiful.",

By the late 1890 s, reformers in smaller communities from New England to the Midwest responded to the betterment impulse and established local improvement organizations. Women dominated many of the groups, and their focus encompassed beautification of home and town. What was lacking was a national organization to foster communication, disseminate ideas, and encourage activity. ${ }^{7}$ To fill this need, several reformers founded the National League for Civic Improvement in 1900 in Springfield, Ohio. The reformers included D. J. Thomas of Springfield, Ohio, the publisher of Home and Flowers; Charles Zueblin of the University of Chicago; and Frank Chapin Bray of Cleveland, the editor of Chautauqua's influential magazine The Chautauquan. The next year, having reflected on its scope, the organizers changed the name to the American League for Civic Improvement, which "expresses obviously a larger idea, not only

\footnotetext{
${ }^{5}$ Wilson 92.
}

${ }^{6}$ William H. Wilson, "The ideology, aesthetics and politics of the City Beautiful Movement," The Rise of Modern Urban Planning, 1806-1914, ed. Anthony Sutcliffe (New York: St. Martin's Press, 1980) 171.

${ }^{7}$ Jon A. Peterson, The Birth of City Planning in the United States, 1840-1917 (Baltimore: Johns Hopkins UP, 2003) 108-109. 
organizations in union, but individuals and firms as well, and the continent rather than the United States as our "parish.","8

The purpose of the League was defined during the second annual convention held in August 1901 at the Pan American Exposition in Buffalo, just north of Chautauqua, and further developed during "Public Beauty Week" the following summer at Chautauqua. A resolution adopted at the convention in 1901 stated:

[T] he movement for better administered and more beautiful cities and for better homes in our country, inaugurated by the American League for Civic Improvement, is attracting wide-spread attention, and, if properly encouraged, will do much for the higher life of our nation. ${ }^{9}$

The vision was a tapestry composed of many strands, from civic beautification projects to a new conception of industrialization that respected the worker and sought improved conditions on the job.

The inclusive list of fourteen advisory council "sections" into which the League was organized underscores the importance to its founders of a wide range of aesthetic activities (the italicized names designate participants in the Chautauqua program):

8 "Plans for the Future: Inaugural Address of President Charles Zueblin. The Twentieth Century City, A Record of Work Accomplished for Civic Betterment, The American League for Civic Improvement," The Home Florist, Vol IV. Oct 1901, No. 4: 65.

${ }^{9}$ Quoted in E. G. Routzahn, "The American League for Civic Improvement," Chautauquan Monthly July 1902: 502. 
Arts and Crafts - Mrs. Conde Hamlin, St. Paul; B. B. Thresher, Dayton, Ohio; Henry Turner Bailey, North Scituate, Mass.; George Wertbrecht, St. Paul; Miss Ella R. Waite, Chicago.

Civic Church - Graham Taylor, Chicago; Richard T. Ely, Madison, Wis.; Charles R Henderson, Chicago; John Willis Baer, Boston.

Libraries and Museums - John Thompson, Philadelphia; Walter L.

Brown, Buffalo; James K. Hosmer, Minneapolis; Miss M. E. Ahrens, Chicago.

Municipal Art - Albert Kelsey, Philadelphia; Dwight H. Perkins,

Chicago; H. K. Bush-Brown, New York; Charles M. Robinson, Rochester; John Duncan, Chicago.

Municipal Reform - Clinton Rogers Woodruff, Philadelphia; Robert E.

Ely, Cambridge; John Martin, New York; John Graham Brooks, Cambridge; Jerome H. Raymond, Chicago.

Parks (outdoor art) — Charles M. Loring, Minneapolis; Frank Foster,

Chicago; Dr. M. D. Mann, Buffalo; H. R. Warder, Chicago.

Preservation of Nature (including forestry) - Miss Mira Lloyd Dock, Harrisburg; Edward Hagaman Hall, New York; C. A. Schenk, Baltimore. Public Nuisances (smoke and advertising) - W. H. Moulton, Cleveland; Chas. H. Benjamin, Cleveland.

Public Recreation (gymnasium, playgrounds, baths, etc.) - Miss $M$. Eleanor Tarrant, Louisville; D. C. Heath, Boston; Dr. Franz Pfister, 
Milwaukee; Dr. D. A. Sargent, Cambridge; Miss Sadie American, New York; Miss Beulah Kennard, Pittsburg.

Rural Improvement (roads, schools, church, homes) - John Craig, Ithaca; Linus Wolverton, Grimsby, Ont.; Thos. H. MacBride, Iowa City, Iowa; Miss Louise Klein Miller, Groton, Mass.

Sanitation — Dr. Justus Ohage, St. Paul; Dr. Bayard Holmes, Chicago;

Dr. C. V. Chapin, Providence; M. N. Baker, New York, Mrs. Ellen H. Richards, Boston.

School Extension (free lectures, vacation schools, parents' associations, etc.) - Joseph Lee, Boston; Henry M. Leipsiger, New York; Frank C.

Bray, Chautauqua; A. S. Bickmore, New York; J. L. Hughes, Toronto.

Social Settlements - Miss Jane Addams, Chicago; Starr Cadwallader,

Cleveland; A. A. Hill, New York; Miss Anna Davies, Philadelphia.

Village Improvement — Miss Jessie M. Good, Springfield [Ohio]; H. B.

Beck, Austin, Texas; Mrs. E. B. Heard, Middleton, Ga.; Miss Caroline Peterson, Honesdale, $\mathrm{Pa}^{10}$

The Chautauqua participants represent slightly more than one-fourth of the committee members and illustrate the important role Chautauqua played as a platform and forum for this national discussion. To the reformers, all of these often-disparate interests meshed in the integrated whole of Civic Improvement; a look at the activities of

10 "Work of the League, General News of Civic Improvement Progress," Home and Flowers September 1902: 22. E. G. Routzahn, "The American League for Civic Improvement," 501-506. 
some of these individuals will provide a framework for understanding aspects that rightfully belong within that movement.

The ideals and activities of the League were to have a lasting effect on the built environment as well as the programming of Chautauqua, which had been established by the industrialist Lewis Miller and the religious leader Bishop John Heyl Vincent during the summer of 1874 as a two-week assembly for Sunday-school teachers. The site Miller and Vincent chose was the inspiring setting of a camp meeting ground on the western shore of a picturesque lake of the same name. The goal of the first Assembly was to provide a home for personal, spiritual, and intellectual growth through continuing education. By the turn of the century, however, Chautauqua had grown beyond these initial goals and become an important locus for the dissemination of progressive ideas. The famous Chautauqua platform offered an important venue where prominent reformers from around the country came to promote their points of view.

During the summer season, Chautauqua put on an extensive program of concerts, lectures, and classes, scheduled throughout the day and evening, that made it a center for aesthetic activism. The programs utilized an eclectic mix of facilities; some dated from the first twenty-five years, while most resulted from a substantial building campaign undertaken after 1903. The important facilities built after 1903 were part of a comprehensive master plan for the reconstruction of the Chautauqua grounds approved by the Institution's board, a plan that grew out of Chautauqua's association with the League for Civic Improvement. The Chautauqua board chose League-member architect Albert Kelsey to be the lead designer. Kelsey, along with landscape architect Warren 
Manning and sculptor J. Massey Rhind, created a lavish blueprint for re-imagining the Chautauqua grounds as a Model Summer City.

With chapters organized around Chautauqua and places with which it was significantly interrelated, this dissertation explores the theme of Civic Improvement through an examination of the program that filled the summer season, the presenters of the program and their activities at their "off-season" homes, and the built environment of the Chautauqua grounds. The first chapter serves as an introduction to Chautauqua and its history and significance. It traces the development of the Institution through its first twenty-eight years and examines the built environment prior to the master plan.

The turn of the century saw not only the transformation of the grounds but the emergence of the second generation of Chautauqua's leaders. The most important was Bishop John Heyl Vincent's son, George Edgar Vincent. George's position as a faculty member in the sociology department of the University of Chicago facilitated a remarkable synergy between Chautauqua and the emergent progressive reform activities in Chicago. Chapter 2 describes this transition and introduces many of the key reformers who influenced the creation and execution of the plan. They fall into two categories: the administrators of Chautauqua and the lecturers, teachers, and other individuals who presented the programs. The second chapter also focuses on the emergence of the American League for Civic Improvement and its influence on the program, the participants, and the built environment of Chautauqua. 
On the last day of the second convention of the League, in August 1901 in Buffalo, the leaders made the seventy-mile trip south to Chautauqua. The speeches and meetings that day led to a joint week-long program the following year. The third chapter explores that August 1902 "Public Beauty Week" program at Chautauqua along with other presentations that year, which led directly to the commissioning of the 1903 plan. Among the reformers who shared the Chautauqua platform during the 1902 season were Chautauqua President George E. Vincent and Hull House founders Jane Addams and Ellen Gates Starr; University of Chicago Professor of Sociology and League founder, aesthetic activist Charles Zueblin; the vice-president of the League, Edwin L. Shuey of Dayton, Ohio; and the president of the Texas Federation of Women's Clubs, Anna J. Pennybacker of Austin, Texas. Many of these individuals were actively engaged in improvement activities in their year-round communities. An examination of their divergent interests develops the dialectic and synthetic argument that their various aesthetic activities and stylistic distinctions were interrelated.

The fourth chapter introduces the influential reform-minded businessmen who comprised the 1902 board of trustees of Chautauqua that commissioned the plan. Although the grounds of Chautauqua were inhabited only during the summer season, for the men who sponsored its redesign, this in no way diminished its importance as a place in which to experience beauty and civic improvement. Active in cities and towns throughout the country, many of them brought to Chautauqua reports of their reform experiences from home and returned to their winter homes with fresh ideas. Their stories serve as a point of entry to the exploration of parallel aesthetic activities in related places 
such as Cleveland, Ohio, South Bend, Indiana, and Olean, New York. Of particular importance was their involvement with the Pan American Exposition in Buffalo and the development of that fair's remarkable sculptural program. Because these men were active in the physical development of their home cities, they frequently worked with designers and planners. This chapter therefore also explores their connection to the two architects who competed with Kelsey to be Chautauqua's master planner, Sidney R. Badgley of Cleveland and E. B. Green of Buffalo. Green deserves emphasis because although not selected to be Chautauqua's master planner, he became the Institution's primary architect as the plan was executed over the next fifteen years.

The fifth chapter, which further expands the thesis geographically, examines the men who created the master plan. The design team included the architect Albert Kelsey, a key figure in the American League for Civic Improvement, and the landscape architect Warren Manning, who became a seminal figure in the history of American landscape design. A particular focus will be the sculptor J. Massey Rhind. Rhind's career parallels the rise in the importance of sculptural decorative programs to civic betterment plans. At the turn of the century there were hundreds of sculptors active in America; some were native born, like Daniel Chester French and Frederick W. MacMonnies, but many, such as Karl Bitter and Rhind, were European émigrés. Their contributions were considered an important vehicle for communicating the ideals of Civic Improvement.

The sixth and last chapter describes the built environment of Chautauqua subsequent to the Kelsey plan. At the turn of the century, Chautauqua was celebrated as a prominent center of religious, ethical, and moral social betterment. A shift in focus, 
from personal growth, the primary focus of the founders, to a more broadly social agenda was reflected in the design of the plan. Three projects will be examined, each with a different program, style, and architect. At the center of the grounds, anchoring the central gathering place, lies the Colonnade building, housing Chautauqua's administration — the only commission Kelsey completed. At the north end of Kelsey's organizing central path, the Arts and Crafts quadrangle executed by the firm of Green and Wicks served as the home of artistic expression for generations of teachers and students. And at the southern terminus of this path, the unique Hall of Christ, designed by Paul Pelz and integrated into Kelsey's plan, is a monument that fully expresses the breadth of Civic Improvement. ${ }^{11}$

${ }^{11}$ For a discussion of the important sources for this dissertation see Appendix 4: Bibliographic Essay, p. 189. 


\section{Chapter 1}

\section{The Foundation and Development of Chautauqua, 1874-1902}

As a permanent facility used primarily as a summer community, Chautauqua attracted reformers from throughout the country: concepts were discussed, plans made, and theories tested and disseminated. The built environment of Chautauqua therefore both reflects and anticipates projects in many locations. For these reasons it is relevant to consider Chautauqua's history, built environment, and ideals.

Established by the industrialist Lewis Miller and the religious leader Bishop John Heyl Vincent, Chautauqua began during the summer of 1874 as a two-week assembly for Sunday-school teachers. The first Assembly sought to provide a home for an experiment in spiritual and intellectual growth through continuing education. Over the years this experiment expanded and evolved into a complete educational program and an annual summer festival under the aegis of the Chautauqua Institution.

In its unique collection of facilities, each summer the Institution offered a wide range of programs reflecting the broad themes of knowledge, art, music, and religion, the themes considered the "pillars" of Chautauqua's mission. ${ }^{1}$ Chautauqua's leaders believed their mission differentiated the Institution from a resort. In his 1901 report to Chautauqua's Board of Trustees, President George E. Vincent explained:

There is a danger that Chautauqua may become merely a successful resort, thought of by friends and the public as a business enterprise. This

\footnotetext{
${ }^{1}$ One of the subtexts that will be explored in this study is the shifting emphasis of Chautauqua's program on each of the pillars over the years. Alfreda L. Irwin, Three Taps of the Gavel: Pledge to the Future, The Chautauqua Story (Chautauqua, New York: Chautauqua Institution, 1987) 23.
} 
conception of Chautauqua would be fatal to its permanence and success. . . . Let the motto for the new century be, "Chautauqua an Institution and an Ideal" - not a business and a summer resort. ${ }^{2}$

By focusing on the development of the built environment and the programming, Chautauqua's leaders insured the continuation of the "Ideal."

The Chautauqua Institution is blessed with a naturally beautiful location on the western shore of Lake Chautauqua, a glacial lake that, at approximately 1300 feet above sea level, is the highest navigable lake east of the Mississippi River. Chautauqua Lake is in the southwestern most corner of New York State, just ten miles from Lake Erie. Approximately nineteen miles long and up to two miles wide, the lake is surrounded by hills that eventually rise to five hundred feet or more. Several ancient ravines perpendicular to the lake that cut through Institution property contain old-growth trees and streambeds littered with fossil rocks. The topography of the grounds is dramatic, with a significant slope up from the lake (fig. 1.1). Historians of Chautauqua from Vincent to Irwin to Simpson have extolled the physical beauty of the setting. Simpson describes the "pastoral setting" of Chautauqua as a "Utopia by the Lake" (fig. 1.2). ${ }^{3}$

Of the several legends about the origin of the name "Chautauqua," the most often repeated is that the name meânn "bag-tied-in-the-middle" or "two-moccasins-tiedtogether" in a local Native American language. Both of these meanings refer to the shape

\footnotetext{
${ }^{2}$ Quoted in Pauline Fancher, Chautauqua: Its Architecture and Its People (Miami: Banyan Books, Inc., 1978) 109.

${ }^{3}$ Jeffrey Simpson, Chautauqua, An American Utopia (New York: Harry N. Abrams, Inc., 1999) 21,17 .
} 
of the lake (fig. i.2). ${ }^{4}$ Founder Bishop John Heyl Vincent reported one of the most evocative legends of the origin of the name in his Chautauqua Movement, quoting from a "historical sketch" by Obed Edson, Esq., published in The Continent on August 22, 1883: Some Indians once encamped upon [Lake Chautauqua's] shore. A young maiden of the party, having eaten of a root growing upon its banks which created a great thirst, stooped to drink of its waters, when she disappeared forever. Hence the name signifying "the place of easy death," or "where one vanishes away."

Vincent interpreted this legend in terms of Chautauqua's mission. He saw the maiden's thirst as representing the need of our souls, quenched by the acquisition of knowledge. Once our "thirst" is satisfied, the death that follows is "but a 'sleep,' . . . peace and rest secured." 6 To Vincent, education was a path to heaven, and Chautauqua was the point of departure for that journey.

The original meeting place for the Assembly was a grove that the founders called the Auditorium, in the woods adjacent to the Point. Benches were set up, and the activities took place in the open air under a natural canopy of mature trees (fig. 1.3).

\footnotetext{
${ }^{4}$ Irwin 7.

${ }^{5}$ John Heyl Vincent, The Chautauqua Movement (1885; Freeport, New York: Books for Libraries Press, 1971) 46-7.

${ }^{6}$ Vincent 47 .
} 
Years later, Bishop Vincent described the scene of the first gathering in the Auditorium on Tuesday, August 4, 1874: ${ }^{7}$

The stars were out, and looked down through trembling leaves upon a goodly, well-wrapped company who sat in the grove, filled with wonder and hope... The old-fashioned pine fires on rude four-legged stands, like tall tables covered with earth, burned with unsteady, flickering flame... . The white tents were very beautiful in that evening light. ${ }^{8}$

Directly behind the grove, a hill rises dramatically to a plane. Vincent saw the topography of the grounds, the steep hill rising up from the Point and lakeshore to the educational facilities at the top of the hill, as an allegory and equated the difficulty of climbing the hill to the difficulty of attaining an education:

There is a Chautauqua farther on. First, there is a lake level; and just above it is the level of the 'Point,' with its pleasant grass, its winding walks, its old Auditorium, shaded and hallowed with memories that have grown through multiplying years ... the friendships that were formed there never to be broken.

But let us go up higher. Beyond the Point and Auditorium level ... a higher Chautauqua, - a long stretch of table-land crowned now with ... Normal Hall, Museum, and Hall of Philosophy.

\footnotetext{
${ }^{7}$ Chautauqua's "Birthday" is celebrated each year as "Old First Night," a ritualized community gathering.

${ }^{8}$ Vincent $257-8$.
} 
Thus from the landing and the beginning of our journey we ascend from the lowest to the highest, and find beauty, delight, pleasant welcomes and rewards, all the way.

There is an upper Chautauqua; and not all who visit the place see it, and not all who become Chautauquans reach it. ${ }^{9}$

To Vincent, climbing the hill, in other words making the important journey of the acquisition of knowledge, led to a sanctified life. The uniquely beautiful configuration of the Chautauqua grounds was the perfect setting for the journey.

At the turn of the twentieth century, the grounds of the Institution fronted about one and one-quarter miles of Lake Chautauqua and measured about three miles in circumference. A pedestrian community, Chautauqua has been described as having "the appearance of a tightly knit small city behind a fence."10 The streets are narrow and the houses are close together, with a mix of public and private buildings. Most of the cottages have front porches, which, together with frequent small green spaces and individual public buildings, are the social gathering places of the community. From its inception Chautauqua has charged admission to the grounds: the founders, Lewis Miller and Bishop John Heyl Vincent, wanted to avoid the encumbrance of "passing the basket." "11 For this fee, Miller and Vincent envisioned a wide range of scheduled events,

\footnotetext{
${ }^{9}$ Vincent $49-50$

${ }^{10}$ Simpson 21 .

${ }^{11}$ The receipts contribute approximately one-third of the Institution's annual budget. An annual fundraising campaign and income from its endowment also contribute approximately one-third each. James Mando, Office of Development, Chautauqua Institution, personal interview, Aug, 2003.
} 
which by 1900 included lectures, concerts, opera and drama performances, and religious programs. Chautauquans also participated in a full range of sports and recreational activities, and children enjoyed a day camp and a pre-school program. Chautauqua also provided an extensive catalogue of classes for adults, with diverse course offerings. ${ }^{12}$

Both Lewis Miller and John Heyl Vincent, the founders of Chautauqua, were successful men who had committed their lives to helping others by enabling them to acquire an education (fig. 1.4). Lewis Miller, born in 1829, made his fortune as the inventor and marketer of the Buckeye Mower and other farm implements. Passionate about education, he had revamped the Sunday-school program of the First Methodist Church in Akron, Ohio, recruiting laymen to add science and nature to the study of the Bible. Bishop John Heyl Vincent was born in Tuscaloosa, Alabama, in 1832. He was raised a Methodist and became a minister at the age of twenty. As a young minister, Vincent came to believe that the narrow Methodist focus on a deeply felt religious feeling, what has been termed the "doctrine of sanctification through grace," did not constitute a sufficient credential for religious educators; ${ }^{13}$ rather Sunday-school teachers should be more widely prepared:

It is common for church people to think that a religious experience is the greatest and often the only qualification necessary to make an individual

\footnotetext{
${ }^{12}$ Today the Chautauqua Summer Schools offer over five hundred courses taught by over three hundred fifty faculty.

${ }^{13}$ Robert W. Fulks, Jr., "The Ideological and Intellectual Development of the Chautauqua Sunday School Assembly at Fair Point, New York, 1874-1876" (Masters thesis, University of Virginia, 1972) 9. See also Timothy L. Smith, Revivalism and Social Reform in Mid-Nineteenth-Century America (New York: Abingdon Press, 1957).
} 
successful in teaching children the truth. ... But there are other qualifications needed besides piety. ${ }^{14}$

Broadening the credentials and views of Sunday-school teachers became his life's work. ${ }^{15}$

Miller and Vincent met in 1868 and, during the next few years, collaborated on a plan to hold a two-week advanced training conference for Sunday-school teachers. Adopting the emerging tenets of the Normal School movement, they hoped that the "norms" they established for Sunday-school teachers would be adopted throughout the country. ${ }^{16}$ During the summer of 1873 they chose the Fair Point Methodist camp meeting ground on the shores of Lake Chautauqua (fig. 1.5). ${ }^{17}$ The program that began the following year was designed to help teachers expand their horizons so they in turn could inspire their students. The first summer, approximately two thousand people attended the Assembly. ${ }^{18}$ To certify the benefit of the experience, Vincent administered a final exam, which covered Bible study as well as educational techniques (fig. 1.6).

14 "Look At the Facts," Chautauqua Assembly Herald 15 June 1876: 1.

${ }^{15}$ On Vincent's contribution to Sunday-school development see Jack L. Seymour, From Sunday School to Church School: Continuities in Protestant Church Education in the United States, 1860-1929 (New York: University Press of America, 1982) 55-78.

${ }^{16}$ A normal school was a school created to train high school graduates to be teachers. Its purpose was to establish teaching standards or norms. On the Chautauqua Normal School see Jesse Lyman Hurlbut, The Story of Chautauqua (New York: G. P. Putnam's Sons, 1921) 17-18. See also Junius Lathrop Meriam, "Normal School Education and Efficiency in Teaching," diss., Columbia University, 1905.

${ }^{17}$ Lewis Miller's brother Jacob owned property at Fair Point.

${ }^{18}$ Estimates of the 1874 Assembly attendance range from several hundred to fifteen thousand people. 
The exam consisted of twenty-two questions. The first seven questions tested the teachers' knowledge of the Bible as well as their religious attitudes. For instance, question six read, "Describe the spirit in which the Sunday School teacher should study the word of God." The next series of questions focused on teaching technique. Questions fourteen and fifteen asked, "What are the various methods by which a teacher may use to the best advantage the EYES of his pupils?" and, "What do you understand by TACT in teaching?" The balance of the questions stressed the importance of the connections between the Church, the Sunday-school, and the home. The emphasis throughout was on a belief in immanence. ${ }^{19}$

To Miller and.Vincent, education was a sacred task. They felt that all knowledge, both secular and religious, emanated from God and was intrinsically sacred. The acquisition of knowledge, therefore, was a method of redemption. ${ }^{20}$ Their belief in the redemptive nature of education — what was termed "immanence" — was consistent with the development of Liberal Protestantism. Early nineteenth-century theologians had come to believe in the "immanence of God in nature and human nature ... a general humanistic optimism . . . a universal religious sentiment ... that lay behind the institutions, scriptures, and creeds of particular religions.,"21 Vincent said, "We found everything contributing to the great idea religion - everything in nature and science and

${ }^{19}$ Test Questions, For the Final Examination at the Sunday School Assembly, Chautauqua Lake, August, 1874. Courtesy Chautauqua Archives.

${ }^{20}$ For a discussion of the ideology of the first three years of the Chautauqua Assembly see Fulks.

${ }^{21}$ William R. Hutchinson, The Modernist Impulse in American Protestantism (Cambridge: Harvard University Press, 1976) 3-4. On Vincent and Liberal Protestantism see Andrew C. Rieser, The Chautauqua Moment, Protestants: Progressives, and the Culture of Modern Liberalism (New York: Columbia University Press, 2003) 94-100. 
art and literature."22 By participating in the Chautauqua program, the Chautauquans would sanctify their individual lives and the lives they touched.

To solidify the Chautauqua program, Vincent persuaded his former parishioner President Ulysses S. Grant to visit during the second season, 1875. As a stage set for the historical meeting of the 18th President of the United States and the first president of Chautauqua, Miller designed a cottage to be prefabricated in his Akron factory. The style of the house replicated an A. J. Downing pattern book model of a Swiss chalet featuring structural exterior cross-hatching and a bracketed porch. The interior walls and ceiling were covered by painted canvas. The cottage was shipped in pieces by train and boat and hastily erected at the northwestern corner of the meeting ground, opposite the pier entry (fig. 1.7). In a scene probably dramatized over time, it is reported that "thirty thousand" people gathered to witness Grant's procession from the Point and across the meeting ground to shake hands with Miller on the front porch of his new cottage. ${ }^{23}$ Chautauqua historian Jeffrey Simpson elaborates:

A song was written by hymnwriter Mary Lathbury for the president; three addresses were made by various dignitaries throughout his visit; and illuminations were presented in the evening, ranging from the pine torches flaring on their poles to fireworks, which the president enjoyed from the porch of the Miller cottage. ${ }^{24}$ 1903: 1.

22 John Heyl Vincent, "The Aula Christi at Chautauqua," Christian Endeavor World 16 April

\footnotetext{
${ }^{23}$ Simpson 37.

${ }^{24}$ Simpson 37.
} 
The national attention this meeting attracted served to legitimize the Chautauqua Assembly.

Consistent with their belief in immanence, the founders of Chautauqua designed a program to provide those in attendance with a remarkable breadth of experience. Within the first three years, the program had expanded to reflect the pillars of the Chautauqua ideal: "religion, knowledge, art, and music." Although Bible classes and religious programs were still emphasized, scientific discussions, temperance lectures, many types of physical education, and musical and cultural events were also available. In the June 15, 1876, edition of the Chautauqua Assembly Daily Herald, Chautauqua's daily newspaper, Vincent wrote, "The original plan of the Sunday-school Assembly at Fair Point has developed into something much larger and more complete as an educational agency than was at first contemplated."25

The broadening of the Chautauqua movement was accelerated by Vincent's and Miller's creation in 1878 of the Chautauqua Literary and Scientific Circle, better known as the CLSC, which helped transform Chautauqua into a national, year-round experience. ${ }^{26}$ The CLSC was a four-year, directed, home-based self-study reading course created to bring the Chautauqua style of learning to people around the country who might

\footnotetext{
${ }^{25}$ John Heyl Vincent, "Who are Welcome to Chautauqua?" Chautauqua Assembly Daily Herald 15 June 1876: 2.

${ }^{26}$ On the history of the CLSC see Charles R. Kniker, "The Chautauqua Literary and Scientific Circle, 1878-1914: an historical interpretation of an educational piety in industrial America," diss., Teachers College, Columbia University, 1969 and Mary Lee Talbot, "A school at home: the contribution of the Chautauqua Literary and Scientific Circle to women's educational opportunities in the Gilded Age, 1874-1900," diss., Columbia University, 1997.
} 
not have other educational opportunities. Bishop Vincent wrote that the CLSC "aims to promote habits of reading and study in nature, art, science, and in secular and sacred literature . . especially among those whose educational advantages have been limited." 27 The CLSC proved to be enormously successful. Vincent reported that by $1891,180,000$ people from around the country, in thousands of reading groups, had enrolled in the program. The range of book topics, from theology to history to physiology to Recreations in Astronomy, continued to expand Chautauqua's focus on a broad ecumenical education (fig. 1.8). ${ }^{28}$ In addition to prescribing the curriculum of reading and study, the CLSC published and distributed the books and held an annual ceremony on the grounds of Chautauqua in the Hall of Philosophy for those who had completed the course work. Importantly, Vincent termed this Recognition Day instead of graduation; it was hoped that the CLSC participants had embraced a lifestyle of learning. To further expand its national reach, Chautauqua published both year-round weekly and monthly magazines covering a wide variety of topics, in addition to a daily newspaper published during the summer season for those in attendance in New York. By the turn of the century, in an era before the advent of rapid communication via the radio, Chautauqua had a remarkable infrastructure for the dissemination of information.

Miller and Vincent's sense of the aesthetic expressed itself in a series of wooden structures added to the Chautauqua landscape during the first twenty-five years of the Assembly. This resulted in a wide variety of facilities such as churches, lecture halls,

\footnotetext{
${ }^{27}$ Vincent, The Chautauqua Movement 45.

${ }^{28}$ Vincent 47.
} 
classrooms, art studios, and gymnasiums built to house the various activities. Reflecting a hierarchy of sizes and styles, the buildings ranged from the modest home for Miller to a large "College" — the "Moorish barn" — as the location for university classes (fig. 1.9).

Vincent's favorite structure was the home of the CLSC programs at the south end of the grounds, an area he named St. Paul's Grove in honor of the apostle who was an important early missionary. Here, Vincent designed an interpretation of the Parthenon in wood, which he called the Hall of Philosophy (1879) (fig. 1.10). Situated at the top of the rise, high over the lake, it was small in scale but painted a gleaming white so it would sparkle in the woods. For Vincent, its style self-consciously connected the (somewhat romanticized) rational ideals of Greek civilization - democracy, knowledge, order, and harmony - to a CLSC education and to Chautauqua. ${ }^{29}$ The Grove is ringed with a typical Chautauqua mix of buildings. Next to the Hall are two small stick-style private cottages and a small-scale church, the Chapel of the Good Shepherd (1901), used for Episcopal services (fig. 1.11). The Chapel has a steeply pitched roof, unassuming exterior, and residential scale. Directly opposite the Hall of Philosophy graduates who had completed the CLSC coursework began to build alumni meeting houses. The first house, Pioneer Hall, of the class of 1882 , has the appearance of a small residential cottage. Next to it the class of 1885 constructed the tiny, charming Octagon House containing one small room for the class to gather in (fig. 1.12). The exterior has a plain

\footnotetext{
${ }^{29}$ The original Hall of Philosophy was replaced by another grand Parthenon designed by E.B. Green in 1906.
} 
façade, but a decorative overhang supported by detailed brackets distinguishes the front entry.

Gifts of separate buildings quickly became unfeasible, so the decision was made to have several classes pool their resources and contribute a building large enough for many classes to use. Erected next to Pioneer Hall, the Alumni Hall for the Chautauqua Literary and Scientific Circle (CLSC), is an over-scaled clapboard cottage containing classrooms, dorm space, and meeting rooms (fig. 1.13). It was designed by Ellis G. Hall and built in 1892 as a gift of the graduating CLSC classes of 1886-1895. ${ }^{30}$

In 1896, in admiration of the development of Chautauqua's programs and facilities, Vincent described some of its remarkable public buildings:

At Chautauqua we find "The Amphitheater" [1879] for public, popular, instructive, and recreational ministries. On Sundays it is used for worship. We find the "College" [1887] for the regular college class-work. In the "Hall of Philosophy" [1879], the more profound discussions take place. In the "Normal Hall" [1885] professional teachers teach teachers to teach ${ }^{31}$ The designers of the Amphitheater borrowed from ancient Greek tradition and placed their seating within an existing ravine near the Point and in the geographic center of the grounds. For the first Assembly in 1874, a large tent had been erected on the flat plane

\footnotetext{
30 "Alumni Hall, Improvements Made This Year - The History of the Building." Chautauqua Assembly Herald 25 July 1902. Hall designed many of the public buildings built between 1885 and 1900, including the Pier Building, the Electric Plant, the Arcade, the Presbyterian and Methodist Episcopal headquarters, and Seaver Gymnasium (Irwin 74). He was based in Syracuse, where for two years he was a partner of Joseph Lyman Silsbee, 1883-85. Irving Gill apprenticed in his office,

${ }^{31}$ Vincent, "The Aula Christi at Chautauqua," 1.
} 
up the hill to accommodate meetings during the frequently rainy weather. The ravine nearby was cleared, a platform constructed, and the tent re-installed in 1877 . The tent was replaced in 1879 by a massive, permanent roof supported by a forest of wooden posts that emphatically recalled the trees and branches of the first meeting place in the grove as if they had been transformed into a modern, man-made structure. The newly named Amphitheater seated approximately five thousand people on benches. As many of the seats had obstructed views, the Amphitheater was rebuilt in 1893 with a steel-trussed roof supported by twenty steel columns. The designer, Ellis G. Hall, retained the look of the original posts at the edges (fig. 1.14). ${ }^{32}$

After its initial opening for the 1879 season, the Amphitheater witnessed almost constant summer activity, and the rhythms and patterns of its use have hardly changed. A 9:30 a.m. non-denominational "Devotional Hour" worship service was followed by a 10:45 a.m. to 12:00 p.m. lecture on the programming department's theme for the week. Beginning at the turn of the twentieth century, the lecture platform topics turned away from primarily religious themes to include civic issues, such as beautification of the home and the built environment, education, and the arts and the Amphitheater stage was the platform for many prominent speakers, including innumerable educators and authors. Following the morning lecture, an early afternoon organ recital was performed several days a week after the organ was installed in 1907. It was followed by a rehearsal for the evening's Amphitheater program.

\footnotetext{
${ }^{32}$ Irwin 74.
} 
The evening program evinced a modification similar to that of the morning lectures. In the early 1880 s the program consisted of a rotation of inspirational lectures such as "Public Opinion and Prohibition" and "Religious Signs of the Times," scientific lectures such as "Recent Solar Wonders as Developed by Lens and Prism," and musical concerts. ${ }^{33}$ At the turn of the century the lecture topics' focus shifted to important issues of social awareness and themes of civic improvement, for example Public Beauty, Arts and Crafts, and "The Social Settlement and the Problem of the Child." (Jane Addams participated in the program that week.) These more serious lectures were interspersed with dramatic readings from works such as Ulysses and The Merry Wives of Windsor and illustrated lectures such as "Younger American Painters and Their More Recent Works" and "The Mighty Ocean." The Chautauquans of this time also enjoyed regular musical events in the evening in the Amphitheater, for example an "Operatic Concert" and "Concert: American Composers, with Orchestra, Male Glee Club, and Soloists.",34

During the late nineteenth century Chautauqua greatly expanded its educational mission. By 1885 the Chautauqua University had been chartered, with multiple divisions including a Chautauqua School of Liberal Arts, a School of Theology, and a School of Languages, as well as the Chautauqua Literary and Scientific Circle (CLSC). To accommodate the dramatic increase in the number of classes offered, a large classroom building, the College, was erected in 1887 at the north end of the grounds. The style that

\footnotetext{
33 "Chautauqua, 1883, Detailed Program," Chautanqua Assembly Herald 4 August 1883: 5.

34 "Revised Program," Chautauqua Assembly Herald 5 July 1902: 2,5.
} 
was chosen, a lavish Moorish fantasy, reflected the grandiose self-image of the Chautauqua leadership.

Just two years earlier, the alumni of the first Assemblies had given a much smaller classroom building in a simple clapboard style. Named to honor the success of the Chautauqua program to establish norms for the education of Sunday-school teachers, Normal Hall provided a venue for continuing the effort (fig. 1.15). For each of the buildings added during these years, Miller and Vincent tried to design an appropriately functional yet aesthetically inspired home for instruction that would complement the natural beauty of the grounds.

By the end of the nineteenth century, a large grande dame Victorian with twin corner towers anchored the flat plane at the center of the grounds. Kellogg Hall, dedicated in 1889, housed the local headquarters of the Women's Christian Temperance Union, along with a kindergarten and classrooms for women's craft classes (fig. 1.16). The opposite end of the plane featured an attractive grouping of four buildings. On one corner stood the Assembly Herald Building, the home of Chautauqua's daily newspaper (fig. 1.17). Built in 1889, it featured a two-story wraparound porch. Across the street was a classically inspired home of the CLSC. Given in 1890 by George Vincent (Bishop Vincent's son) and Theodore-Flood, the publishers of the CLSC books and The Chautauquan, the monthly magazine, the building contained the CLSC offices and a meeting hall for three hundred people. Perhaps to emphasize the importance of the CLSC program, its headquarters was adorned on two sides by the first classical columns on the Chautauqua grounds (fig. 1.18). Next to the CLSC headquarters, Newton Hall 
(1881), a museum, housed curios and artifacts from the Near East, including a mummy on loan from Mount Union College (fig. 1.19). Designed in a vaguely Italianate style with a two-story tower section and a prominent cornice, Newton Hall was funded by Lewis Miller's brother Jacob, who named it for his wife. ${ }^{35}$

Directly across the street from the Museum and diagonally across from the Herald Building, the Children's Temple, built in 1878 by Lewis Miller, was one of the first buildings constructed on the flat plane above the lake (fig. 1.20). Working with the architects Walter Blythe and Jacob Snyder, Miller had developed a building type he thought would facilitate the Uniform Lesson System of Sunday-school education. In this system, a single weekly lesson based on a passage from scripture would be learned by all of the students, regardless of age, but in an age-appropriate manner. In Miller's plan, smaller classrooms on one or two levels surrounded a large open space, the "rotunda." The classrooms were separated from the rotunda by movable partitions such as folding doors or sliding shutters. The Sunday-school superintendent explained the lesson of the week from a central position in the rotunda within view of all of the students. The partitions would then be closed, and each class would discuss the lesson. At an appointed time, all of the partitions would open, and the entire school would recite the lesson. ${ }^{36}$ Named for his hometown, where Miller first developed the design for the First Methodist Episcopal Church in 1866, the Akron Plan became a widely popular typology in the

\footnotetext{
${ }^{35}$ Irwin $23,24$.
}

${ }^{36}$ American Religious Buildings, The Akron Plan Sunday School, Sacred Places. Web. See also Jeanne Halgren Kilde, When Church Became Theatre: The Transformation of Evangelical Architecture and Worship in Nineteenth-Century America (New York: Oxford UP, 2002). 
Midwest and Eastern U.S. In his version of the Akron Plan for Chautauqua, Miller created a large, fairly plain, cruciform building with a decorative cupola.

The rest of the precinct had a collection of modest wooden buildings. Vincent Avenue, on the axis from the Point and the original park-like gathering place, was fronted on both sides by a row of commercial shops (fig. 1.21). The shops featured a wide variety of goods for sale, including milk and meat, as well as notions and general grocery and hardware items. Nearby a visitor could also stop by the bakery, the post office, or a restaurant, or even shop for furniture. In addition to the conveniences typical of a small town, facilities were built to house Chautauqua's burgeoning programming. Separate buildings were erected for the school of languages for example, and the "tabernacle" welcomed Jewish visitors. Closer to the Amphitheater and across from the restaurant, a small chapel and a landscaped "chapel park" were created, complete with men's and women's restrooms. Perhaps the most unusual of the small-scale wooden buildings was the "pyramid," a section model of the great pyramid of Cheops that was used for interactive classes on ancient history (fig. 1.22).

Each of these facilities, representing a widely divergent and eclectic aesthetic sensibility, reflected Chautauqua's initial mission, and was used for frequent programming over the years: Although in need of repair at the turn of the century, they remained focal points for the realization of Miller and Vincent's dream of the sacred acquisition of knowledge. These first buildings, exclusively of wood, would be followed by a second "modern" series of more substantial structures built during the first years of the twentieth century. 
This major building campaign was promoted by the second generation of Chautauqua's leaders, especially Bishop John Heyl Vincent's son, George E. Vincent. Prompted by the younger Vincent, the Board of the Chautauqua Institution commissioned a plan with the hope that the grounds would serve as a place of inspiration: a Model Summer City. ${ }^{37}$ The new facilities created during these years were in a wide range of styles and scales reflecting the broad expression of the Civic Improvement agenda. This movement, which gained prominence during the late nineteenth and early twentieth centuries, came into being in part in reaction to the dehumanizing aspects of late nineteenth-century life. Civic Improvement fully expressed the belief that beautification of the environment - public, private, and experiential — would improve quality of life.

37 "Making Chautauqua a Model," Chautauquan Monthly Aug. 1903: 450. 


\section{Chapter 2}

\section{Chautauqua's Second Generation: The Influence of the American League for Civic Improvement}

The reimagining of the built environment of the Chautauqua grounds and the shift in the Chautauqua program to a paradigm of Civic Improvement reflected changing attitudes as younger leaders took on a more influential role. At the turn of the century, the theme of societal betterment in all of its various forms could be heard from Chautauqua's platforms and seen in plans for public venues and private spaces. Close consideration of this group of influential Chautauqua administrators, as well as some of the prominent speakers who graced the Amphitheater and the Hall of Philosophy will give context to these changes.

\section{William Rainey Harper}

In 1883 the next generation of Chautauqua's leaders began to emerge when Bishop Vincent brought the brilliant young William Rainey Harper to Chautauqua (fig. 2.1). Harper (1856-1906), who had received his doctorate in philology from Yale at the age of nineteen, initially taught Hebrew classes. His talents were quickly recognized, and he was made Principal of the Chautauqua College of Liberal Arts in 1887. ${ }^{1}$ Well respected as an author, educator, and administrator, Harper was recruited by John D. Rockefeller, Sr., to be the first president of the re-established University of Chicago in

${ }^{1}$ On the history of the Chautauqua College of Liberal Arts see Alfreda L. Irwin, Three Taps of the Gavel: Pledge to the Future, The Chautauqua Story (Chautauqua, New York: Chautauqua Institution, 1987) $75-82$. 
$1890{ }^{2}$ Harper retained his position at Chautauqua through 1898 and remained active in the Chautauqua program as a frequent Amphitheater lecturer until his death.

Harper's study of the language of the Bible led him to an appreciation of the various cultures and religious points of view expressed through the voices of the historic authors. Rather than fostering skepticism, he felt critical study of biblical linguistics helps the reader discover the "immutable meaning of God's will" and is a process deserving of lifelong effort. ${ }^{3}$ Only through a commitment of time can the student develop true understanding. Harper argued that the "ideal spirit" of scholarship and the institutions that fostered study should be "caution.", Rather than a static curricular emphasis, all points of view should be welcomed and carefully considered, since "the college world is the most democratic world that exists."

To provide a facility that represented a world of democratic scholarship, Harper asked Henry Ives Cobb (1859-1931), an eminent architect of the time, to design a campus for the University of Chicago patterned after the great universities of England: Oxford and Cambridge (fig. 2.2). ${ }^{6}$ In his selection of the collegiate Gothic style, Harper

${ }^{2}$ On Harper at the University of Chicago see Conrad Cherry, Hurrying Toward Zion: Universities, Divinity Schools, and American Protestantism (Bloomington, Indiana: Indiana University Press, 1995) 113.

${ }^{3}$ Richard J. Storr, Harper's University; The Beginnings: A History of the University of Chicago. (Chicago: U of Chicago P, 1966) 18.

${ }^{4}$ William Rainey Harper, "Some Ideals of University Education," Chautauqua Assembly Herald 7 August 1893: 5.

${ }^{5}$ Quoted in Storr, caption to pictures following 238.

${ }^{6}$ On the development of the University of Chicago campus see Jean F. Block, The Uses of Gothic: Planning and Building the Campus of the University of Chicago, 1892-1932 (Chicago: Univ. Chicago 
demonstrated his awareness of the aesthetic impact of the built environment. He believed that the architectural style of medieval England, the style favored by Arts and Crafts theorist John Ruskin, would foster a collegial democratic society. ${ }^{7}$ The students and faculty would form an intellectual community inspired by a beautiful, self-contained, inward-facing complex. At a ceremony celebrating the laying of a cornerstone for a student building on the campus in 1901, Harper's view was seconded by a close associate who said, "The University takes pride in her laboratories, but she also covets for her students something of the charm of life in the cloisters and quadrangles of Oxford and Cambridge; ... . she would unite in a larger brotherhood all student groups, and foster among them a spirit of wider fraternity.",

Harper also believed that the university should be the center of its community's scholarship. If the university became too removed from its constituency, it risked losing its relevance. His solution was an adult outreach division of the University of Chicago that he called University Extension, patterned after the Chautauqua Literary and Scientific Circle (CLSC). Like Miller and Vincent, Harper believed that lifelong

Library, 1983). Harper worked closely with the University's Trustees' Committee on Buildings and Grounds. The membership included Martin A. Ryerson, Charles L. Hutchinson, and Thomas W. Goodspeed. Block 8.

${ }^{7}$ Storr, caption to pictures following 238.

${ }^{8}$ George E. Vincent. Quoted in Storr, caption to pictures following 238. For the president's house, Harper and Cobb collaborated on an Arts and Crafts composition of roman brick with Bedford limestone accents. The house has deep gables with prominent dormers and overhangs and a broad front porch. Cobb's interpretation of the collegiate Gothic intensified when the school hired Shepley, Rutan \& Coolidge to continue the project. Coolidge preferred a more historically accurate style. Arts and Crafts architecture encompasses "diverse attitudes and contradictions toward style, image, history, the region, the machine, materials, nature, and how life should be lived." Richard Guy Wilson, "American Arts and Crafts Architecture: Radical though dedicated to the Cause Conservative," in Wendy Kaplan, "The Art that is Life": The Arts \& Crafts Movement in America, 1875-1920 (Boston: Bulfinch, 1987) 101-127. 
education would lead to a deeper understanding of the Bible and would yield greater piety.

\section{George Edgar Vincent}

By 1888, Bishop Vincent's son George Edgar Vincent (1864-1941) had begun taking a more active role in Chautauqua's leadership as well (fig. 2.3). George, who had grown up spending his summers at Chautauqua, did his undergraduate work at Yale (1885) and received his doctorate in sociology from the University of Chicago in 1896, with a dissertation entitled The Social Mind and Education. In this early exploration of the function of society, he argues, "In the process of social evolution men's ideas, judgments, and desires have been combined into products which, transmitted from generation to generation, react upon individuals, and are in turn modified by them."9 This sense that we are both influenced by our society and can impact its direction would form the basis of his work in education and his career at Chautauqua and would reinforce the Institution's mission of absorbing and disseminating the critical themes of the time.

In 1888 John Heyl Vincent was elected bishop and, with increasing demands on his schedule, asked George to assist him with the Chautauqua program. George was named Vice Principal of Instruction that year and became Principal in 1898. The Reverend Jessie Hurlbut, an active participant in the program and an early historian of Chautauqua, said of George's influence, "Very soon every department of Chautauqua,

\footnotetext{
${ }^{9}$ George Edgar Vincent, The Social Mind and Education (New York: MacMillan, 1897) vi.
} 
both in its lecture platform and its educational work, felt the touch of a master hand."10 In 1892 he joined Harper at the University of Chicago as a fellow in the department of sociology and became a full professor in 1904. Recognized as a superb administrator, George Vincent was made Dean of the Faculties of the University of Chicago in 1907. That same year he was named President of the Chautauqua Institution, a position he held until 1915. ${ }^{11}$ George left the University of Chicago to become President of the University of Minnesota in 1911, only to be recruited by John Rockefeller to be President of the Rockefeller Foundation from 1917 until his retirement in 1929.

Working closely together during the academic year at Chicago and during the summer at Chautauqua, William Rainey Harper and George E. Vincent endeavored to make both institutions leading centers of learning housed in beautiful built environments. ${ }^{12}$ At the same time the Chautauqua Movement spread well beyond what the novelist and social commentator Sinclair Lewis called "Mother Chautauqua."13 All across the country, by the beginning of the twentieth century, one could participate in the CLSC book club experience and enjoy the periodicals. In each case the participant was encouraged to develop a more sophisticated, educated, and worldly perspective. For many Americans, Chautauqua had become a large, successful, and well-respected

\footnotetext{
${ }^{10}$ Jessie Lyman Hurlbut, D.D., The Story of Chautauqua (New York: G. P. Putnam's Sons, The Knickerbocker Press, 1921) 272-273.

${ }^{11}$ See Appendix 1, p. 184 for a chart detailing Chautauqua's Presidents.

${ }^{12}$ The two men became in-laws. Paul Vincent Harper, son of William Rainey Harper, married Isabel Vincent, George Vincent's daughter. Hurlbut 266.

${ }^{13}$ Sinclair Lewis, Main Street (1920; New York: Signet Classic, 1961) 256.
} 
purveyor of higher education. A headline from the monthly magazine The Chautauquan in July 1902 proclaimed the Institution's sense of its own importance: "Chautauqua, the Largest Institution for Higher Education in the World"' (fig. 2.4). ${ }^{14}$

Vincent and Harper's contributions accelerated the shift in Chautauqua's mission; art, music, and knowledge became as important as religion. This shift paralleled an increasing concern on the part of many Christians for ethical social renewal, a movement known as the Social Gospel. ${ }^{15}$ Influenced by theorists like the Baptist minister Walter Rauschenbusch and the economist Richard T. Ely, reformers saw a divine role in social betterment; the liberal Christian belief in God's immanence had blurred the separation of secular and sacred. The Social Gospel preached an application of Christian values beyond the Church to society as a whole. An activist church - a "Civic Church" would lift up the poor and protect the most indigent from the destructive aspects of laissez-faire capitalism. ${ }^{16}$ In 1887, Ely responded to an invitation from Harper to lecture and teach classes at Chautauqua, a relationship that lasted for many years. ${ }^{17}$

14 "Chautauqua: The Largest Institution for Higher Education in the World," Chautauquan Monthly July 1902: 340. The Chautauqua Institution published a monthly magazine from Oct. 1880 to Feb. 1911.

${ }^{15}$ On the Social Gospel see Sydney E. Ahlstrom, A Religious History of the American People (New Haven: Yale University Press, 1972) 785-804. See also Cherry 185-212.

${ }^{16}$ Olivier Zunz, Why the American Century (Chicago: U Chicago P, 1998) 27-28.

${ }^{17}$ In his autobiography, Ely described a seven-year relationship with Chautauqua beginning in 1884. His biographer, Benjamin Rader, corrects the timeline to begin in 1887 and continue to 1894 . Recent research indicates a much longer relationship lasting to at least 1901. Richard T. Ely, Ground Under Our Feet (New York: Macmillan, 1938) 81; Benjamin G. Rader, The Academic Mind and Reform, The Influence of Richard T. Ely in American Life (Lexington, Kentucky: U of Kentucky P, 1966) 64; "Chapel of the Good Shepherd," Chautauqua Assembly Herald, August 2, 1901: 1. 


\section{Richard T. Ely}

Richard Theodore Ely (1854-1943) was born in the small town of Ripley, New York, on the shore of Lake Erie about twenty miles west of Chautauqua (fig. 2.5).

Shortly after his birth, his family moved to a farm on the outskirts of Fredonia, also in Chautauqua County. As harsh in the long winters as it is beautiful in the summer, his family's home, a short commute to the Chautauqua grounds, remained a place of respite throughout his parents' lives. At home he was exposed to both his father's ardent Presbyterian faith and his passion for education. With his parents' encouragement, Ely decided to pursue an academic career, excelling first at the local Fredonia Academy. After one year at Dartmouth College, he transferred to Columbia University, where he received a bachelor's degree in philosophy (1876). While living in New York, he examined his beliefs and decided to move away from the church of his father and join the Protestant Episcopal Church. His biographer, Benjamin Rader, believes he "found the theology and maintenance of the spirit of Christian love more congenial."18 Having won a prestigious fellowship to study abroad, Ely shifted his focus to the study of economics at the University of Heidelberg.

Through the influence of professor Karl Knies at Heidelberg, Ely embraced the approach of the German Historical School of economics. To Knies, economics should not be an abstract science, but rather a means to reform; the formulas economists developed should reflect their ethical beliefs. For the rest of his career, Ely strove to find

\footnotetext{
${ }^{18}$ Rader 6.
} 
a way, through his scientific study, to improve the quality of life. He completed his Doctor of Philosophy summa cum laude in 1879 and after further travel and study in Europe began a long and distinguished career as teacher and author, first at Johns Hopkins (1881-1892), then at the University of Wisconsin (1892-1925), and later at Northwestern University (1925-1933). ${ }^{19}$

While at Chautauqua, Ely taught classes based on his belief in what he termed "Social Solidarity." He wrote his first edition of Outlines, which he titled Introduction to Political Economy (1889), for the Chautauqua Literary and Scientific Circle (CLSC). ${ }^{20}$ Here he expressed the general philosophy and principles that guided his life's work. ${ }^{21}$ His main focus was on the quality of life and just compensation of workers and a concern that the nation's wealth was far too concentrated in the hands of a few. He argued against the evils of child labor, proposing instead provisions for "healthful play" such as playgrounds. He was opposed to the inappropriate labor of women - "under conditions which imperil the family" - and working on Sunday. He despaired of public corruption, and he believed that the workweek should be shortened by allowing a half-day on Saturday. And although he advocated for a larger role for government, he disliked socialism, preferring a Church-based solution to problems. ${ }^{22}$

\footnotetext{
${ }^{19}$ Rader 2-27.
}

${ }^{20}$ Richard T. Ely, An Introduction to Political Economy (New York: Chautauqua Press, 1889). Subsequent editions of Outlines appeared until 1937.

${ }^{21}$ Ely was an active member of the ALCI Advisory Section Council, Civic Church. "Work of the League, General News of Civic Improvement Progress," Home and Flowers September 1902: 22.

${ }^{22}$ Ely, Ground Under Our Feet 88-91. 
Ely clearly enjoyed his connection to Chautauqua. Despite a lifetime of working with undergraduate and graduate students during the academic year at leading institutions, he began the section in his autobiography entitled "I Teach at Chautauqua:" "It was largely through Chautauqua that I was able to exercise my greatest influence."23 He particularly appreciated the Chautauqua audience. He read in their faces a cross-section of American life... Men in their shirt-sleeves, others in their Sunday best, all listened quietly, intently, their upturned faces plainly revealing their emotions. They were often profoundly moved by the discourses they heard, they were always interested. Nowhere else could they, farmers and laborers, get the solid mental food they were being fed so liberally here. ${ }^{24}$

Ely's fondness for Chautauqua was expressed in a contribution to the built environment. In 1901 he helped to raise the funds to create the Chapel of the Good Shepherd, with its small scale and steeply pitched roof. ${ }^{25}$ Built by the Episcopalian community of Chautauqua, the Chapel was designed for intimate gatherings (fig. 1.11).

Ely also appreciated the interaction with the other Chautauqua teachers, lecturers, and administrators. He was particularly close to the Reverend Phillips Brooks (18351893), the well-respected orator from Trinity Church, Boston, and President Charles W.

$$
\begin{aligned}
& { }^{23} \text { Ely } 79 . \\
& { }^{24} \text { Ely } 80 . \\
& { }^{25} \text { "Chapel of the Good Shepherd," } 1 .
\end{aligned}
$$


Eliot (1834-1926) of Harvard. ${ }^{26}$ His years in Chautauqua overlapped with the transition in leadership from Bishop John Heyl Vincent to his son George. Ely had watched George mature into a leader open to new ideas yet guided by the traditions established during Chautauqua's first twenty-five years. He quotes George as believing that "Chautauqua must be kept in close and sympathetic connection with the great currents of national life. It must be a center from which the larger and more significant movements may gain strength and intelligent support," an apt summation of the Institution's double role of taking in and radiating outward the best of the nation's intellectual, social, and artistic ideas. ${ }^{27}$

To George Vincent the most successful individual was one "who seeks the richest realization of himself in order to render the highest service to his fellows. ${ }^{928}$ Reflecting the attitudes of the new leadership, the goal of the Chautauqua program, which had initially been to promote personal redemption, had to a large degree evolved into an effort to promote the improvement of modern life.

With the change in emphasis of the programming came a change in the makeup of the attendees. What had originally been a summer home for religious educators became the destination for people interested in progressive reform. These changes reflected a

\footnotetext{
${ }^{26}$ Ely 80 .

${ }^{27}$ Ely 86.

${ }^{28}$ George E. Vincent, "Community - Lyceum - School: 'Chautauqua as an Educational Center," Chautauqua Assembly Herald 12 July 1902: 3.
} 
new national American spirit. ${ }^{29}$ On Saturday, August 19, 1899, then Governor of New York Theodore Roosevelt delivered a National Army Day speech from the Chautauqua Amphitheater platform in celebration of the veterans of the Spanish American and Civil Wars. The "vast crowds and great enthusiasm" were the largest since President Grant's visit a generation earlier. ${ }^{30}$ In his speech, Roosevelt expressed the confidence of a new, modern, American nation:

The greatest good the war with Spain did, was that beneath the same banner marched the sons of the blue and the gray; the nation is now united in deed as in name.... We are now all Americans. ... [W]e should recognize the good qualities in every man, north or south, high or low, Jew or Gentile, provided only that he is a good American. ${ }^{31}$

The new leaders of Chautauqua were prepared for the Institution to play a national leadership role during the years that followed. ${ }^{32}$ The Chautauqua program would serve as a model of inclusion for the nation to emulate.

The remarkable building campaign undertaken at the turn of the century expressed Chautauqua's confidence and its sense of the significant role it was being called upon to play, and as the architecture of the grounds changed to reflect the evolving

${ }^{29}$ See Zunz.

30 "National Army Day, Governor Roosevelt the Guest of Honor, The Governor's Great Speech," Chautauqua Assembly Herald 19 August 1899: 1.

31 "National Army Day," 1.

${ }^{32}$ Chautauqua was incorporated as an "Institution" by the State of New York in 1902. 
attitudes of Chautauqua's leaders, the increased emphasis on societal improvement brought Chautauquans together with a deeply felt communality of purpose. The grounds, which had been oriented toward personal sanctification for the first twenty-five years of Chautauqua's history, were redesigned to be perceived as a "Model Summer City" — the participants" "spiritual" home in the sense expressed by a modern president of Chautauqua: "There are emblematic anchors in our lives, places that evoke a safe haven, provide comfort, affirm our experience and open our minds. [Chautauqua is] such a place." ${ }^{, 33}$ The building campaign of the early twentieth century created the modern Chautauqua, which generations of participants have indeed come to relate to as a model summer city.

\section{The American League for Civic Improvement}

As the nineteenth century drew to a close, local civic groups throughout the country focused on small-scale improvement projects. Born of efforts begun in the mid 1800s to reclaim an idealized past in small New England towns, the "village improvement" impulse spread west. By the 1890 s local improvement organizations, many associated with women's groups, were active from Pennsylvania to California and from Virginia to Georgia. ${ }^{34}$ Whether landscaping around the local train station or

${ }^{33}$ Christmas card 2003, Tom and Jane Becker.

${ }^{34}$ Jon A. Peterson, The Birth of City Planning in the United States, 1840-1917 (Baltimore: Johns Hopkins UP, 2003) 109. 
planning for new street paving or sidewalks, local organizations were actively pursuing cleanliness, order, and beautification. ${ }^{35}$

The impulse and the efforts of the local improvement organizations resonated with a forward-thinking magazine publisher based in Springfield, Ohio, D. J. Thomas. ${ }^{36}$ Since 1896 Thomas had been publishing a monthly magazine, How to Grow Flowers. His original editorial mission was home beautification through the cultivation and display of flowers. In 1899, Thomas published a series of reports on the activities of the improvement societies, authored by an activist local librarian, Miss Jessie M. Good, that generated an enthusiastic response from the How to Grow Flowers readership. With the November 1900 edition of his magazine, Thomas fully embraced the mission of popularizing the activities of the improvement groups, changing the name to Home and Flowers, An Illustrated Monthly Magazine Devoted to the Home Beautiful (fig. 2.6) in recognition of the shift in the editorial mission:

The notable movement for public beauty of the present is largely due to the efforts of our publication in behalf of a deeper interest in outdoor art. The influence of this work has been felt in every section of the country, and as a direct result dozens of improvement societies have been formed.

\footnotetext{
${ }^{35}$ Peterson 109. See also E. G. Routzahn, "The American League for Civic Improvement," Chautauquan Monthly July 1902: 501-506.

${ }^{36}$ As the westward terminus of the National Road (Cumberland Road), Springfield was at the crossroads of American commerce in the later half of the nineteenth century.
} 
There is general recognition of our journal as the organ and exponent of "the wider movement for public beauty.",37

To Thomas, there was a deep connection between public beauty and a beautiful home:

It has come to be generally recognized that in the home lies the hope of civilization. ... The home beautiful is the home attractive, and the home from which radiate power and hope. Let there be cultivated in the homes of a country the love of beauty, and the result will be evidences of art everywhere. .. . Public beauty and civic pride will be found most prevalent in that land where is made manifest in the home life the widest recognition of the mission of art. The love and culture of flowers is the most potent factor in the development of that spirit of beauty which is to redeem mankind and establish true civilization, through the influence of environment. $^{38}$

Each month, in addition to articles about the cultivation of gardens and flowers, the magazine would include a detailed report on the "Work of Civic Improvement" around the country.

The November 1900 edition of Home and Flowers also announced the formation of a new national organization to promote civic improvement. John J. Hoppes, the president of the Springfield Improvement League, and fellow Springfield activists Jessie

\footnotetext{
37 "A Name Appropriate to Our Wider Field," Home and Flowers, Nov. 1900: 8.

38 "A Name Appropriate," 8.
} 
Good and John L. Zimmerman joined Charles Zueblin of the University of Chicago, Frank Chapin Bray of Cleveland, the editor of the influential magazine The Chautauquan, and others for a convention in Springfield on October 10, 1900, sponsored by Thomas and the Home and Flowers magazine. Zueblin was elected chairman of the convention, and an organizing constitution and an executive committee were formed, creating the National League of Improvement Associations. ${ }^{39}$ The executive committee consisted of Zimmerman, president; Edwin L. Shuey, Dayton, Ohio, first vice president; Mrs. Conde Hamlin, St. Paul, Minn., second vice president; E. G. Routzahn, Dayton, Ohio, recording secretary; Thomas, corresponding secretary; Bray, treasurer; and Good, organizer.

As an association formed for the coordination of multiple local groups, the League functioned as a clearinghouse for ideas. The December edition of Home and Flowers included stenographic reports on the speeches given during the October 1900 convention. The address of Frank Chapin Bray summarized the object of the organization: "[In that] better homes must come from [a] bettered environment ... [the League should] put into communication all societies taking part in the work of public and home improvement." Bray went on to say that the "basis of this movement is very much broader than most of us are likely to realize... . The movement for public beauty comprehends architecture and sculpture, the various branches of agriculture, horticulture

${ }^{39}$ The first name given to the organization was The National League of Improvement Clubs, but by the next month the organization was titled The National League of Improvement Associations. See "The National League of Improvement Clubs," Home and Flowers, Nov. 1900: 9 and "A Notable Event in American Progress," Home and Flowers, Dec. 1900: 8. 
and floriculture, and sanitation." He gives a long list of "new terms" that represent the various activities brought together under the umbrella of the new League. These include:

Park and outdoor art association

League for social service

Landscape and Cottage gardening

Table decoration and Bouquet making

The good roads movement

Improved railway stations

Model factory homes

The betterment of factory conditions

In all of these fields he recommends an "experimental method" of scientific process. All of the work of the improvement associations should be pursued and then studied as to its effectiveness. The task of the League was to encourage and disseminate accounts of the activities and their results. ${ }^{40}$

As editor of the Chautauquan, the widely read organ of the Chautauqua Literary and Scientific Circle (CLSC), Frank Chapin Bray was in a position to add the influence of Chautauqua to efforts to promote the League. Born in 1866 in Salineville, Ohio, Bray worked as a printer and editor while in school at Wesleyan University. After graduation in 1890, he became the city editor of the Herald, the local Middletown, Connecticut, newspaper. Bray subsequently worked his way through a series of newspaper and journal

40 "Address of Frank Chapin Bray Before Improvement Convention, Springfield, O., October 10," Home and Flowers, Dec. 1900: 9. For a complete list of the "new terms" see Appendix 2, p. 185. 
positions as editor before joining the Chautauquan in 1899 . He remained editor until the merger of the Chautauquan with the Independent in 1914. In 1906 he added the position of managing editor of the Chautauqua Press, which published the study courses of the CLSC. ${ }^{41}$ Like Home and Flowers magazine, the Chautauquan became an important advocate for the League.

The next year the League held its annual convention during the summer at the Pan American Exposition in Buffalo, just north of Chautauqua. As reported in the September 1901 Home and Flowers, the meeting was well attended and was significant for the shift in leadership from Zimmerman to Charles Zueblin. The Tuesday morning session served as a recap of the previous year's activities. Affiliated associations were asked to give brief reports addressing the topic "What We Have Done and How We Did It." That evening Charles Zueblin gave an illustrated lecture entitled "The Renascence [sic] of Civic Beauty." Clearly impressed by the talk, a reviewer described it as "one of his inimitable lectures, illustrated by beautiful stereopticon views., 43

The convention also included work sessions; new committees were announced to effect changes in the constitution and by-laws and to consider nominations and the location of the League's headquarters. The organizing committee included the familiar names of Thomas, Shuey, Bray, and Zueblin, and added Albert Kelsey, an architect from

41 "Bray, Frank Chapin, American editor and educator," Encyclopedia Americana (New York: J.D. Lyon Co., 1918) 423.

42 "Successful Civic Beauty Rally, Annual Convention of American Improvement League," Home and Flowers, September 1901: 8.

43 "Successful Civic Beauty Rally," 8. 
Philadelphia, the "chairman of the committee of experts of the Art Federation of Philadelphia, and president of the Architectural League of America." Kelsey was the featured speaker the following evening. The title of his well-received illustrated lecture was "The City of the Future." 44

The committee on changes in constitution and by-Laws proposed that the name of the organization become the "American League for Civic Improvement." As Zueblin explained:

This federation is now to include not only local improvement societies and individuals working for this goal, but commercial membership in recognition of the value of co-operation with the great economic agencies which of necessity contribute to material advance. The new name, American League for Civic Improvement, expresses obviously a larger idea, not only organizations in union, but individuals and firms as well, and the continent rather than the United States as our "parish."45

They further recommended that the mission statement read, "Its object shall be to bring into communication for acquaintance and mutual helpfulness all organizations, firms and individuals interested in the promotion of outdoor art, public beauty, town, village and neighborhood improvement." In addition, they clarified the role of the officers and established annual dues of $\$ 2.00$ for individual members and $\$ 10.00$ ("or

44 "Successful Civic Beauty Rally," 10.

45 "Plans for the Future: Inaugural Address of President Charles Zueblin. The Twentieth Century City, A Record of Work Accomplished for Civic Betterment, The American League for Civic Improvement." The Home Florist, Oct 1901: 65. 
such larger sum as each may elect") for commercial members. These changes were adopted unanimously. On the motion of the committee on nominations, a new board was elected that included Albert Kelsey. ${ }^{46}$

By September 1902 the League was organized into fourteen advisory council "sections." Each section brought together people who were well known in their area; as previously noted, many were connected to Chautauqua, for example: Henry Turner Bailey (Arts and Crafts), Albert Kelsey (Municipal Art), Richard T. Ely (Civic Church), and Jane Addams (Social Settlements). ${ }^{47}$ To the civic improvement reformers, all of these areas of interest had to function together to affect society; it was the purpose and goal of the League to facilitate the coordination of that effort. The League was to have a lasting effect on the built environment as well as the programming of Chautauqua.

\section{Charles Zueblin}

As the new president of the League, the aesthetic activist Charles Zueblin played an increasingly influential role (fig. 2.7). Zueblin's career in Chicago began when the new president of the University of Chicago, William R. Harper, turned to his former student at Yale to be the first secretary of the university's extension division. Zueblin (1866-1924) was born in Pendleton, Indiana, and did undergraduate work at both the University of Pennsylvania and Northwestern University, as well as graduate work in the ministry at Yale. He pursued Old Testament studies at Leipzig until January 1891, when he decided to focus on political and social science. He moved to Chicago and became

\footnotetext{
46 "Successful Civic Beauty Rally," 9.

47 "Work of the League," 22. See also Routzahn, 501-506.
} 
one of the earliest residents of Hull House. Zueblin was hired by Harper and became full professor of sociology in 1902, a position he held until his "resignation" (dismissal) in 1908. ${ }^{48}$ In addition to being a co-founder of the American League for Civic Improvement, he co-founded the Northwestern University Settlement House with his wife, Rho Fisk Zueblin, in 1892 (fig. 2.8). Their energies were directed to many of the "sections" of the League. Zueblin (with Rho) was also a founding member of the Chicago Arts and Crafts Society. He was a popular lecturer and wrote extensively on urban reform and city planning. Rho Fisk Zueblin was the author of an important series on the Arts and Crafts Movement published in the Chautauquan.

Throughout his long career, Zueblin connected aesthetic improvement beautification - with social improvement. For example, the Northwestern University Settlement sponsored a wide range of aesthetic facilities and activities, including a picture library; classes in sewing, embroidery, dressmaking, and elocution; a music school with lessons in voice, piano, violin, chorus, and band; and dancing. The Settlement also housed many organizations, including clubs with literary and musical interests, such the Paderewski Singing Society. ${ }^{49}$

Zueblin was aware of the inherent tension between well-meaning reformers and those to be "reformed." Rather than emphasizing the power of experts to "fix" society,

${ }^{48}$ Zueblin, like William Morris before him, became increasingly critical of the concentration of wealth during his era. See "Wealth, First of Professor Zueblin's Lectures on Contemporary Society, The Definition of Wealth - The Land Question - The Possession of Natural Resources - Taxation Monopolies - Distribution." The Chautauqua Assembly Herald 15 July 1903: 2-3. His overt criticism of some of the benefactors of the University of Chicago led to his dismissal.

${ }^{49}$ Robert A. Woods and Albert J. Kennedy, Handbook of Settlements (New York: Charities Publiation Committee, 1911) 66-67. 
he believed in participatory reform, favoring an educated public who could play an active role in social reform. In an early sociological study of the Jewish Ghetto of Chicago, Zueblin, while decrying the overcrowded tenement living conditions, documented a vibrant community engaged in aesthetic activities. He admired the music and theatrical activities of the Jewish community. About Metropolitan Hall, the "dramatic and operatic centre of the Ghetto," he said:

To one who looks below the surface, however, there is almost unalloyed delight in the pure, simple amusements of these people. . . As it is, the presence of this theatre is a most hopeful social and educational sign. ${ }^{50}$ He was also sympathetic to efforts to provide community-wide education, including a Jewish-run settlement house, a privately endowed manual training school, and numerous independent literary societies. For Zueblin, the goal of reform was an educated society living in, and inspired by, a beautiful built environment. He believed that "the ideals of a people soon find expression in their architecture," and "according to tradition and prophecy, life began in a garden and is to end in a heavenly city. . . We should be paving our way toward such a result." 51

The board of the American League for Civic Improvement (ALCI) held its annual convention from August $12^{\text {th }}$ to $15^{\text {th }}$ at the Pan American Exposition (May $1-$ November 2, 1901) in Buffalo, New York. The Exposition was a glorious celebration of modernity;

\footnotetext{
${ }^{50}$ Charles Zueblin, "The Chicago Ghetto," Jane Addams, Hull-House, Maps and Papers (New York: Crowell, 1895) 101-103.

${ }^{51}$ Charles Zueblin, American Municipal Progress (New York: Macmillan, 1902) 274-275.
} 
the exterior of the exposition buildings were lavishly lit with thousands of light bulbs. Unfortunately, the exposition is best remembered as the setting for the assassination of President McKinley on August 6. But speaking the day before, McKinley summarized the excitement of the event:

Expositions are the timekeepers of progress. They record the world's advancements. They stimulate the energy, enterprise, and intellect of the people, and quicken human genius. They go into the home. They broaden and brighten the daily life of the people. They open mighty storehouses of information to the student ... ${ }^{52}$

On the last day of the convention of the ALCI in Buffalo, members of the League board traveled seventy miles south to lecture to the Chautauqua attendees. On Thursday, August 15, Zueblin gave a 4:00 p.m. address, and first vice president Shuey spoke in the Hall in the evening. The title of Zueblin's talk was "Public Beauty." A captivating speaker, he connected civic pride to personal pride, explaining that just as we take care of our clothes and personal appearance, so too should we endeavor to make our surrounding environment attractive. He related his sense of the beautiful to the natural. "Public beauty is possible in two directions, in a return to nature so far as that is practicable, and in making more true and more fully adapted to nature the works of man." He expressed the notion that the beautifying of our communities should focus on landscaping our streets and yards and, wherever possible, on establishing public parks within "convenient

\footnotetext{
${ }^{52}$ Paul Finkelman and James Percoco, Milestone Documents of American Leaders (Dallas: Schlager Group, 2009).
} 
reach" of the public. He mentioned with admiration the park system of Boston, the "Emerald Necklace" (1878) designed by Frederick Law Olmsted. In addition to landscaping, Zueblin's talk focused on schools — both the beautification of buildings and playgrounds and the inclusion of aesthetic considerations in the curriculum. He concluded by tracing the connection of the CLSC reading groups organized by Bishop Vincent to the civic action organizations promoted by Zueblin's League and to the good work of the extension division of the University of Chicago, an early indication of the web of relationships underpinning the overlapping movements and aesthetic impulses of the time. ${ }^{53}$

\section{Edwin L. Shuey}

In the evening, the vice president of the League, Edwin L. Shuey, gave an illustrated lecture entitled "Practical Efforts for Home Improvement." In his introduction he highlighted the main themes of the Civic Improvement movement. "The influence of comfort and beauty on the character and contentment of the nation is great," he said, arguing that without the positive effects of beauty, "we are in great danger." $\mathrm{He}$ emphasized that American workers had become so disenfranchised by the deplorable conditions of contemporary industrial life that both productivity and quality of product had suffered. "We must educate every one of them in those things which go to make up everyday business life, and the comforts that may be had for the doing. When this is done we shall have gone a long way in solving great problems that trouble us." He was

53 "Improvement Day, Meeting of the American League of Civic Improvement at Chautauqua Thursday" Chautauqua Assembly Herald 16 Aug. 1901:1, 5. 
proud of the fact that although much of the earliest work of the movement was done by voluntary neighborhood organizations, the cause of beautification had begun to be taken up by corporations. Shuey focused his talk on positive changes occurring in his hometown, Dayton, Ohio. ${ }^{54}$

Edwin Longstreet Shuey was born January 3, 1857, in Cincinnati, Ohio (fig. 2.9). Two years later his family moved to Dayton, where he attended public school and became an honor student. He received an undergraduate degree with honors from Otterbein University in 1877 and was awarded a Masters of Arts in 1880. The next year he received a Law degree and became a teacher, first at Green Hill Seminary in Indiana and Fostoria Academy in Ohio, and then at Otterbein. In 1885 he began a twelve-year period as the head of the book department of the United Brethren Publishing House in Dayton. His contributions included developing the successful United Brethren Book Store and writing a handbook for the "United Brethren in Christ." He was also the American editor of the teacher's aids that accompanied the new edition of the "International Teacher's Bible.,"55

In 1897 Shuey joined the National Cash Register Co. (NCR) of Dayton as the head of the newly created "Welfare Work" department. Before the advent of the modern cash register, business receipts were hand calculated with varying degrees of accuracy. A properly working cash register provided accurate calculations at the end of the day and

54 "Improvement Day," 1, 5.

${ }^{55}$ Dennis Boeshore Shuey, History of the Shuey Family in America, From 1732 to 1919 (Galion. Ohio: Published for the members of the Shuey Family, By the Author, 1919) 178-179. 
decreased employee theft as well. A Dayton entrepreneur, John Henry Patterson (18441922), had the foresight to develop, patent, and promote the modern cash register, which became an enormously successful enterprise. ${ }^{56}$

Patterson's NCR was one of the companies that pioneered improved conditions for workers in the United States at the turn of the century. "Welfare Work," as it was called, was a wide-ranging concept that incorporated many activities of the League for Civic Improvement and included both the physical comfort of the employees and forward-thinking personnel practices. ${ }^{57}$ A contemporary author, Mary Lathrop Goss, defined it as

1) Special consideration for physical health, safety, and comfort wherever labor is performed. 2) Opportunity for recreation. 3) Educational advantages. 4) Provision of suitable sanitary homes. 5) Provident funds, insurance, pensions, savings, loans, etc. ${ }^{58}$

As practiced at the National Cash Register Co., the improvements to the workplace included remarkably complete programs of employee meals, health care, profit-sharing,

${ }^{56}$ On John H. Patterson and the history of the National Cash Register Co. see Samuel Crowther, John H. Patterson, Pioneer in Industrial Welfare (New York: Doubleday, Page \& Co., 1923); Judith Sealander, Grand Plans, Business Progressivism and Social Change in Ohio's Miami Valley, 1890-1929 (Lexington, Kentucky, UP of Kentucky, 1988).

${ }^{57}$ For more on the use of the term "Welfare Work" at the turn of the century see E. Wake Cook, Betterment; Individual, Social, and Industrial, or Highest Efficiency Through the Golden Rules of Right Nutrition; Welfare Work; and the Higher Industrial Developments (New York: Frederick A. Stokes, 1906).

${ }^{58}$ Mary Lathrop Goss, Welfare Work by Corporations (Phil: American Baptist Publication Society, 1911) 14-15. 
libraries, education, and recreation and expanded beyond the workplace to include beautification of housing, gardens, and parks. ${ }^{59}$

The centerpiece was a newly designed factory with an abundance of natural light. Patterson was proud of having pushed his architect, Frank Mills Andrews (1867-1948), to design a masonry-sheathed steel frame building, eighty percent of which was windows (fig. 2.10). ${ }^{60}$ For the comfort of the employees all of the windows were operable; when they were sealed for the winter, a sophisticated ventilation system replaced the air in each room with fresh, heated air every fifteen minutes. The interior walls were painted soothing colors rather than with the typical stark whitewash, and the interior decoration, which included plants, was designed to be calming and comforting. To make the area more beautiful and to serve as an inspiration to the residential neighborhood, Patterson asked John Charles Olmsted (1852-1920), the nephew and adopted son of Frederick Law Olmsted, to landscape the grounds of the factory (fig. 2.11).

Patterson also emphasized personal hygiene, and at a time when few people had indoor plumbing the factory provided baths, showers, restrooms, and lavatories, as well as break rooms for both males and females. ${ }^{61}$ In addition NCR instituted employersponsored meals that were subsidized by the company, as well as shorter workdays. At a

\footnotetext{
${ }^{59}$ Sealander 20.

${ }^{60}$ The New York-based Andrews had a very successful career. He was the architect for the State Capitols of Kentucky and Montana as well as numerous hotels and factories in New York, Washington D.C., and New Haven. He was awarded a medal from the Royal Society of Arts, London, in 1911. "F.M. Andrews Dies; A Noted Architect, Designer of the Hotel McAlpin and Other Large Structures Won British Award," obituary New York Times 3 September 1948.

${ }^{61}$ Sealander 22. The descriptions of Patterson uniformly describe him as a health fanatic. He is said to have bathed five times a day.
} 
time when the twelve-hour workday was commonplace, NCR employees were expected to work nine and a half hours but were compensated for ten. Patterson's concept of improvement extended beyond the physical wellbeing of his employees to include their educational development. For men, the company offered classes, including English composition and salesmanship, and numerous apprenticeship programs in trades such as carpentry and window glazing. The women workers had a similarly wide list of choices that included the study of languages, nursing, and stenography, as well as cooking, sewing, and embroidery. ${ }^{62}$

The goal of the improved working conditions was not purely beneficent; it was, rather, increased worker involvement and pride in achieving higher productivity and finished goods of better quality. The founder and CEO of NCR, John Patterson, was fond of relating the story that in 1894 over fifty thousand dollars worth of machines that had been sold in England were returned as defective. Patterson believed that NCR workers had sabotaged the shipment. He came to the conclusion that his company's success was linked to the success and happiness of his employees. The slogan the company adopted and proudly displayed on colorful banners throughout the factory was "It Pays."

Shuey described his years developing the Welfare Work concept in Factory People and Their Employers, How Their Relations Are Made Pleasant and Profitable, A Handbook of Practical Methods and the Relations of Employer and Employe[e],

\footnotetext{
${ }^{62}$ Sealander 23.

${ }^{63}$ Sealander 29,194.
} 
published in $1900 .^{64}$ In his introduction, he developed the same themes he would express in his Chautauqua lecture a year later:

the first essential of successful manufacturing is ability in employer and employe $[\mathrm{e}]$ in office and factory. ... But when united with this ability are to be found recognition of one another's rights, sympathy with one's fellows and the human touch which has characterized the makers of the best in the world's history, thus is developed the real strength of society and the truest form of successful manufacturing. ${ }^{65}$

To Shuey, success combined morality and profitability.

The aim here is to show that .. . unfavorable surroundings are not only evil, but unbusiness-like; not only unnecessary, but bad policy; and that fair treatment and generous recognition of manhood and womanhood not only are morally right but also are financially wise and prudent. ${ }^{66}$

The dynamic presenters of the ALCI board found a receptive audience at Chautauqua. Their message of Civic Improvement - of beautification of home and community and improved conditions in the work place — resonated powerfully with listeners who had chosen a vacation focused on social service. And the second

${ }^{64}$ Edwin L. Shuey, Factory People and Their Employers, How Their Relations Are Made Pleasant and Profitable, A Handbook of Practical Methods and the Relations of Employer and Employe[e] (New York: Lentilhon, 1900).

${ }^{65}$ Shuey $11-12$

${ }^{66}$ Shuey 13. Although primarily focused on the National Cash Register Co., Shuey's book provides a comprehensive look at the improvement activities of many other companies. He mentions similar activities at ninety-one different employers (213-215). 
generation of Chautauqua's leaders was inching toward a decision to formalize its position as a place of instruction and inspiration by creating a Model Summer City. 


\section{Chapter 3}

\section{Public Beauty: Chautauqua Embraces the Ideals of Civic Improvement}

The presentations to Chautauqua by the visiting board members of the American League for Civic Improvement during the summer season of 1901 were very well received, and by the next year Chautauqua had fully embraced the ideals of Civic Improvement. On July 5, 1902, League member Frank Chapin Bray, also the editor of the well-respected monthly, the Chautauquan, announced a reorganization of his editorial board reflecting the integration of ALCI leaders with Chautauqua. The new board members included such familiar names as George E. Vincent; Jane Addams of Hull House; Charles Zueblin; Edwin L. Shuey; Jessie M. Good of Springfield, Ohio, librarian of the Warden Free Library; and D.J. Thomas, president and manager of the Floral Publishing Company and publisher of Home and Flowers, also of Springfield, Ohio. ${ }^{1}$

Bray also reported that many subjects important to the League reflected in the organization of the Advisory Council Sections would be explored in upcoming issues: "Parks, Municipal Art, Libraries, Museums, Social Settlements, Municipal Reform, Public Recreation, School Extension, Civic Church, Public Nuisances, Preservation of Nature, Sanitation, [and] Village Improvement."2

1 "The Chautauquan, An Outline of Features Which will be Presented During the Coming Year," The Chautauqua Assembly Herald 5 July 1902: 4.

2 "The Chautauquan, An Outline of Features," 4. 
To further integrate the Chautauqua program with the goals of the ALCI, the League and Chautauqua jointly sponsored a week on Public Beauty (August 18-25, 1902) on the Chautauqua grounds. The week included both afternoon and evening presentations by luminaries in the improvement movement. Albert Kelsey, the past president of the Architectural League of America, spoke on Tuesday evening at 8:00 on "The Municipal Art and Science Exhibit at the St. Louis World's Fair" then being planned. Charles Zueblin of the American League for Civic Improvement presented twice: Wednesday at 4:00 in the afternoon on "Education and Democracy" and Thursday evening at 8:00 on "Washington Old and New," about the new plans for the U.S. capitol. ${ }^{3}$

\section{Anna Pennybacker}

The first speaker of the week was Anna Pennybacker, the president of the Texas Federation of Women's Clubs. In her talk, Pennybacker related the three major areas of improvement activities federation members had pursued during the previous few years, all of which concerned beautification through education. First, they had arranged to expand the library system in the state from six to sixty libraries. They had also arranged for an art gallery to travel throughout the state visiting schools and small towns. And

${ }^{3}$ "Public Beauty Week, First Conference - 'Woman's Work for Civic Betterment' - Program for the Week," Chautauqua Assembly Herald 19 August 1902: 4. The following summer the ALCI held its annual convention during a conference on "Beauty" at Chautauqua, July 14-17, 1903. J. Horace McFarland (1849-1958) of Harrisburg, PA was elected president. "The American League for Civic Improvement," Chautauqua Assembly Herald 15 July 1903: 1. 
lastly, they had successfully lobbied the state to provide the funding for women's buildings to be constructed at the state college in Denton, Texas. ${ }^{4}$

Anna J. Hardwicke (Mrs. Percival V.) Pennybacker (1861-1938) was an educator, author, woman suffrage advocate, reformer, and clubwoman (fig. 3.1). She was born in Petersburg, Virginia, graduated from high school in Leavenworth, Kansas, in 1878, and moved with her family to Texas later that year. The following year, on a scholarship, she attended the Sam Houston Normal Institute, the first normal school in the Southwest, in Huntsville, Texas. While in school in Huntsville, she met her future husband, Percival V. Pennybacker; they were married in 1884. With her husband's encouragement, Pennybacker wrote $A$ New History of Texas (1888), which was adopted by the state of Texas as its primary history textbook for the next forty years. Until his death in 1899 , Percival published and marketed the textbook and collaborated with Anna in developing fledgling school systems in rural Texas. After her husband's death, Pennybacker and her three children settled permanently in Austin, near the University of Texas, and began a life-long pattern of spending summers in Chautauqua. ${ }^{5}$

Pennybacker's connection to the women's club movement began in 1882 and 1883, before her marriage, while she was living with her family in Carthage, Missouri. It was here that she joined a Chautauqua Literary and Scientific Circle (CLSC) reading group. During her years of study intended for self-improvement, the group discussed

4 "Public Beauty Week, First Conference," 4. For more on Anna Pennybacker see: Kelley M. King, Call Her a Citizen, Progressive-Era Activist and Educator Anna Pennybacker (College Station, TX: Texas A\&M UP, 2010).

\footnotetext{
${ }^{5}$ King xi-xii; Helen Knox, Mrs. Percy V. Pennybacker, An Appreciation (New York: Fleming H. Revell Co., 1916) 98.
} 
topics including English and Greek history, literature, astronomy, psychology, and the Bible. ${ }^{6}$ Struck by the concatenation of organizations, Hurlbut has suggested that the CLSC reading circles focused on self-improvement evolved into women's groups whose platform was civic improvement.

It is the opinion of the writer that if one could ascertain the history of the woman's clubs that now cover the country, and ascertain their origin, it would be found that nearly all of the older woman's clubs arose out of Chautauqua Circles whose members, after completing the prescribed course, took up civics or politics, or literature. It would be an interesting study, to ascertain how far the general federation of Women's Clubs of America was an outgrowth of the Chautauqua movement. ${ }^{7}$

Pennybacker clearly enjoyed the sense of common purpose and comradeship the Carthage club provided; for the rest of her life she was involved with women's clubs. She went on to found a CLSC reading circle while living in Tyler, Texas, in 1886 and was instrumental in the establishment of a permanent chautauqua and CLSC program in Boulder, Colorado, in $1898 .^{8}$ Her involvement with club life continued to expand, and she eventually became the president of the Texas Federation of Women's Clubs (1901-

\footnotetext{
${ }^{6}$ King 25-26.

${ }^{7}$ Jesse Lyman Hurlbut, The Story of Chautauqua (New York: G. P. Putnam's Sons, 1921) 158-
} 159.

${ }^{8}$ King 45, 66. During the last quarter of the nineteenth century, over one hundred and fifty permanent chautauquas began around the country. For more on the Colorado Chautauqua see Mary Galey, The Grand Assembly, The Story of Life at the Colorado Chautauqua, Centennial Edition (Sun City, CA: Winlock Publishing, 1981, 1998). 
1903). Pennybacker later held the position of president of the national organization of women's clubs, the General Federation of Women's Clubs, from 1912 to $1916 .^{9}$ The summer she stepped down from the national organization, she assumed the leadership of the Chautauqua Women's Club, a position she held until $1937 . .^{10}$

The development of many of the Texas libraries Pennybacker described in her Chautauqua address followed a similar pattern. A local group of civic-minded women organized as a club and established a small library, often in a borrowed space, perhaps above a local storefront. Over time, as usage and support increased, the women petitioned Andrew Carnegie for a grant to build a new stand-alone building. The resulting edifice — typically a classically inspired temple of learning — was frequently the most imposing building in town. ${ }^{11}$ The Carnegie Public Library of Bryan (1902), in southeast Texas, for example, began when the Mutual Improvement Club, "composed of twenty enthusiastic women," sent an appeal to Carnegie. Following the usual prescribed arrangement, Carnegie donated ten thousand dollars on condition that the city agree to set aside a thousand dollars (ten percent of Carnegie's contribution) annually for operation

\footnotetext{
${ }^{9}$ King 75-87, 95-126.
}

${ }^{10}$ King 127-128. See also Janet Myers Northrup \& The Chautauqua Women's Club, Founding Women: Inspiration and Impact on Chautauqua and the Nation (Rochester, NY: Mountain Air Books, 2009) 35, 41-47. Pennybacker's influence at Chautauqua after 1916 was enormous. She served as an Institution trustee from 1916-1938, introduced many important women speakers including Eleanor Roosevelt, and raised the funds necessary to "save" the Institution from bankruptcy during the Depression.

${ }^{11}$ On the Texas libraries associated with the Texas Federation of Women's Clubs, including nonCarnegie facilities, see Texas State Library Association, Handbook of Texas Libraries (Austin, Texas:

Texas State Library Association, 1904) 62. 
and maintenance. ${ }^{12}$ A Texas Agricultural and Mechanical College professor, Fred R. Gieseckie, designed the Bryan library, a two-story red brick building in a Greek cross plan with a temple portico and four Corinthian columns (fig. 3.2). The ground floor contained an entrance hall, reading rooms, stacks for books, offices, and toilets. The upper floor functioned as a meeting and gathering space for the women's club, with a central hall and clubrooms. ${ }^{13}$

In her talk Pennybacker also described the Traveling Art Gallery. It consisted of reproductions of classic art judged by the women of the federation to be beautiful, instructive, and uplifting. An example from the Italian Renaissance was the Sistine Madonna (1513-1514), one of Raphael's last canvases, painted for the high altar of San Sisto in Piacenza, Italy (fig. 3.3). ${ }^{14}$ The canvas is a large (104 in. $x 77$ in.) triangular group scene of six figures with a wonderful sense of circular movement that initiates in the image of Saint Sixtus, who is looking up towards the Christ Child and Mary, and continues through the billowing of Mary's cloak to the image of Saint Barbara, whose gaze in turn directs the viewer down to two cherubs at the base of the canvas.

${ }^{12}$ Handbook 18-19. On the Carnegie Libraries see Abibail A. Van Slyck, Free to All: Carnegie Libraries \& American Culture, 1890-1920 (Chicago: U Chicago P, 1995); George S. Bobinski, Carnegie Libraries: Their History and Impact on American Public Library Development (Chicago: ALA, 1969); Robert E. Lee, "Texas Library Development: Its Relation to the Carnegie Movement, 1898-1915" (MA Thesis, UT Austin, 1959). History.

${ }^{13}$ Handbook 18-19. "Bryan's Carnegie Library," brochure. Carnegie Center of Brazos Valley

${ }^{14}$ The painting was moved to Dresden, Germany in 1754 . It was well known as part of the Neues Konigliches Museum collection at the turn of the twentieth century. Rebecca Richmond, $A$ Woman of Texas, Mrs. Percy V. Pennybacker (San Antonio, Texas: Naylor Co., 1941) 90. 
Although there is a puzzling sense of trepidation in the faces of the Christ Child and Mary, at the turn of the century the painting was viewed as an ideal expression of beauty. In his book How To Judge of a Picture (1889), published by the Chautauqua Press as a CLSC selection, the critic and author John C. Van Dyke describes the Sistine Madonna as "sublime," and he underscores the impact of the painting by ascribing high moral standing to Raphael, whose character, he writes, "was as beautiful and fair as his Sistine Madonna."15

The traveling gallery and Raphael's painting in particular had a powerful effect and were well received. In her biography of Pennybacker, Chautauqua author Rebecca Richmond relates the story of an awestruck child:

A certain small boy is remembered who stood for some moments before the copy of the Sistine Madonna. Asked what he thought it meant, he said he didn't know, but that it kind of made him feel as though he hadn't loved his mother enough. ${ }^{16}$

Richmond's conclusion to the boy's story sweetly summarizes the motivation of the activities of the federation: "The women, now and again, were not without reward."17

Pennybacker and the Federation also focused their attention on education for women in the state. Their successful petitioning of the state legislature led to the

${ }^{15}$ John C. Van Dyke, How to Judge of a Picture, Familiar Talks in the Gallery With Uncritical Lovers of Art (New York: Chautauqua Press, 1889) 137, 150.

\footnotetext{
${ }^{16}$ Richmond 90.

${ }^{17}$ Richmond 90.
} 
construction of a new central building in Denton, Texas, as a home for the Girl's Industrial School (1902) (fig. 3.4). ${ }^{18}$ The new building contained all the functions of a small college: dorm rooms, classrooms, a dining hall, a library, and administrative offices. As designed by Dodson and Scott of San Antonio, the form of the building recalls the iconic Massachusetts State House by Charles Bullfinch (1798): a classical temple portico over an arcade, surmounted by a dome. For the women's college building, the composition is pared down — there are only six Corinthian columns, and the dome is much smaller. ${ }^{19}$ When the first woman graduated in 1904, the Federation's goal of preparing a new class of women equipped with both a liberal education and the skills to be successful in the modern industrial age began to be realized.

During her summers in Chautauqua, Pennybacker developed a close working relationship with George Vincent. On the occasion of her stepping down from the presidency of the General Federation of Women's Clubs, Vincent wrote the following tribute:

To Mrs. Percy V. Pennybacker I extend hearty congratulations. From the days when at Chautauqua she gave unmistakable indications of unusual abilities, I have followed with interest her development into national leadership among women. She combines marked executive capacity with

${ }^{18}$ Stella L. Christian, History of the Texas Federation of Women's Clubs (Houston: Dealy-AdeyElgin Co., 1919) 47. The name of the school changed to College of Industrial Arts in 1905, to Texas State College for Women in 1934, and to Texas Woman's University in 1957.

${ }^{19}$ Jay C. Henry, Architecture in Texas, 1895-1945 (Austin: U Texas P, 1993) 97-98. 
well-poised judgment, unquenchable enthusiasm and singular persuasive power. $^{20}$

\section{Jane Addams}

\section{Ellen Gates Starr}

Vincent was very conscious of what he described as Chautauqua's "concentric circles of educational influence." From his vantage point at their hub, he wanted the program to reflect his belief in the "Chautauqua ideal of individual obligation to the whole." 21 For that reason, Vincent arranged for the Chautauqua program during that same summer of 1902 to reflect social themes in addition to Public Beauty, among them the development of the Settlement House and the Arts and Crafts Movement. The keynote speaker during Settlement Week was the sociologist Jane Addams (1860-1935) of the Chicago-based settlement Hull House. Addams and Ellen Gates Starr (1859-1940) had created Hull House in January 1895, inspired by their visit to Toynbee Hall, a settlement house founded by Canon Barnett in 1885 in south London. Their goal was to influence positively, through educational initiatives that included handicrafts, the neighborhood immediately surrounding their depressed South Side location at 335 South Halsted Street. In discussing the London project, Addams said that she was impressed by the "primal ideal that a group of University men should reside in the poorer quarter of

\footnotetext{
${ }^{20}$ Knox 166.

${ }^{21}$ George E. Vincent, "Community - Lyceum - School: 'Chautauqua as an Educational Center," Chautauqua Assembly Herald 12 July 1902: 3.
} 
London for the sake of influencing the people there toward better local government and a wider social and intellectual life.,22

Starr in particular was very enamored of the Arts and Crafts ideal. She believed that the soul of modern man in the industrial age was in "a state of siege. He is fighting for his life."23 In describing the work of Hull House, she quoted William Morris: "To each man is due the solace of art in his labor, and the opportunity of expressing his thoughts to his fellows through that labor."24 To this end she organized a bookbinding operation, as well as a museum to showcase and encourage the creative talents of the artisans of her neighborhood. Despite the difficulty of the struggle, Starr believed in the power of beauty to effect change:

And when one sees how almost miraculously the young mind often responds to what is beautiful in its environment, and rejects what is ugly, it renews courage to set the leaven of the beautiful in the midst of the ugly, instead of waiting for the ugly to be first cleared away. ${ }^{25}$

Hull House became the center of Arts and Crafts activity in Chicago. In 1897, Charles and Rho Fisk Zueblin and artists, teachers, business leaders, and sympathetic

22 Jane Addams, Hull-Hoüse, Maps and Papers (New York: Crowell, 1895) vii. Hull House became the model for many settlement projects. See Robert A. Woods and Albert J. Kennedy, eds. Handbook of Settlements (New York: Arno P, 1970). On Addams see Louise W. Knight, Citizen: Jane Addams and the Struggle for Democracy (Chicago: U Chicago P, 2005). See also Daphne Spain, How Women Saved the City (Minneapolis: U Minnesota P, 2001).

${ }^{23}$ Addams 178.

${ }^{24}$ Addams 167.

${ }^{25}$ Addams 165. 
members of the social elite joined Starr and Addams in founding the Chicago Society of Arts and Crafts (CSAC), based on the classes and programs at the House. The society's first president was George Mortimer Rendel Twose (d. 1924), an Englishman who taught woodworking at the Chicago Manual School and at the Hull House shops. The secretary was Ellen Waite, a wealthy socialite who had become a social worker. Other charter members were the architects Frank Lloyd Wright (1867-1959) and Allen (1858-1929) and Irving K. Pond (1857-1939). The Pond brothers designed the first addition to the Hull House complex, an art gallery in a Ruskinian Gothic style. ${ }^{26}$

The Chicago Society of Arts and Crafts constitution expressed the desire of its founders to make significant social changes through the belief in beauty. Arts and Crafts thought was the basis of a program of civic improvement, industrial reorganization through an emphasis on handcrafted manufacture, and social betterment through continuing education. ${ }^{27}$ The society members believed that by relieving the tedium of life in the factory, the incorporation of art into everyday activity would improve working conditions. Through activities such as those sponsored by Hull House, an engaged, educated, emergent middle class would foster a participatory democracy. The members also argued that improved, well-designed facilities would inspire and nurture the hands-

\footnotetext{
${ }^{26}$ On the origins of the Chicago Society of Arts and Crafts see Mary Jo Deegan and Ana-Maria Wahl, On Art, Labor, and Religion, Ellen Gates Starr (New Brunswick, NJ: Transaction, 2003) 16-28. See also Eileen Boris, Art and Labor, Ruskin, Morris, and the Craftsman Ideal in America (Philadelphia: Temple UP) 32-52. Allen and Irving K. Pond also designed the Northwestern University Settlement House.
}

${ }^{27}$ Boris 46. 
on and educational programs. ${ }^{28}$ The goal of the Society was to help create what Zueblin had termed "a heavenly city."29

\section{Graham Taylor}

During the Chautauqua summer lectures of 1902, the Rev. Dr. Graham Taylor (1851-1938), a professor of sociology at Chicago Theological Seminary, made the connection between the Social Gospel and the social settlements. Taylor was deeply involved with civic improvement; he served on the Civic Church advisory council section of the ALCI. The term Civic Church was an expression of a new activist role for the church in the improvement of society. Taylor was also the founder of the Chicago Common's Social Settlement, where he had been in residence with his family since 1895. The curriculum of the Common's Settlement included programs in aesthetic improvement such as Delsartian elocution and physical culture, as well as folk dancing. ${ }^{30}$ As he explained in Chautauqua, Taylor believed that "the conditions of personal growth are social." To the true Christian, community service must be paramount: "The name which will rise in the annals of his race will not be the man whom the most serve, but the man who serves the most." He added, "Christian people everywhere must hold

${ }^{28}$ Wendy Kaplan, ed, The Arts and Crafts Movement (London: Thames and Hudson, 1991) 58-59.

${ }^{29}$ Charles Zueblin, American Municipal Progress (New York: Macmillan Co., 1902) 274-275.

${ }^{30}$ Linda J. Tomko, Dancing Class: Gender, Ethnicity, and Social Divides in American Dance, 1890-1920 (Bloomington: Indiana UP, 1999) 166. 
themselves responsible for the dynamics of social progress." He concluded his eloquent remarks by saying, "The only selfhood that is worth having grows out of service."31

Based on a belief in the Social Gospel, the reformers' hope was that through the hands-on, aesthetic Arts and Crafts activities, a newly sensitized, educated citizenry would coalesce and foster democratic reform. To further stimulate democratic participation, new gathering spaces made inspiring through beautification, such as parks, plazas, and halls, would be added to the urban fabric. ${ }^{32}$ Indeed, the second president of the American League for Civic Improvement, Charles Zueblin, writing in the Chautauquan Monthly, focused the enthusiasm of the local organizations and connected their efforts to the larger vision of Progressive reform. ${ }^{33}$ Borrowing from the Arts and Crafts theory that collective individual workmanship would improve the quality of output and life elsewhere, as it had at Hull House, Zueblin emphasized "the new civic spirit."34 He felt that the beautification of cities through the work of individuals organized as

31 "Devotional Hours, Dr. Graham Taylor — 'Social Conditions of Personal Progress' Personal Responsibility and Social Progress," Chautauqua Assembly Herald 5 July, 1902: 7. See also: Graham Taylor, Religion in Social Action (New York: Dodd, Mead and Company, 1913) and Louise Carroll Wade, Graham Taylor, Pioneer for Social Justice, 1851-1938 (Chicago: U Chicago P, 1964).

${ }^{32}$ See Kevin Mattson, Creating a Democratic Public, The Struggle for Urban Participatory Democracy During the Progressive Era (University Park, PA: Pennsylvania State UP, 1998).

${ }^{33}$ Jon A. Peterson, The Birth of City Planning in the United States, 1840-1917 (Baltimore: Johns Hopkins UP, 2003) 423.

${ }^{34}$ Charles Zueblin, "The New Civic Spirit," Chautauquan Monthly Sept 1903: 55-59. One of the "sections" of the work of the League was the Arts and Crafts. See "The American League for Civic Improvement," Florence N. Levy, ed., American Art Annual, 1903-1904 (New York: American Art Annual, 1903) 264. 
communities is "in happy contrast to the disintegrating forces of the industrial revolution and a valuable factor in the large cooperative life of the municipality.",35

\section{Charles Mulford Robinson}

The City Beautiful dimension of Civic Improvement gained momentum (and its name) with the publication in 1903 of Modern Civic Art: or The City Made Beautiful, by Charles Mulford Robinson. Robinson, a journalist who served on the "Municipal Art" section of the ALCI, explicitly connected City Beautiful to the Social Gospel. He believed that the city - and society - could be returned to a state of grace through beautification; to him, civic improvement projects were "jewels as sparkling and as precious to a city as were the gems in the prophet's vision of the new Jerusalem,",36 "Modern civic art can now hope to banish 'the slum," " he wrote, "thus to redeem the tenement." ${ }^{.37}$ The city was to be sanctified through intervention. To City Beautiful reformers like Robinson, "municipal beauty [leads to] the widespread modern spirit of social service. ... That breathes life into civic art. [It is] not aristocratic, but democratic; Christian, not pagan." 38

The idea that active participation in the creation of beauty leads to an improved society is one of the critical tenets expressed by the founders of the Arts and Crafts Movement, John Ruskin and William Morris. In the Arts and Crafts ideal adopted by

${ }^{35}$ Zueblin, "The New Civic Spirit," 59.

${ }^{36}$ Charles Muflord Robinson, Modern Civic Art: or The City Made Beautiful (New York: G.P. Putnam's Sons, 1903) 5.

${ }^{37}$ Robinson 9.

${ }^{38}$ Robinson 23. 
Civic Improvement reformers, the craftsman contributes to a healthy society through the creation of beauty; in a fully functioning society the worker is an artist, not an "automaton." 39 The July 16, 1902 Chautauqua Assembly Herald expressed the goals of the Movement:

The Arts and Crafts idea is a return to art in workmanship and to manufacture as a means of individual expression. ... On the economic side, the movement is undoubtedly a reaction against the large machine production of the present time. .. . "The iron wheels grind out the good, the true and the beautiful in human lives"... . So it is certain that two things are necessary for the production of beauty - responsibility and freedom. .. . This correlation is held fundamental by the craftsman, that in expressing himself through an artistic manufacture he is also broadening and strengthening his own character. Personality grows through expression. $^{40}$

These ideals had implications for education, about which Charles W. Eliot, president of Harvard University from 1869 to1909, wrote, "The main object in every school should be, not to provide the children with means of earning a livelihood, but to show them how to live a happy and worthy life, inspired by ideals which exalt and dignify both labor and pleasure." 41 The connection of joyous hand labor with spiritual

\footnotetext{
39 "Arts and Crafts Number," Chautauqua Assembly Herald, 16 July 1902: 2.

40 "Arts and Crafts Number," 2.

${ }^{41}$ Kaplan 301.
} 
and intellectual development, a hallmark of the Arts and Crafts philosophy, was shared

by progressive educators such as John Dewey. The ideal education was seen to combine

exposure to the fine and applied arts, as well as the more traditional liberal arts

curriculum of math, history, literature and classical languages. ${ }^{42}$

\section{Charles Rohlfs}

At the turn of the century, then, Chautauqua became a center of the Arts and

\section{Crafts aspect of Civic Improvement as the Institution's emphasis on personal}

improvement of the participants expanded to include aesthetic considerations. Lectures

at the Amphitheater and the Hall of Philosophy expounded on the benefit of living a life

filled with an appreciation of beauty. The very busy Chautauqua summer of 1902 saw

attention paid to these ideals during the first Arts and Crafts Conference. The keynote

speaker for the week was Charles Rohlfs (1853-1956), an exceptional artisan of

42 In her essay on "The Role of the School" in The Art That is Life, Wendy Kaplan ties the spread of the reform ideal of the Arts and Crafts Movement to the establishment of school programs to teach the creation of crafts. A belief in the positive effect of doing craftwork by hand and the effort to foster a commercially successful class of "craftsmen and designers who would make American goods competitive with European imports" were two of the underlying motives for the spread of schools and the inclusion of craftwork in school curricula.

The art historian and educator Florence N. Levy, writing in Art and Progress, expressed the importance of including art work in schools: "Art is no longer considered a non-essential 'frill,' but an important method of teaching. It is not 'art for art's sake' merely, but "art for life's sake."

A necessary component was a well-trained core of arts educators to teach these classes. During the last quarter of the nineteenth century a number of schools were founded to prepare arts educators. In 1873, for example, the Massachusetts State Normal School was established in Boston in an effort to prepare teachers to teach the industrial arts. The Pratt Institute was formed in Brooklyn in 1887 to offer courses in both industrial and fine arts, and the Department of Fine Arts of the Teachers College of Columbia University was established in 1897, ten years after the founding of the school. The New York State School of Clayworking and Ceramics opened in 1900 at Alfred University in the Finger Lakes region. In addition to such specialized programs, other universities began to add applied arts programs such as ceramics, metal craft, weaving, furniture making, and design to their offerings. Further west in New York State, the summer program of the Chautauqua Institution was also helping to prepare teachers. Kaplan 301-303. Levy quoted in Kaplan 302. 
handmade furniture from Buffalo. Although he did not outwardly identify with the philosophy of Ruskin and Morris, Rohlfs was the epitome of the Arts and Crafts craftsman. He passionately pursued the creation of highly decorated, unique pieces of furniture (fig. 3.5). In his introduction to Rohlfs's address, George Vincent emphasized that Rohlfs's unconventionality, his individuality of expression, and his joy in creation was an ideal approach that should be emulated by the audience, concluding:

The Chautauqua management is confident that this movement represents a practical force of our times, that it has a deserved place on our program, and that in according it this recognition we are not trimming our sails to a passing breeze, but are recognizing something which means a great deal to these men and is vital to industrial affairs. ${ }^{43}$

Although Rohlfs was asked to speak about "The True and False in Furniture," his talk primarily focused on the role of the individual, both in the creation of the piece of furniture and its appreciation. Proud to be identified as an "amateur," he argued that individual taste should be paramount. Rather than defining what was "true," he declared, "our cry is for an intelligent standard, a cessation of indiscriminate buying and the giving of attention to the art element." His hope was that just as a stone thrown into a pond

43 "Arts and Crafts Conference. 'The True and False in Furniture,' Opening Conference of Arts and Crafts Week." Chautauqua Assembly Herald 15 July, 1902: 3. 
creates ripples that extend to the outer edges, the creation of functional pieces of art through individual effort would have a positive effect on society. ${ }^{44}$

The conference also included an address by William C. (Caryl) Cornwell (18511932), who introduced the work and philosophy of William Morris, as well as a presentation by H. J. Baker, the new director of Chautauqua's School of Arts and Crafts, on the history of the art of pottery. ${ }^{45}$ Beginning that same summer, the Summer Schools offered classes in the creation of both fine and decorative art, as well as courses designed to facilitate the instruction of these skills. Teachers visiting Chautauqua who participated in these classes learned to include these skills in their own classrooms.

Each month from October 1902 to June 1903, a promotional series on the history of the Arts and Crafts Movement appeared in the Chautauquan Monthly. The author of the series, Rho Fisk Zueblin, asked, in the October issue, "But what has made a Movement of the Arts and Crafts? Some feeling and idea, rather than that of simple art and dexterity. ... We shall interpret this more lasting and more universal purpose as the

44 "Walks and Talks. Mr. Charles Rohlfs on the Art Principle in Furniture." Chautauqua Assembly Herald 15 July, 1902: 1. "Arts and Crafts Conference. 'The True and False in Furniture,' 3. See also Joseph Cunningham, The Artistic Furniture of Charles Rohlfs (New Haven: Yale UP, 2008).

45 "William Morris. A Lecture by Mr. W. C. Cornwell of Buffalo. A Review of the Life and Work of a Great Artist and Craftsman, a Decorator, Designer, Dyer, Weaver, Illuminator, Binder and Printer." Chautauqua Assembly Herald 16 July, 1902: 1, 6-7. Cornwell, a banker from Buffalo, had served on the executive committee of the Art Committee of the Pan American Exposition, 1901. He began his career as a journalist but transitioned to banking, becoming the president of the City Bank of Buffalo. He helped found the New York State Bankers' Association, serving as its first president. Mark Twain Project. Web.

Cornwell was a painter all of his life. His watercolor, "Ethnology Building, Pan-American Exposition," was displayed at the exposition. Catalogue of the Exhibition of Fine Arts (Buffalo: David Gray, 1901) 79. "Arts and Crafts Conference. The Final Meeting of the Week Held in the Hall Yesterday." Chautauqua Assembly Herald 19 July, 1902: 4. Baker was the principal of High School Manual Training in Buffalo. He resigned his position to be the full time director of the Chautauqua Arts and Crafts Village. "Notes From the Field," Chautauquan Monthly Vol. 36, September, 1902-March, 1903: 85 . 
Arts and Crafts Movement proper."46 Of the works themselves she wrote in November, "The keynote of all this production and of all work justly belonging to the Arts and Crafts Movement is that the thing produced is its own inspiration and reward," 47 and in May she connected the efforts at Chautauqua to the general Arts and Crafts Movement:

There is also much activity and a good deal of enthusiasm in various summer schools where the teaching of the crafts has formed either an important feature or has been the central idea. At Chautauqua there is now a good deal of work done under the instruction in the crafts. ${ }^{48}$

The second generation of Chautauqua's leaders had embraced the connection between education and the creation of beauty through the making of handicrafts. Under the direction of Henry Turner Bailey, the chief administrator of the Arts and Crafts program from 1906 to 1917, the Chautauqua Institution became a leader in arts education.

\section{Henry Turner Bailey}

Bailey was born December 9, 1865, in North Scituate, Massachusetts, and was supervisor of drawing at a school in Lowell, Massachusetts, during his education at the Massachusetts Normal Art School in Boston (fig. 3.6). After graduating in 1887, he served as the state supervisor of drawing for Massachusetts until 1903, when he took over

${ }^{46}$ Rho Fisk Zueblin, "The Arts and Crafts Movement, Pre-Raphaelites: The Beginnings of the Arts and Crafts Movement," Chautauquan Monthly October 1902: 60.

${ }^{47}$ Rho Fisk Zueblin, "The Arts and Crafts Movement, A Survey of the Arts and Crafts in England," Chautauquan Monthly November 1902: 169. May 1903: 174.

${ }^{48}$ Rho Fisk Zueblin, "The Education of the Producer and the Consumer," Chautauquan Monthly 
the position of editor of The School Arts Book (fig. 3.7). As an acknowledged leader of the Arts and Crafts Movement, Bailey directed the Arts and Crafts advisory council section of the American League for Civic Improvement. In 1898 he was asked to represent the United States government at the International Art Congress in Brussels. He served in a similar capacity in 1908 in London and again in 1912 in Dresden. He became director of the Chautauqua Summer School of Arts and Crafts in 1906, leaving that position in 1917 to join the Cleveland School of Art (now Cleveland Institute of Art) as Dean and stayed with the Cleveland School until shortly before his death in 1931. Bailey was a member of numerous clubs and societies, including the Twentieth Century Club, the Society of Arts and Crafts, the Copley Society, and the Society of Printers in Boston. $^{49}$

Throughout his professional life, Bailey wrote and lectured extensively. He authored over twenty books, as well as many papers and articles. Most of his books including First Year in Drawing, The Great Painters' Gospel, Art Education, and The Magic Realm of the Arts - were small works, artfully bound, meant to be appreciated as much for their presentation as their content. Bailey also edited The School Arts Book, a monthly magazine designed to encourage teachers to include the creation of fine and decorative arts in their curriculum. As editor, he wrote articles, and chose articles by others, that expressed his view of the powerful effect of an appreciation of beauty in daily

49 "Henry Turner Bailey," The National Cyclopedia of American Biography (New York: James T. White, 1930 and 1933 editions) 101, 306-307. See also Nancy Coe Wixom, Cleveland Institute of Art, The First Hundred Years, 1882-1982 (Cleveland: Cleveland Institute of Art, 1983) 28-32 and the "Henry Turner Bailey," (obituary) Chautauquan Weekly 3 December 1931: 3. A biography of Bailey is being prepared by Jean Bailey Gaede, his granddaughter. 
life. The aesthetic sense, whether applied to architecture or old masters paintings, to drawing plants or weaving baskets, was explored each month in critical essays and "how to" articles. Bailey was quite decided in his aesthetic opinions. In an article entitled "Acceptable Plant Drawing," in the September 1905 edition of the magazine, Bailey explained:

Whatever the subject, — spelling, language, geography, arithmetic, nature, — school papers should be beautiful. Each sheet is an opportunity for training in craftsmanship. "What is worth doing at all is worth doing well." A sheet of plant drawing is no exception. ${ }^{50}$

Bailey went on to say, "Good results do not come through luck." He then gave very clear instructions with illustrated examples of good and bad drawings of plants (fig. 3.8). ${ }^{51}$

Each month the magazine typically included a clear, concise primary grade curriculum authored by Bailey. The goal was to "lead the children from following their private whims, to drawing thoughtfully to tell a story or illustrate an incident in the best way they could."52 To Bailey, the creation of art was directly linked to an appreciation of art.

He also solicited articles from well-known contemporary educators, such as the president of Harvard, Charles W. Eliot, and Arthur Wesley Dow, the director of the

\footnotetext{
${ }^{50}$ Henry Turner Bailey, “Acceptable Plant Drawing," The School Arts Book September 1905: 20.

${ }^{51}$ Bailey 20.

${ }^{52}$ Henry Turner Bailey, School Arts Book March 1908: 514.
} 
Department of Fine Arts at Columbia University's Teachers' College. "B3 "Beauty and Democracy," Eliot's lead article for the September 1905 edition, expressed the connection between an aesthetic sense and successful government:

The final aim of government ... is to make life happy. ... The reduction of evil is a direct benefit. ... The democratic goal is the happiness of the common mass. Among the means of increasing innocent pleasurable sensations and emotions for multitudes of men and women, none is more potent than the cultivation of the sense of beauty. ${ }^{54}$

In the September 1907 edition, Dow contributed an article entitled "Picture Study, A Symposium" outlining a suggested interactive program for the study of art history by young children. He suggested age- and grade-appropriate activities, including the relating of background stories by the teacher and the tracing of a print of the painting under discussion on onion skin for grades one and two (older children could copy the painting using various media). ${ }^{55}$

While at Chautauqua, Bailey was a frequent lecturer on the Amphitheater platform and at other venues. On July 30, 1906, he gave a lecture on "Village Improvement at Chautauqua" in Higgins Hall. In this, his first Chautauqua talk reported in the Chautauquan Daily, Bailey expressed many of the themes he was to explore during

${ }^{53}$ Bailey's instructional style and technique were influenced by Arthur Wesley Dow's Composition, (13 ${ }^{\text {th }}$ ed.) (1899; New York: Doubleday, Doran, 1929). The best biography of Dow remains Frederick C. Moffatt, Arthur Wesley Dow (1857-1922) (Washington, D.C.: Published For the National Collection of Fine Arts By the Smithsonian Institution Press, 1977).

${ }^{54}$ Charles W. Eliot, "Beauty and Democracy," School Arts Book Sept. 1905: 1-2.

${ }^{55}$ Arthur Wesley Dow, "Picture Study, A Symposium," School Arts Book Sept. 1907: 496. 
his association with the Institution. He felt that Chautauqua should be a place where "Beauty" is studied, created, and reflected in the physical facilities. He applauded the community for having created an "improvement association" to encourage a "general cleanliness of the place" and for having adopted a comprehensive plan for future development. Specifically, he advised the adoption of the Kelsey plan and the creation of the Plaza at the center of the two major axes. He believed that the Plaza, "the great central court, around which the principal buildings will be grouped, with its approach from the lake, will, in time, make Chautauqua preeminent for civic beauty."56

Bailey noted that Chautauqua's "chief charm" was its rural environment, "which ought to be preserved." He felt that the Hall of Philosophy fit this image but that the new Colonnade Building was "a city building and smacks of paved streets and concrete walks." He suggested that, as Chautauqua was being rebuilt,

[i]t would be a fine thing if those who are rebuilding could agree to adopt a uniform style of domestic architecture, such as a building with shingled walls stained a golden brown, and the roof a moss-green. This style is sufficiently elastic to be appropriate to the bungalow with sheathed partitions and to the palatial home. ${ }^{57}$

Bailey made six additional suggestions, ranging from improved drainage and a better system of paths to an exhortation to paint all of the buildings a uniform cream

56 "Improving Chautauqua: Many Practical Suggestions by Mr. Henry Turner Bailey," Chautauquan Daily 30 July 1906: 7.

\footnotetext{
57 "Improving Chautauqua" 7.
} 
color. Another idea was the construction of "a magnificent clock tower, ... a great stone tower" in the center of the Plaza, which would chime the hour and have a bell to be rung for announcements. It would also be a vantage point for views of Chautauqua and the area. After stressing all of these civic and community goals, he concluded, "[A] more beautiful Chautauqua can only come through the sinking of personal whim and pride beneath catholic, teachable, cooperative spirit."

Bailey spoke frequently during the next ten summer seasons at Chautauqua. A consistently popular lecturer, he often entertained his audience by drawing on a blackboard to illustrate his points. Each time he spoke, he explored variations on his theme of the value of incorporating Beauty into one's life. He frequently distributed a card imprinted with his philosophy of Beauty (fig. 3.9). During the 1916 season, he gave a series of four lectures on "The Enjoyment of Beauty in Nature." In successive discussions of plants, trees, landscape, and living things, Bailey described a shared national desire for "knowledge, love, and beauty" and maintained that fulfilling this desire by being open to the beauty of the natural world around us fulfills and completes our lives. $^{59}$

In 1902, the first year of the organization of Arts and Crafts classes at Chautauqua, offerings included drawing and painting, "pyrography, the burning of wood in artistic designs and finish, . . basket weaving, . . . benchwork for teachers, art

\footnotetext{
58 "Improving Chautauqua" 7.
}

59 "In Plant Life," Chautauquan Daily 15 August 1916: 1-2; "Beauty in the Trees," Chautauquan Daily 16_August 1916: 1-2; "In the Landscape," Chautauquan Daily 18 August: 1,8; "In Living Things," Chautauquan Daily 19 August 1916: 2. 
furniture, woodcarving, art metal work, Venetian iron work, bookbinding, whittling, clay modeling, [and] paper and card-board construction." ${ }^{60}$ By 1907, with the program under Bailey's direction, the curriculum had expanded. Three courses were offered in art history, each focused on Italian art of the Renaissance, along with courses in design, constructive wood work, cane and rush seating, art metal, wood carving, basketry, textile design, leather working, bookbinding, portrait and cast drawing, outdoor sketching, and still life and flower painting. The description of the course in handwork for primary grade teachers explained that it "forms a link between the work of the kindergarten and that of the shop," a focus of Bailey's interest. ${ }^{61}$

\section{Private Cottages}

As the Arts and Crafts program expanded at Chautauqua, owners of private homes chose to express sympathy with the goals of civic improvement, and many of the cottages built during these years took on the handcrafted, rustic look of the Arts and Crafts. Although some of the cottages were grand expressions of the style and enjoyed prominent lakeside locations, others were quite modest in scale. Two of the large summer residences built at this time are the Norton cottage at 49 North Lake Drive (1900) and the Studebaker cottage at 34 South Lake Drive (1902). The design of both of these large "cottages" combines classical and rustic Arts and Crafts elements. Clement Studebaker's middle child, Ann, and her husband Charles A. Carlisle built 34 South Lake

60 "Chautauqua Summer Schools, Season of 1902," Chautauqua Assembly Herald 5 July 1902: 3.

61 "Arts and Crafts Work, Plans for Next Summer's Schools, The Courses and Instructors," Chautauquan Weekly 11 April 1907: 1,5,6,7. 
Drive on the site of her father's home, a magnificent lakeside location. ${ }^{62}$ It incorporates a symmetrical façade with heavy brackets supporting a gabled overhang above the front door, rhythmically undulating shingle details, and a rubble chimney (fig. 3.10). Similarly, the O. W. Norton cottage, designed by Chicago architect Howard van Doren Shaw (1869-1926), combines a carved Palladian decorative element above the door with organic, tree-branch porch columns on its balanced façade (fig. 3.11). ${ }^{63}$ The interiors of both cottages are true Arts and Crafts in feel, with heavy exposed beams, carved woodwork, and art glass.

Many of the small-scale cottages of this time display a vernacular bungalow style, including 7 McClintock Ave. (1909), built by O. S. Lang, the builder of the Darwin Martin House (1905) in Buffalo designed by Frank Lloyd Wright. Lang had relocated to Maple Springs, across the lake from Chautauqua, to capitalize on the increased development around the lake. The architect was G. A. Mang of Buffalo, and the owner of the home, C. C. Taylor, lived year-round in Chautauqua and was responsible for printing the Chautauquan. ${ }^{64} 7 \mathrm{McClintock}$ has a wide wraparound porch, a rhythmic

62 "Public Improvements, New Cottages." Chautauqua Assembly Herald 7 July 1902: 6.

${ }^{63}$ Property file, 49 North Lake Drive. Chautauqua Institution Archive. O. W. (Oliver Willcox) Norton (1839-1920) was a wealthy industrialist from Chicago. He and his brother founded Norton Brothers, a manufacturer of cans and sheet metal goods, a predecessor venture to their American Can Company. During the Civil War, he served as a bugler under Colonel Strong Vincent, a cousin of Bishop John Heyl Vincent, his apparent connection to Chautauqua. As a bugler during the War, Norton is credited for writing and performing "Taps." He also wrote a well-respected history of the Gettysburg battle, The Attack and Defense of Little Round Top, Gettysburg, July 2, 1863 (New York: Neale Publishing, 1913). Norton supported such Civic Improvement initiatives as libraries and orchestras. Jari Villanueva, TwentyFour Notes That Tap Deep Emotions (tapsbugler. Web.) Norton's son, Ralph Hubbard Norton (18751953), served as Chautauqua President from 1944-1946.

64 "Cottage Building Activity, Additions and Improvements to Chautauqua's Dwellings," Chautauqua Assembly Herald 6 July, 1902: 2. 
shingle pattern, and hand-cut brackets. An unusual feature is a multi-part, partial second floor characterized by an intricately articulated roofline (fig. 3.12). One of the more unusual cottages in the Arts and Crafts style is 20 Hurst Ave (1914). The small-scale cottage has an Asian-inspired curved roof that encompasses a front veranda. Exposed brackets under the extended eaves of the roof complete the reference (fig. 3.13). These Arts and Crafts cottages set up an active dialogue with their Queen Anne and stick-style Victorian neighbors.

George Vincent and the leaders with whom he surrounded himself intended that the encompassing experience of Chautauqua transform participants. He hoped that as the Chautauquans proceeded to the various venues throughout the day — from morning lectures to afternoon Arts and Crafts classes and evening concerts - they would become socially aware, aesthetically responsive, active, civic-minded citizens. Just as the American League for Civic Improvement served as an umbrella organization for a continuum of activities, so these multiple aspects of civic improvement - - women's clubs, City Beautiful, Social Gospel, Settlements, and Arts and Crafts - coalesced in the Chautauqua Institution. Frank Chapin Bray was fond of saying, Chautauqua is "the largest improvement association in the world," infusing in its site and programs the notion of beauty as an instrument of personal and public improvement and social change. $^{65}$

${ }^{65}$ American League for Civic Improvement, "The Twentieth Century City, A Record of Work Accomplished for Civic Betterment," The Home Florist October 1901: 36. 


\section{Chapter 4}

\section{Chautauqua's Trustees: Clement Studebaker, Wilson M. Day, Frank Wayland} Higgins, and Charles A. Sweet at Chautauqua and on the National Stage

Just as the planned reconstruction of the grounds of the Chautauqua Institution into a model summer city of improvement was influenced by speakers and administrators, the decision to commission the plan was, in part, a function of the backgrounds, home-town activities, and individual priorities and skills of the Chautauqua board. The trustees' participated in a wide array of reform activities illustrative of many of the sections delineated by the organization of the American League for Civic Improvement (ALCI), including the planning and execution of the great expositions of the turn of the century. The four board members who will be highlighted also sponsored significant building campaigns in their home communities, during which they had worked with the two architects chosen to compete with Albert Kelsey to be Chautauqua's master planner — Studebaker and Day with Sidney R. Badgley of Cleveland, and Sweet and Higgins with E. B. Green of Buffalo. Sweet also links Chautauqua with Karl Bitter, whose sculptures epitomized the artistic aspirations of the time.

Many of the men who guided Chautauqua understood that their wealth and success was intimately connected to the health of their home communities. They were deeply committed advocates for beautification. Whether they were planning public celebrations, building churches for their communities, or homes for themselves, their efforts were directed toward designing meaningful additions to the landscape. These 
dedicated men loved Chautauqua, and their experiences with the powerfully memorable yet temporary expositions, so popular at the turn of the century, led them to embrace the notion that their summer home could be developed into a permanent exemplar of Civic Improvement.

The practical experience and personalities of the founders of Chautauqua, the Rev. John Heyl Vincent and Lewis Miller, had led to a congenial division of administrative responsibility. Although both men were very involved with all aspects of the Chautauqua experience, Vincent, as "Superintendent of Instruction," was primarily responsible for the programming, while Miller, a successful businessman, was named chairman and focused on the physical plant of the grounds and on the finances — what Vincent termed "material interests." Vincent observed that the "work of the Assembly had been distributed among six departments, - Instruction, Entertainment, Supplies, Order, Recreation, Sanitary." From the beginning, a board was formed to ensure that the assembly would be well organized and the visitors comfortable.

\section{Clement Studebaker}

When Miller died in February 1899, Clement Studebaker (1831-1901) assumed the former's responsibilities as chairman of the Chautauqua board (fig. 4.1). His steady leadership, while brief, helped to maintain Chautauqua's stability. Studebaker had begun his career as an educator but soon drifted back to his father's vocation, blacksmithing and carriage fabrication. He settled in South Bend, Indiana, at the age of nineteen and began

\footnotetext{
${ }^{1}$ John Heyl Vincent, The Chautauqua Movement (1885; Freeport, New York: Books for Libraries Press, 1971) 255-256.
} 
his own blacksmithing business with his older brother Henry (1826-1895). He married Charity Bratt in 1851; their two children died in infancy. A year after Charity's death in 1863, he married Anna Milburn Harper, a widow and the daughter of George Milburn, a local wagon manufacturer. The Studebakers had three children who grew up spending summers in Chautauqua, George Milburn (1865-1939), Anne (1868-1931), and Clement, Jr. (1871-1932). In 1868 Clement and Henry formally incorporated the Studebaker Brothers' Manufacturing Co. to craft wagons and carriages, with Clement as president. The growth of the business was remarkable; by 1901 the factory was reported to be the largest in the world, covering ninety-five acres, employing over two thousand workers, and producing 75,000 vehicles annually. ${ }^{2}$

In addition to work and family, Studebaker devoted his time and considerable resources to community and church service. He had joined the Methodist Episcopal Church in 1868 and for the rest of his life supported its efforts to improve the quality of its member's lives through education. ${ }^{3}$ In 1872, Studebaker and his wife Anna established the Laurel Mission, whose outreach program included a Sunday school. ${ }^{4} \mathrm{He}$ was also enthusiastic about the program of the Y.M.C.A. in South Bend, and, convinced that its approach of emphasizing both mental and physical culture would lead to the

2 "Clement Studebaker," The National Cyclopaedia of American Biography: Being the History of the United States, As Illustrated in the Lives of the Founders, Builders, and Defenders of the Republic, and of the Men and Wornen who are Doing the Work and Moulding the Thought of the Present Time, Volume XI (New York: James T. White \& Co., 1901) 109.

${ }^{3}$ Jan B. Young, The Life of Clement Studebaker, TS (1998, 2002, 2009) 136.

${ }^{4}$ History, Saint Paul's Memorial Methodist Church, Yesterday-Today-Tomorrow, 1883-1960 (South Bend, Indiana: self published, 1960) 10. 
development of spirituality, he encouraged others to support it: "I believe that men of means can in no way use some of their surplus to better advantage than by assisting to promote Young Men's Christian Associations."

Studebaker rose to prominence through his involvement with the church, soon assuming a leadership role. At the General Conference of 1880 , he was elected to the Book Committee, the group that published and promoted the teachings of the church, a role he maintained for twelve years. ${ }^{6}$ He particularly enjoyed representing his district at the national conferences, where he felt he could help to shape the direction of the church. $^{7}$ He was also interested in politics, serving as a delegate to the national Republican conventions in 1880 and 1888, and he represented the United States at both the Pan-American Congress in Washington (1889-90) and the Paris Exposition of $1889 .^{8}$ Studebaker became acquainted with Miller and Vincent through his involvement with the Methodist Church, and he joined the Chautauqua board in 1883. His passion for Chautauqua is evident in a letter he wrote to Lewis Miller in January 1887:

I feel that what is being done by and for Chautauqua will live long after you and I are laid to rest, and I am anxious so far as time and powers will permit to aid in building higher and higher this monument of intellectual

\footnotetext{
${ }^{5}$ Young 146-147.

${ }^{6}$ Young 147.

${ }^{7}$ Young 141.

${ }^{8}$ National Cyclopedia of American Biography: Volume XI 109. See also, Anderson \& Cooley, South Bend and The Men Who Have Made It. Historical, Descriptive, Biographical (South Bend: The
} Tribune Printing Co., 1901) 101-102. 
and spiritual development and growth. I feel sure that the names of the founders and those who early assisted in preserving and upbuilding the fair structure will go down to posterity as among those to whom the world will owe a debt of gratitude. To have some share in perpetuating the Chautauqua idea must also be accounted worthy service. ${ }^{9}$

Studebaker also had an interest in architecture. Before beginning the construction of "Tippecanoe," his South Bend home, he made numerous trips to Chicago in 1885 to interview architects, visit homes and estates, and consider materials. He chose Henry Ives Cobb as his architect. ${ }^{10}$ The home Cobb designed was enormous, with approximately forty rooms, twenty fireplaces, and almost 24,000 square feet of living space on four floors. For "Tippecanoe," Cobb interpreted the Richardson Romanesque style popular at the time - a stone exterior, with contrasting round arched details for windows and entranceway (fig. 4.2). ${ }^{11}$ The interior was filled with well-crafted, carved woodwork and had a massive front hall entry stair. Construction took three years and cost an estimated $\$ 250,000 .^{12}$

Another major architectural project Studebaker pursued was the construction of a large new Methodist church in South Bend. Over time, the congregation at Saint Paul's

\footnotetext{
${ }^{9}$ Quoted in: Young 150-151.

${ }^{10}$ Cobb would subsequently help William Rainey Harper design the University of Chicago.

${ }^{11}$ On the name of the house "two theories exist, one pertains to the Indian History of the Region, and the second pertains to Clem Studebaker's friendship with President Benjamin Harrison."
}

Tippecanoe Place Restaurant. Web.

${ }^{12}$ History of Tippecanoe Place 1, Tippecanoe Place Restaurant. Web. 
had outgrown Milburn Chapel, the small church building given by the Studebakers in 1883 in honor of Anna's father. The process of creating a new church took on fresh momentum in September 1899 when Doctor James G. Campbell became pastor. Campbell had a well-deserved reputation as an experienced builder. A committee was formed and after a thorough search that again involved interviews and travel to sites, it selected Sidney R. Badgley, a respected architect from Cleveland. In April 1900, at Studebaker's suggestion, Milburn Chapel was sold to the Hungarian Roman Catholic congregation and the proceeds applied to the construction of the new church. All of the additional funds for both the church building and the furnishings were a gift of the Studebakers. $^{13}$

Sidney R. Badgley (1850-1917) was born in Ontario, Canada, and began his career drawing the plans used in his father's construction business. He trained to be an architect through an apprenticeship in the office of Toronto-based architect, R. C. Windeyer, during which time he helped with the design for Massey Hall, a Toronto concert hall. After extensive travel throughout the United States and Canada, he settled in Cleveland in 1887. He was a member of the Methodist Church, the Chamber of Commerce, and the Civil Engineers' Club. Fluent in the popular styles of the day, Badgley was equally comfortable with Romanesque Revival (Pilgrim Congregational Church, Cleveland, 1893-1894) (fig. 4.3), Georgian Revival (the Jones Home for Friendless Children, Cleveland, 1902) (fig. 4.4), and Gothic Revival (Saint Paul's

\footnotetext{
${ }^{13}$ History, Saint Paul's Memorial Methodist Church, Yesterday-Today-Tomorrow, 1883-1960
} (South Bend, Indiana: self published, 1960) 16. 
Methodist Church, South Bend, 1901-1903) (fig. 4.5). Badgley's design for the Pilgrim Church was one of the first to devote the majority of its space to a community center; it included a library, rooms for meetings, and spaces for recreation, including a gymnasium. His plan was exhibited at the Paris Exposition of $1900 .{ }^{14}$ Whether in his ecclesiastic projects, public buildings, or private residences, Badgley's designs served to beautify their environment.

His Saint Paul's Methodist Church is a large-scale interpretation of the Gothic in Indiana blue limestone. The front of the building has a highly asymmetrical three-part composition. The central, and largest, section features a gable roof and a symmetrical twin entrance, each entrance having paired doors inset in a round archway. Over the doors is a prominent stringcourse of contrasting stone extending the length of the section, topped by an overscaled, round-arched stained glass window depicting "Christ Surrounded by the Gospel Writers." To the right of the entry section is a diminutive tower, which stands in contrast to the massive square tower to the left.

Shortly after the cornerstone-laying ceremony on May 12, 1901, the Studebakers left for a trip to Europe. Mr. Studebaker was in poor health, and they hoped that travel and a spa visit would improve his condition. While in Germany, they toured the Mayer \& Co. Glass Works in Munich and were so impressed by the beauty of a large window depicting Saint Paul preaching from Mars Hill in Athens that they offered to have a

\footnotetext{
${ }^{14}$ Cleveland Landmark Commission, Cleveland Architects, Sidney R. Badgley, City Planning Commission, City of Cleveland. Web.
} 
duplicate made and installed in the new church (fig. 4.6). ${ }^{15}$ The large window in the east wall of the sanctuary is thirty by eighteen feet, has thirty-six different people represented, and cost $\$ 40,000$. The Studebakers believed that the beauty of the experience of the new church would serve to inspire the congregation. ${ }^{16}$

Sadly, the European trip only further weakened Studebaker's condition, and he died on November 27, 1901, shortly after returning to South Bend. Two years earlier, he had assumed the chairmanship of the Chautauqua board with reluctance, as his health was already failing. Though he was concerned that he couldn't give the institution the attention and energy it deserved, he knew that some of the trustees could be counted on to share the leadership, particularly George Vincent and Wilson M. Day of Cleveland. ${ }^{17}$ Studebaker's trust in them was not misplaced: as we have seen, Vincent was instrumental in facilitating the growth of Chautauqua. Day was also a very effective voice for change.

\section{Wilson M. Day}

Wilson M. Day (1850-1929) was born in Clarion, Pennsylvania, and moved with his family to Cleveland, Ohio, where he attended local public schools, continuing on to the preparatory department of Allegheny College in Meadville, Pa., and the Jamestown Collegiate Institute in Jamestown, N.Y. (fig. 4.7). He completed his education at Ohio Wesleyan University in Delaware, Ohio, receiving a bachelor's degree in the classical

${ }^{15}$ A Guide to the Art Treasures (South Bend: St. Paul's Memorial United Methodist Church, self published pamphlet, 2010) 5.

${ }^{16}$ History, Saint Paul's Memorial Methodist Church, Yesterday-Today-Tomorrow, 1883-1960 (South Bend, Indiana: self published, 1960) 18. See also A Guide to the Art Treasures (South Bend: St. Paul's Memorial United Methodist Church, self published pamphlet, 2010).

${ }^{17}$ Young 151. 
course in 1871 and a master of arts in 1874 . He moved back to Cleveland in 1882 and began a long career in business and public service. Throughout his life, Day was passionate about education, arguing in his contribution to an anniversary celebration of his college entitled "The Graduate in Business" that a college education was necessary for success in business. ${ }^{18}$

Day was equally enthusiastic about private business and the public interest. A newspaper editor, he was the president of the Cleveland Printing and Publishing Company as well as the first vice president of the Union Building and Loan Company. In 1896, Day was described as "a most active and intelligent advocate of all measures proposed for the city's good."19 He had represented the interests of the region as the Cleveland Commissioner to the World's Columbian Exposition in 1893. He had also been the president of the Committee of Industry of the Board of Trade and was instrumental in its reorganization into the Chamber of Commerce, serving as an original board member and then as president of the Chamber from 1895 to $1896 .{ }^{20}$ In this capacity Day led a forward-looking effort to promote the growth of Cleveland. Working closely with the local government, the Chamber saw to it that information was

${ }^{18}$ W. G. Williams, Fifty years of History of the Ohio Wesleyan University, Delaware, Ohio. 18441894 (Cleveland, OH: Cleveland Printing and Publishing Co., 1895) 181-185.

${ }^{19}$ James Harrison Kennedy, A History of the City of Cleveland, Its Settlement, Rise, and Progress, 1796-1896 (Cleveland: Imperial Press, 1896) 521.

${ }^{20}$ The Cleveland World, "The World's" History of Cleveland, Commemorating the City's Centennial Anniversary (Cleveland: The Cleveland World, 1896) 357. 
disseminated, the freight facilities were improved, and legislation was enacted to encourage new business to locate in the city. ${ }^{21}$

Day dedicated much of his life to promoting civic improvement interests, serving as a trustee of the Cleveland General Hospital, the Deaconess Home, the Epworth Memorial M. E. Church, and the Ohio Wesleyan University, as well as of Chautauqua. During his time as a trustee of the Epworth Church, the congregation moved into a new building designed by Badgley (fig. 4.8). Dedicated on May 7, 1893, the large, domed building was very well received. A reviewer for the New York Times described it as being of "St. Lawrence marble, rock hewn, in irregular blocks. . . The architectural style is a combination of the Byzantine and the Romanesque, in an unusual but remarkably effective and artistic manner." 22 The building celebrated the founding in 1889 in Cleveland of the Epworth League, a young peoples' social service organization with the motto "Look Up, Lift Up." The League represented the joining together of five societies for the young people of the Methodist Church. By setting aside differences and rivalries, the Epworth League enjoyed enormous growth over the next four years, with half a million members participating in over 9000 chapters across the country and worldwide. A 16 by 32-foot stained glass window representing the Epworth "wheel" of consolidation was a key feature of the church. ${ }^{23}$ Badgley's design also called for a large Akron-plan

${ }^{21}$ William Ganson Rose, Cleveland, The Making of a City (Kent, OH: Kent State UP, 1990) 537.

22 "Epworth League Memorial, The Beautiful Building to be Dedicated To-day." The New York Times May 7, 1893: np. For more on the Epworth League see: J. B. Robinson, The Epworth League. Its Place in Methodism, A Manual (New York: Eaton \& Mains, 1890).

23 "Carpentry and Building, Epworth League Memorial," Building Age, Vol. 15 (New York: David Williams, 1893) 143. 
Sunday school of eighteen classrooms with hydraulically powered rising doors, grouped around a central reading space. The total capacity of the school with all of the doors fully open was 2800 students and teachers. As at the Pilgrim Church, Badgley included meeting spaces to be used by the League as well as by women's clubs.

In 1895, Day's position of leadership within the local business community led the Mayor, Robert E. McKisson, to ask him to serve on a special citizens' committee to address the long-standing problem of Cleveland's paucity of water. With some irony, the city, built at the juncture of the Cuyahoga River and Lake Erie, relied on small reservoirs constructed in 1885 , which simply did not supply enough to the city. When a series of devastating fires raged unchecked for lack of water pressure and equipment, the Mayor formed a committee of city leaders. Their conclusion was to insist on the construction of a massive lake tunnel and water-intake tube. Begun in 1896, these feats of engineering became the basis of the city's modern water supply. ${ }^{24}$

1895 was a very full year for Day; that summer he was also appointed directorgeneral of the Cleveland Centennial Commission, which would also commemorate the eighty-third anniversary of Commodore Oliver Hazard Perry's (1785-1819) victory over the English on Lake Erie. ${ }^{25}$ In addition to a series of extremely elaborate commemorative

${ }^{24}$ Elroy McKendree Avery, A History of Cleveland and Its Environs, The Heart of New Connecticut, Volume I, Historical (Chicago: The Lewis Publishing Company, 1918) 435-436.

${ }^{25}$ Although discussions began as early as 1893 , plans for the celebration of the centennial of Cleveland's founding in 1796 didn't begin in earnest until the summer of 1895 . A commission of luminaries led by McKisson and representatives of the Ohio state government, including the governor, chose Day to direct the festivities. The schedule was set for the next summer's activities to begin on the anniversary of Moses Cleaveland's arrival at the mouth of the Cuyahoga, the twenty-second of July, and to end on the tenth of September. Avery 287-289. At midnight a one-hundred gun salute executed by the Cleveland Light Artillery (Battery A) symbolically closed the first century and opened the celebration. The first day's events - Founder's Day - featured a series of speeches given by Governor Bushnell and other 
events, several structures were fashioned to mark the centennial. A log cabin reminiscent of a popular "Log Cabin in Ye Olden Times" of the 1876 Philadelphia Fair was constructed on the northeast section of the Public Square (fig. 4.9) and dedicated on the afternoon of July $21^{\text {st }}$ with tributes to Cleveland's generations of early settlers. ${ }^{26}$ Just as the earlier Philadelphia cabin had been situated next to the "New England Modern Kitchen" to represent one hundred years of progress, the Cleveland log cabin was "strategically placed across the street from a modern bank building," contemporary historian John Bodnar has noted. ${ }^{27}$ His conclusion is that the proximity should be read as a statement of progress from "poverty to wealth.,"28

Another specially designed edifice was an illuminated, monumental arch, 79 feet high, 106 feet wide, and 20 feet thick, consisting of a wooden frame covered with a combination of lath and plaster called staff (fig. 4.10). Although built to be temporary, the stark white arch was topped with an observation deck festooned with a double row of flags. It was erected on the Public Square between the log cabin and an 1894 memorial column designed by architect/sculptor Levi T. Scofield (1842-1917) commemorating the

notables, as well as a parade. Many of the following days were given a theme of specific focus: Founder's Day was followed by New England Day (July 23); Wheelmen's Day (July 24), featuring an eight mile parade by nine divisions of bicycle riders; Women's Day (July 28); Early Settlers' Day (July 29); and Western Reserve Day (July 30), dedicated to the pioneers. Each day's activities celebrated the past and included inspirational meetings, speeches, special entertainment, and parades. Rose 574.

${ }^{26}$ Rose 573.

${ }^{27}$ Linda P. Gross, Theresa R. Snyder, Philadelphia's 1876 Centennial Exhibition (Chicago: Arcadia Publishing, 2005) 124.

${ }^{28}$ John Bodnar, Remaking America: Public Memory, Commemoration, and Patriotism in the Twentieth Century (Princeton: Princeton UP, 1992) 93. 
soldiers and sailors who lost their lives in the Civil War. ${ }^{29}$ The composition of monument, arch, and log cabin encouraged by Day and the Cleveland Centennial Commission served to both inspire and express civic pride as well as to set the stage for the revelry. ${ }^{30}$

With Studebaker's untimely death, the board of Chautauqua turned to Day to be the next president. Chautauqua historian Alfreda Irwin describes his management style as "active"; although president for only two years (1902-1903), he accomplished a great deal. His efforts led to a streamlined, more modern administration. He moved the offseason administrative functions to Cleveland, where he could better oversee business affairs, ${ }^{31}$ and he facilitated the change in corporate structure whereby Chautauqua became the Chautauqua Institution, by act of the New York State Legislature (1902). New utilities were constructed on the grounds, including a modern electric plant. Day was

${ }^{29}$ The monument's highly decorated stone base is topped with a polished black, Quincy stone column 125' tall. The design and construction of the monument was not without controversy. The site chosen was already occupied by a memorial erected in 1860 to Perry's victory over the British. Bodnar 9395.

${ }^{30}$ Five years later Cleveland elected a new Progressive mayor, Tom L. Johnson (1854-1911, mayor 1901-1909). With Johnson's support another built expression of civic pride was planned: an ensemble of seven public buildings that became known as the Cleveland Group Plan. It resulted from the efforts of the Group Plan Commission (1902) comprised of Daniel Burnham, Arnold Brunner, and John Carrere. Their 1903 report created a 500'-wide mall with a series of uniformly classically inspired public buildings: Federal Building (1910), Cuyahoga County Courthouse (1911), Cleveland City Hall (1916), Public Auditorium (1922), Public Library (1925), Board of Education Administration (1930), and Cuyahoga County Administration (1957). The Encyclopedia of Cleveland History.

${ }^{31}$ The Institution's administrative offices were moved back to Chautauqua in 1904. Alfreda L. Irwin, Three Taps of the Gavel: Pledge to the Future, The Chautauqua Story (Chautauqua, New York: Chautauqua Institution, 1987) 82. 
also instrumental in guiding the board through the process of commissioning the 1903 architectural and landscaping plan. ${ }^{32}$

\section{Frank Wayland Higgins}

Assisting in the passage of the legislation that created the Chautauqua Institution was another strong advocate for civic improvement, Governor Frank Wayland Higgins (1856-1907) (fig. 4.11). Higgins was born in Rushford, a small town in the southern tier of New York State, approximately ninety miles east of Chautauqua. His formal education was limited to the local Academy for elementary school and the Riverview Military Academy in Poughkeepsie for high school. After a short but successful venture in the mercantile business in Michigan, Higgins returned home to join and expand his father's wide-ranging business interests. The Higgins family controlled "vast tracts" of land in Michigan, Wisconsin, Washington, and other western states, where they harvested timber and developed mineral rights. They also had significant interests in banks, glass factories, and electric utilities, as well as a chain of grocery stores. Higgins's father, Orrin Trail Higgins, died in 1889, and Frank relocated the family business to nearby Olean, New York. ${ }^{33}$

Often described as unaffectedly modest despite his great wealth, Higgins was encouraged to enter politics. $=\mathrm{He}$ first served as a delegate to the Republican National Convention in Chicago in 1888 and then was elected in 1893 to represent Cattaraugus and Chautauqua counties in the state senate. He became a Chautauqua trustee the next

\footnotetext{
${ }^{32}$ Irwin 84

33 "Empire State's Incoming Chief Magistrate," New York Times November 18, 1904.
} 
year and continued to serve the Institution even after he was elected New York's Lieutenant Governor (1903-1904) and then Governor (1905-1906). ${ }^{34}$

Throughout his career in public office, Higgins expressed his commitment to Civic Improvement through his pursuit of a progressive agenda of social and environmental concerns. In his first address as Governor to the state assembly — fifteen years before the Nineteenth Amendment to the United States Constitution gave women the right to vote - he argued forcefully for extending suffrage to women in special tax elections. He was also well known as a conservative guardian of the public's funds. In a carefully considered plan to improve the state's highway system, Higgins proposed an equitable method of cost sharing between the state, counties, and townships. The goal of the wide-reaching plan was to provide reasonable access to an improved state road to every farm in the state. The governor's office correctly predicted that the concomitant increase in land values of the adjacent properties would lead to increased tax revenue to pay for the investment. Consistent with his environmental sensitivity and sense of aesthetic improvement, he saw to it that the roads were landscaped with abundant shade trees. ${ }^{35}$ At the local level in his adopted hometown of Olean, Higgins supported such civic improvement projects as the library, the park system, and the General Hospital. ${ }^{36}$

${ }^{34}$ Higgins was first elected in 1893 to the state senate from the $32^{\text {nd }}$ district that included Cattaraugus, Chautauqua, and Allegany counties. He was next elected in 1895 from the newly configured $50^{\text {th }}$ district that eliminated Allegany county. Higgins married Kate C. Noble, the daughter of Aaron Harrison Noble, of Sparta, Wisc., June 5, 1878. They had two sons and a daughter. "Frank Wayland Higgins," The National Cyclopaedia, Volume XIII (New York: James T. White \& Co., 1906) 551-552.

${ }^{35}$ William J. Gabler, "Frank Wayland Higgins: New York's ‘Forgotten Governor,"” M. A. Thesis, St. Bonaventure University, July 2002: 83,129-130.

36 "Will of Ex-Gov. Higgins," Higgins Binder, Olean Historical and Preservation Society. 
Higgins's home on the Chautauqua grounds, along the lakefront at 42 South Lake Drive in a prestigious location three doors from Bishop Vincent's home, was one of a series of moderate-scale Victorian-style buildings developed in the early 1880 s to give wealthy Chautauquans restful lake views and a respite from the density of the inner core of houses (fig. 4.12). Although seemingly a single-family residence like its neighbors, it actually was a side-by-side duplex used by his brother's family as well; the twin gables and side entrances to the porch designate separate dwellings.

Higgins's sense of the aesthetic was further expressed in two building projects. To honor their father, Higgins and his sister, Clara K. Smith, commissioned a small multi-purpose facility to be built at the north end of the grounds of Chautauqua.

Constructed of pressed brick with terra cotta trim, with a single large gable roof, heavy piers, and an entrance composed of repeating round arches, Higgins Memorial Hall is an interpretation of the Romanesque (fig. 4.13). The Hall was ready for the 1895 season with a lecture room seating four hundred, a small library, a parlor, and a kitchen. A commentator in the Assembly Herald noted apropos of the "beautiful building, [It] is a hopeful sign of the permanence of what many have regarded as a temporary summer town, that such a structure should be erected here." As the first masonry building in a modern style on the grounds, the Hall prompted initial discussions at the administrative and board level about the future of Chautauqua's facilities. ${ }^{37}$

The second project, Higgins's home in Olean, stands in contrast to the Memorial Hall (fig. 4.14). Where the Hall is an aggressively "modern" work, reflecting the latest in

\footnotetext{
37 "Chautauqua for 1895," The Chautauqua Assembly Herald 25 July 1895: 1.
} 
new design, his colonial revival home is far more conservative. Designed by E. B. Green in 1897, it is a symmetrical, two-story composition with a temple front consisting of a pediment over four Ionic columns. A carriage drive leads past a porte corchère on the side of the main house to a carriage house at the rear. Set back on a deep lot just off the main business street of Olean, Union Street, and across from a public square, Higgins's home had a very visible presence. The building embodied his self-image - successful, powerful, yet understated. Higgins felt great pride in his home, and his strong personal relationship with his architect was an important aspect of the Chautauqua trustees' decision to have Green succeed Kelsey as the Institution's primary architect in $1907 .^{38}$

\section{Charles A. Sweet}

Another Chautauqua board member with strong reform and planning bona fides was Buffalo-based banker Charles A. Sweet (1836-1903). The son of a New England farmer, Sweet overcame a limited formal education and the untimely death of his father to become a successful businessman and reformer. Moving to Troy, New York, he joined the firm of Bradley \& Toles, a regional stone transportation business. At the age of twenty-six he moved to Buffalo to direct the firm's interests and was named a partner when Mr. Bradley retired. In 1881 he was elected president of the Third National Bank in Buffalo, a position of influence he held for twenty-one years. ${ }^{39}$ The new bank

${ }^{38}$ Ed Evans. Hidden Treasure: The Chautauqua Commission of Buffalo's E. B. Green (New York: Evans, 2005).

${ }^{39}$ Sweet replaced Abram Altman, who resigned in disgrace, having been accused of stealing the large sum of $\$ 45,000$ from the bank to cover losses in commodity speculation. The bank sued to recover the loss and remained solvent. "A Bank President in Trouble. A Resignation in Buffalo and a Suit for a Large Deficiency." New York Times September 10, 1881. 
headquarters on the corner of Main and Swan Streets downtown was a five-story

Renaissance-inspired palazzo topped with a prominent cornice (fig. 4.15).

Buffalo was the westward terminus of the Erie Canal, which had opened on

October 26,1825 , and boasted an extensive railway system as well as a major harbor on Lake Erie. As a consequence, it functioned as the gateway for goods and services flowing across the country and flourished as an industrial and transportation center, an engine for wealth creation. Joseph Ellicott (1760-1826) laid out the original plan for the city in 1804 in a style reminiscent of Pierre L'Enfant's plan for the District of Columbia. (Ellicott had earlier helped his brother Andrew survey the new U. S. capital.) In 1870, Frederick Law Olmsted and Calvert Vaux further developed the plan, adding an extensive park and parkway system. In Olmsted and Vaux's plan, Delaware Avenue, the three-mile straight stretch of road that connected the downtown with the northeast quadrant, became the main thoroughfare to an idyllic pastoral landscape, Delaware Park. Prominent Buffalonians competed with each other to build homes on Delaware Avenue that would be statements of wealth, power, and influence. Some patrons brought in prominent architects, including H. H. Richardson and McKim, Mead \& White, but many used local designers. ${ }^{40}$

${ }^{40}$ For more on the development of Delaware Avenue, see: Francis R. Kowsky, "Chapter Two, Delaware Avenue, Buffalo, New York," in Jan Cigliano and Sarah Bradford Landau, eds., The Grand American Avenue, 1850-1920 (San Francisco: Pomegranate Artbooks; The Octagon, the Museum of the American Architectural Foundation, 1994) 35-63, esp. 45-55. Richardson is credited with the William Dorsheimer House, 434-438 Delaware Avenue (1869-1871), and just before his death he designed the William H. Gratwick House, 776 Delaware Avenue (1888). It was completed by Shepley, Rutan \& Coolidge. McKim, Mead \& White did four houses on Delaware Avenue: the Williams-Butler House, at 672 (1896-1899), the Williams-Pratt House at 690 (1896), the Robert Root House at 650 (1894), and the Metcalfe House at 125 North Street and Delaware Avenue (1882). 
The architect for twenty-six of the buildings along Delaware Avenue was E. B. Green, of the firm of Green and Wicks. Architects Edward Broadhead Green (18551950) and William Sydney Wicks (1854-1919) had formed their partnership in Auburn, New York, in 1881 and moved to Buffalo later that year. Both were part of the first generation of architects trained in American architectural schools, Green at Comell and Wicks at MIT. While not overly innovative, the firm mastered the neoclassical styles popularized by McKim, Mead \& White. Many of the firm's Delaware Avenue projects were successful, but 824 designed for George V. Forman (1895), 830 for George B. Matthews (1901), and 888 for Charles W. Goodyear (1902), were particularly strong. Each represents a variation on the theme of classical revival; together they show the firm's wide range and ability. The Forman House, of yellow Roman brick, has a simple, unifying geometry and a grand temple front with Ionic columns, while the red brick Matthews House is a far more complex composition in an Elizabethan Tudor style, with intersecting gable slate roofs and corbelled chimney stacks (figs. 4.16, 4.17). The immense Goodyear House - it was said to require one and a half tons of coal a day to heat - is also of red brick but features a symmetrical, three-part composition in the French Regency style, with a mansard roof and highly detailed cast-stone dormers (fig. 4.18).

As a bank president during Buffalo's period of greatest economic growth, Charles Sweet was involved in many projects, both public and private. He was considered "one of the most cautious, clear-headed and sagacious" bankers of Buffalo, a reputation that 
led to other leadership positions. ${ }^{41}$ Like Studebaker and Day, he was affiliated with the Methodist Episcopal Church. He was a founder and trustee of the Delaware Avenue (now Asbury Delaware Avenue) M. E. Church, whose Gothic revival building, designed by John H. Selkirk (1876), added yet another eclectic element to one of Buffalo's premier boulevards. In addition to being a director of both the Fidelity Trust and Guaranty Company and the Citizens' Gas Company, he was active in Buffalo city planning organizations. One of these, the Grade Crossing Commission of 1888, was established to implement an extensive plan to force the railroads to build above-grade crossings for trains, in a city whose enormous rail traffic (some 250 passenger trains a day, on 638 miles of railroad) led to extensive delays and sometimes-fatal accidents as trains intersected pedestrian and vehicular traffic. The plan also called for a massive new Union passenger station and new freight depots. The nine men selected for the commission represented the primary business interests of Buffalo, including the Merchants' Exchange, the Lumbermen's Exchange, the Businessmen's Association, the Grocers' Association, and the Common Council. The commission's charge was to contract with the railroads to effect the multi-million dollar solution. ${ }^{42}$

${ }^{41}$ See for instance "The National Bank Question. Financiers taking a Glowing View of the Future of the System," New York Times November 18, 1883. In this article, Sweet gave a reasoned, conservative opinion on the question of the U.S. government's plan to reduce the level of national debt.

42 "Improvement in Buffalo, A Plan At Last to be Rid of Grade Crossings. A Menace to the Persons and Business of Citizens to be Removed - Great Railroad Buildings." New York Times June 8, 1888. 
Sweet's leadership ability was further recognized when he was appointed to the Board of General Managers for New York. ${ }^{43}$ It was in this capacity that he was placed in charge of the New York State pavilion at the Columbian Exposition in Chicago in $1893 .^{44}$ He and his associates on the board chose an inclusive approach to the exhibit, which was to represent New York's manufacturers and products. The building itself, executed by McKim, Mead \& White, was an over-scaled model of the Villa Medici in Rome, the home of the French Academy. The Board of Managers showcased the wares of thousands of individuals and companies. General Electric and Westinghouse promoted their innovations in electricity, and Tiffany \& Company dazzled visitors with a glittering array of the latest jewelry designs. The extensive displays included agricultural products, greenhouse plants, and a extensive selection of New York wines. The pavilion also housed a plethora of New York memorabilia, both historical and contemporary. In 1894, the board published a 650-page guidebook, New York at the World's Columbian Exposition, that lists all of the exhibits, companies, and people who contributed to New York's effort. $^{45}$

\footnotetext{
${ }^{43}$ In preparation for the World's Columbian Exposition of 1893 each state created a board of managers who were charged with creating an exhibit that would represent the various manufacturers and products of that state. See for example: World's Columbian Exposition. State of Michigan. The Act of the Legislature Creating the Board of World's Fair Managers for the State of Michigan. Rules and Regulations of the Board and General Information Concerning the Exposition. First Edition. Issued by the State Board, April, 1892. (Flint, Michigan: W.H. Werkheiser \& Sons, 1892) 5-10. On the Fair see David F. Burg, Chicago's White City of 1893 (Lexington: UP Kentucky, 1976) and Reid Badger, The Great American Fair: The World's Columbian Exposition \& American Culture (Chicago: N. Hall, 1979).

${ }^{44}$ Memorial and Family History of Erie County, New York, Volume II, Biographical \& Genealogical (New York: The Genealogical Publishing Company, 1906-8) 297-299.

${ }^{45}$ Chaim M. Rosenberg, America At the Fair: Chicago's 1893 World's Columbian Exposition (Chicago: Arcadia Publishing, 2008) 217-218.
} 
Eight years later, as a member of the finance committee for the Pan-American Exposition of 1901, Sweet was again involved in the planning and execution of a major exposition. ${ }^{46}$ Held in Buffalo, its goal was to inspire the nation through a lavish display of art and architecture to embrace a future of civic improvement. The theme enunciated in 1897 by the organizers of the fair, the Bureau of American Relations, was "to promote commercial and social interests among the States and countries of the Western Hemisphere." ${ }^{\text {47 }}$ Although the planning was delayed by the outbreak of the SpanishAmerican War, the successful conclusion of the conflict in 1898 served to heighten the feeling of hemispheric identity. The official seal designed by Raphael Beck depicted the continents of North and South America as women in colorful flowing garb clasping hands over Latin America (fig. 4.19). The theme was further expressed through the choice of a Spanish Renaissance style of architecture in a rainbow of colors. ${ }^{48}$ The organizers consciously chose to avoid the Roman classicism and palette of Chicago's 1893 Fair, the White City. The site selected was a large farm adjacent to Olmsted's Delaware Park. Although the farm was flat and devoid of trees, the exposition visitor could experience the park's undulating pastoral landscape as a prelude to the intensity of the fair.

${ }^{46}$ Official Catalogue and Guide Book to the Pan-American Exposition, With Maps of Exposition and Illustrations, Buffalo, N.Y., U.S.A., May $1^{\text {st }}$ to Nov. $1^{\text {st }} 1901$ (Buffalo: Charles Ahrhart, 1901) 9.

${ }^{47}$ Official Catalogue and Guide Book 5.

${ }^{48}$ See: Kerry S. Grant, The Rainbow City, Celebrating Light, Color, and Architecture at the PanAmerican Exposition, Buffalo, 1901 (Buffalo: Canisius College P, 2001). 
It is likely that Sweet and Higgins invited their fellow Chautauqua trustees and administrators to join them for a tour of the Pan-American Exposition, just seventy miles north, during the summer of 1901. They would have been very proud of what their state and city had accomplished and particularly impressed with the contributions of their architect E. B. Green. The creation of the exposition was a remarkable achievement. To effect the construction of the complex project in a relatively short time, multiple committees were formed to address specific concerns. The individual projects were allocated to a Board of Architects under the direction of John Merven Carrère (18581911), of Carrère and Hastings in New York City. Green was one of only three Buffalo architects on the board commissioned to design buildings at the fair, a signal recognition of the firm's stature. Of the four buildings assigned to Green \& Wicks, the Electricity Building and the Machinery and Transportation Building were constructed of staff in the Spanish Renaissance vocabulary: a fantasy of domes, arches, towers, and columns topped by a red tile roof. The body of the Machinery and Transportation Building was green with accents of red, brown, and green (fig. 4.20). The Electricity Building was painted a warm yellow with gray and green trim (fig. 4.21$){ }^{49}$ Both buildings, indeed all of the main buildings of the fair, were festooned with an array of electric lights, making the fair equally accessible at night (fig. 4.22). The organizers seemed to imply that modern life could vanquish the rhythm of day and night.

${ }^{49}$ Eliza Northwood, Architecture, Sculpture, and Color Schemes at the 1901 Pan-American Exposition, History of Buffalo. Web. See also David Gray, ed., Art Hand-Book, Sculpture, Architecture, Painting, Official Handbook of Architecture and Sculpture and Art Catalogue to the Pan-American Exposition (Buffalo: David Gray, 1901) 40-41. 
Two of the fair buildings were to be permanent, the New York State pavilion and the third of Green's commissions, the Albright Art Gallery. For both of these projects, the Board of Architects stepped away from their commitment to colorful extravagance and instead specified classical forms of white marble. As the promised future home of the Buffalo Historical Society, the New York State building was designed by Buffalobased architect George Cary to be "an edifice of substantial and enduring character." The exterior, a large rectangle with a pedimented temple front, was said to resemble "a Grecian Temple of the Doric order" (fig. 4.23). ${ }^{50}$ The interior contained a dining room, a 250-person "audience-hall," and over 10,000 square feet of exhibition space.

Green's Albright Art Gallery also used a classical vocabulary but was a far more elegant and successful composition (fig. 4.24). To tie Delaware Park together visually with the intense fair grounds, Green situated the gallery on an elevated knoll overlooking the lake. Perhaps inspired by the great nineteenth-century museums of Europe - Leo von Kelze's Glyptothek in Munich (1816-20) or Schinkel's Berlin Altes Museum (182330) - or by Charles Atwood's Palace of Fine Arts for the 1893 Columbian Exposition, Green selected the high Ionic order of the Erectheion. The eastern façade is a carefully detailed, five-part composition having a central portico with a double row of Ionic columns. Perpendicular side-loggias connect the portico to the north and south wings of the building, which are shorter than the portico and consist of basilicas complete with caryatid porches, a collaboration of the architect and the sculptor Augustus Saint-

\footnotetext{
${ }^{50}$ Official Catalogue and Guide Book 27.

${ }^{51}$ Gray 42-43.
} 
Gaudens (1848-1907). The western side of the gallery, which faces Elmwood Avenue, has a central hemicycle and side loggias. In all, seventy-four freestanding columns ring the building. The composition benefits from Green's interest in historical accuracy. He copied many of the ancient Greek techniques to fool the eye - columns, for example, have a slightly convex profile and are positioned with a minor lean to the center so as to appear straight.

The Albright Art Gallery was originally conceived as the permanent home for the Buffalo Fine Arts Academy. Since its founding in 1862, the Academy had striven to fulfill its mission to make art an integral part of the life of Buffalo and to make it "free to all. ${ }^{, 52}$ The gallery was created with a gift, reported to have been $\$ 350,000$, from John J. Albright (1848-1931). ${ }^{53}$ Albright was born in Virginia and grew up in Scranton, Pennsylvania, where he attended public schools. He completed his secondary education at the Williston Academy in Easthampton, Massachusetts. Founded by Samuel Williston (1795-1874), who installed himself as the main faculty member, the school featured an unusual dual curriculum. Williston combined a classical division and an innovative scientific division. ${ }^{54}$ Albright went on to matriculate at the Rensselaer Polytechnic Institute in Troy, New York. After graduation in 1868, he entered the coal industry, first selling and soon transitioning to shipping coal by rail to the West. So much of the rail

\footnotetext{
${ }^{52}$ For more on the Academy see Willis O. Chapin, The Buffalo Fine Arts Academy, A Historical Sketch (Buffalo: Published by the Academy, 1899) 14.

53 “Buffalo's Fine Arts Academy." New York Times February 3, 1900.

${ }^{54}$ A Brief History of The Williston Northampton School, The Williston Northampton School. Web.
} 
business passed through Buffalo that Albright relocated there in 1883 to take advantage of its central role in the westward shipment of coal. A creative, forward-thinking entrepreneur, he also had interests in steel, banking, and hydroelectric power. His community activities in support of the Civic Improvement agenda were many and varied, including support for the Nichols and Franklin schools, the Unitarian Universalist Church, and the South Park Botanical Gardens, and he was extensively involved with the Pan-American Exposition, serving on the Finance Committee with Sweet. ${ }^{55}$

When it became obvious that a sufficient supply of marble would not be available and that the Albright gallery could not be ready in time, Green's fourth contribution, the Art Building, was hastily planned and executed as a modest home for the exposition's art display (fig. 4.25). Construction on the new gallery did not begin until December 1900, and it was not opened to the public until June 17,1901 . Situated in the southwestern corner of the fairgrounds across the lake from the unfinished Albright, the Art Building was a large, single-story rectangle of rough red brick with entrances on both the north and south sides. The interior plan consisted of a series of interconnected galleries around the perimeter (fig. 4.26). The north (rear) entrance led directly into the gallery's central architectural feature, the Statuary Court, defined by interior columns. In the center stood Augustus Saint-Gaudens's equestrian statue of General Sherman, which had won a grand

55 "John J. Albright, Excerpts from The Ivy Grows Again: A History of the Albright Estate from 1890 to the Present" by Betsy Taylor, Published by Nardin Academy in 1998," in "John J. Albright." Buffalo History. Web. 
prix for the sculptor at the Paris Exposition of 1900 (fig. 4.27). ${ }^{56}$ The galleries were illuminated by natural light from a frieze of windows under the eaves. ${ }^{57}$

To build on the enormous popularity of the sculptures that were part of the Chicago 1893 World's Columbian Exposition and to express the desired status and prestige of a world-class fair, the Buffalo board planned an extensive decorative sculptural program to grace the grounds of the exposition in addition to the works featured in the Art Building. The reformers who directed the exposition hoped that visitors would aspire to the ideals expressed by the art.

To select a director to coordinate the department of sculpture, the exposition board asked the National Sculpture Society for a suggestion; they reportedly unanimously recommended Karl Bitter (1867-1915) ${ }^{58}$ Although Chautauqua has not placed an emphasis on sculpture, a consideration of Bitter's work, especially for the 1893 and 1903 expositions, throws into high relief the varied didactic and inspirational thrust of artistic production characteristic of the turn of the century.

Bitter was born and trained in Vienna and studied art at the imperial School for Applied Arts, the Kunstgewerbeschule, and then sculpture at the Kunstakademie, the School of Fine Arts. He graduated into a world exploding with appreciation for the plastic arts. Vienna was undergoing a major transformation with the creation of the

${ }^{56}$ Gray 79.

${ }^{57}$ Official Catalogue and Guide Book 29. See also "Art Building," "Doing the Pan ..." Pan American Exposition Buffalo 1901. Web.

58 "Karl Bitter Dies of Auto Injuries, Sculptor Won Fame at 21 by Designing Famous Trinity $\$ 200,000$ Bronze Doors. Began Career in Vienna, Winner of Medals in World's Greatest ExpositionsHis Colossal Groups at Chicago Fair," New York Times 11 April 1915. 
Ringstrasse, which included a substantial sculptural program. Bitter's first employment was as an apprentice. ${ }^{59}$ He emigrated to the United States in 1889 , settled into a studio in downtown Manhattan, and had the great fortune to come to the attention of Richard Morris Hunt (1827-1895), then the dean of American architects. Almost immediately Hunt gave Bitter work on the interior of the mansion he was completing on Fifth Avenue. ${ }^{60}$

Bitter's career as a sculptor was consolidated in early 1891 when he was a winner of a competition to design a set of decorative bronze doors for New York's Trinity Church as a memorial to John Jacob Astor III. As conceived by Hunt, each of the three main entrances to Upjohn's prominent Gothic Revival icon would have a set of paneled doors in the manner of Ghiberti's for the Florentine Baptistery (1401-1422). Trinity's were to be based on the expulsion from paradise. The competition featured many of the most prominent sculptors of the day and produced two other winners, J. Massey Rhind (1860-1936), who would figure prominently in the 1903 Chautauqua renewal, and Charles Henry Niehaus (1855-1935).

Bitter again collaborated with Hunt at the 1893 Chicago Exposition. For the central Administration Building designed by Hunt, Bitter conceived the sculptural program as a vast allegorical composition (fig. 4.28). At the level of the four small corner domes at the base of the large dome crowning the building he placed sculptures representing aspects of modern society: Commerce, Industry, Justice, Religion, War,

\footnotetext{
${ }^{59}$ Ferdinand Schevill, Karl Bitter, A Biography (Chicago: U Chicago P, 1917) 5-7. See also: James M. Dennis, Karl Bitter; Architectural Sculptor, 1867-1915 (Madison: U Wisconsin P, 1967).

${ }^{60}$ Schevill 20.
} 
Peace, Science, and Art. Each of the twelve sculptures on the corner pavilions symbolized an ideal virtue: Charity, Truth, Strength, Abundance, Tradition, Liberty, Joy, Diligence, Education, Unity, Patriotism, and Theology. Bitter also included single figures: The Fishermaid, Neptune, Air, Diana Harvesting, Blacksmith, Chemistry, and Electricity. Groups at the entrances illustrating the basic elements of Water, Air, Earth, and Fire completed the ensemble. ${ }^{61}$

As the director of sculpture for the 1901 Pan-American Exposition, Bitter authored the program, picked the sculptors, and facilitated the creation of the many works displayed. In the overview of the sculptural program that he prepared for the Official Handbook, he clearly delineated his focus on the meanings of the works:

In considering the problem of a scheme of sculpture for the Pan-American Exposition, it seemed that a truly artistic decoration should first of all have a clear, distinct, and well-defined meaning; that the ideas to be expressed and the subjects to be represented should be selected with care and regard for their appropriateness even before questions as to the manner of rendering were considered. ${ }^{62}$

Working closely with the architects to coordinate message and placement, Bitter proposed subjects that told the story of the development of mankind. The allegories were divided into three general categories: tributes to the great natural resources of the

${ }^{61}$ John Joseph Flinn, Official Guide to the World's Columbian Exposition (Chicago: The Columbian Guide Company, 1893) 47.

${ }^{62}$ Karl Bitter, "The Sculpture Plan," Gray 49. Bitter's article also appeared in a slightly edited form as "Sculpture at the Buffalo Exposition," The Criterion 19 May 1901: 14-18. 
Americas, representations of the institutions of governance that "insure a liberal and peaceable enjoyment of such wealth, ${ }^{, 63}$ and depictions of the contributions of what Bitter called the "genius of man. . . Our invention, industry, and ingenuity." ${ }^{64}$ In all, forty-nine artists executed over five hundred sculptures; sculptors included Daniel Chester French (1850-1931), Frederick MacMonnies (1863-1937), Saint-Gaudens, and John Quincy Adams Ward (1830-1910). ${ }^{65}$ To Bitter, the chance to influence positively the lives of the many visitors to the fair through the message permeating the works of art was more important than the style of the various sculptors. He was content that although "a strictly uniform result" would not be the outcome, inasmuch as the training and education of the sculptors varied, the result was "interesting and pleasing."

Bitter directly contributed only a small fraction of the art works. At the main entry to the exposition, a Triumphal Causeway was created to cross the water separating Olmsted's Delaware Park from the main fairgrounds (fig. 4.29). It was decorated with sculpture symbolic of the "national attributes" of the United States and was meant to be welcoming to all visitors. For each of the corners of the causeway, Bitter created a sculptural group entitled "The Standard-Bearers": a pylon featuring a pair of women symbolizing North and South America, holding the shield of the United States, surmounted by a colossal equestrian figure, atop a rearing horse thirty feet tall (fig. 4.30).

\footnotetext{
${ }^{63}$ Karl Bitter, "The Sculpture Plan," Gray 49.

${ }^{64}$ Karl Bitter, "The Sculpture Plan," Gray 50.

${ }^{65}$ For a complete list of the sculptors see Appendix 3, p. 187.

${ }^{66}$ Karl Bitter, "The Sculpture Plan," Gray 53.
} 
The overall height of the group was forty-six feet. Two of the horsemen represented "Peace" and the other two "Power." The message conveyed by these heroic figures was successful triumph over "feudalism, slavery, and subordination to tyrannical power." Peace, with a lyre in one hand and a banner in the other, is emblematic of the peace which is the fruit of such a victory. Power, with a shield and standard is emblematic of the power which such a struggle engenders. ${ }^{67}$

The sculptures were very well received. An early biographer of Bitter, Ferdinand Scheville quotes Saint-Gaudens as saying they "were the best product of the sculptor's art within the confines of the Exposition."

To accomplish the overwhelming task of creating so many works in a short period of time, and ever mindful of the budget, Bitter established a special exposition studio at Weehawken, New Jersey, across the river from New York City. Each sculptor was asked to submit a small-scale model of his work, and Bitter and a team of highly motivated young apprentices fashioned the full-sized copy made of staff. Bitter credits the use of a special pointing machine designed by a young sculptor, Robert T. Payne (1870-1946), for facilitating the accuracy of the reproduction and reducing the cost.

Among the more than eight million visitors crossing the Triumphal Causeway between May $1^{\text {st }}$ and November $2^{\text {nd }}, 1901$, were the attendees of the annual convention of the American League for Civic Improvement held from August $12^{\text {th }}$ to the $15^{\text {th }}$. In his well-known discussion of the turn-of-the-century expositions, “"The White City” and

\footnotetext{
67 "Catalogue of Sculpture," Gray 58.

${ }^{68}$ Schevill 34.
} 
After," League founder and president Charles Zueblin expressed great admiration for what was accomplished in Buffalo. He saw the expositions as models for forwardthinking urban planners. He was particularly impressed with the Buffalo fair's departure from the emphatic unity of the White City of Chicago: the variety in the architecture and the sculpture was more reflective of the "diversified elements" found in modern cities, he opined. "It was individual, picturesque, often even startling. Yet it was entirely harmonious and practical. It demonstrated that there need be no loss of individuality in collective activity ${ }^{\prime \prime 9}$ - still another notion central to civic improvement that was to be borne out in the new design for Chautauqua.

${ }^{69}$ Charles Zueblin, “"The White City' and After," A Decade of Civic Development (Chicago: U Chicago $P, 1905)$ 76-77. 


\section{Chapter 5}

\section{Chautauqua's Master Planners: Albert Kelsey, J. Massey Rhind, and Warren H.}

\section{Manning}

During its October 11, 1902, meeting, the Board of Trustees of the Chautauqua Institution selected a designer for a new master plan. ${ }^{1}$ The board had asked three architects to present ideas - unfortunately, their presentations do not survive. The decision to select a planner must have been contentious, as each candidate had strong support on the board: E. B. Green of Buffalo, who had previously worked with trustees Charles Sweet and Frank Higgins; Sidney R. Badgley of Cleveland, with whom Clement Studebaker and Wilson Day had experience; and Albert Kelsey of Philadelphia, of the American League for Civic Improvement. Although the minutes taken at that meeting do not reflect a rationale, it is likely that the selection of Kelsey was based on his credentials as a popular leader of the Civic Improvement movement. It was subsequently reported in Chautauqua's daily newspaper, The Assembly Herald, that Kelsey had presented Warren H. Manning, a landscape architect, and J. Massey Rhind, a sculptor, as part of his design team (figs. 5.1, 5.2, 5.3). ${ }^{2}$

During the course of their careers, these practitioners fully committed themselves to the goal of Civic Improvement through beautification; however their work over the

\footnotetext{
${ }^{1}$ Minutes of October 11, 1902, Board meeting, 4.

${ }^{2}$ Minutes of October 23, 1903, Board meeting, 10. "The Model Chautauqua. Announcement of
} Plans Prepared by Architect Albert Kelsey," The Chautauqua Assembly Herald 3 July 1903: 3. "Making Chautauqua a Model," Chautauquan Monthly Aug. 1903: 458-460. 
years was expressed in a range of disparate styles. They seemed to find productive the creative tension between formal and informal approaches. Although they were all conversant with the classic academic solution, an examination of a selection of their projects underscores the argument that beautification included stylistic variation.

Kelsey first visited Chautauqua to participate in "Public Beauty Week," August 18-22, 1902, giving a very well received address, illustrated with lantern slides, on Tuesday, August $19^{\text {th }}$ at 8:00 in the evening. His topic was his design for "The Municipal Art and Science Exhibit at the St. Louis World's Fair," the "Model City." This first view of his plans for the exhibit excited the Chautauqua crowd and prompted discussion of the grounds as a permanent model of Civic Improvement. It is clear that Kelsey's status as an acknowledged leader of the Civic Improvement Movement, a board member of the American League for Civic Improvement, the president of the Architectural League, as well as the designer of the "Model City" served him well in the competition to be Chautauqua's master planner.

\section{Albert Kelsey}

Kelsey expressed great admiration for Chautauqua. During the following summer (1903) he spoke again in the Amphitheater, this time to unveil his master plan for the grounds. ${ }^{3}$ A week before his talk, in a Chautauqua Assembly Herald article, he referred to the development of the Chautauqua program as a "successful endeavor and a steadily increasing influence in the cause of public education." He went on to explain that the

\footnotetext{
${ }^{3}$ Kelsey spoke at 8 PM on Saturday, July 18, 1903. "Who's Who, Brief Biographical Sketches of Prominent Persons on the Program Next Week," The Chautauqua Assembly Herald 11 July 1903: 1.
} 
increasing architectural demands of Chautauqua should be met "in a manner befitting the victorious power of the Institution." In his "broad and comprehensive" plan, he hoped to lay out "a tangible extension of beautiful surroundings towards which Chautauqua should gradually conform, and an educational example which could later bear fruit in the local civic endeavors of visitors and students. ${ }^{4}$

As Chautauqua matured from "the tent age to the flimsy wooden age" to what Kelsey described as "a period of permanent construction and orderly growth," his plan would provide the framework. He expressed two main areas of improvement. First, he suggested a goal of compositional clarity. He divided the grounds into centers representing different activities, athletic separate from intellectual. In addition, two main cross axes directed a visitor from each entry to a spine running the length of the grounds. Second, he proposed a sequence of new purpose-built facilities in a lavish, classically inspired style - from an Arts and Crafts complex in the north to a new Hall of Philosophy and Hall of Christ in the south - each facility adding to the beauty of the grounds and expressing the joy of learning. ${ }^{5}$

The son of Albert Warren Kelsey (1840-1921), a scholar and writer, Philadelphiabased Albert Kelsey (1870-1950) was born in St. Louis, Missouri, and moved to Philadelphia as a child. ${ }^{6}$ He received his early training (1894-1895) as an apprentice in

\footnotetext{
4 "The Model Chautauqua," 3.

${ }^{5}$ Albert Kelsey, "The New Chautauqua," House \& Garden Aug. 1903: 51-52.

${ }^{6}$ Albert Warren Kelsey was from Boston and served in the Navy during the Civil War. For
} several years after the war he spent time in Paris, where he was a contributor to the Paris edition of the New York Herald. While living in Montmartre he shared a studio with his friend from Belmont, Winslow Homer (1836-1910). "Golden Wedding for the Kelseys, Naval Veteran and Wife Will Observe 
the office of Frank Furness (1839-1912). He completed his studies at the University of Pennsylvania in 1895, and in 1896 he won the university's fourth annual Traveling Scholarship, which enabled him to spend a year in Europe studying the problems of urban planning. ${ }^{7}$ Upon his return he worked with the firm of Cope \& Stewardson and was active in the T-Square Club Atelier. ${ }^{8}$ Kelsey is best known as a planner and administrator, but he had a successful architectural practice in partnership (fl. 1898-1905) with Robert G. Kennedy (1850-1913) and Frank A. Hays (d. 1930), with whom he designed numerous homes and public projects in and around Philadelphia, including the first plan for the Philadelphia Parkway (later the Benjamin Franklin Parkway). ${ }^{9}$ He was a founder and the first president of the Architectural League of America (1899) and an

Anniversary at Chestnut Hill." Newspaper clipping, Floyd Scrapbook, June 1919, Germantown Historical Society, p. 91. Nicolai Cikovsky, Jr., Winslow Homer (Washington, D.C.: National Gallery of Art, 1995) 393.

${ }^{7}$ The competition for the prestigious scholarship was open to University of Pennsylvania students and to architects under the age of thirty who had practiced in Pennsylvania for at least a year prior to the competition.

${ }^{8}$ Founded in 1885 by Walter Cope (1860-1912) and John Stewardson (1858-1896) and joined by Emlyn Stewardson (John's younger brother, 1863-1936) in 1887, the architectural firm of Cope \& Stewardson was very prolific and influential in Philadelphia at the turn of the century. Masters of the collegiate Gothic style, they designed buildings for the campuses of Bryn Mawr, the University of Pennsylvania, Princeton, and Washington University in St. Louis, among others. They also contributed a wide range of both residential and commercial buildings in a variety of styles to the city of Philadelphia. Cope \& Stewardson (fl. 1885-1912). Philadelphia Architects and Buildings. Web. "The T-Square Club was organized in 1883 with the purpose of stimulating a desire for knowledge of design by means of monthly competitions... The club has ... foster[ed] a spirit of camaraderie and mutual understanding between the architects and their assistants...An atelier in connection with the work of the Society of Beaux Arts Architects is being successfully conducted, and the annual exhibitions of the club are important factors in the artistic life of Philadelphia." Simon Newton Dexter North, Francis Graham Wickware, Albert Bushnell Hart, The American Yearbook, A Record of Events and Progress, 1910 (New York: D. Appleton and Co., 1911) 743.

${ }^{9}$ Hays withdrew from the partnership in 1900 to serve full-time as a faculty member at the University of Pennsylvania School of Architecture. The firm continued as Kennedy \& Kelsey until 1905, when Kennedy retired to Scotland. Kennedy, Hays \& Kelsey (fl. 1898-1900). Philadelphia Architects and Buildings. Web. 
early board member of the American League for Civic Improvement. Beginning in 1905, he teamed with Paul Cret (1878-1945) to develop competition entries, and together they were successful in winning the design competition for the Pan American Union building in Washington, D.C. (1908-1910) (fig. 5.4). ${ }^{10}$ In connection with his Civic Improvement work, he created the "Model City" plan for the 1904 St. Louis World's Fair, the Louisiana Purchase Exposition. $^{11}$

Kelsey and other architects of his generation founded the Architectural League of America as an organization to promote and professionalize the practice of architecture. The first organizing convention, bringing together representatives of architecture clubs around the country, was held June 2 and 3, 1899, in Cleveland. As the first president and as editor of its reports, he became the League's leading spokesperson. In the 1900 report he explained that architecture could be a business, a profession, or an art. "As a business, it involves building; as a profession, it has to do with design and building, and, as an art, it includes the former elements and becomes a vehicle of thought." He was very critical

\footnotetext{
${ }^{10}$ Paul Philippe Cret was born and educated in France. He immigrated to the United States in 1903 and became the head of the architecture department at the University of Pennsylvania, a position he held for thirty-four years. On Cret and the Pan American Union building see: Elizabeth G. Grossman, The Civic Architecture of Paul Cret (Cambridge: Cambridge UP, 1996) and Theophilus B. White, Paul Philippe Cret, Architect and Teacher (Philadelphia: Art Alliance P, 1973).

11 "Making Chautauqua a Model," 458-459. See also: Joshua Lawrence Chamberlain, University of Pennsylvania, Its History, Influence, Equipment and Characteristics, Volume 2, University Sons (Boston: R. Herndon Co., 1902) 216-217. "University of Pennsylvania, General Alumni Society," Alumni Register, October 1900 (Philadelphia: Brown Bros., 1900) 224. George E. Thomas, Jeffrey A. Cohen, Michael J. Lewis, Frank Furness: The Complete Works (New York: Princeton Architectural Press, 1996) 41, 55.
} 
of those older, "eminent" members of the profession who he believed approached architecture primarily as a business. ${ }^{12}$

The convention produced what the organizers termed "two dominant convictions":

First, That the architectural club has an important and unique civic relation, that it may lead its city's development in beauty, and that it may and must interest the public and co-operate with it: and Second, That much as we revere precedent, that it is not honest to follow it blindly, that progress demands of us that we make our work express our civilization as correctly as the works of antiquity interpreted their times, and that our duty is to study conditions and guide development along organic lines, placing Progress before Precedent, and showing our meaning by building our ideals and by solving problems of utility in terms of beauty. ${ }^{13}$

Clearly the goal of the organization was to promote architecture as an art.

For two years, 1900-1902, Kelsey was involved in the planning of a project intended to help Philadelphia take its place among the world's great cities. While featuring existing landmarks; "the Washington Monument, the imposing dome of the Roman Catholic Cathedral and the lofty tower of the City Hall," the plan was to realize a

\footnotetext{
${ }^{12}$ Albert Kelsey, ed., Architectural League of America, Architectural Annual (Philadelphia: The Architectural Annual, 1900) 16.

${ }^{13}$ Kelsey 15.
} 
"road to the park" - the long-held dream of a boulevard to connect downtown

Philadelphia with Fairmount Park. Building on the efforts of the previous thirty years, he helped to organize the "Art Federation of Philadelphia." The new association included prominent representatives of many of Philadelphia's cultural organizations. Their primary focus was the formation of a boulevard committee, and their work led to a proposal, put forward by a member of the technical committee, architect Wilson Eyre, Jr. (1858-1944) and drawn by Kelsey, that called for a tree-lined road to connect the center of the city with the park although interrupted by the existing Logan Square (fig. 5.5). For the plan Kelsey designed a new Soldiers and Sailors Monument with twin spires to expand Logan Square and frame views of the City's landmarks (fig. 5.6). Further discussion led to the formation of a subsequent organization, the "Parkway Association." This new group adopted a modified plan proposed by the architect William J. McAuley (fl. 1884-1904) that clarified the layout (fig. 5.7). As the secretary of the new association, Kelsey prepared an illustrated promotional booklet detailing comparable projects around the world and recounting the development of the Philadelphia Parkway. Participating in a large-scale urban planning process with multiple constituents further prepared Kelsey for his work in St. Louis and Chautauqua. ${ }^{14}$

${ }^{14}$ Albert Kelsey, ed., The Proposed Parkway for Philadelphia: a direct thoroughfare from the public buildings to the Green Street entrance of Fairmount Park: containing a review of the various movements for a diagonal boulevard and the original argument in favor of a plaza before the northern facade of the City Hall (Philadelphia: Parkway Association, 1902) quote p. 18. Herbert C. Wise, "The Boulevard Project in Philadelphia," House \& Garden July 1902, Vol. II, No. 7: 319-323. See also, David B. Brownlee, Building the City Beautiful: The Benjamin Franklin Parkway and the Philadelphia Museum of Art (Philadelphia: Philadelphia Museum of Art, 1989). 
While he was working through his ideas for Chautauqua, Kelsey was also focused on his plan for a "Model City" at the St. Louis Exposition. The following year he was bitterly disappointed with its realization. As he described in the article "A Municipal Exhibit," published in July 1904 shortly after the fair opened, "ample funds, a splendid location and plentiful opportunity were at hand, and the result is interesting and valuable in detail, but, as a whole, it is a failure." He states that the organizers ignored his carefully prepared drawings and that "not one building is located in its true relation to the Town Hall and the Civic Pride Monument."

He describes in detail "what the Municipal Improvement Section at St. Louis might have been," carefully outlining preferred light fixtures and paving surfaces. For Kelsey the exhibit was to have demonstrated what could be done in all communities to promote improvement, even those with limited budgets. He had hoped that the "Model City" would show "that what is most needful in the improvement of municipalities is not more money, but a more intelligent and earnest interest in the subject." The grand scale of the exposition failed to promote his concept that beautification could occur even without the ideal circumstances of the richest architectural treatment. ${ }^{15}$

Two years later Kelsey received a commission from the Chautauqua board to design a substantial multi-use building next to the intersection of the new cross axes. Known as the "Colonnade" building, it was used for retail shops and administration offices, with housing on the third floor (fig. 5.8). The three-story red brick structure features large corner piers and eight double-height sandstone Ionic columns across the

\footnotetext{
${ }^{15}$ Albert Kelsey, “A Municipal Exhibit," Architectural Review 11 (July 1904) 185-188.
} 
front. The monumental scale of the new building dwarfed the existing structures in the immediate area. The decision to build it of brick reflected Kelsey's desire for a sense of permanence for future additions to the Chautauqua landscape of public facilities. His use of traditional classic elements connected Chautauqua to an image of iconic status.

Two subsequent major projects, the Haddington Branch of the Free Library of Philadelphia and the Carson College for Orphan Girls, both begun in 1912, further illustrate the range of Kelsey's skill as a designer. For the Haddington Branch project, he imaginatively adapted a beaux-arts classical idiom to great effect (fig. 5.9). The building, of red brick and with white trim, was recognized by a contemporary critic as having a "Georgian colonial feeling" and described as an example of "the "Architecture of Humanism' - the style of the Renaissance, modified to conform with the characteristic local Philadelphia architecture." ${ }^{\prime 6}$ A broad set of steps leads to an unusual entry. Instead of the typical columns and portico, Kelsey, perhaps influenced by his work with Cret, chose as the central feature of the façade a double-height open archway (fig. 5.10). This thirty-foot archway protrudes in a half-round of brick from the front door and creates a light-filled, welcoming vestibule. The plan of the library is a large inverted T with a 104foot-long main reading room across the front and a children's room on the perpendicular axis toward the back. The light from the vestibule filters through a large, round, arched glass system into which the paired front doors are set. It illuminates the reading room

\footnotetext{
${ }^{16}$ C. Matlack Price, "Haddington Branch, The Free Library of Philadelphia, Albert Kelsey, Architect," Architectural Record, Volume 40, July-December 1916 (New York: Architectural Co., 1916) 48.
} 
and is visible even in the children's room. With unifying windows and a stringcourse to tie the composition together, the library reads as a dignified, harmonious whole.

The Carson College for Orphan Girls, by contrast, was to be read as a "rambling English village" (fig. 5.11). In this project, drawing perhaps on his experience as an apprentice in the Furness office, he conceived of the project as a series of distinct yet attached cottages, each in a playful English country vernacular. His hope was that the built environment of the school would encourage individuality. The program included an administration building, a gymnasium, an auditorium, classrooms, and multiple dwellings in which small groups of the girls would live as families rather than in a large dormitory. All of the facilities surround an open court and are "scattered along a winding road.",17 The home for orphan girls was the dream of Robert Carson of Philadelphia, who left $\$ 5,000,000$ in his will for its creation. The funds became available upon the death of his widow in $1912 .^{18}$ Although the Carsons were childless, they believed that they could make an important contribution to society if orphaned girls were able to live in an appealing, nurturing home/school from the ages of six or eight until eighteen. In his use of local stone, half-timbering, and shingle roofs, Kelsey believed that he was creating an atmospheric, beautiful setting to encourage the girls' imaginations. Whether monumental or modest, Kelsey's projects all served to improve the built environment.

${ }^{17}$ To further encourage individuality, uniforms were not permitted, and a school rule specified that no three orphans could dress alike. "Where No Three Orphans May Dress Alike, Girls in Carson College to be Saved from Deadly Sameness - An Architect's Original Interpretation of a Rich Man's Vision," New York Times June 11, 1916.

18 "College for Orphan Girls. Estate of \$5,000,000 Left by Robert Carson of Philadelphia New Available," New York Times, July 5, 1912. 


\section{J. Massey Rhind}

Perhaps inspired by the work of Karl Bitter, the sculptural program director of the Pan-American Exposition, Kelsey suggested that the sculptor J. (John) Massey Rhind (1860-1936) join the Chautauqua design team. ${ }^{19}$ Rhind's concepts for the 1903 Chautauqua plan included three main groups of sculptures, each designating a central gathering place. The first was to be at the new main auditorium in the center of the grounds and the intersection of the new axes — what Kelsey called the "beating heart of civic life" on the grounds. Here Rhind proposed a grouping of iconographic complexity. In the center of a circle inlaid in a stone plaza, a central bronze of an idealized female figure of "heroic size," representing Education, was to be "seated on the throne of knowledge and bestowing a laurel wreath upon the ages." Around her in the circle were to be images of the twelve signs of the zodiac, to imply that although Chautauqua was a seasonal community, her gifts were a reward in every month of the year. ${ }^{20}$

The second group of figures was to flank a new monumental staircase, "three hundred and seventy-five feet in length and one hundred feet wide," leading from the pier entry and Miller Park up to the new auditorium. Here Rhind suggested allegorical sculptures in marble depicting the work of the Institution: one was "Christianity supported by Science and Literature," and another was "Summer Rest, Home Study and

\footnotetext{
19 "Making Chautauqua a Model," 458-460.

${ }^{20}$ Kelsey, "The New Chautauqua," 51.
} 
Athletics." He felt that these could give an effective synopsis of the Chautauqua idea for new visitors to the grounds. ${ }^{21}$

The last grouping was to be a "Fountain of Triumph" on the flat plane adjacent to the Hall of Philosophy. Having completed their four-year directed course of study, the Chautauqua Literary and Scientific Circle (CLSC) graduates were encouraged to come to the Chautauqua grounds to participate in a graduation ceremony. In the Kelsey/Rhind conception, the elaborate ceremony would begin with an entry from the water through a new lakefront propylea. The graduates would process up to the Hall of Philosophy through the elaborate Golden Gate, there to receive the wisdom of speakers and be awarded diplomas. After the ceremony, the gathered would make their way to an "open air informal meeting" at the Fountain. And as described by Kelsey, the graduates and their friends, coming from the tension of the ceremonies within the temple into the freshness and brilliancy without, would find an outward symbol of their joy in this inspiring group and in the sight and sound of running water. ${ }^{22}$

For reasons to be noted below, his inspired sculptural program was never realized.

The New York City-based Rhind had extensive experience with creating large public decorative sculptures: his work adorns Grant's Tomb and the Exchange Court Building in New York, Fairmount Park in Philadelphia, and the Farmer's Bank building

\footnotetext{
${ }^{21}$ Kelsey, "The New Chautauqua," 52.

${ }^{22}$ Kelsey, "The New Chautauqua," 56.
} 
in Pittsburgh, among others. ${ }^{23}$ He had emigrated from Scotland to America at the age of twenty-nine. ${ }^{24}$ A third generation sculptor, he received his early training from his father, John Rhind (1828-1892), who enjoyed a successful career as a classicist based in Edinburgh. The younger Rhind continued his training under the tutelage of (Aimé-) Jules Dalou (1838-1902) in Lambeth, England, where Dalou, a French master of Rodininspired post-classicism and a supporter of republican political causes, had taken refuge in 1871. Under Dalou, Rhind expanded his technique beyond the strict classicism of his early training. With Dalou's return to Paris in 1879, Rhind went to the Royal Academy, receiving three gold medals in one year, "the first student who ever scored such a success." ${ }^{25}$ With the encouragement of the president of the Royal Academy, Sir Frederick Leighton, Rhind joined Dalou in Paris for another two years of study. Once back in England, Rhind met and married the daughter of Hugh Barclay, a well-known Glasgow-based architect. Despite his father's admonition to the contrary - "There is no sculptural art in America ... You'll starve" - Rhind and his new bride left for New York in $1889 .^{26}$

Fortunately, the timing of Rhind's arrival in New York coincided with the advent of Civic Improvement and the acceptance of the plastic arts as an important component of

23 "Making Chautauqua a Model," 460.

${ }^{24}$ Although the outline of Rhind's biography is consistent, the details vary among the secondary sources. I have primarily relied on N. MacDonald, "A Genius of the Chisel," Munsey's v.14, March 1896: $671-679$.

\footnotetext{
${ }^{25}$ MacDonald 672.

${ }^{26}$ J. Massey Rhind. Wikipedia. Web.
} 
beautification. His skill as a sculptor was acknowledged when, along with Charles Henry Niehaus (1855-1935) and Karl Bitter (1867-1915), he was selected in early 1891 to design a set of bronze doors for New York's Trinity Church as a memorial to John Jacob Astor III. Rhind's design was a series of panels illustrating scenes from the Bible, including "The Expulsion of Adam and Eve," in the manner of Ghiberti's famous doors for the Florentine Baptistery (fig. 5.12) ${ }^{27}$

By 1893, Rhind, already considered a major sculptor, was selected to create a fountain in Washington Park, in Albany, in memory of New York Senator Rufus H. King. Sculptor John Quincy Adams Ward (1830-1910), functioning as a consultant, had asked Rhind to participate in a competition with Daniel C. French (1850-1931), Ephraim Keyser (1850-1937), and Charles Niehaus. The decision to select Rhind was made by members of the King family and a committee of luminaries in the art world, including Ward, architect Richard M. Hunt, and Daniel Huntington, then president of the National Academy of Design. ${ }^{28}$

The fountain depicts the story from Exodus (17:6) of Moses smiting Mount Horeb and bringing forth water to quench the thirst of the Israelites (fig. 5.13). The image of Moses as caregiver suited the Senator's memorial, in the eyes of his family. In Rhind's fountain, Moses is shown standing astride the rock of Horeb, poised to strike. The people of Israel, reaching for the water, are represented in different stages of life by four separate sculptures (figs. 5.14, 5.15, 5.16, 5.17): a mother with two children ("Childhood"), a

\footnotetext{
${ }^{27}$ MacDonald 674.

28 "Rock of Horeb In Bronze, The Beautiful King Fountain Which Adorns Albany," New York Times 1 Oct. 1893.
} 
maiden with a water urn ("Youth"), a man with a sword ("Manhood"), and an old man leaning on his staff ("Old Age"). ${ }^{29}$ The style of the fountain is a study in contrasts. The large rock, quarried nearby, was left with a rough-hewn finish. The naturalistic bronze figure of Moses, ten feet tall and arms outstretched, dominates the composition. The other four bronzes are life-sized and negotiate the base of the rock to seek water. These figures reflect Rhind's exposure to the expressionistic style of Rodin and Dalou. They are dynamic, gestural images portrayed in the moment of life's actions - nursing a child, carrying a jug of water, and supporting oneself on a staff, bent with old age. The fountain was very well received. The reviewer for the New York Times commented that the novel juxtaposition of rough-hewn rock and bronze was a "successful combination."30 Another reviewer at the time wrote, "For originality and dramatic effect, there is nothing in America to surpass it." ${ }^{\prime 31}$

In a work of beauty, the subject of Moses, the lawgiver, as a giver of lifeaffirming sustenance underscores the connection between morality and aesthetics that was central to Civic Improvement. Earlier in the century, Thomas Cole explained in his influential Essay on American Scenery of 1835, "There is in the human mind an almost inseparable connection between the beautiful and the good, so that if we contemplate the one the other seems present. ${ }^{, 32}$ Reformers of the Progressive Era believed that the

\footnotetext{
29 "Rock of Horeb In Bronze."

30 "Rock of Horeb In Bronze."

${ }^{31}$ MacDonald 675.

${ }^{32}$ Quoted in John W. McCoubrey, American Art 1700-1960, Sources and Documents (Englewood
} Cliffs, NJ: Prentice-Hall, 1965) 99. 
inclusion of beauty in daily life would ameliorate many of society's problems. To these reformers, the definition of beauty was open to significant stylistic variety. The Civic Improvement movement combined religious social sanctification through an activist civic church, societal improvement through education, and the inspiration of a beautiful setting.

As the nineteenth century drew to a close, infill projects were begun in many states to beautify the built environment. These interventions included green spaces such as Chautauqua's Plaza and urban parks such as Albany's Washington Park, often featuring a comprehensive program of monuments and water features. ${ }^{33}$ The sponsors of the parks believed that the designed open spaces would function as an inspirational respite from the intensity of urban reality. Another type of metropolitan infill project was the lavish civic building. ${ }^{34}$ The desire for inspirational settings combined with a rising sense of civic pride led city governments to develop a diverse array of glorious Beaux Arts civic projects including courthouses, post offices, libraries, city halls, and state capitol buildings. In homage to the classical style, the designers of these projects frequently included an allegorical sculptural program.

A third type of Civic Improvement project became popular as business leaders chose to express their sympathy with reform ideals by building beautiful new corporate headquarters. Bruce Price's (1845-1903) American Surety Building (1894-1896), with

${ }^{33}$ William H. Wilson, The City Beautiful Movement (Baltimore: Johns Hopkins UP, 1989) 36-43.

${ }^{34}$ Michele H. Bogart, Public Sculpture and the Civic Ideal in New York City, 1890-1930 (Washington: Smithsonian Institution Press, 1997) 6 and entire. 
sculptures by Rhind, was an exemplar of this new urban typology, a beautiful tall corporate building with a strong moral message (fig. 5.18). Price's design popularized the translation of the classical tripartite column into a tall building. ${ }^{35}$ Working with an irregular corner site, Price divided each façade into a three-story base, a twelve-story shaft, and a six-story cap. He treated the fourth and fifteenth stories as transitional. The base features a five-bay-wide portico - a double-height Ionic colonnade with six fluted columns, which supports an entablature with a foliate frieze. Above the entablature is the fourth story, an attic comprised of six Rhind sculptures — one above each column - that alternate with windows. A bandcourse completes the base. The walls of the midsection are subdivided into seven rows of rectangular windows and read as banded piers with vertical strips framing the windows. The elaborate six-story cap begins with a stringcourse, which supports a colossal colonnade of Corinthian pilasters surmounted by a prominent stone cornice and a crowning parapet of gilded metal acroteria. ${ }^{36}$

Remarkably, Price treated each of the four sides of the tower the same, even though the building was not freestanding. He said, "The most fortunate thing in connection with [the American Surety Building] is the making of four exposed sides

\footnotetext{
${ }^{35}$ Precedents include Adler \& Sullivan's Wainwright Building, St Louis (1890-91), Post's
} Havemeyer Building (1892, demolished), and Harding \& Gooch's Postal Telegraph Company Building, 253 Broadway, NY (1892-94).

${ }^{36}$ In 1920-22 a significant addition designed by Herman Lee Meader added four bays on both the Broadway and Pine Street sides of the building and added two penthouse stories, which dramatically increased the rentable space. These additions obscured many of the original details. This description is based on observation of drawings and photographs of the original building and the Landmarks Preservation Commission Report, dated June 24, 1997; Designation List 283, LP-1934. 
entirely alike, a thing which had not been previously done in New York."37 He believed that as the newly developing skyscraper form would tower over the adjacent cityscape, architects should carefully consider its relationship to the surrounding buildings. His conception for the American Surety was "a campanile with four pilaster faces, the seven flutes being represented by seven rows of windows." His conclusion was that "the tower solution is the only artistic solution to the problem of high design." ${ }^{\text {38 }}$ The new form of the beautiful tower was intended to have a positive influence on the lives of New Yorkers. Price hoped that the building would function as beautiful inspiration for employees and passers-by. It would also act as a symbol of the sensitivity of the management of the American Surety Company to the social agenda of the Civic Improvement Movement.

To complete the artistry of the composition, Price included a striking sculptural program by Rhind. ${ }^{39}$ His six Maidens top Price's grand Ionic entry portico. The "sisters" represent allegorically the qualities of peace, truth, honesty, fortitude, self-denial, and fidelity. The allusion to the Erechtheion is obvious, but in "the little old temple behind the Parthenon," the caryatids are fully sculpted in the round and are weight-bearing. ${ }^{40}$

${ }^{37}$ Quoted in Barr Ferree, "A Talk with Bruce Price," The Great American Architects Series, Architectural Record, 5 (June 1899) in Great American Architects Series Nos. 1-6; May 1895-July 1899 (rpt. New York: Da Capo, 1977) 75.

${ }^{38}$ Ferree 76.

${ }^{39}$ In the years before Price's project, similar sculptural embellishment was employed, particularly in Europe, but on much shorter buildings. Examples include, Henri Rieek (arch) and Auguste Rodin (sc), Cornelis Building, Brussels, 1872, and Ballu and Deperthes (archs) with 230 various sculptors, Hotel de Ville, Paris, 1873-92. See Penelope Curtis, Sculpture 1900-1945, After Rodin (New York: Oxford, 1999).

${ }^{40}$ MacDonald 675. 
Rhind's figures, in contrast, are each posed on a low plinth in front of a pilaster; they stand erect, their faces impassive. The differences between them are limited to symbolic accoutrements, arm position, stance, and drapery. It was important to him that the figures be incorporated into the architecture:

I have tried, as far as possible, and where the subject would permit, to compose them as though they were a part of the building, rather than as a decoration or addition; in this way keeping the figures, in pose and drapery, in accord with the architectural line of the building proper. ${ }^{41}$

The folds in the drapery of all of the figures, while quite lush and fully articulated, are emphatically vertical and echo the flutes of the Ionic columns below (figs. 5.19, 5.20). His effort to incorporate the sculpture and the architecture was admired by contemporary

\footnotetext{
${ }^{41}$ J. Massey Rhind, "Proposed Treatment of Figures to be Placed on the American Surety Company's Building," American Architect and Building News 25 May 1895: 83. In Rhind's original conception, the six figures were to be read from left to right as new symbols of "Progress." "Fidelity" is first, her hands clasped together in front of her body, suggesting "faith given and received." "Science" is next, holding representations of electricity, to Rhind "the greatest [scientific phenomenon] of all, both as a means of progress, and consequently, a benefactor to man." "Manufacture," an important aspect of economic progress, is next to the figure that represents "Peace." She is shown holding a "reaping hook" in her right hand, "pressing against the drapery," and a stalk of "Indian-corn" in her left. To Rhind, this figure connected to modern agriculture - she symbolized "the Goddess of Prosperity" — and so he substituted the modern crop for the classical "conventional wheat sheath." "Art" is represented as a sculptress holding a mallet in her right hand and a small "finished figure" in her left. "Fortitude," on the far right, is depicted with hands clasped in front of her resting on the hilt of a sword. This figure, which Rhind also refers to as "Surety," most clearly represents the corporate entity responsible for the project. The American Surety Company was in the business of providing surety bonds, a type of performance insurance for individuals and corporations. Rhind saw this important business function as a last line of defense - his figure suggests strength and solidity. When completed, the images of Science, Manufacture, and Art were replaced with the more classically derived concepts of Truth, Beauty, and Self-denial. The Meader enlargement of the American Surety Building necessitated significant reworking of the original sculptures, including the addition of two at the south end.
} 
critics. N. MacDonald, writing for Munsey's Magazine, expressed the view that "his work gains by the harmony."42

Stylistically, the figures in the American Surety ensemble are quite different from the women depicted at the King Memorial fountain. The range of styles can be read as symbolic representations of different modes of beautification. Where the Surety Maidens are erect and architectonic, the figures at the fountain are portrayed in naturalistic action. Part of the explanation lies in their material (stone versus bronze) and architectonic function, but even more important is the difference in the allegorical message being conveyed - indeed, at the time "the most common manifestation of the ideal woman in American art was as allegory, symbol, or metaphor." ${ }^{, 43}$ The figures at the King fountain express four different stages of life - a life of struggle, triumph, decline, and renewal. The Maidens, in contrast, represent women as ideal figures. These Maidens would never raise children or fetch and carry water. As a critic of the time suggested, they are not expected to participate in the business conducted in the Surety Building or even to play the role of inspirational spouse - the woman behind the man. They are instead purely decorative symbols of ideal attributes. $^{44}$

A few years later Rhind was asked to contribute a very similar grouping for the front of the Park Row Syndicate Building (1896-1899) just six blocks north. The

\footnotetext{
${ }^{42}$ MacDonald 675 .

${ }^{43}$ On the "Ideal" representation of women at the turn of the twentieth century, see Bailey Van
} Hook, Angels of Art, Women and Art in American Society, 1876-1914 (University Park, PA: Penn State UP, 1996) 90 .

${ }^{44}$ Elizabeth E. Newport, "Kindred Spirits After All," The Art Interchange 41: 50-51. 
developer for the speculative office building was a syndicate led by the entrepreneur reformer August Belmont, Jr. (1851-1924). ${ }^{45}$ Although best known as an avid thoroughbred horseracing supporter - the famed Belmont Stakes race was named for his father - Belmont shared the goals of the Civic Improvement Movement. He is credited with many important contributions to the quality of life of New York City, including the establishment of the Interborough Rapid Transit subway line, the creation of Belmont Park, and the development of the Park Row Building. ${ }^{46}$

Unfortunately, Belmont's architect for the building, Robert Henderson Robertson (1849-1919), designed a mid-block infill skyscraper with little of the elegance of Price's building. Robertson borrowed the tripartite composition but made no effort to articulate the side or back walls. He also substituted a pair of rather awkward cupolas for Price's powerful cornice. At twenty-nine stories — twenty-six floors and three-story cupolas the Park Row building held the record as the world's tallest building for nine years (fig. $5.21)$.

Although Robertson's structure does not share the classical reference of the Surety portico, he included a row of four of Rhind's "Maidens" at the fourth floor (fig. 5.22). For this project Rhind named the figures Wisdom, Calculation, Energy, and Courage, attributes which represent "essential factors that go to make up the character of a successful business man of the finest type." ${ }^{, 47}$ Each of the sculptures is set on a

${ }^{45}$ The Park Row Building. New York Architecture. Web.

${ }^{46}$ Christopher J. Cyphers, The National Federation and the Making of a New Liberalism, 19001915 (Westport, CT: Praeger, 2002) 33.

${ }^{47}$ Newport 50 . 
decorative stone bracket attached to the façade of the building. Rather than solely emphasizing their architectonic qualities, Rhind has sculpted more fully developed, freestanding figures in the round. Perhaps for this reason they appear to be more expressive than their counterparts down the street. But as at the Surety building, these women are largely undifferentiated ideal allegorical types, with small, subtle differences. Each of the women is posed holding a different symbolic element: Courage, a sword; Energy, a lamp; Wisdom, a Cobra; and Calculation, a quill pen and scroll. An observer at the time discovered far greater variations in body type and facial features. Her favorite was "Calculation...the noblest of the four," in whose face she saw "superior intelligence...with a tense look of reckoning, but in profile it appears girlishly innocent and lovely." ${ }^{48}$ Robertson's building was not well received, but Rhind's contribution was judged successful. "In this group [of sculptures,] success springs from a nobleness of educated yet strongly individual thought, and skill to interpret this thought purely, sanely and simply. ${ }^{, 49}$

As the Park Row project neared completion, Rhind was asked to contribute sculptural elements to the new Wayne County Court House in downtown Detroit, a glorious example of a Civic Improvement building (fig. 5.23). The Detroit based architectural firm of John and Arthur Scott and Company designed the massive four-story Beaux-Arts structure. Begun in 1896, the lavish monument to civic excess - "the most sumptuous building in Michigan" - took six years to complete and cost over

\footnotetext{
${ }^{48}$ Newport 50.

${ }^{49}$ Newport 51.
} 
$\$ 1,600,000 .^{50}$ It was part of a grand planned intervention to widen a downtown cross street into a boulevard, with the courthouse as a terminating focal point for the new Cadillac Square.

The baroque fantasy of a composition includes a grand central staircase that leads to a monumental Corinthian portico. The lower two stories are covered with rusticated granite, and the upper three stories are of Ohio sandstone that matches a four-tiered tower replete with a Corinthian colonnade. The tower is topped with a gilded cupola. At the base of the tower, emphasizing the boundaries of the entry portico, Rhind designed two heroic quadrigas (but with three horses) representing "Progress" (fig. 5.24). The virtually identical sculptures of bronze are active compositions composed of an idealized female figure with a flowing gown, astride a chariot propelled by three "wild steeds." The horses are led by two partially clothed youths. The image of Progress, presented as barely contained but harnessed energy, is in sympathy with the opulence of the grand statement of the civic architecture. At the turn of the century, Detroit and Wayne County were enjoying very rapid economic development. ${ }^{52}$

In these mature works, Rhind combined the classical with the expressionistic. The idealized women are very close in style to the New York "Maidens;" they are quite

${ }^{50}$ W. Hawkins Ferry, The Buildings of Detroit, A History (Detroit: Wayne State UP, 1980) 210.

${ }^{51}$ Roger B. Stein, "Charles Willson Peale's Expressive Design: The Artist in his Museum," Marianne Doezema and Elizabeth Milroy, eds. Reading American Art (New Haven: Yale UP, 1998) 76, N54.

${ }^{52}$ On the growth of Detroit and Wayne County see Olivier Zunz, The Changing Face of Inequality: Urbanization, Industrial Development, and Immigrants in Detroit, 1880-1920 (Chicago: U of Chicago $\mathrm{P}, 1982$ ). 
stiff and impassive. The men, in contrast, are depicted in full stride, and the horses are exciting bundles of muscular movement. Rhind's ability to sculpt in a wide range of styles was appreciated during his career. He enjoyed critical acclaim whether working in the classical mode of his early training with his father, as at the Surety and Park Row Buildings, or in the more expressive style of Rodin he learned while working with the French master Dalou, as at the Wayne County Court House and the King Memorial. His work was termed excellent and "admirably contained and unified;" $; 3$ he was referred to as a "genius of the chisel." ${ }^{154}$ His work was also appreciated as making a significant contribution to the improvement of the health of cities. "The assistance of Mr. Rhind and his kind proves past question that we of America are fast learning the lessons taught by education and refinement." ${ }^{\prime 55}$ The hope of critics and reformers of the time was that the transformation of the environment through the inclusion of works of beauty would hasten moral reform.

\section{Warren H. Manning}

The third member of the design team for Chautauqua, Warren H. Manning (18601938), was born in Reading, Massachusetts, to Jacob Warren Manning, a nurseryman, and Lydia Manning, a watercolorist. In later years he credited his mother with his lifelong commitment to "making America a finer place to live,"

\footnotetext{
${ }^{53}$ John A'Beckett, "A Scotch-American Sculptor," The Art Interchange 48: 85.

${ }^{54}$ MacDonald 671.

${ }^{55}$ A'Beckett 86.

${ }^{56}$ Quoted in Robin Karson, The Muses of Gwinn: Art and Nature in a Garden Designed by
} Warren H. Manning, Charles A Platt, \& Ellen Biddle Shipman (New York: Sagapress, Inc., 1995) 21. 
gained an expertise in horticulture and planting design. In 1888 he joined the firm of Frederick Law Olmsted, Sr., in Brookline, Massachusetts, where he was in charge of the firm's planting plans, working on hundreds of major projects around the country, including the World's Columbian Exposition in Chicago and park systems in most major cities. Manning also specified the planting plans for numerous private homes, including the Biltmore in Asheville, North Carolina (1888-1895). In 1896, after eight years with Olmsted, Manning established his own office, believing that the firm would eventually be under the direction of Olmsted's sons. During the next forty-two years he became a major figure in the history of landscape architecture ${ }^{57}$ not the least of his contributions was the training of many of the best landscape architects of the next generations, including Charles Gillette (1886-1969), Dan Kiley (1912-2004), and Garret Eckbo (1910$2000)^{58}$

From early on in his career, Manning believed that exposure to the beauty of an improved landscape would positively impact the quality of life.

The chief purpose of a park is to provide a place where the feeble, the sick and those wearied and worn by fatiguing labor, or close application to

${ }^{57}$ Among his many accomplishments as a mature landscape practitioner, Manning contributed an early appreciation of Thomas Jefferson as a landscape designer, in collaboration with the then supervisor of the University of Virginia buildings and grounds, William A. Lambeth. Their book, Thomas Jefferson as an Architect and a Designer of Landscapes (Boston: Houghton Mifflin, 1913), helped to rekindle interest in Jefferson and early American classical architecture. The volume included a master plan drawn by Manning for the extension of the University grounds.

${ }^{58}$ Robin Karson, "Warren Henry Manning (1860-1938), landscape architect, horticulturist, planner, author," Pioneers of American Landscape Design, Charles A. Birnbaum, Robin Karson, eds. (New York: McGraw-Hill, 2000) 236-242. See also: Robin Karson, The Muses of Gwinn: Art and Nature in a Garden Designed by Warren H. Manning, Charles A Platt, \& Ellen Biddle Shipman (New York: Sagapress, Inc., 1995). 
business, or studies, or the excitement and noise of busy city streets, can secure an entire change of scene and be refreshed by the quiet enjoyment of secluded rural landscapes, and of the details of the trees, shrubs and flowers, that are combined to form such a scene; and in their proper place, the more showy garden-like formal arrangements of exotic and garden plants. $^{59}$

Armed with this conviction and perhaps feeling slightly isolated in his own firm, Manning was instrumental in founding two important organizations, the American Park and Outdoor Art Association (1897) and the American Society of Landscape Architects (1899). He first suggested that landscape architects needed a professional association in a letter to fellow Olmsted apprentice Charles Eliot (1859-1897). ${ }^{60}$ In rebuffing his inquiry, Eliot argued that there were simply too few active professionals and proposed instead a "general association, to be made up of all who desire the advancement of landscape art." ${ }^{, 61}$ Manning followed through on Eliot's suggestion, and in May 1897 he

\footnotetext{
${ }^{59}$ Warren Manning, "The Purpose and Practice of Landscape Architecture," Transactions of the Indiana Horticultural Society for the Year 1893, Being a Report of the Thirty-Third Annual Meeting, Held in the City of Indianapolis, November 8, 9 and 10, 1893, Together With Reports of Local Societies, Selected Papers, Etc., Etc. W. H. Ragan, Secretary, (Indianapolis: Wm. B. Burford, Contractor for State Printing and Binding, 1894) 102-103.

${ }^{60}$ See Norman T. Newton, Design on the Land, The Development of Landscape Architecture (Cambridge, Massachusetts: Belknap P, 1971) 385-392.

${ }^{61}$ Charles William Eliot, Charles Eliot, Landscape Architect (Boston: Houghton Mifflin, 1902) 703. This poignant biography, written by a father for his son, describes a practitioner fully committed to the goal of improvement. The subtitle of the book reads "A lover of nature and of his kind, who trained himself for a new profession, practiced it happily, and through it wrought much good."

Despite his tragic death at age thirty-seven, Eliot holds an outsized position of influence in the history of landscape architecture. He pioneered the resource-based design method used to great effect in the development of the Boston Municipal Park System. His writings in support of landscape preservation, published most often in the influential magazine, Garden and Forest, were instrumental in the establishment of the Massachusetts Trustees of Public Reservations (1891), the first land preservation
} 
and landscape architects John C. Olmsted of Boston and George E. Kessler of Kansas City, as well as a large group of commissioners, superintendents, designers, and park officials, met in Louisville, Kentucky, to found the American Park and Outdoor Art Association (APOAA). Louisville was then constructing a new park system designed by the Olmsted firm and was at the center of the park movement. ${ }^{62}$ Manning was elected secretary, and in the report he compiled after the first meeting summarized the goal of the organization:

For the purpose of promoting the conservation of natural scenery, the acquirement and improvement of land for public parks and reservations, and the advancement of all outdoor art having to do with the designing and fitting of grounds for public and private use and enjoyment. ${ }^{63}$

Where the American League for Civic Improvement (ALCI) had begun as a grass-roots movement supported by the Home and Flowers magazine published by D. J. Thomas and had attracted experts over time (Kelsey, for example, joined during the second year), the APOAA's founders were landscape and park specialists, and in their efforts to broaden their base and extend their influence they offered their expertise to newer organizations such as the ALCI. Through their interaction, the groups found that

organization, and the Boston Metropolitan Park Commission (1893). See also Newton 318-336, and Keith N. Morgan, "Eliot, Charles (1859-1897) landscape architect," Pioneers of American Landscape Design, Charles A. Birnbaum, Robin Karson, eds. (New York: McGraw-Hill, 2000) 107-109.

62 Jon A. Peterson, The Birth of City Planning in the United States, 1840-1917 (Baltimore: Johns Hopkins UP, 2003) 116.

${ }^{63}$ First Report of the Park and Outdoor Art Association (Louisville, Kentucky: Park and Outdoor Art Association, 1897) iii. 
"outdoor art" included all aspects of beautification — parkland management was as important as sculptural programs and advertisement regulation. After several years of discussion, the two groups' close association led to a merger consummated at the St. Louis Louisiana Purchase Exposition of $1904 .^{64}$

Manning continued to advocate for an organization of landscape professionals, however. He found a sympathetic collaborator in Samuel Parsons, Jr. (1844-1923) of New York City, who had been a partner of Calvert Vaux and was engaged as the landscape architect to the expanding City of New York. Parsons had also explored the idea of a professional association, as early as February 1898. By the end of that year Manning joined him in New York for a preliminary meeting. This time Manning was able to convince the Olmsted brothers to participate, and on January 4, 1899, the three Boston-based landscape architects joined eight others in New York to found the American Society of Landscape Architects. Not unexpectedly, the background and experience of the eleven "original Fellows" in this nascent profession varied widely. None had formal academic training in landscape architecture; their backgrounds ranged from civil engineering to nursery and design apprenticeships. Their preferred styles also differed, some emphasizing geometric "formal" designs and others a more "natural" curvilinear effect and native woodland plantings. Despite their varied approaches, all

${ }^{64}$ "Proposed Merging of Civic Organizations," Municipal Journal and Engineer Vol. XVI, No. 6, June, 1904: 272. See also: Wilson 50. 
were active in the Civic Improvement movement; all shared the belief that they were contributing to a beautified environment. ${ }^{65}$

Manning's designs reflect a flexibility born of resolving the frequent conflict between a respect for existing natural surroundings and a client's wish for perceived symbols of status. To begin a project, he first took inventory of the existing conditions — a resource-based design method built on the pioneering work of Charles Eliot in Boston. Although Manning preferred a naturalistic style that featured native plants (fig. 5.25), his pragmatic approach to design often featured more formal elements. Drawing on his experience in the Olmsted office, he created landscapes that combined both the rectilinear Italian and French style and the lessons of English-style picturesque environments found in projects like the brilliant Central Park and the Biltmore. ${ }^{66}$ The resulting combination of elements frequently resulted in a complex yet harmonious landscape environment (fig. 5.26).

For Chautauqua, Manning inclined toward the natural and focused on the existing stands of mature trees. Having thoroughly examined the grounds, he concluded that although there were many "discordant architectural features," the trees served to "harmonize. .. They frame in attractive views and shut out unattractive ones at many points; they give a beautiful dappling of light and shade on what would otherwise be unattractive bare walls and raw surfaces." His plan, therefore, did not involve a

\footnotetext{
${ }^{65}$ Newton $387-391$.

${ }^{66}$ On Central Park see Newton 267- 289. See also Paula Ann Mohr, "A Artificial Constructions' and Object Lessons in a Sacred Landscape: The Art and Architecture of Central Park, 1858-1880" (Diss. UVA, 2007). On the Biltmore see Newton 346-351.
} 
wholesale destruction of the trees; instead it was carefully adjusted to the existing conditions and called for a "small amount of cut and fill." In many cases he suggested repositioning younger specimens to obtain a greater effect (fig. 5.27). To further screen what the designers deemed unacceptably "untidy" backyards and "blank" walls, Manning proposed "a continuous belt of shrubs or vines on fences." over time the natural beauty of the grounds.

The Kelsey/Manning/Rhind plan influenced the rebuilding of the Chautauqua grounds for many years. Their organizational scheme of bisecting avenues gives clarity to the experience of a visitor. Whether one arrives by boat at the pier or at the Main Gate, a path leads directly to the Colonnade Building and the Plaza. A second path runs the length of the grounds from the Arts and Crafts Quadrangle (and other fine and performing arts facilities) located at the north end to the Plaza and the Amphitheater in the middle and on to the Hall of Philosophy at the south. Manning's beloved trees were nurtured and protected, lending a charming shade canopy throughout. Chautauqua's donors focused their energy on new infrastructure and facilities for the presentation of programming. As a result, unfortunately, Rhind's sculptural program, of all the proposals, received the least support and was never realized.

Despite the exclusion of the sculptures, a visitor to the summer season of Chautauqua still experiences an inspiring place that is the built expression of the extensive scope of Civic Improvement pursuits. The programs still include a mix of presentations from forward-thinking reformers and performances of beautiful secular and

\footnotetext{
${ }^{67}$ Quoted in Kelsey, "The New Chautauqua," 56.
} 
sacred music. The buildings, both private and public, represent a harmonious blend in a wide variety of tastes and styles. And the physical setting of the homes, hotels, and presentation venues continues to combine an eclectic mix of formal landscapes and natural environments. 


\section{Chapter 6}

\section{The Evolution of the Model Summer City, 1903-1917}

The reform movements of the turn of the century and the zeitgeist that produced the World's Columbian Exposition and the Pan-American Exposition all passed through Chautauqua and left their mark, as did many of the leaders and artistic professionals who brought them to fruition. These movements and the artistic styles they generated intersected with one another at Chautauqua, and perhaps because of this intersection produced an ideal of beauty in which stylistic variety was subsumed into an inclusive concept of harmony (witness the shift from the "White City" to the variegated scheme of the Pan-American Exposition). It is therefore appropriate to turn to Chautauqua to see how this unity in diversity played out and how the grandiosity of designers accustomed to world's fairs impacted a small seasonal settlement on a New York lake.

\section{The Master Plan}

Chautauqua's important public buildings from its second twenty-five years date to a 1903 master plan designed by architect Albert Kelsey, landscape architect Warren Manning, and sculptor J. Massey Rhind. The express goal of the plan was to establish Chautauqua as a "Model Summer City of Improvement." According to Kelsey, Chautauqua at the turn of the century was one "of those places, which seem to have 'just growed." "1 He was specifically reacting to the haphazard curvilinear streets and the inexpensive stick-style frame houses often crowded together on former tent platforms.

\footnotetext{
1 "Making Chautauqua a Model," Chautauquan Monthly Aug. 1903: 449.
} 
Now, in poor condition after years of harsh western New York winters and a lack of maintenance, they recalled the dirty, overcrowded conditions of America's cities (fig. 6.1). ${ }^{2}$ The Kelsey/Manning/Rhind plan addressed both concerns. The plan melded the existing picturesque natural ravines with a formal, urban grid of streets, oriented both parallel and perpendicular to the Lake, that was to be punctuated with frequent small green spaces. The creation of a broad north/south axis clarified the organization of the plan and imposed a Beaux-Arts sensibility. This new boulevard on the relatively level plateau of the grounds, parallel to the Lake, would connect the College and a new Arts and Crafts facility at the north end with St. Paul's Grove, a rebuilt Hall of Philosophy and a new Hall of Christ at the south. An east/west axis would bisect the grounds, leading from the traditional pier/point entry at the lake, up the hill to a new roadway gate. Each major axis was accentuated by the creation of red brick paths to be used exclusively for pedestrian traffic. At the intersection, the two axes would be even wider, creating a major central rectangular greensward on the plane - a plaza (figs. i.1, 6.2, 6.3). To facilitate the construction of the new gathering place Kelsey suggested removing most of the existing wooden buildings.

The Kelsey plan also called for important major new public buildings at each end of the new streets as well as around the green space. In his plan a dramatic set of stairs led from the pier/point entry and the original meeting place to the flat plane above. At the top of the hill he proposed an enormous domed facility designed to house the

\footnotetext{
${ }^{2}$ In her architectural history Masters thesis, Kathleen Froome argues that the original form of the Chautauqua grounds, like many camp meeting grounds, follows the curves of the meeting place, Miller Park. Kathleen Ann Froome, The Sacred and Secular Landscape of Chautauqua, 1874-1890 (Masters Thesis, University of Virginia, 1988).
} 
Chautauqua program. In addition to a half-timbered, irregularly shaped, medieval Arts and Crafts center (fig. 6.4), he suggested the replacement of the existing pier entry facility on the point (fig. 6.5) with an imposing pier palace in an extravagant, historicizing, Venetian style (fig. 6.6). Further down the lake, directly below the Hall of Philosophy, he proposed a propylaea, a Grecian-inspired lake front entry, as the starting point for a dramatic ceremonial procession for those participating in the Chautauqua Literary and Scientific Circle (CLSC) Recognition Day (fig. 6.7). ${ }^{3}$

In an article that appeared in House \& Garden in August 1903, Kelsey described the plan as at an early stage, "in embryo," and in need of further development, but he produced a widely published version of it with strikingly rendered drawings of the proposed buildings to generate enthusiasm and publicity. The plan's mix of grand classical styles reflected Chautauqua's lofty image and mirrored many aspects of Civic Improvement. His hope was that as the plan was implemented, Chautauqua, as a permanent model of Civic Improvement, would "become an educational example bearing fruit throughout the country." At the very least, the plan "sets up a tangible ideal of beautiful surroundings amid which work and study may be carried on." ${ }^{4}$

The dramatic scale and opulence of Kelsey's original conception did indeed create excitement and help with fundraising, but it was as an ideal that it ultimately exercised its influence: most of his extravagant building ideas were considered too

3 "Making Chautauqua a Model," Chautauquan Monthly Aug. 1903: 450.

${ }^{4}$ Albert Kelsey, "The New Chautauqua," House \& Garden Aug 1903: 49, 51. Perhaps the plan's influence was at its broadest during these months as many more people saw the Kelsey plan in print than would visit the grounds. 
ostentatious and expensive and were never built. Nonetheless, the Kelsey plan created a blueprint for the future development of the Chautauqua grounds. Although Kelsey's design for a new home for Arts and Crafts classes at the north end of the grounds was not executed, ground was broken in 1909 for a successful Arts and Crafts Quadrangle, designed by the Buffalo firm of Green and Wicks, at the same location. A new campanile and pier building, also by Green (1911) was substituted for the Venetian fantasy at the pier; the Italianate Miller Bell Tower, whose bells punctuate the day, has become the iconic symbol of the Institution (fig. 6.8).

\section{The Plaza}

The new greensward and its surrounding ensemble of buildings, one of them designed by Kelsey, became the central focus of the Chautauqua grounds though even the greensward was scaled down. Kelsey's major new administration building at the north end anchored the Plaza. Originally named the "Arnold," this structure is now known as the "Colonnade" (figs. 5.8, 6.9). ${ }^{5}$

The Colonnade (1906), a large, classically inspired red brick building with painted wooden trim, is a symbol of the prestige and status of the Chautauqua Institution. Set on a full width plinth stair, it features a large center section with a colonnade of eight monumental Ionic columns made of sandstone. This section is connected by recessed hyphens to flanking piers, which are stepped forward. A continuous entablature and cornice tie the five-part composition together. The large-scale symmetrical facade

\footnotetext{
${ }^{5}$ The first drawing for the Colonnade Building bears the name "The Arnold," for N. T. Arnold,
} Ridgeway, PA., a Chautauqua trustee from 1905 until he died in 1906. His family did not pursue the project. 
exudes power and self-confidence. Approximately one hundred and seventy feet in width, it stands in contrast to the surrounding cottages, which are typically twenty to thirty feet wide. The ground floor originally housed a series of shops, with the piano nobile used for offices for the president of the Institution and for other administrative functions.

Directly in front of the Colonnade Building, Manning created a geometric parterre of planting beds and walkways. Historical precedents for a composition combining a monumental facade and a patterned plaza such as Manning's include Michelangelo's Campidoglio (begun in 1537), Karl Friedrich Schinkel's (1781-1841) Berlin Altes Museum (1824-28), and the United States Capitol and Mall (1791-1815). To the board of the Institution, this facade and plaza helped to represent Chautauqua as an open, inviting, and yet powerful national presence.

Just one year after it opened, the Colonnade was destroyed by fire. Edward B. Green, who had participated in the Pan-American Exposition and the competition for master planner, succeeded Kelsey as Chautauqua's architect and supervised the reconstruction of Chautauqua (fig. 6.10). Masters of the neoclassical style and the Romanesque revival, he and his associates at Green and Wicks, the leading firm in Buffalo, designed over three hundred seventy major buildings in the northeastern United States, over one hundred sixty of these in the city of Buffalo. ${ }^{6}$

\footnotetext{
6 "Mr. Henry Turner Bailey...here last Saturday," Chautauquan Weekly, 1 October 1908: 4. The Chautauqua Institution published a weekly magazine from 30 August 1906 to 30 Nov. 1933. Sadly, the Colonnade has been destroyed by fire twice. The second fire was during the winter of 1961. Today's Colonnade shares the same form and program as the original but differs in some details, such as the windows. The parterre Manning designed for the Plaza was simplified in 1946. Today, the greensward is a continuous lawn with symmetrical planting beds.
} 
As Chautauqua's architect, Green was commissioned to design an ensemble of buildings to complete the perimeter of the Plaza. In his plan for the Colonnade reconstruction, Green replaced the attic with a hipped roof and made minor changes to the façade. However his redesign added a significant new facility extending from the eastern end of the building and completing that corner of the Plaza. The new Pergola, which contained an ice-cream store, became a popular gathering place (fig. 6.11). Next to the Pergola, Green added an imposing colonnaded Post Office in 1909, and the Institution installed a bookstore on its ground floor (fig. 6.12). The western side of the Plaza was a mix of private residences and a small hotel (fig. 6.13). Such a mix of public and private facilities is a hallmark of Chautauqua's urban context, contributing to its ambience. With the completion of the Plaza, a key element of Chautauqua's Civic Improvement plan, the center of the grounds shifted from the original circular gathering place near the lake to the more formal, geometric, central green space. ${ }^{7}$

\section{The Arts and Crafts Quadrangle}

To Civic Improvement reformers, living in an uplifting, beautiful environment should be combined with the personal creation of beauty, both fine art and hand-crafted work. By 1902 the Chautauqua curriculum had expanded to include a eclectic array of Arts and Crafts courses (fig. 6.14). An Arts and Crafts department was organized with

${ }^{7}$ In 1931, the Smith Memorial Library, in a grand Georgian Revival style, was added to the south end of the Plaza, opposite the Colonnade Building. "Smith Library Planned in Harmony With Plaza." Chautauquan Daily 4 August 1931: 10.

In 1946, the Plaza was dedicated to the memory of Arthur Bestor (1879-1944), president of the Institution from 1915-1944. The Plaza was also redesigned that year; the Pergola was removed and a Refectory in a complementary style was added on the south side of the monumental Post Office, completing the east side of the Plaza. 
Henry J. Baker as the first director, succeeded by Frank G. Sanford, an Instructor in Manual Arts at the State Normal School in Oneonta, New York. ${ }^{8}$ In 1906, in an effort to upgrade the Arts and Crafts offerings, Chautauqua asked a young specialist in arts education, Henry Turner Bailey, to join its staff (for more on Bailey see Chapter 3 and fig. 3.6).

In 1902 the Arts and Crafts program was housed in a collection of small clapboard, stick-style buildings and tents recycled from other localities around the Chautauqua grounds and set up as an Arts and Crafts Village near the road gate at the corner of Ames and Palestine Avenues (fig. 6.15). Although they were adequate, the ad hoc nature of these facilities led to dreams of better quarters. ${ }^{9}$ That same year Sanford prepared a sketch of a permanent Arts and Crafts village. A detail from this plan illustrates extended second floors and heavy half-timbering in a crisscross pattern, giving the complex a Swiss/German, medieval feel (fig. 6.16). The next year, in his master plan for Chautauqua, Albert Kelsey suggested a permanent home for the Arts and Crafts program on a hilltop at the north end of the grounds. The site encompassed the setting for the ornate "Moorish Barn," built in 1887 for classrooms for the Chautauqua University program, which was already in disrepair (and was demolished in 1916).

\footnotetext{
${ }^{8}$ Many important figures in the Arts and Crafts Movement from New York State participated in the Chautauqua program, including Charles Rohlfs, creator of wood furniture. See Coy L. Ludwig, The Arts \& Crafts Movement in New York State, 1890s-1920s, (New York: Gallery Association of New York State, 1984) 82-83 and 87-88. Although, Elbert Hubbard, the founder of Roycroft (who had created a "Chautauqua" line of premium products for distribution while with the Larkin Co.) participated in the CLSC program (1892) however, he spent very little time on the grounds and there is no evidence of Gustav Stickley's involvement in Chautauqua. Jon Schmitz, Archivist, Chautauqua Institution Archives, personal interview, Nov. 2003. 40.

${ }^{9}$ Frank Chapin Bray, A Reading Journey through Chautauqua (Chautauqua, New York, 1905) 39-
} 
Kelsey's plan was for a large, irregularly shaped, closed courtyard of two-storied gabled pavilions connected by a lower one-story covered arcade (fig. 6.4). The central feature was a clock tower along the north side of the complex. This version of a permanent home for the Arts and Crafts was not built. Instead, Henry Turner Bailey developed the plans for the Chautauqua Arts and Crafts Center Quadrangle with Franklyn J. Kidd (1873-1942), an associate with the Buffalo-based architectural firm of Green and Wicks. ${ }^{10}$

The Thursday, November 12, 1908, edition of the Chautauquan Weekly announced: "New Quadrangle of Buildings Begun Back of the College Building - A Comprehensive and Artistic Plan." In a romantic tribute to a meeting of the minds earlier that fall "under the spreading chestnut tree in the rear of the college," the Weekly described a meeting of the President of the Institution, Dr. George Vincent; the general manager, Dr. Arthur Bestor; the representative of the architectural firm of Green and Wicks, Mr. Kidd; and Mr. Bailey. Together these men "laid down the main lines of the

${ }^{10}$ Upon the dissolution of the Green and Wicks partnership in 1917, Green joined his son as Green \& Son and Kidd joined Wicks as Wicks, Kidd, \& Hopkins. American Contractor Vol. 38, number 43, October 27, 1917: 61. Kidd subsequently formed a partnership with his brother, William Andrew Kidd. Kidd Brothers were the successors to Green in Chautauqua and had a long and successful career in Buffalo. In Chautauqua they designed the Smith Memorial Library (1931). In Buffalo they are best known for their designs for George Rand: the Rand House (1918-1923), a Tudor revival mansion, and the Rand Building (1929). The art deco Rand Building, at 29 stories, was Buffalo's tallest skyscraper for many years. The Kidd brothers also collaborated with Eliel and Eero Saarinen on the Kleinhans Music Hall (1938-1940). Obituary, New York Times December 12, 1942, and Henry F. Withey, Elsie R. Withey, Biographical Dictionary of American Architects (Deceased) (Los Angeles: New Age Pub. Co., c1956) 341. 
plan," which called for a large open quadrangle with a covered walkway extending around the inner circumference, to be built in stages as funds permitted. ${ }^{11}$

Construction began on a central pavilion twenty-five feet deep and forty-five feet wide, which was used as a lecture hall (fig. 6.17). The pavilion was fully integrated into flanking shops and studios, creating an overall length of 210 feet parallel to the lakefront. The construction was carried out by the crew of the Institution under the direction of Superintendent George W. Rowland. ${ }^{12}$ Only the initial block parallel to the lake was finished for the summer of $1909 .{ }^{13}$ The Weekly of May 5, 1910, announced the beginning of the north wing with the construction of a thirty by fifty-two-foot section known as the "Weave Room." The north side of the quadrangle eventually extended 135 feet toward the lake, and a similar wing was built to the south. ${ }^{14}$ The entire project was finished c. 1917 (fig. 6.18).

11 "New Quadrangle of Buildings Begun Back of the College Building - A Comprehensive and Artistic Plan," Chautauquan Weekly 12 November 1908: 1-2. Bestor succeeded George Vincent as president in 1915. He served until 1944, longer than any other president.

${ }^{12}$ The Shingle Style of the Arts Quadrangle established the architectural vocabulary for additional development around College Hill. Among other buildings, a wonderful piano studio, also designed by Green and Wicks, was built up the hill just beyond the Quadrangle. It was dedicated on August 6, 1912, to the memory of William H. Sherwood, for twenty-two years the Head of the Piano Department of the Chautauqua Summer Schools and beloved piano teacher. The building is forty by ninety feet and is almost a mirror image of the Arts Quadrangle. The body is covered with the same brown shingles, but here a pergola of "milk bottle" cement columns surrounds the outside of the building.

${ }^{13}$ The Arts and Crafts program was part of the Chautauqua Summer Schools, which were run as a separate financial entity from the Institution. The tuition charged the students was used for the administration of the programs, teachers' salaries, and upkeep and construction of facilities. If the Institution had room in its budget, the board voted to contribute toward the school's expenses. Projects were planned to be built over time and were carefully budgeted accordingly.

\footnotetext{
14 “Arts and Crafts Growth," Chautauquan Weekly 5 May 1910: 2.
} 
Seen in its entirety the Arts and Crafts Quadrangle is a three-sided courtyard, one room deep, open to a view of the lake. The courtyard façade of the building has a covered loggia with a colonnade of cement columns reflecting a simplified classicism; they are Tuscan-inspired "milk bottles" with minimal capitals and without bases (fig. 6.19). The middle section of the Quadrangle, parallel to the Lake, consists of a central pavilion with symmetrically disposed art studios on either side and dual chimneys at the edges. A central gambrel roof with an inset of a band of five windows is centered over the entry. On the inner façade, a pattern of small double windows above the roof of the loggia forms a partial clerestory centered on each bay. The large, undivided studios to each side were designed to be bright and airy, with tall sash windows in both front and rear to allow light and cross ventilation. The courtyard is completed by two parallel sections of the same design perpendicular to the middle section. These wings of the Quadrangle terminate in pavilions patterned after the original central hall (fig. 6.20). Each is connected by a covered breezeway to another freestanding pavilion element that again repeats the form of the hall. These final pavilions have two columns in antis and a hipped gambrel roof. The overall effect is one of logical symmetry and balance.

The main body of the Quadrangle is covered with a long, low, unifying roof of green shingles that curve and soften the valleys of the roof at the juncture of the opposing gables and at the corners. Brown shingles cover the façade. The columns and the trim of the building are painted a cream color. In the choice of colors, materials, and forms, the Arts and Crafts Quadrangle is a rustic interpretation of a classical building. As an 
expression of Civic Improvement, it is a fitting home for Chautauqua's arts and crafts classes. $^{15}$

Upon completion of the Arts and Crafts Quadrangle, Chautauqua could boast that the initial dream "that no other summer school in the country ... has so complete and picturesque a plant" had come true. The anonymous writer of the November 12, 1908, Weekly article believed that "when completed this new group of buildings will present an appearance not unlike some of the charming old monasteries of Italy."16 Perhaps Bailey and Kidd were looking to such historic sources. Another possible inspiration for the concept of the Arts Quadrangle was the Lawn at the University of Virginia (1817-1826) designed by Thomas Jefferson. Chautauqua has the familiar open rectangular plan and surrounding row of understated columns (figs. 6.21, 6.22). Yet while Jefferson's details honor the historical precedent of Roman antiquity, the Chautauqua Quadrangle exudes the rustic simplicity of the Arts and Crafts. While the Lawn exists to extend the classical model of intellectual exploration and detachment and the Chautauqua version represents a hands-on ethic, both are "academical villages" encouraging congregation, conversation, and relaxation.

\section{Hall of Christ}

As the nineteenth century ended, a Chautauquan could not possibly attend all of the programs and courses offered: they frequently included three different choices at 8:00

\footnotetext{
${ }^{15}$ For a discussion of American Arts and Crafts architecture, see: Richard Guy Wilson, "American Arts and Crafts Architecture: Radical though Dedicated to the Cause Conservative," "The Art that is Life": The Arts \& Crafts Movement in America, 1875-1920, ed. Wendy Kaplan (Boston: Bulfinch Press, 1987) 101-131.

16 "New Quadrangle of Buildings," 1-2.
} 
a.m., 8:30 a.m., and 9:00 a.m. and four different choices at 10:00 a.m. The Institution staff scheduled programming all afternoon and evening, including lectures on the various aspects of Civic Improvement as well as such diverse topics as travel destinations and world poets, along with activities such as baseball games, band concerts, and "readings" with musical accompaniment by a local orchestra. ${ }^{17}$ For the first two years of the Chautauqua Assembly, attendance at the religious programming had been mandatory, but as the offerings expanded this regulation was relaxed. Bishop Vincent had preached a belief in immanence and the redemptive power of education. His son George added an emerging awareness of the nature of modern society. By 1900, the focus of the programming was shifting from a personal Christianity to the Social Gospel — the social consciousness implicit in citizenship - a shift which found expression in the restructuring of the grounds of Chautauqua as a permanent model of Civic Improvement.

As the George E. Vincent era progressed and the buildings and landscaping of the grounds began to reflect this shift, Bishop John Heyl Vincent, increasingly concerned that Chautauqua was losing its original religious/Christian focus, sounded a different call for unity in diversity:

With this development of studies at Chautauqua, and after we had enrolled so many classes and groups in so many and such varied branches, the thought came that it might be well to emphasize the reality of the unity we had found and felt, and the reality of that unity in Christ. ${ }^{18}$

17 "Complete Schedule," Chautauqua Assembly Herald 23 July 1897: 4.

${ }^{18}$ John Heyl Vincent, "The Aula Christi at Chautauqua," Christian Endeavor World 16 April 1903: 1. 
Five years later he was still sounding the same alarm:

The American people, especially we Protestant Americans, are very much in danger of losing the benefit of reverent approach in our public service to the invisible God whom we worship. It behooves us to have a place of quiet, of reverence, for retreat, for meditation, for instruction in the things that relate to Jesus Christ, the author and finisher of our faith. ${ }^{19}$

With such thoughts in mind, Vincent proposed a new building to recapture Chautauqua's original focus. He called it Aula Christi or The Hall of the Christ (fig. 6.23). The facility would not be a church or place of worship; instead, it would be "devoted exclusively to the study of the Man of Nazareth, in which every day, at all hours, there shall be under most skilful [sic] direction, courses of study in the life, words, deeds, spirit, and results of His life." 20 Vincent wanted it to be central. "First of all, it is to stand in the center of Chautauqua, to represent Christ as the center of all learning and life, the key to the true and eternal wisdom." 21 As it turned out, the project took thirteen years to build, was located in a different, secondary location, and was never truly completed. $^{22}$

19 "The Vesper Hour," Chautauquan Monthly Nov. 1908: 444.

20 "Aula Christi," Chautauquan Monthly Nov, 1903: 368.

21 "The Hall of Christ: The Site of the New Institution Appropriately Dedicated," Chautauqua Assembly Herald 19 Aug. 1896: 5.

${ }^{22}$ At each stage of the development of the Hall of Christ, a major gift was secured to provide the impetus for construction. These gifts proved to be isolated and sporadic, however, leading to significant delays. Miss Helen Gould, daughter of Jay Gould, contributed \$5,000; N. T. Arnold, \$3,000; the Massey family estate, $\$ 10,000$; Miss Lillian Massey, $\$ 1,000$; Old First Night giving, over $\$ 12,000$. 
Vincent's architect was Paul J. Pelz (1841-1918), best known for his work with John L. Smithmeyer (1832-1908) at the Library of Congress in Washington, D. C. (187392). Born in Germany, Pelz immigrated to the United States to join his father at the age of sixteen. Having begun his training in Breslau, he apprenticed to Detlef Lienau (18181887) in New York. Prior to his work in Washington, he designed many lighthouses as the chief draftsman and civil engineer for the United States Lighthouse Board. ${ }^{23}$ A master of the classical vocabulary, Pelz considered himself a "Jeffersonian" and would go on to design a number of sympathetic buildings at the University of Virginia, including Randall Hall (1899) and the University Medical School (1901-04), each of red brick with white trim and a pedimented front ${ }^{24}$ (figs. 6.24, 6.25).

Pelz embraced the Hall of Christ project, giving eloquent interviews to the Herald during frequent visits to the Chautauqua grounds. He described the Hall of Christ as a "unique" project, a "forerunner," and felt that "eventually every city in the land will have its own." The Hall was not to be a place of worship per se, but rather "a place where spiritual truths will be taught, the same as in every science ... not a house of prayer, but a house where Christian people go for enlightenment in matters transcendental.",25

The style Pelz and Vincent chose was classical. Pelz explained:

${ }^{23}$ Albert Bernhardt Faust, The German Element in the United States, With Special Reference to its Political, Moral, Social, and Educational Influence, Vol. II (Boston: Houghton Mifflin, 1909) 321. 21 July 1900: 5.

24 "The Hall of the Christ, Architect Pelz on a Visit of Inspection," Chautauqua Assembly Herald

25 "The Hall of the Christ, Architect Pelz," 1. 
The building follows classic lines, the Roman-Greek, because Christ made his appearance when the Roman application of the Greek lines was the dominant style then prevailing in the architecture of the civilized world, thus bringing the mind into the line of proper thought and expression. ${ }^{26}$

Pelz planned lavish interior details. On the walls, he envisioned murals portraying "fifty or more" parables based on Bible stories, to "import His divine truth." The ceiling would be divided into three large square panels. The painting on the first panel was to represent the "Golden Age," depicting Adam and Eve receiving instructions from God; the second, Christ at the Sermon on the Mount, as an incarnation of the Divine; and the third, the "New Jerusalem," the second coming of Christ. Of the murals, the clearest idea will be gained by reference to the dome paintings in the United States capitol by Brumidi. ... These mural paintings will lead up to the statue of Christ, which will be a replica of the Thorwaldsen [sic] statue of Christ in the Copenhagen Frauenkirche. ${ }^{27}$

On a bright, sunny Tuesday, August 18, 1896 (the day before the CLSC Recognition Day), a gala procession made up of "Roger's Band," a choir, some "girl banner-bearers clad in white," and the half-dozen dignitaries who were to take part in the ceremony "marched out to the Academia grove" just north of the central Plaza to dedicate the site for the new Hall of Christ. Lewis Miller, on behalf of the board, officially set

\footnotetext{
26 "The Hall of the Christ, Architect Pelz," 5.

27 "The Hall of the Christ, Architect Pelz," 1.
} 
aside the plot of land. Bishop Vincent then, "with impressive solemnity, offered the Prayer of Consecration," intoning:

To Thee, therefore, we now consecrate this ground for the building of a holy temple of research, worship, and obedient surrender to Thee. What we give is already Thine own. But to us Thou hast given it, and Thou dost permit us to give it back to Thee. ${ }^{28}$

But despite the momentary enthusiasm, momentum waned. Construction never began at this central site and the project was never fully funded; potential donors focused on other projects.

Four years later, on August 7, 1900, another equally impressive ground breaking service was held. This time cornerstones were laid, but the site had shifted to the far south end of the grounds, St. Paul's Grove, the area dedicated to the Chautauqua Literary and Scientific Circle (CLSC) and the Hall of Philosophy. ${ }^{29}$ The Hall of Christ featured prominently in Kelsey's 1903 plan as the southern terminus of his new boulevard, where he felt it would function as part of an important ensemble to express the various "moods and passions of the place. ${ }^{, 30}$ Nonetheless, the Hall of Christ remained unfinished for eight years. Finally, in March of 1908, the Chautauquan Weekly announced that enough funds had been secured to complete the project. John T. Noye Hoyt, an architect from

28 "The Hall of Christ, The Site... Dedicated," 4.

${ }^{29}$ As St. Paul spread the Gospel of Christ, the CLSC was to spread Vincent's dream of a sacred education. "Cornerstone Laid, Impressive Ceremonies at the Hall of the Christ," Chautauqua Assembly Herald 8 Aug. 1900: 4.

${ }^{30}$ Albert Kelsey, "The New Chautauqua," 52. Kelsey's decision to feature the existing Hall of Christ project speaks to the inclusive nature of his plan, his sensitivity to Bishop Vincent, and his considerable political skill as a planner. 
Buffalo, was hired to modify the Pelz plans, and the contract for finishing the building was signed. ${ }^{31}$ This time the Chautauquan Weekly article was realistic in tone and assessment:

It is planned to make the dedication of the Hall of Christ the chief event of the coming season. Although it will be many years before the building is entirely complete with its mural decorations, tablets, statuary, library, marble fountains, and other art work... ${ }^{32}$

Set on a knoll, the Hall of Christ is grandly impressive; it seems to dwarf the other buildings ringing the Grove. With a classical pedimented porch, a rectangular body, and flanking wings, the form of the building is reminiscent of Thomas Jefferson's Virginia State Capitol (1785-89) in Richmond, Virginia, which introduced the classical style to the United States, and perhaps further indicates Pelz's admiration of Jefferson's architecture.

The porch is reached by a broad set of steps leading to a grand, oversized wooden entry door. The building is of wide beige brick, with flush grouting joints to give a smooth appearance, and the exterior is decorated with such classical details as wreaths and garlands. The iconography of the bas-relief on the entry pediment features the Bible with rays extending in all directions, suggesting the worldwide dissemination of truth. ${ }^{33}$ The long, flat surface of the sides of the Hall is surmounted by a series of clear glass

${ }^{31}$ The contract was given to E. J. Bailey from Brocton, NY, who was then building the grand Mayville, NY, Courthouse.

32 "Hall of Christ," Chautauquan Weekly 23 April 1908: 4.

${ }^{33}$ Richard Campen, Chautauqua Impressions: Architecture and Ambience (Chagrin Falls, Ohio: West Summit Press, 1984) 45. 
windows set off with small Ionic pilasters. A square apse is decorated with horizontal bands of geometric, interwoven fretwork around egg-and-dart forms. Each side of the apse has a large, arched window with a lavishly decorated keystone and sill below which are inset cornerstones imported from Palestine, said to weigh over one thousand pounds each. These enormous stones connect the Hall of Christ to the Holy Land both physically and symbolically, as do the two decorative marble tablets, also imported from Palestine, which cover the stones. The tablet on the west side is inscribed "Nazareth," and the one on the east side, "Jerusalem" (figs. 6.26. 6.27).

At the dedication of August 7, 1900, it was reported:

In the cornerstone[s] were placed: The Bible, The Chautauquan, The Assembly Herald containing a description of the Hall of the Christ, Chautauqua circulars, photographs of the Grounds, Lafayette dollar, photo of Mr. Lewis Miller and Bishop John H. Vincent, photo of the Hall, constitution and by-laws of Chautauqua, annual report of 1899, map of Chautauqua and official program for the day. ${ }^{34}$

The selection implies that to Vincent, this Christ-focused, sacred center of Chautauqua would outlive, perhaps should outlive, the increasingly secularized Civic Improvement program.

Although the exterior feels grand, with lavish classical details, on close examination, the building seems incomplete. For instance, the external niches on either side of the entry were never filled with the planned sculptures. The interior is also

\footnotetext{
34 "Cornerstone Laid," 4.
} 
disappointing; none of the extensive decorative program was ever executed. In place of the murals planned by Pelz are great expanses of empty wall (fig. 6.28). The effect is of a blank canvas set off by architectural elements: paired Ionic columns and rich moldings. ${ }^{35}$ The lack of funding for the decorative program corresponded to the shifting values of the Chautauquans: the financial supporters of the Institution were focused on more engaging projects to create a model of Civic Improvement, such as the Plaza, with its ensemble of monumental buildings, and the Arts and Crafts Quadrangle.

The Hall of Christ opened for the 1909 season and was formally dedicated on August 4, 1909. Given Chautauqua's national presence at the time, many newspapers around the country ran the story. The Los Angeles Times characterized the Hall of Christ as "the only building of its kind in the world," sixteen years in the planning. Illustrated with a prominent picture of the Hall, the article reported Vincent's hopes for its use as a "reminder to all of Christ as the heart of Christian civilization and of the Christian church. ${ }^{36}$ The story of the dedication was also reported in the Kansas City Star and the Boston Globe, among other newspapers. ${ }^{37}$

For many years after it opened, the Hall of Christ was used as planned: each day classes focused on the life of Christ were held. But just as the decorative program of the building was left unfinished, enthusiasm for daily Bible study classes at the Hall of Christ waned, and they faded from the Chautauqua program. An examination of the daily

\footnotetext{
${ }^{35}$ A newly restored organ was installed for the 2001 season.

36 "Aula Christi, Unique Hall of Christ Dedicated at Chautauqua," Los Angeles Times 29 August
} 1909: 261 .

37 "A Building to be Devoted Exclusively to the Ana of Christ," Kansas City Star 22 Aug. 1909. "Only Building of Its Kind in the World," Boston Globe 22 Aug. 1909. 
programs over time shows a shift to a broadened curriculum of presentations centered on the agenda of improvement - ecumenical ethics and morals. This change of use over time serves as a symbol of Chautauqua's shift of vision from Bishop Vincent's goal of personal redemption through education to George Vincent's goal of Chautauqua as a model summer home to foster an educated altruistic citizenship. Ironically, although the Hall of Christ was never finished, it is the most imposing edifice on the grounds, a monument built during Chautauqua's second great building campaign to the lost focus of the first twenty-five years. As a part of the eclectic mix of Chautauqua's expression of Civic Improvement, the Hall of Christ functions as a reliquary, a repository housing the dreams of Chautauqua's initial mission. 


\title{
Conclusion: Successors - J. Horace McFarland and Clement Studebaker, Jr.
}

\author{
We aim to do small things for large places, large things for small places, and \\ good things for all places. ${ }^{1}$
}

Charles Zueblin, quoted by J. Horace McFarland, 1904

At the turn of the century the famous Chautauqua platform was an important venue where reformers from around the country expressed their belief in improving the aesthetic quality of the built environment. Although the speakers shared the ideal that beautification led to an improved quality of life, their stylistic solutions were varied. The Chautauqua Board's choice to commission a master plan, and the subsequent building campaign, should be read as the built representation of this ideal. The wide range of complementary styles chosen for the Chautauqua grounds formed an integrated whole, a Model Summer City of Improvement.

Albert Kelsey unveiled his Master Plan at Chautauqua on July 18, 1903; his was the featured presentation during the second "Civic Improvement Week." He had previously presented his talk in Philadelphia on June 16, to a roomful of invited guests in the gallery of the Art Club. ${ }^{2}$ The invitation to the Philadelphia event described the goals

\footnotetext{
1 "Message of Civic Improvement," 6. McFarland evidently enjoyed this quote. This was the second time he included it in a Chautauqua speech. He had previously used a slightly modified version on the $19^{\text {th }}$ of July 1903. "As our Professor Zueblin has epigrammatically expressed it, the League will do small things for large places, large things for small places, and better things for all places." "National Improvement. Last Conference of Civic Week Addressed by President J. H. McFarland, Dick J. Crosby, W. R. Gregg, and Dr. Earl Barnes." The Chautauqua Assembly Herald 20 July 1903: 1.

${ }^{2}$ Founded in 1898, The Art Club had as its goals "to advance the knowledge and love of the Fine Arts, through the exhibition of works of Art, the acquisition of books and papers for the purpose of forming
} 
of the plan: "The Trustees [of Chautauqua] feel that the time has come when the increasing architectural demands of the Assembly should be met in a manner befitting the victorious power of the Institution." The improvements clarified the experience of visitors with two new avenues that bisected the grounds. In addition, Kelsey proposed numerous additional facilities reflecting the programmatic emphasis on a wide variety of civic improvement activities. Throughout, the great canopy of mature trees was to be preserved. Chautauqua's built environment would be "an educational example which would later bear fruit in the local civic endeavors of visitors and students." ${ }^{3}$ The enormous enthusiasm engendered by the release and publication of the plan further cemented Chautauqua's commitment to reflect the various aspects of Civic Improvement in the built environment.

The second American League for Civic Improvement (ALCI) conference, held in Chautauqua from July $13^{\text {th }}$ to $17^{\text {th }}, 1903$, celebrated the accomplishments of the previous year. "There is a wonderful civic awakening in all parts of the country," it was reported, "and the expert service of the League is in great demand for the proper direction of efforts for home and public improvement." ${ }^{4}$ Vice President Shuey presided over the

an Art library, lectures upon subjects pertaining to Art, receptions given to men or women distinguished in Art, Literature, Science or Politics, and by other kindred means, and to promote social intercourse among its members." Art Club of Philadelphia, Charter, Constitution and By-Laws of the Art Club of Philadelphia with House Rules, Report of the Board of Directors, and List of Members (Philadelphia: The Art Club, 1898) 13.

3 "The Model Chautauqua. Announcement of Plans Prepared by Architect Albert Kelsey." The Chautauqua Assembly Herald 3 July 1903: 3.

4 “The American League for Civic Improvement. Prominent Persons Here to Attend the Meetings - Chautauqua's Relation to the League." The Chautanqua Assembly Herald 15 July 1903: 1. 
presentations of participants from such far-flung places as Groton, Massachusetts, Goldsborough, North Carolina, and Shreveport, Louisiana. Although the projects varied in size and scale, in each case the speakers stressed that the successes could be replicated in other locations. Throughout the week, the presenters also emphasized the connections between the League and Chautauqua: "Chautauqua," the Assembly Herald proclaimed, "is clearly the center of the present wave of improvement effort, especially in view of the plans formulated by Mr. Kelsey.",

\section{J. Horace McFarland}

During the Civic Improvement week the ALCI also announced reorganization. A new president, J. Horace McFarland, was elected, and in another example of the intimacy of the relationship between the ALCI and Chautauqua, a new executive board was created that included Chautauquan Clement Studebaker, $\mathrm{Jr}^{6}{ }^{6}$ The transition from Zueblin to McFarland positioned the League — and its successor, the American Civic Association - as a voice for improvement for the next twenty years.

J. Horace McFarland (1859-1948) moved to Harrisburg, Pennsylvania, as a young child and devoted his life to the betterment of the state's capital (fig. c.1). ${ }^{7}$ His father owned both a printing shop and plant nursery, interests McFarland combined in a long career as a printer and publisher of horticultural catalogues, journals, and books. A

\footnotetext{
5 "Civic Conference." The Chautauqua Assembly Herald 15 July 1903: 1. "The American League for Civic Improvement." 1.

6 "The American League for Civic Improvement." 1.

${ }^{7}$ On McFarland see: Ernest Morrison, J. Horace McFarland, A Thorn for Beauty (Harrisburg: Commonwealth of Pennsylvania, Pennsylvania Historical and Museum Commission, 1995).
} 
master printer and a savvy businessman, he pioneered color photograph reproduction, and his Mount Pleasant Press became nationally known. Passionate about beautification, in his later years he became an expert in the propagation of roses. As a founder and president of the American Rose Society, he developed the method of classification and identification that became the standard. In the late 1890s his interests expanded to additional aspects of Civic Improvement when he joined the Civic Club of Harrisburg formed by Mira Lloyd Dock and others. ${ }^{8}$

A Harrisburg native, Mira Lloyd Dock (1853-1945) was a witty, charming, and effective advocate for beautification (fig. c.2). After years running her father's household as a surrogate mother to her five siblings, she entered the University of Michigan at the age of forty-two to follow her dream of studying botany and forestry. She returned to Harrisburg in 1897 and, allying herself with the Pennsylvania Federation of Women's Clubs, threw herself into a career of organizing and promoting improvement. The next year she was instrumental in founding the Harrisburg Civic Club to focus attention on that city's needs. An accomplished photographer, she combined her academic pursuits with a developing passion for the preservation of natural areas, and she became a popular lecturer. In subsequent years she represented the State Federation of Pennsylvania Women and the City Parks Association of Philadelphia at the International Congress of Women in London, England, and joined both the American Park and Outdoor Art

\footnotetext{
${ }^{8}$ Dock participated in the Chautauqua program on August 4, 1911. "Department of Instruction: Official Program, Friday, August 4, 9:00 AM Women's Club, 'Forestry and Birds." The Chautauquan Daily 4 August 1911: 1.
} 
Association (APOAA) and the ALCI, the latter as director of the Preservation of Nature advisory council section. ${ }^{9}$

Dock's closest ally in the promotion of Civic Improvement was McFarland; she encouraged his involvement in both the ALCI and the APOAA. ${ }^{10}$ Through her involvement in the APOAA, Dock also developed a friendship with landscape architect Warren Manning, who became intimately involved in planning in Chautauqua. Working together, they created and promoted a plan for the reimagining of Harrisburg ${ }^{11}$ that addressed many of the problems endemic in older industrial centers, including unpaved or poorly paved streets, a lack of park space, and a generally rundown condition. As a riverfront city, Harrisburg also had banks despoiled by sewage, garbage, and coal dust from nearby mines. The campaign to improve Harrisburg began with a well-received talk Dock delivered on December 20, 1900, to the city's elite Board of Trade and its guests. As an example of Dock's persuasiveness, twenty-one members of this group raised a bond issue to implement an improvement plan. A committee of seven city fathers, including McFarland, selected experts to make specific recommendations. A consulting engineer from New York City, James H. Fuertes, worked on a solution to the sewage, drainage, and water supply issues, while M. R. Sherred, of Newark, New Jersey,

\footnotetext{
${ }^{9}$ Norman L. Lacasse, "Biography, Mira Lloyd Dock," Pennsylvania Department of Environmental Protection. Web. See also "Mira Lloyd Dock, A Register of Her Papers in the Library of Congress, Prepared by Melinda K. Friend," Manuscript Division, Library of Congress, Washington, D. C., 2008.

${ }^{10}$ Morrison 90.

${ }^{11}$ On the Harrisburg Plan see: "An Elite Campaign for Beauty and Utility in Harrisburg," William H. Wilson, The City Beautiful Movement (Baltimore: Johns Hopkins UP, 1989) 126-146.
} 
addressed the paving concerns, and Manning developed the boulevard and park plan (fig. c.3). ${ }^{12}$

As early as 1901, the members of the ALCI and the APOAA considered their efforts and agendas similar enough to warrant discussion of a merger. At its 1901 convention in Buffalo, the ALCI formed a committee consisting of Bray, Zueblin, and Shuey to meet with a similar group from the APOAA to examine "close affiliation" of the two groups. ${ }^{13}$ McFarland was an important bridge between the two organizations. He had been an influential member of the APOAA since 1899, when he delivered an address entitled "Improvement of Factory and Home Grounds" at its June meeting in Detroit, and in 1903 he became the third president of the ALCI, succeeding Charles Zueblin. ${ }^{14}$ After years of discussion, the two improvement organizations, represented by over one hundred delegates, met in a joint session during the St. Louis World's Fair and emerged on June 14, 1904, as the American Civic Association, with McFarland as president. McFarland's twenty-year tenure as the spokesperson for the Association was testament to his commitment and clarity of focus.

Although both Zueblin and McFarland were knowledgeable, opinionated experts, Zueblin was an abstract thinker who understood and expressed the complexities of improvement, an impassioned orator whose message could be controversial, while McFarland was far more prescriptive and practical. For instance, during the 1903 Civic

\footnotetext{
${ }^{12}$ Wilson 133. See also Morrison 72-73.

${ }^{13}$ American League for Civic Improvement, Nation-Wide Civic Betterment (Chicago: The American League for Civic Improvement, 1903) 2.
}

\footnotetext{
${ }^{14}$ Morrison 90.
} 
Improvement week at Chautauqua, Zueblin presented an afternoon lecture entitled "Wealth" from the Amphitheatre platform. In this thoughtful rumination on the nature of wealth and the stratification of the economy, his approach was to raise questions rather than provide answers, and he touched on many issues that resonate today. Using as his point of departure Ruskin's definition of wealth as "the possession of the valuable by the valiant," he first explored what was valuable: natural resources, for example — raw materials, land, and food. In recognition of the great disparity of wealth at the time he asked: Who has the right to control and profit from these sources of wealth? Should all share them equally? He also questioned whether those fortunate few who control so much are truly valiant. Most people worked extremely long, arduous hours for very little compensation, while a few had enormous unearned, often inherited, incomes. Zueblin wondered if there should be some form of tax, an income or especially an inheritance tax, "for the more equal distribution of wealth so that everyone may have more than the bare necessities of life." He argued for a just society, based on the ideal of "not mere possession but use of possession." 15

One year later, McFarland addressed the Chautauqua Amphitheater audience on "The Message of Civic Improvement." The subtitle of the Herald headline — "A Practical Address" - captured the tone of the message. McFarland emphasized that although organizations played an important role in civic improvement, the actions of individuals were paramount. Using clear, concise examples, he outlined what they should

\footnotetext{
15 "Wealth, First of Professor Zueblin's Lectures on Contemporary Society, The Definition of Wealth - The Land Question - The Possession of Natural Resources - Taxation - Monopolies Distribution." The Chautauqua Assembly Herald 15 July 1903: 2-3.
} 
do: first, clean their homes, and plant gardens not only to provide food but also to beautify. He was very critical of what he called "fancy flower beds," despairing of the formal plantings of "interlopers, foreigners which have been introduced into our floral business by merchants for commercial reasons." His preference was for native, naturalistic plantings such as the Wooded Island of the 1893 World's Fair, a stand of irises near a rail station in Chicago, and a field of rose mallows (hibiscus) in his hometown of Harrisburg.

One's focus should then broaden out from the home to the local school grounds, the park, and the town. In each case McFarland gave specific directions for what should and shouldn't be done. On school grounds, for example, the children should be active participants in planting trees and grass. He added that we should agitate for more parkland in our communities - "parks are not a luxury" - and as one example of improving our townscapes, he argued that there should be a ban on telegraph poles: "There is no reason why the wires should not be put under ground." He concluded his remarks with an admonition to the Chautauqua crowd to "go out on the premises where you may be staying, and do what you can to make them beautiful. In so doing you will be hastening "the more beautiful Chautauqua." "16 The audience for McFarland's remarks was comprised of both first-time visitors who would take his message home with them and long-term Chautauquans whose focus was the beautification of the Chautauqua

\footnotetext{
16 "Message of Civic Improvement. Practical Address by Mr. J. Horace McFarland Yesterday Morning." The Chautauqua Assembly Herald 14 July 1904: 6.
} 
grounds and the implementation of the Kelsey plan. One of the latter was Clement Studebaker, Jr.

\section{Clement Studebaker, Jr.}

As the youngest child of Clement Studebaker (1831-1901), who was an early supporter of Miller and Vincent and a Chautauqua board member from 1883 to 1901, Clement, Jr. (1871-1932) spent the summers of his formative years on the Chautauqua grounds. In 1899, the year his father assumed the presidency of Chautauqua, he married Alice Rhawn of Philadelphia,. Although he joined the family wagon and automobile business in South Bend after graduation from Northwestern University, rising to become treasurer and second vice president, he resigned in 1914 to pursue a career developing utility businesses based in Chicago. His success equaled his father's, as he became the president of both the North American Light and Power Company and the Illinois Power and Light Corporation. ${ }^{17}$

The younger Studebaker clearly shared his father's passion for civic improvement. In addition to serving on the executive board of the ALCI, he was very active in the Union League of Chicago, which began during the Civil War as an organization of Northern sympathizers who supported the causes of national unification and full equality and voting rights for African Americans. By the turn of the century the focus had shifted to include the establishment and support of many of the important cultural institutions of Chicago, including the Art Institute, Orchestra Hall, the

17 “C. Studebaker Jr., Utilities Man, Dies." The New York Times 4 Dec. 1932. 
Auditorium Theatre, and the Field Museum. ${ }^{18}$ Studebaker was also affiliated with the Lotos Club of New York, a prominent organization whose objective was to foster the creative betterment of society. ${ }^{19}$ He also shared his father's passion for Chautauqua, serving on the Chautauqua board from 1903 until his untimely death in 1932.

The impact of Studebaker's sympathy for the ideals of improvement can be seen in the unique Chautauqua home he built for his family. The large house at 39 North Lake Drive is a complex amalgam of styles that exemplifies the multifaceted nature of Civic Improvement (fig. c.4). The exterior façade is shingled, with a triangular fenestration pattern of a paired window, a flattened interpretation of a Palladian window, and a sculptural, ogee-arched pocket porch over a pair of broad first floor porches. All of these elements are in harmonious conversation, subsumed beneath an overscaled Dutch gambrel roof. The interior has a similar interplay of disparate styles. The living room is a symphony of the Arts and Crafts aesthetic. It features dark wood paneling and beams, a rubble stone fireplace, and an inglenook (fig. c.5). A set of wooden doors leads to a rich, paneled stairwell with a carved wooden banister. Opposite the living room fireplace and through an open doorway, the dining room, also an inspired composition exudes an entirely different aesthetic. It has finely carved woodwork painted white, reminiscent of eighteenth-century England (fig. c.6). The highly detailed wooden dining room mantle

\footnotetext{
18 "About the Club," The Union League of Chicago. Web.
}

${ }^{19}$ The constitution of the Lotos Club states: "The objectives of this institution shall be to promote and develop literature, art, sculpture, music, architecture, journalism, drama, science, education and the learned professions, and to that end to encourage authors, artists, sculptors, architects, journalists, educators, scientists and members of the musical, dramatic, and learned professions in their work, and for these purposes to provide a place of assembly for them and other persons interested in and sympathetic to them, and their objectives, effort and work." "History and Objectives," The Lotos Club of New York. Web. 
stands directly opposite the stonework surround of the living room fireplace, the two works of beauty captured in a dialogue of competing styles (fig. c.7).

The Studebaker house is a successful composition, melding various approaches literally under one roof; it encapsulates in miniature the sometimes contradictory qualities of the expression of beauty. Similarly, the grounds of Chautauqua are a compilation of styles synthesized into a harmonious whole. From the rustic shingles of the Arts Quadrangle to the formality of the Plaza to the monumental form of the Hall of Christ, Chautauqua should be read as the built expression of the complex compendium which was Civic Improvement.

Chautauquans today experience a well-planned, inspired community that reflects the aspirations of Civic Improvement. The clarity of organization derived from Kelsey's vision enhances the experience. Although most present-day visitors arrive at the main roadway gate at the opposite end of the grounds from the lake access used in Kelsey's day, his planned axis, now paved with red brick, leads to the center of the grounds, the Plaza. Here on the flat plane, another red brick path leads north to theatre, opera, and fine arts, including the Arts and Crafts Quadrangle, and south to the Amphitheatre, the Hall of Philosophy, and the Hall of Christ. Throughout the grounds, carefully maintained mature-growth trees, so important to Manning, provide shade and visual interest. The clarity of organization engages in a lively discussion with the rich interplay of public and private places and the variously wild and well-tended landscape. All of the wide-ranging aspects of Civic Improvement percolate in the eclectic mix of architectural styles and scales. 
The Chautauqua Board and the planners of the turn of the century succeeded in achieving their goal of creating their Model Summer City of Improvement. As one walks through the grounds, one is keenly aware of the harmony, order, beauty, and vivacity of the environment. One appreciates the aesthetic contrasts, large and small, in every direction - the wild ravines as a foil for the formal gardens and for the beautifully planted flower gardens gracing the small front yards of most homes; the unity and utility of the buildings enhanced by the creative tension between their variegated styles; the domesticated landscape set off by the natural beauty of the lake and its ancient, glaciercarved contours. The planners succeeded in combining the unrefined surroundings with the national impulse for Civic Improvement, achieving the original and idealized whole that is Chautauqua, and what worked so well then has stood the test of time, a testament to these forward-thinking individuals who wished to promote social betterment through the beauty of the built environment. 


\section{Appendix 1}

\section{Chautauqua Presidents ${ }^{1}$}

$\begin{array}{ll}\text { Lewis Miller } & 1874-1899 \\ \text { Clement Studebaker } & 1899-1902 \\ \text { Wilson M. Day } & 1902-1903 \\ \text { W. H. Hickman } & 1903-1906 \\ \text { George E. Vincent } & 1907-1915 \\ \text { Arthur E. Bestor } & 1915-1944 \\ \text { Ralph Norton } & 1944-1946 \\ \text { Samuel M. Hazlett } & 1946-1956 \\ \text { W. Walter Braham } & 1956-1960 \\ \text { J. William Carothers } & 1960-1963 \\ \text { George L. Follansbee* } & 1963-1964 \\ \text { Curtis W. Haug** } & 1964-1970 \\ \text { Oscar E. Remick } & 1971-1977 \\ \text { Robert R. Hesse } & 1977-1983 \\ \text { Daniel L. Bratton } & 1984-2000 \\ \text { Scott McVay } & 2000-2003 \\ \text { Thomas M. Becker } & 2003-\end{array}$

*John A. Reed, executive vice president, summer, fall 1963

**Joseph C. Clarke, executive vice president, October 1970 to August 1971

${ }^{1}$ Alfreda L. Irwin, Three Taps of the Gavel: Pledge to the Future, The Chautauqua Story (Chautauqua, New York: Chautauqua Institution, 1987) 10, updated. 


\section{Appendix 2 \\ The New Terms of Civic Improvement}

Excerpted from:

"Address of Frank Chapin Bray Before Improvement Convention, Springfield, Ohio, October 10.

In looking up material on this subject I found such a jumble that it seemed to me of value to make a list of new terms that have arisen from the organization of such societies as we have tried to incorporate in the National League, some of which may be very familiar and some of which may not be:

Civic leagues.

Park and outdoor art association.

League for social service.

Society for the promotion of agriculture.

Trustees of public reservations.

Forestry Commissions.

International horticulture union.

Landscape gardening.

Cottage gardening.

Window gardening.

School gardens.

Vacation schools.

Table decoration.

Bouquet making.

Arbor day.

Division of forestry (Department of Agriculture).

Agricultural experiment stations.

Nature study leaflets. (Cornell University.)

Home and garden course for girls at Tuskegee.

Tree planting association.

The good roads movement.

Public swimming baths. 
Monument and municipal art commissions.

Improved railway stations.

The park and playground movement.

Rest houses (for people who trade in small communities).

Model factory homes.

The betterment of factory conditions, such as Mr. Moulton, of Cleveland, has photographed and described.

Local flower shows with prizes.

Phenology: the study of the relation of climate to plants and animals.

Agronomy: scientific husbandry. Emphasized by Russian and German experiments in the exchange of country and city school children.

Such a list, though incomplete, may serve to stimulate investigation of a movement more far-reaching than we have been in the habit of appreciating."1

${ }^{1}$ Address of Frank Chapin Bray Before Improvement Convention, Springfield, Ohio, October 10 Home and Flowers December 1900: 9-10. 


\section{Appendix 3}

\section{Sculptors of the Pan American Exposition Buffalo, New York 1901}

Adams, Herbert, New York

Amateis, L., Washington

Anderson, Hans Christian, Newport, R. I.

Baerer, Henry, New York

Barnard, George Gray, New York

Bartlett, Paul W., New York

Bissell, George Edwin, Mt. Vernon, N. Y.

Bitter, Karl, New York

Boyle, John J., Philadelphia

Brewster, George T., New York

Bush-Brown, H. K., New York

Cowper, William, New York

Elwell, Edwin F., New York

French, Daniel Chester, New York

Gellert, John, New York

Gerlich, Gustave, Hoboken, N. J.

Goddard, Ralph, New York

Godebrod, Louis A., New York

Grafly, Charles, Philadelphia

Hamann, C. F., New York

Hartley, Jonathan S., New York

Jaegers, Albert, New York

Konti, Isidore, New York

Lenz, Oscar, New York

Loester, M., New York

Lopez, Charles A., New York

Lukeman, Augustus, New York

MacMonnies, Frederic, New York

McNeil, H. A., New York

Martiny, Philip, New York

Matzen, Herman N., New York

Niehaus, Charles H., New York

Partridge, William Ordway, New York

Perry, Roland Hinton, New York

Potter, E. C., New York

Pratt, Bella L., Boston 
Proctor, A. Phimister, New York

Roth, Frederick G., Buffalo

Rukstuhl, F. Wellington, New York

Rumsey, Charles Cary, Buffalo

Saint-Gaudens, Augustus, New York

Schwarzott, Maximilian, New York

Scudder, Janet, Terre Haute, Indiana

Shrady, Henry Merwin, New York

Tafft, Charles E., New York

Tonetti, Mr. and Mrs. Michael (Mary Lawrence), New York

Ward, John Quincy Adams, New York

Weimann, A., New York

Whitney, Mrs. Harry Payne, New York

Yandell, Enid, Kentucky 


\section{Appendix 4: Bibliographical Essay}

Beginning in 1876 the Chautauqua Institution published a daily newspaper during the summer season. A stenographer was sent to each talk, and a transcript was published. These newspapers are an invaluable resource. From 1880 to 1914 the Institution also published a very influential monthly magazine, The Chautauquan, and from 1906 to 1933, the Chautauqua Weekly. Each publication served as an important outlet for the ideas of the day. In addition to the Chautauqua sources, other primary sources of the time include the writings of both Bishop John Heyl Vincent and George Vincent, as well as Albert Kelsey, Charles Zueblin, Edwin Shuey, Frank Chapin Bray, Henry Turner Bailey, Richard Ely, Jane Addams, and Ellen Gates Starr. As the primary organ for the promotion of the American League for Civic Improvement, Home and Flowers, An Illustrated Monthly Magazine Devoted to the World Beautiful, 1900-1903, contains essential articles describing the work of the League.

Key sources on political and social history as well as the important books on Chautauqua, the City Beautiful, and the Arts and Crafts are integral to this dissertation. Three of the best overviews of the Progressive Era are the classic The Age of Reform: From Bryan to F.D.R. by Richard Hofstadter (1955), The Search for Order, 1877-1920 by Robert H. Wiebe (1967), and Why the American Century? by Olivier Zunz (1998). ${ }^{1}$

\footnotetext{
${ }^{1}$ Richard Hofstadter, The Age of Reform: From Bryan to F.D.R. (New York: Knopf, 1955);
} Robert H. Wiebe The Search for Order, 1877-1920 (New York: Hill and Wang, 1967); Olivier Zunz, Why the American Century? (Chicago: U Chicago P, 1998). 
Each explores America's industrialization and modernization and the rise of the middle class; none makes more than a passing reference to the role of aesthetics in society.

The important books on the City Beautiful Movement and the Arts and Crafts focus narrowly on their subjects. ${ }^{2}$ They are, respectively, The Birth of City Planning in the United States, 1840-1917 by Jon A. Peterson (2003) and The City Beautiful

Movement by William H. Wilson (1989), and Art and Labor: Ruskin, Morris, and the Craftsman Ideal in America by Eileen Boris (1986), The Arts and Crafts_Movement by Elizabeth Cummings and Wendy Kaplan (1991), and Redesigning the World: William Morris, the 1880s and the Arts and Crafts by Peter Stansky (1996).

The books that trace the history of Settlement houses, American Settlement Houses and Progressive Social Reform by Domenica M. Barbuto (1999), Spearheads for Reform: The Social Settlements and the Progressive Movement, 1890-1914 by Allen Freeman Davis (1967), and Americans in Process: A Settlement Study by Robert A. Woods (1903), explore the key participants and the sources and impact of the Settlements, generally without recognition of the role of aesthetics. ${ }^{3}$ In An American Urban Residential Landscape, 1890-1920: Chicago in the Progressive Era (2009), Craig

\footnotetext{
${ }^{2}$ Jon A. Peterson, The Birth of City Planining in the United States, 1840-1917 (Baltimore: Johns Hopkins UP, 2003); William H. Wilson, The City Beautiful Movement (Baltimore: Johns Hopkins UP, 1989); Eileen Boris, Art and Labor: Ruskin, Morris, and the Craftsman Ideal in America (Philadelphia: Temple UP, 1986); Elizabeth Cummings and Wendy Kaplan, The Arts and Crafts Movement (London: Thames and Hudson, 1991); Peter Stansky, Redesigning the World: William Morris, the 1880s and the Arts and Crafts (Palo Alto: Society for the Promotion of Science and Scholarship, 1996).

${ }^{3}$ Domenica M. Barbuto, American Settlement Houses and Progressive Social Reform (Phoenix, AR: Oryx UP, 1999); Allen Freeman Davis, Spearheads for Reform: The Social Settlements and the Progressive Movement, 1890-1914 (New York: Oxford UP, 1967); Robert A. Woods, Americans in Process: A Settlement Study (Boston: Houghton, Mifflin, 1903).
} 
Turnbull examines how neighborhood improvement associations impacted Chicago at the turn of the century. Although this is an excellent source for many aspects of beautification, he has chosen not to focus on such aspects of improvement as Arts and Crafts, Municipal Art, Public Recreation, Social Settlements, or Civic Church. ${ }^{4}$

Similarly, rather than examining the source and effect of the beautification of the built environment of the Chautauqua grounds, the history of the Institution has been written primarily to promote attendance at the summer festival. In 1943, longtime Chautauquan Rebecca Richmond published Chautauqua: An American Place, in which she describes the Chautauqua she loves, a uniquely beautiful site with mind-opening intellectual programming and high moral character. Although Theodore Morrison's Chautauqua, A Center for Education, Religion, and the Arts in America (1974) is more scholarly than Richmond's work, he repeats many of her stories and shares her conclusions. Alfreda Irwin, Chautauqua's archivist and for many years the editor of the Chautauquan Daily wrote the most comprehensive history of Chautauqua, Three Taps of the Gavel: Pledge to the Future, The Chautauqua Story, which appeared in 1987 and remains the best overview of Chautauqua's development. Irwin examines the physical as well as programmatic changes over time. Andrew Rieser successfully places Chautauqua in a historical and cultural context in The Chautauqua Moment (2003); his is a more critical view. ${ }^{5}$ All of these works celebrate the belief that Chautauqua is an important

\footnotetext{
${ }^{4}$ Craig Turnbull, An American Urban Residential Landscape, 1890-1920: Chicago in the Progressive Era (Amherst, NY: Cambria, 2009).

${ }^{5}$ Rebecca Richmond, Chautauqua: An American Place (New York: Duell, Sloan \& Pierce, Inc., 1943); Theodore Morrison, Chautauqua, A Center for Education, Religion, and the Arts in America (Chicago: University of Chicago Press, 1974); Alfreda L. Irwin, Three Taps of the Gavel: Pledge to the
} 
Model Summer City of inspiration. What is lacking in this scholarship is an attempt to connect the varied aesthetic expressions of the reform movements as they converge at

Chautauqua.

Future, The Chautauqua Story (Chautauqua, New York: Chautauqua Institution, 1987); Andrew C. Rieser, The Chautauqua Moment: Protestants, Progressives, and the Culture of Modern Liberalism (New York: Columbia University Press, 2003). The earliest effort, R. M. Warren's Chautauqua Sketches: Fair Point and the Sunday-School Assembly (Buffalo: H. H. Otis, 1878) set the tone repeated through the years. Warren described Chautauqua's idyllic setting and meaning ful programming. Bishop John Heyl Vincent's The Chautauqua Movement (1885; Freeport, New York: Books for Libraries Press, 1971), expressed his goals for Chautauqua. This remains an important source for the original intent of the Chautauqua Assembly. The next works, Frank Chapin Bray's A Reading Journey Through Chautauqua (Chautauqua, New York: Chautauqua Institution, 1905); Jesse Lyman Hurlbut's The Story of Chautauqua (New York: G. P. Putnam's Sons, 1921); and Hugh A. Orchard's Fifty Years of Chautauqua, Its Beginnings, Its Development, Its Message, and Its Life (Cedar Rapids, Iowa: The Torch Press, 1923) preceded Richmond's with a message and style similar to hers. Kathleen Ann Froome's The Sacred and Secular Landscape of Chautauqua, 1874-1890 (Masters Thesis, University of Virginia, 1988) began the examination of Chautauqua as a sacred landscape, describing the development of the Grounds in the context of camp meetings. Mary Frances Bestor Cram's Chautauqua Salute: A Memoir of the Bestor Years (Chautauqua, N.Y., 1990) presented a personal remembrance of her father, Arthur Bestor, president of Chautauqua between 1915 and 1944. The most recent studies of Chautauqua, Pauline Fancher's Chautauqua: Its Architecture and Its People (Miami, Florida: Banyan Books, Inc., 1978); Richard N. Campen's Chautauqua Impressions (Chagrin Falls, Ohio: West Summit Press, 1984); Jeffrey Simpson's Chautauqua, An American Utopia (New York: Harry N. Abrams, Inc., 1999); and Laurie A. Watters'A Year in Chautauqua (New York: Park Bench Press, 2000) promote Chautauqua through pictures. They are primarily valuable as photographic records of the development of the grounds. Simpson's is the most complete and Watters's the most visually successful. 


\section{Bibliography}

\section{Archives, Library Collections, and Historical Societies}

American Planning and Civic Association records. 1909-1910. Collection No. 2777.

Division of Rare and Manuscript Collections, Cornell University Library, Ithaca, NY.

Biltmore Estate Forestry Department manager's center records, series R. Archives

Division, Museum Services Department, The Biltmore Company, Ashville, NC.

Carnegie Center of Brazos Valley History, Bryan, TX.

Center for History, South Bend, IN.

Chautauqua Institution Archives, Chautauqua, NY.

Cleveland Landmarks Commission, Cleveland, $\mathrm{OH}$.

Dayton History, Dayton, OH.

DePauw University and Indiana United Methodism Archives, Greencastle, IN.

Dock, Mira Lloyd. "A Register of Her Papers in the Library of Congress, Prepared by Melinda K. Friend." Manuscript Division, Library of Congress, Washington, DC.

Higgins binder. Olean Historical and Preservation Society, Olean, NY.

Kelsey family papers. Chestnut Hill Historical Society, Philadelphia, PA.

Manning, Warren H. Papers, 1882-1998. MS 218. Special Collections Department, Iowa State University, Ames, IA.

---. Manning Collection. Patrick J. Morgan Cultural Center, Lowell Center for Lowell History, University of Massachusetts Lowell.

New York Public Library, Special Collections, New York, NY.

St. Paul's Memorial United Methodist Church, South Bend, IN.

University of Virginia, Special Collections, Charlottesville, VA. 
Urban Design Associates, Pittsburgh, PA.

Vincent, John Heyl. Papers. BridArch 301.25. Bridwell Library, Perkins School of Theology, Southern Methodist University, Dallas, TX.

The Western Reserve Historical Society, Cleveland, $\mathrm{OH}$.

\section{Primary Sources}

\section{Periodicals}

The Chautauquan, A Monthly Magazine of Things Worth While (hereafter referred to as the Chautauquan Monthly). Oct. 1880-Feb. 1911.

Chautauquan Weekly. 30 Aug. 1906-30 Nov. 1933.

A'Beckett, John. "A Scotch-American Sculptor." Art Interchange Apr. 1902: 85.

“An Address from the Executive Board." Home and Flowers Jan. 1901: 13,16.

"Address of Frank Chapin Bray Before Improvement Convention, Springfield, O., Oct. 10." Home and Flowers Dec. 1900: 9.

"Agitation, Education, Organization: Improvement League News Notes." Home and Flowers Aug. 1902: 22-23.

American Contractor 27 Oct. 1917: 61.

American League for Civic Improvement. "The Twentieth Century City, A Record of Work Accomplished for Civic Betterment." Home Florist Oct. 1901: 36.

“The American League for Civic Improvement.” New Outlook 18 Oct.1902: 423-424.

"Annual Convention of Workers for Civic Improvement, Official Program of Meeting of National League of Improvement Associations." Home and Flowers Aug. 1901: 1.

"Arts and Crafts Growth: Second Section of Quadrangle Now Being Built. Chautauquan Weekly 5 May 1910: 2. 
"Arts and Crafts: New Quadrangle of Buildings Begun Back of the College Building - A Comprehensive and Artistic Plan." Chautauquan Weekly 12 Nov. 1908: 1-2.

"Arts and Crafts Work, Plans for Next Summer's Schools: The Courses and Instructors." Chautauquan Weekly 11 Apr. 1907: 1, 5-7.

Bailey, Henry Turner. "Acceptable Plant Drawing." School Arts Book Sept. 1905: 2021.

---. “The Age of Innocence." Chautauquan Monthly July 1911: 152-154.

---. "The American Museum." School Arts Book Sept.1907: 3-7.

---. “Animals That Will Stand." School Arts Book Sept. 1907: 572-581.

---. "The Arts and Crafts in Public Schools." School Arts Book Jan. 1907: 363-374.

---. "Art Appreciation." Chautauquan Monthly July 1911: 124-162.

---. "Erasmus." Chautauquan Monthly July 1911: 141-145.

---. "Group of Infants." Chautauquan Monthly July 1911: 131-133.

---. "Hans Holbein the Younger." Chautauquan Monthly July 1911: 145-148.

---. "Japanese Influence in American Schools." Lotus 15 Dec. 1903.

---. "Leonardo da Vinci." Chautauquan Monthly July 1911: 129-131.

---. "L'Indifferent." Chautauquan Monthly July 1911: 157-159.

---. "L'Infante Marguerite." Chautauquan Monthly July 1911: 148-150.

---. “Mona Lisa." Chautauquan Monthly July 1911: 126-128.

---. "Portrait of the Artist." Chautauquan Monthly July 1911: 137-139.

---. "Rembrandt." Chautauquan Monthly July 1911: 139-141.

---. "Rubens." Chautauquan Monthly July 1911: 134-137.

---. "Sir Joshua Reynolds." Chautauquan Monthly July 1911: 154-157.

---. School Arts Book Mar. 1908: 514. 
---. "Self-Surrender in Art Taste." Chautauquan Monthly Apr. 1903: 437.

---. "Velasquez." Chautauquan Monthly July 1911: 150-152.

---. "Wall Decoration in School Rooms." Chautauquan Monthly 29 Nov. 1913: 247.

---. "Watteau." Chautauquan Monthly July 1911: 160-162.

"Beautiful American Cities, Latest Achievements of the American League for Civic Improvement." Home and Flowers May 1902: 32-33.

Bitter, Karl. "Sculpture at the Buffalo Exposition." The Criterion 19 May 19 1901: 14 18.

Brunner, Arnold. "Cleveland's Group Plan." Proceedings of the Eighth National Conference on City Planning, Cleveland, June 5-7, 1916. New York: National Conference on City Planning, 1916.

"Carpentry and Building, Epworth League Memorial." Building Age 15: 143.

Carrere, John M. "City Improvement From the Artist Standpoint." Western Architect 15 Apr. 1910: 40+.

"Charles Zueblin Dead." Chautauquan Weekly 18 Sept. 1924: 4.

"Chautauqua Arts \& Crafts Guild." Chautauquan Weekly, Arts and Crafts Edition 11 Apr. 1907: 1-3.

"Chautauqua Reorganization." Chautauquan Monthly May 1899: 191.

"Chautauqua: The Largest Institution for Higher Education in the World." Chautauquan Monthly July 1902: 340.

"Chautauqua, The New Center of Progressive Effort for Human Uplift." Home and Flowers June 1902: 8-9.

"Civic Improvement Progress." Home and Flowers June 1902: 25-26.

"Civic Improvement Reading List." Home and Flowers Oct. 1902: 26-27.

"Civic Symposium: The Most Important Event in Civic Improvement." Chautauquan Monthly Aug. 1903: 477-483. 
“Cleveland's New Public Buildings." Home and Flowers June 1902: 4-5.

Cranston, Mary R. “The New Industrialism.” Chautauquan Monthly Aug. 1903: 499501.

Dow, Arthur Wesley. "Color Exercise With Wood Blocks." School Arts Book Jan. 1907: 562-566.

---. "Picture Study, A Symposium." School Arts Book Sept. 1907: 496-497.

Eliot, Charles W. "Beauty and Democracy." School Arts Book Sept. 1905: 1-3.

"Evolution of Chautauqua, Twenty-nine Years of Growth." Chautauquan Monthly July 1902: 349-352.

Fenollosa, Ernest F. “The Place in History of Mr. Whistler's Art.” Lotus 15 Dec. 1903.

"For Civic Betterment, Annual Convention of Improvement Workers." Home and Flowers Aug. 1902: 1.

"For the Promotion of Civic Beauty, The National League of Improvement Associations." Home and Flowers Dec. 1900: 10.

"Good Work for Civic Betterment, News of Improvement Societies and Workers." Home and Flowers Jan. 1902: 24-25, 32.

"Good Work for Civic Betterment, Encouraging News of the American League for Civic Improvement." Home and Flowers Feb. 1902: 25+.

"Hall of Christ." Chautauquan Weekly 23 Apr. 1908: 4.

"Henry Turner Bailey," Obituary. Chautauquan Weekly 3 Dec. 1931: 3.

“Hon. Lewis Miller." Chautauquan Monthly May 1899: 139-141.

“How a City Park Was Beautified." Home and Flowers June 1902: 4-5.

“How Two Towns Were Improved." Chautauquan Monthly Aug. 1903: 522-523.

"Improvement League Convention, Notable Gathering St. Paul Will Welcome." Home and Flowers Sept. 1902: 1-2. 
"Interest Throughout the Nation, Widespread Attention to Work for Civic Beauty." Home and Flowers Apr. 1901: 12.

Kelsey, Albert. "A Municipal Exhibit." Architectural Review July 1904: 185-188.

---. "The New Chautauqua." House \& Garden Aug. 1903: 49-52.

Kelsey, Albert, and Warren H. Manning. "Reports of Experts to the Chautauqua Commission on Public Art and Architecture, in Making Chautauqua a Model." Chautauquan Monthly July 1903.

MacDonald, N. “A Genius of the Chisel." Munsey's Mar. 1896: 671-679.

"Making Chautauqua a Model." Chautauquan Monthly Aug. 1903: 449-462.

"Making Your Town Beautiful." Chautauquan Weekly 23 July 1914: 6.

"The Movement for Public Beauty, Growing General Interest in Civic Improvement." Home and Flowers March 1901: 14.

"Mr. Henry Turner Bailey .. . here last Saturday." Chautauquan Weekly 1 Oct. 1908: 4.

"A Name Appropriate to Our Wider Field." Home and Flowers Nov. 1900: 8.

"The National League of Improvement Clubs." Home and Flowers Nov. 1900: 9+.

Newport, Elizabeth E. "Kindred Spirits After All." Art Interchange Oct.1901: 50-51.

"News Notes of Improvement Work, How Civic Beauty Effort is Growing in Power." Home and Flowers Sept. 1901: 15-16.

“A Notable Event in American Progress." Home and Flowers Dec. 1900: 8.

"Notes From the Field." Chautauquan Monthly Sept. 1902-March 1903: 85.

"Park and Outdoor Art Association, Annual Meeting of Landscape Gardeners" Organization." Home and Flowers Aug. 1901: 3-6.

"Plans for a Year of Active Work, Progressive Policy of Civic Improvement League." Home and Flowers Oct. 1901: 12-13. 
"Plans for the Future: Inaugural Address of President Charles Zueblin. The Twentieth Century City, A Record of Work Accomplished for Civic Betterment, The American League for Civic Improvement." Home Florist Oct. 1901: 65.

Pond, Irving Kane. "The Life of Architecture." Architectural Record 1905: 146-160.

Powell, E. P. "The Farm Beautiful, Anyone May Cultivate the Beautiful and Make Money at It." Home and Flowers Feb. 1902: 12-13.

Price, C. Matlack. "Haddington Branch, The Free Library of Philadelphia - Albert Kelsey, Architect. Architectural Record 40 (1916): 44-62.

"Program of Buffalo Convention, Notable Event in Civic Improvement Circles." Home and Flowers June 1901: 9-11.

"Proposed Merging of Civic Organizations." Municipal Journal and Engineer June 1904: 272.

"Reconstructed Chautauqua, A Type of the City Beautiful." Architects And Builders Journal Feb. 1904: 18-21.

Rexford, Eben E. "Who [sic] We Improved Our Cemetery." Home and Flowers May 1901: 8 .

Rhind, J. Massey. "Proposed Treatment of Figures to be Placed on the American Surety Company's Building." American Architect and Building News 25 May 1895: 83.

Robinson, Charles Mulford. “The Town's Opportunity, How it May Do More Than the City for a More Beautiful American Life." Home and Flowers Feb. 1902: 8-9.

---. "The Town's Opportunity, How Improvement Work May be Made Popular." Home and Flowers Aug. 1902: 8-9.

"Round Table Survey of Civic Betterment." Chautauquan Monthly May 1903: 195-203.

Routzahn, E. G. "The American League For Civic Improvement." Chautauquan Monthly July 1902: 501-506.

Smith, Payson. "School Improvement League of Maine." Home and Flowers Sept. 1902: 3-4.

Sperry, Arthur. "What Flowers Have Done For Cleveland, Excellent Results of the Generosity of an Enterprising Newspaper." Home and Flowers Feb. 1902: 1-5. 
“St. Paul's Improvement. Civic Progress." Home and Flowers Aug. 1902: 2.

"Successful Civic Beauty Rally, Annual Convention of American Improvement League." Home and Flowers Sept. 1901: 8-11.

"Survey of Civic Betterment, A Civic Institute At Chautauqua." Chautauquan Monthly Sept 1903: 69-80.

Tsanoff, S. V. "Educational Playgrounds." Home and Flowers May 1902: 4-6.

"Two Notable Civic Betterment Events, Public Beauty Week at Chautauqua a Grand Success, American Park and Outdoor Art Convention." Home and Flowers Oct. 1902: 1-4.

Van Brunt, Henry. "The Columbian Exposition and American Civilization." Atlantic Monthly May 1893: 584+.

Van Norman, Louis E. "As To The 'Practical Utility' of Beauty." Home and Flowers Oct. 1902: 8-9.

---. "Beauty and Culture in the Farmer's Life." Home and Flowers May 1902: 8-10.

---. "The Country Woman and the Life Beautiful." Home and Flowers June 1902: 6-7.

---. "For a More Beautiful St. Louis." Chautauquan Monthly Aug. 1903: 443-448.

---. "Why Not Attractive School Surroundings?" Home and Flowers Sept. 1902: 8.

---. "Why Not The Life Beautiful Now?" Home and Flowers Feb. 1902: 14-15.

“The Vesper Hour." Chautauquan Monthly Nov. 1908: 444.

Vincent, John Heyl. "The Aula Christi at Chautauqua." Christian Endeavor World Apr. 1903: 1 .

“Weaving Foundations." School Arts Book May 1905: 521.

Whiting, Lilian. "The Life Beautiful, How the Surroundings of Every Home May Help Toward It." Home and Flowers Jan. 1902: 12-13, 33.

--.. "The Life Beautiful, Meaning of the Poetic Side of Our Existence." Home and Flowers Aug. 1902: 6. 
---. "The Life Beautiful, Pictures, Music and Conversational Intercourse in the Home." Home and Flowers May 1902: 7, 28.

---. "The Life Beautiful, 'The Ornaments of a Home Are the Friends Who Frequent It." Home and Flowers Oct. 1902: 10-11, 14.

Wise, Herbert C. "The Boulevard Project in Philadelphia." House \& Garden July 1902: 319-323.

"The Work of Civic Improvement, News of Organized Effort For Outdoor Art." Home and Flowers May 1901: 12-15.

"Work of the League, General News of Civic Improvement Progress." Home and Flowers Sept. 1902: 22-23.

Zueblin, Charles. "The New Civic Spirit." Chautauquan Monthly Sept 1903: 55-59.

Zueblin, Rho Fisk. "The Arts and Crafts Movement in English Letters." Chautauquan Monthly Dec. 1902. Pt. 3 of a series, The Arts and Crafts Movement, begun Oct. 1902.

---. "Continental Tendencies of the Arts and Crafts." Chautauquan Monthly Mar. 1903. Pt. 6 of a series, The Arts and Crafts Movement, begun Oct. 1902.

---. "The Economics of the Arts and Crafts Movement - Consumption." Chautauquan Monthly Feb. 1903. Pt. 5 of a series, The Arts and Crafts Movement, begun Oct. 1902.

---. "The Economics of the Arts and Crafts Movement - Production." Chautauquan Monthly Jan. 1903. Pt. 4 of a series, The Arts and Crafts Movement, begun Oct. 1902.

---. "The Education of the Producer and the Consumer." Chautauquan Monthly May 1903. Pt. 8 of a series, The Arts and Crafts Movement, begun Oct. 1902.

---. "The Patronage of the Arts and Crafts." Chautauquan Monthly June 1903. Pt. 1 of a series, The Arts and Crafts Movement, begun Oct. 1902.

---. "Pre-Raphaelites: The Beginnings of the Arts and Crafts Movement." Chautauquan Monthly Oct. 1902. Pt. 1 of a series, The Arts and Crafts Movement, begun Oct. 1902. 
---. "The Production of Industrial Art in America." Chautauquan Monthly Apr. 1903.

Pt. 7 of a series, The Arts and Crafts Movement, begun Oct. 1902.

---. "A Survey of the Arts and Crafts Movement in England." Chautauquan Monthly Nov. 1902. Pt. 2 of a series, The Arts and Crafts Movement, begun Oct. 1902.

\section{Newspaper Articles}

Chautauqua Assembly Herald. 15 June 1876-28 Aug. 1905.

Chautauquan Daily. 29 June 1906-present.

"1878-1903, Twenty-fifth C. L. S. C. Anniversary." Chautauqua Assembly Herald 11 July 1903: 7.

"About The Grounds." Chautanqua Assembly Herald 30 July 1887: 1.

"Alumni Hall." Chautauqua Assembly Herald 25 July 1902: 1.

"American Art Hopeful: Public Art And Public Buildings Improving, Says Mr. Zueblin." Chautauquan Daily 30 July 1909: $1+$.

"American Ideals: Mr. Charles Zueblin Inquired If There Are Any and If So What." Chautauquan Daily 28 Aug. 1920: 5.

"The American League For Civic Improvement: Prominent Persons Here to Attend the Meetings - Chautauqua's Relation to the League." Chautauqua Assembly Herald 15 July 1903: 1 .

"The American League For Civic Improvement: Report of the Annual Convention Now in Session at Chautauqua." Chautauqua Assembly Herald 14 July 1903: 1.

"Art and Archeology." Chautauquan Daily 11 July 1916: 1+.

“Art Center and Zoo." Chautauquan Daily 10 July 1915: 3.

"The Arts and Crafts." Chautauquan Daily 17 July 1917: 1. 
"Arts and Crafts: Address by H.T. Bailey of Summer Schools." Chautauquan Daily 12 July 1917: $1+$.

"Arts and Crafts and the Settlement." Chautauqua Assembly Herald 9 July 1902: 2+.

"Arts and Crafts Conference: The Final Meeting of the Week Held in the Hall Yesterday." Chautauqua Assembly Herald 19 July 1902: 4.

"Arts and Crafts Conference: 'The True and False in Furniture.' Opening Conference of Arts and Crafts Week." Chautauqua Assembly Herald 15 July 1902: 3.

"Arts and Crafts Number." Chautauqua Assembly Herald 16 July 1902: 1+.

"An Arts and Crafts Village." Chautauqua Assembly Herald 20 Aug. 1902: 1.

"Arts and Crafts: Yesterday was Visiting Day - Interest Rapidly Developing in the School." Chautauqua Assembly Herald 10 July 1902: 3.

"Aula Christi, Unique Hall of Christ Dedicated at Chautauqua." Los Angeles Times 29 Aug. 1909: 261.

Bailey, Mary K. "Great-granddaughter visits Bailey home in North Scituate." Chautauquan Daily 17 Aug. 1977: 4.

"A Bank President in Trouble: A Resignation in Buffalo and a Suit for a Large Deficiency." New York Times 10 Sept. 1881.

"Beauty in Common Things: Obligation to Recognize It Shown by Mr. Bailey." Chautauquan Daily 8 July 1909: 2.

"Beauty in Nature: Mr. Henry Turner Bailey Gave an Insight to Chautauquans." Chautauquan Daily 21 July 1913: 8.

"Beauty in the Trees." Chautauquan Daily 16 Aug. 1916: 1+.

“Buffalo's Fine Arts Academy.” New York Times 3 Feb. 1900.

"A Building to be Devoted Exclusively to the Ana of Christ." Kansas City Star 22 Aug. 1909 .

"Chapel of the Good Shepherd." Chautauqua Assembly Herald 2 Aug. 1901.

“Charles Zueblin, 'Emerson, the Idealist and Individualist."” Chautauquan Daily 18 
July 1911: 2 .

“Chautauqua, 1883, Detailed Program." Chautauqua Assembly Herald 4 Aug. 1883: 5.

"Chautauqua Architecture: Inheritance of Form and Symbol Described By Mr. Bailey." Chautauquan Daily 17 July 1909: 1+.

"Chautauqua: A Summer City. Chautauqua Institution, Historical Sketch by Captain Frederick W. Hyde." Chautauqua Assembly Herald 1 Aug. 1902: $1+$.

"Chautauqua Assembly Elects Officers." New York Times 18 Jan. 1902.

Chautauqua Assembly Daily Herald 15 June 1876: entire.

"Chautauqua for 1895." Chautauqua Assembly Herald 25 July 1895: 1.

"Chautauqua In 1909: Many Changes and Improvements Add To Beauty of Grounds." Chautauquan Daily 2 July 1909: 1.

“The Chautauqua Institution." Chautauqua Assembly Herald 5 July 1902: 4.

"Chautauqua Summer Schools, Season of 1902." Chautauqua Assembly Herald 5 July 1902: 3 .

"The Chautauquan: An Outline of Features Which Will be Presented During the Coming Year." Chautauqua Assembly Herald 5 July 1902: 4.

"City Improvement." Chautauqua Assembly Herald 15 July 1903: 5.

"City Improvement: Civic Betterment Conference Addressed by Mrs. L. M. McCall, Professor S. H. Clark, Mrs. Conde Hamlin, Mrs. E. W. Biddle, and Principal W. H. Stevens." Chautauqua Assembly Herald 17 July 1903: 5.

"Civic Conference: Village Improvement Topic for Second Conference." Chautauqua Assembly Herald 15 July 1903: 1.

"Civic Week: Forecast of Notable Meetings of Civic Institute, at Chautauqua, under Auspices of the American League for Civic Improvement." Chautauqua Assembly Herald 10 July 1903: 2.

"C. L. S. C. Round Table: Mr. Zueblin Says Our Government Left Too Much to Lawyers." Chautauquan Daily 24 July 1911: 7. 
"College for Orphan Girls: Estate of \$5,000,000 Left by Robert Carson of Philadelphia Now Available." New York Times 5 July 1912.

"College of Liberal Arts." Chautauqua Assembly Herald 30 July 1887: 3.

"Color Symbolism: Appropriateness of Special Colors for Special Decorative Work." Chautauquan Daily 12 July 1909: 2.

"The Common Life: Mr. Charles Zueblin Closes Lecture Series On Implications of Democracy." Chautauquan Daily 31 July 1909: 1+.

"Complete Schedule." Chautauqua Assembly Herald 23 July 1897: 4.

"Constitution Antiquated: Mr. Zueblin Says It Is Based On Pernicious Ideal." Chautauquan Daily 27 July 1909: 1+.

"Cornerstone Laid, Impressive Ceremonies at the Hall of the Christ." Chautauqua Assembly Herald 8 Aug. 1900: 4.

"Cottage Building Activity: Additions and Improvements to Chautauqua's Dwellings." Chautauqua Assembly Herald 6 July, 1902: 2.

“C. Studebaker Jr.: Utilities Man, Dies.” New York Times 4 Dec. 1932.

"Department of Instruction: Official Program, Friday, Aug. 4, 9:00 AM, Women's Club, 'Forestry and Birds."' The Chautauquan Daily 4 Aug. 1911: 1.

"Devotional Hours: Dr. Graham Taylor - 'Social Conditions of Personal Progress,' Personal Responsibility and Social Progress." Chautauqua Assembly Herald 5 July, 1902: 7.

"Dr. Harper Banqueted: By the Assembly." Chautauqua Assembly Herald 25 July 1891: 4.

"Drift of the Day." Chautauqua Assembly Herald 14 July 1902: 4.

Dunning, Rev. A. E. "Bishop John H. Vincent: a Practical Christian Idealist." Chautauqua Assembly Herald 6 Aug. 1902: 1+.

“Editorial: Dr. William R. Harper." Chautauqua Assembly Herald 25 July 1891: 1.

"The Education of Lincoln: A Lecture by President George E. Vincent." Chautauquan Daily 6 Aug. 1912: 1+. 
"Educational Conference: Mr. Henry Turner Bailey Made Address on 'The Social Ideal in Education."” Chautauquan Daily 22 July 1913: 5.

"Empire State's Incoming Chief Magistrate: Close Range Character Sketch of Francis Wayland Higgins - Plain 'Frank' to his Fellow-townsmen - Fond of Bowling and Golf - His Varied Business Interests - A Charming Family Circle." New York Times 13 Nov. 1904.

"Epworth League Conference: Gov. McKinley Lauds the Society for Its International Character." New York Times 30 June 1893.

"Epworth League Memorial: The Beautiful Building to be Dedicated To-day." New York Times 7 May 1893.

"Fancy-Work and Handicraft." Chautauquan Daily 29 July 1915: 3.

"Flowers and Their Uses." Chautauquan Daily 30 July 1915: 2.

"F. M. Andrews Dies: A Noted Architect, Designer of the Hotel McAlpin and Other Large Structures Won British Award." Obituary. New York Times 3 Sept. 1948.

"Franklyn J. Kidd." Obituary. New York Times 11 Dec. 1942.

"Good Coloring: How to Get It." Chautauquan Daily 28 July 1915: 1+.

"The Hall of Christ: The Site of the New Institution Appropriately Dedicated." Chautauqua Assembly Herald 19 Aug. 1896: 5.

"The Hall of the Christ: Architect Pelz on a Visit of Inspection." Chautauqua Assembly Herald 21 July 1900: 5.

"The Harrisburg Plan." Chautauqua Assembly Herald 15 July 1903: 6.

"Mr. Henry Turner Bailey: On Seeing Beauty in Pictorial Art." Chautauquan Daily 7 Aug. 1913: 1.

"The Home Beautiful: An Illustrated Lecture by Henry Turner Bailey." Chautauquan Daily 11 Aug. 1910: 1.

"Important Resolutions: American League for Civic Improvement Closes Its Sessions at Chautauqua With Resolutions Concerning Future Work." Chautauqua Assembly Herald 21 July 1903: 6. 
"Improvement Day: The National League of Improvement Associations in Session Here Today." Chautauqua Assembly Herald 15 Aug. 1901.

"Improvement Day: Meeting of the American League of Civic Improvement at Chautauqua Thursday." Chautauqua Assembly Herald 16 Aug. 1901: 1+.

"Improvement in Buffalo: A Plan At Last to be Rid of Grade Crossings. A Menace to the Persons and Business of Citizens to be Removed - Great Railroad Buildings." New York Times 8 June 1888.

"Improving Chautauqua: Many Practical Suggestions by Mr. Henry Turner Bailey." Chautauquan Daily 30 July 1906: 7.

"In Living Things." Chautauquan Daily 19 Aug. 1916: 2.

"In Plant Life." Chautauquan Daily 15 Aug. 1916: 1+.

"In the Landscape." Chautauquan Daily 18 Aug. 1916: $1+$.

"Justice: Professor Zueblin's Fourth Address At The Amphitheater." Chautauqua Assembly Herald 20 July 1903: 1+.

"Karl Bitter Dies of Auto Injuries: Sculptor Won Fame at 21 by Designing Famous Trinity $\$ 200,000$ Bronze Doors. Began Career in Vienna, Winner of Medals in World's Greatest Expositions - His Colossal Groups at Chicago Fair." New York Times 11 Apr. 1915.

"King Memorial Fountain: Ornament to Washington Park in Albany." New York Times 8 Oct. 1893.

"Knowledge Not Culture: Mr. Zueblin Says Cultured People Must See Facts In Right Situations." Chautauquan Daily 29 July 1909: 1+.

"League of Civic Improvement Meets." New York Times 25 May 1902.

"Look At the Facts." Chautauqua Assembly Daily Herald 15 June 1876: 1.

"Lowell: Treated As A Publicist And Humanist." Chautauquan Daily 19 July 1911: 1.

"Making Your Town Beautiful." Chautauquan Daily 20 July 1914: 1+.

"Man And Woman: The Complementary Relation Of The Sexes." Chautauqua 
Assembly Herald 16 July 1903: $1+$.

"Manual Dexterity: Mr. H.T. Bailey Says Children Should be Trained Therein." Chautauquan Daily 24 Aug. 1911: 2.

"Mark Twain: Mr. Charles Zueblin Discusses Him as Humorist and Reformer." Chautauquan Daily 21 July 1911: 7.

"Message of Civic Improvement: Practical Address by Mr. J. Horace McFarland Yesterday Morning." Chautauqua Assembly Herald 14 July 1904: 6.

"The Model Chautauqua: Announcement of Plans Prepared by Architect Albert Kelsey." Chautauqua Assembly Herald 3 July 1903: 3.

"Mr. Ralph Norton Gives Exposition of the Trustees' Action In Plaza Improvements." Chautauquan Daily 1 July 1946: 1+.

"Municipal Progress: Address By Clinton Rogers Woodruff On A Timely Subject, What Has Been Accomplished in Various Cities Through the Organizations Known as Reform Clubs." Chautauqua Assembly Herald 14 July 1903: 1+.

"National Army Day: Governor Roosevelt the Guest of Honor, The Governor's Great Speech." Chautauqua Assembly Herald 19 Aug. 1899: 1+.

"The National Bank Question: Financiers Taking a Glowing View of the Future of the System." New York Times 18 Nov. 1883.

"National Improvement: Last Conference of Civic Week Addressed by President J. H. McFarland, Dick J. Crosby, W. R. Gregg, and Dr. Earl Barnes." Chautauqua Assembly Herald 20 July 1903: 1.

"New Hall of Philosophy." Chautauqua Assembly Herald 18 Aug.1902: 1+.

"Newer Ideals of Peace." Chautauqua Assembly Herald 8 July 1902: 5.

"Not Good Sports: Business Men Lack Courage, Says Mr. Zueblin." Chautauquan Daily 28 July 1909: 1+.

"Only Building of Its Kind in the World." Boston Globe 22 Aug. 1909.

"Opening of the $29^{\text {th }}$ Annual Assembly." Chautauqua Assembly Herald 5 July 1902: $1+$. 
"Politics" The Third of Professor Zueblin's Series of Addresses." Chautauqua Assembly Herald 18 July 1903: $1+$.

"Pottery, Printing, Binding." Chautauqua Assembly Herald 2 Aug. 1902: 3.

"The Principles Involved in Popular Education: A Lecture by Dr. William R. Harper of Chicago." Chautauqua Assembly Herald 8 Aug. 1902: 2.

"Public Beauty Week: First Conference - 'Woman's Work for Civic Betterment' Program for the Week." Chautauqua Assembly Herald 19 Aug. 1902: 4.

"Public Improvements." Chautauqua Assembly Herald 7 July 1902: 6.

"The Rational and the Rationalistic Higher Criticism: A Lecture Delivered in the Amphitheatre, Aug. 2, 1892, by Dr. W. R. Harper, Pres. of the University of Chicago." Chautauqua Assembly Herald 4 Aug. 1892: 2+.

"Recognition Day." Chautauqua Assembly Herald 13 Aug. 1902: 1+.

"Revised Program." Chautauqua Assembly Herald 5 July 1902: 2+.

"Rock of Horeb In Bronze: The Beautiful King Fountain Which Adorns Albany." New York Times 1 Oct. 1893.

"Seeing Greece: Mr. Henry Turner Bailey Told of Two Ways." Chautauquan Daily 26 July 1913: 5.

"Selection and Arrangement." Chautauquan Daily 29 July 1915: 1.

"Smith Library Planned in Harmony With Plaza." Chautauquan Daily 4 Aug. 1931: 10.

"Social Settlement Number." Chautauqua Assembly Herald 8 July 1902: 1+.

"Some Ideals of University Education: A Lecture Delivered in the Amphitheatre, July 31, 1893, by Dr. W. R. Harper, Pres. of the University of Chicago." Chautauqua Assembly Herald 7 Aug. 1893: 5.

"Summer School Notes." Chautauquan Daily 15 July 1911: 5.

"Summer Schools Needs: Six Most Desired Physical Betterments." Chautauquan Daily 9 July 1915: 5.

"Symbolism of Color." Chautauquan Daily 20 Aug. 1913: 2. 
"A System of Education: Abstract of an Address Delivered in the Amphitheatre, July 5, 1893, at the Opening of the Chautauqua College of Liberal Arts, by Principal W. R. Harper, President of the University of Chicago, Chicago, Ill." Chautauqua Assembly Herald 15 Aug. 1893: 2.

"Theseus and Minotaur." Chautauquan Daily 12 July 1916: 1+.

"This Year and the Next." Chautauqua Assembly Herald 20 Aug. 1902: 1+.

"Three Lectures: Abstracts of Those Given this Week by Dr. George Vincent." Chautauqua Assembly Herald 5 July 1902: 8.

"The Unity of Beauty." Chautauquan Daily 8 Aug. 1913: 5.

Vincent, George E. "Community - Lyceum - School: 'Chautauqua as an Educational Center." Chautanqua Assembly Herald 12 July 1902: 3.

Vincent, John Heyl. "Who are Welcome to Chautauqua?" Chautauqua Assembly Daily Herald 15 June 1876: 2.

"Walks and Talks: Mr. Charles Rohlfs on the Art Principle in Furniture." Chautauqua Assembly Herald 15 July, 1902: 1.

"Wealth: First Of Professor Zueblin's Lectures On Contemporary Society." Chautauqua Assembly Herald 15 July 1903: 2.

"What to do With Heirlooms." Chautauquan Daily 31 July 1915: 1+.

"Where No Three Orphans May Dress Alike: Girls in Carson College to be Saved from Deadly Sameness - An Architect's Original Interpretation of a Rich Man's Vision." New York Times 11 June 1916.

"Who's Who: Brief Biographical Sketches of Prominent Persons on the Program Next Week." Chautauqua Assembly Herald 11 July 1903: 1.

"Who's Who: Pertinent Paragraphs Pertaining to People on the Program, Mr. Henry Turner Bailey." Chautauquan Daily 8 July 1915: 2.

"William Deans Howells: 'Critic and Socialist,' as Analyzed by Mr. Zueblin." Chautauquan Daily 22 July 1911: 2.

"William Morris: A Lecture by Mr. W. C. Cornwell of Buffalo. A Review of the Life 
and Work of a Great Artist and Craftsman, a Decorator, Designer, Dyer, Weaver, Illuminator, Binder and Printer." Chautauqua Assembly Herald 16 July, 1902: $1+$.

"W. M. Day: Former C. of C. Head, Dies. Retired Editor and Publisher to be Buried Today in Santa Cruz." Cleveland Plain Dealer 30 Dec. 1929: 3.

"Woman's Club: Mr. Bailey Speaks on 'Art in the General Federation." Chautauquan Daily 24 July 1911: 5.

"Woman's Day." Chautauqua Assembly Herald 18 July 1902: 1+.

"The World Beautiful: Lecture Illustrated With Drawings and Lantern Slides." Chautauquan Daily 15 July 1910: 5.

"World's Fair Appointments: Gov. Flower Selects Managers to Work With the Commissioners." New York Times 13 Apr. 1892.

"XI. Arts and Crafts" (Summer Schools Offerings). Chautauquan Daily 8 July 1916: 2.

\section{Web Sources}

"About the Club." Union League Club of Chicago. 6 Nov. 2011.

Albright Art Gallery, 1902, Buffalo, NY. Albright-Knox Art Gallery. 5 Dec. 2011.

American Surety Building, 1894-1896, New York, NY. Early Office Museum, 2000. 7 Nov. 2007.

Art Building, 1901. Pan American Exposition, Buffalo, NY. The Buffalonian. 5 Dec. 2011.

Carson College for Orphan Girls, 1912, Flourtown, PA. Ebay, 2009. 8 Aug. 2011.

Jenks, Bro. Christopher Steven. "The Akron Sunday School Plan." American Religious Buildings. From Common Bond, 1995. 3 Sept. 2010.

Rhind, J. Massey. "Four Maidens" or "Caryatids," Park Row Building, 1899. Diane Durante, Forgotten Delights. 7 Nov. 2007. 
--.. "King Memorial Fountain," Albany, NY. Postcard. Ebay. 7 Nov. 2007.

Twain, Mark. "To William C. Cornwell." 5-15? Apr. 1873. Mark Twain Project, 2002. 23 July 2011.

\section{Other}

Becker, Tom and Jane. 2003. Christmas card.

Conroe, Douglas. Vice-President, Operations, Chautauqua Institution. Personal Interviews. Nov. 2003-Nov. 2011.

Haney, Gwenyth, Community Collections Manager, Dayton History, Dayton, OH. Personal interview.

Landmarks Preservation Commission. "American Surety Company Building." Designation List 283, LP-1934. June 24, 1997. PDF file.

Mando, James. Office of Development, Chautauqua Institution. Personal interview. Aug. 2003.

Minutes of Annual Meeting of Chautauqua Trustees. Chautauqua Institution Archives. Twenty-Sixth, Cleveland, Ohio, Jan. 11, 1900.

Twenty-Seventh, Cleveland, Ohio, Jan. 10, 1901.

Twenty-Eighth, Buffalo, New York, Jan. 16, 1902.

Twenty-Ninth, Chautauqua, New York, Oct. 11, 1902.

Thirtieth, Chautauqua, New York, Oct. 23, 1903.

Thirty-First, Chautauqua, New York, Oct. 14, 15, 1904.

Thirty-Second, Buffalo, New York, Oct. 28, 1905.

Thirty-Third, Buffalo, New York, Oct. 30, 1906.

Thirty-Fourth, Buffalo, New York, Oct. 29, 1907.

Mid-Winter, Buffalo, New York, Feb. 12, 1909.

Mid-Winter, Buffalo, New York, Feb. 11, 1910.

Schmitz, Jon. Archivist, Chautauqua Institution Archives. Nov. 2003-Nov. 2011. Personal interviews.

"Sidney R. Badgley." Cleveland Architects. Cleveland Landmarks Commission; n.d. PDF file.

Thews, Rev Tom. St. Paul's Memorial United Methodist Church, South Bend, IN. 
Personal interview.

\section{Books, Pamphlets, and Brochures}

Addams, Jane. The Spirit of Youth and the City Streets. New York: Macmillan, 1923.

Addams, Jane, et al. Hull-House Maps and Papers. New York: Crowell, 1895.

The Alumni Register of the University of Pennsylvania, October 1900. Philadelphia: General Alumni Society of the University of Pennsylvania, 1900.

American Federation of Arts. American Art Directory. New York: R. R. Bowker, 1903.

American League for Civic Improvement. Nation-Wide Civic Betterment. Chicago: The American League for Civic Improvement, 1903.

Anderson \& Cooley. South Bend and The Men Who Have Made It. Historical, Descriptive, Biographical. South Bend: Tribune Printing Co., 1901.

Bailey, Henry Turner. "The Beauty Lover's Creed." ca. 1903. Chautauqua Institution Archives.

---. The Flush of the Dawn: Notes on Art Education. New York: Atkinson, Mentzer \& Grover, 1910. Courtesy of the Chautauqua Institution Archives, Chautauqua, NY.

---. The Magic Realm of the Arts, suggesting incidentally, The Importance of Fads. Worcester: Davis P, 1928. Courtesy of the Chautauqua Institution Archives, Chautauqua, NY.

---, ed. School Arts Book. 11 vols. Worcester: Davis P, 1903-1911.

---. The Tree Folk. Cambridge: Washburn \& Thomas, 1925. Courtesy of the Chautauqua Institution Archives, Chautauqua, NY.

---. The Victorious Surrender. Boston: Pilgrim P, 1911. Courtesy of the Chautauqua Institution Archives, Chautauqua, NY.

The Book of Clevelanders, A Biographical Dictionary of Living Men of the City of Cleveland. Cleveland: Burrows Bros., 1914.

Bray, Frank Chapin. A Reading Journey Through Chautauqua. Chautauqua: 
Chautauqua Institution, 1905.

Bryan's Carnegie Library. Bryan, TX: Carnegie Center of Brazos Valley History, n.d. Brochure.

Caffin, Charles H. American Masters of Sculpture. New York: Doubleday, 1913.

Chamberlain, Joshua Lawrence, ed. University Sons. Boston: R. Herndon Co., 1902. Vol. 2 of University of Pennsylvania, Its History, Influence, Equipment and Characteristics. 2 vols. 1901-1902.

Chapin, Willis O. The Buffalo Fine Arts Academy, A Historical Sketch. Buffalo: "Published by the Academy," 1899.

Chautauqua Summer Schools: 1941 Session, July 7-Aug. 15. Chautauqua: Chautauqua Institution, 1941.

The Chautauquan: Official Program, $88^{\text {th }}$ season, 1961, July 2-Aug. 27. Chautauqua: Chautauqua Institution, 1961.

The Chautauquan: Adult Education, 1961. Chautauqua: Chautauqua Institution, 1961.

Christian, Stella L. History of the Texas Federation of Women's Clubs. Houston: DealyAdey-Elgin, 1919.

Cook, E. Wade. Betterment: Individual, Social, and Industrial or Highest Efficiency Through the Golden Rules of Right Nutrition; Welfare Work; and the Higher Industrial Developments. New York: Frederick A. Stokes, 1906.

Cram, Mary Frances Bestor. Chautauqua Salute: A Memoir of the Bestor Years. Chautauqua: Chautauqua Institution, 1990.

David, Philip, ed. The Field of Social Service. Boston: Small, Maynard, 1915.

Dow, Arthur Wesley. Composition. 1899. 13 ${ }^{\text {th }}$ ed. New York: Doubleday, 1929.

Eliot, Charles William. Charles Eliot, Landscape Architect. Boston: Houghton Mifflin, 1902.

Ely, Richard T. Ground Under Our Feet: An Autobiography. New York: Macmillan, 1938.

---. Outlines of Economics. Meadville, PA: Chautauqua Century P, 1893. 
---. Social Aspects of Christianity and Other Essays. New York: Thomas Y. Crowell, 1889.

---. The Strength and Weakness of Socialism. New York: Chautauqua P, 1894.

---. Studies in the Evolution of Industrial Society. New York: Chautauqua P, 1903.

First Report of the Park and Outdoor Art Association. Louisville, KY: Park and Outdoor Art Association, 1897.

Flinn, John Joseph. Official Guide to the World's Columbian Exposition. Chicago: The Columbian Guide Co., 1893.

Fox, Joan, and Dorothy Hill. Official Walking Tour Guidebook of the Chautauqua Institution. Chautauqua: n.p., 1999.

Goss, Mary Lathrop. Welfare Work by Corporations. Philadelphia: American Baptist Publication Society, 1911.

Gray, David, ed. Art Hand-Book, Sculpture, Architecture, Painting, Official Handbook of Architecture and Sculpture and Art Catalogue to the Pan-American Exposition. Buffalo: David Gray, 1901.

---. Catalogue of the Exhibition of Fine Arts. Buffalo: David Gray, 1901.

A History of the City of Buffalo, Its Men and Institutions, Biographical Sketches of Leading Citizens. Buffalo: Buffalo Evening News, 1908.

Kelsey, Albert. The Proposed Parkway for Philadelphia, A Direct Thoroughfare From the Public Buildings to the Green Street Entrance to Fairmount Park: containing a review of the various movements for a diagonal boulevard and the original argument in favor of a plaza before the northern facade of the City Hall. Philadelphia: The Parkway Association, 1902.

Kelsey, Albert, ed., Architectural League of America, The Architectural Annual. Philadelphia: The Architectural Annual, 1900.

Kelsey, Albert, Theodore Marburg and Municipal Art Society of Baltimore. The City of the Future: Its Activities, Aims and Hopes. Baltmore?: s.n., 1902?.

Kennedy, James Harrison. A History of the City of Cleveland, Its Settlement, Rise, and Progress, 1796-1896. Cleveland: Imperial Press, 1896. 
Knox, Helen. Mrs. Percy V. Pennybacker, An Appreciation. New York: Fleming H. Revell Co., 1916.

Levy, Florence N., ed., American Art Annual, 1903-1904. New York: American Art Annual, 1903.

Manning, Warren. "The Purpose and Practice of Landscape Architecture." W. H. Ragan, Secretary. Transactions of the Indiana Horticultural Society for the Year 1893, Being a Report of the Thirty-Third Annual Meeting, Held in the City of Indianapolis, Nov. 8, 9 and 10, 1893, Together With Reports of Local Societies, Selected Papers, Etc., Etc. Indianapolis: Wm. B. Burford, Contractor for State Printing and Binding, 1894.

Manning, Warren, and William A. Lambeth. Thomas Jefferson as an Architect and a Designer of Landscapes. Boston: Houghton Mifflin, 1913.

Maxwell, William H. The City and the Child. New York: Playground Assoc. of America, 1909.

Memorial and Family History of Erie County, New York, vol, 2, Biographical \& Genealogical. New York: Genealogical Publishing Company, 1906-8.

Meriam, Junius Lathrop. "Normal School Education and Efficiency in Teaching." Diss. Columbia University, 1905.

Nelson, E. T., ed. Ohio Wesleyan University, Delaware, Ohio, 1844-1894. Cleveland: Cleveland Printing and Publishing, 1895.

North, Simon Newton Dexter, Francis Graham Wickware, and Albert Bushnell Hart. The American Yearbook, A Record of Events and Progress, 1910. New York: D. Appleton, 1911.

Official Catalogue and Guide Book to the Pan-American Exposition, With Maps of Exposition and Illustrations, Buffalo, N.Y., U.S.A., May $1^{\text {st }}$ to Nov. $1^{\text {st }} 1901$. Buffalo: Charles Ahrhart, 1901.

Official Program, Sixty-Eighth Annual Session, 1941-July and Aug.. Chautauqua: Chautauqua Institution, 1941.

Pilgrim Church, History and Directory, 1859-1929. Cleveland: Pilgrim Congregational Church, 1929. 
Price, C. Matlack, Albert Kelsey, and Paul Philippe Cret. The American Union and Its Annex, Washington, D. C.: A Study in Plan \& Detail. New York: Architectural Record, 1913.

Robinson, Charles Mulford. City Planning: With Special Reference to the Planning of Streets and Lots. New York: Putnam, 1916.

---. The Improvement of Towns and Cities: or The Practical Basis of Civic Aesthetics. New York: Putnam, 1901.

---. Modern Civic Art: or The City Made Beautiful. New York: G. P. Putnam's Sons, 1903. New York: Arno P \& New York Times, 1970.

Robinson, J. B. The Epworth League. Its Place in Methodism. A Manual. New York: Eaton \& Mains, 1890.

Schevill, Ferdinand. Karl Bitter: A Biography. Chicago: U of Chicago P, 1917.

Schuyler, Montgomery. American Architecture and Other Writings. Ed. William H. Jordy and Ralph Coe. Cambridge, MA: Belknap, 1961.

Shuey, Dennis Boeshore. History of the Shuey Family in America, From 1732 to 1919. Galion, OH: Published for the members of the Shuey Family By the Author, 1919.

Shuey, Edwin L. Factory People and Their Employer: How Their Relations Are Made Pleasant and Profitable, A Handbook of Practical Methods and the Relations of Employer and Employe[e]. New York: Lentilhon, 1900.

Small, Albion W., and George E. Vincent. An Introduction to the Study of Society. New York: American Book, 1894.

St. Paul's Memorial United Methodist Church. A Guide to the Art Treasures. South Bend, IN: self-published, 2010. Pamphlet.

Stickley, Gustav. Craftsman Homes: Architecture and Furnishings of the American Arts and Crafts Movement. 1909. New York: Dover, 1979.

Storr, Richard J. Harper's University: The Beginnings, A History of the University of Chicago. Chicago: U of Chicago P, 1966.

Swaback, Vernon D. The Creative Community: Designing for Life. Scottsdale: Images, 2003. 
Taft, Lorado. The History of American Sculpture. New York: Macmillan, 1930.

Taylor, Graham. Religion in Social Action. New York: Dodd, Mead, 1913.

Texas State Library Association. Handbook of Texas Libraries. Austin, TX: Texas State Library Association, 1904.

Van Dyke, John C. How to Judge of a Picture, Familiar Talks in the Gallery With Uncritical Lovers of Art. New York: Chautauqua Press, 1889.

Vincent, George E. The Social Mind and Education. New York: Macmillan, 1897.

---. Summer Schools and University Extension. Albany, NY: J. B. Lyon, 1904.

Vincent, John Heyl. The Chautauqua Movement. 1885. Freeport, NY: Books for Libraries, 1971.

Vincent, Leon H. John Heyl Vincent: A Biographical Sketch. New York: MacMillan, 1925.

Warren, R. M. Chautauqua Sketches: Fair Point and the Sunday-School Assembly. Buffalo: H. H. Otis, 1878.

Williams, W. G., comp. Fifty years of History of the Ohio Wesleyan University, Delaware, Ohio. 1844-1894. Cleveland, OH: Cleveland Printing and Publishing, 1895.

Woods, Robert Archey. Americans in Process: A Settlement Study. Boston: Houghton, Mifflin, 1903.

---. Handbook of Settlements. 1911. New York: Arno P, 1970

---. The Settlement Horizon. New York: Russell Sage Foundation, 1922.

The Worlds. History of Cleveland, Commemorating the City's Centennial Anniversary. Cleveland: Cleveland World, 1896.

World's Columbian Exposition. State of Michigan. The Act of the Legislature Creating the Board of World's Fair Managers for the State of Michigan. Rules and Regulations of the Board and General Information Concerning the Exposition. First Edition. Issued by the State Board, Apr., 1892. Flint, MI: W.H. Werkheiser \& Sons, 1892. 
Zueblin, Charles. A Decade of Civic Development. Chicago: U of Chicago P, 1905.

---. American Municipal Progress. New York: Macmillan, 1902.

---. The Religion of a Democrat. New York: B. W. Huebsch, 1903.

\section{Secondary Sources}

\section{Periodicals}

Chambliss, Julian C. "Perfecting Space: J. Horace McFarland and the American Civic Association." Pennsylvania History: A Journal of Mid-Atlantic Studies 77.4, (2010): 486-497.

Culp, Paul M. "Carnegie Libraries of Texas." Texas Libraries 43 (1981): 260.

Droth, Martina. "The Ethics of Making: Craft and English Sculptural Aesthetics c. 18511900." Journal of Design History 17.3 (2004): 221-236.

"J. Horace McFarland and the City Beautiful Movement." Journal of Urban History 7 (1981): 315-334.

\section{Newspaper Articles}

Gray, Christopher. "Streetscapes/The American Surety Building: An 1890's Skyscraper May Become a Landmark." New York Times 28 Jan. 1996.

---. "Streetscapes/The Park Row Building, 15 Park Row: An 1899 'Monster' That Reigned High Over the City." New York Times 12 Mar. 2000.

\section{Web Sources}

About the Albright-Knox: History, Albright-Knox Art Gallery. 18 Feb. 2011.

Andrews, Frank M. (Mills). Biographical Dictionary of Cincinnati Architects, 17881940, 2008. 5 Oct. 2010.

Badgley, Sidney R. The Encyclopedia of Cleveland History, 1997. 5 March 2011. 
Brief History of TWU. Texas Woman's University. 20 Dec. 2010.

A Brief History of The Williston Northampton School. The Williston Northampton School. 18 Aug. 2011.

Carnegie Libraries in Texas. Texas Escapes. 16 Dec. 2010.

Cleveland Anniversary Celebrations. The Encyclopedia of Cleveland History, 1997. 23 Mar. 2011.

Cleveland Necrology File. Cleveland Public Library. 5 March 2011.

Cordery, Stacy A. Pennybacker, Anna J. Hardwicke. Texas State Historical Association. 28 Nov. 2010.

Eck, Susan. Art Building, "Doing the Pan...," 2001. 15 Feb. 2011.

Edward Brodhead Green - Biography. Buffalo as an Architectural Museum. 20 Jan. 2011.

George Edgar Vincent. American Sociological Association. 5 Dec. 2011.

"Grand Army Plaza: William Tecumseh Sherman." New York City Department of Parks \& Recreation. 22 Nov. 2011.

Grant, Kerry S. Karl Bitter at the Pan Am. Buffalo as an Architectural Museum. 28 Feb. 2011.

Haddington Branch of the Free Library of Philadelphia, 1912. Philadelphia Speaks. 19 Feb. 2011.

History and Objectives. The Lotos Club of New York. 6 Nov. 2011.

History of the 1905 Albright Art Gallery. Buffalo as an Architectural Museum. 18 Feb. 2011.

“History of Tippecanoe Place." PDF. Tippecanoe Restaurant-About Us. 11 Sept. 2011.

J. Massey Rhind. Wikipedia. 1 Mar 2011.

Johannesen, Eric. Architecture. The Encyclopedia of Cleveland History, 1998. 2 June 
2009.

---. Fairs and Expositions. The Encyclopedia of Cleveland History, 1998. 31 Mar. 2011.

John Henry Patterson (NCR Owner). Academic Dictionaries and Encyclopedias. 6 Oct. 2010.

Johnson, Tom L. The Encyclopedia of Cleveland History, 1997. 24 March 2011.

Jones Home of Children's Services, Inc. The Encyclopedia of Cleveland History, 1997. 5 March 2011.

Kelsey, Albert (1870-1950), Projects. Philadelphia Architects and Buildings. 23 July 2011.

Kennedy, Robert Gray (1850-1913). Philadelphia Architects and Buildings. 23 July 2011.

Lacasse, Norman L. Biography, Mira Lloyd Dock. Pennsylvania Department of Environmental Protection, 1997. 12 Nov. 2011.

The Mall. The Encyclopedia of Cleveland History, 1998. 24 Mar. 2011.

Miller, Kalin. McFarland, J. Horace. Pennsylvania State University, 2006. 22 June 2011.

New York Governor Francis Wayland Higgins. National Governors Association. 4 Apr. 2011.

Northwood, Eliza. Architecture, Sculpture, and Color Schemes at the 1901 Pan-

American Exposition. Buffalo Architecture and History, 2002. 13 Feb. 2011.

OMB: Old Main Building. Texas Woman's University. 20 Dec. 2010.

Palmer's Views, 1910. PDF. Town of Tonowanda. 15 July 2011.

The Pan-Am's Who's Who. Buffalo as an Architectural Museum. 20 Jan. 2011.

Pan-American Union Building, 1908-1910, Washington, DC. archINFORM, 22 Nov. 2011.

The Park Row Building. New York Architecture. 11 Sept. 2007. 
The Park Row Building. New York Architectural Images. 7 Nov. 2007.

Schmidt, Paul. A Brief Personal History of the Chautauqua Cinema, appended by Bill Schmidt, Owner. Uniplex Cinemas. 17 Feb. 2011.

"Sidney R. Badgley." Landmarks Commission - Cleveland City Planning Commission. 5 Mar. 2011.

Raphael, Sistine Madonna. Safron Arts, 13 Dec. 2010.

Soldiers' and Sailors' Monument. Soldiers and Sailors Monument. 3 Apr. 2011.

Some About the King Fountain. Washington Park Conservancy. 16 Nov. 2007.

Tatman, Sandra. Cope \& Stewardson (fl. 1885-1912). Philadelphia Architects and Buildings. 23 July 2011.

---. Hays, Frank Alliston (d. 1930). Philadelphia Architects and Buildings. 23 July 2011.

---. Kelsey, Albert (1870-1950). Philadelphia Architects and Buildings. 23 July 2011.

---. Kennedy, Hays \& Kelsey (fl. 1898-1900). Philadelphia Architects and Buildings. 23 July 2011.

Taylor, Betsy. John J. Albright, Excerpts from 'The Ivy Grows Again: A History of the Albright Estate from 1890 to the Present.' Buffalo Architecture and History, 1998. 25 Aug 2011.

Wayne County Courthouse. National Park Service. 11 Sept. 2007.

William McKinley: Last Speech. Milestone Documents of American Leaders, 2009. 11 Dec. 2010.

Young, Terence. Social Reform Through Parks: The American Civic Association's Program for a Better America. Journal of Historical Geography 22.4 (1996): 460-472. ScienceDirect. 24 Oct. 2009.

\section{Books}

Ahlstrom, Sydney E. A Religious History of the American People. New Haven: Yale UP, 1972. 
Appleton, Jay. The Experience of Landscape. New York: Wiley, 1975.

Aron, Cindy S. Working at Play: A History of Vacations in the United States. New York: Oxford UP, 1999.

Art Club of Philadelphia. Charter, Constitution and By-Laws of the Art Club of Philadelphia with House Rules, Report of the Board of Directors, and List of Members. Philadelphia: The Art Club, 1898.

The Arts of the American Renaissance. New York: Hirschl \& Adler Galleries, 1985.

Avery, Elroy McKendree. A History of Cleveland and Its Environs: The Heart of New Connecticut. Volume I, Historical. Chicago: Lewis Publishing Company: 1918.

Badger, Reid. The Great American Fair: The World's Columbian Exposition \& American Culture. Chicago: N. Hall, 1979.

Barbuto, Domenica M. American Settlement Houses and Progressive Social Reform. Phoenix, AR: Oryx P, 1999.

Barrie, Thomas. Spiritual Path, Sacred Place: Myth, Ritual, and Meaning in Architecture. Boston: Shambala, 1996.

Bayless, Pamela. The YMCA at 150: A History of the YMCA of Greater New York, 18522002. New York: YMCA of Greater New York, 2002.

Belfer, Lauren. City of Light. New York: Random, 1999.

Birnbaum, Charles A., and Robin Karson, eds. Pioneers of American Landscape Design. New York: McGraw, 2000.

Block, Jean F. The Uses of Gothic: Planning and Building the Campus of the University of Chicago, 1892-1932. Chicago: U Chicago Library, 1983.

Bobinski, George S. Carnegie Libraries: Their History and Impact on American Public Library Development. Chicago: ALA, 1969.

Bodnar, John. Remaking America: Public Memory, Commemoration, and Patriotism in the Twentieth Century. Princeton: Princeton UP, 1992.

Bogart, Michele H. Public Sculpture and the Civic Ideal in New York City, 1890-1930. Washington: Smithsonian Institution Press, 1997. 
Boris Eileen. Art and Labor: Ruskin, Morris, and the Craftsman Ideal in America. Philadelphia: Temple UP, 1986.

"Bray, Frank Chapin, American editor and educator." Encyclopedia Americana. New York: J.D. Lyon, 1918.

Brereton, Joel. "Sacred Space." The Encyclopedia of Religion. Ed. Mircea Eliade. New York: Simon, 1987.

Brownlee, David B. Building the City Beautiful: The Benjamin Franklin Parkway and the Philadelphia Museum of Art. Philadelphia: Philadelphia Museum of Art, 1989.

Burg, David F. Chicago's White City of 1893. Lexington: UP Kentucky, 1976.

Burke, Doreen Bolger, et al. Metropolitan Museum of Art. In Pursuit of Beauty: Americans and the Aesthetic Movement. New York: Rizzoli, 1987.

Callen, Anthea. Angel in the Studio. London: Astragal, 1979.

Campen, Richard N. Chautauqua Impressions: Architecture and Ambiance. Chagrin Falls, OH: West Summit, 1984.

Carson, Mina Julia. Settlement Folk: Social Thought and the American Settlement Movement, 1885-1930. Chicago: U of Chicago P, 1990.

Case, Victoria, and Robert Ormond Case. We Called It Culture: The Story of Chautauqua. Freeport, NY: Books For Libraries, 1948.

Chambers, John Whiteclay. The Tyranny of Change: America in the Progressive Era, 1890-1920. New Brunswick: Rutgers UP, 2000.

Cherry, Conrad. Hurrying Toward Zion: Universities, Divinity Schools, and American Protestantism. Bloomington: Indiana UP, 1995.

Chidester, David, and Edward T. Linenthal. American Sacred Space. Bloomington: Indiana UP, 1995.

Cigliano, Jan, and Sarah Bradford Landau, eds. The Grand American Avenue, 18501920. San Francisco: Pomegranate Artbooks, 1994.

Cikovsky, Nicolai, Jr. Winslow Homer. Washington, DC: National Gallery of Art, 
1995.

Clark, John Burton. The Banners and Mosaics of Chautauqua, 1882-1992. Chautauqua: Alumni Association of CLSC, 1992.

Conkling, Edgar C. Frederick Law Olmsted's Point Chautauqua: The Story of an Historic Lakeside Community. Buffalo: Canisius College Press, 2001.

Cranz, Galen. Politics of Park Design: A History of Urban Parks in America. Cambridge, MA: MIT P, 1982.

Craven, Wayne. Sculpture in America. Newark: U of Delaware P, 1984.

Crocker, Kathleen, and Jane Currie. Images of America: Chautauqua Institution, 18741974. Charleston: Arcadia, 2001.

Crowther, Samuel. John H. Patterson: Pioneer in Industrial Welfare. Garden City, NY: Doubleday, 1923.

Cumming, Elizabeth, and Wendy Kaplan. The Arts and Crafts Movement. London: Thames and Hudson, 1991.

Cunningham, Joseph. The Artistic Furniture of Charles Rohlfs. New Haven: Yale UP, 2008 .

Curtis, Penelope. Sculpture 1900-1945: After Rodin. New York: Oxford, 1999.

Cyphers, Christopher J. The National Federation and the Making of a New Liberalism, 1900-1915. Westport, CT: Praeger, 2002.

Dabakis, Melissa. Visualizing Labor in American Sculpture: Monuments, Manliness, and the Work Ethic, 1880-1935. Cambridge: Cambridge UP, 1999.

Davis, Allen Freeman. Spearheads for Reform: The Social Settlements and the Progressive Movement, 1890-1914. New York: Oxford UP, 1967.

Davis, John. The Landscape of Belief: Encountering the Holy Land in NineteenthCentury American Art and Culture. Princeton: Princeton UP, 1996.

Dearinger, David B., ed. Rave Reviews: American Art and Its Critics, 1826-1925. New York: National Academy of Design, 2000.

Deegan, Mary Jo. Jane Addams and the Men of the Chicago School, 1892-1918. New 
Brunswick: Transaction, 1988.

Dennis, James M. Karl Bitter, Architectural Sculptor, 1867-1915. Madison: U of Wisconsin P, 1967.

Doezema, Marianne, and Elizabeth Milroy, eds. Reading American Art. New Haven: Yale UP, 1998.

Duncan, Thomas William. O, Chautauqua. New York: Coward, McCann, 1935.

Eliade, Mircea. The Sacred and the Profane: The Nature of Religion. New York: Harcourt Brace, 1987.

Ely, Richard C. The Story of Economics in the United States. Ed. Samuels, Warren J. New York: JAI, 2002. Research in the History of Economic Thought and Methodology 20-C.

Etlin, Richard A. Symbolic Space. Chicago: U of Chicago P, 1994.

Evans, Ed. Hidden Treasure: The Chautauqua Commission of Buffalo's E. B. Green. New York: Evans, 2005.

Fancher, Pauline. Chautauqua: Its Architecture and Its People. Miami: Banyan, 1978.

Faust, Albert Bernhardt. The German Element in the United States, With Special Reference to its Political, Moral, Social, and Educational Influence, Vol. II. Boston: Houghton Mifflin, 1909.

Ferry, W. Hawkins. The Buildings of Detroit: A History. Detroit: Wayne State UP, 1980.

Fielding, Mantle. Mantle Fielding's Dictionary of American Painters, Sculptors \& Engravers. New York: Apollo, 1986.

Finkelman, Paul, and James.Percoco. Milestone Documents of American Leaders. Dallas: Schlager Group, 2009.

Froome, Kathleen Ann. "The Sacred and Secular Landscape of Chautauqua. 18741890." MA thesis U of Virginia, 1988.

Fryd, Vivien Green. Art \& Empire: The Politics of Ethnicity in the United States Capitol, 1815-1860. New Haven: Yale UP, 1992. 
Fulks, Robert William, Jr. "The Ideological and Intellectual Development of the Chautauqua Sunday School Assembly at Fair Point, New York, 1874-1876." MA thesis U of Virginia, 1972.

Gabler, William J. "Frank Wayland Higgins: New York's 'Forgotten Governor,"” MA Thesis St. Bonaventure U, 2002.

Galey, Mary. The Grand Assembly: The Story of Life at the Colorado Chautauqua, Centennial Edition. Sun City, CA: Winlock, 1998.

Gardner, Albert TenEyck. American Sculpture: A Catalogue of the Collection of the Metropolitan Museum of Art. New York: Metropolitan Museum of Art, 1965.

Gilbert, James Burkhart. Perfect Cities: Chicago Utopias of 1893. Chicago: U of Chicago P, 1991.

Gould, Joseph E. The Chautauqua Movement: An Episode in the Continuing American Revolution. New York: State U of New York P, 1961.

Grant, Kerry S. The Rainbow City: Celebrating Light, Color, and Architecture at the Pan-American Exposition, Buffalo, 1901. Buffalo: Canisius College P, 2001.

"The Great American Architects Series, Architectural Record, 5 (June 1899)." Great American Architects Series Nos. 1-6; May 1895-July 1899. Rpt. New York: Arno, 1977.

Green, Nancy E., and Jessie Poesch. Arthur Wesley Dow and American Arts \& Crafts. New York: American Federation of Arts; Abrams, 2000.

Greene, Virginia A. The Architecture of Howard Van Doren Shaw. Chicago: Chicago Review P, 1998.

Gross, Linda P., and Theresa R. Snyder. Philadelphia's 1876 Centennial Exhibition. Chicago: Arcadia, 2005.

Grossman, Elizabeth G. The Civic Architecture of Paul Cret. Cambridge: Cambridge UP, 1996.

Harris Cyril M., ed. Illustrated Dictionary of Historic Architecture. New York: Dover, 1977.

Harrison, Harry P. Culture Under Canvas: The Story of Tent Chautauqua. [c. 1958] Westport: Greenwood, 1978. 
Hayden, Dolores. Seven American Utopias: The Architecture of Communitarian Socialism, 1790-1975. Cambridge: MIT P, 1976.

Hayes, Rebecca Saunders. "George Edgar Vincent, Son of Chautauqua." MA thesis U of Virginia, 1990.

Henry, Jay C. Architecture in Texas, 1895-1945. Austin: U of Texas P, 1993.

Hofstadter, Richard. The Age of Reform: From Bryan to F.D.R. New York: Knopf, 1955.

Hopkins, C. Howard. History of the YMCA in North America. New York: Association $\mathrm{P}, 1951$.

Hurlbut, Jesse Lyman. The Story of Chautauqua. New York: Putnam, 1921.

Hutchinson, William R. The Modernist Impulse in American Protestantism. Cambridge: Harvard UP, 1976.

Huth, Hans. Nature and the American: Three Centuries of Changing Attitudes. Lincoln, NB: U of Nebraska P, 1957.

Irwin, Alfreda L. Three Taps of the Gavel: Pledge to the Future. The Chautauqua Story. Chautauqua, NY: Chautauqua Institution, 1987.

Johannesen, Eric. Cleveland Architecture, 1876-1976. Cleveland: Western Reserve Historical Society, 1979.

Kahler, Bruce Robert. "Art and Life: The Arts and Crafts Movement in Chicago, 1897 1910." Diss. Purdue U, 1986.

Kaplan, Wendy. "The Art that is Life": The Arts \& Crafts Movement in America, 18751920. Boston: Bulfinch, 1987.

Karson, Robin. A Genius for Place: American Landscapes of the Country Place Era. Amherst: U of Massachusetts P, 2007.

---. The Muses of Gwinn: Art and Nature in a Garden Designed by Warren H. Manning, Charles A Platt, \& Ellen Biddle Shipman. New York: Sagapress, 1995.

Karson, Robin, ed. Masters of American Garden Design III: The Modern Garden in 
Europe and the United States. Proceedings of the Garden Conservancy Symposium Held March 12, 1993 at the Paine Webber Building in New York, New York. Cold Spring, NY: Garden Conservancy, 1994.

---. Masters of American Garden Design IV: Influences on American Garden Design, 1845-1940: Proceedings of the Garden Conservancy Symposium Held March 12, 1993 at the Paine Webber Building in New York, New York. Cold Spring, NY: Garden Conservancy, 1995.

Kasson, Joy S. Marble Queens and Captives: Women in Nineteenth-Century American Sculpture. New Haven: Yale UP, 1990.

Kett, Joseph F. The Pursuit of Knowledge Under Difficulties: From Self-Improvement to Adult Education in America, 1750-1990. Stanford: Stanford UP, 1994.

Kilde, Jeanne Halgren. When Church Became Theatre: The Transformation of Evangelical Architecture and Worship in Nineteenth-Century America. New York: Oxford UP, 2002.

King, Kelly M. Call Her a Citizen: Progressive-Era Activist and Educator Anna Pennybacker. College Station, TX: Texas A\&M P, 2010.

Knight, Louise W. Citizen: Jane Addams and the Struggle for Democracy. Chicago: U of Chicago P, 2005.

Kniker, Charles R. "The Chautauqua Literary and Scientific Circle, 1878-1914: An historical interpretation of an educational piety in industrial America." Diss. Teachers College, Columbia U, 1969.

Kowsky, Francis R., et al, eds. Buffalo Architecture: A Guide. Cambridge, MA: MIT P, 1981.

Lears, T. J. Jackson. No Place of Grace: Antimodernism and the Transformation of American Culture, 1880-1920. Chicago: U of Chicago P, 1981.

Lee, Robert E. "Texas Library Development: Its Relation to the Carnegie Movement, 1898-1915." MA Thesis UT Austin, 1959.

Leiris, Michel. "The Sacred in Everyday Life." Trans. Betsy Wing. The College of Sociology (1937-39). Ed. Denis Hollier. Minneapolis: U of Minnesota P, 1988.

Leone, Paul, and Mary Poshka. Around Chautauqua Lake: 50 Years of Photographs, 1875-1925. Westfield, NY: Chautauqua Region Press, 1997. 
Lewis, Sinclair. Main Street. 1920. New York: Signet, 1961.

The Life of Clement Studebaker n. p.: Jan B. Young, 1998, 2002, 2009.

Logan, Frederick M. Growth of Art in American Schools. New York: Harper, 1955.

Lucy, William H. Returning to the Future: Implications of Chautauqua's Spatial Pattern. Unpublished essay, c. 1998.

Ludwig, Coy L. The Arts \& Crafts Movement in New York State, 1890s-1920s. Hamilton, NY: Gallery Assn. of New York State, 1984.

Mattson, Kevin. Creating a Democratic Public; The Struggle for Urban Participatory Democracy During the Progressive Era. University Park, PA: Pennsylvania State UP, 1998.

McCoubrey, John W. American Art 1700-1960: Sources and Documents. Englewood Cliffs, NJ: Prentice-Hall, 1965.

Menand, Louis. The Metaphysical Club: A Story of Ideas in America. New York: Farrar, 2001.

Meyer, Marilee Boyd. Inspiring Boston's Arts and Crafts Movement Reform. New York: Abrams, 1997.

Mills, Cynthia. Monuments to the Lost Cause: Women, Art, and the Landscapes of Southern Memory. Nashville: U of Tennessee P, 2003.

Moffatt, Frederick C. Arthur Wesley Dow (1857-1922). Washington: Smithsonian P, 1977.

Mohr, Paula Ann. "'Artificial Constructions' and Object Lessons in a Sacred Landscape: The Art and Architecture of Central Park, 1858-1880." Diss., U of Virginia, 2007.

Morrison, Ernest. J. Horace McFarland: A Thorn for Beauty. Harrisburg: Pennsylvania Historical and Museum Commission, 1995.

Morrison, Theodore. Chautauqua: A Center for Education, Religion, and the Arts in America. Chicago: U of Chicago P, 1974.

Nash, Eric Peter. Manhattan Skyscrapers. Princeton: Princeton Architectural P, 1999. 
The National Cyclopedia of American Biography, 1930 and 1933 ed. New York: James T. White.

Nauta-Rodriguez, Debra. Pan American Union Building, Washington, D. C. Charlottesville, VA: School of Architecture, University of Virginia, 1998.

Nawrocki, Dennis Alan. Art in Detroit Public Places. Detroit: Wayne State UP, 1999.

Newton, Norman T. Design on the Land: The Development of Landscape Architecture. Cambridge, MA: Belknap P, 1971.

Northrup, Janet Myers, and the Chautauqua Women's Club. Founding Women: Inspiration and Impact on Chautauqua and the Nation. Rochester, NY: Mountain Air Books, 2009.

Orchard, Hugh A. Fifty Years of Chautauqua: Its Beginnings, Its Development, Its Message, and Its Life. Cedar Rapids, IA: Torch P, 1923.

Otto, Rudolph. The Idea of the Holy. London: Oxford UP, 1923.

Pyne, Kathleen A. Art and the Higher Life. Austin, TX: U of Texas P, 1996.

Peterson, Jon A. The Birth of City Planning in the United States, 1840-1927. Baltimore: Johns Hopkins UP, 2003.

Rader, Benjamin G. The Academic Mind and Reform: The Influence of Richard T. Ely in American Life. Lexington, KY: U of Kentucky P, 1966.

Reiff, Daniel D. Houses From Books: Treatises, Pattern Books, and Catalogs in American Architecture, 1738-1950, A History and Guide. University Park: Pennsylvania State UP, 2000.

Richmond, Rebecca. A Woman of Texas: Mrs. Percy V. Pennybacker. San Antonio, TX: Naylor Co., 194.1.

---. Chautauqua: An American Place. New York: Duell, 1943.

Rieser, Andrew C. The Chautauqua Moment; Protestants, Progressives, and the Culture of Modern Liberalism. New York: Columbia UP, 2003.

Rockefeller, Steven C. John Dewey: Religious Faith and Democratic Humanism. New York: Columbia UP, 1991. 
Rodger, Daniel T. Atlantic Crossings: Social Politics in a Progressive Age. Cambridge, MA: Belknap, 1998.

Rose, William Ganson. Cleveland: The Making of a City. Kent, OH: Kent State UP, 1990.

Rosenberg, Chaim M. America At the Fair: Chicago's 1893 World's Columbian Exposition. Chicago: Arcadia, 2008.

Sanders, Barry. A Complex Fate: Gustav Stickley and the Craftsman Movement. New York: Wiley, 1996.

Sanders, Barry, ed. The Craftsman: An Anthology. Santa Barbara: Peregrine Smith, 1978 .

Savage, Kirk. Standing Soldiers, Kneeling Slaves: Race, War, and Monument in Nineteenth-Century America. Princeton: Princeton UP, 1997.

Scott, Pamela. Buildings of the District of Columbia. New York: Oxford UP, 1993.

Sealander, Judith. Grand Plans: Business Progressivism and Social Change in Ohio's Miami Valley, 1890-1929. Lexington, KY: UP of Kentucky, 1988.

Searing, Helen, ed. In Search of Modern Architecture: A Tribute to Henry-Russell Hitchcock. New York: Architectural History Foundation; Cambridge, MA: MIT P, 1982.

Sears, John F. Sacred Places: American Tourist Attractions in the Nineteenth Century. Amherst: U of Massachusetts P, 1989.

Seymour, Jack L. From Sunday School to Church School: Continuities in Protestant Church Education in the United States, 1860-1929. New York: UP of America, 1982.

Simpson, Jeffrey. Chautauqua: An American Utopia. New York: Abrams, 1999.

Smith, Timothy L. Revivalism and Social Reform in Mid-Nineteenth-Century America. New York: Abingdon P, 1957.

Southworth, Michael, and Eran Ben-Joseph. Streets and the Shaping of Towns and Cities. New York: McGraw, 1996. 
Spain, Daphne. How Women Saved the City. Minneapolis, MN: U of Minnesota P, 2001.

Stansky, Peter. Redesigning the World: William Morris, the 1880s, and the Arts and Crafts. Palo Alto: Society for the Promotion of Science and Scholarship, 1996.

Starr, Ellen Gates. On Art, Labor, and Religion. Ed. Mary Jo Deegan and Ana-Maria Wahl. New Brunswick, NJ: Transaction, 2003.

Stern, Robert A. M. New York 1900: Metropolitan Architecture and Urbanism, 18901915. New York: Rizzoli, 1983.

Talbot, Mary Lee. "A school at home: the contribution of the Chautauqua Literary and Scientific Circle to women's educational opportunities in the Gilded Age, 18741900.” Diss. Columbia U, 1997.

Tapia, John E. Circuit Chautauqua: From Rural Education to Popular Entertainment in Early Twentieth Century America. Jefferson, NC: McFarland, 1997.

Thomas, George E., Jeffrey A. Cohen, and Michael J. Lewis. Frank Furness: The Complete Works. New York: Princeton Architectural P, 1996.

Tomko, Linda J. Dancing Class: Gender, Ethnicity, and Social Divides in American Dance, 1890-1920. Bloomington: Indiana UP, 1999.

Triggs, Oscar Lovell. Chapters in the History of the Arts and Crafts Movement. New York: Arno, 1979.

Turnbull, Craig. An American Urban Residential Landscape, 1890-1920: Chicago in the Progressive Era. Amherst, NY: Cambria, 2009.

Urban Design Associates. Nature, Art, and Architecture: Chautauqua Institution Garden District. Chautauqua: Chautauqua Institution, 2002.

Van Gennep, Arnold. The Rites of Passage. Chicago: U of Chicago P, 1960.

Van Hook, Bailey. Angels of Art: Women and Art in American Society, 1876-1914. University Park, PA: Penn State UP, 1996.

---. The Virgin \& the Dynamo: Public Murals in American Architecture, 1893-1917. Athens, OH: Ohio UP, 2003.

Van Slyck, Abigail A. Free to All: Carnegie Libraries \& American Culture, 1890-1920. 
Chicago: U of Chicago P, 1995.

Via, Marie, and Marjorie Searl, eds. Head, Heart and Hand: Elbert Hubbard and the Roycrofters. New York: U of Rochester P, 1994.

Wade, Louise C. Graham Taylor: Pioneer for Social Justice, 1851-1938. Chicago: U of Chicago P, 1964.

Watters, Laurie A. A Year in Chautauqua. New York: Park Bench, 2000.

Wells, L. Jeanette. A History of the Music Festival at Chautauqua Institution from 1874 to 1957. Washington: Catholic U of America P, 1958.

White, Theophilus B. Paul Philippe Cret, Architect and Teacher. Philadelphia: Art Alliance P, 1973.

Whittemore, Francis D. George Washington in Sculpture. Boston: Marshall Jones, 1933.

Wiebe, Robert H. The Search for Order, 1877-1920. New York: Hill and Wang, 1967.

Wilson, Richard Guy. Modern Architecture in America: Visions and Revisions. Ames: Iowa State UP, 1991.

Wilson, Richard Guy, ed. Thomas Jefferson's Academical Village: The Creation of an Architectural Masterpiece. Charlottesville: UP of Virginia, 1993.

---. The American Renaissance, 1876-1917. New York: Brooklyn Museum, 1979.

Wilson, Richard Guy, and Sara A. Butler. The Campus Guide: University of Virginia. An Architectural Tour. New York: Princeton Architectural P, 1999.

Wilson, William H. The City Beautiful Movement. Baltimore: Johns Hopkins UP, 1989.

---. From Architecture to Object: Masterworks of the American Arts and Crafts Movement. New York: Hirschl \& Adler Galleries, 1989.

---. "The Ideology, Aesthetics, and Politics of the City Beautiful Movement." The Rise of Modern Urban Planning, 1800-1914. Ed. Anthony Sutcliffe. New York: St. Martin's, 1980.

Withey, Henry F., and Elsie R. Withey. Biographical Dictionary of American Architects (Deceased). Los Angeles: New Age, c1956. 
Wixom, Nancy Coe. Cleveland Institute of Art: The First Hundred Years, 1882-1982. Cleveland: Cleveland Institute of Art, 1983.

Wolf, John D., et al. Saint Paul's Memorial Methodist Church, Yesterday-TodayTomorrow, 1883-1960. South Bend, IN: St. Paul's Memorial Church, 1960.

Wolner, Edward W. Henry Ives Cobb's Chicago: Architecture, Institutions, and the Making of a Modern Metropolis. Chicago: U of Chicago P, 2011.

Zald, Mayer N. Organizational Change: The Political Economy of the YMCA. Chicago: U of Chicago P, 1970.

Zunz, Olivier. The Changing Face of Inequality: Urbanization, Industrial Development, and Immigrants in Detroit, 1880-1920. Chicago: U of Chicago P, 1982.

---. Philanthropy In America: A History. Princeton: Princeton UP, 2012.

---. Why the American Century? Chicago: U of Chicago P, 1998. 


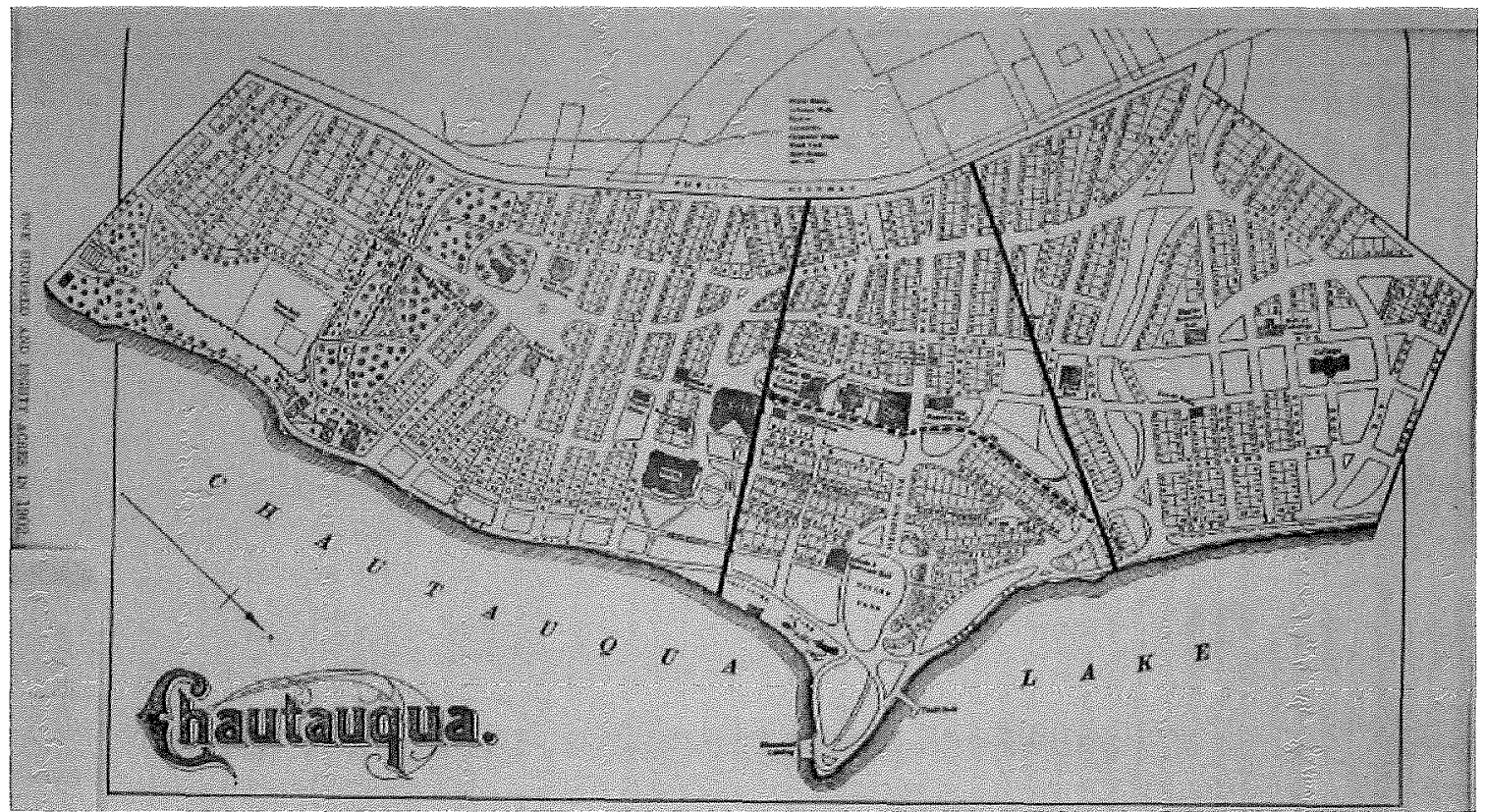

Figure i.1

Chautauqua Institution map, 1902. (Courtesy of Chautauqua Institution Archives.) 


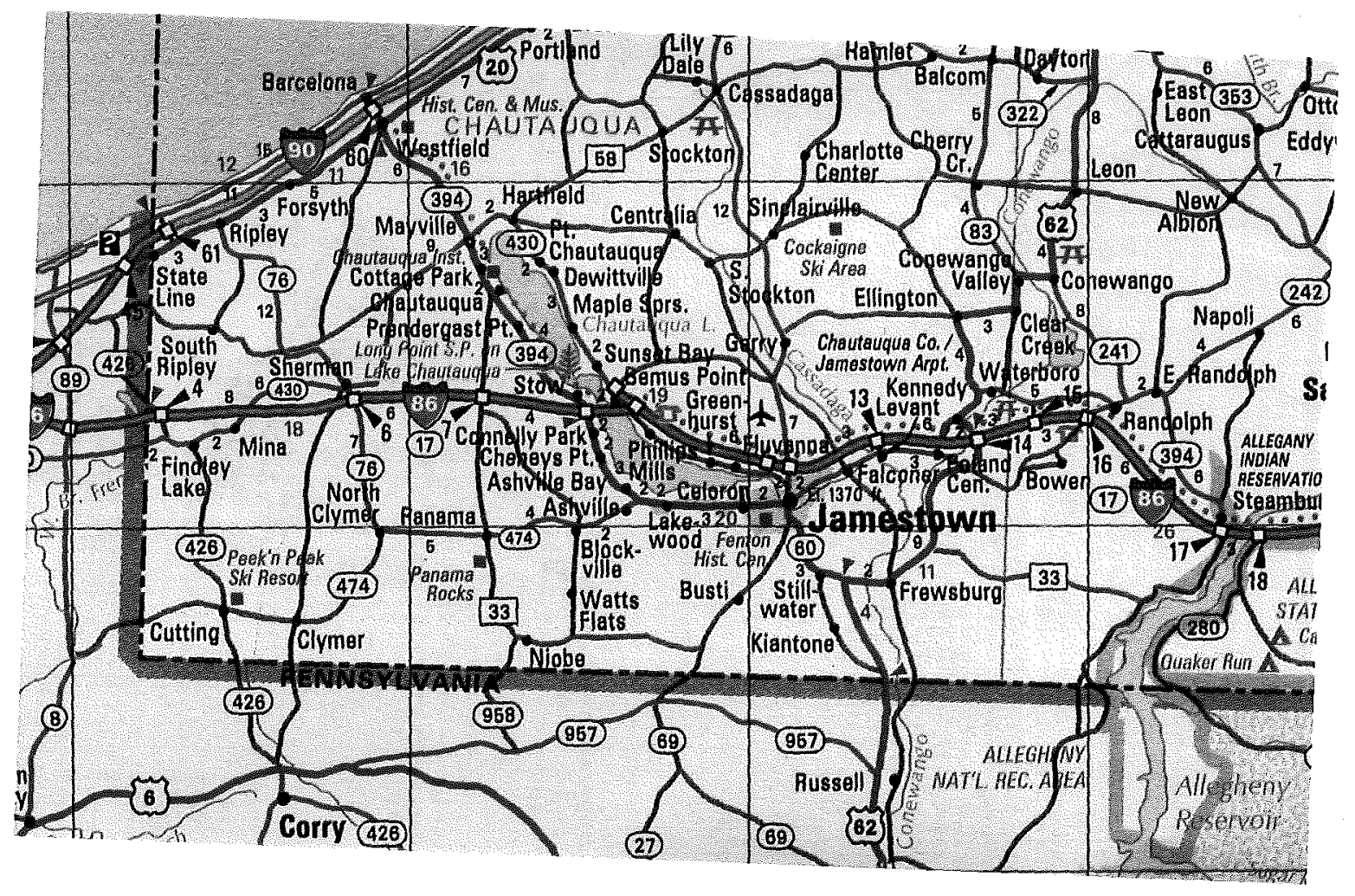

Figure i.2

Chautauqua Lake region. (Rand McNally: New York State Map.) 


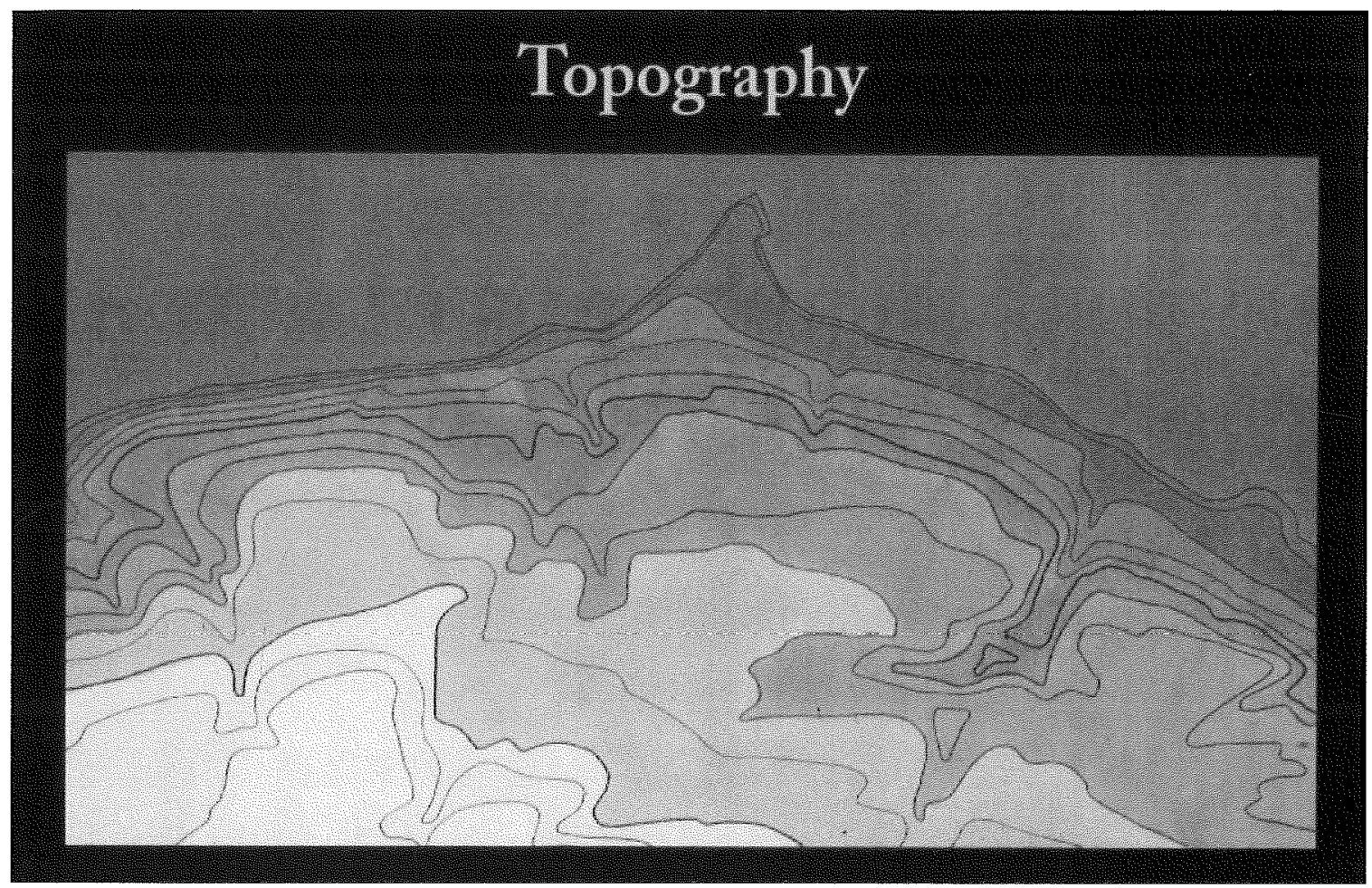

Figure 1.1

Topography of Chautauqua Institution. (Courtesy of Urban Design Associates.) 


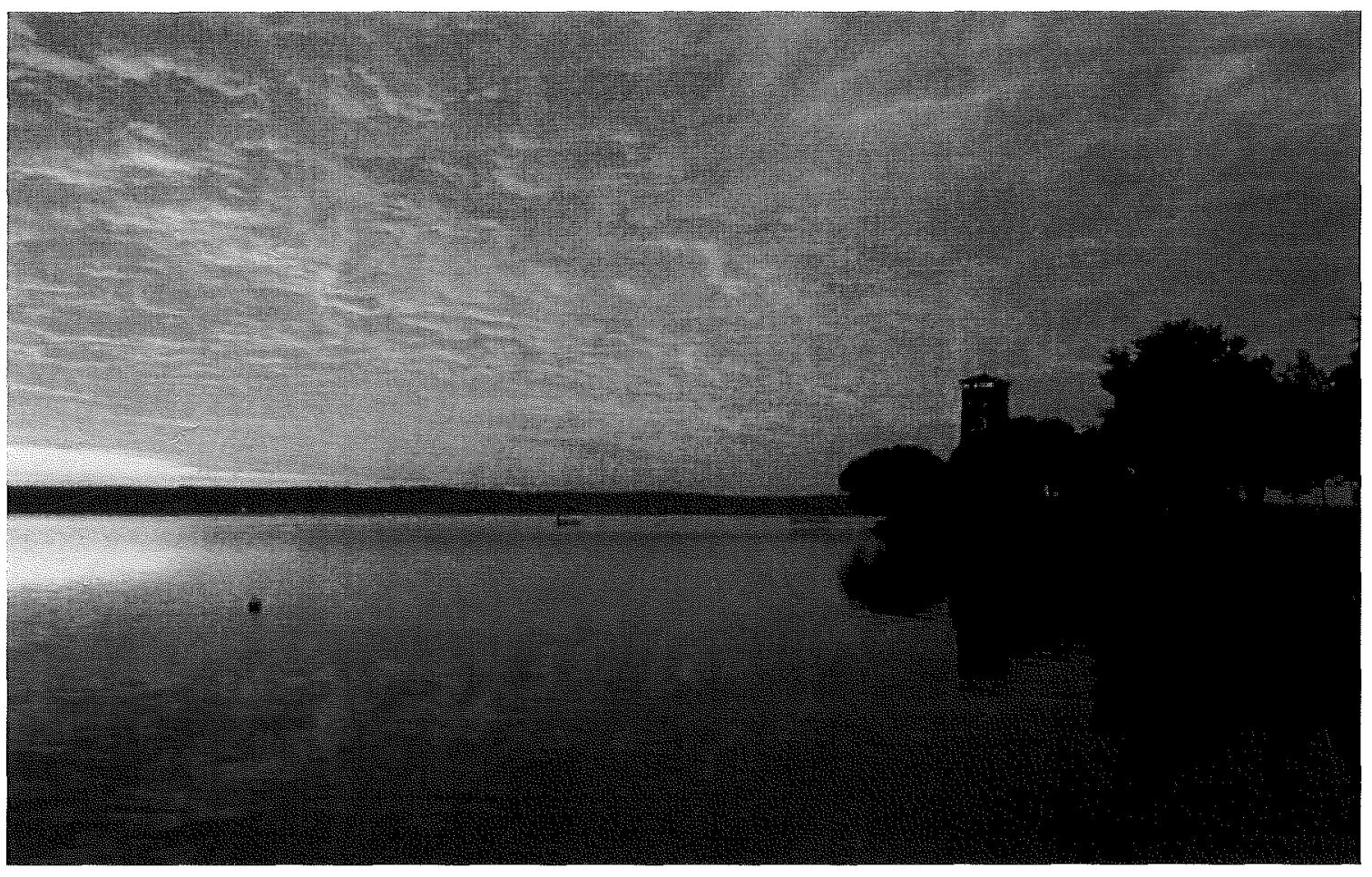

Figure 1.2

Chautauqua Lake. (Jeffrey Simpson. Chautauqua, An American Utopia, 124.) 


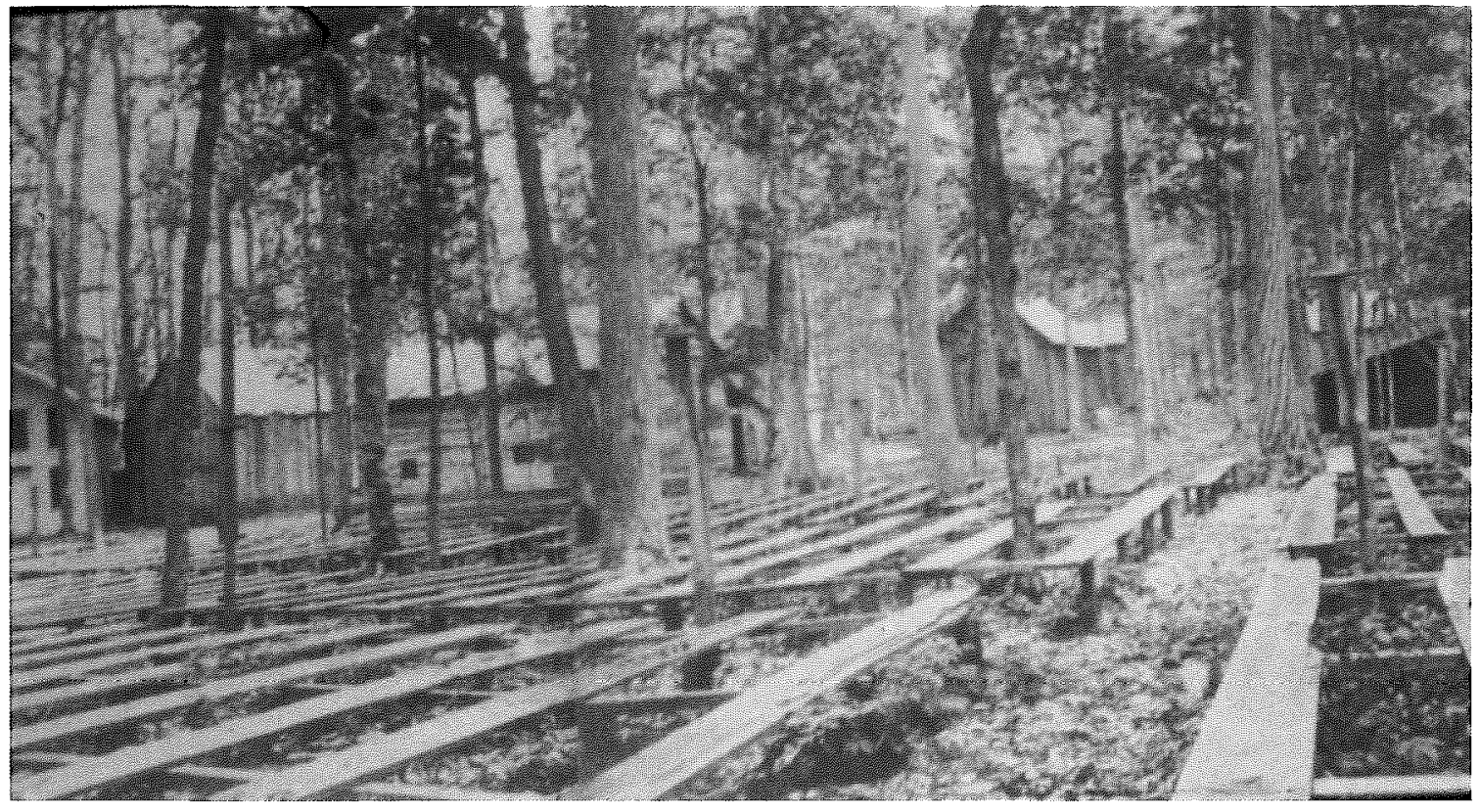

Figure 1.3

"Auditorium" (Miller Park), 1875. (Courtesy of Chautauqua Institution Archives.) 

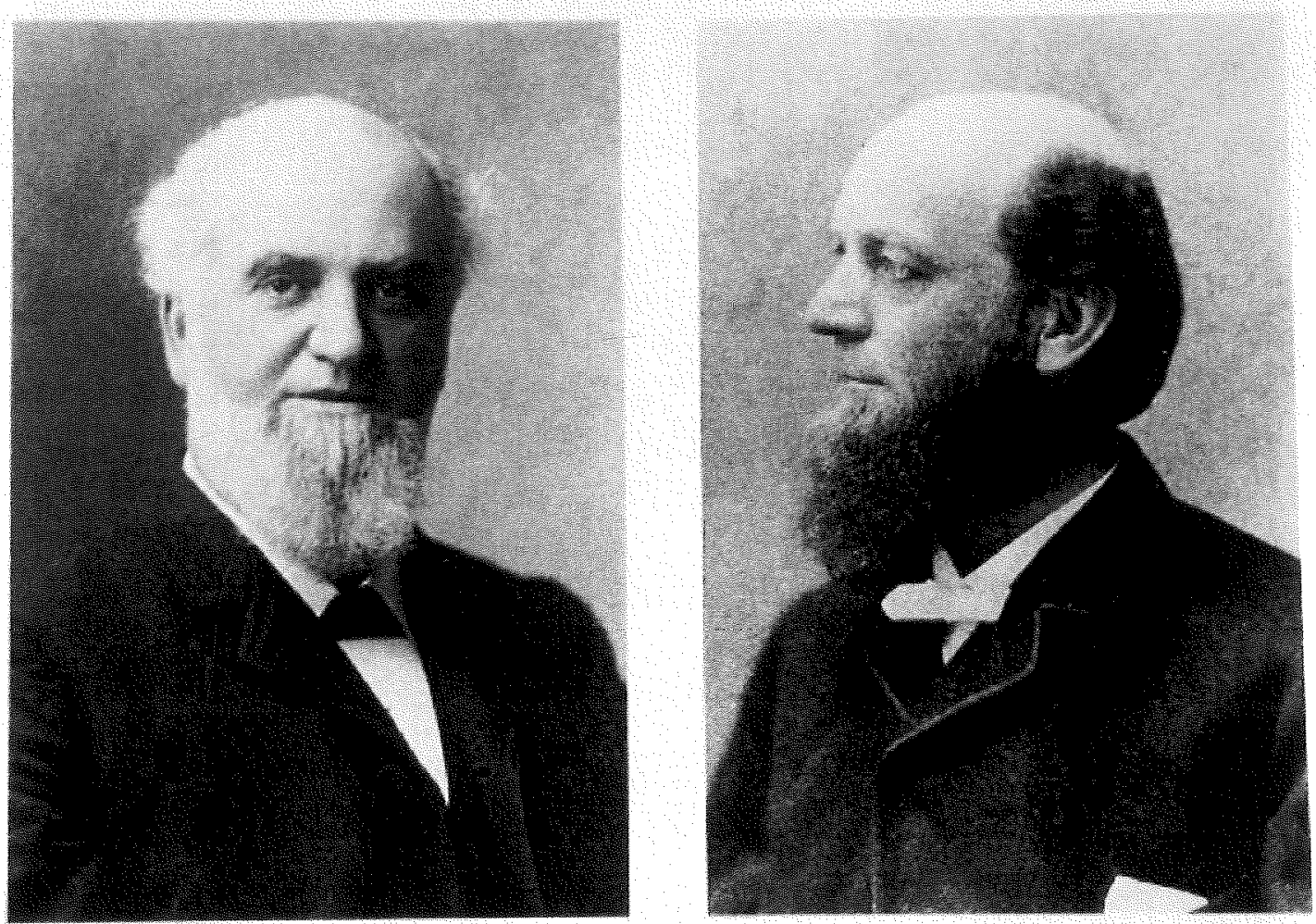

Figure 1.4

Lewis Miller and Bishop John Heyl Vincent. (Courtesy of Chautauqua Institution Archives.) 


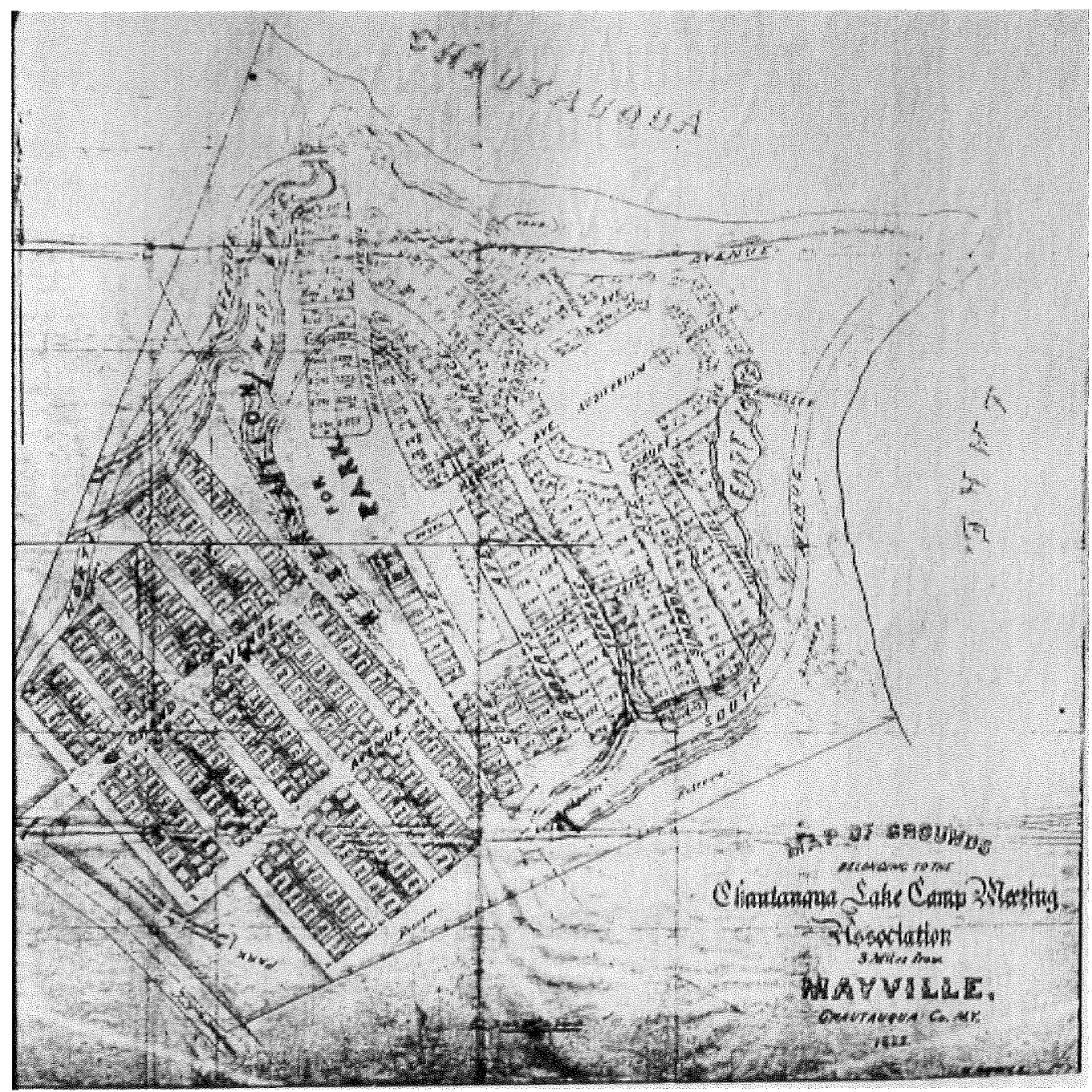

Figure 1.5

Chautauqua Lake Camp Meeting map, 1874. (Courtesy of Chautauqua Institution Archives.) 


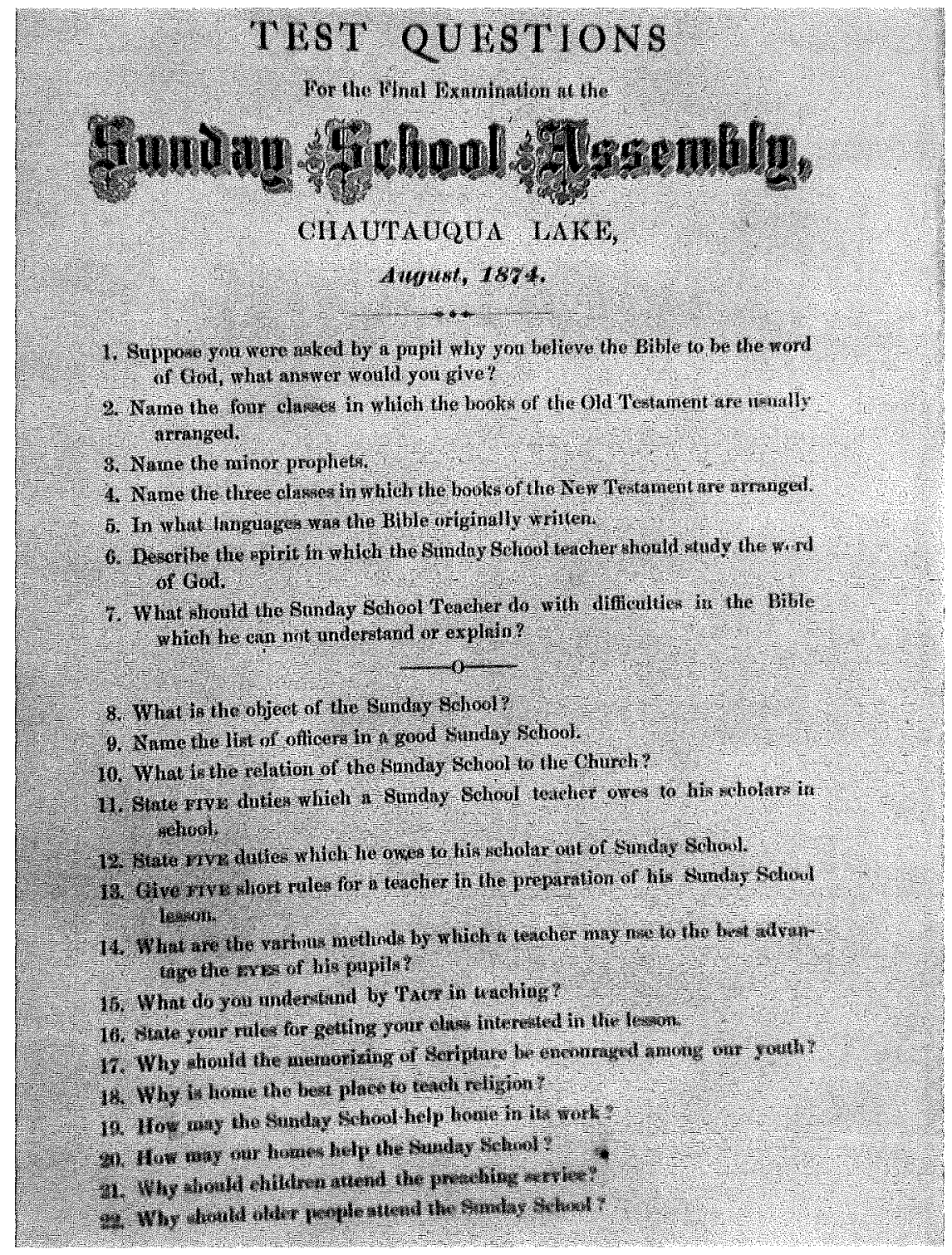

Figure 1.6

"Test Questions: For the Final Examination at the Sunday School Assembly, Chautauqua Lake, August, 1874." (Joseph E. Gould. The Chautauqua Movement: An Episode in the Continuing American Revolution, n. pag.) 


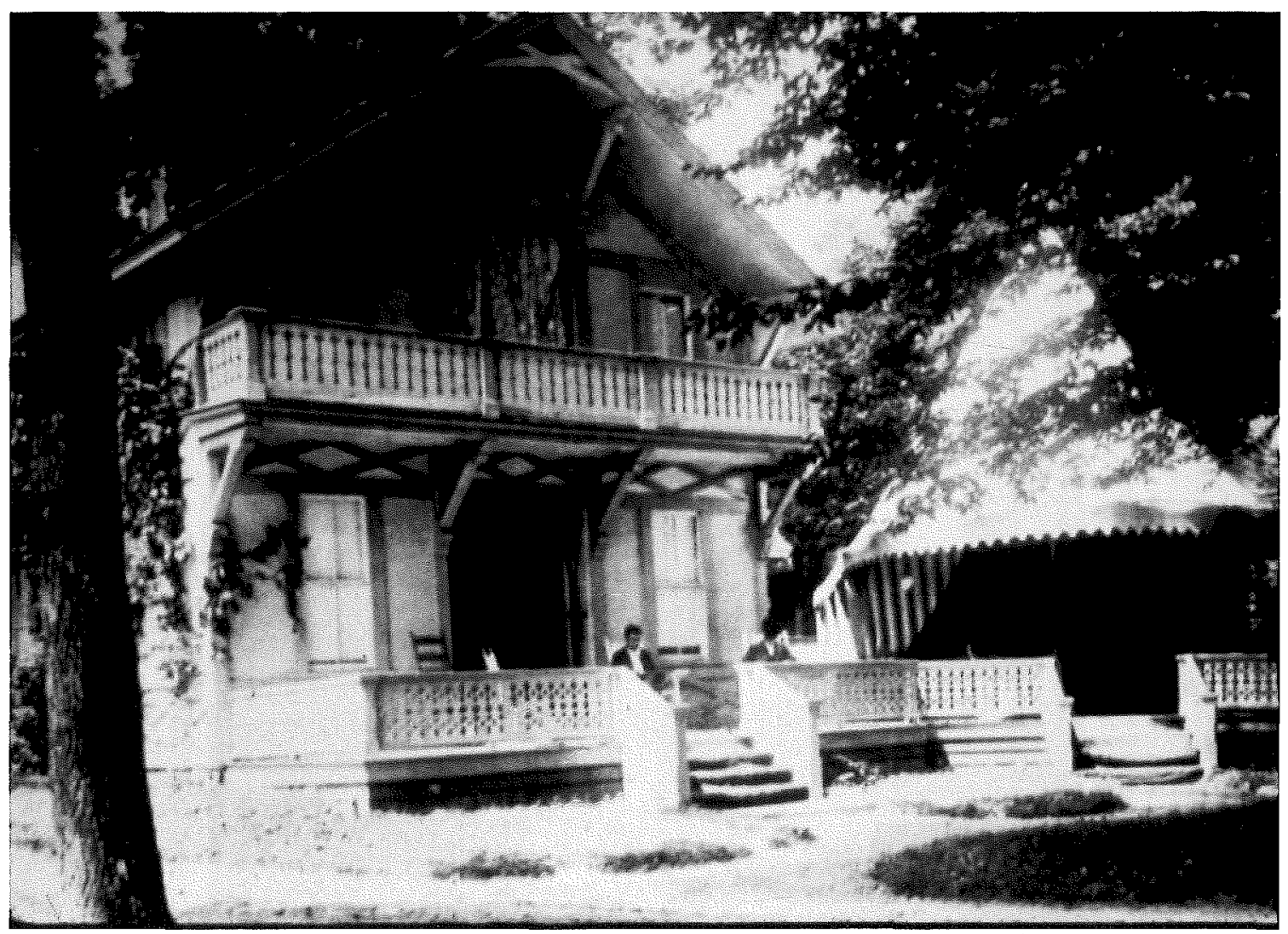

Figure 1.7

Lewis Miller. Miller cottage, 1875, c. 1876. (Courtesy of Chautauqua Institution Archives.) 


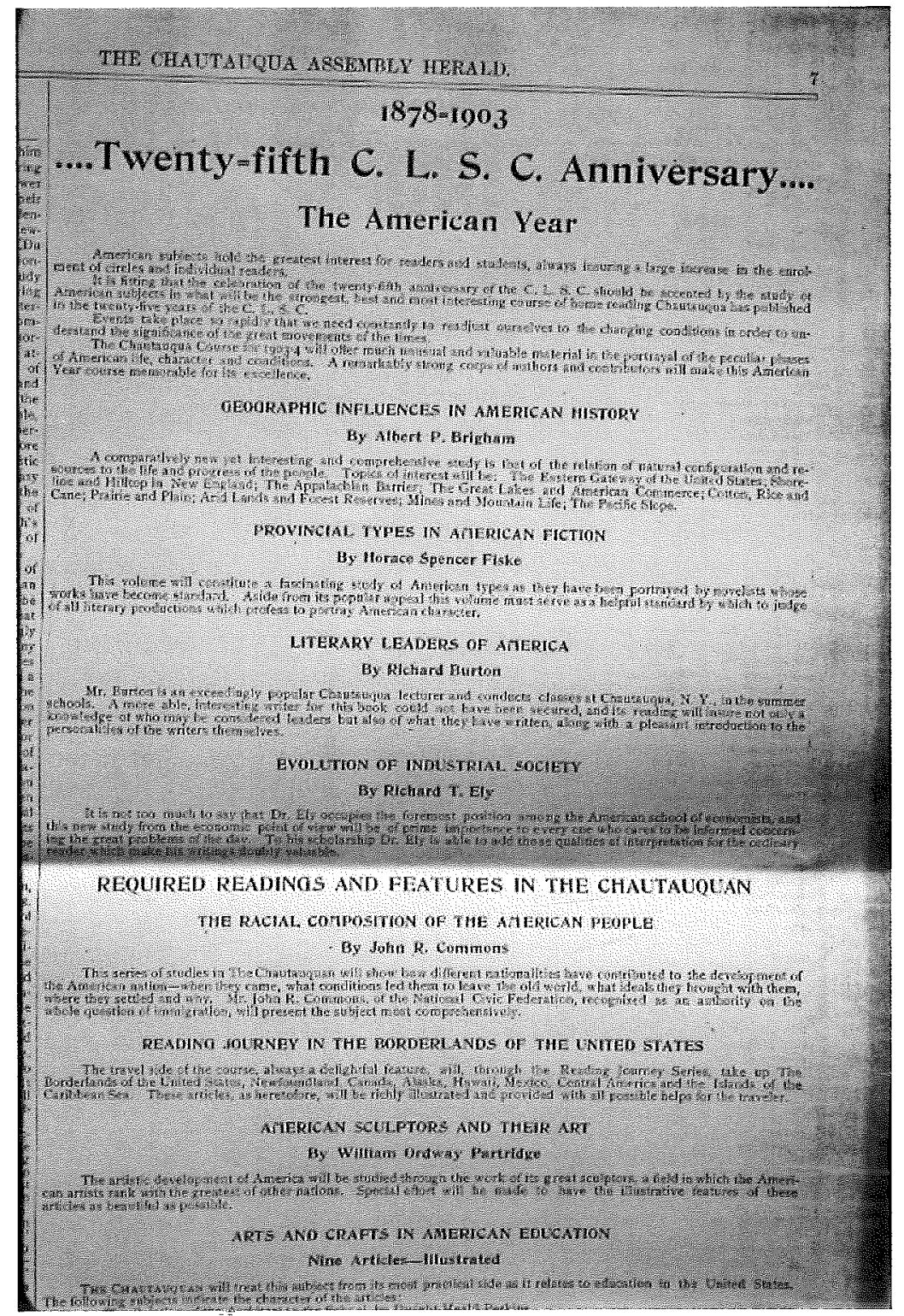

Figure 1.8

Twenty-fifth C. L. S. C. Anniversary. (The Chautauqua Assembly Herald 11 July 1903: 7.) 


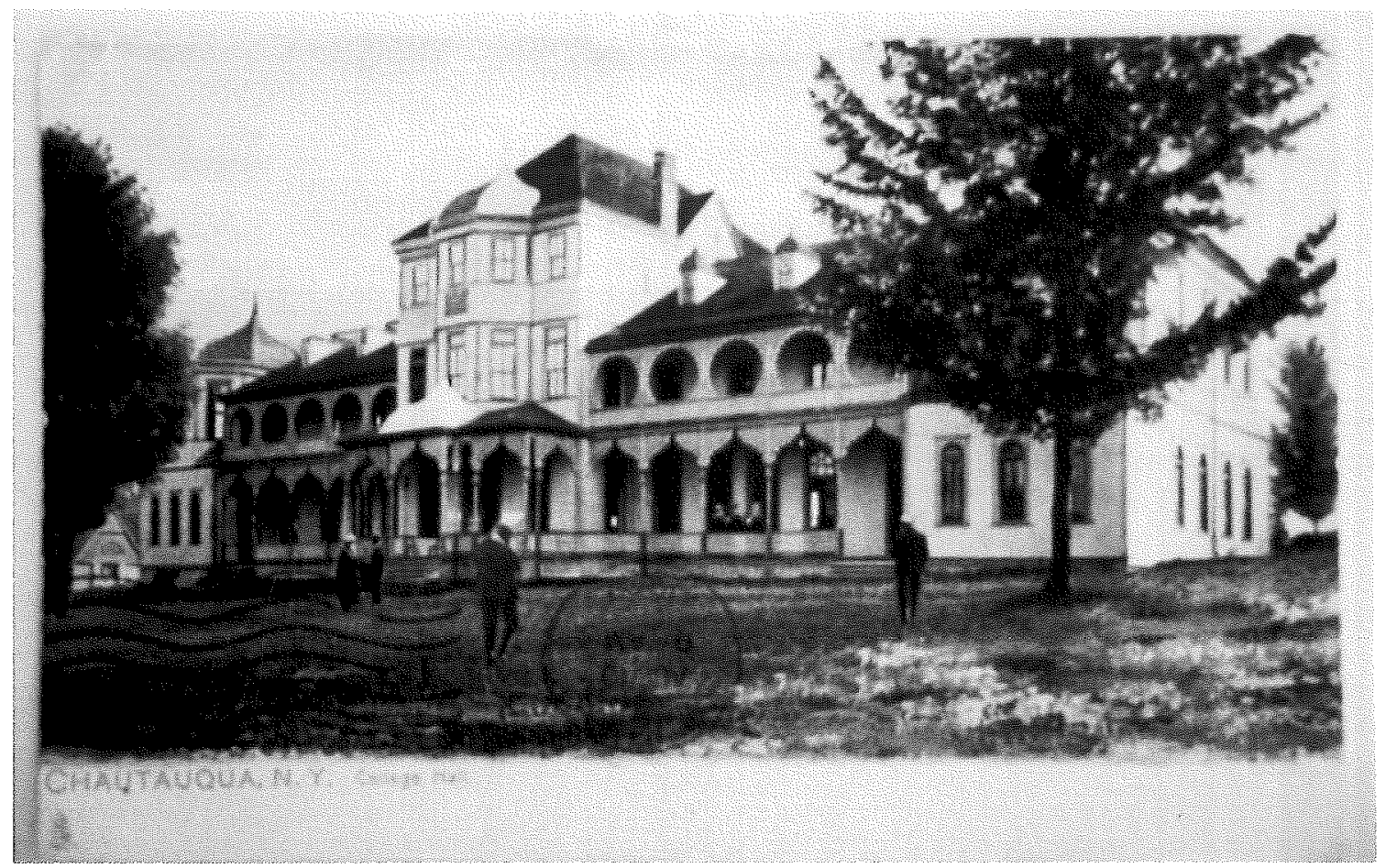

Figure 1.9

The College, "Moorish Barn," 1887, postcard. (Courtesy of Chautauqua Institution Archives.) 


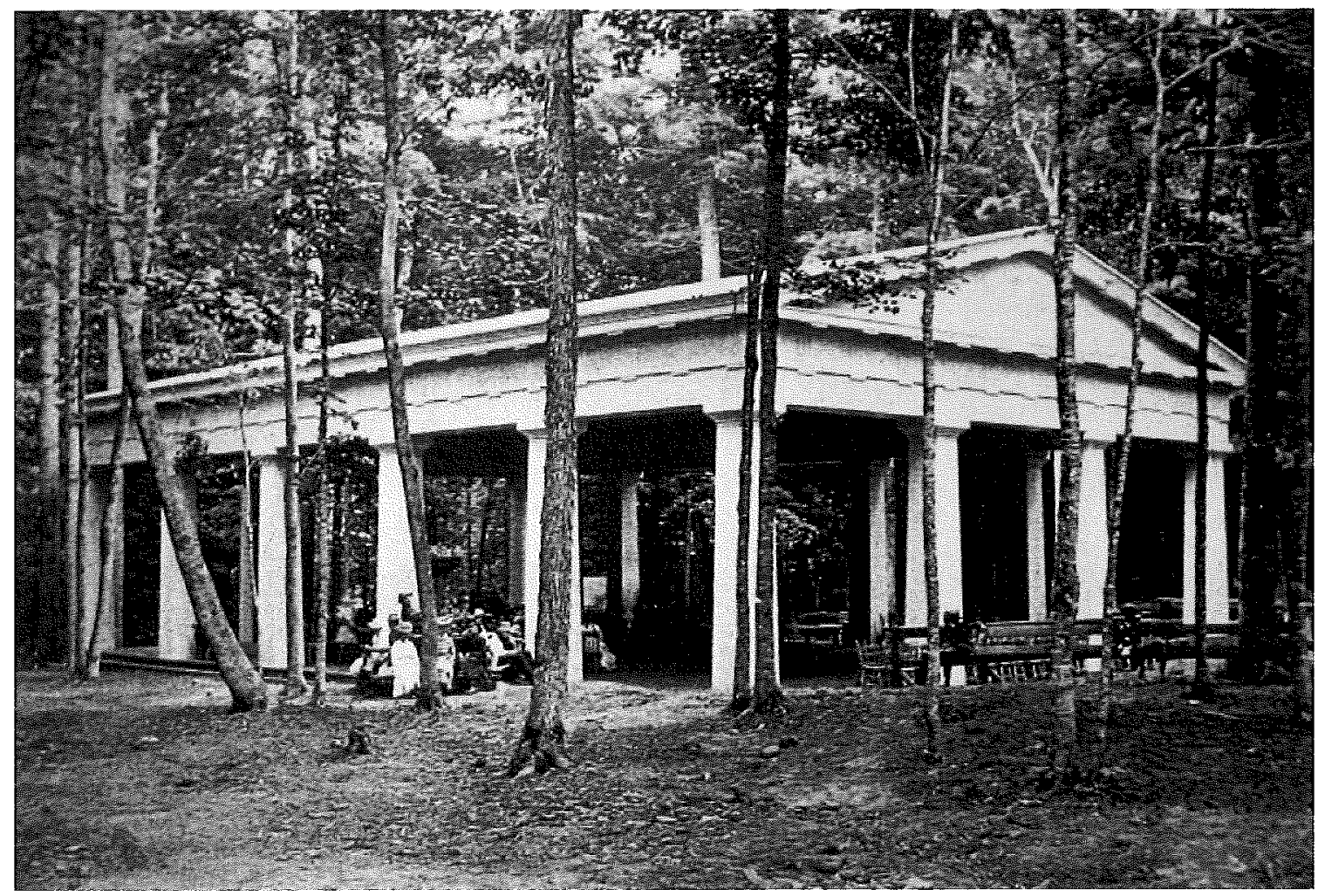

Figure 1.10

Bishop John Heyl Vincent. Hall of Philosophy, 1879. (Courtesy of Chautauqua Institution Archives.) 


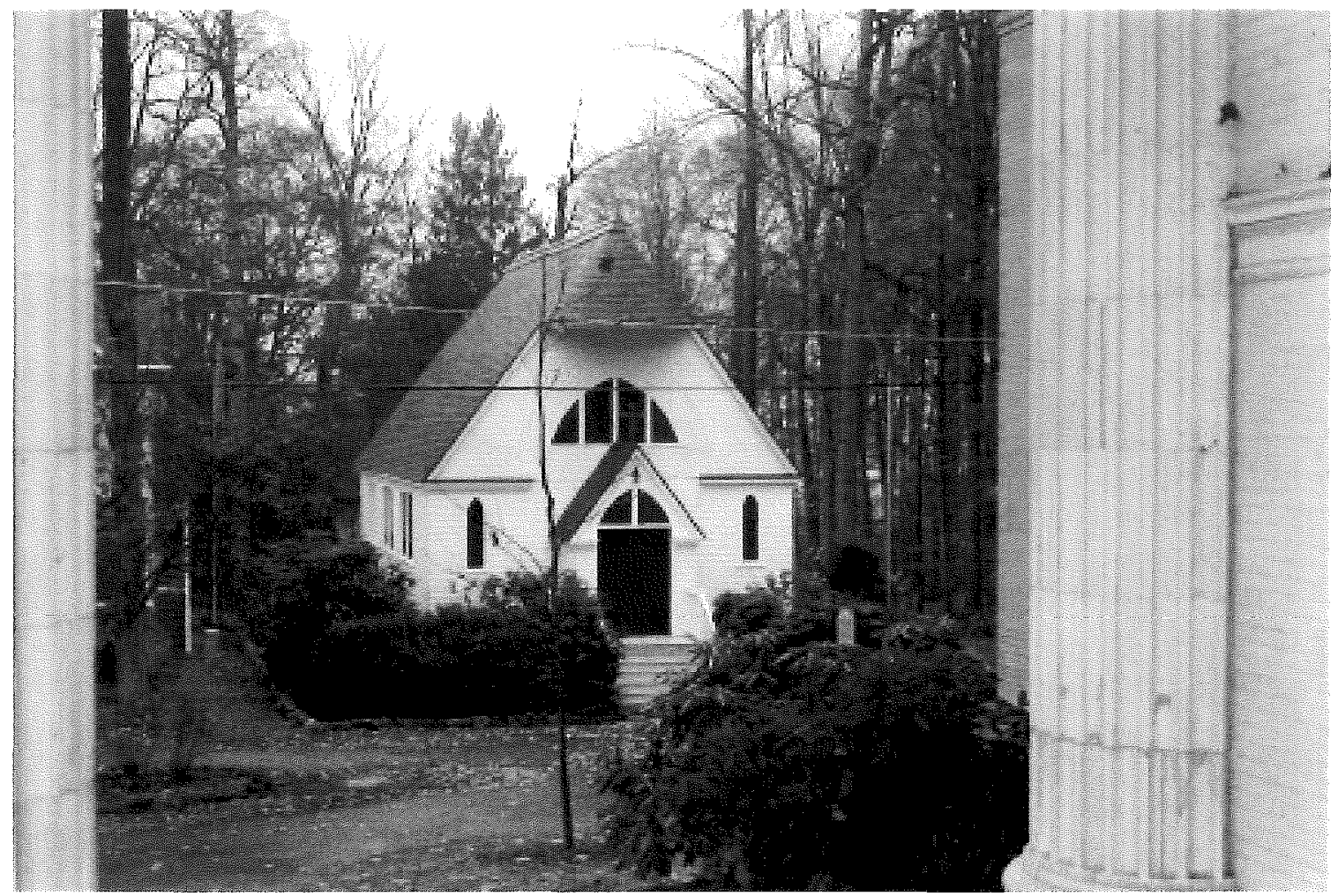

Figure 1.11

Chapel of Good Shepherd, c. 1894 (view from Hall of Christ). (Author's photograph, 2002.) 


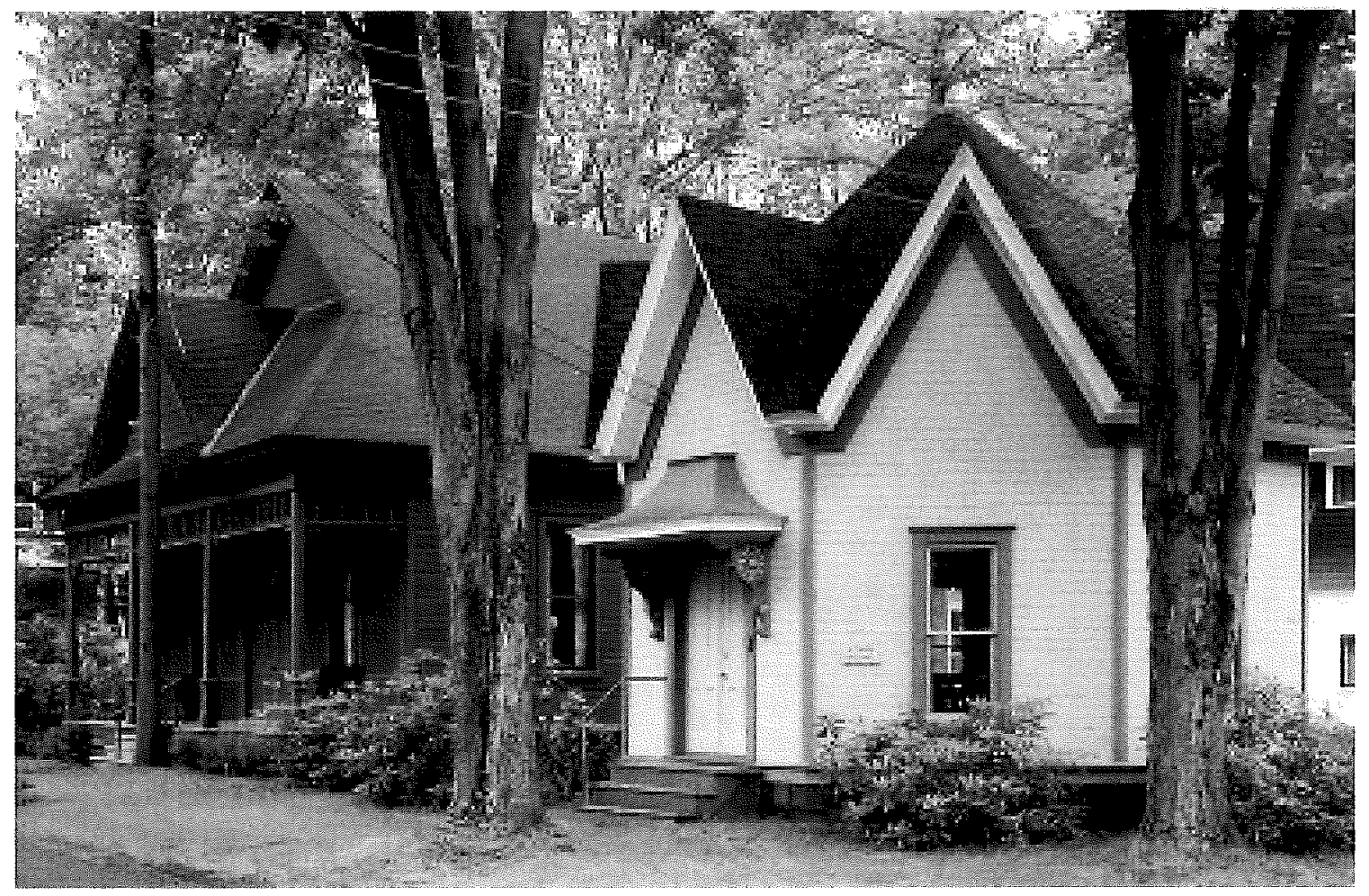

Figure 1.12

Pioneer Hall, 1885. Octagon Building, 1886. (Author's photograph, 2000.) 


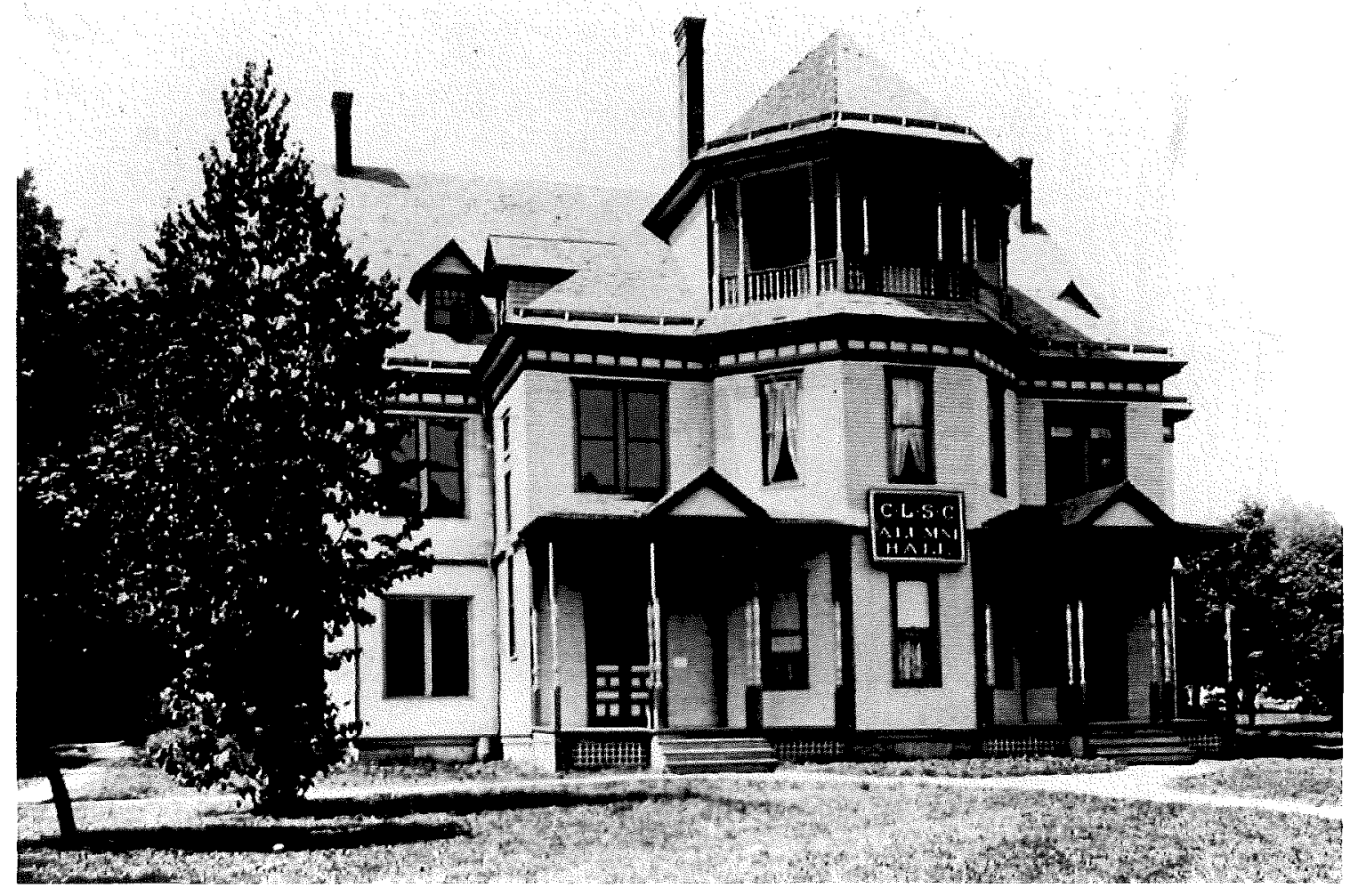

Figure 1.13

Ellis G. Hall. Alumni Hall, 1892. (Courtesy of Chautauqua Institution Archives.) 


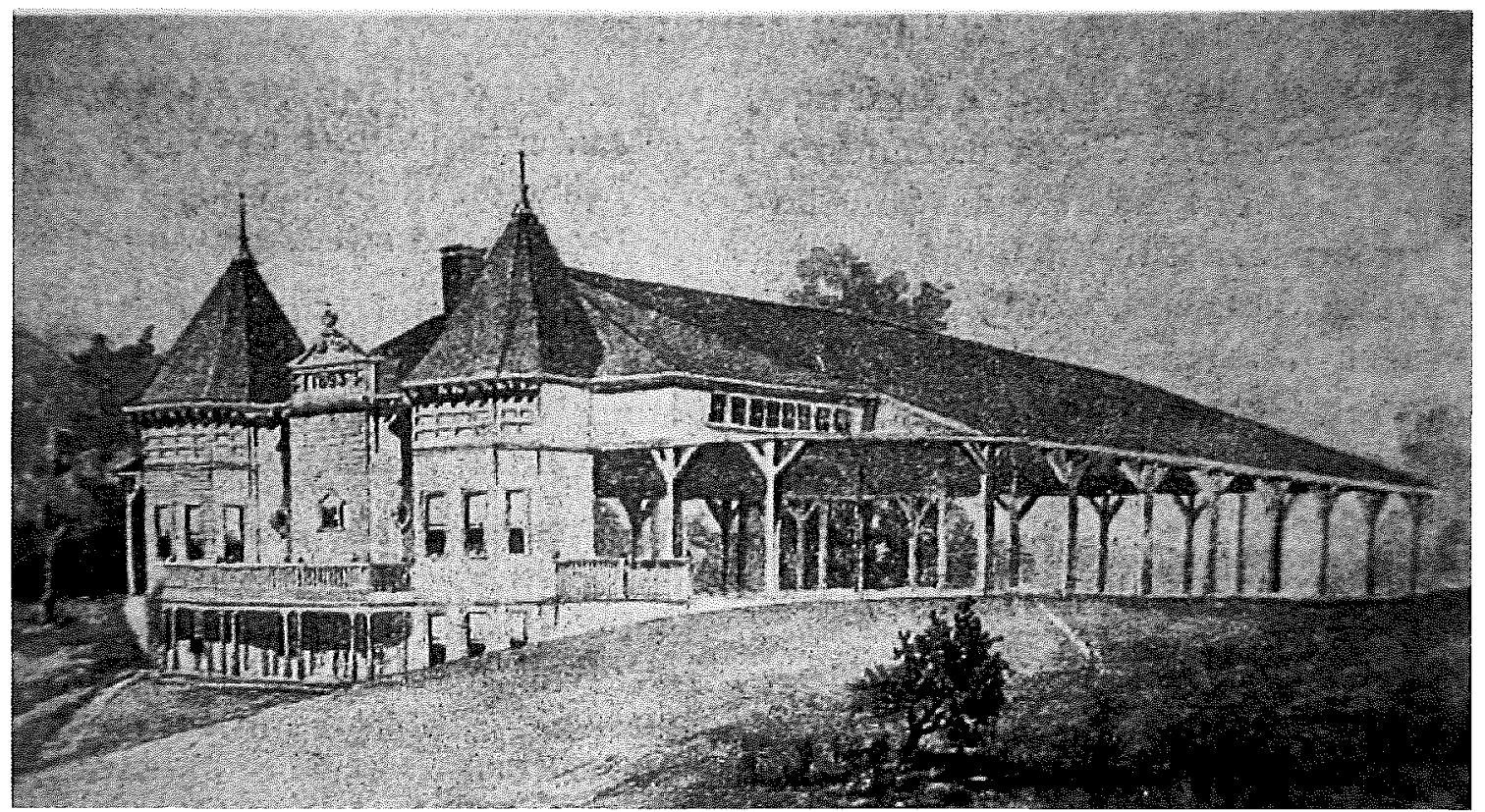

Figure 1.14

Amphitheater, 1879. (Courtesy of Chautauqua Institution Archives.) 


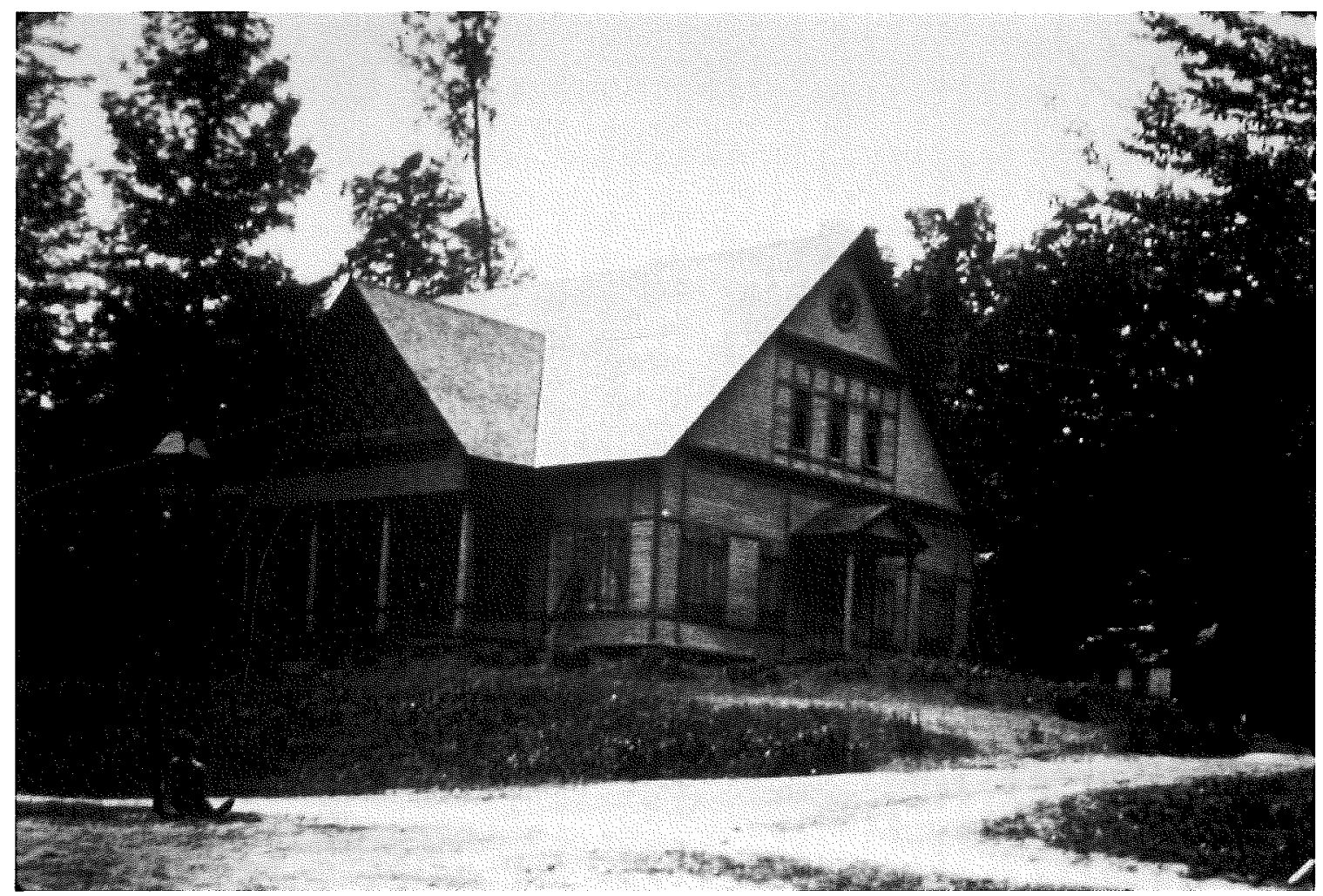

Figure 1.15

Normal Hall, 1885. (Courtesy of Chautauqua Institution Archives.) 


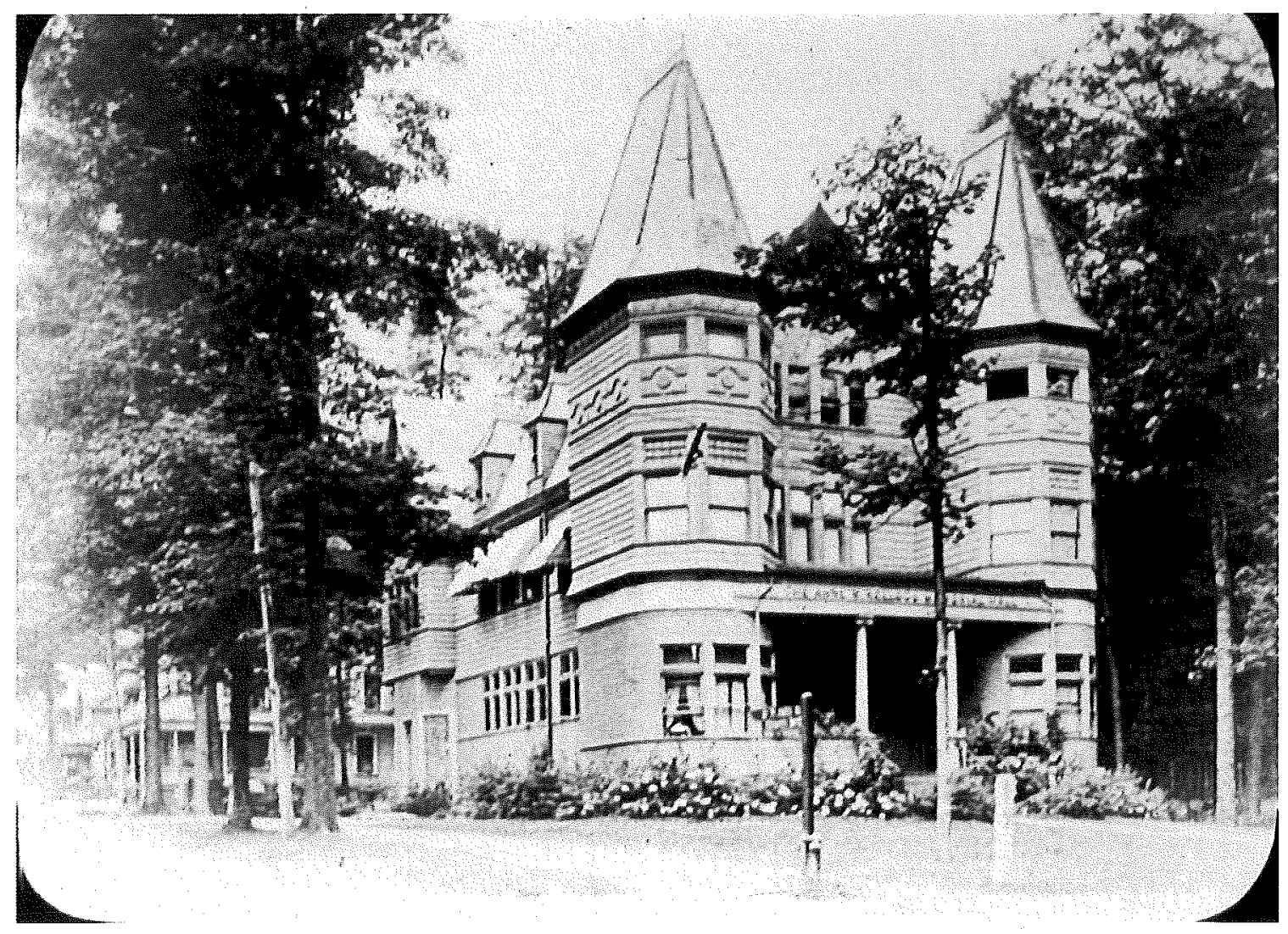

Figure 1.16

Kellogg Hall, 1889. (Courtesy of Chautauqua Institution Archives.) 


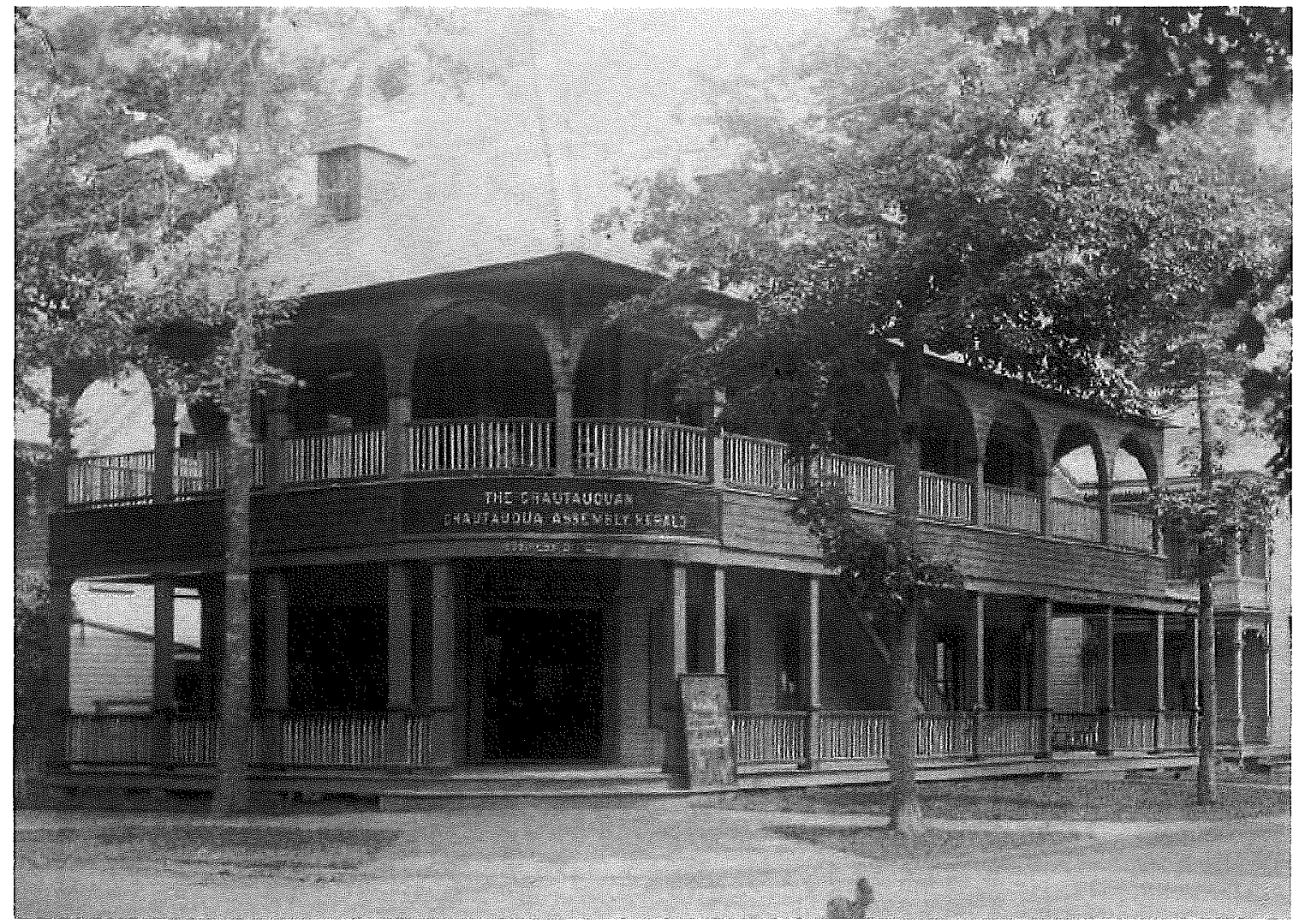

Figure 1.17

Assembly Herald Building, 1889. (Courtesy of Chautauqua Institution Archives.) 


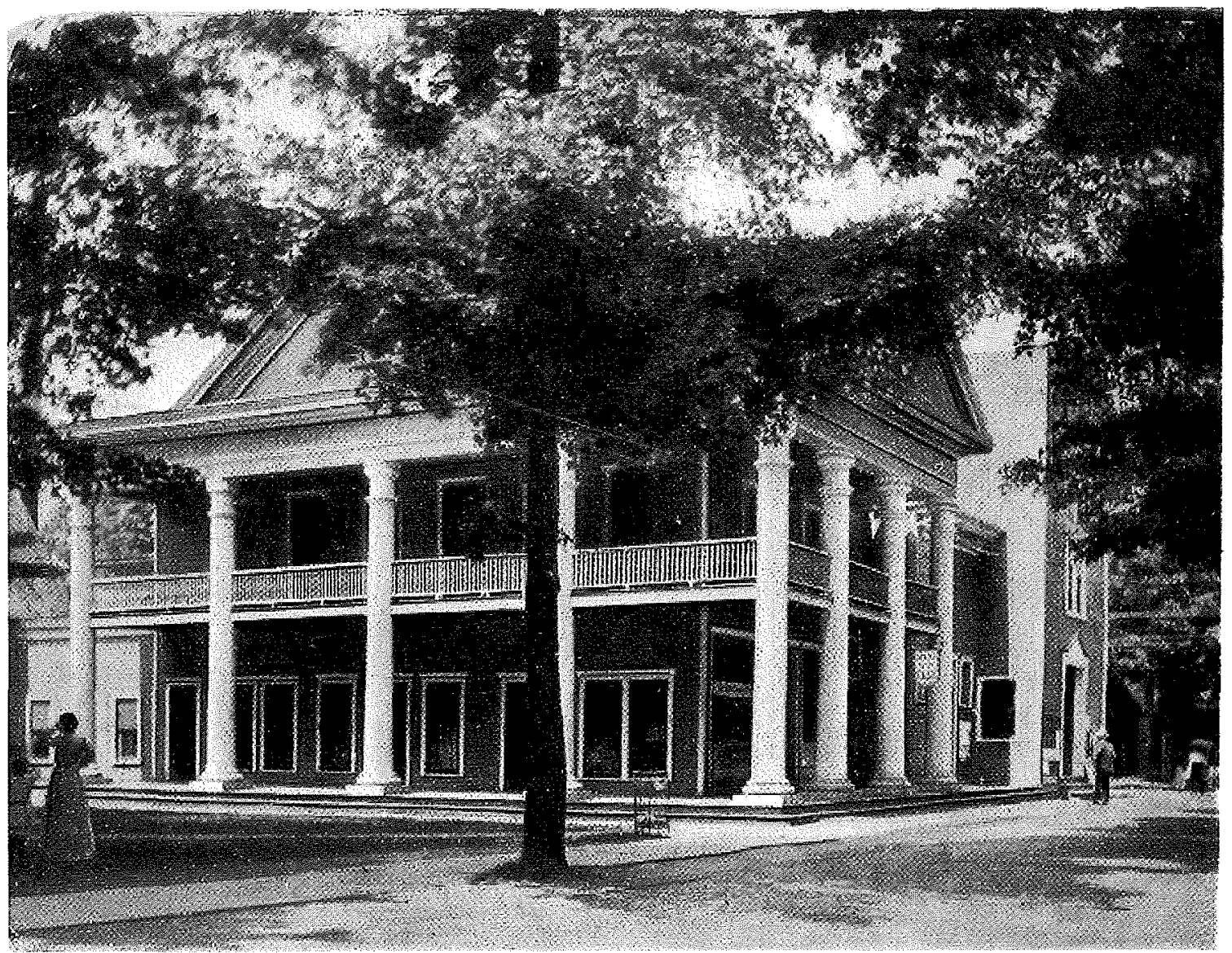

Figure 1.18

Chautauqua Literary and Scientific Circle (CLSC) Building, 1890. (Courtesy of Chautauqua Institution Archives.) 


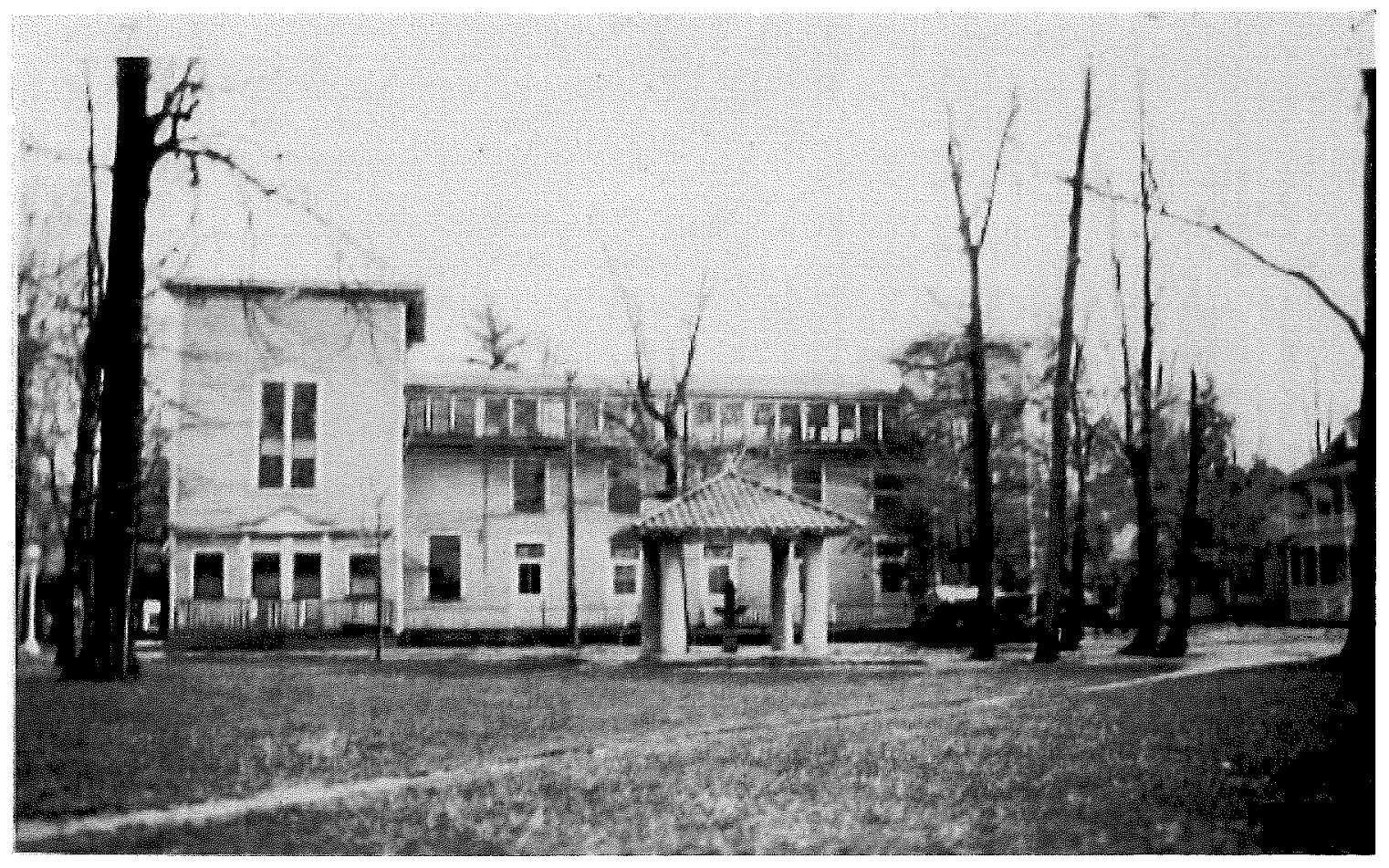

Figure 1.19

Newton Hall, 1881. (Courtesy of Chautauqua Institution Archives.) 


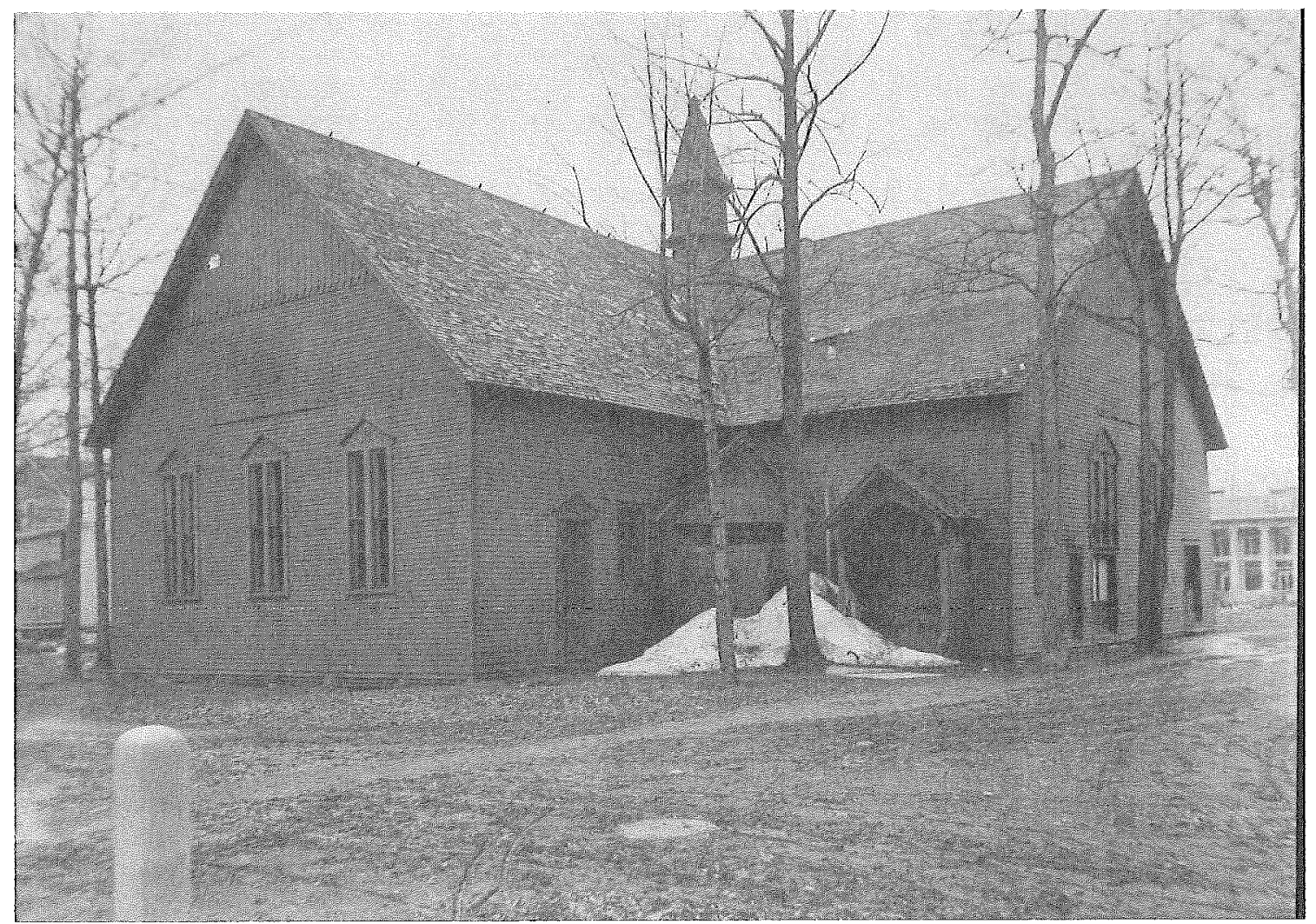

Figure 1.20

Children's Temple, 1878. (Courtesy of Chautauqua Institution Archives.) 


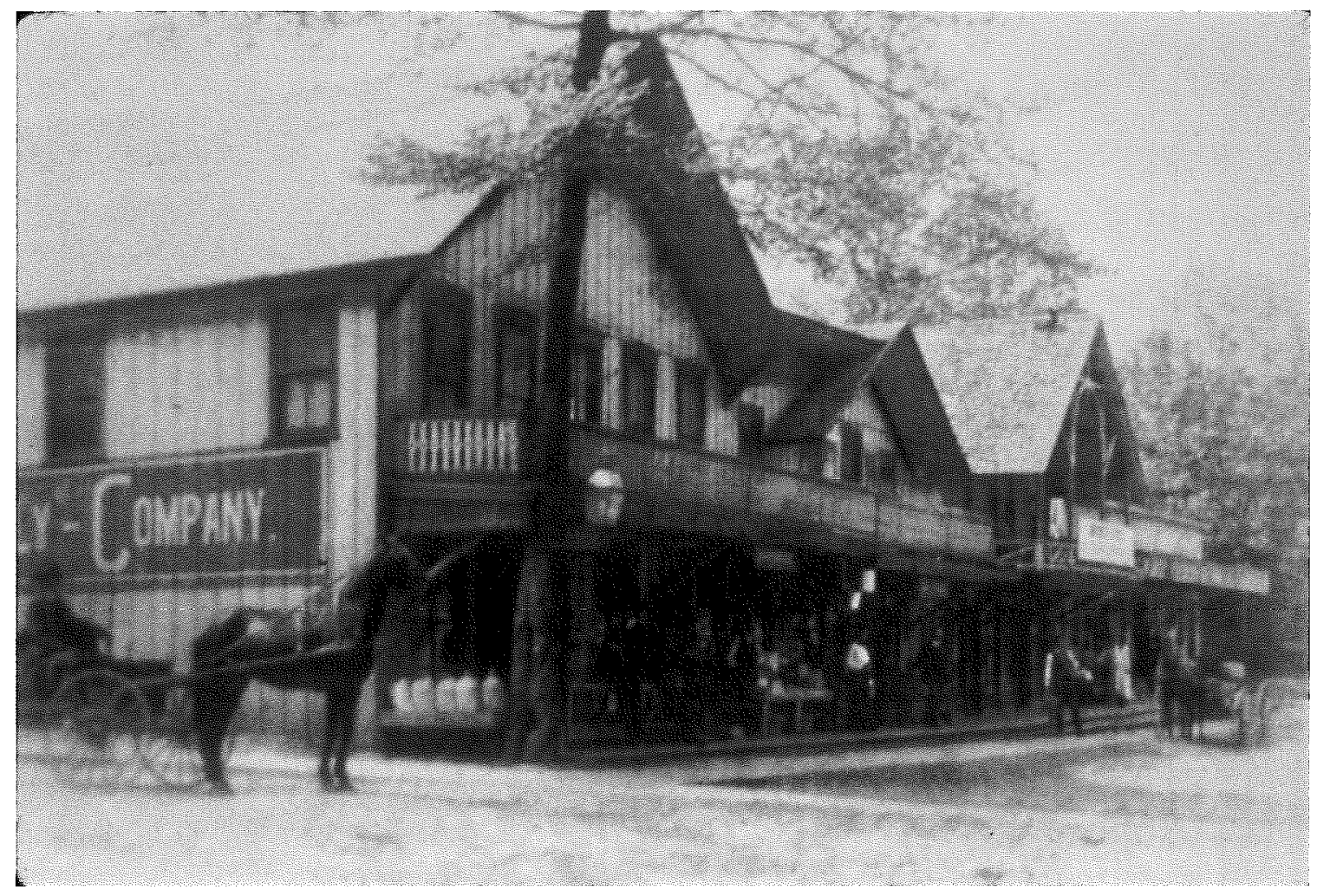

Figure 1.21

Shops along Vincent, c. 1900. (Courtesy of Chautauqua Institution Archives.) 


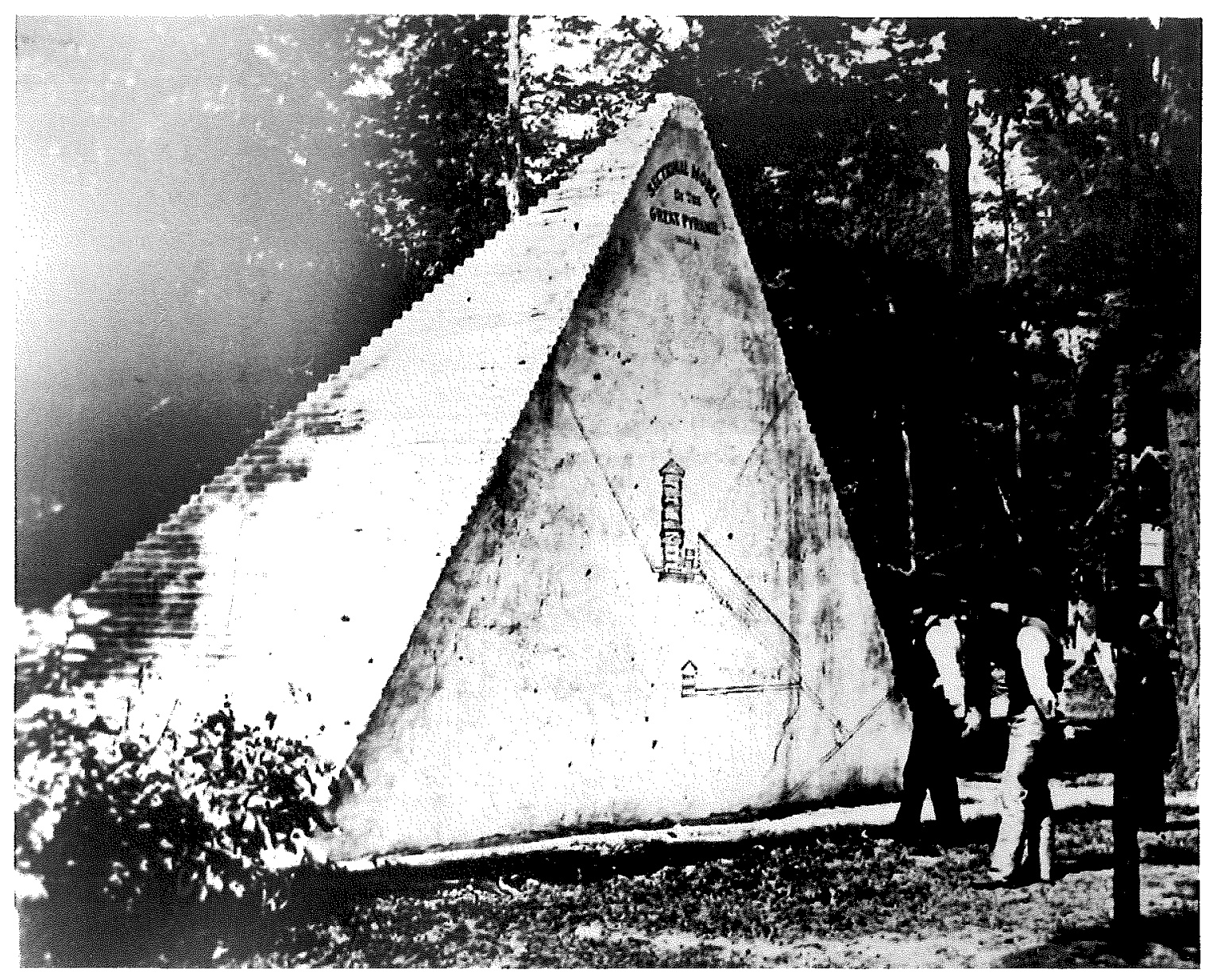

Figure 1.22

Cheops Pyramid, c. 1900. (Courtesy of Chautauqua Institution Archives.) 


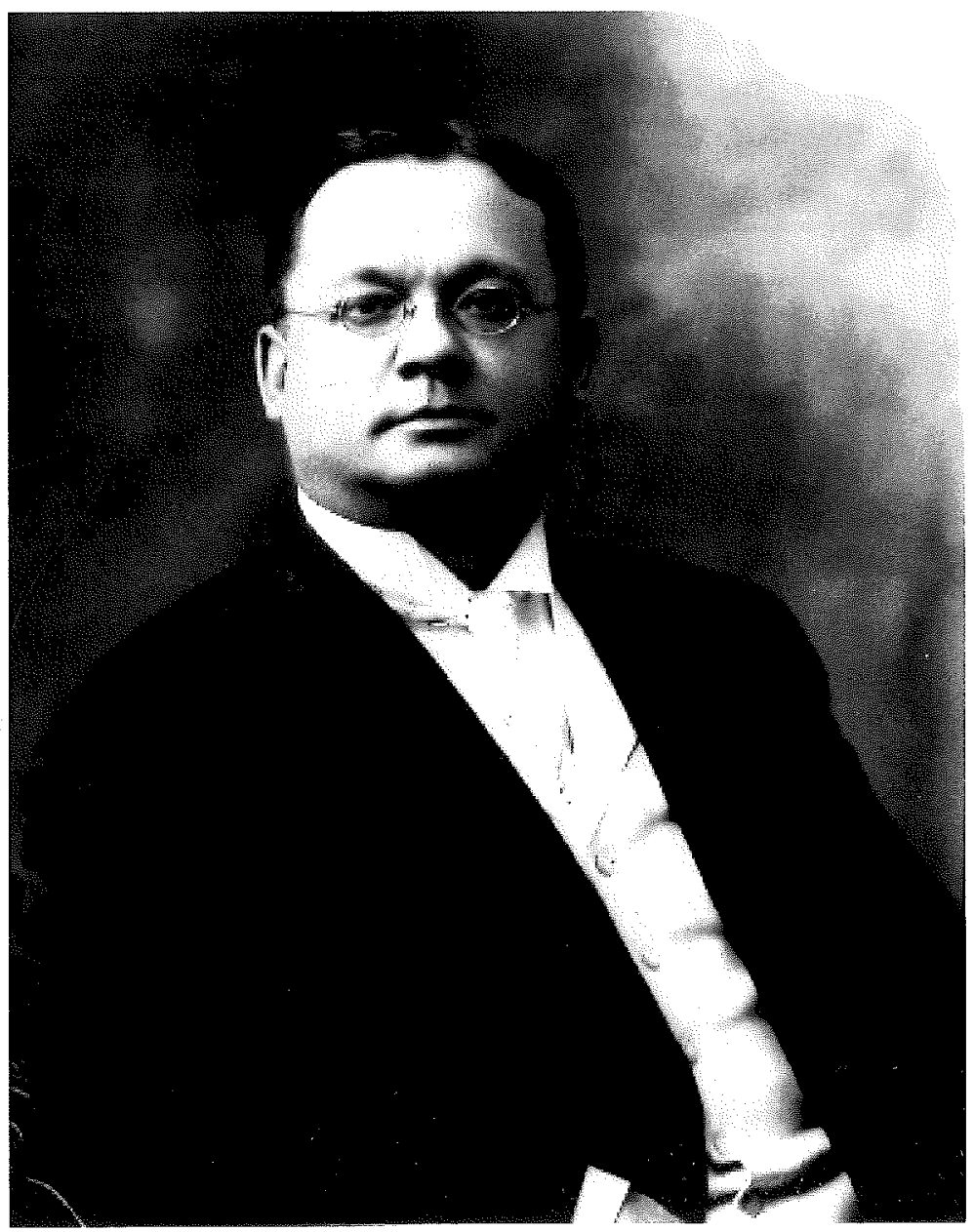

Figure 2.1

William Rainey Harper. (University of Chicago, Department of Astronomy and Astrophysics. Web.) 


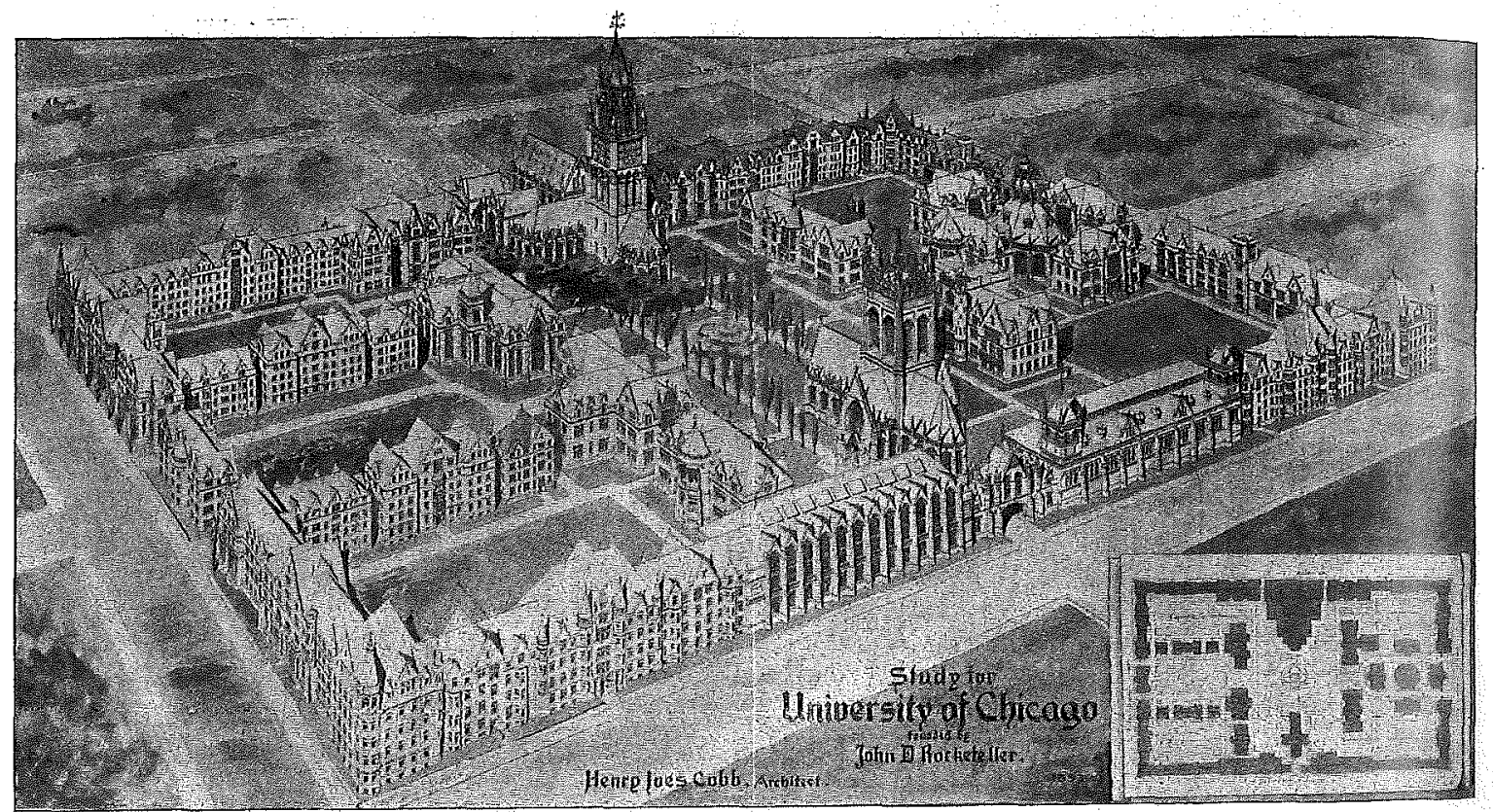

Figure 2.2

Henry Ives Cobb. Study for University of Chicago, 1893. (Edward W. Wolner. Henry Ives Cobb's Chicago: Architecture, Institutions, and the Making of a Modern Metropolis, 192.) 


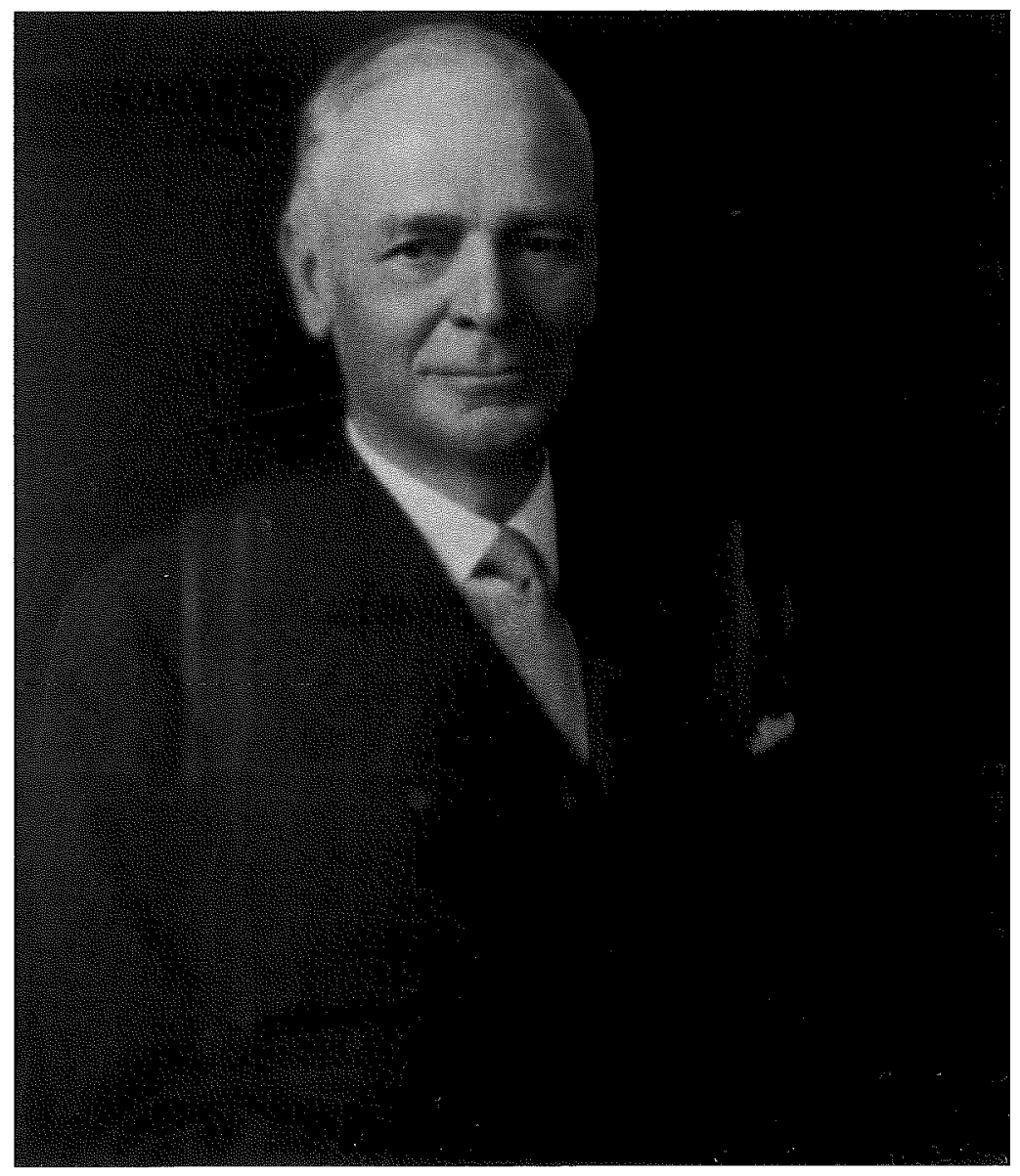

Figure 2.3

George Edgar Vincent. (American Sociological Association. Web.) 


\section{Chautauqua: The Largest Institution} for Higher Education in the World

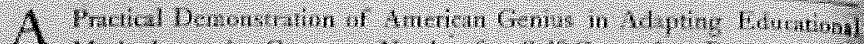

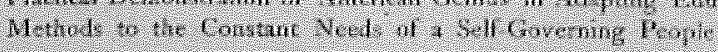

\section{迥}

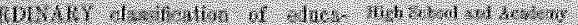

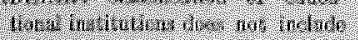

Lit.

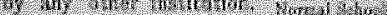

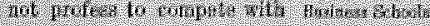

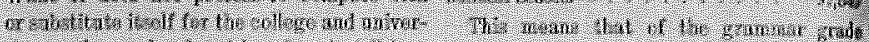

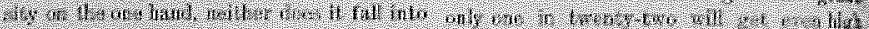

r.

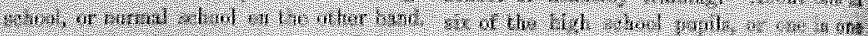

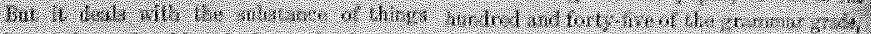

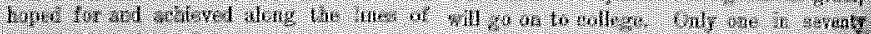

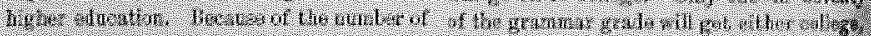

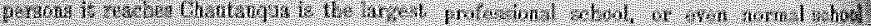

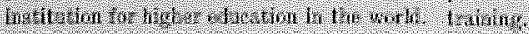

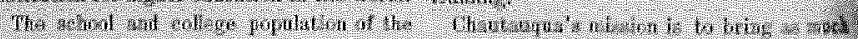

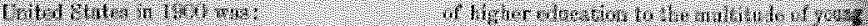

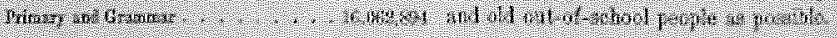

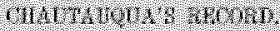

3.

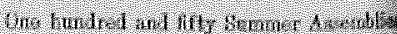

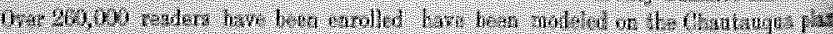

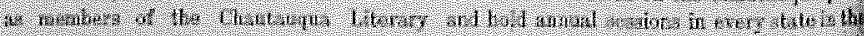

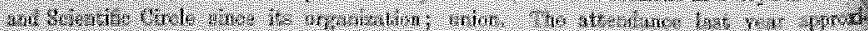

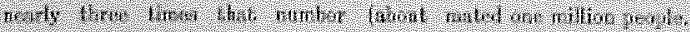

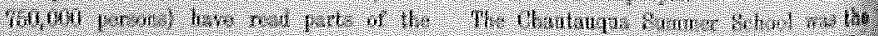

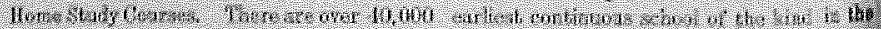

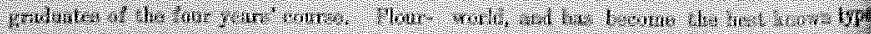

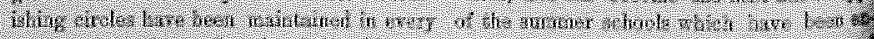

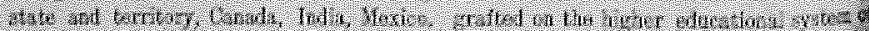

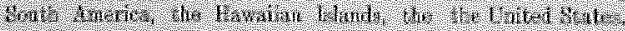

W

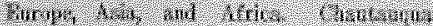

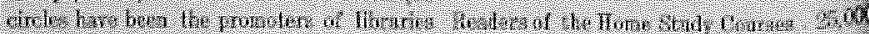

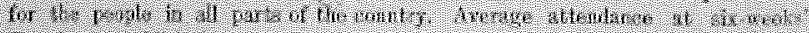

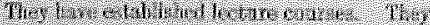

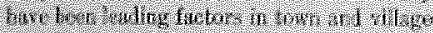

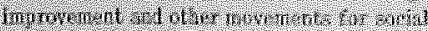

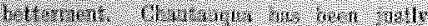

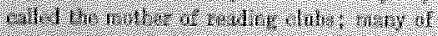

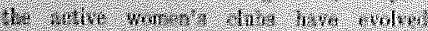
Whe tw 1 ,

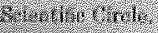

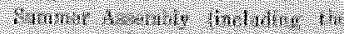

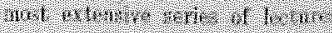

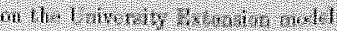

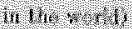

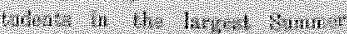

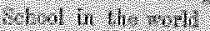

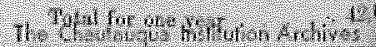

wh
4
4
4
4

Figure 2.4

"Chautauqua: The Largest Institution for Higher Education in the World." (The Chautauquan. July 1902.) 


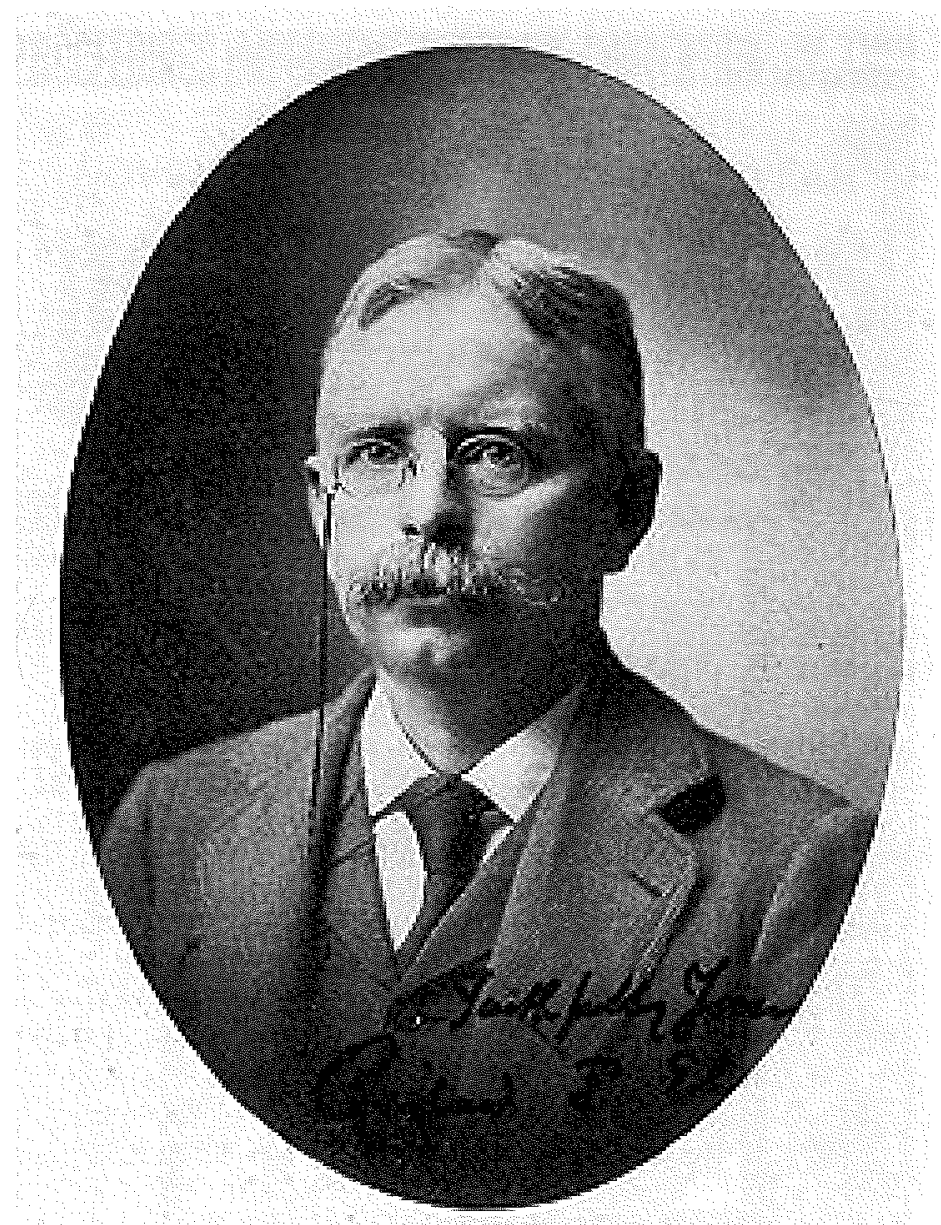

DHoklos A. T, 14n,

Figure 2.5

Richard Theodore Ely (1854-1943). (Wikipedia. Web.) 


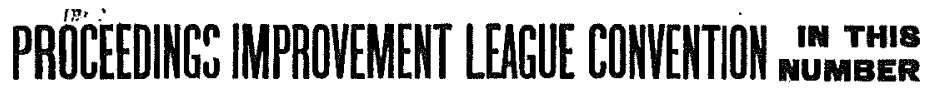

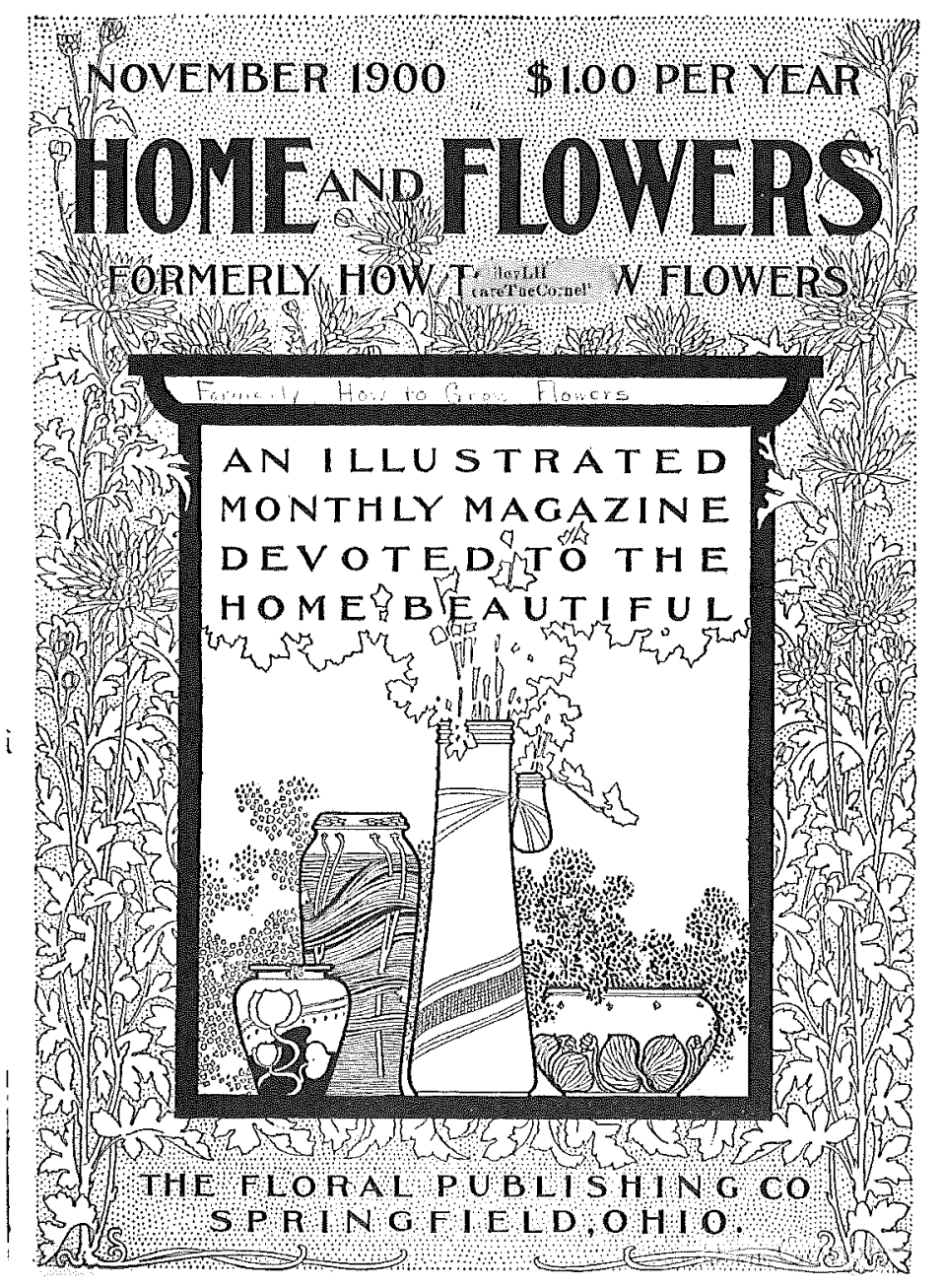

Figure 2.6

Home and Flowers. November 1900, title page. 


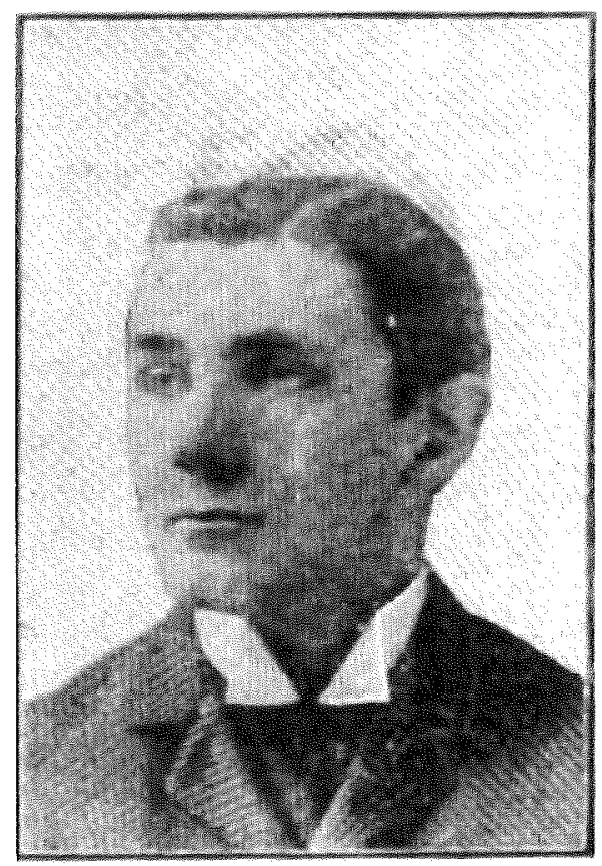

Figure 2.7

Charles Zueblin (1886-1924). ("The National League of Improvement Clubs." Home and Flowers Nov. 1900: 9.) 


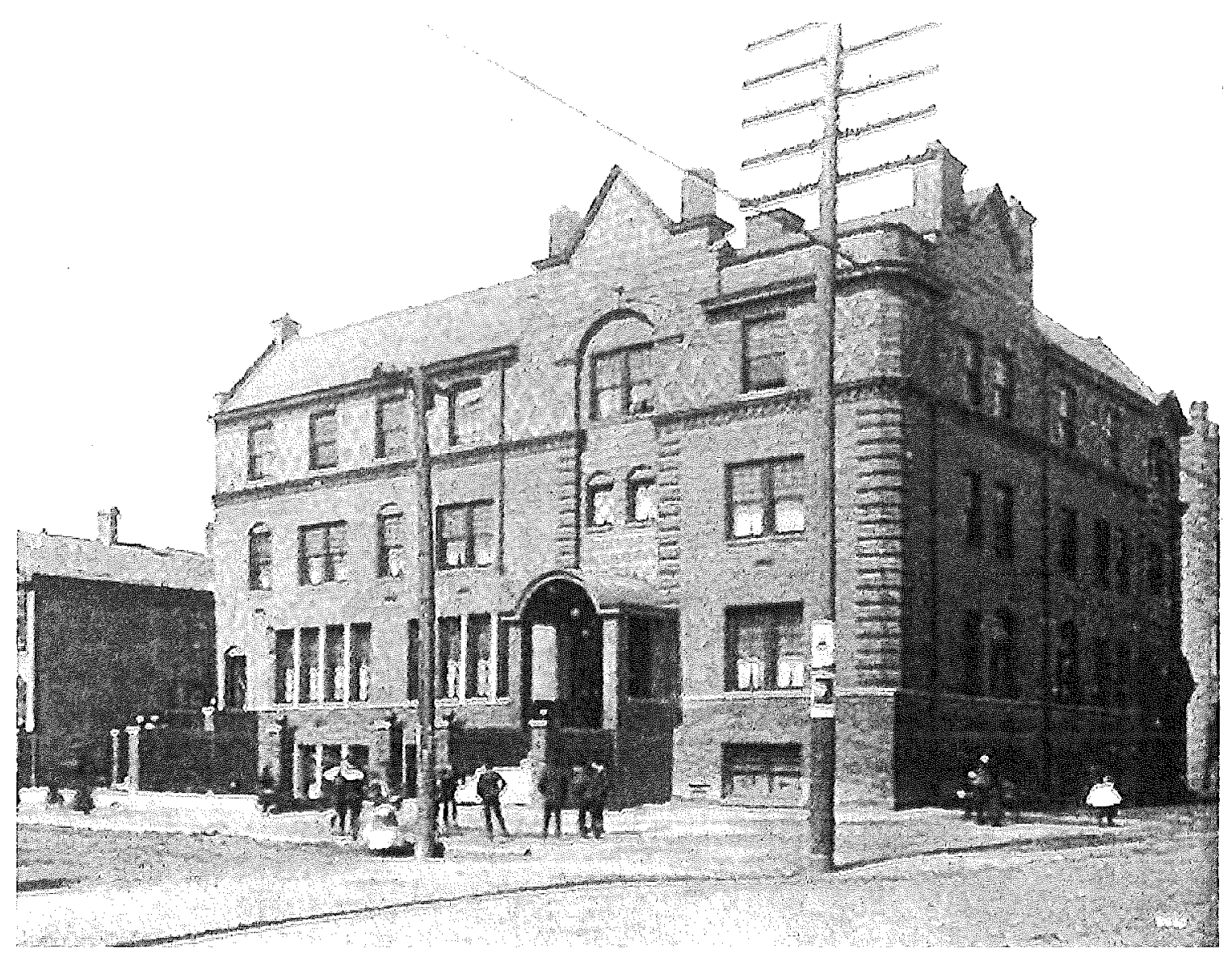

Figure 2.8

Pond and Pond. Northwestern University Settlement House. (Irving Kane Pond, "The Life of Architecture." Architectural Record 1905: 150.) 


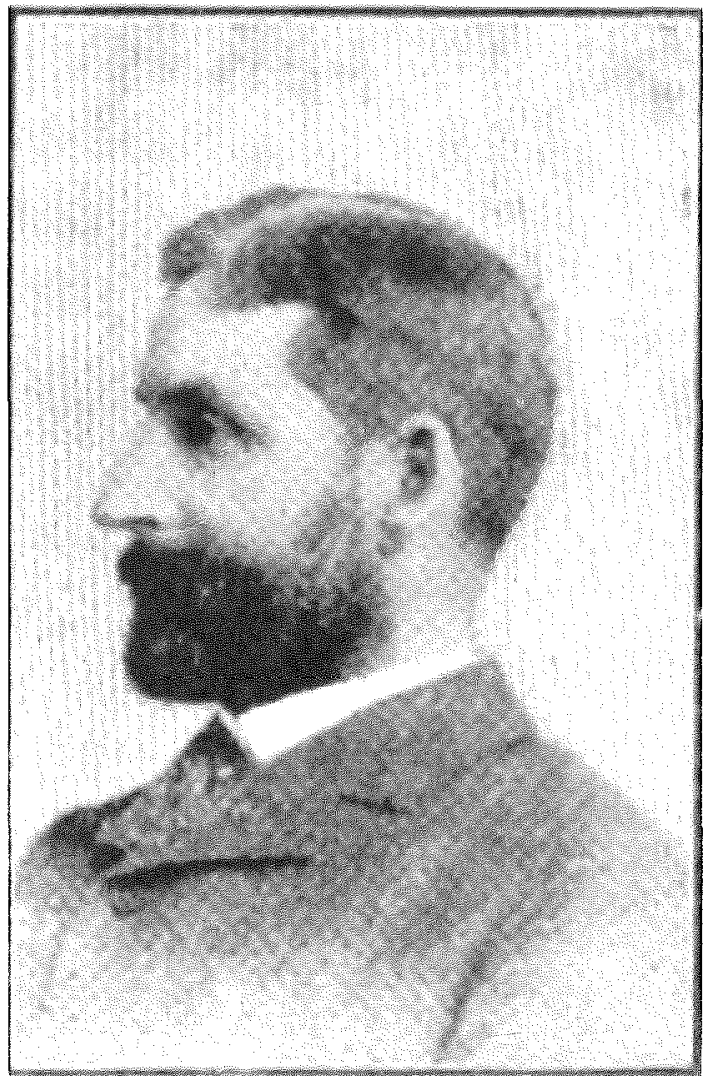

Figure 2.9

Edwin L. Shuey (1857-1924). ("The National League of Improvement Clubs." Home and Flowers Nov. 1900: 9.) 


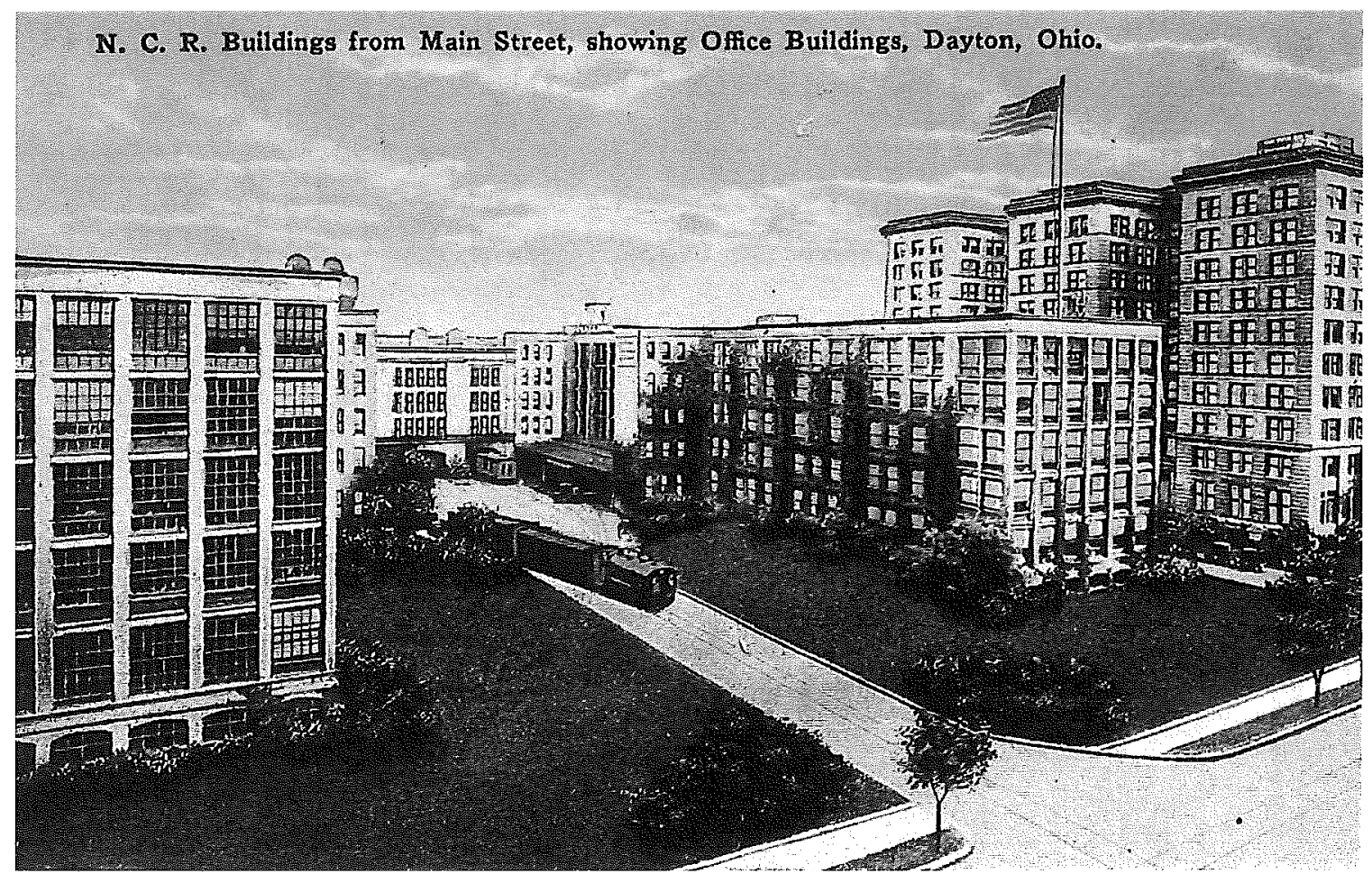

Figure 2.10

Frank Mills Andrews. N. C. R. Buildings from Main Street, postcard. 


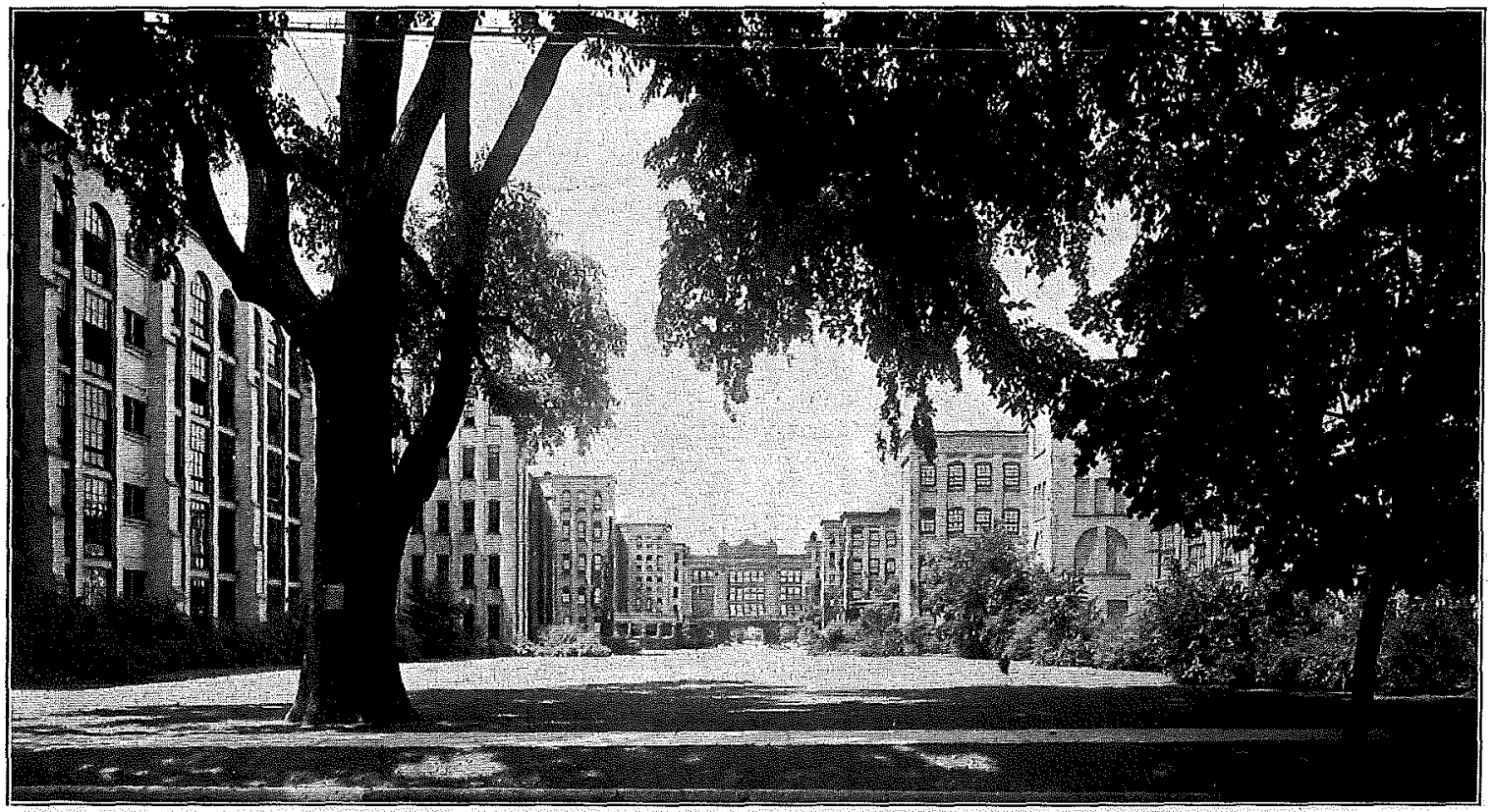

Figure 2.11

John Charles Olmsted (1852-1920). NCR Grounds. (Samuel Crowther. John H. Patterson, Pioneer in Industrial Welfare: opposite 183.) 


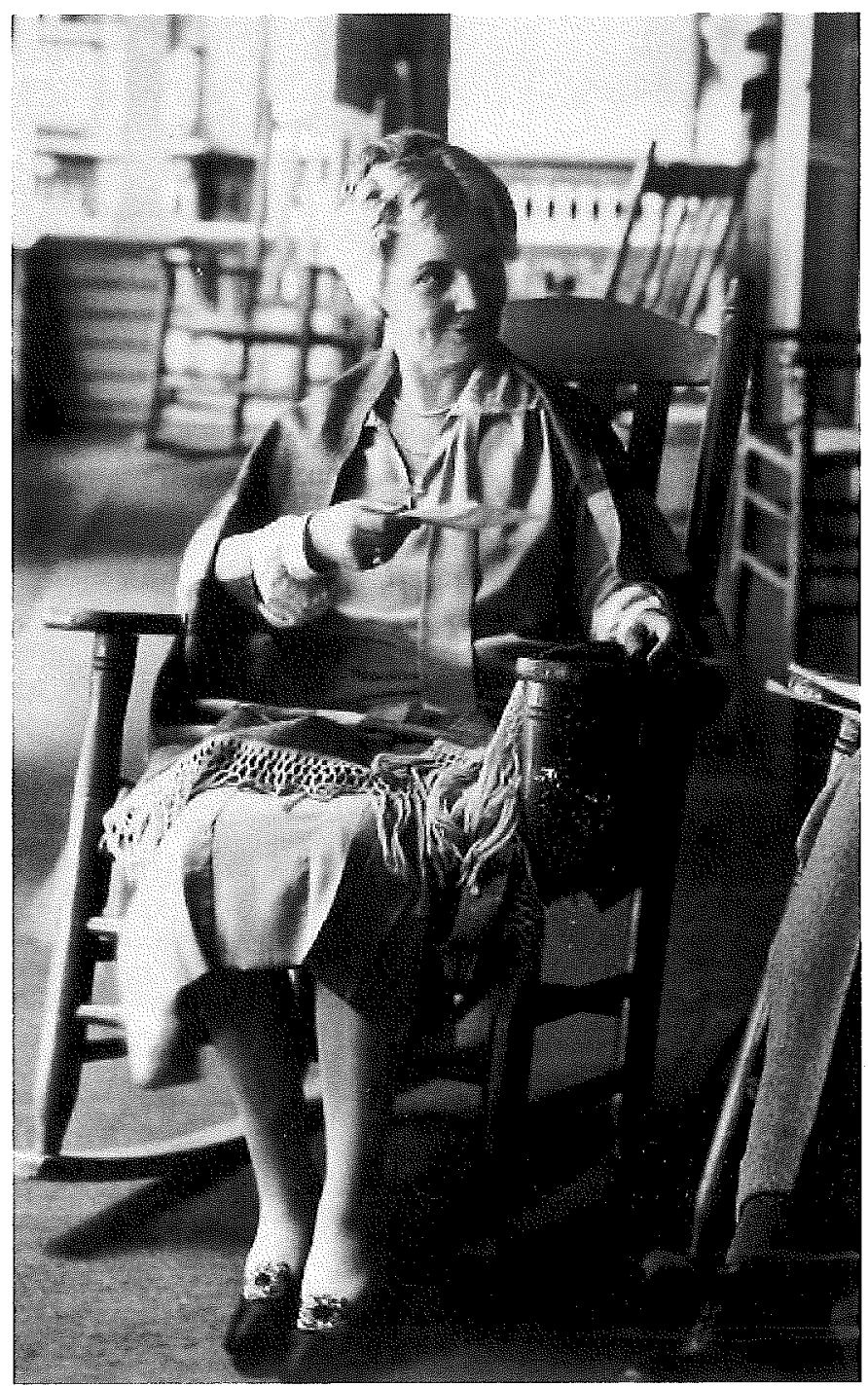

Figure 3.1

Anna J. Pennybacker (1861-1938). (Courtesy of Chautauqua Institution Archives.) 


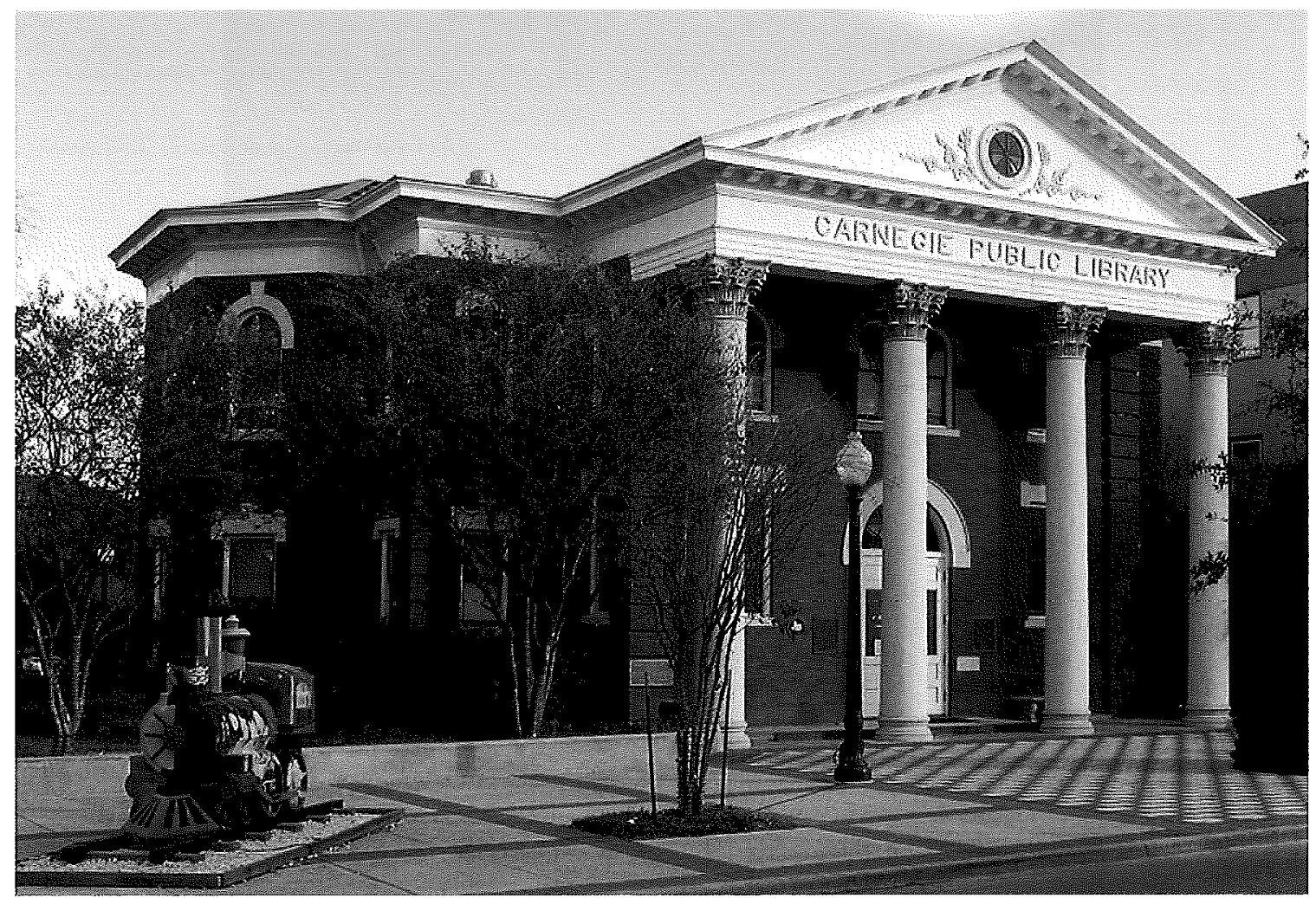

Figure 3.2

Fred R. Gieseckie. Carnegie Public Library, 1902, Bryan, Texas. (Wikipedia. Web.) 


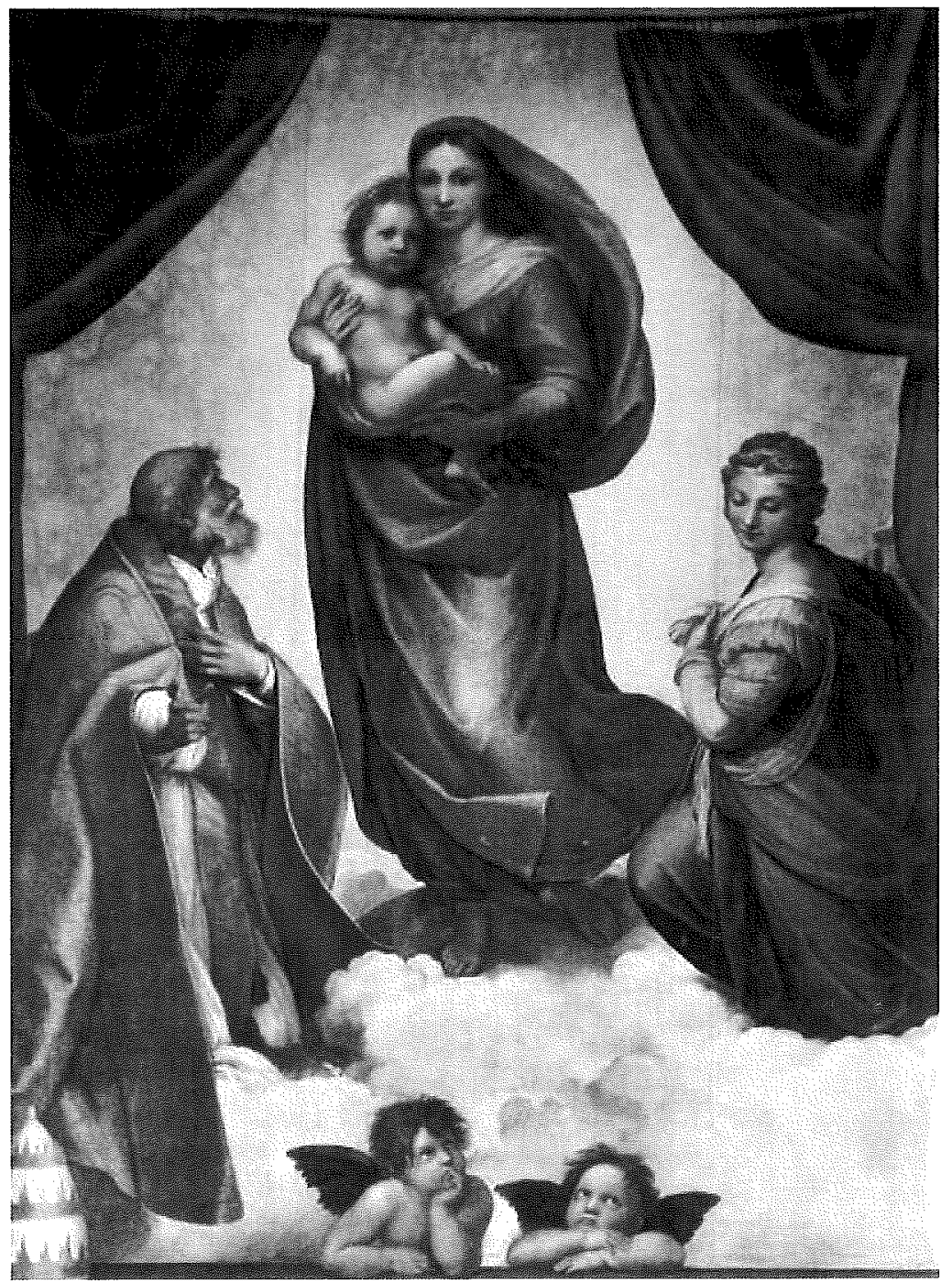

Figure 3.3

Raphael. Sistine Madonna (1513-1514). (Wikipedia. Web.) 


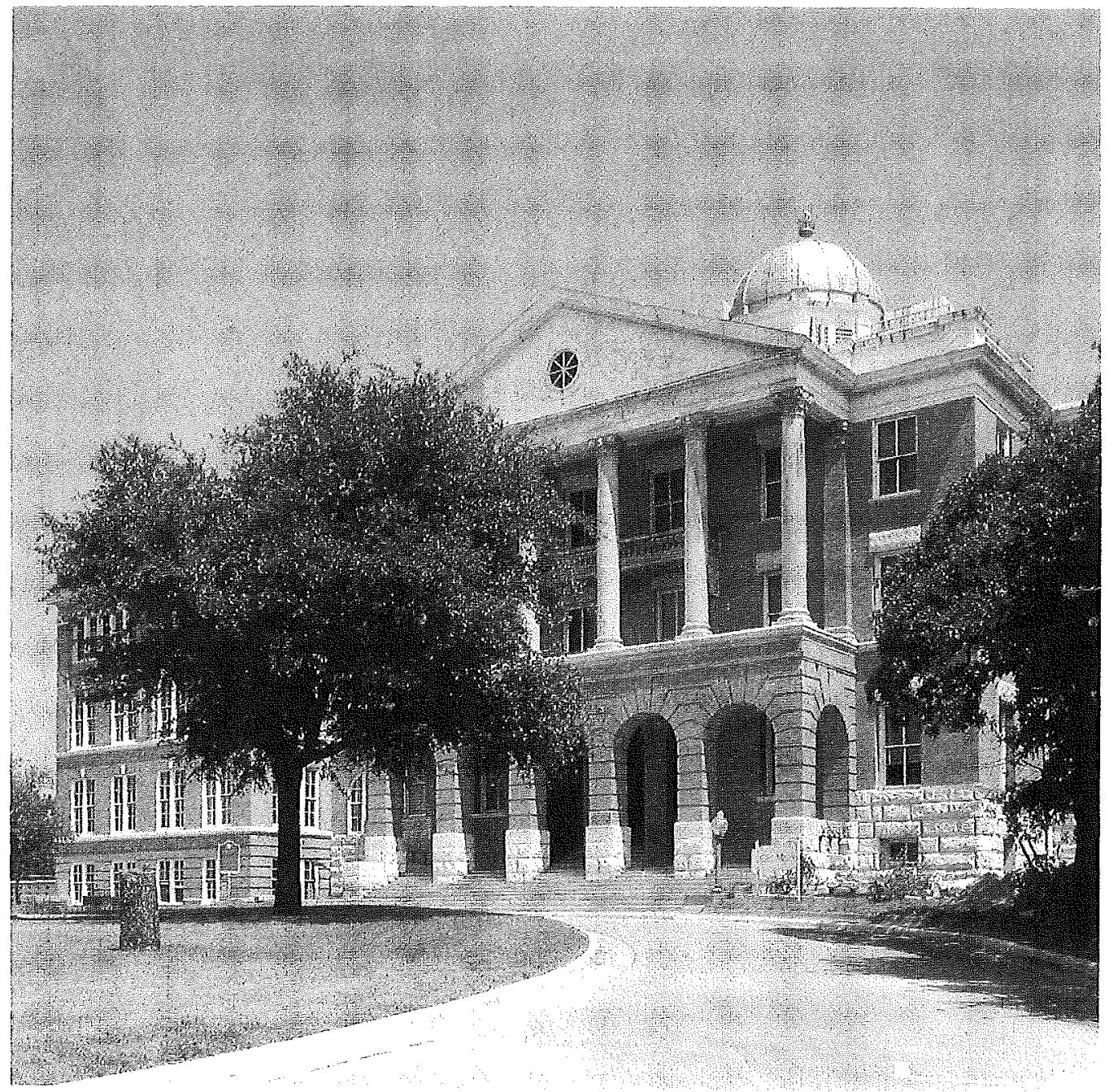

Figure 3.4

Dodson and Scott. Girl's Industrial School (1902). (Jay C. Henry. Architecture in Texas, 1895-1945, 98.) 

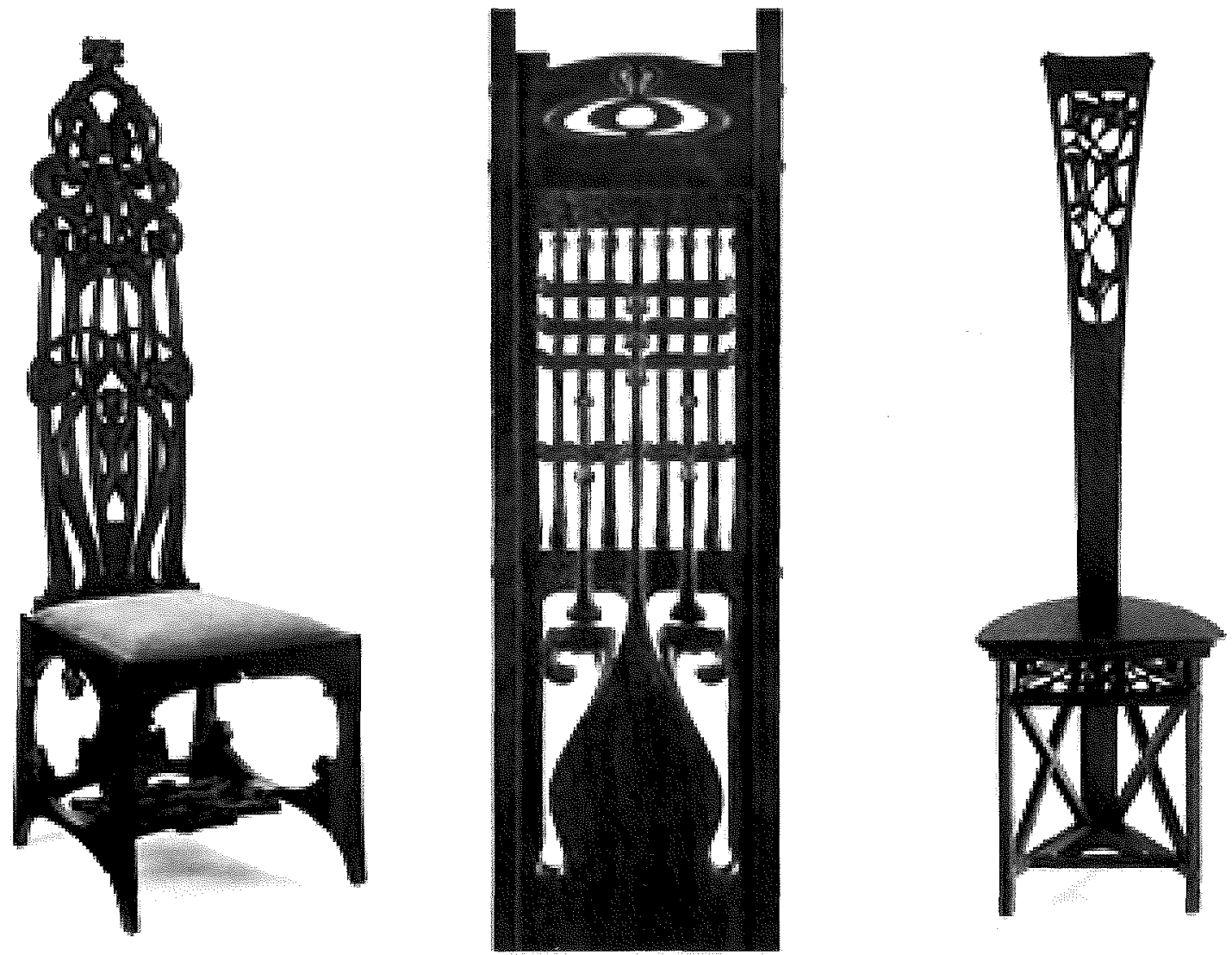

Figure 3.5

Charles Rohlfs (1853-1956). Furniture. (Wikipedia. Web.) 


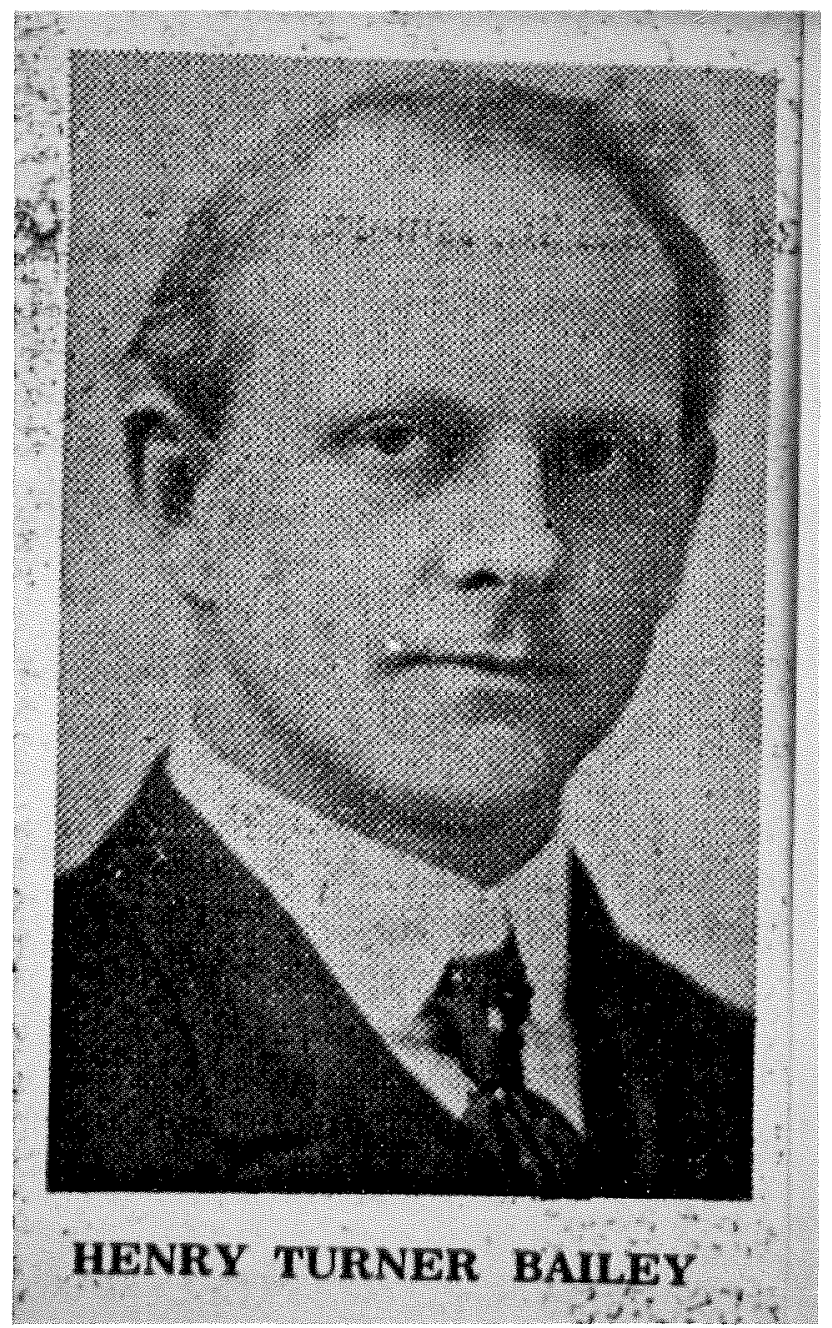

Figure 3.6

Henry Turner Bailey (1865-1931). (Courtesy of Chautauqua Institution Archives.) 


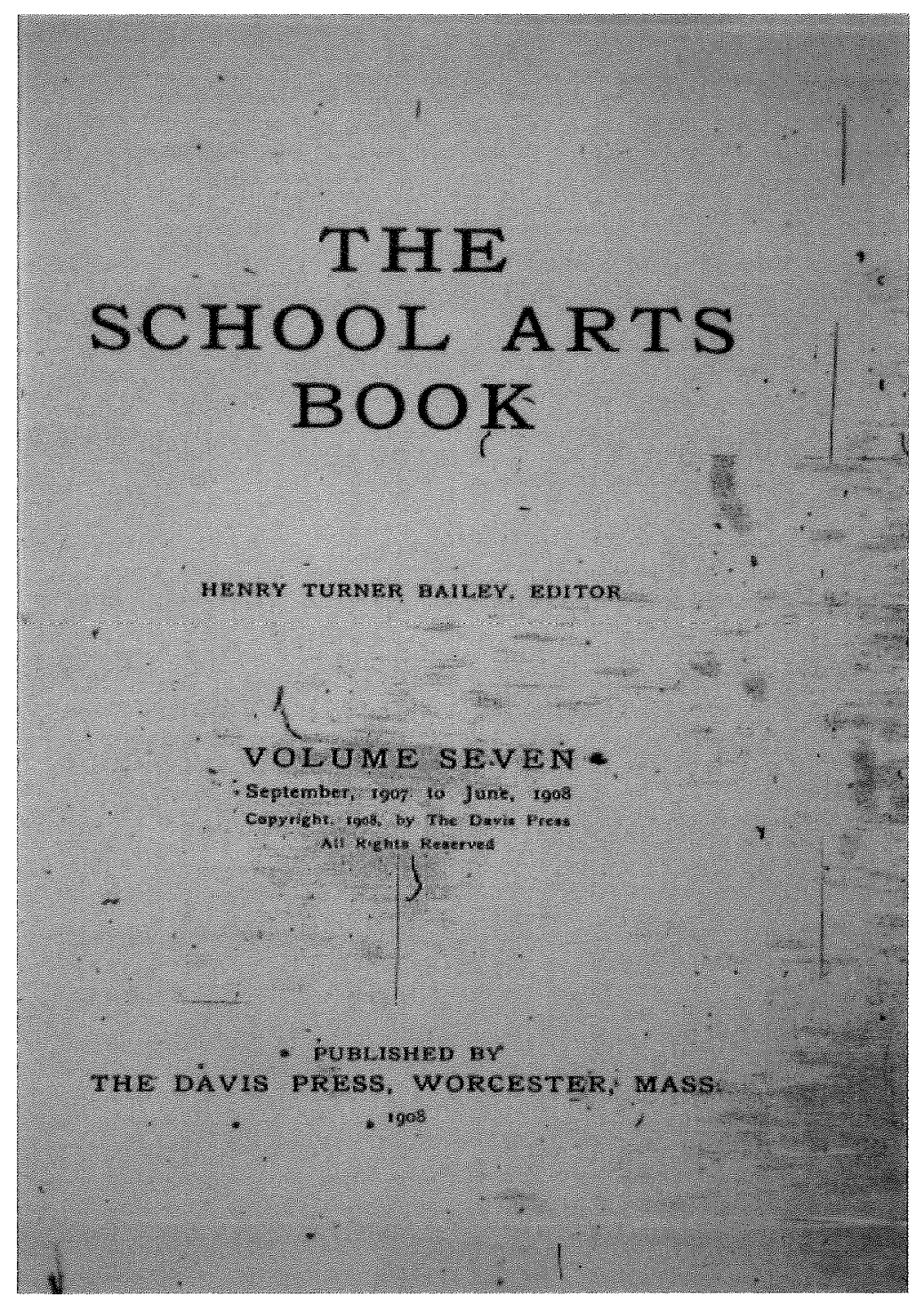

Figure 3.7

The School Arts Book, cover page, Henry Turner Bailey, ed. Vol. 7, September 1907 to June 1908. (Special Collection, New York Public Library.) 


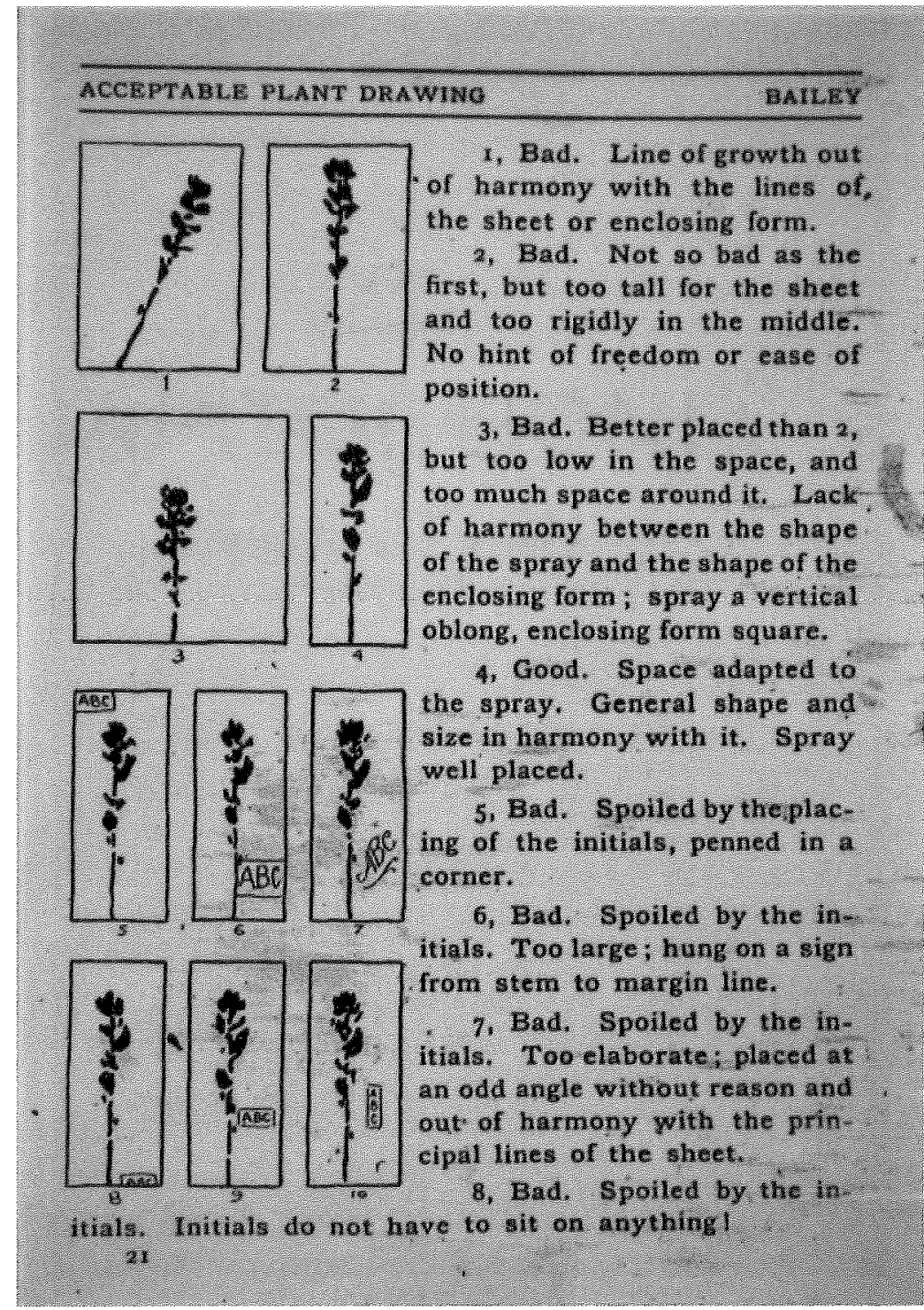

Figure 3.8

Henry Turner Bailey, "Acceptable Plant Drawing." The School Arts Book, Vol. 7, September 1907 to June 1908: 21. (Special Collection, New York Public Library.) 
THE BEAUTY LOVER'S

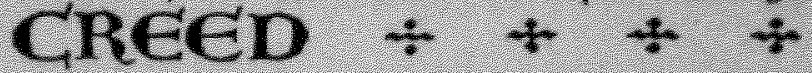
- I believe in Beauty as the manifestation of triumphant life. $\div$ - I bdieve in looking for Beauty everywhere; watching for it, searching for it in the great and in the small, in the umusual and in the comunonplace things of this wonderful world. $\div 3 \div \div+$ $\div$ I believe in working for Benuty ahways; planning for it, trying for it in the making of all that has to be made, and in the doing of all that has to be done. $4 \div \div \div$ $\div$ I belicve in living the Beanty. ful life; a life in right relation to the lives of others and in harrno. ny with the eternally unfolding life of God. + + +

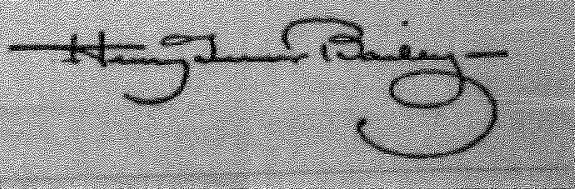

Figure 3.9

Henry Turner Bailey. The Beauty Lover's Creed. (Courtesy of Chautauqua Institution Archives.) 


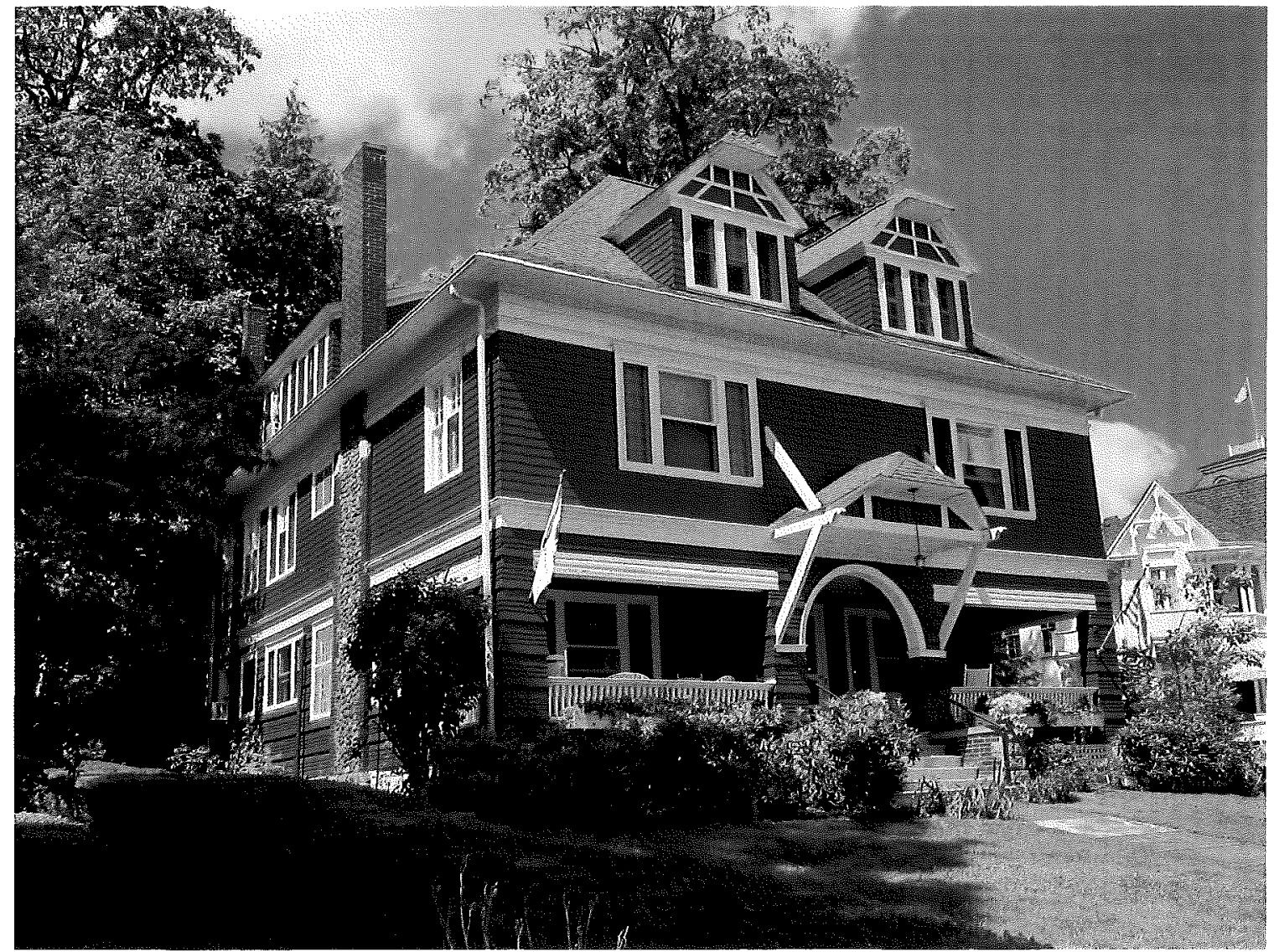

Figure 3.10

Studebaker/Carlisle Cottage, 1902. 34 South Lake Drive, Chautauqua, NY. (Author's Photograph, 2011) 


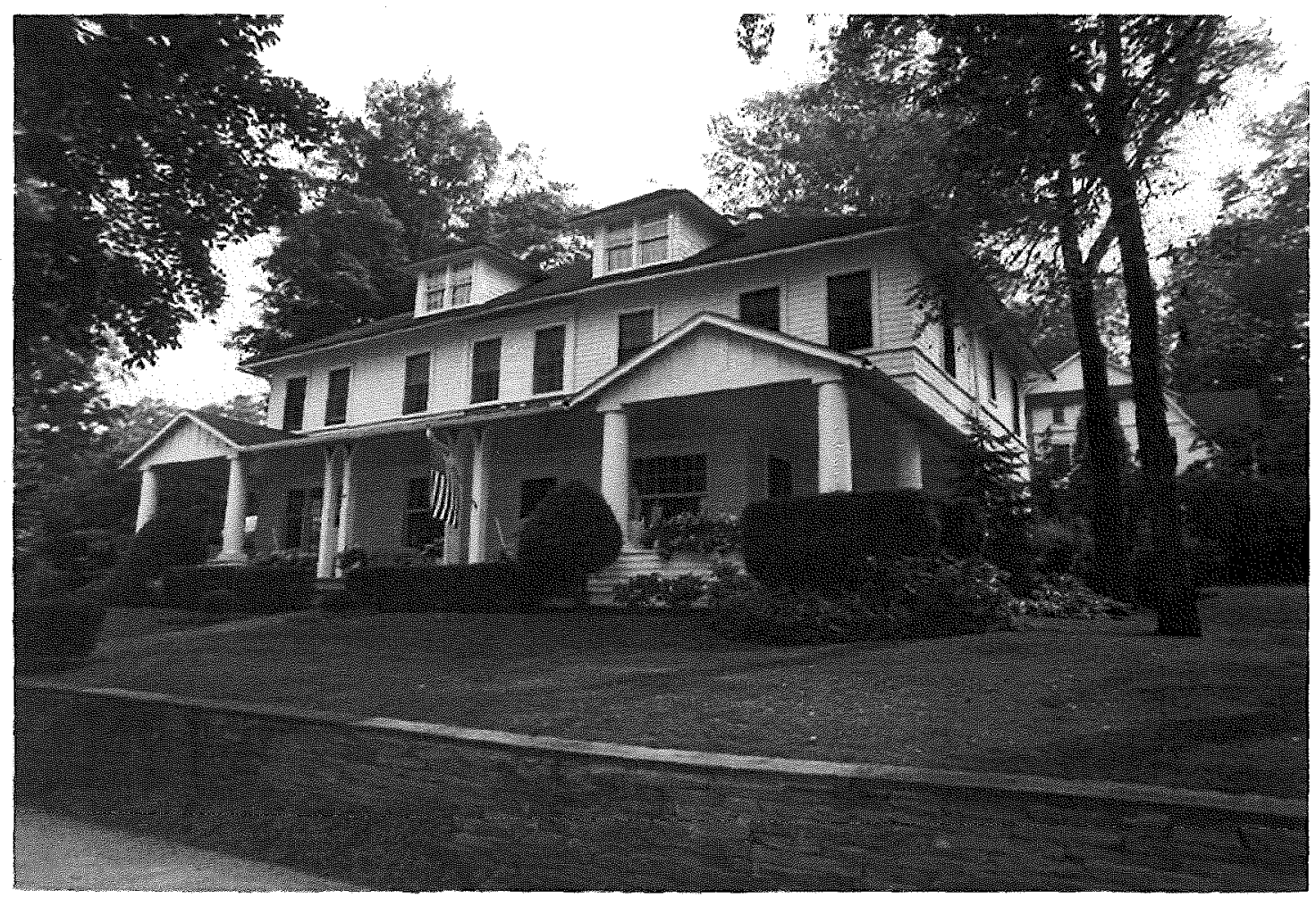

Figure 3.11

Howard Van Doren Shaw (1869-1926). O. W. Norton Cottage, 1900, 49 North Lake Drive, Chautauqua, NY. (Courtesy of Chautauqua Institution Archives.) 


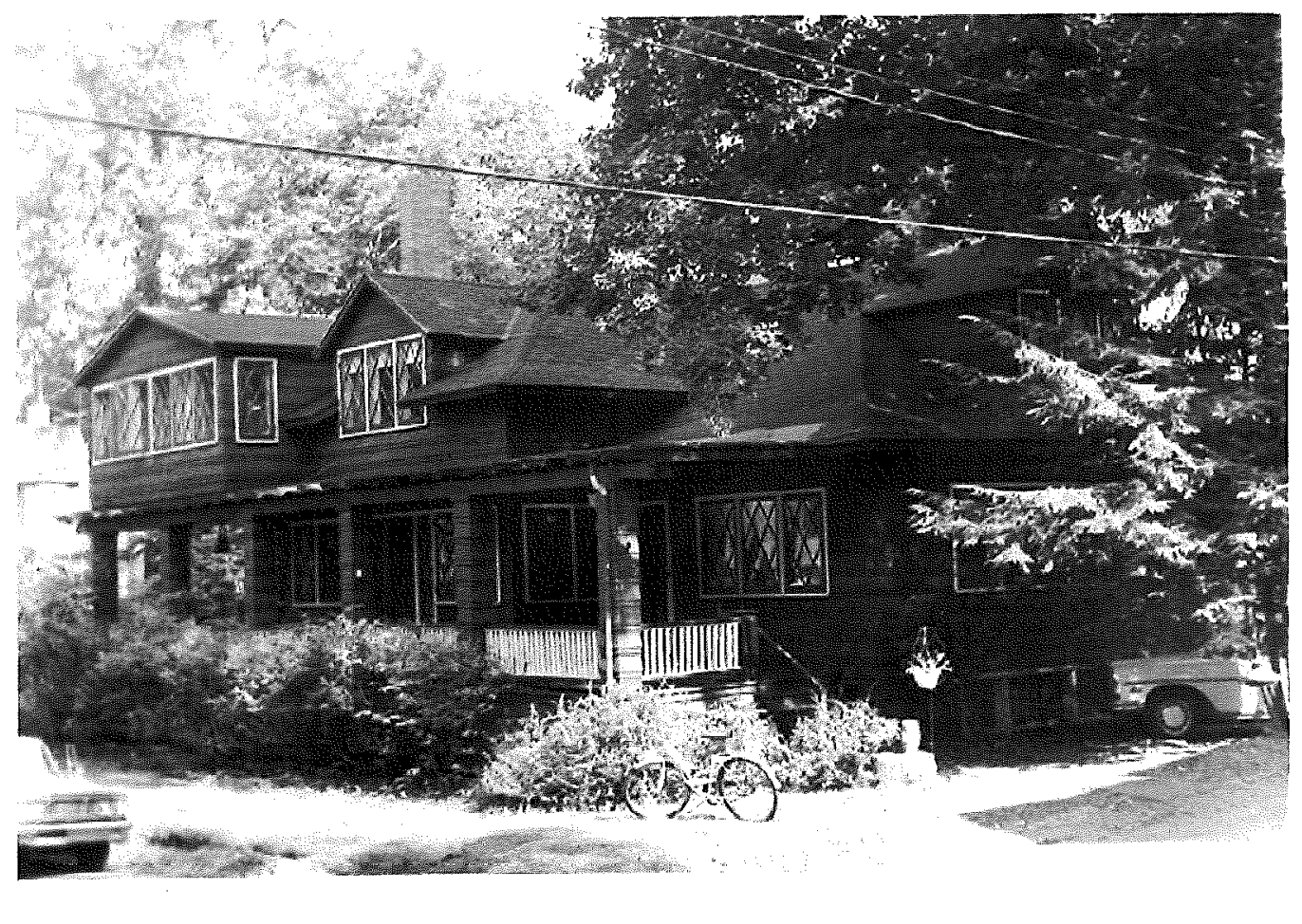

Figure 3.12

G. A. Mang. C. C. Taylor House, 1909, O. S. Lang, builder, 7 McClintock Ave., Chautauqua, NY. (Courtesy of Chautauqua Institution Archives.) 


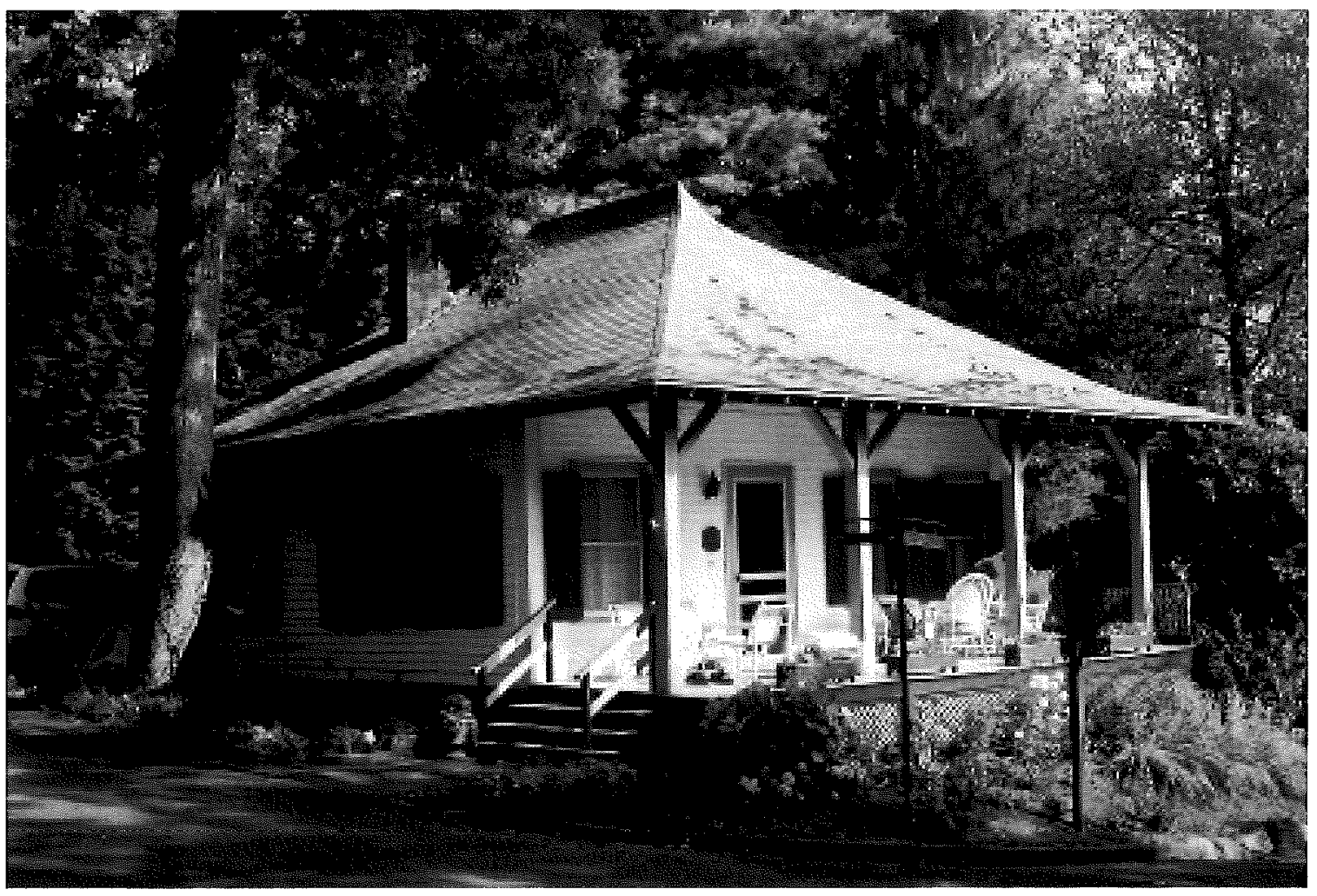

Figure 3.13

20 Hurst Ave., 1914, Chautauqua, NY. (Author's Photograph, 2010.) 


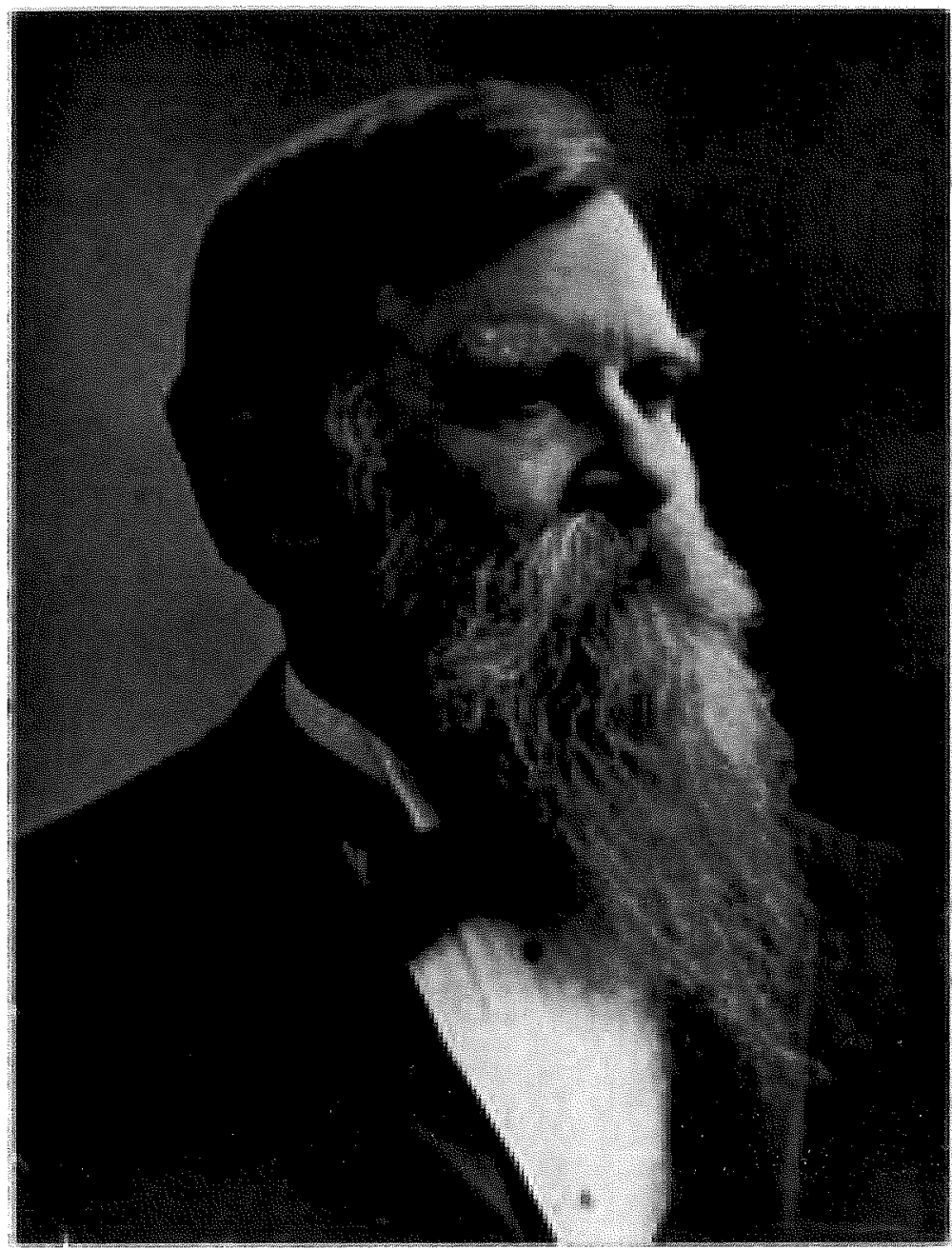

Figure 4.1

Clement Studebaker (1831-1901). (Tippecanoe Place Restaurant. Web.) 


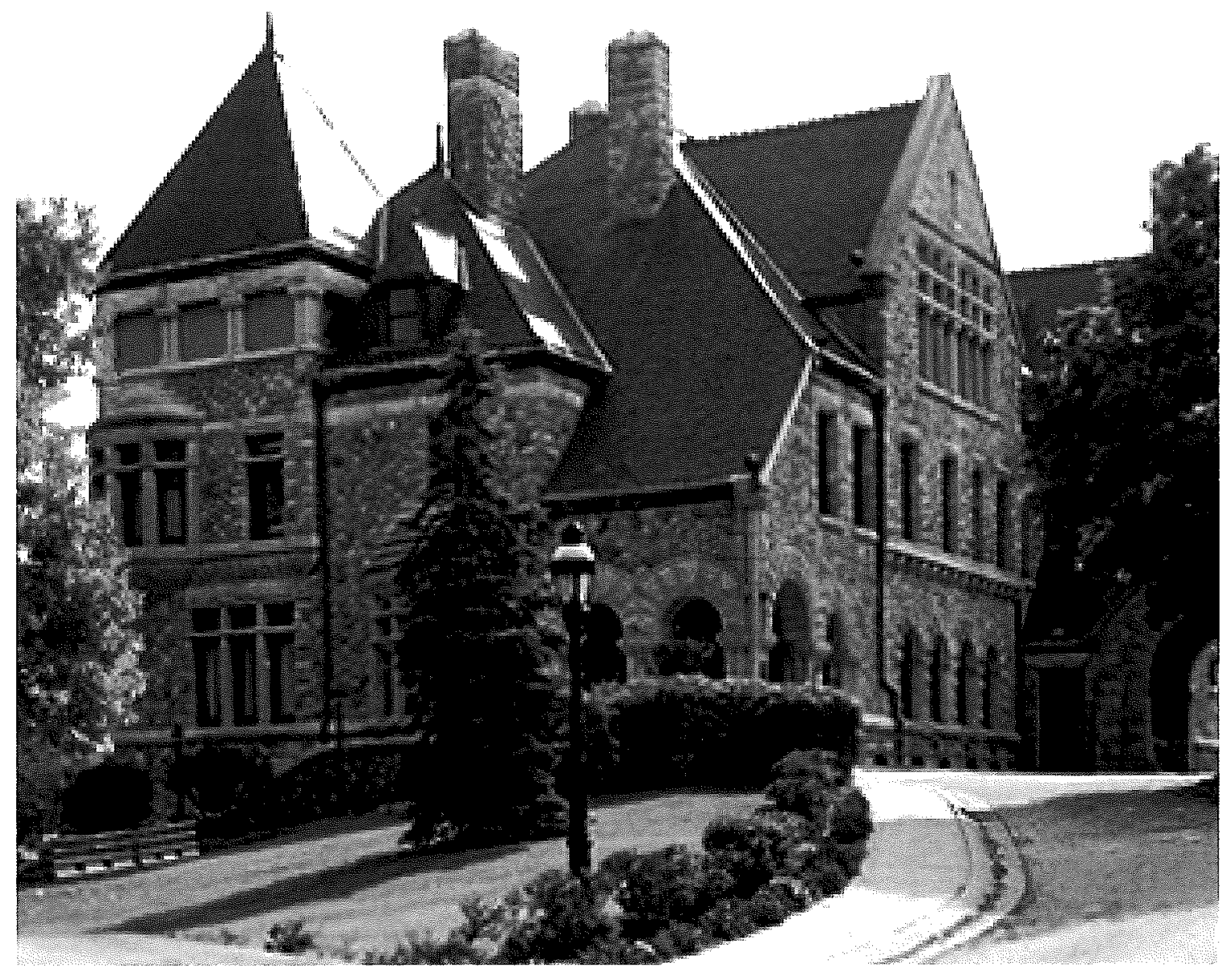

Figure 4.2

Henry Ives Cobb. Tippecanoe Place, 1889. (Tippecanoe Place Restaurant. Web.) 


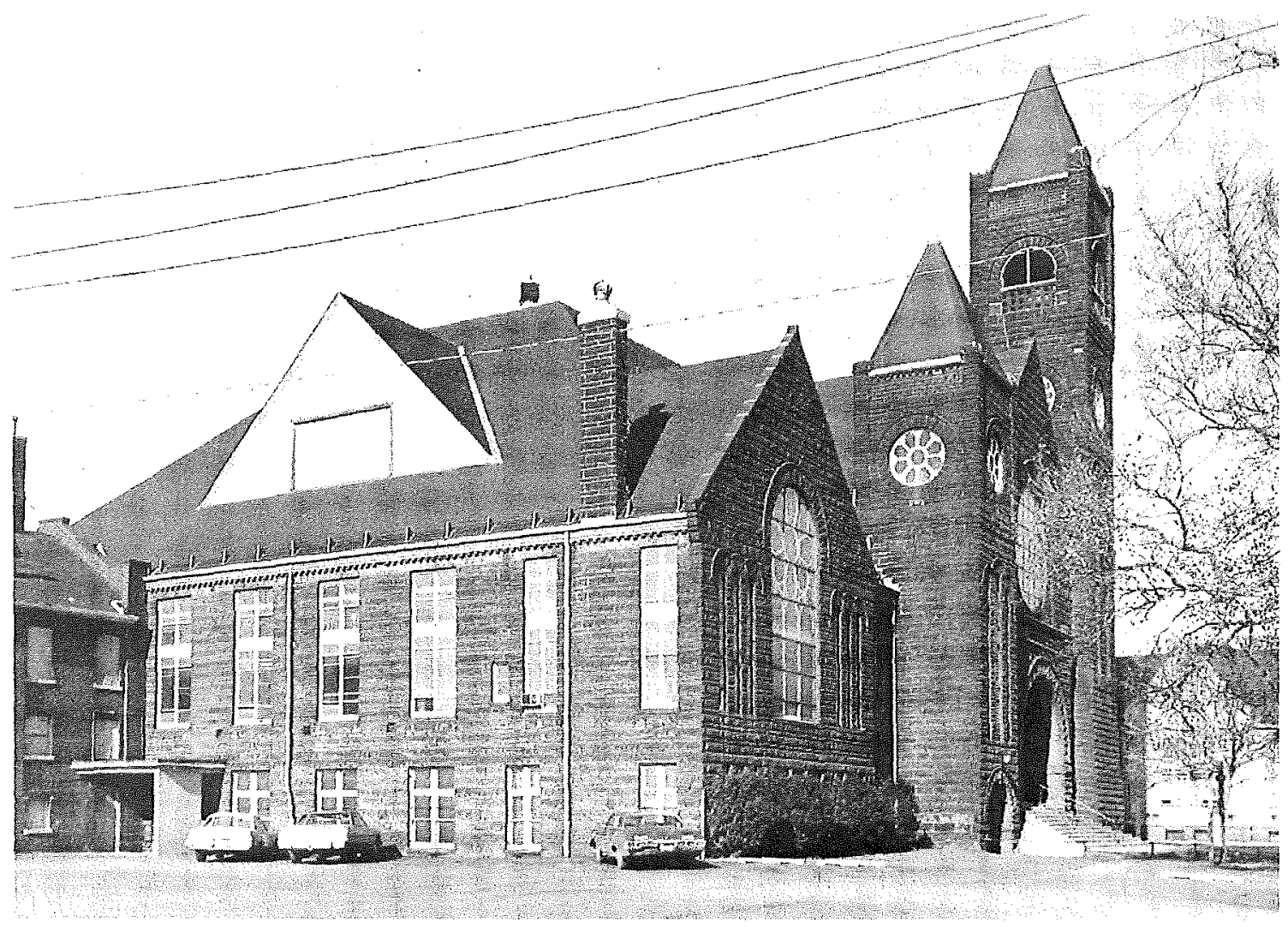

Figure 4.3

Sidney R. Badgley. Pilgrim Congregational Church, 1893-1894. (Eric Johannesen. Cleveland Architecture, 1878-1976, 52.) 


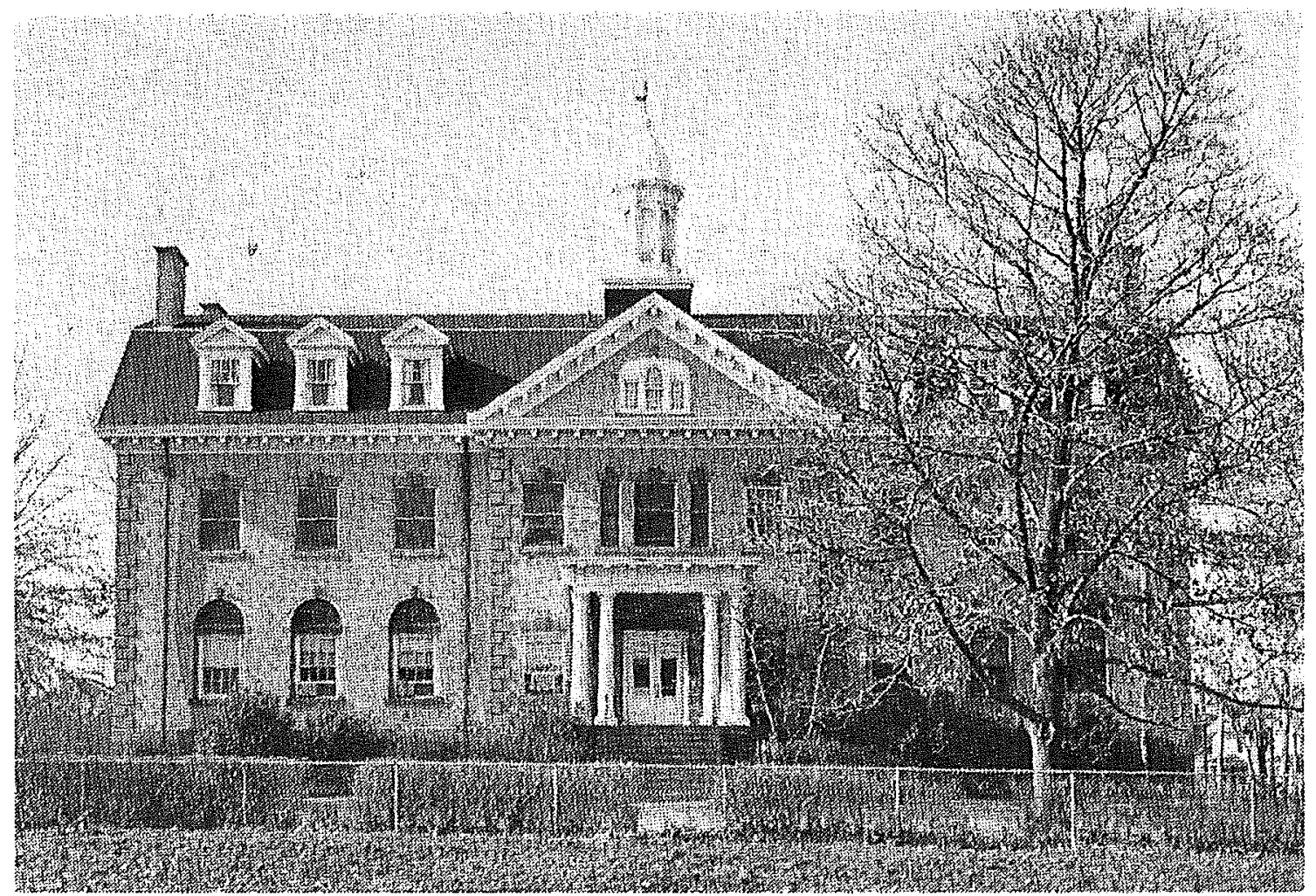

Figure 4.4

Sidney R. Badgley. Jones Home for Friendless Children, 1902. (Eric Johannesen. Cleveland Architecture, 1878-1976, 56.) 


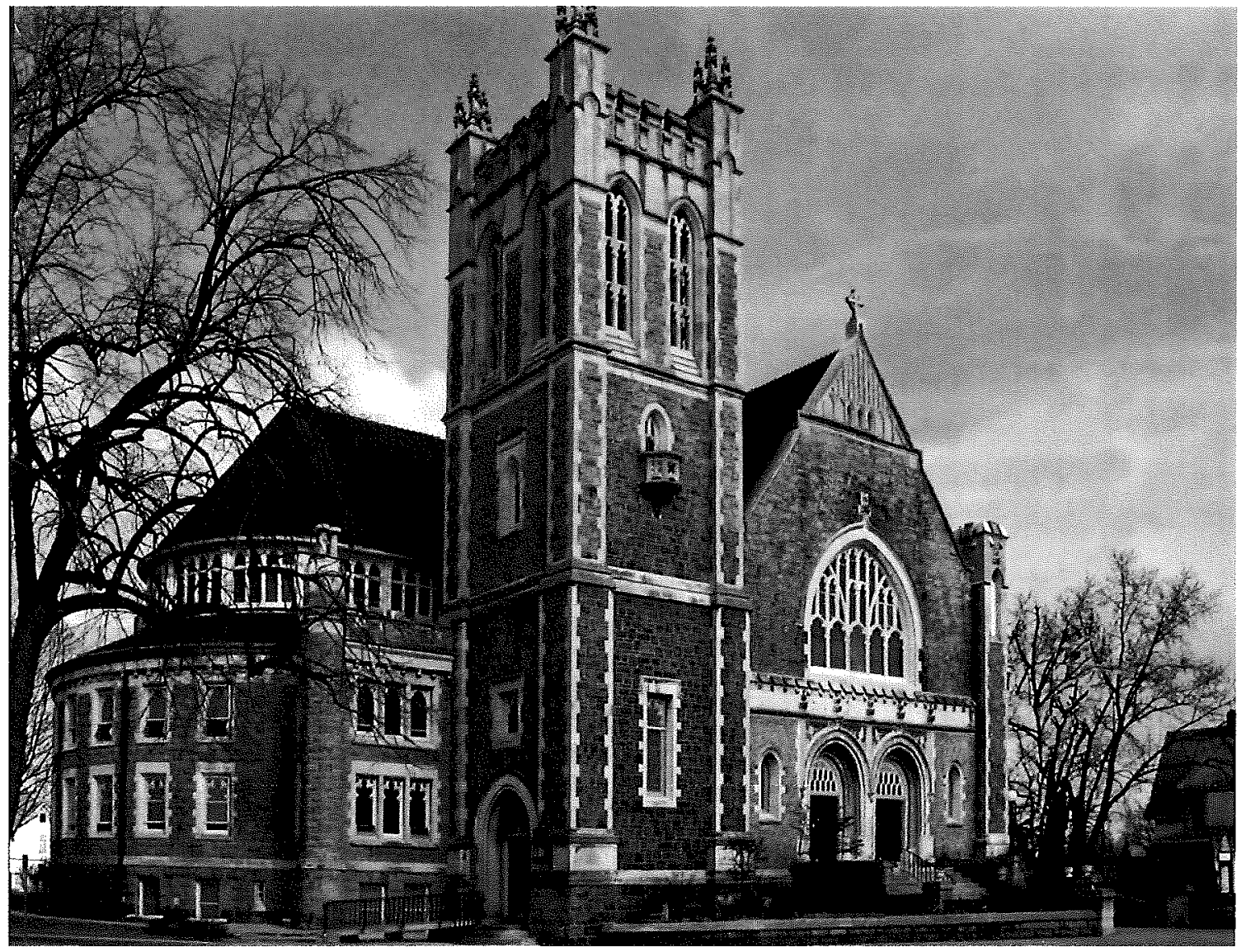

Figure 4.5

Sidney R. Badgley. Saint Paul's Methodist Church, South Bend, IN, 1901-1903.

(Courtesy of Saint Paul's Methodist Church.) 


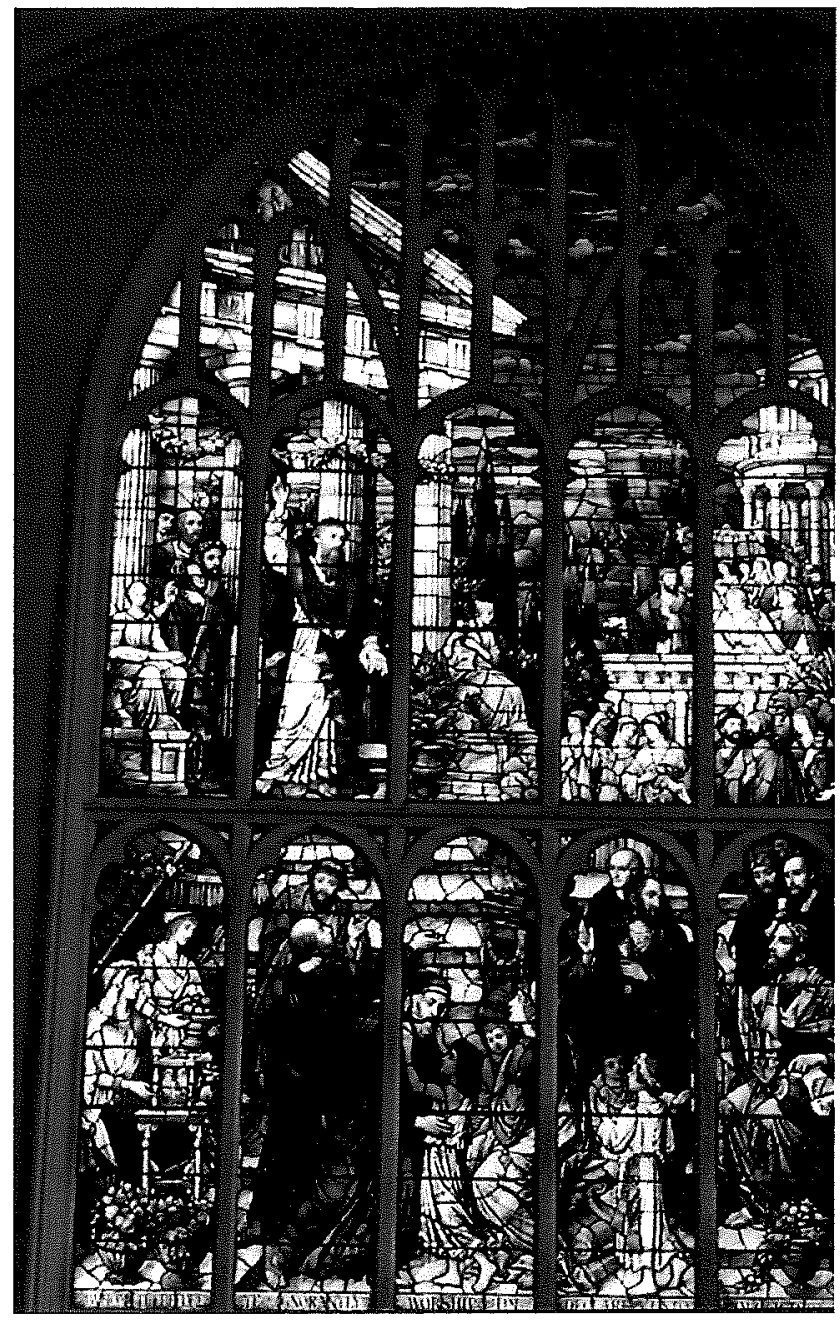

Figure 4.6

Saint Paul Preaching From Mars Hill in Athens. Saint Paul's Methodist Church, South Bend, IN, 1901-1903. (Courtesy Saint Paul's Methodist Church.) 


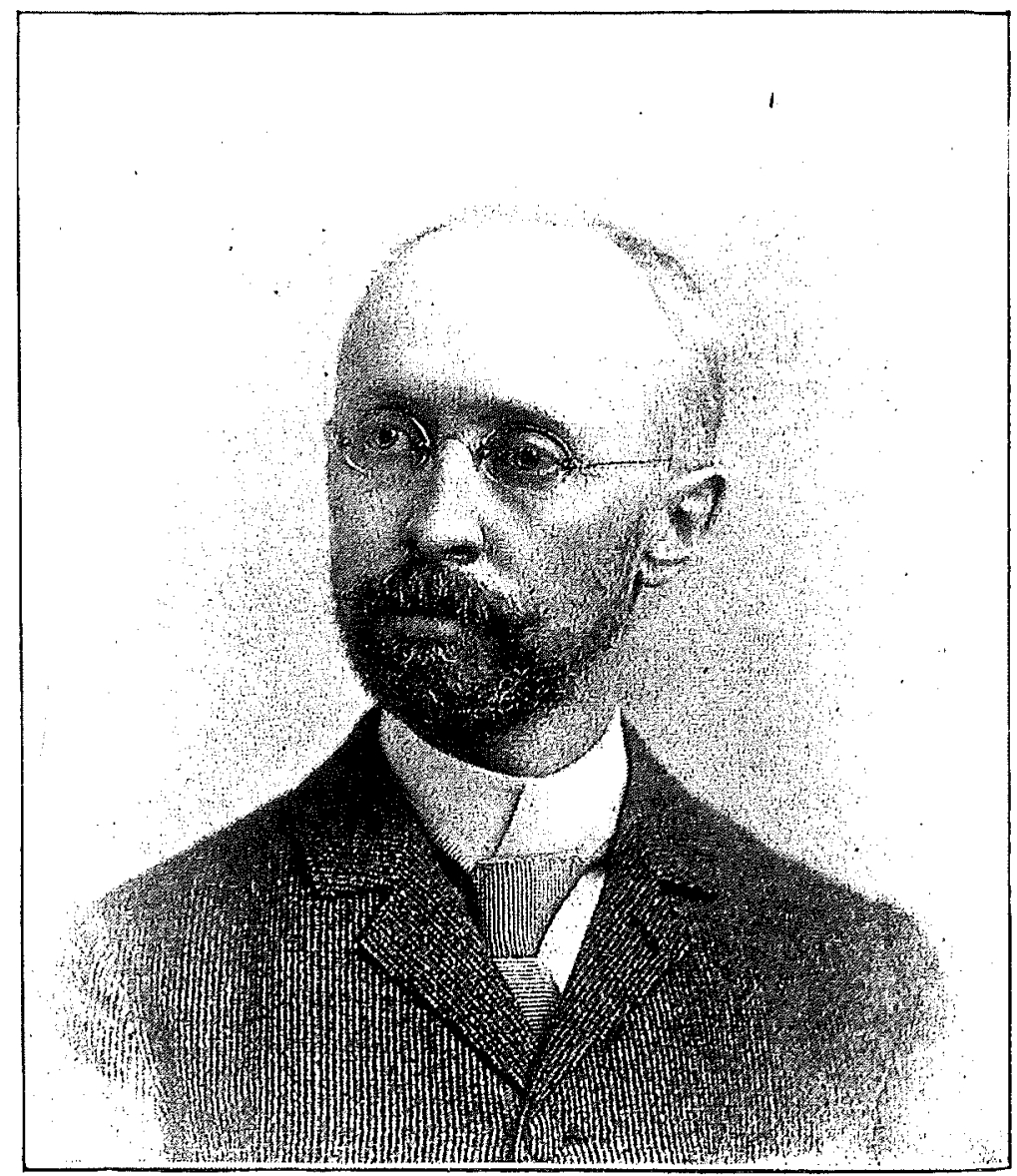

W. M. Day.

Figure 4.7

Wilson M. Day (1850-1929). ("The World's" History of Cleveland, Commemorating the City's Centennial Anniversary, 1896, n. pag.) 


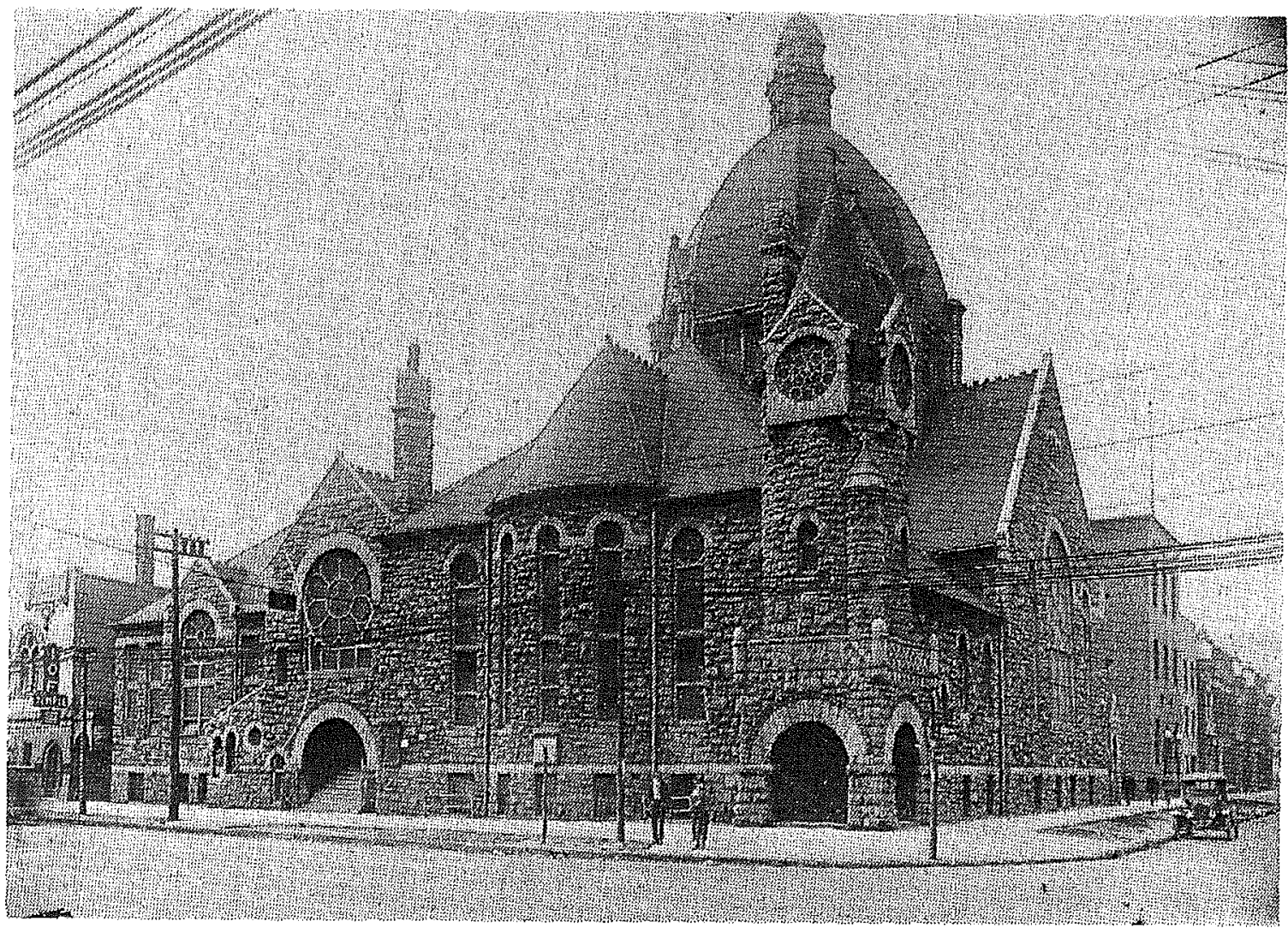

Figure 4.8

Sidney R. Badgley. Epworth Memorial Methodist Church, 1893. (Eric Johannesen. Cleveland Architecture, 1878-1976, 53.) 


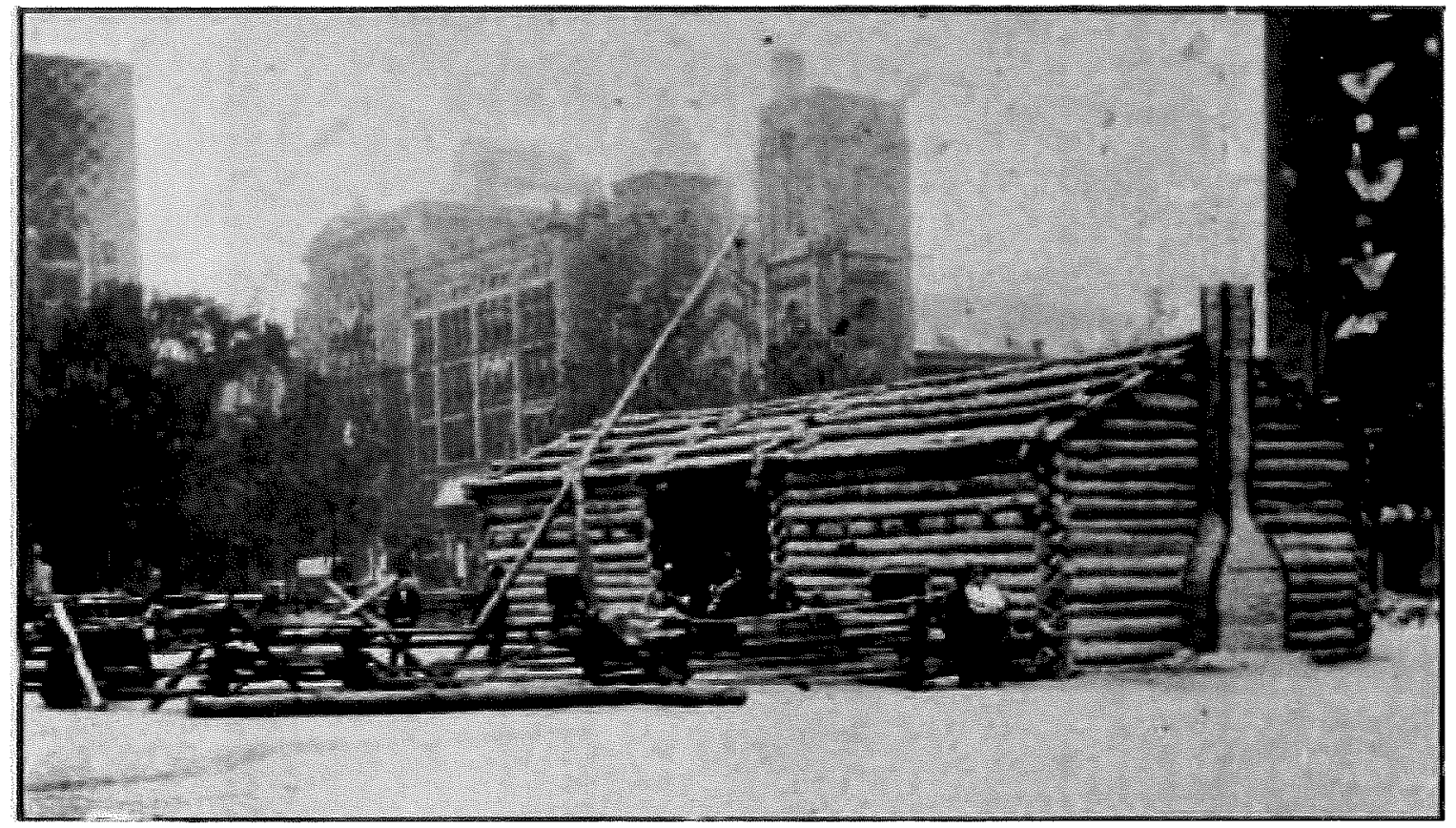

Figure 4.9

Cleveland Centennial Log Cabin, 1896. (Album of the Western Reserve Centennial.) 


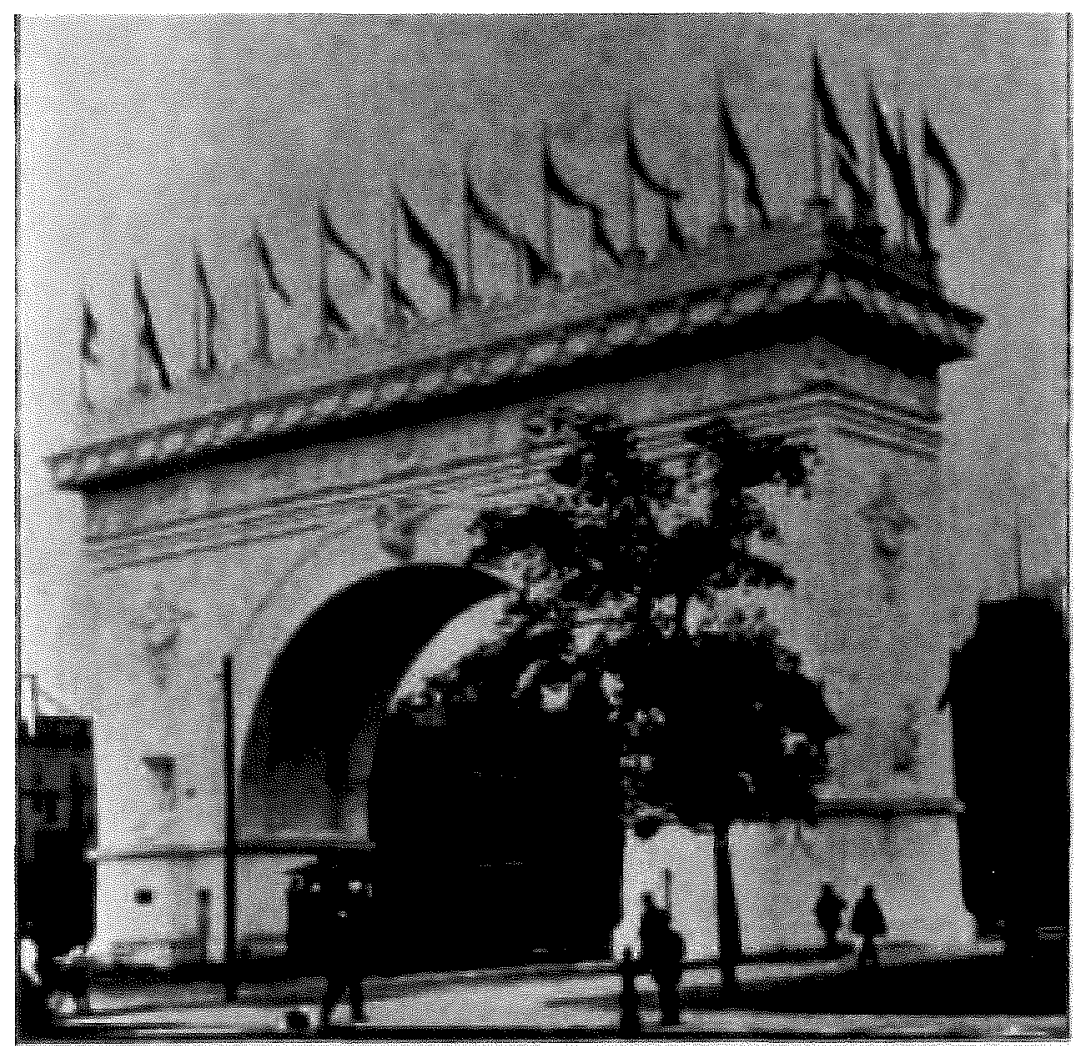

CENTENINIAL ARCH.

Figure 4.10

Cleveland Centennial Arch, 1896. (Album of the Western Reserve Centennial.) 


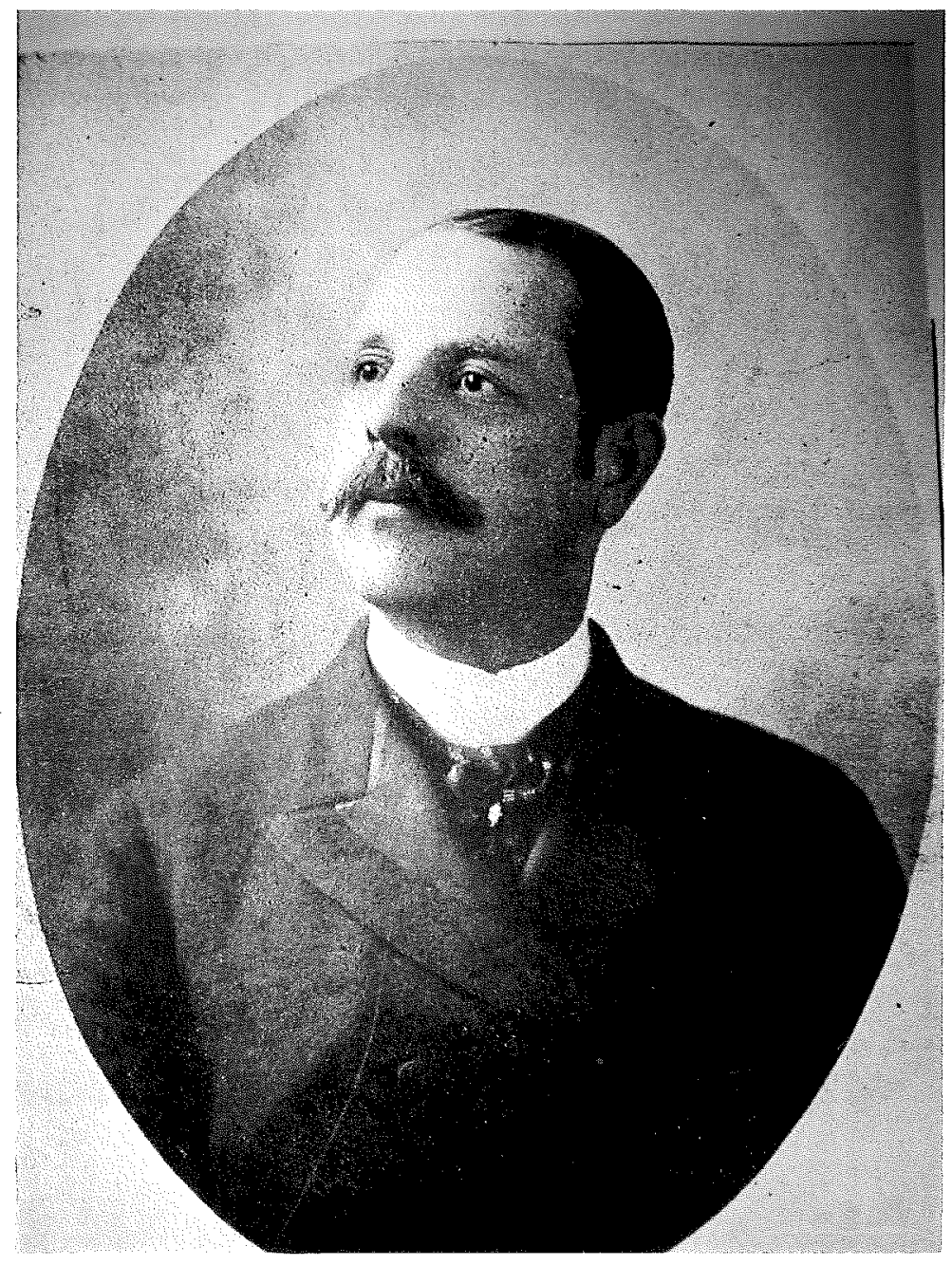

Figure 4.11

Frank Wayland Higgins (1856-1907). (Courtesy of Olean Historical and Preservation Society.) 


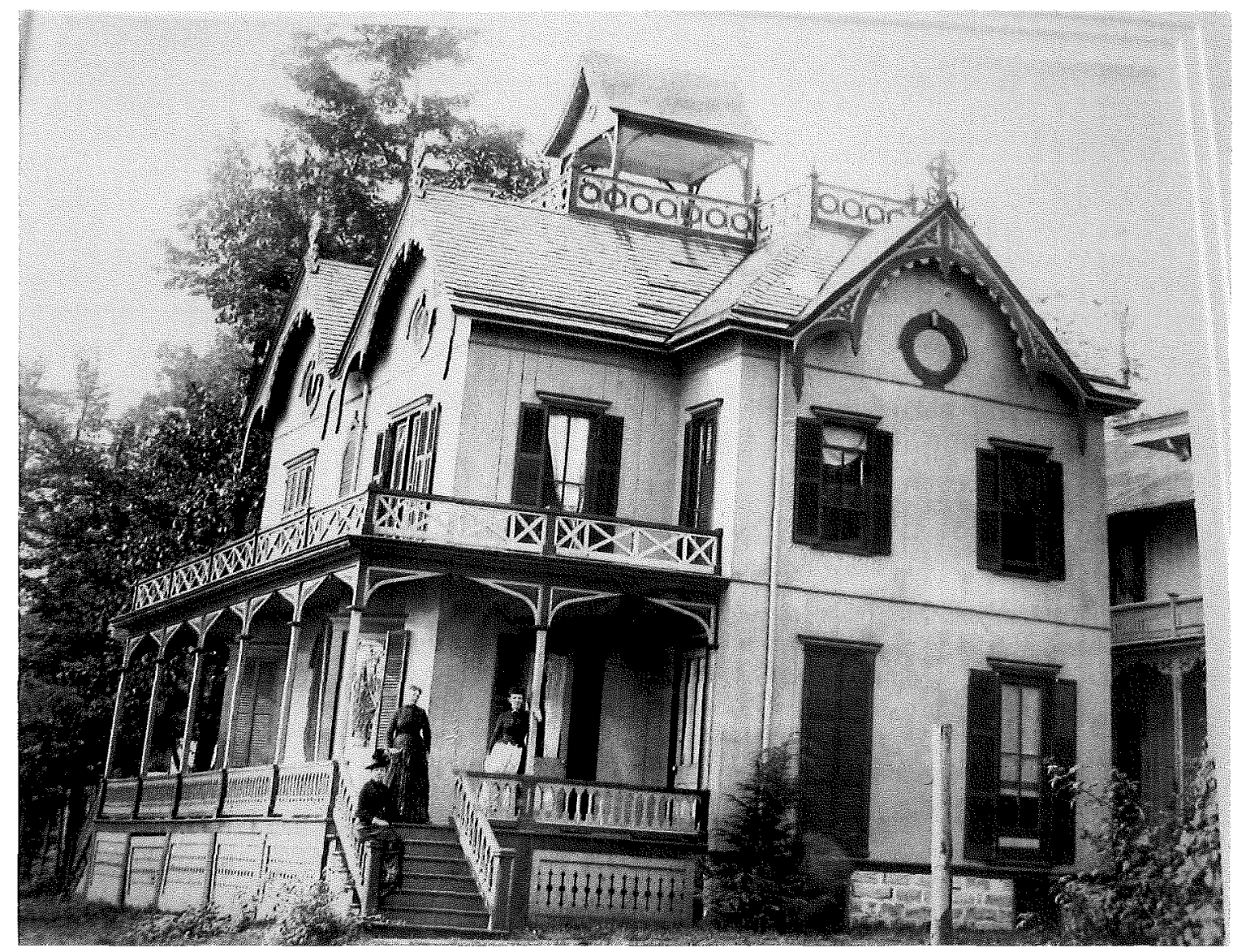

Figure 4.12

Higgins Cottage, 42 South Lake Drive, Chautauqua, NY. (Courtesy of Chautauqua Institution Archives.) 


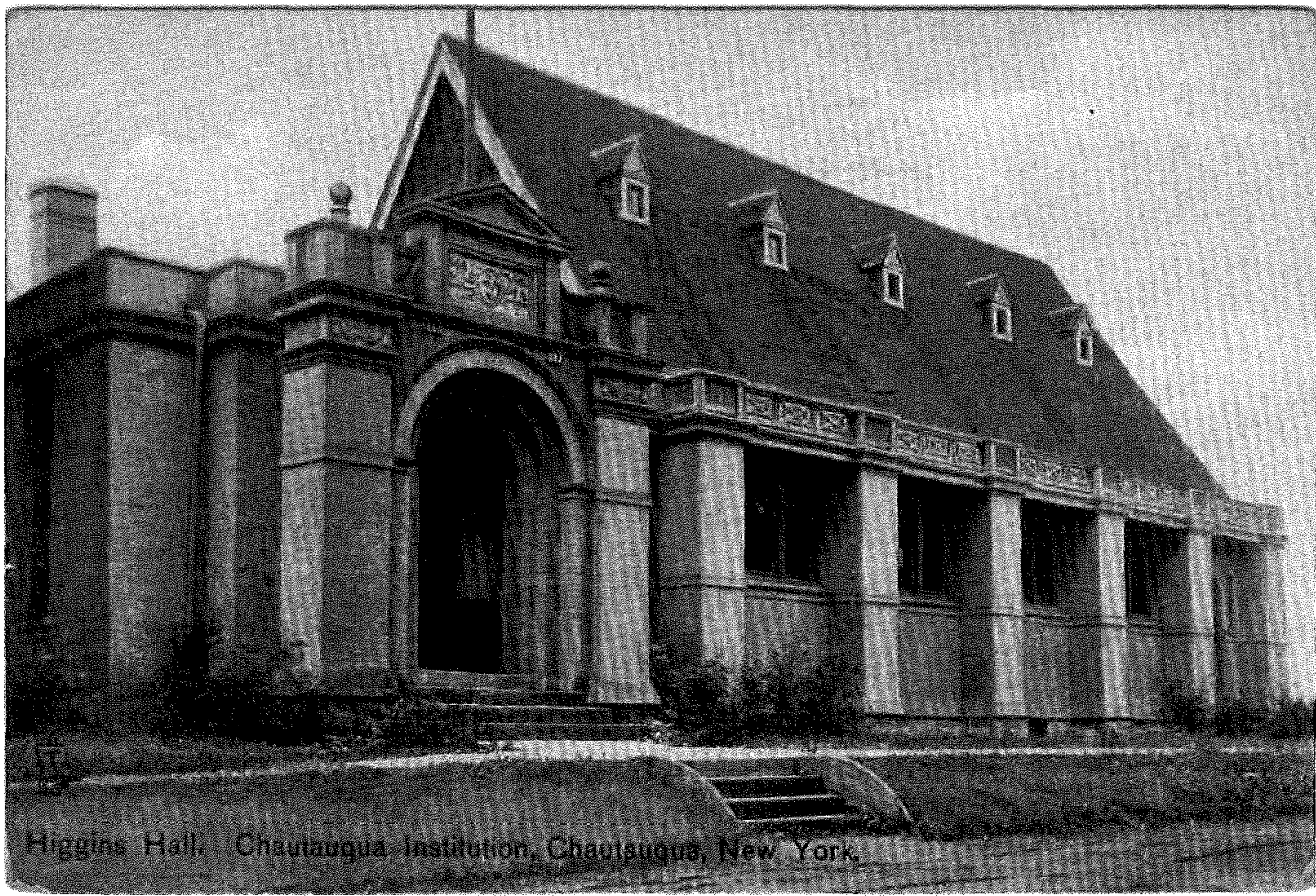

Figure 4.13

Higgins Hall, 1895, Chautauqua, NY., postcard. (Courtesy of Chautauqua Institution Archives.) 


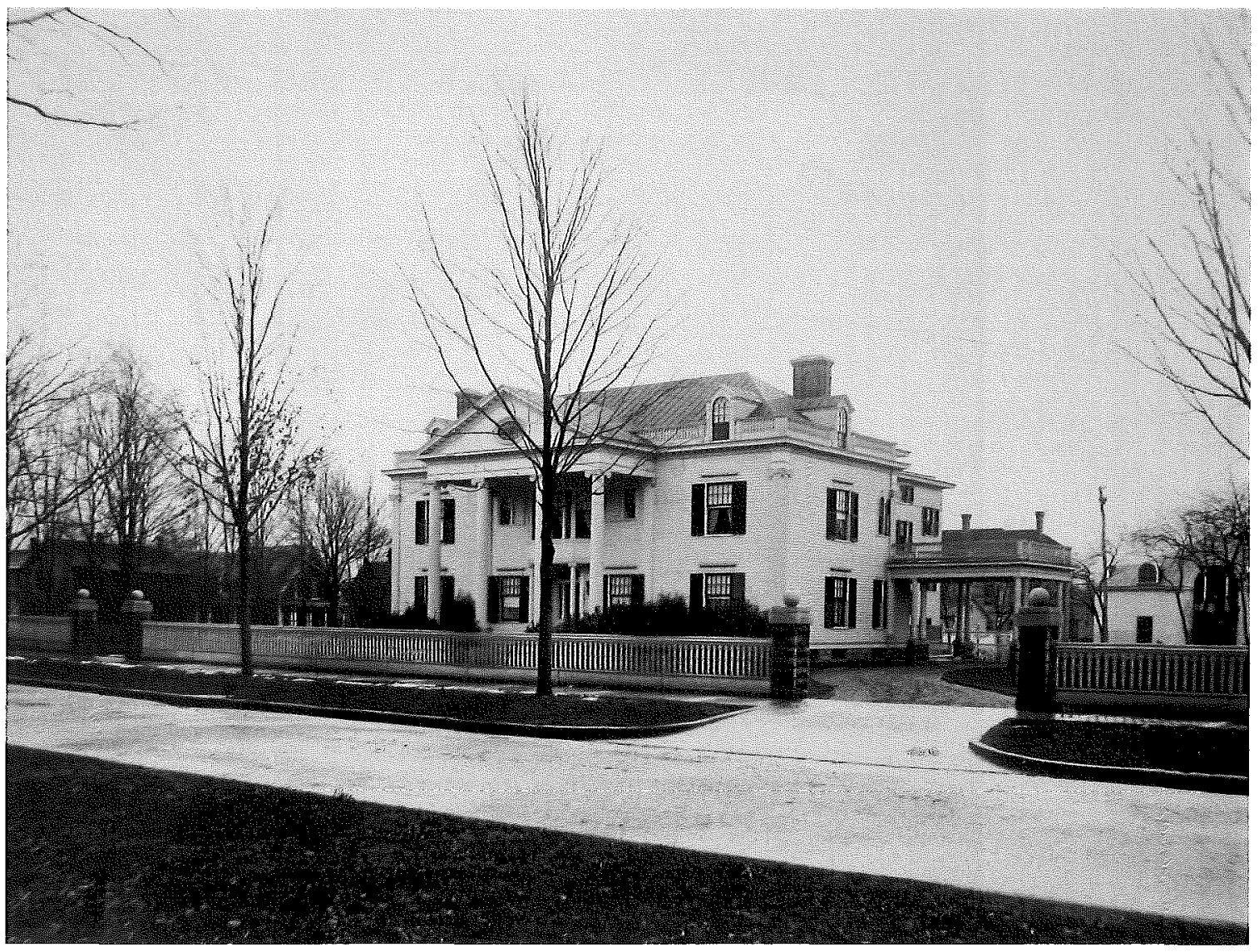

Figure 4.14

E. B. Green. Higgins Home, 1897, Olean, NY. (Courtesy of Olean Historical and Preservation Society.) 


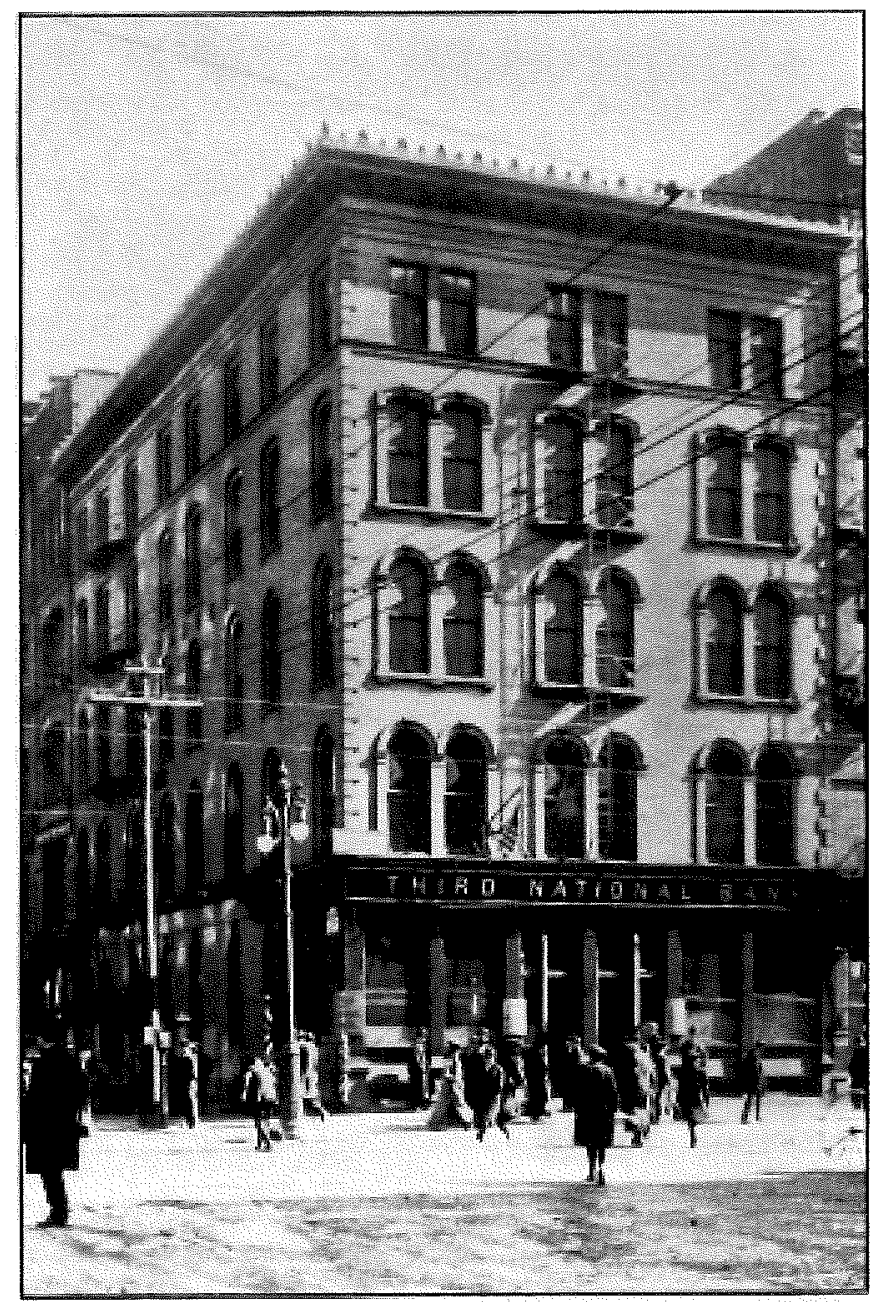

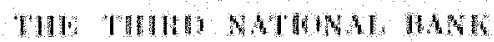

Figure 4.15

The Third National Bank, Buffalo, NY. (A History of the City of Buffalo, 63.) 


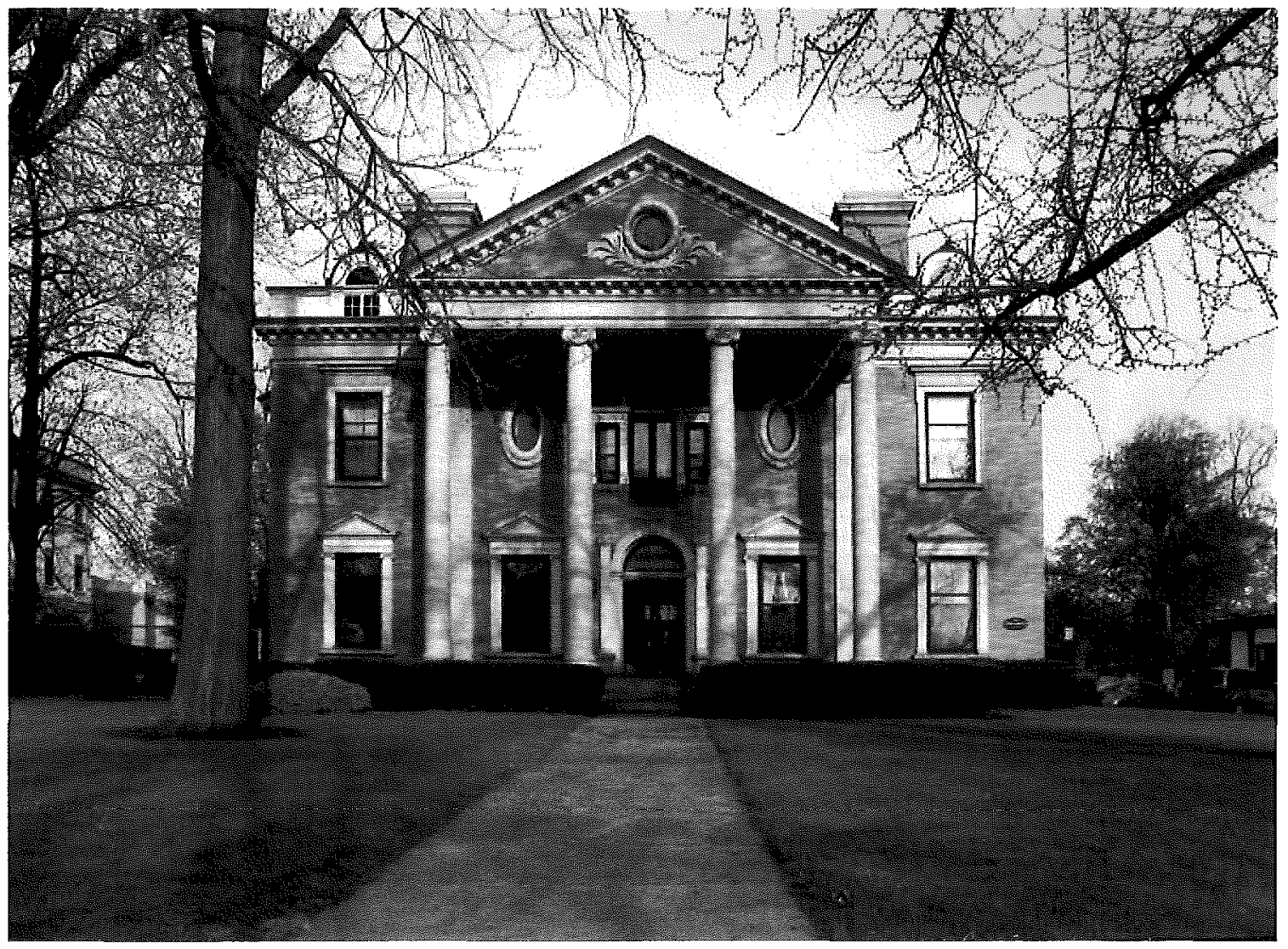

Figure 4.16

E. B. Green. George V. Forman House, 1895, 824 Delaware Ave., Buffalo, NY. (Buffalo as an Architectural Museum. Web.) 


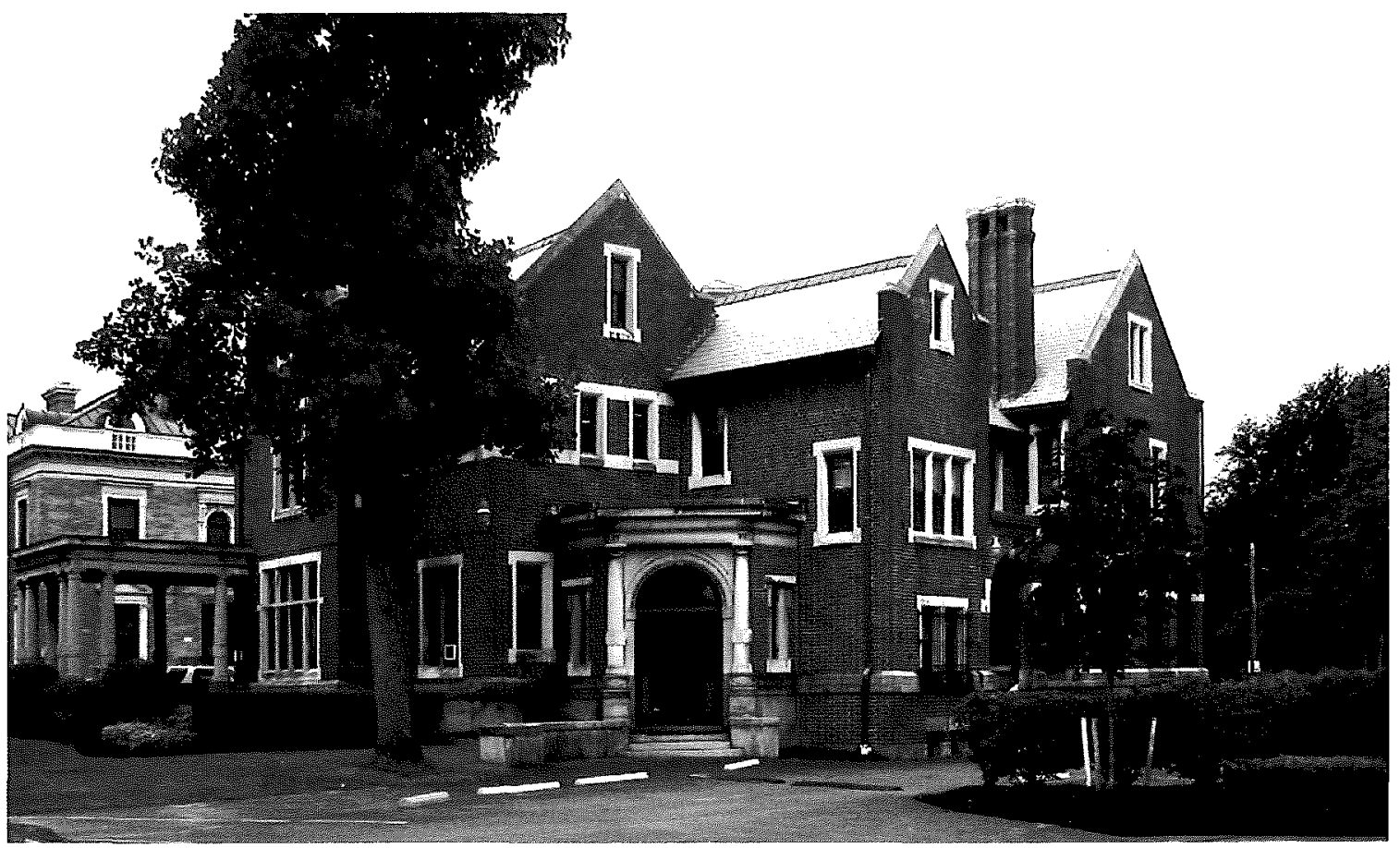

Figure 4.17

E. B. Green. George B. Matthews House, 1901, 830 Delaware Ave., Buffalo, NY.

(Buffalo as an Architectural Museum. Web.) 


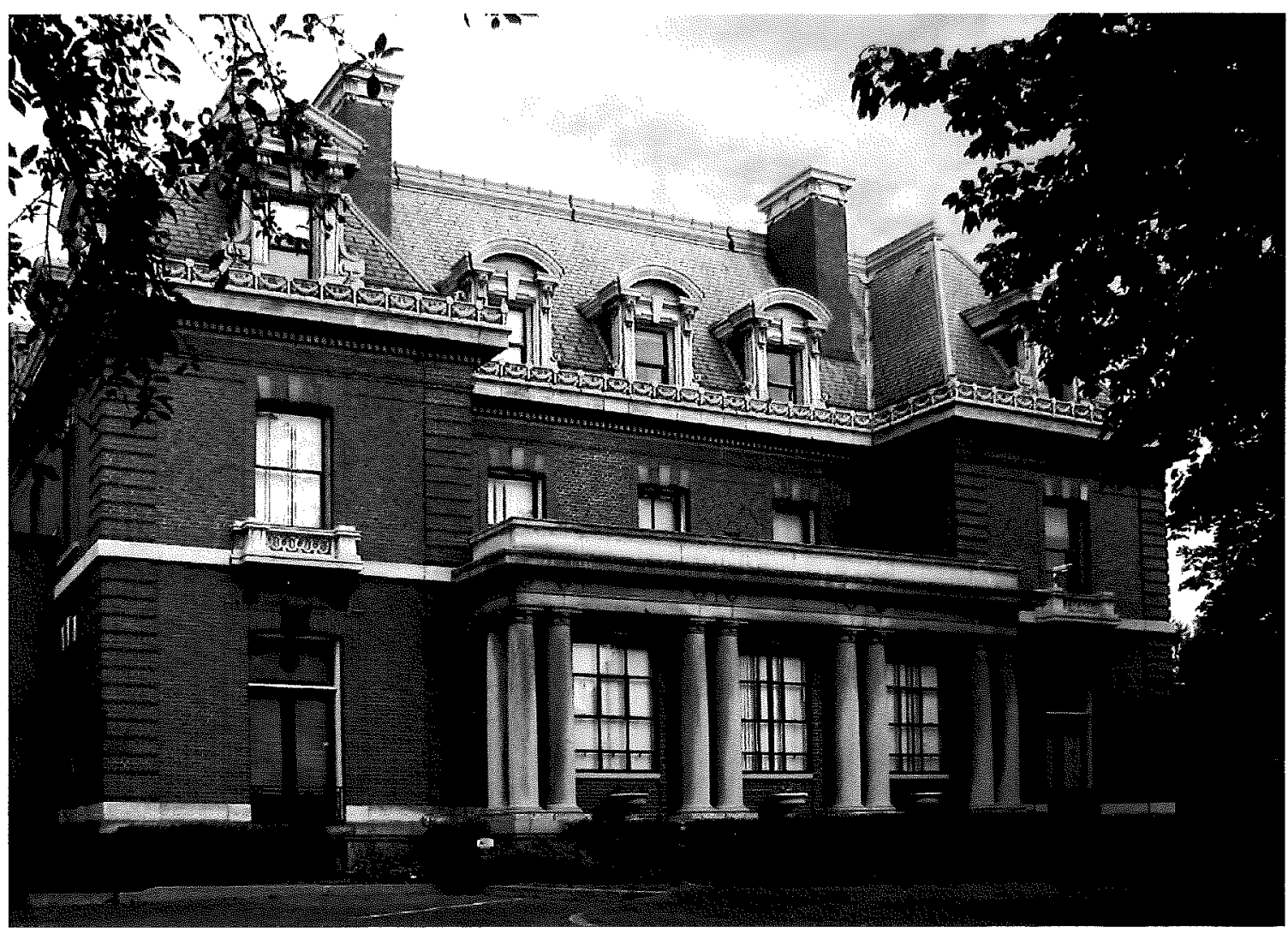

Figure 4.18

E. B. Green. Charles W. Goodyear House, 1902, 888 Delaware Ave., Buffalo, NY.

(Buffalo as an Architectural Museum. Web.) 


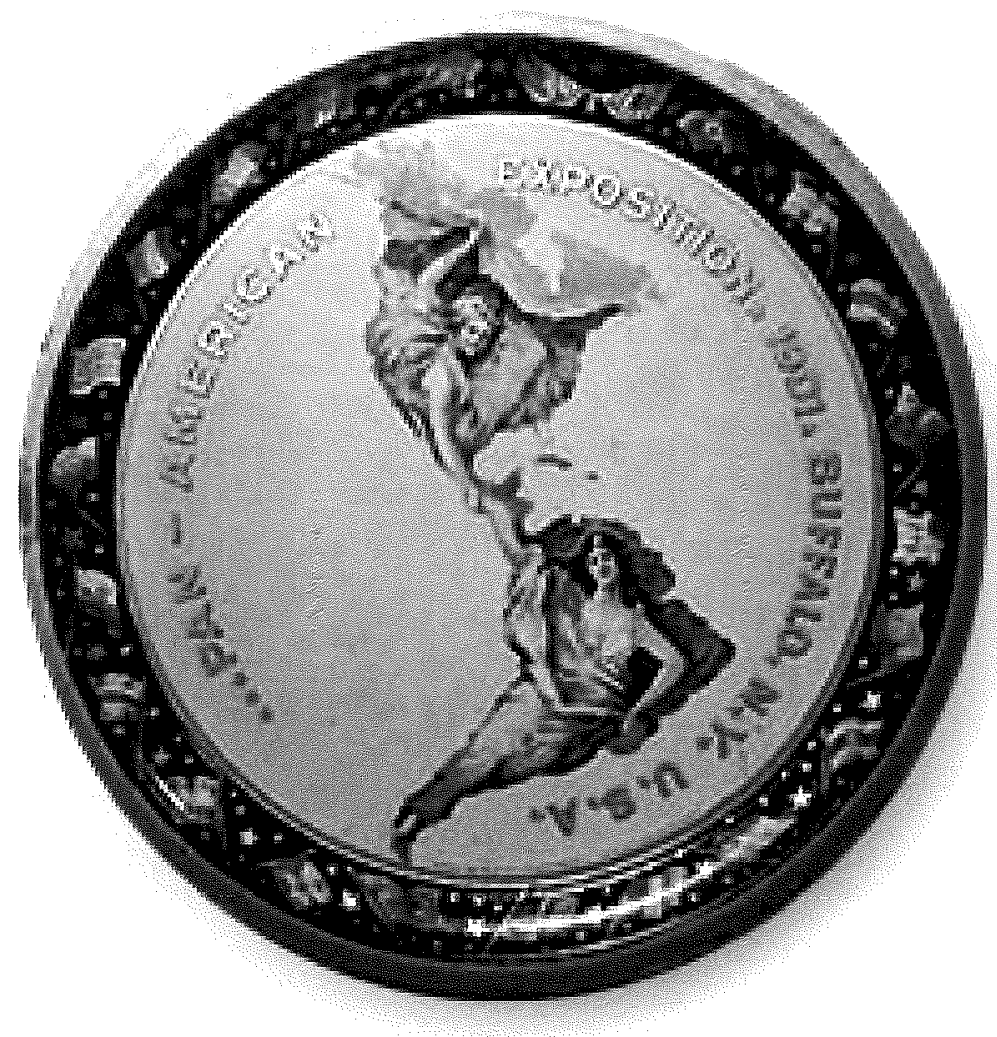

Figure 4.19

Raphael Beck. Great Seal of Pan-American Exposition, 1901. ("Doing the Pan..." PanAmerican Exposition Buffalo, 1901. Web.) 


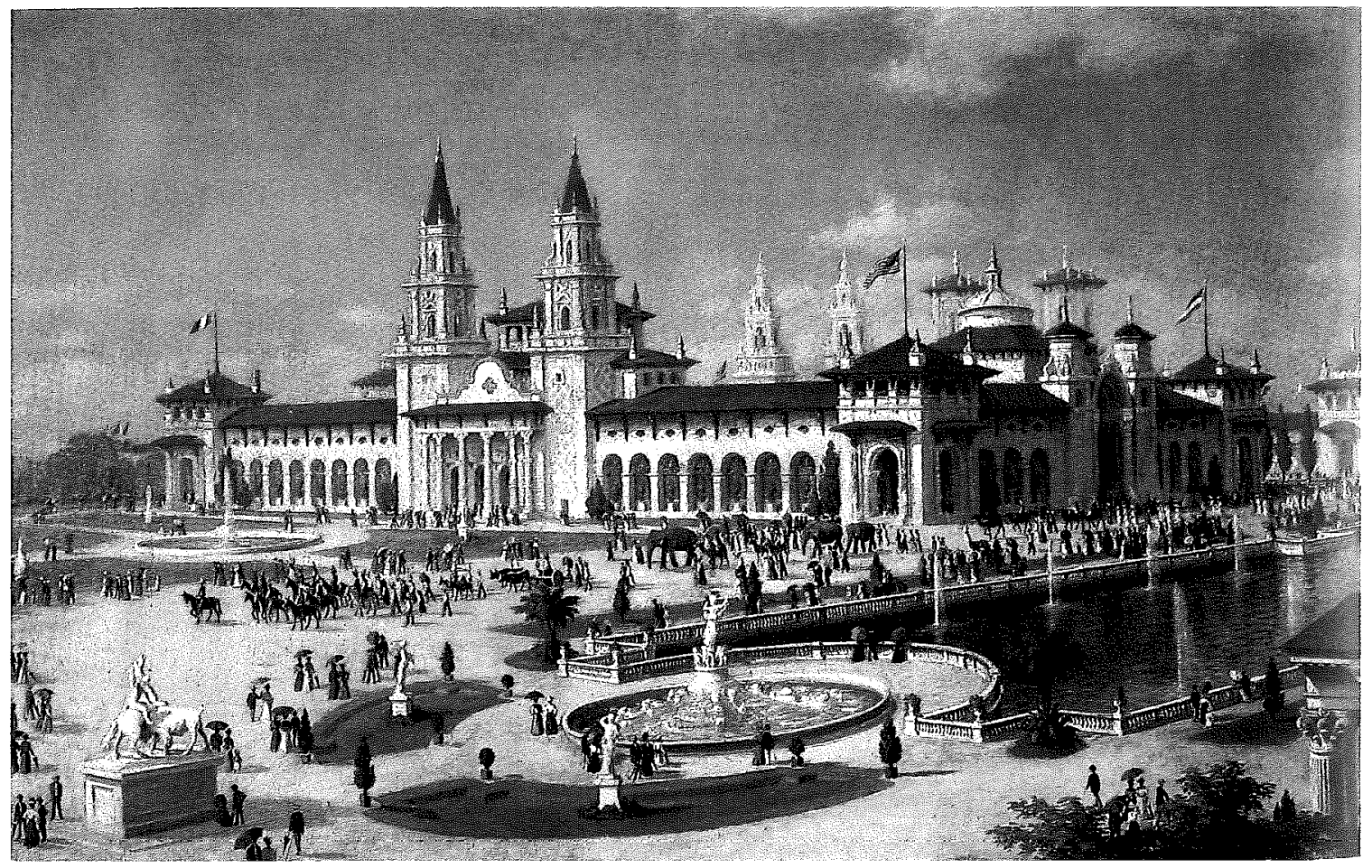

Figure 4.20

E. B. Green. Machinery and Transportation Building, Pan-American Exposition, Buffalo, 1901. (Kerry S. Grant. The Rainbow City, Celebrating Light, Color, and Architecture at the Pan-American Exposition, Buffalo, 1901, 57.) 


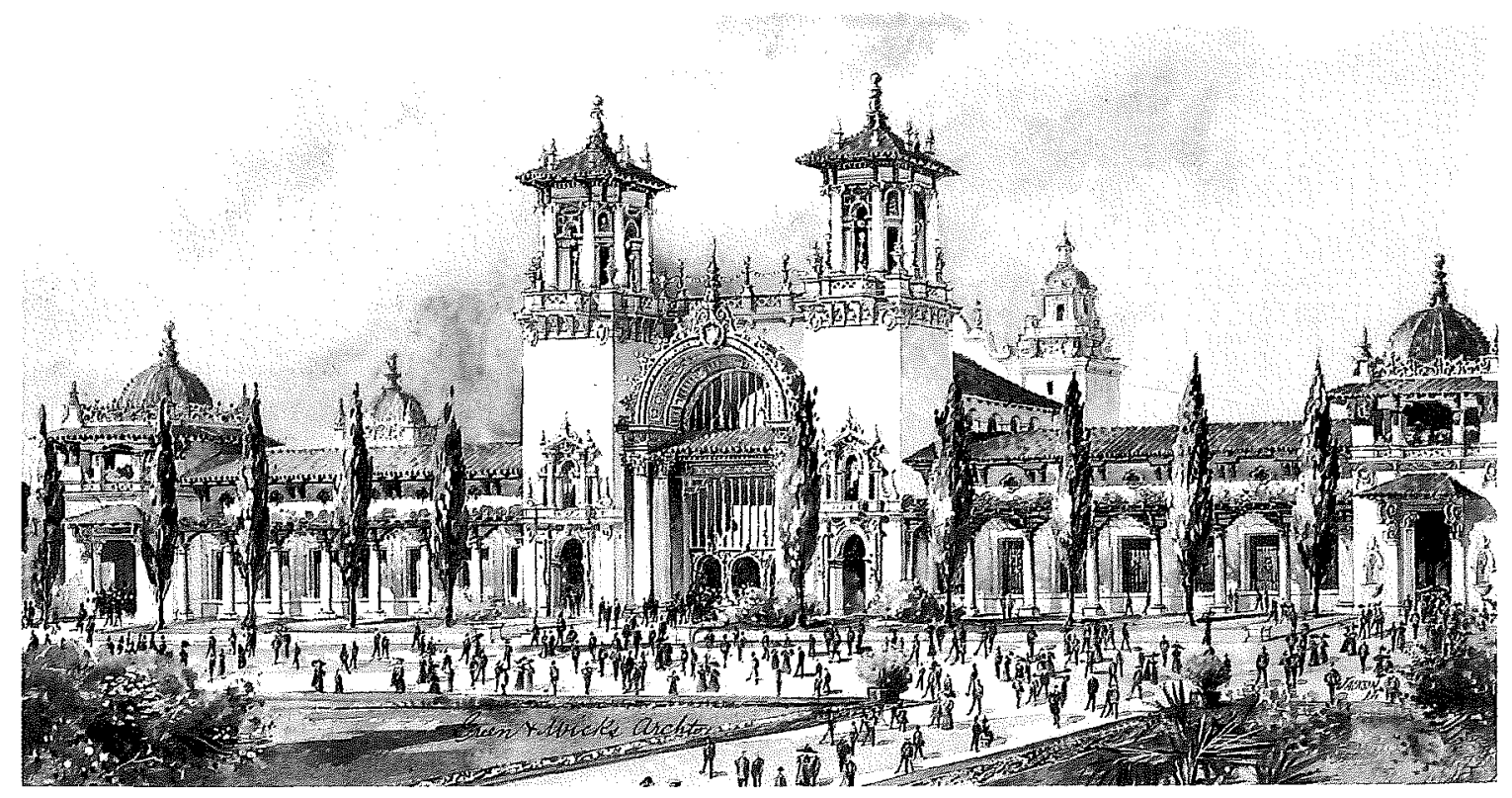

Figure 4.21

E. B. Green. Electricity Building, Pan-American Exposition, 1901. (Kerry S. Grant. The Rainbow City, Celebrating Light, Color, and Architecture at the Pan-American Exposition, Buffalo, 1901, 72.) 


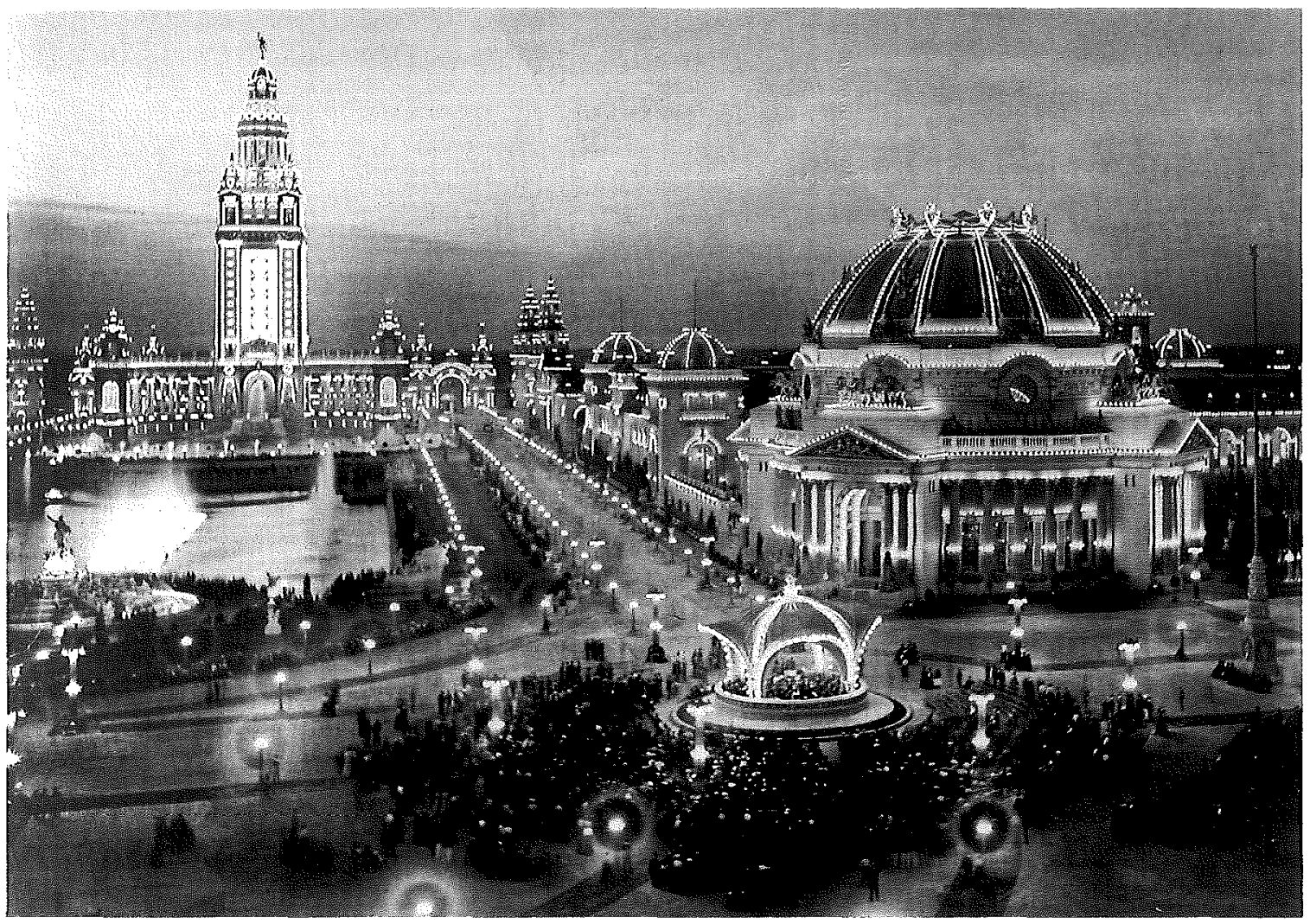

Figure 4.22

Pan-American Exposition at Night, 1901. John Galen Howard, Electric Tower, left; George Cary, Ethnology Building, right. (Kerry S. Grant. The Rainbow City, Celebrating Light, Color, and Architecture at the Pan-American Exposition, Buffalo, 1901, 111.) 


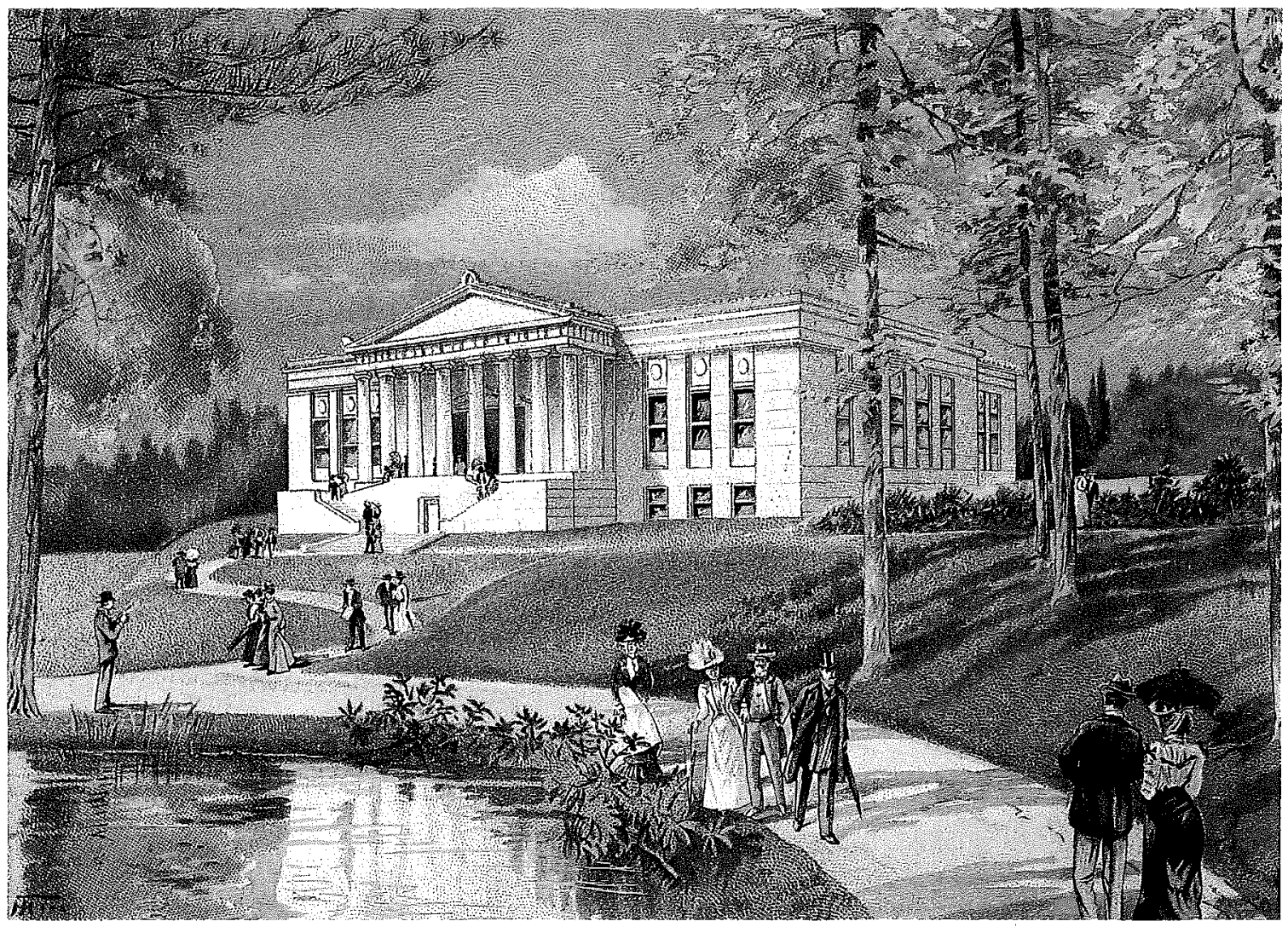

Figure 4.23

George Cary. New York State Building, Pan-American Exposition, 1901. (Kerry S. Grant. The Rainbow City, Celebrating Light, Color, and Architecture at the PanAmerican Exposition, Buffalo, 1901, 22.) 


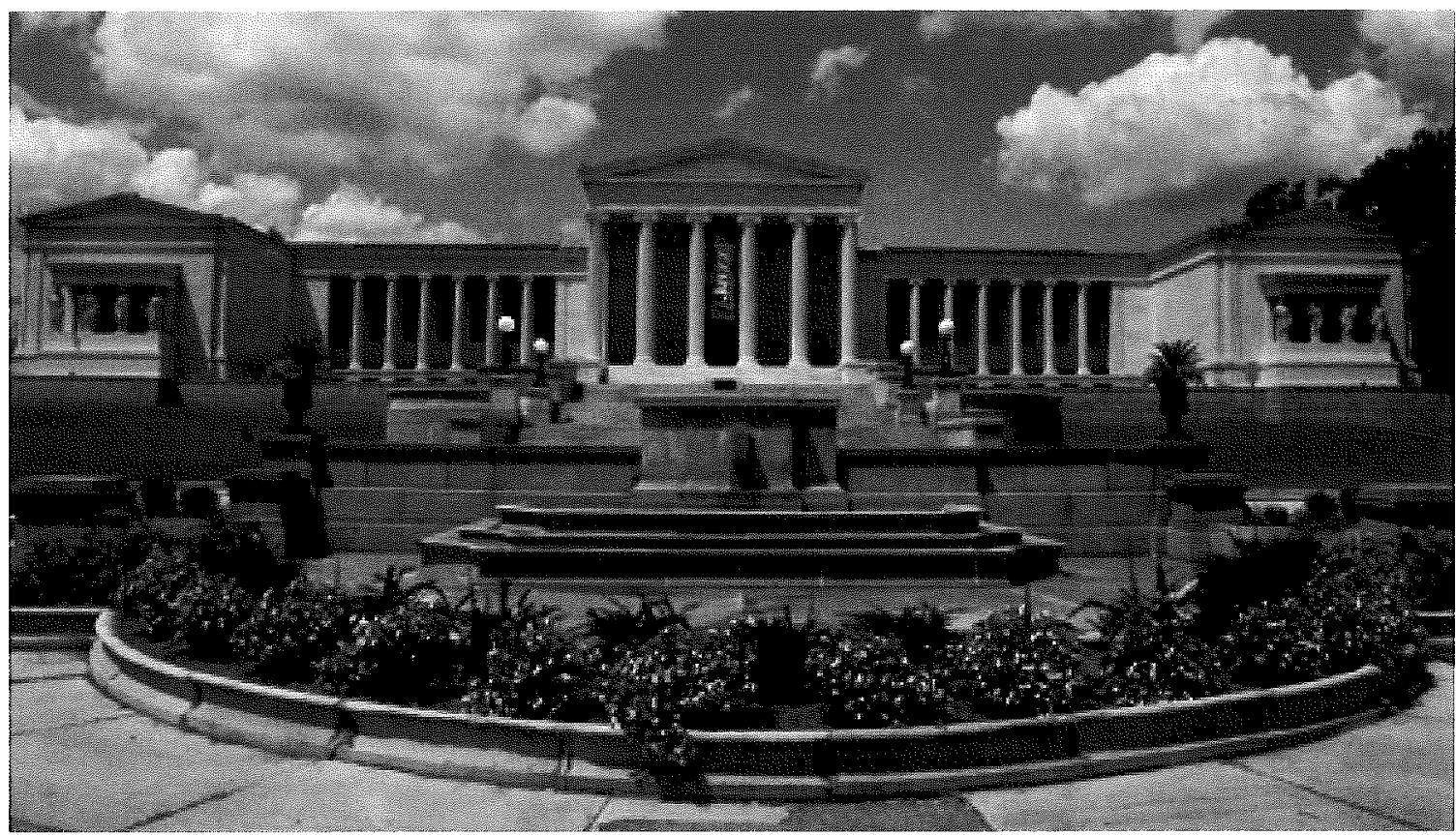

Figure 4.24

E. B. Green. Albright Art Gallery, 1902, Buffalo, NY. (Albright Knox Art Gallery. Web.) 


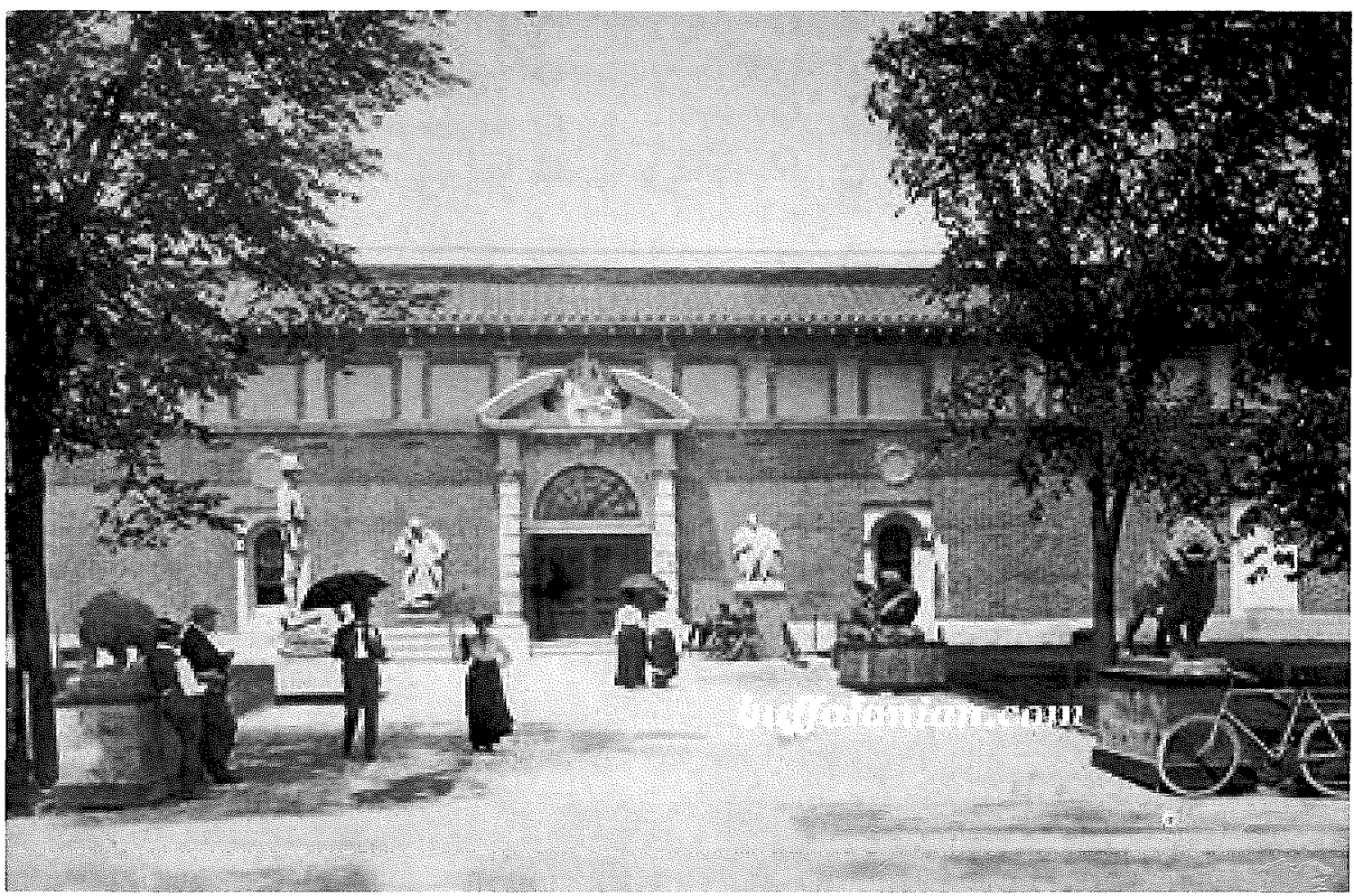

Figure 4.25

E. B. Green. Art Building, 1901, Pan-American Exposition, Buffalo, NY. (The Buffalonian. Web.) 


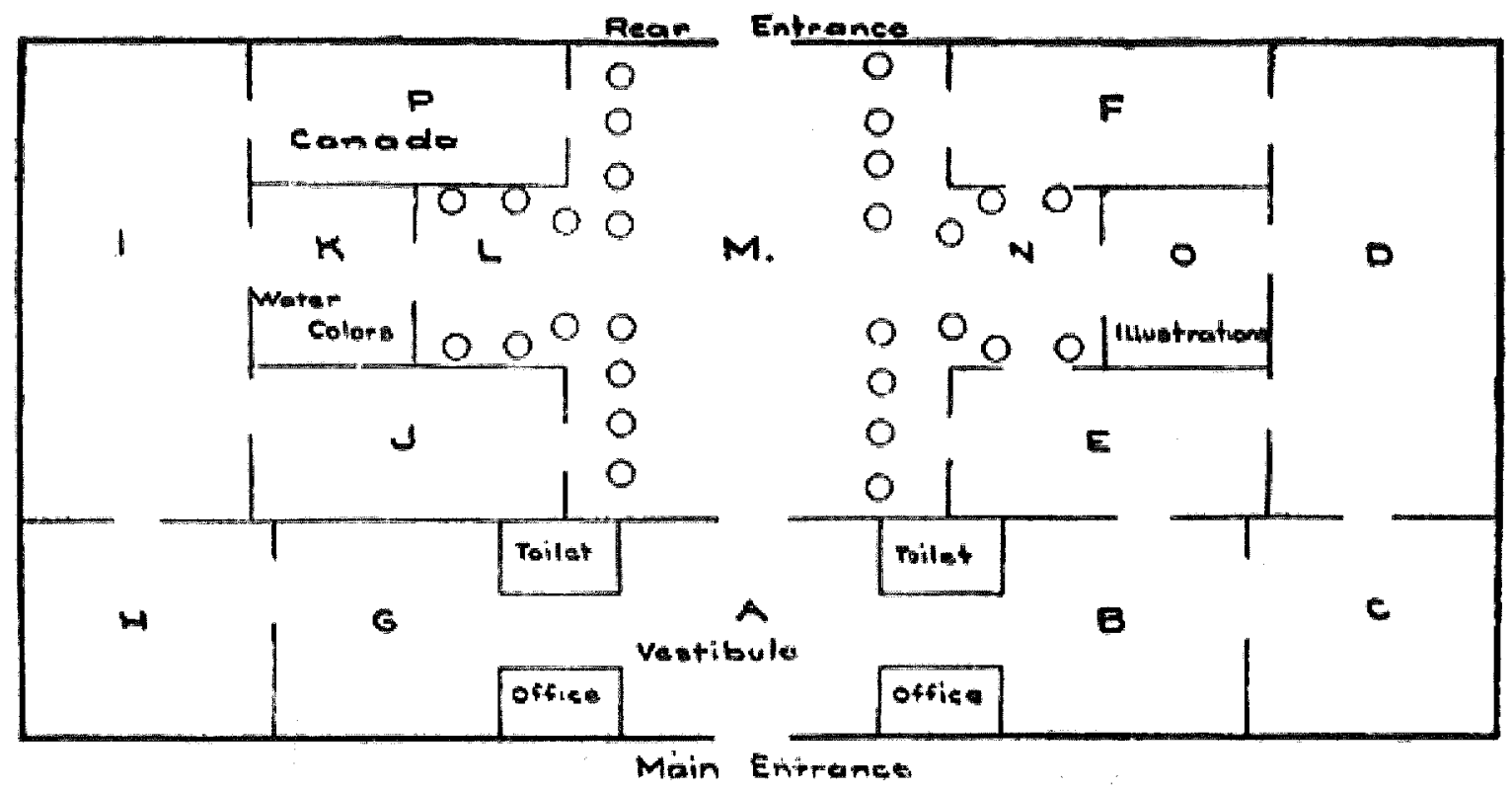

Figure 4.26

E. B. Green. Art Building Plan, 1901, Pan-American Exposition, Buffalo, NY. ("Doing the Pan..." Pan-American Exposition Buffalo, 1901. Web.) 


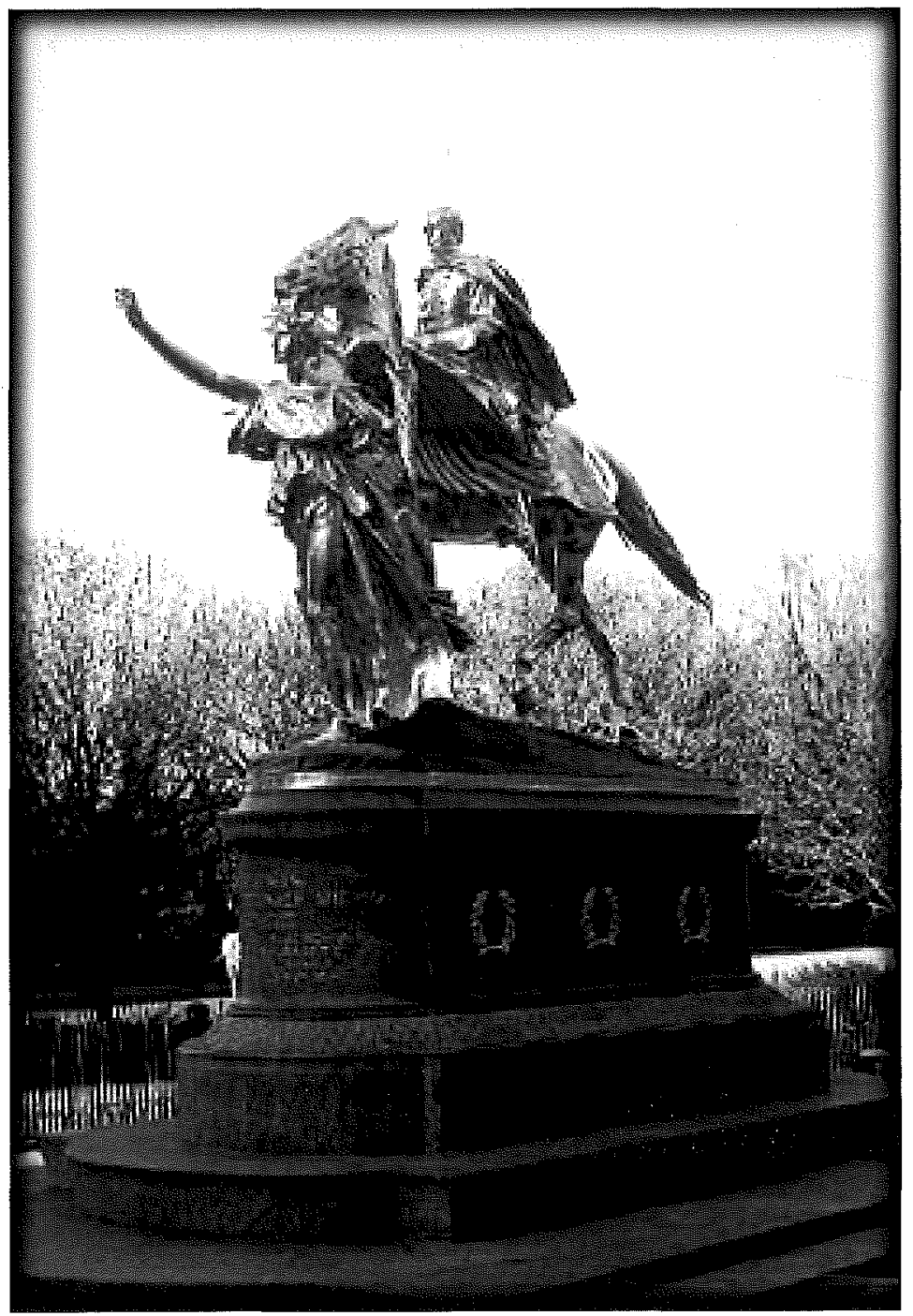

Figure 4.27

Augustus Saint-Gaudens. William Tecumseh Sherman. (New York City Department of Parks \& Recreation. Web.) 


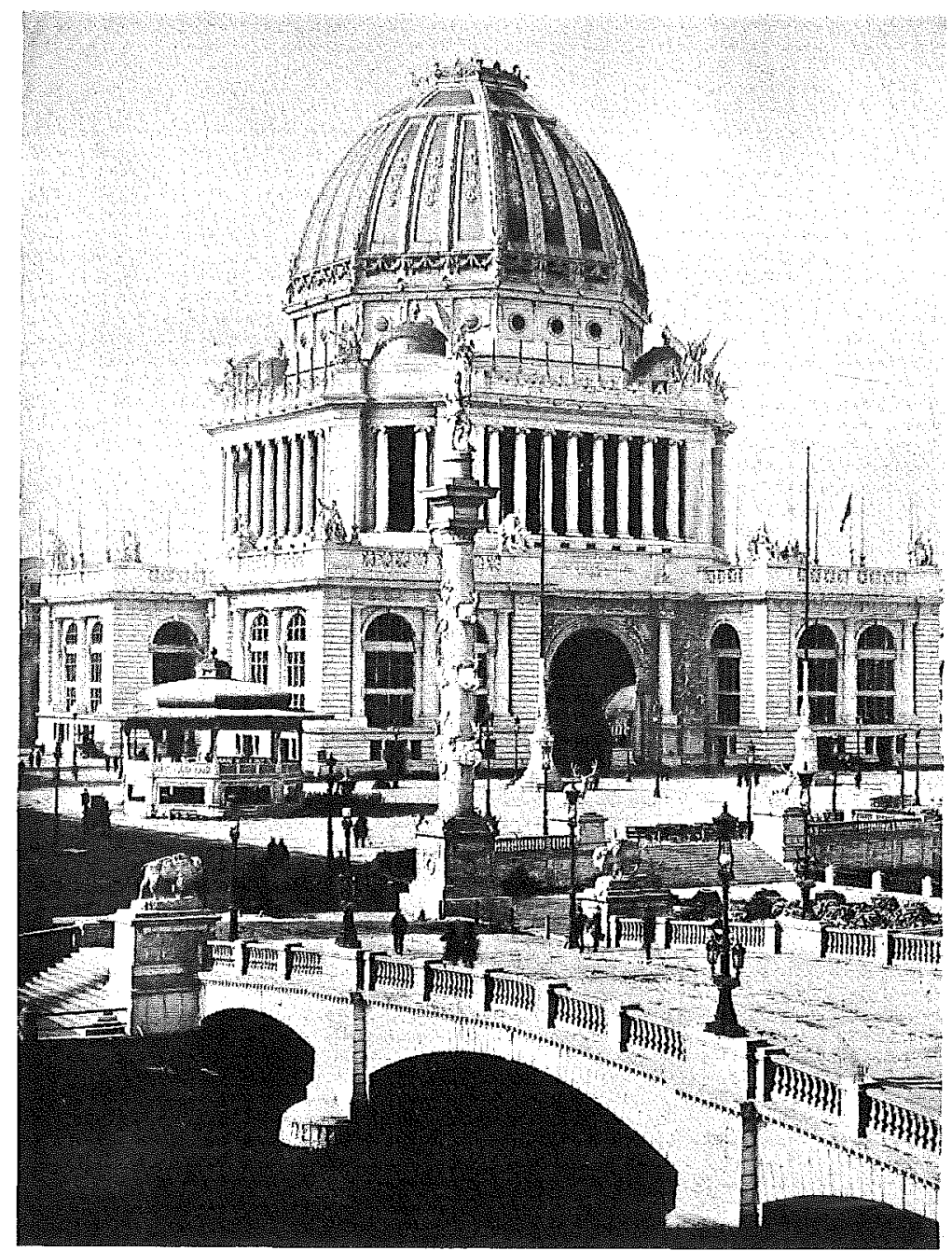

Figure 4.28

Richard Morris Hunt, Karl Bitter. Administration Building, World's Columbian Exposition, 1893, Chicago, IL. (James M. Dennis. Karl Bitter, Architectural Sculptor, 1867-1915, 43.) 


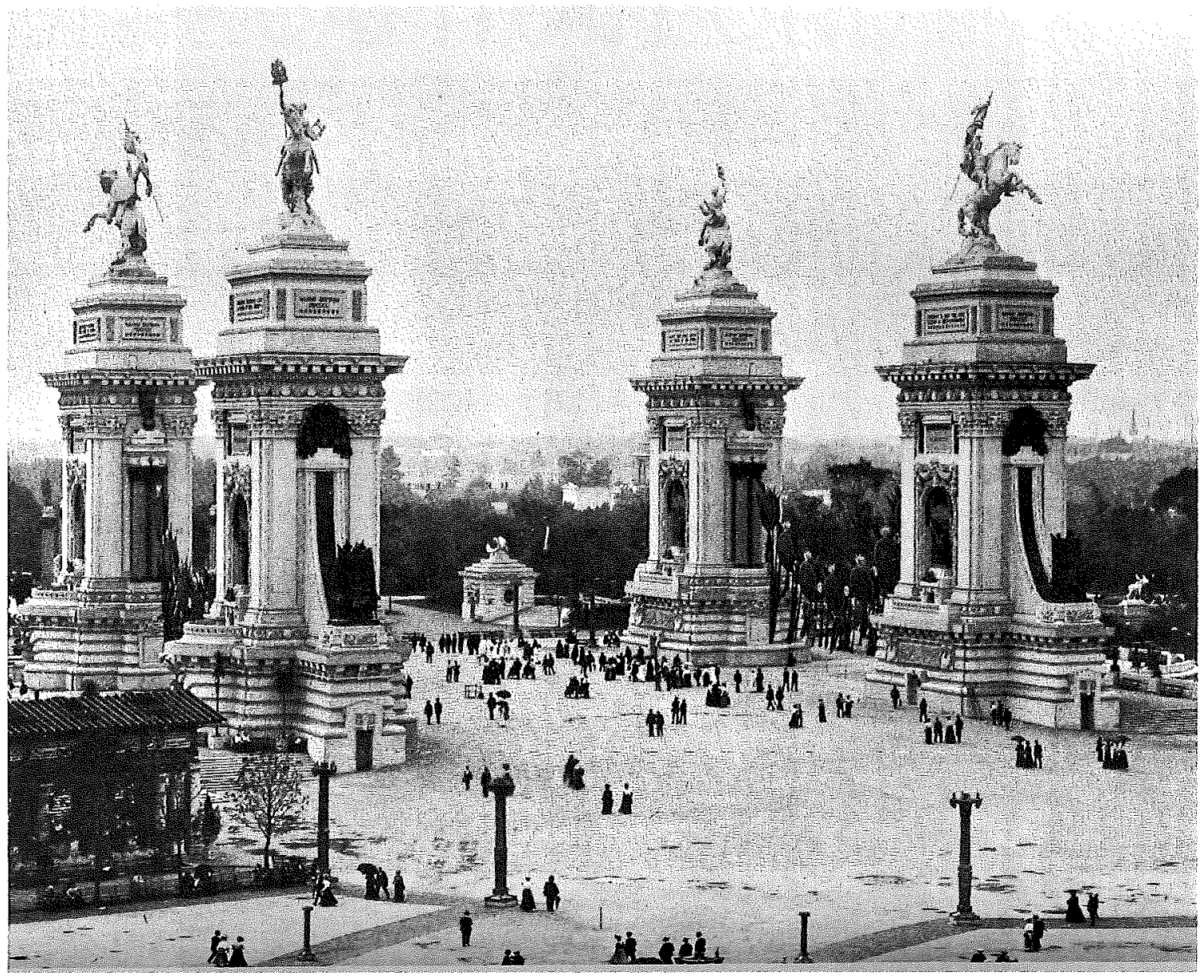

Figure 4.29

John M. Carrère, Karl Bitter. Triumphal Causeway. (James M. Dennis. Karl Bitter, Architectural Sculptor, 1867-1915, 108.) 


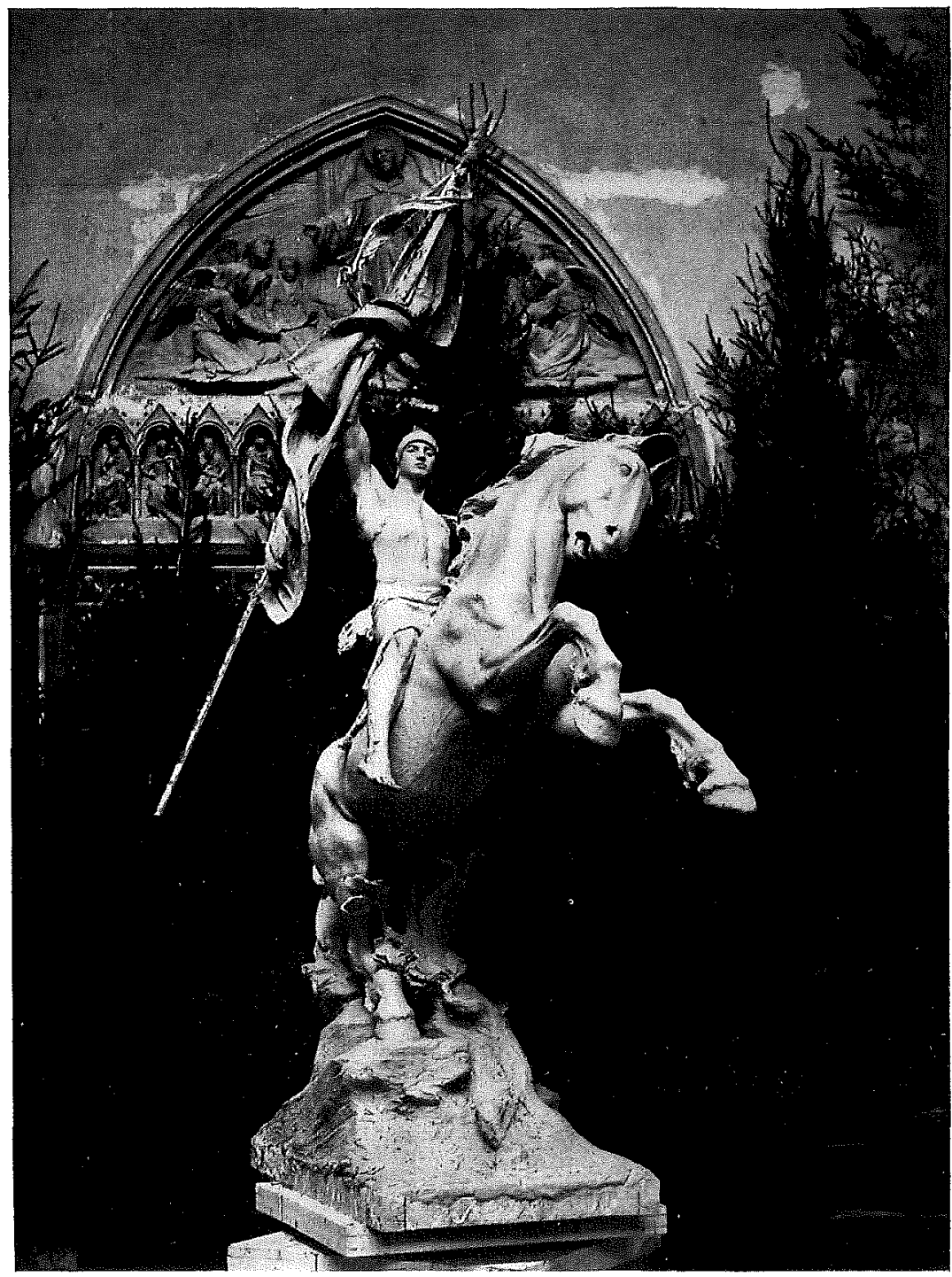

Figure 4.30

Karl Bitter. Standard Bearer: Power, Pan-American Exposition, 1901. (Ferdinand Schevill. Karl Bitter: A Biography. Pic. 11.) 


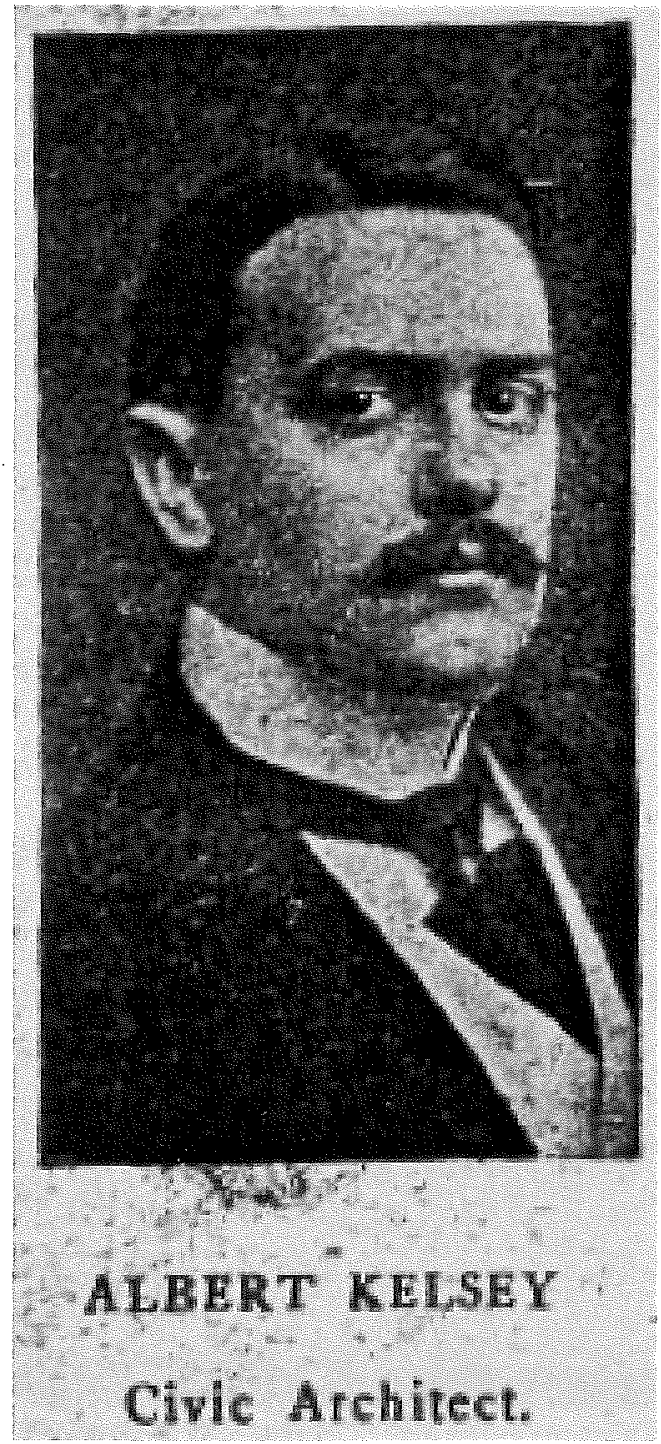

Figure 5.1

Albert Kelsey. (Courtesy of Chautauqua Institution Archives.) 


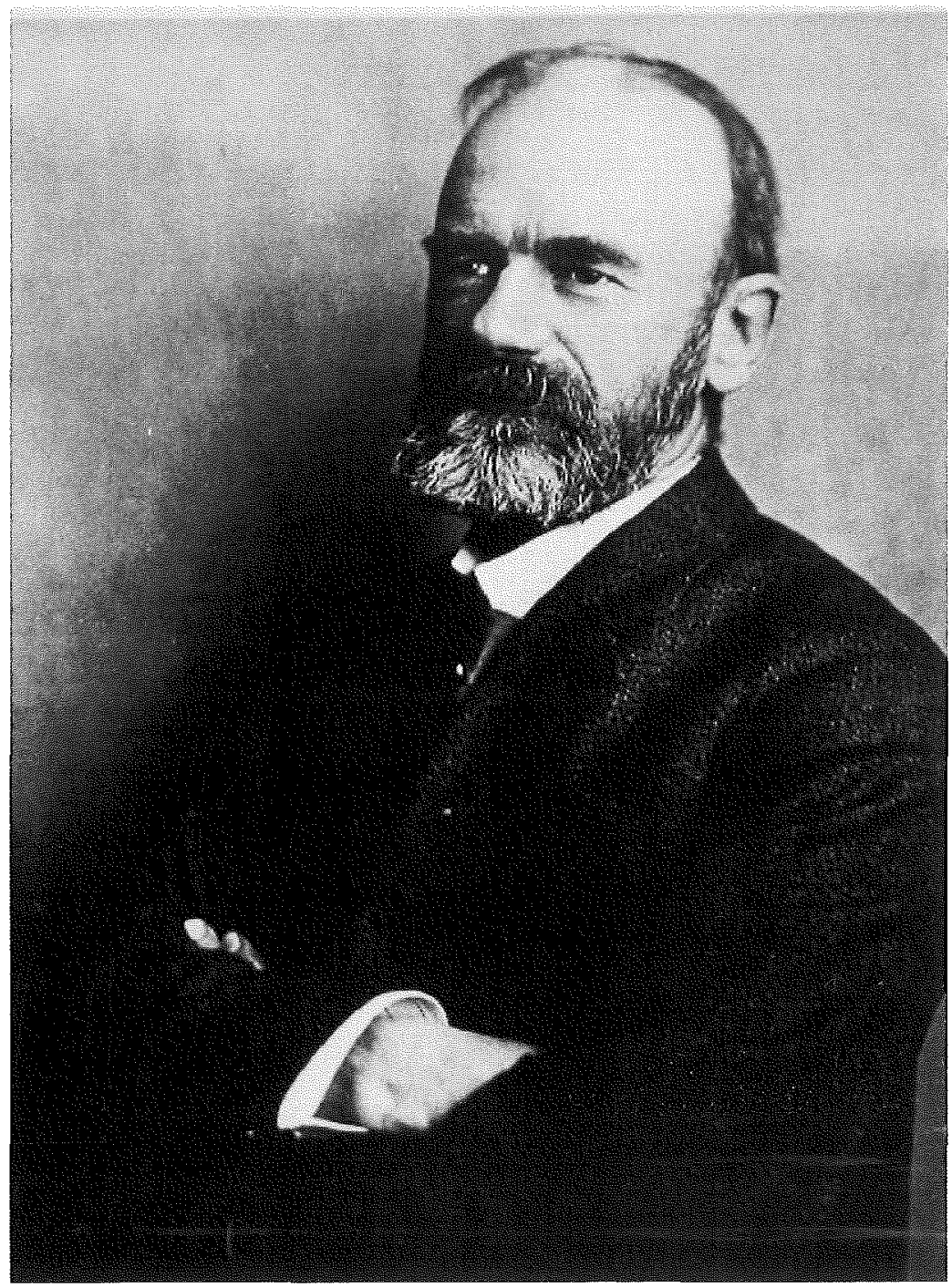

Figure 5.2

Warren H. Manning. (Robin Karson. The Muses of Gwinn: Art and Nature in a Garden Designed by Warren H. Manning, Charles A Platt, \& Ellen Biddle Shipman, 22.) 


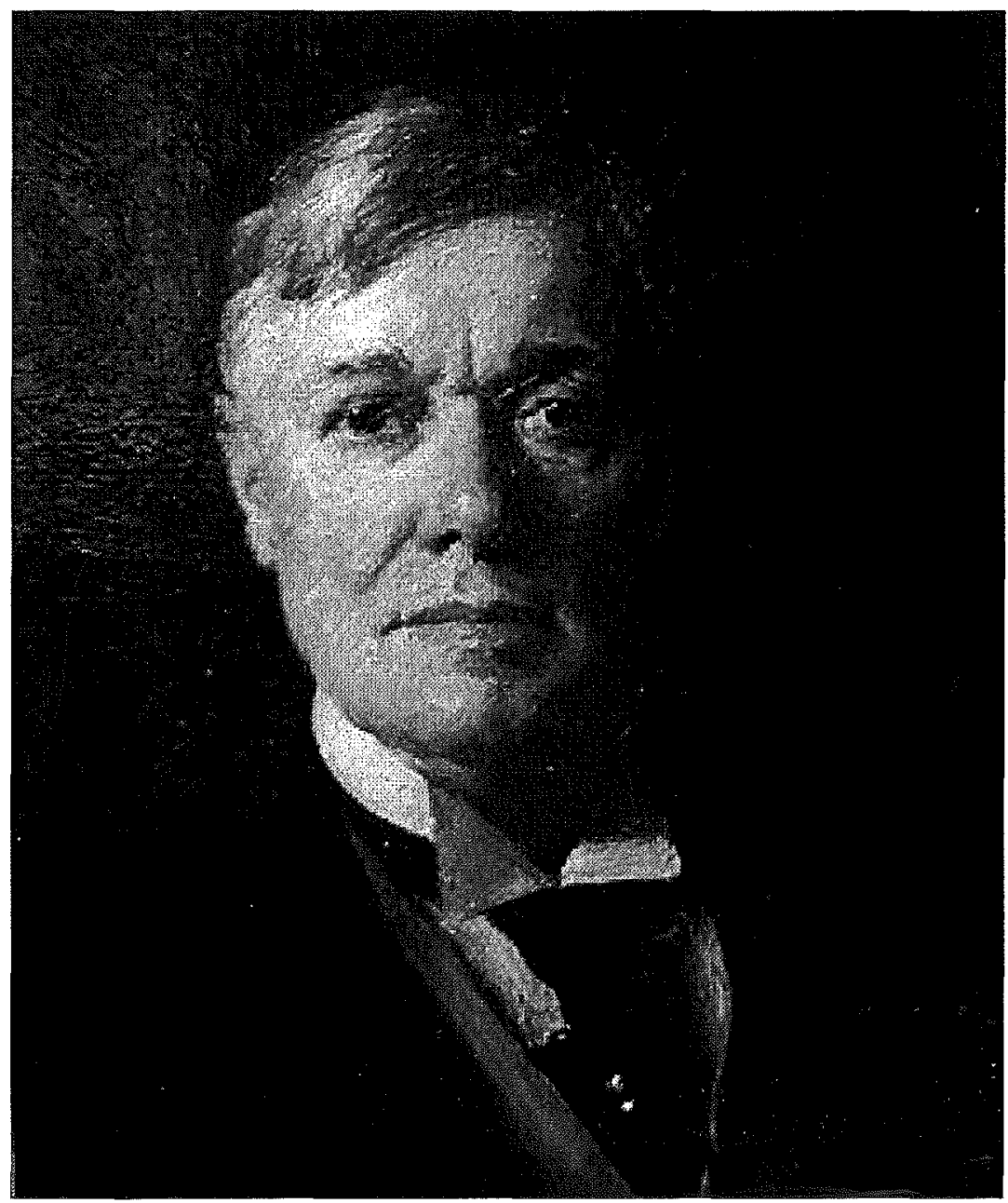

Figure 5.3

J. Massey Rhind (1860-1932). (Go Antiques. Web.) 


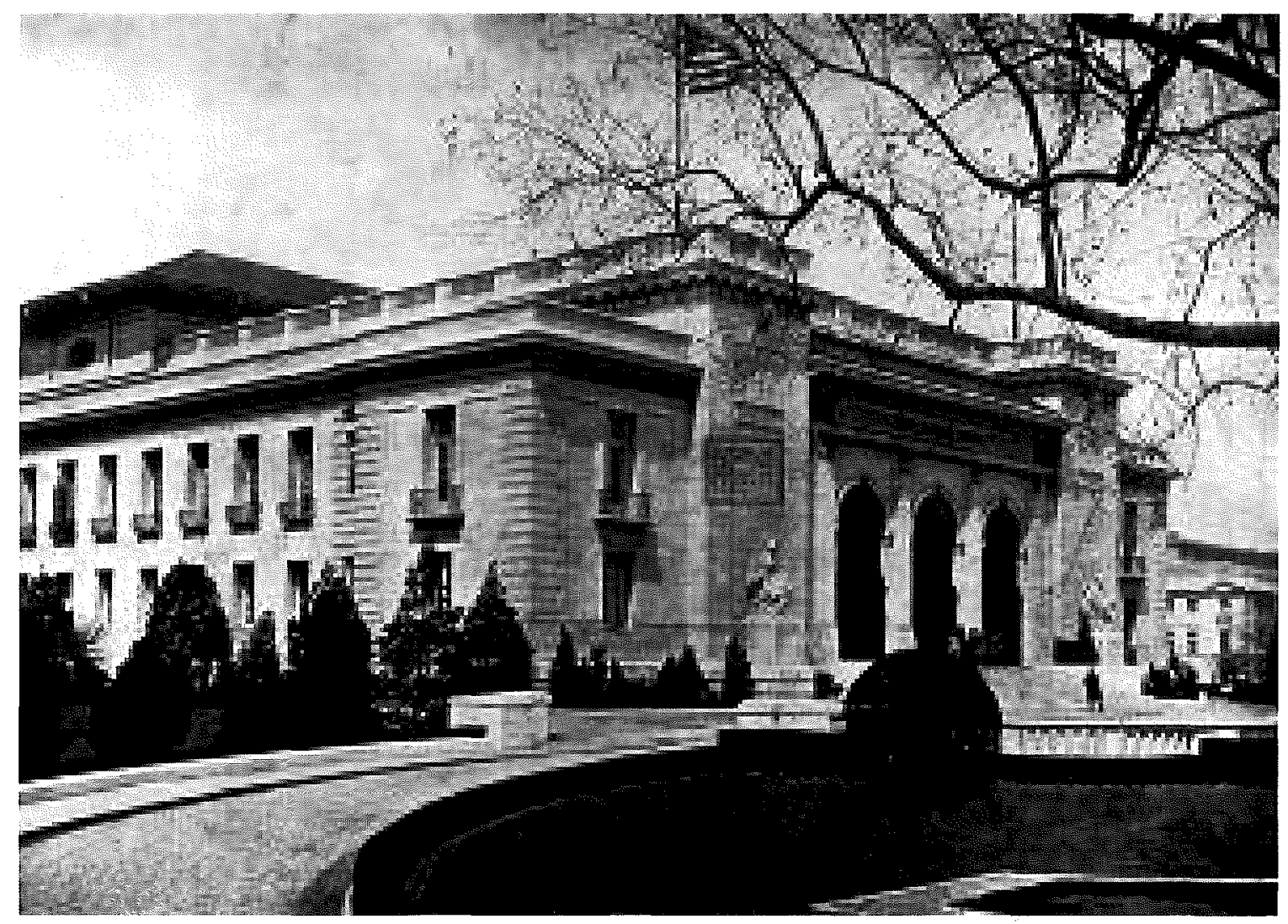

Figure 5.4

Paul Philippe Cret, Albert Kelsey. Pan-American Union Building, 1908-1910, Washington, D.C. (archINFORM. Web.) 


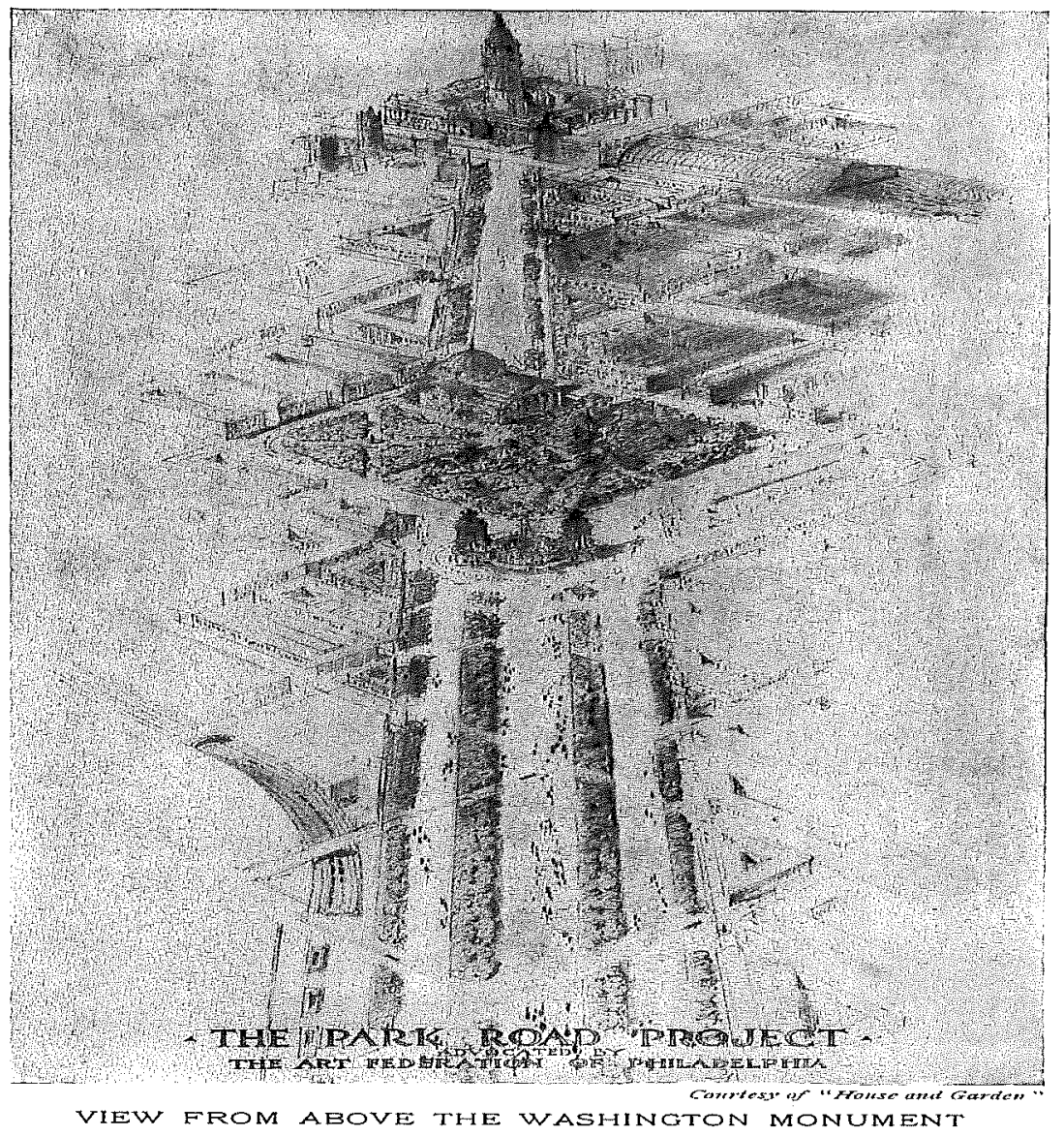

Figure 5.5

Albert Kelsey. The Park Road Project, 1902. (Albert Kelsey. The Proposed Parkway for Philadelphia, A Direct Thoroughfare From the Public Buildings to the Green Street Entrance to Fairmount Park: containing a review of the various movements for a diagonal boulevard and the original argument in favor of a plaza before the northern facade of the City Hall, 16.) 


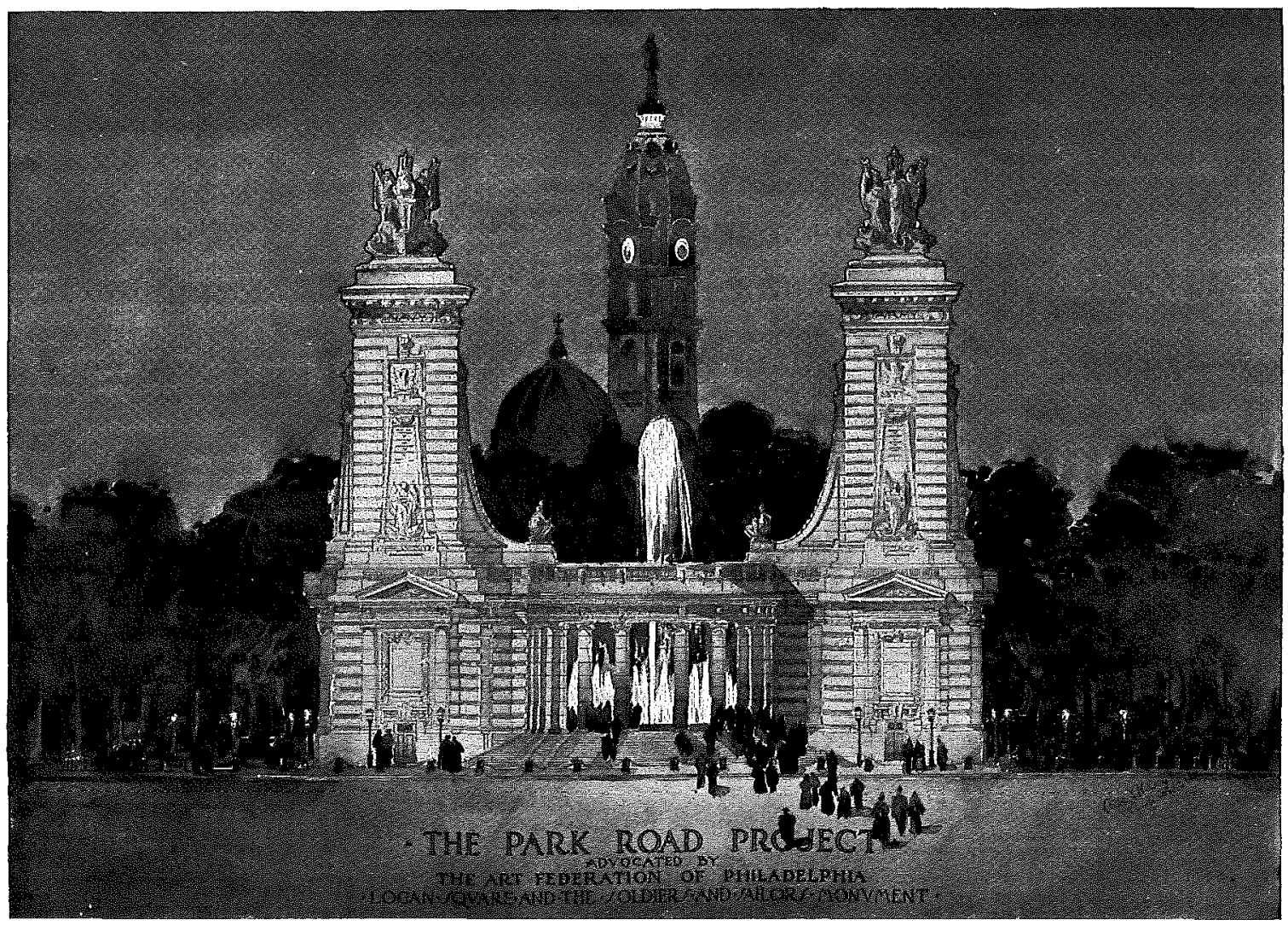

Figure 5.6

Albert Kelsey. The Park Road Project, 1902. (Albert Kelsey. The Proposed Parkway for Philadelphia, A Direct Thoroughfare From the Public Buildings to the Green Street Entrance to Fairmount Park: containing a review of the various movements for a diagonal boulevard and the original argument in favor of a plaza before the northern facade of the City Hall, 18.) 


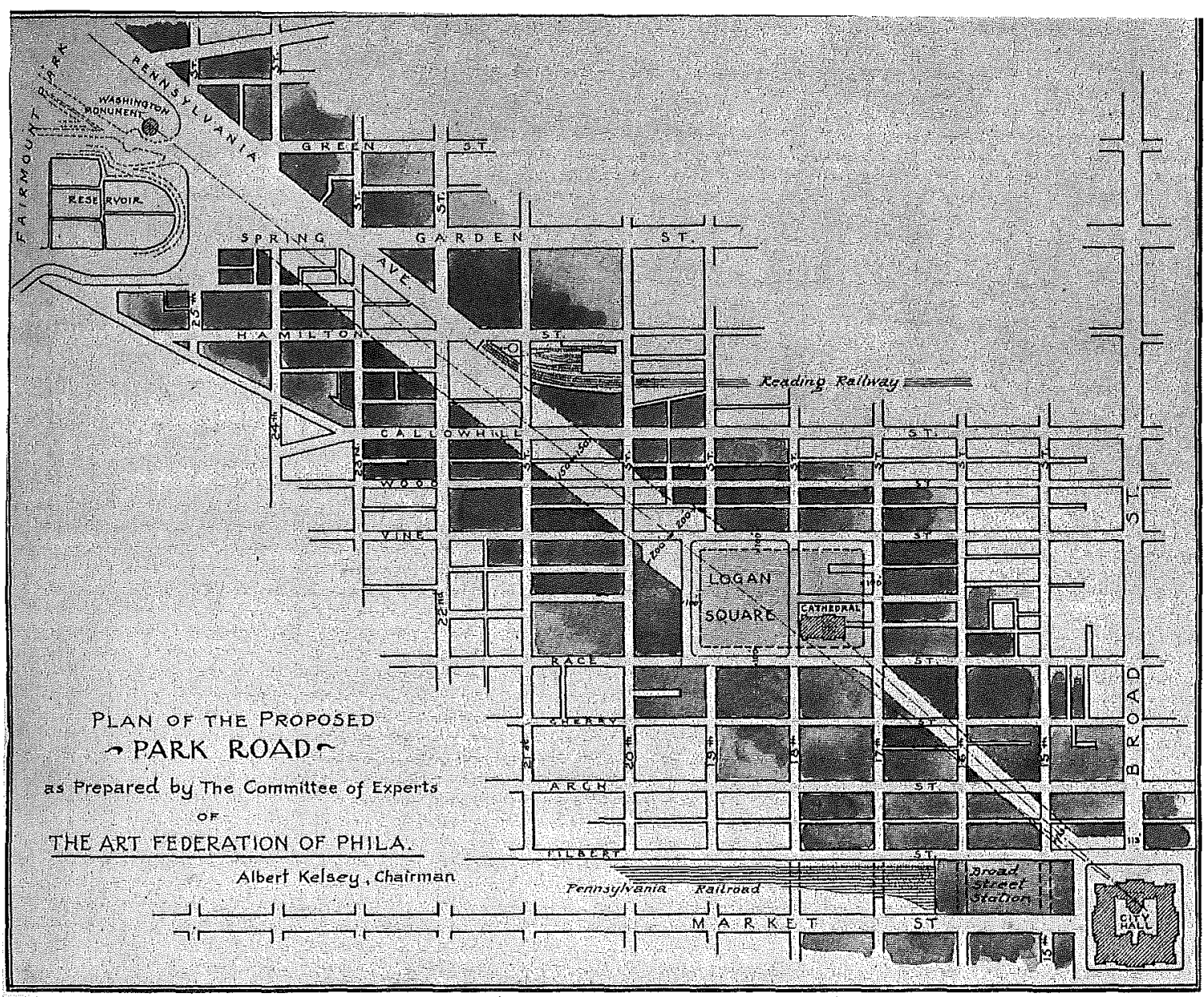

THE PARK ROAD PROJECT

Courtesy of "House and Garden"

Figure 5.7

Albert Kelsey. The Park Road Project, 1902. (Albert Kelsey. The Proposed Parkway for Philadelphia, A Direct Thoroughfare From the Public Buildings to the Green Street Entrance to Fairmount Park: containing a review of the various movements for a diagonal boulevard and the original argument in favor of a plaza before the northern facade of the City Hall, 17.) 


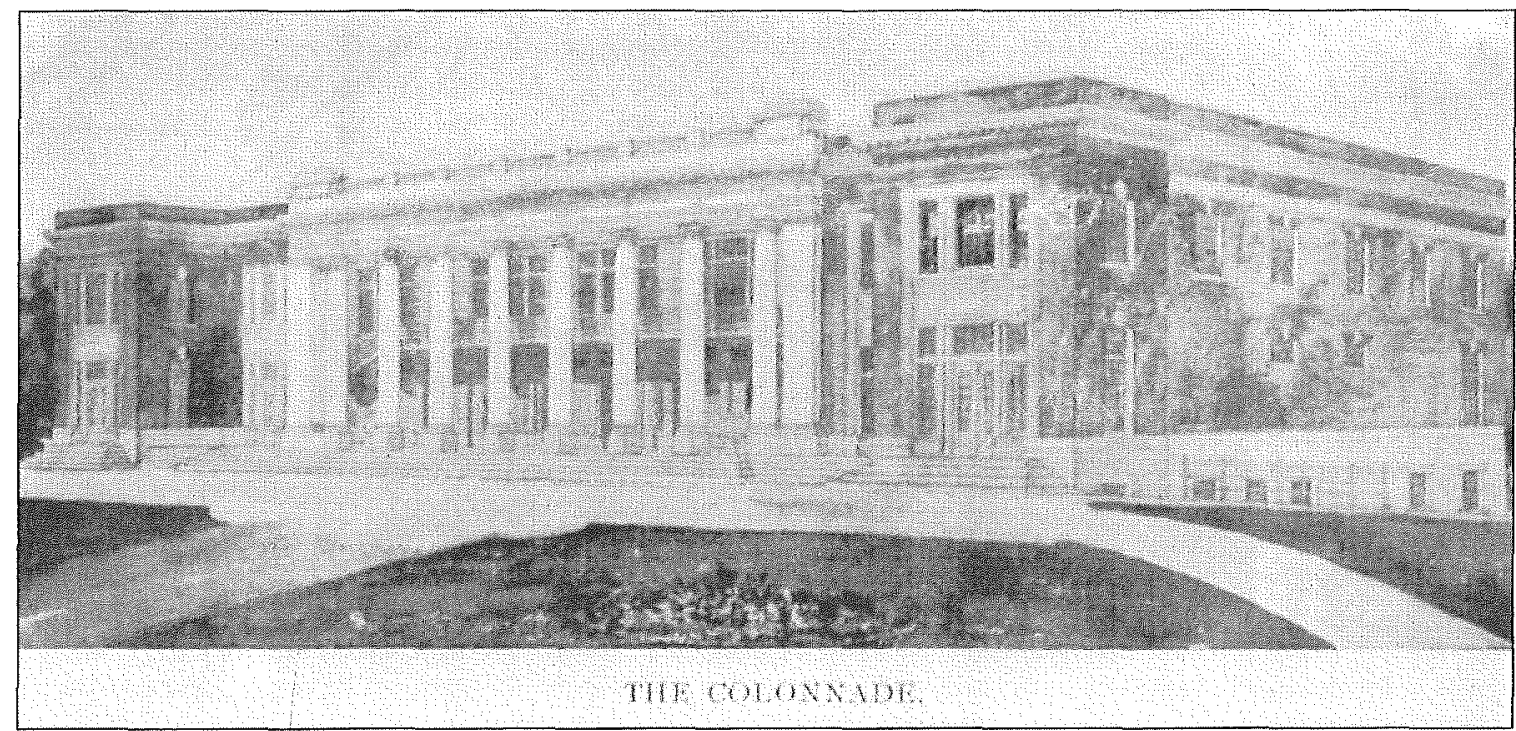

Figure 5.8

Albert Kelsey. The Colonnade, 1906. (Courtesy of Chautauqua Institution Archives.) 


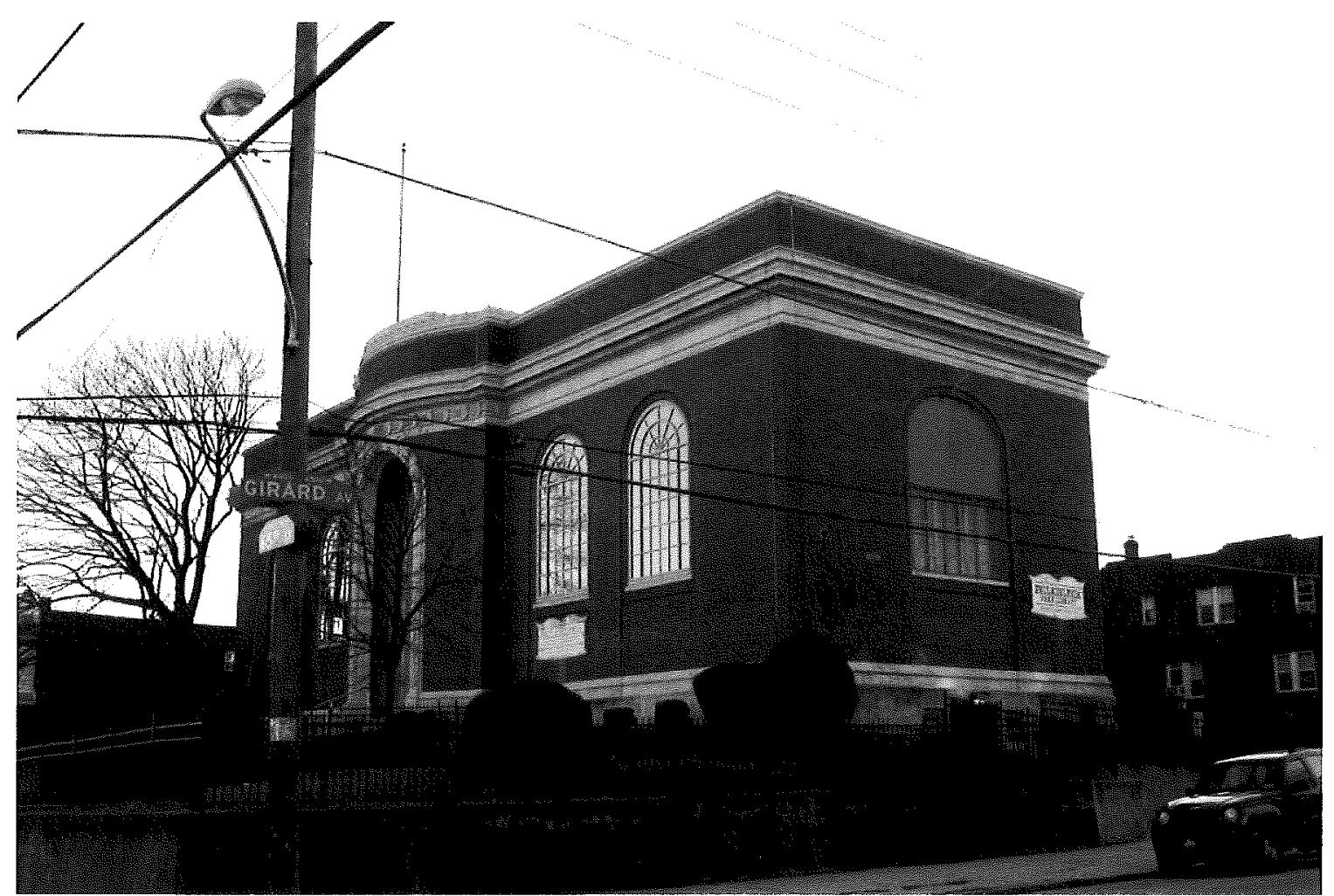

Figure 5.9

Albert Kelsey. Haddington Branch of the Free Library of Philadelphia, 1912. (Philadelphia Speaks. Web.) 


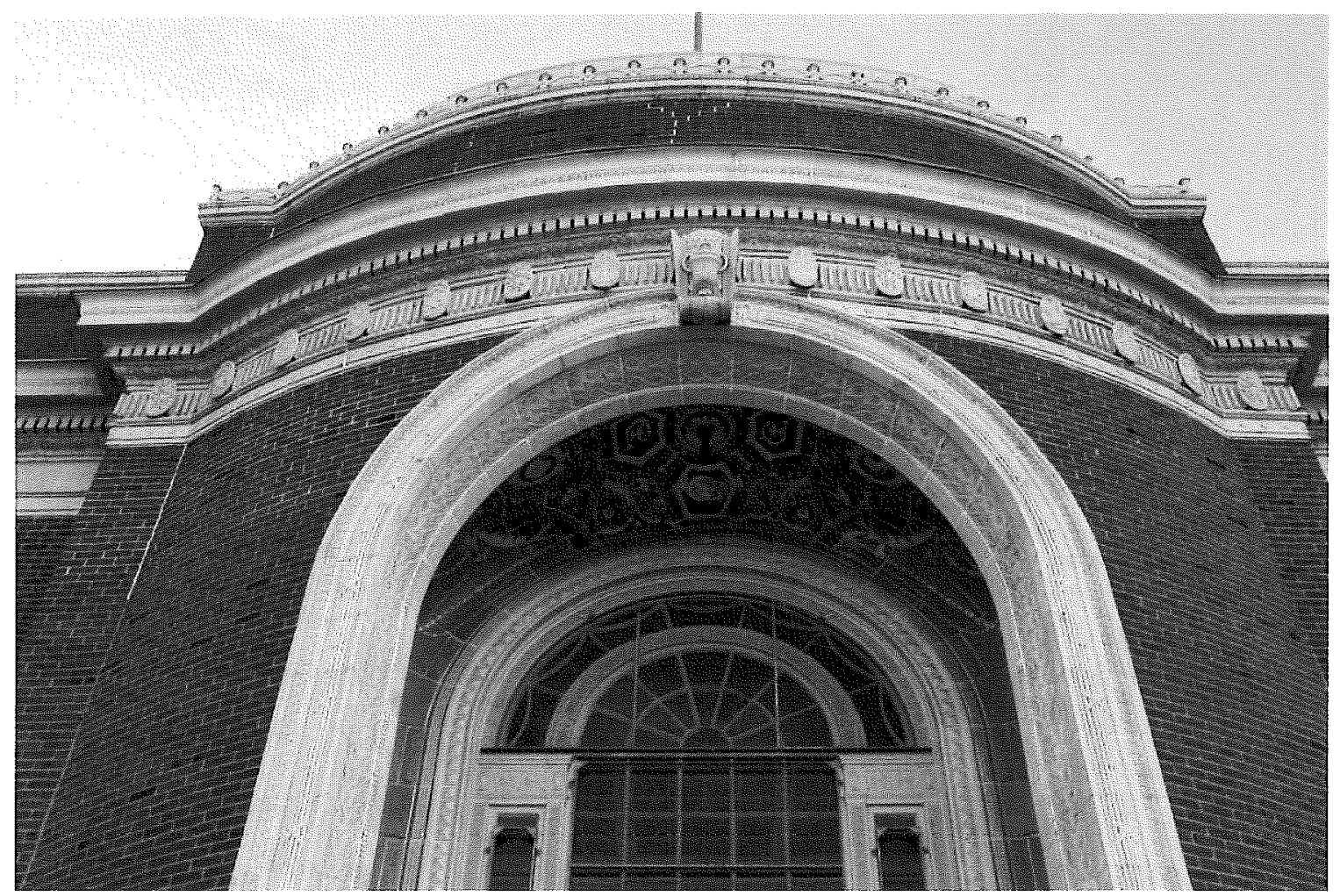

Figure 5.10

Albert Kelsey. Haddington Branch of the Free Library of Philadelphia, 1912, entry detail. (Philadelphia Speaks. Web.) 


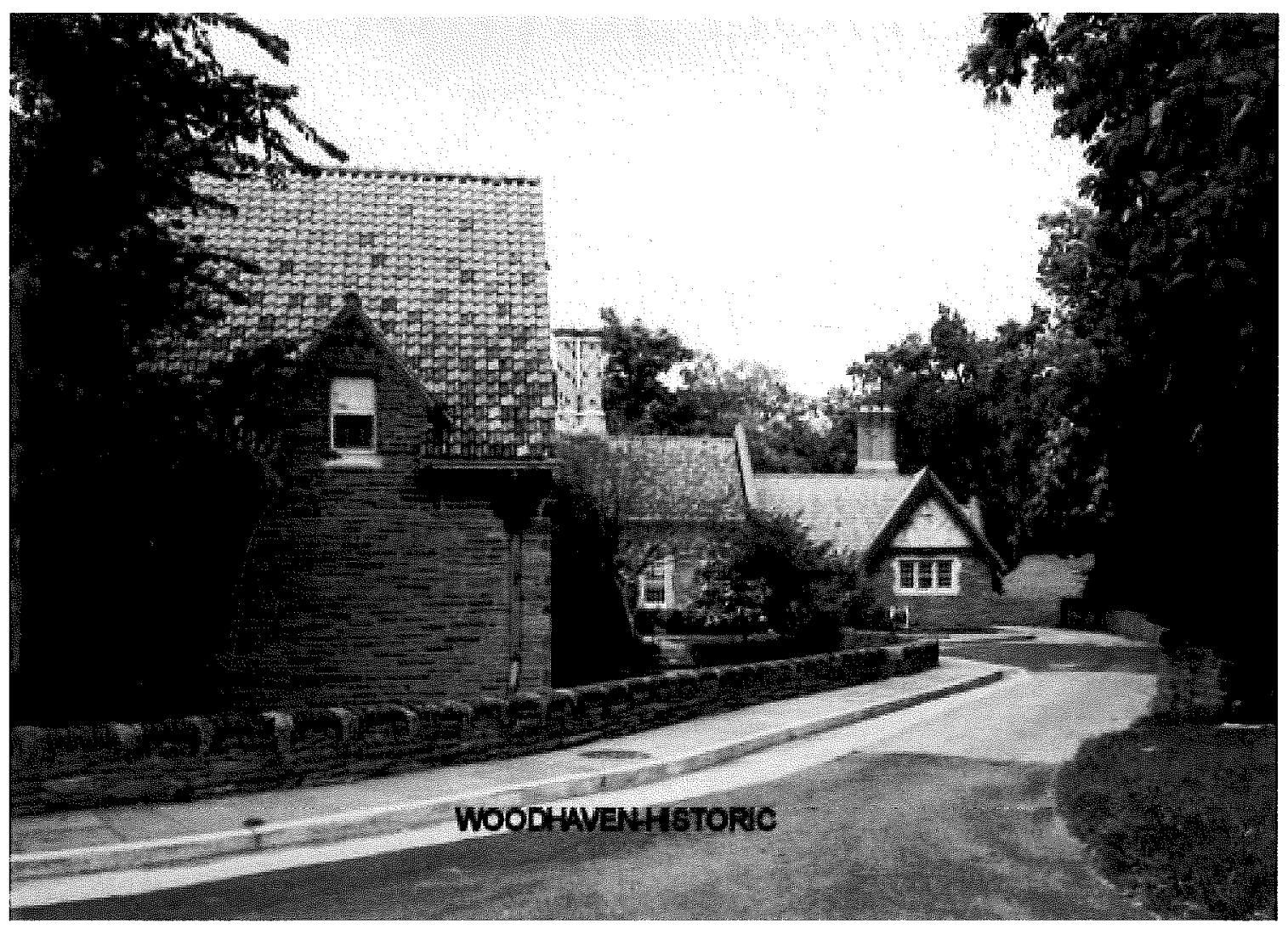

Figure 5.11

Albert Kelsey. Carson College for Orphan Girls, 1912, Flourtown, PA. (Ebay. Web.) 


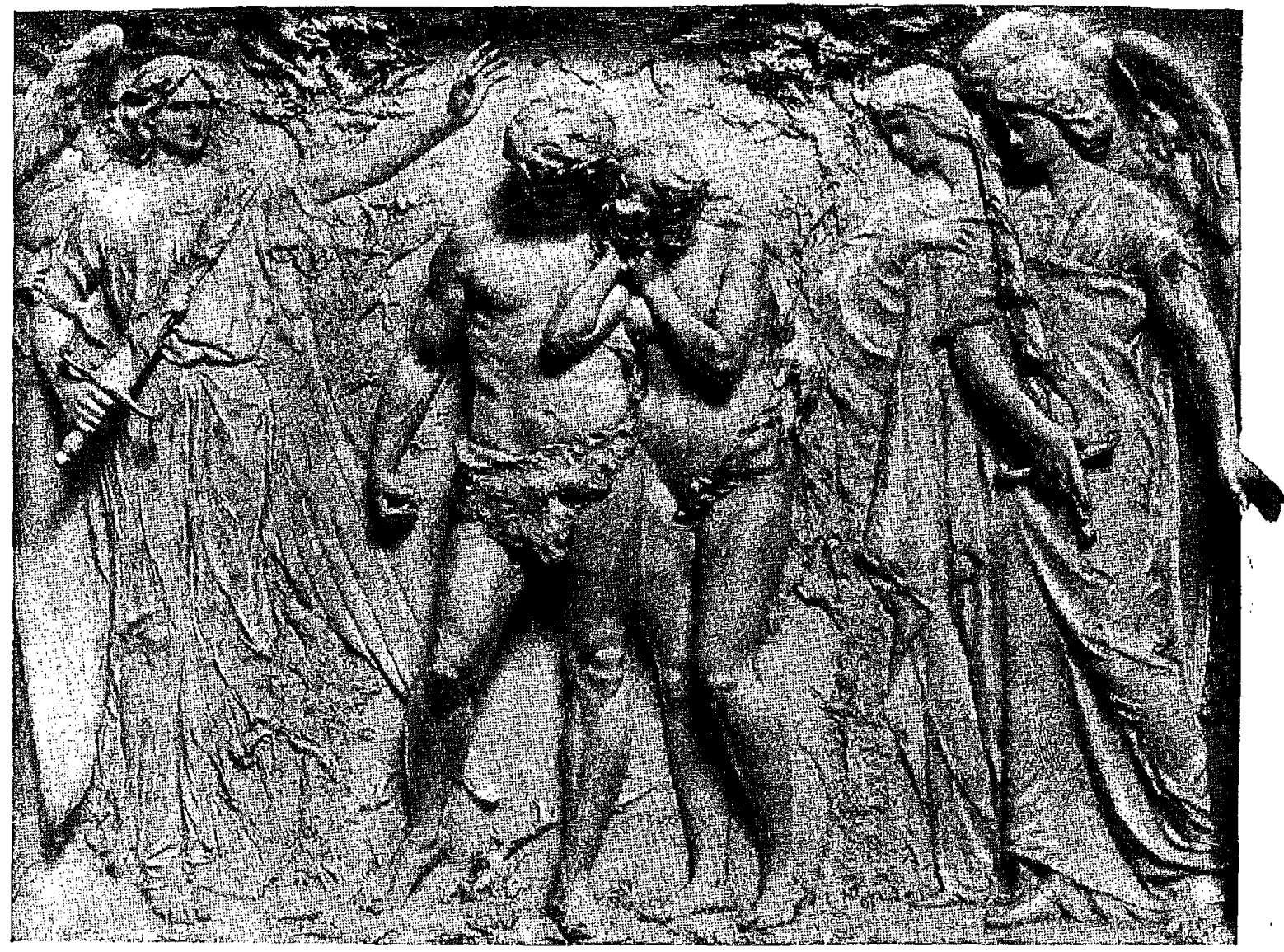

"The Expulsion of Adam and Eve"-Design for the Doors of Trinity Church, New York.

Figure 5.12

J. Massey Rhind. The Exputsion of Adam and Eve, 1890. (N. MacDonald, "A Genius of the Chisel." Munsey's, vol. 14: 673.) 


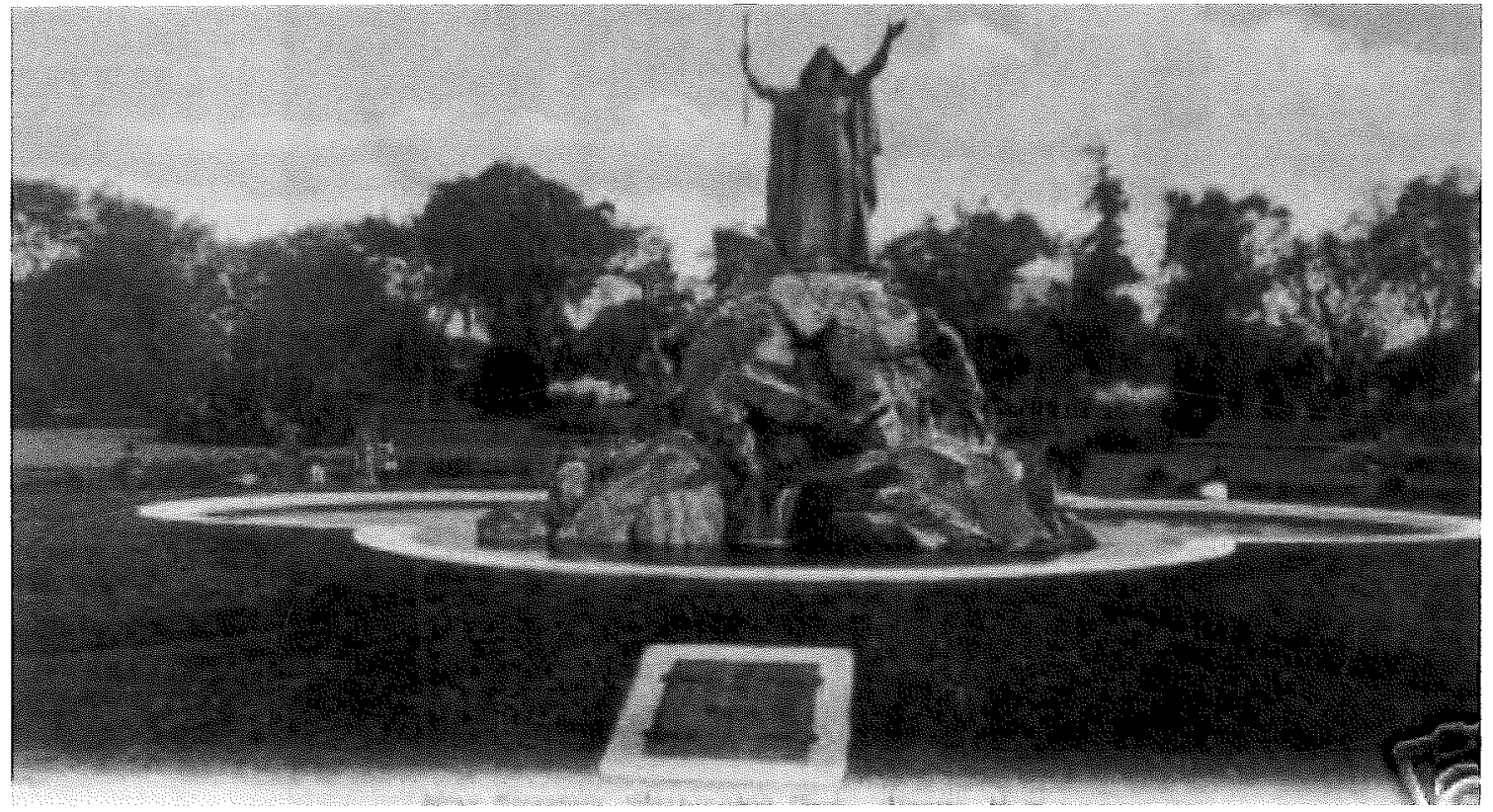

Figure 5.13

J. Massey Rhind. The King Memorial Fountain, 1893, postcard. (Ebay. Web.) 


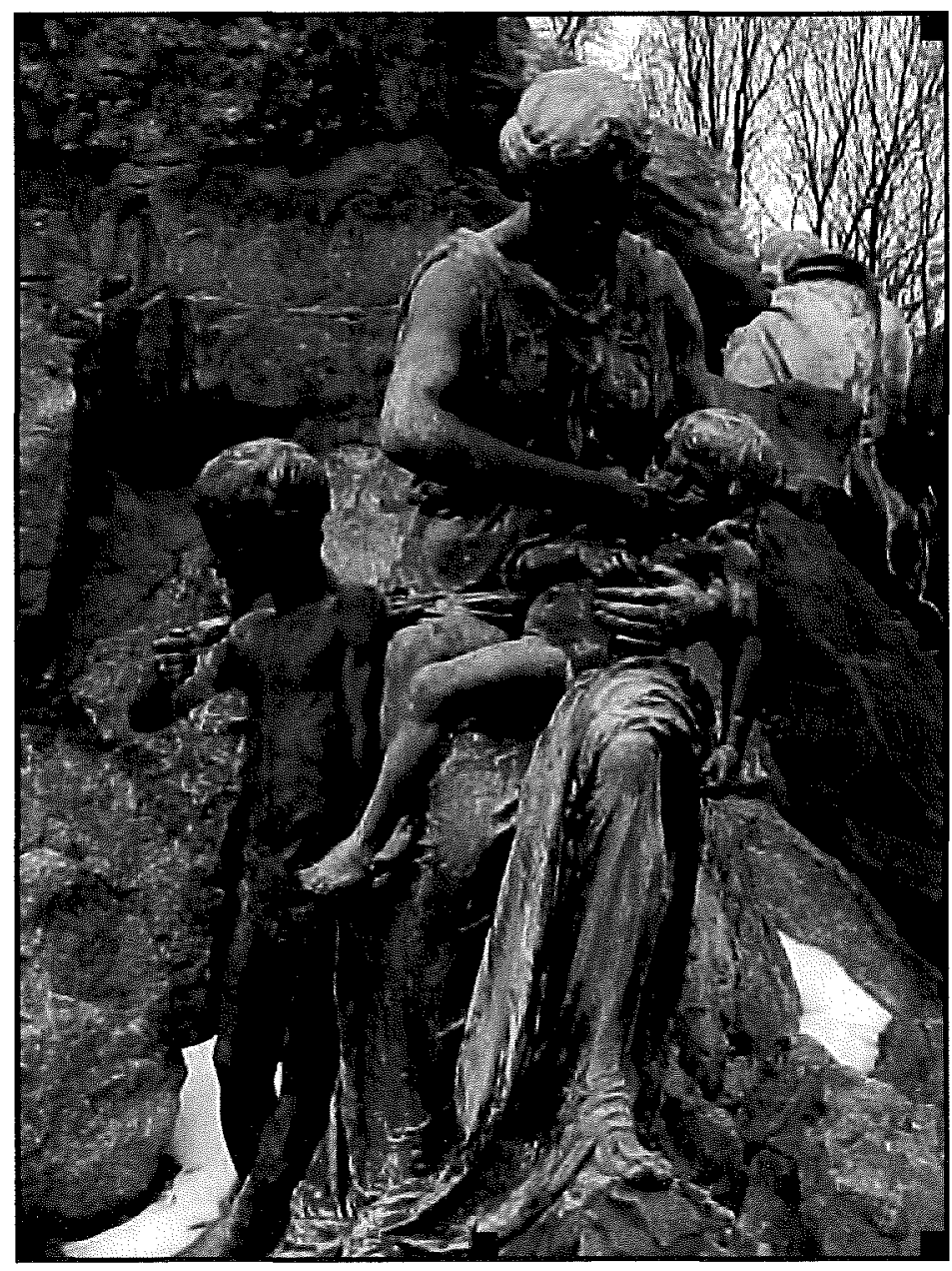

Figure 5.14

J. Massey Rhind. The King Memorial Fountain, Childhood, 1893. (Washington Park Conservancy. Web.) 


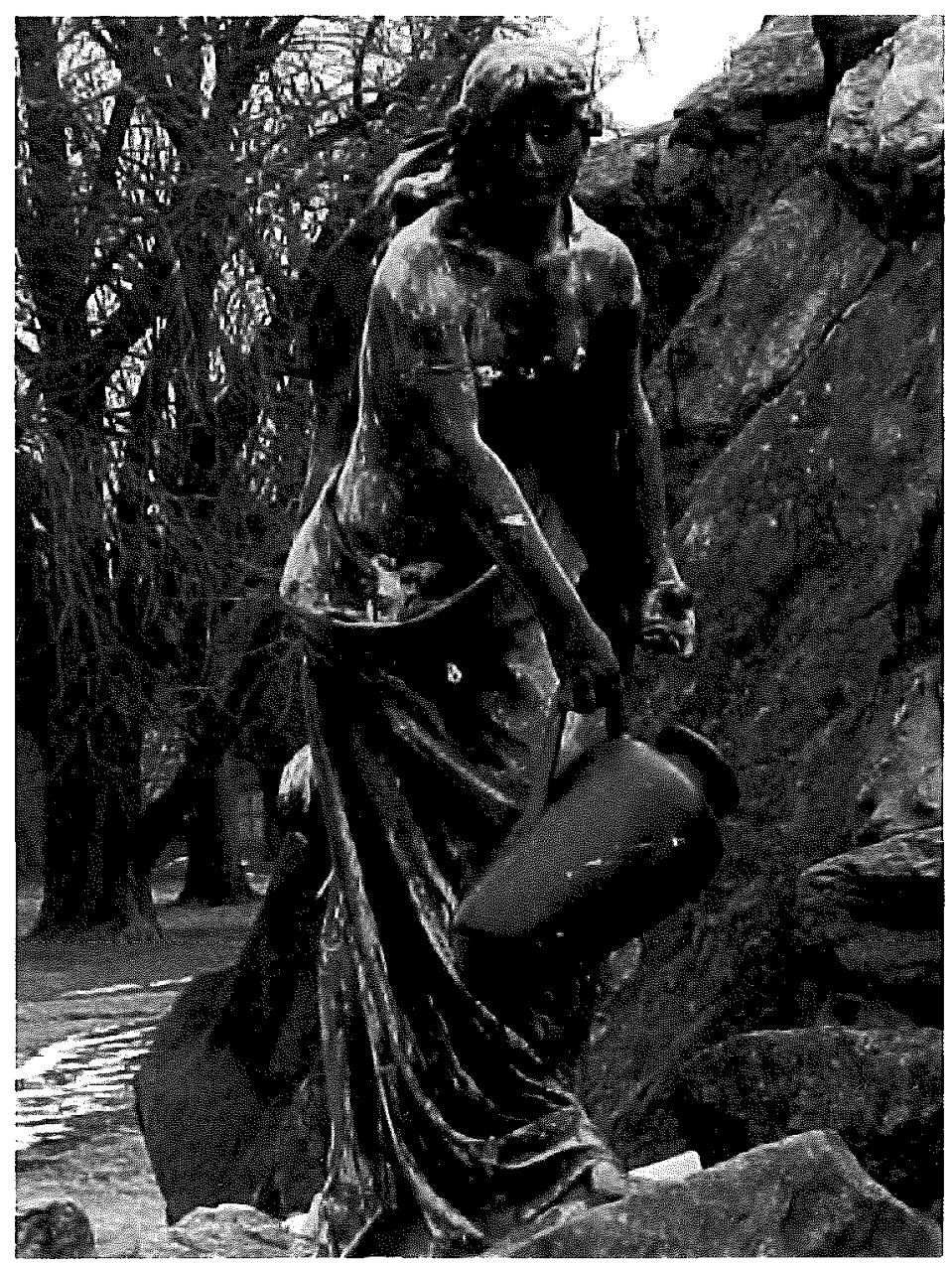

Figure 5.15

J. Massey Rhind. The King Memorial Fountain, Youth, 1893. (Washington Park Conservancy. Web.) 


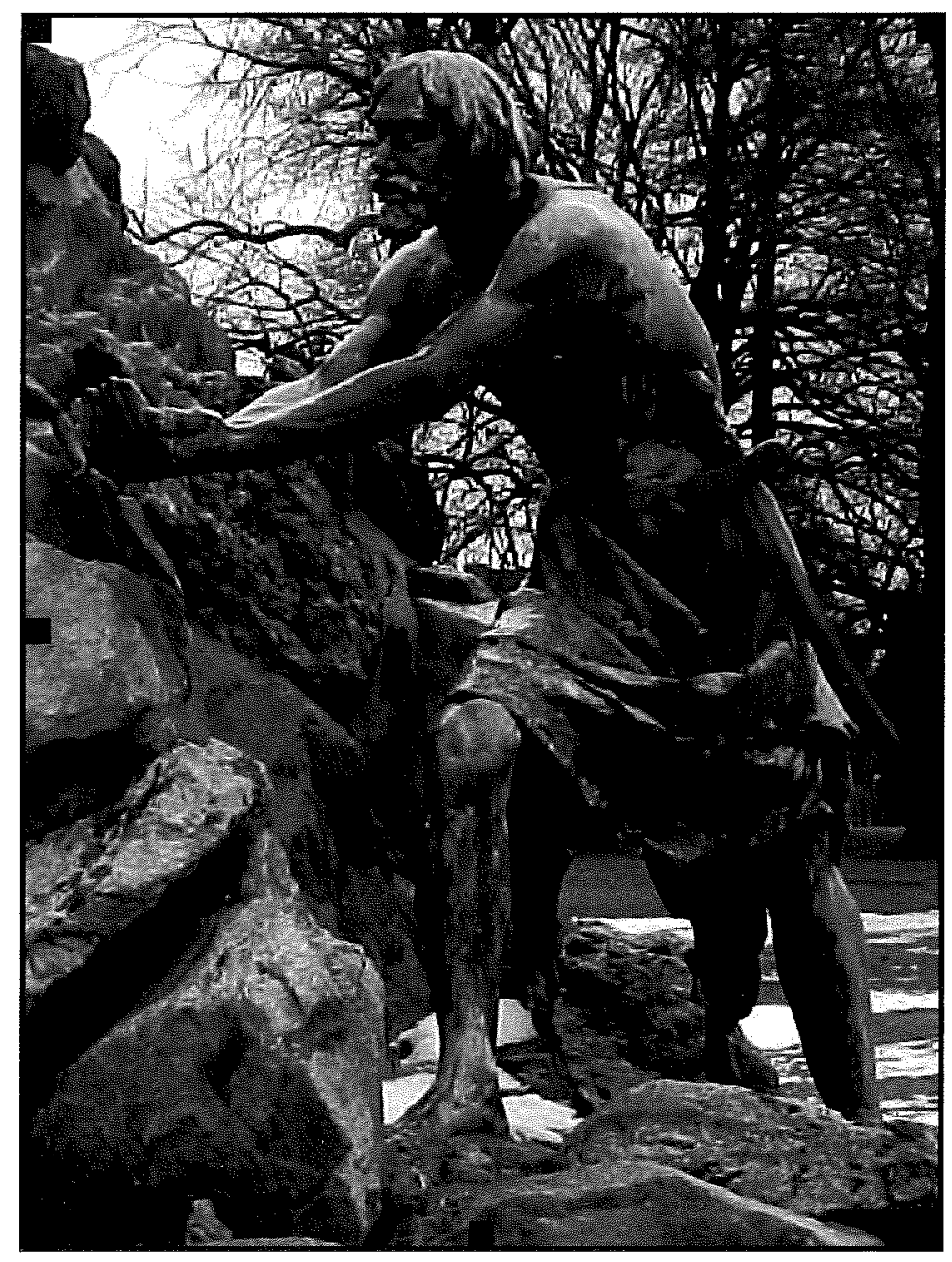

Figure 5.16

J. Massey Rhind. The King Memorial Fountain, Manhood, 1893. (Washington Park Conservancy. Web.) 


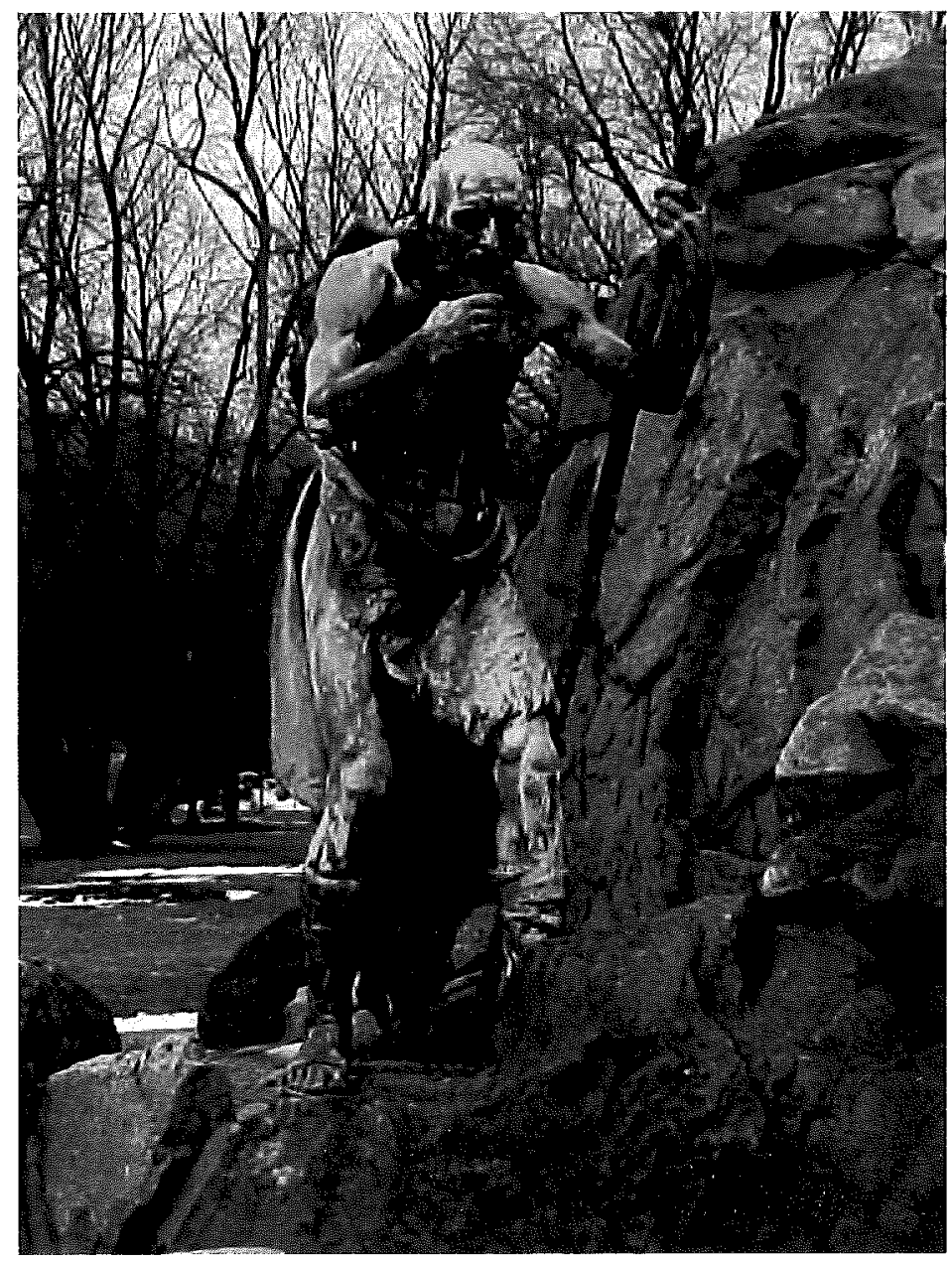

Figure 5.17

J. Massey Rhind. The King Memorial Fountain, Old Age, 1893. (Washington Park Conservancy. Web.) 


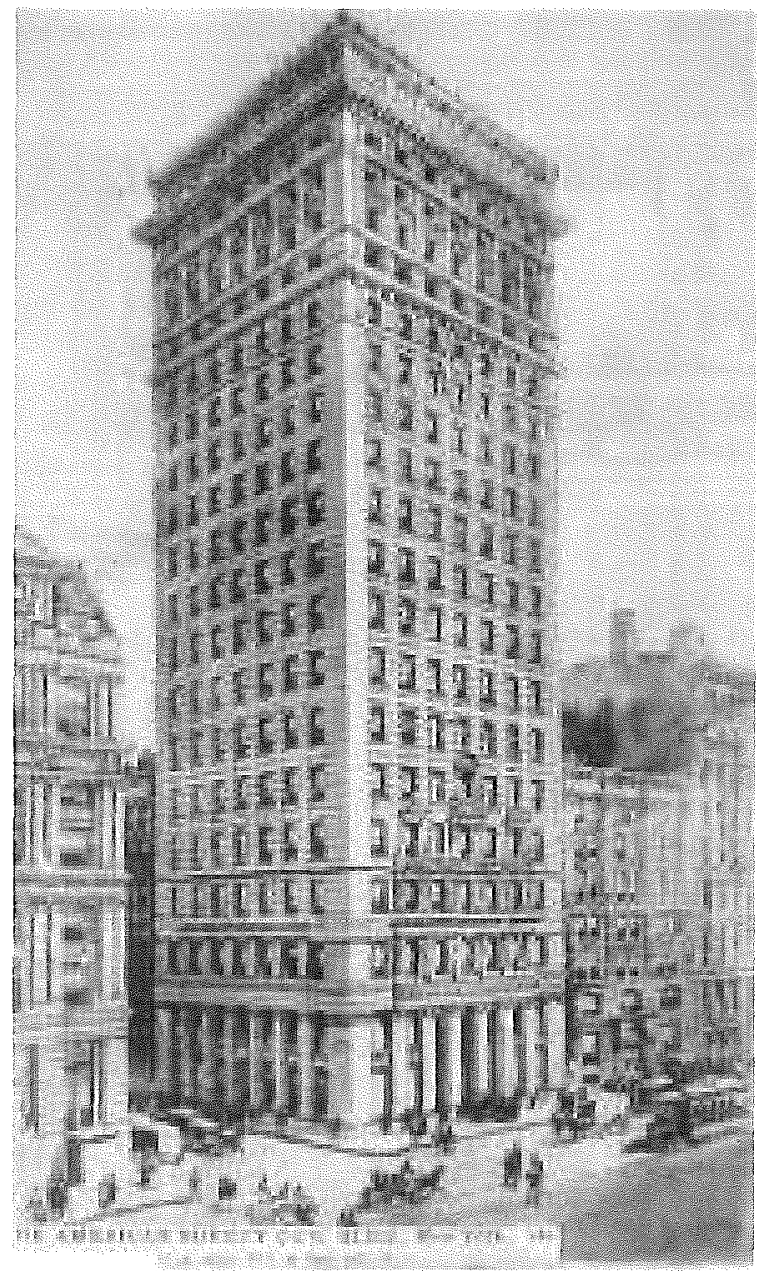

Figure 5.18

Bruce Price (1845-1903). American Surety Building (1894-1896), New York, NY. (Office Museum. Web.) 


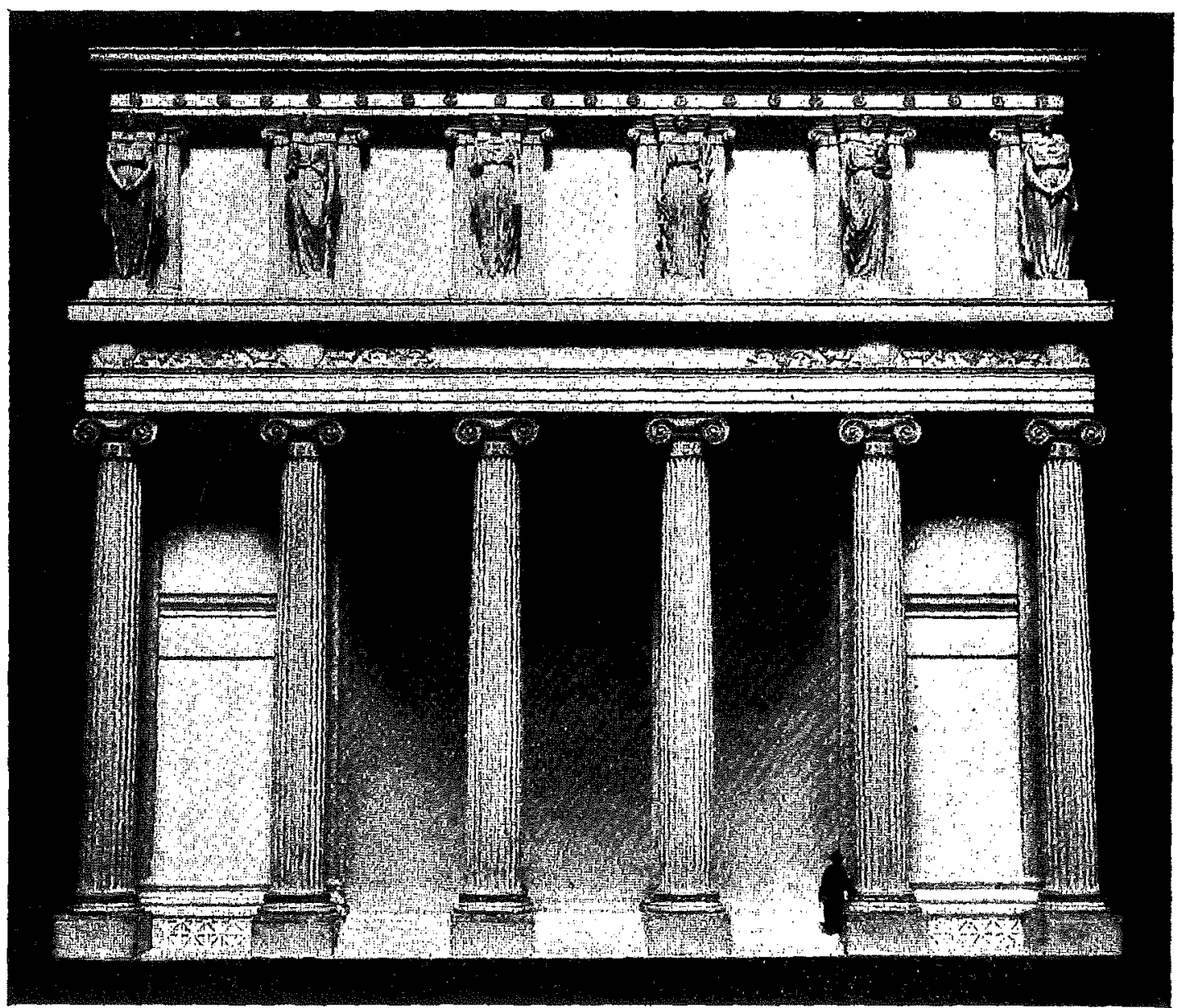

Portico of the American Surety Building, Now York.

Figure 5.19

Bruce Price, J. Massey Rhind. Portico of the American Surety Building, 1894. (N. MacDonald, "A Genius of the Chisel." Munsey's, vol. 14: 672.) 


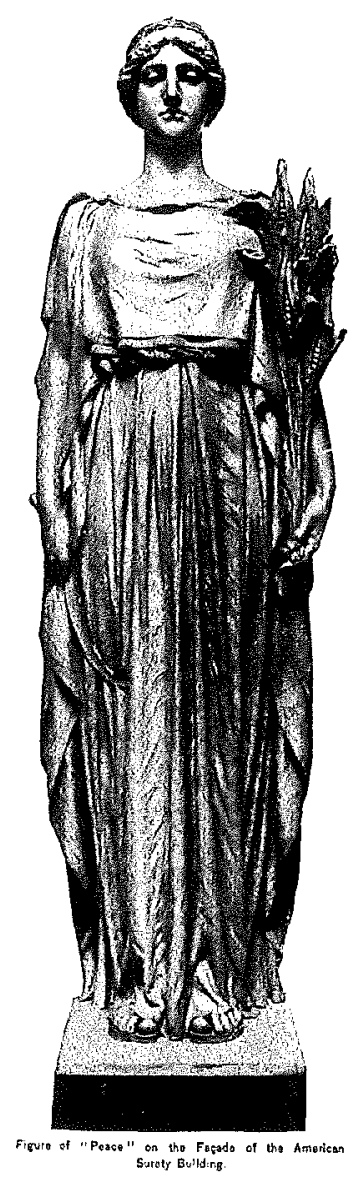

Figure 5.20

J. Massey Rhind. Peace, The American Surety Building, 1894. (N. MacDonald, "A Genius of the Chisel." Munsey's, vol. 14: 671.) 


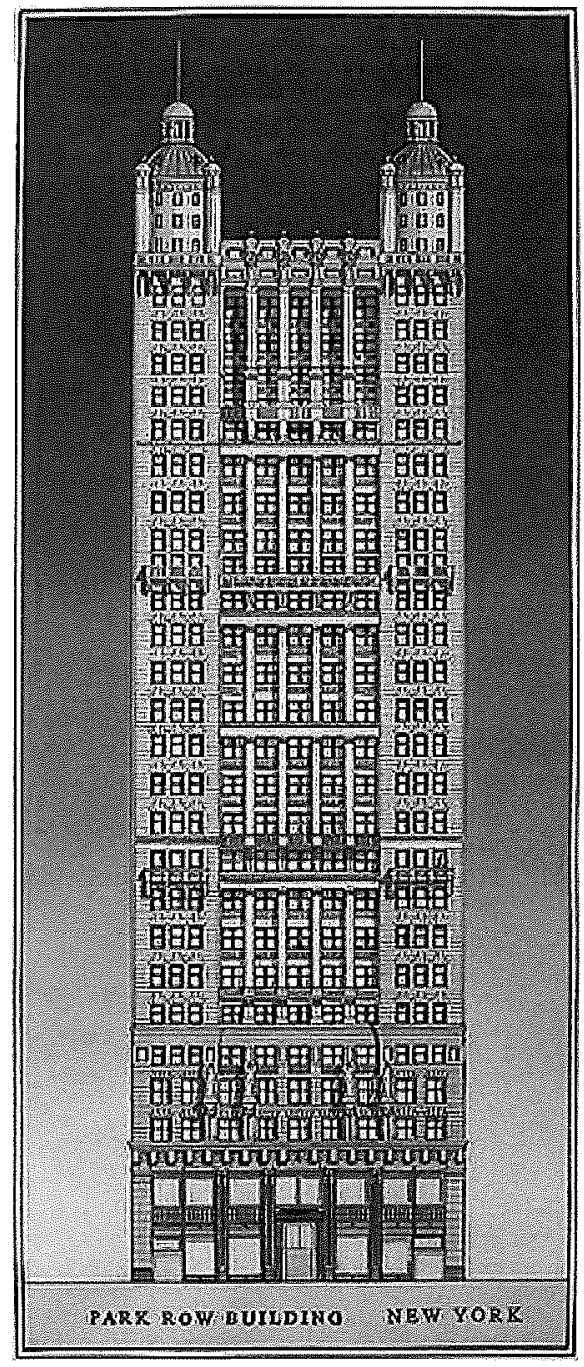

Figure 5.21

Robert Henderson Robertson. The Park Row Building, 1896-1899. (Wikipedia. Web.) 


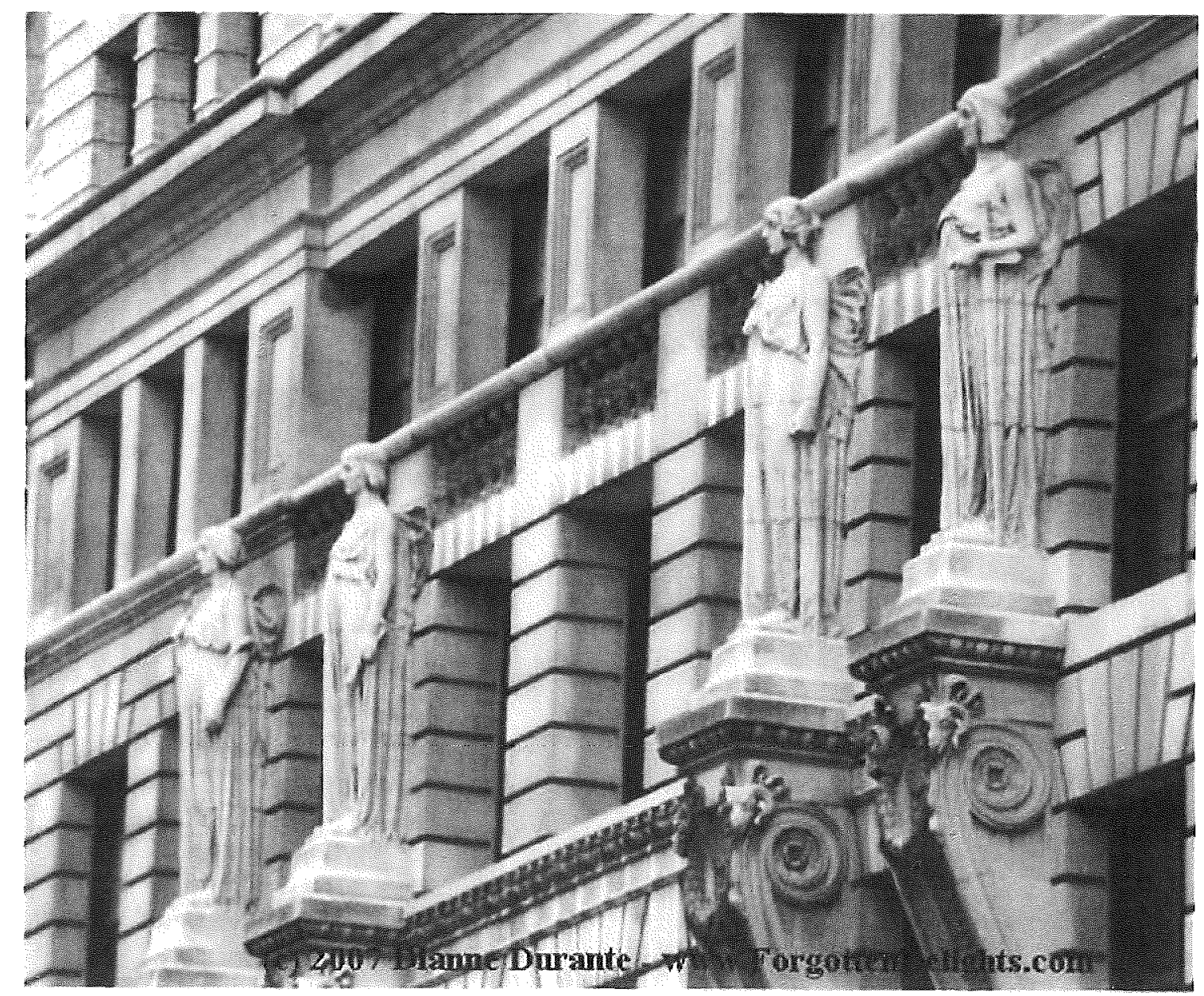

Figure 5.22

J. Massey Rhind. Four Maidens, Park Row Building, 1899. (Dianne Durante, Forgotten Delights. Web.) 


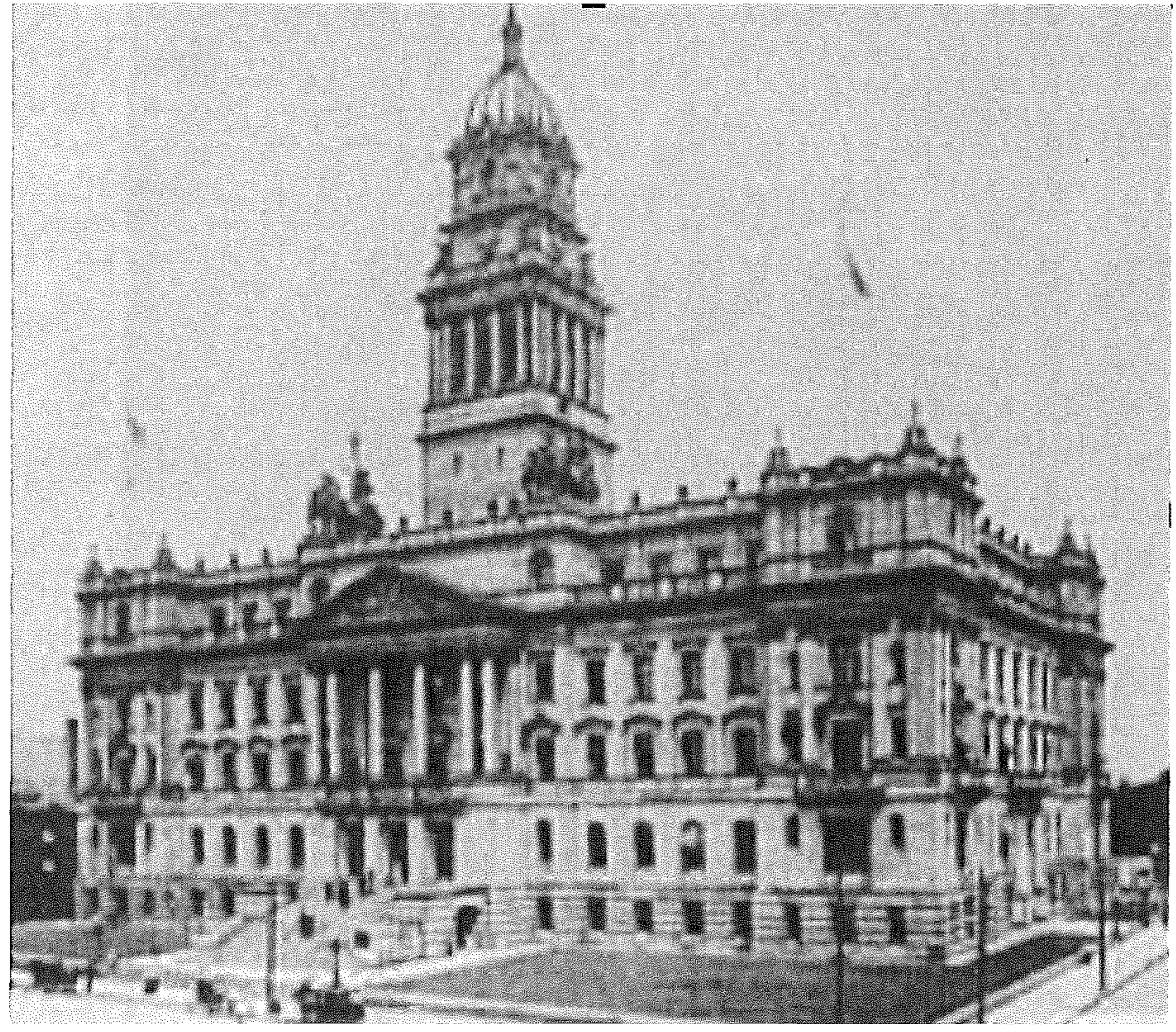

Figure 5.23

John and Arthur Scott \& Co. Wayne County Courthouse, c 1905. (National Park Service. Web.) 


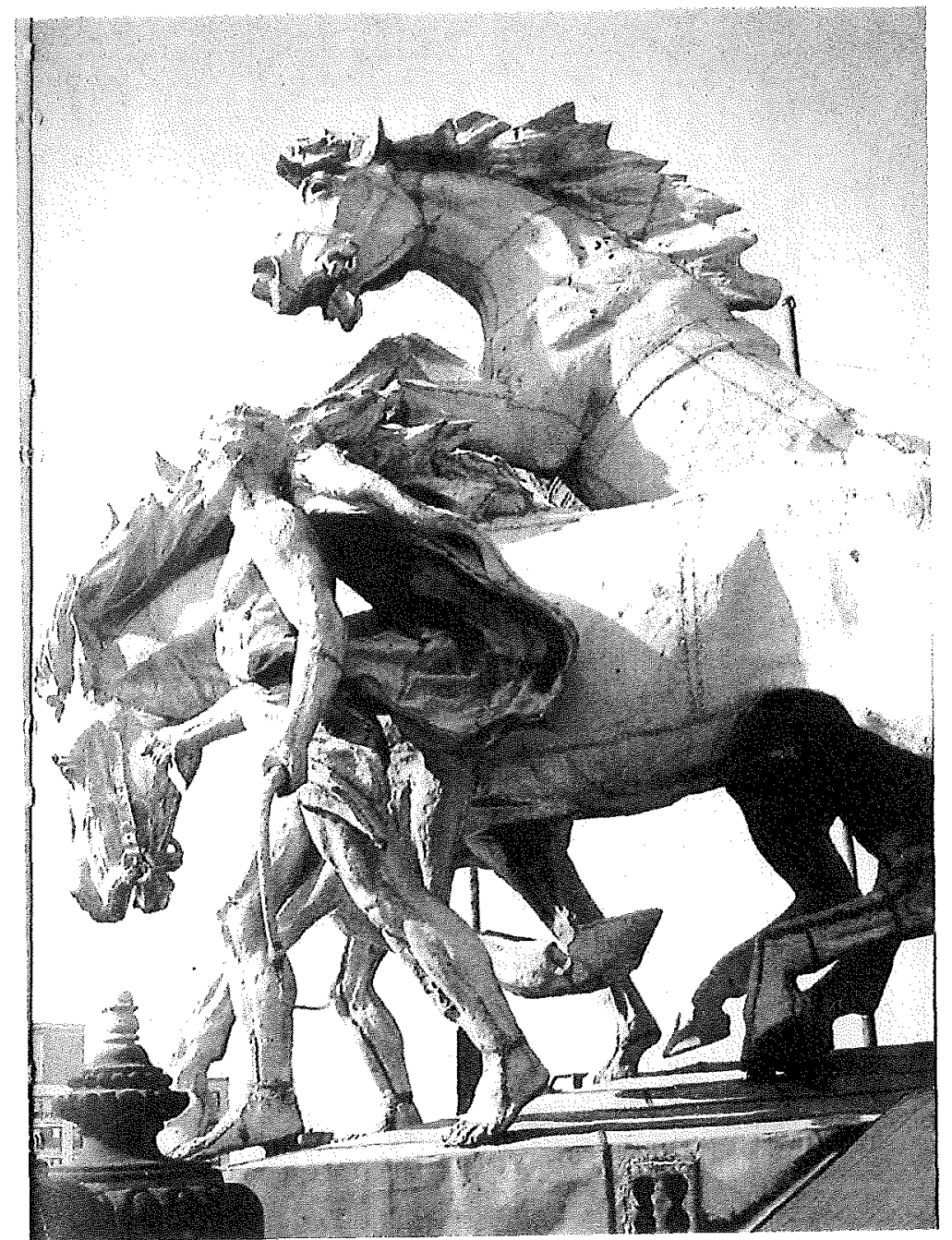

Figure 5.24

J. Massey Rhind. Progress, 1899. (Dennis Alan Nawrocki. Art in Detroit Public Places, 25.) 


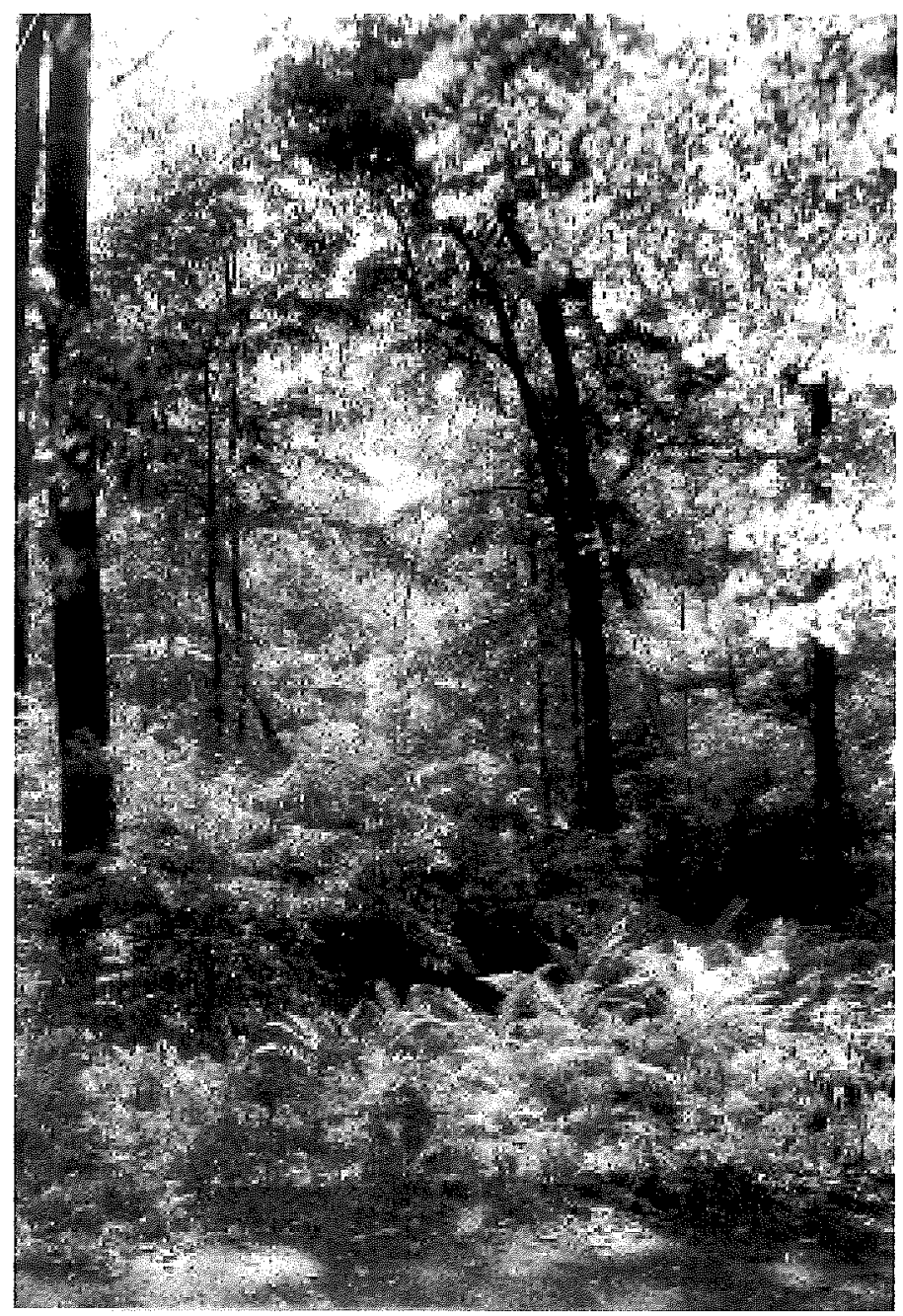

Figure 5.25

Warren Manning. Ferns and rhododendron, wild garden, Gwinn estate, Cleveland, OH, c. 1930. (Robin Karson. A Genius For Place, American Landscapes of the Country Place Era, 45.) 


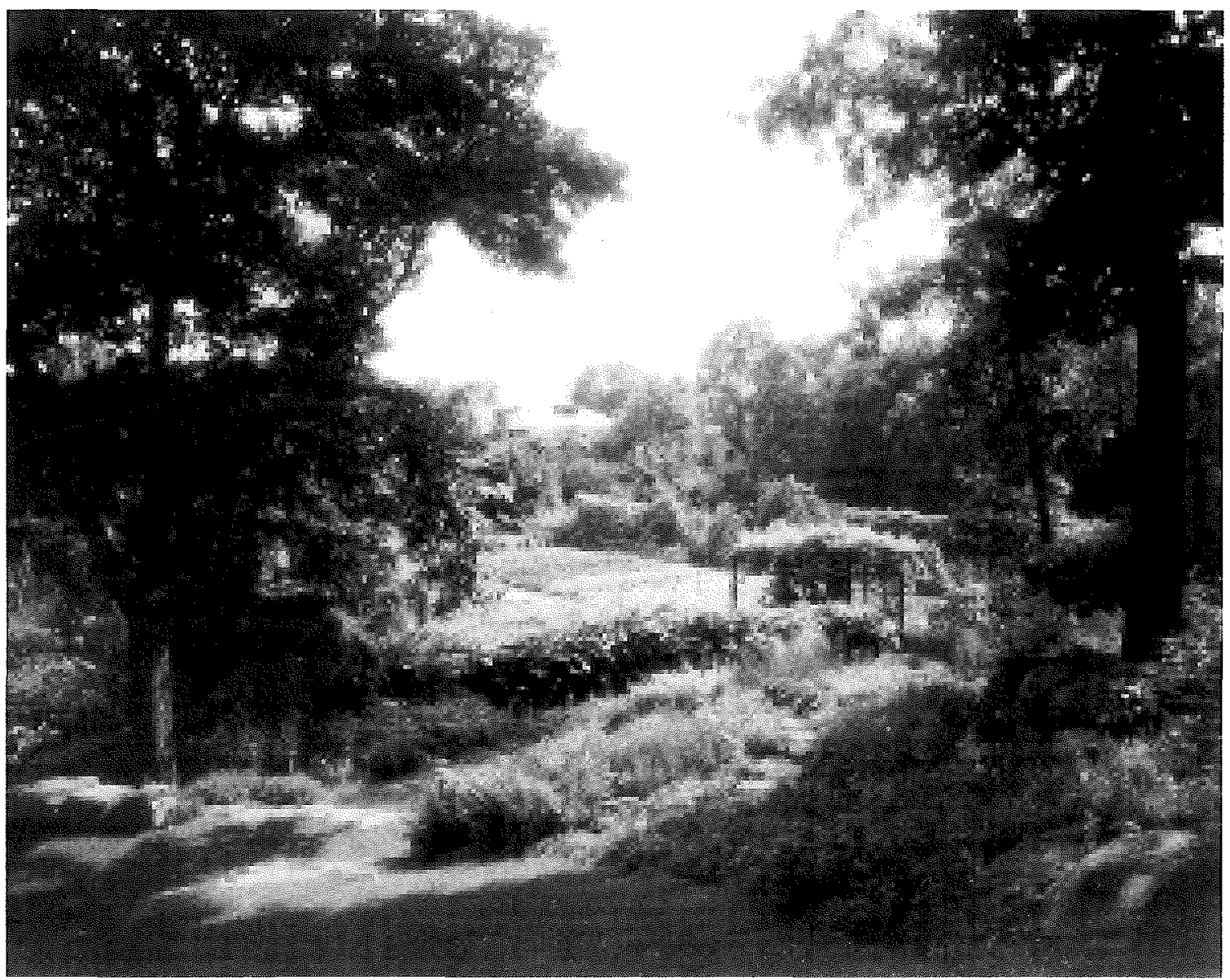

Figure 5.26

Warren Manning. Elon Hooker estate, Greenwich, CT, designed 1909-14. (Robin Karson. A Genius For Place, American Landscapes of the Country Place Era, 39.) 


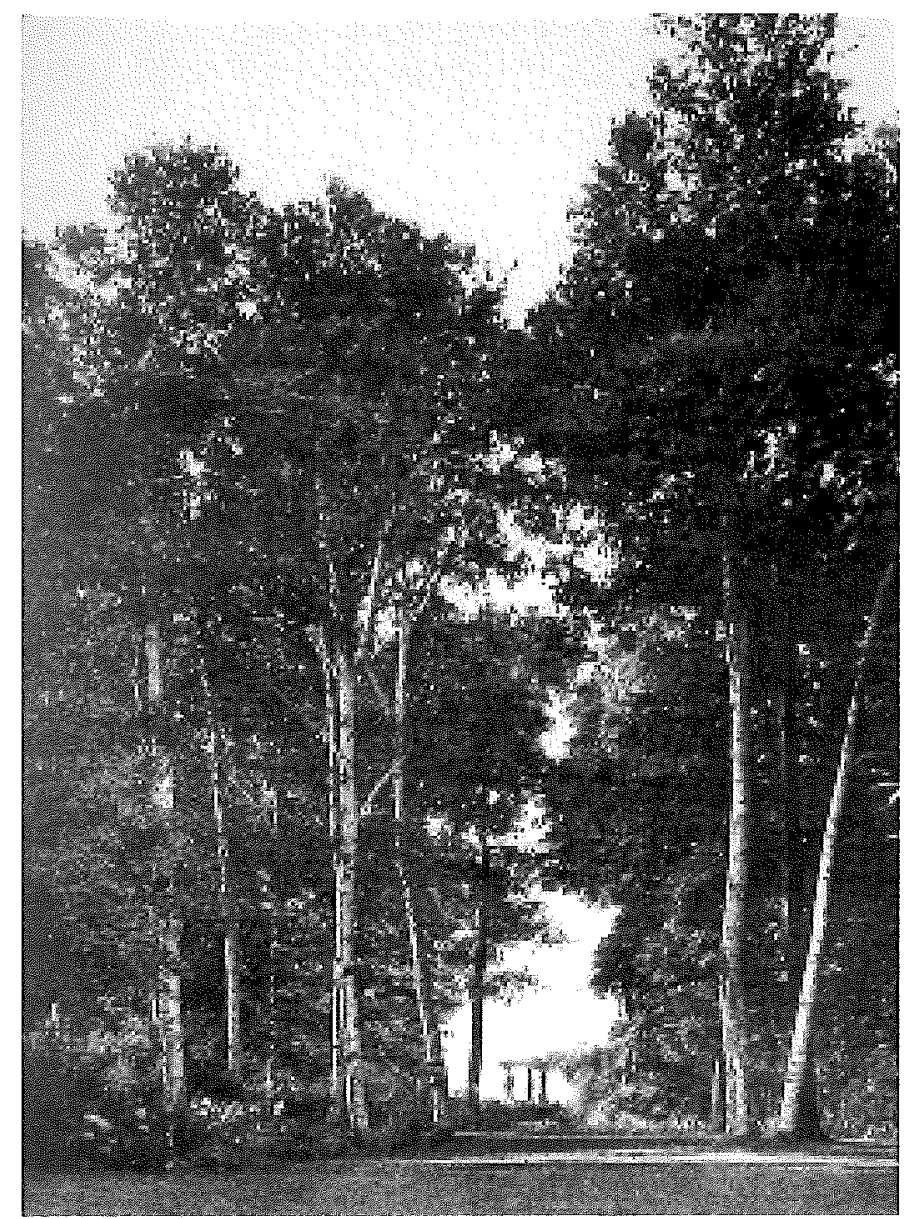

Figure 5.27

Warren Manning. Ravello and overlook, Walden (Cyrus McCormick Jr. estate), Lake Forest, IL, designed 1896. (Robin Karson. A Genius For Place, American Landscapes of the Country Place Era, 35.) 


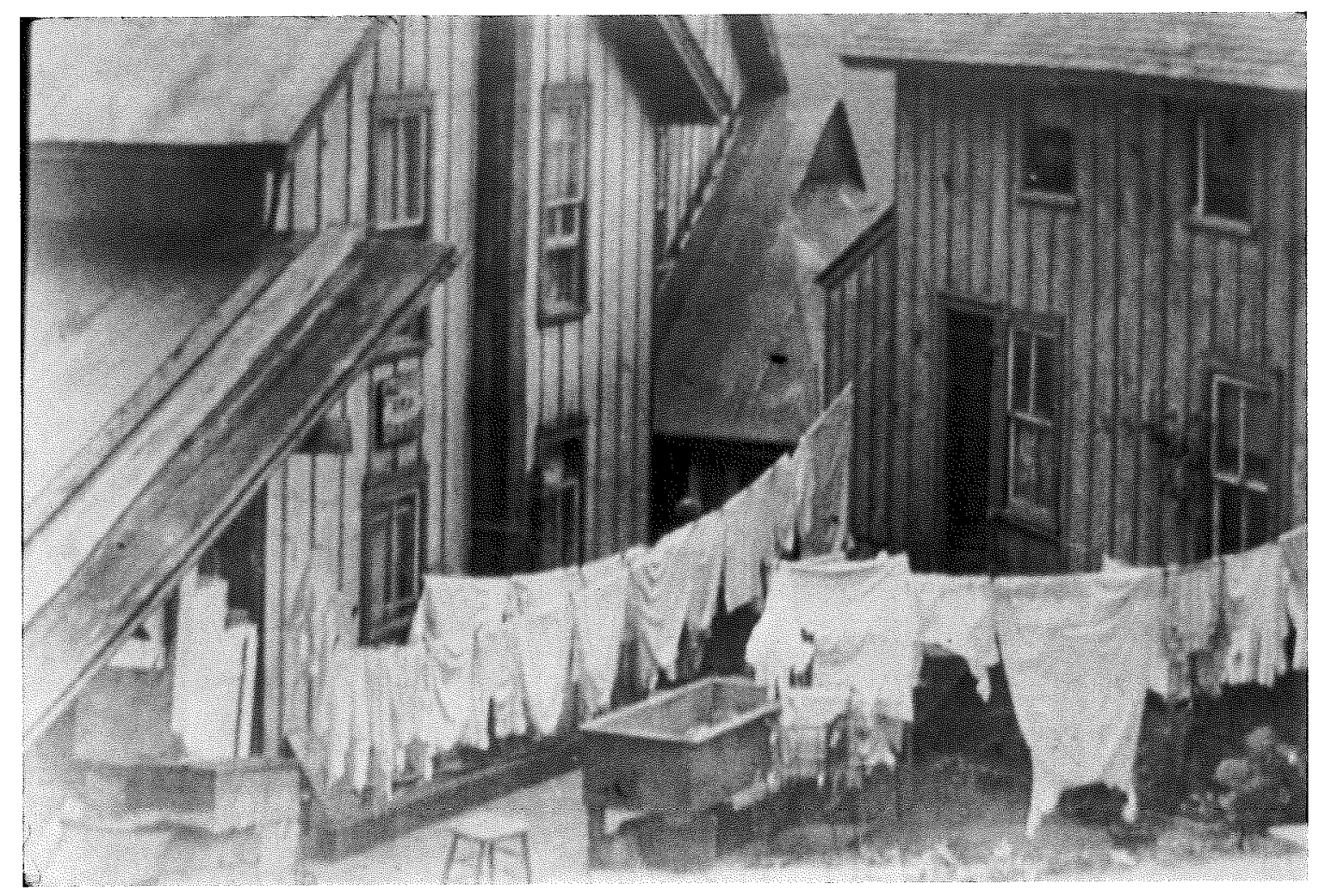

Figure 6.1

Chautauqua density, c. 1890. (Courtesy of Chautauqua Institution Archives.) 


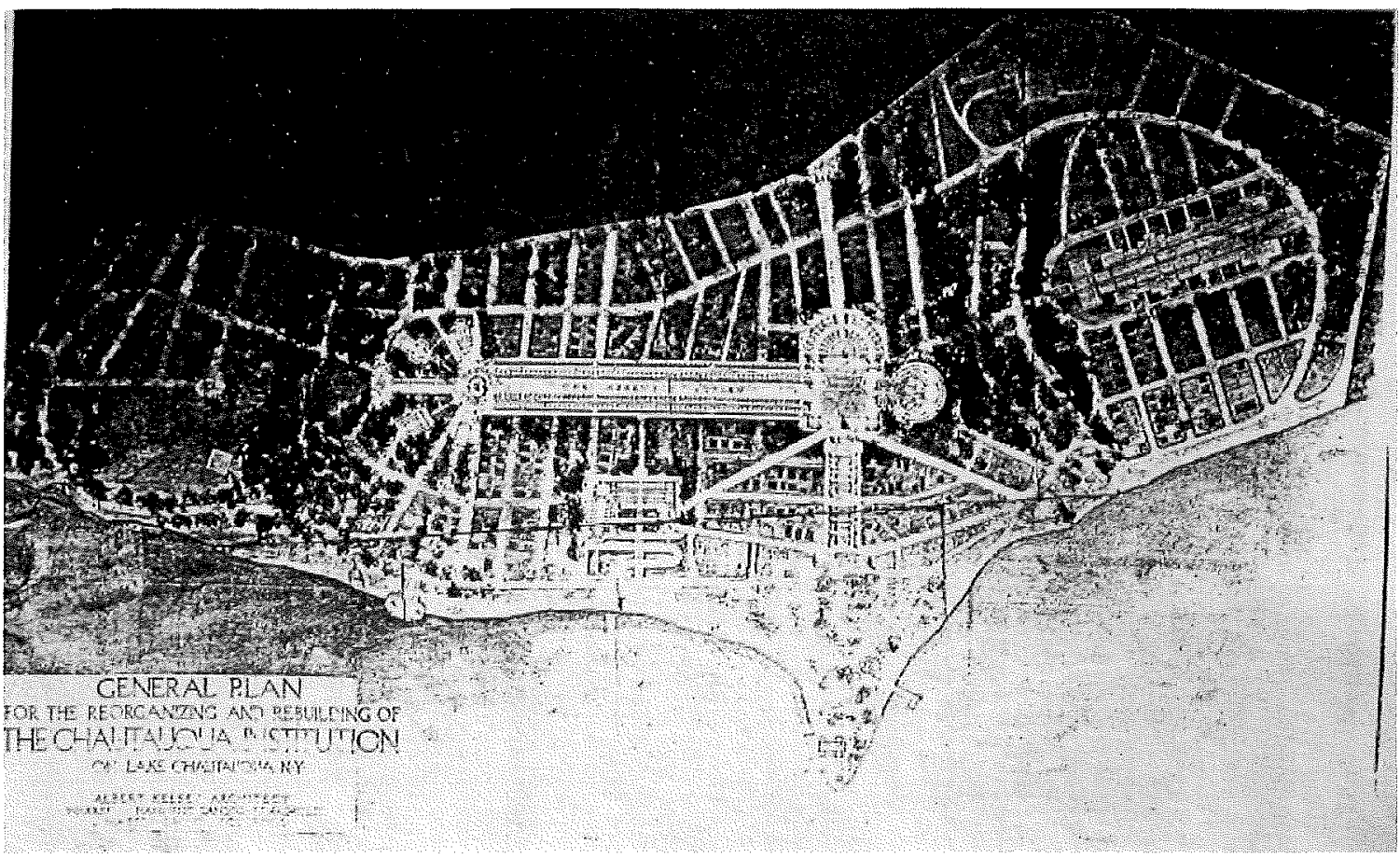

Figure 6.2

Albert Kelsey. General Plan for the Reorganizing and Rebuilding of the Chautauqua Institution, 1903. (Courtesy of Chautauqua Institution Archives.) 


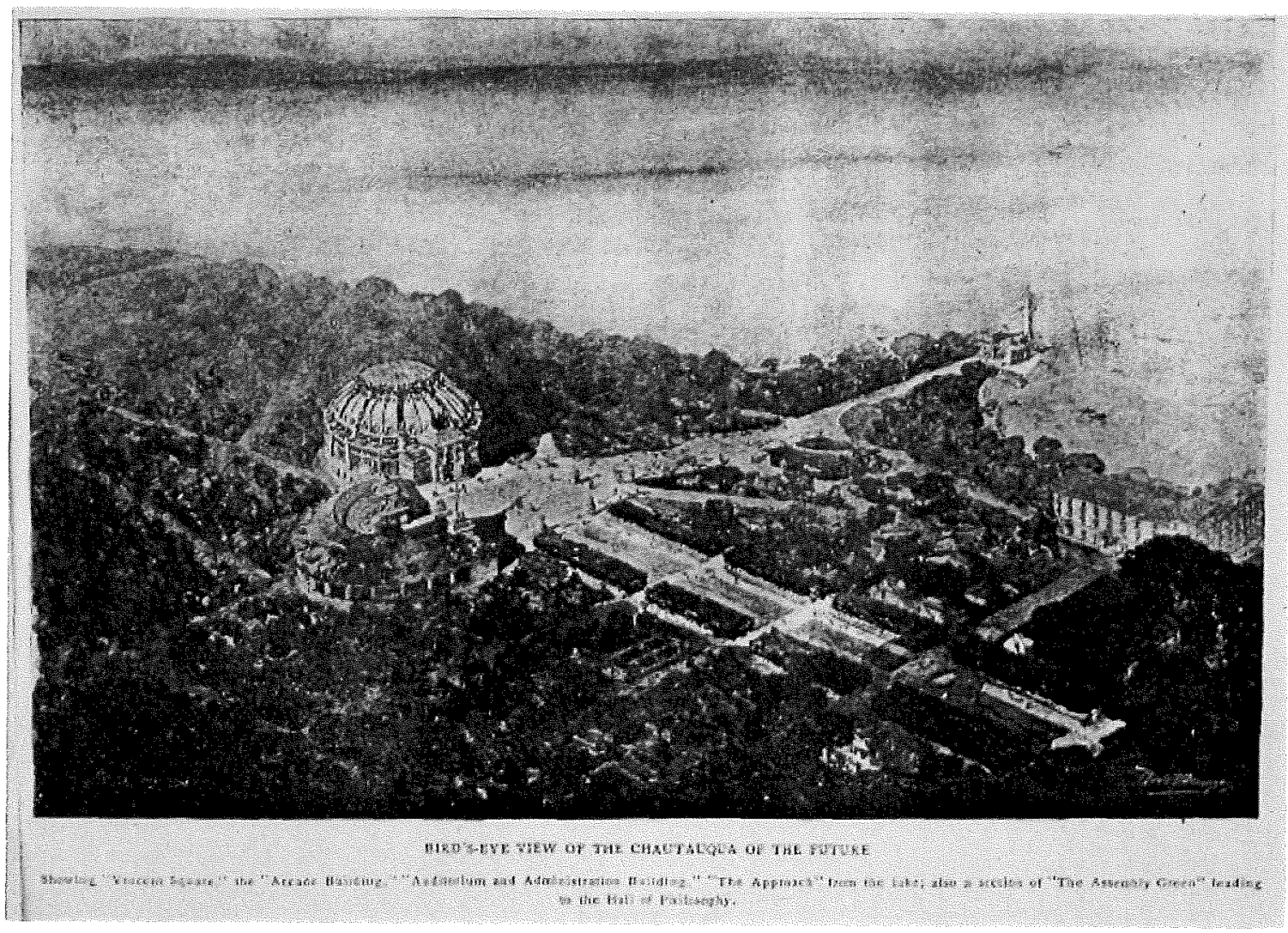

Figure 6.3

Albert Kelsey. Bird's-Eye View of the Chautauqua of the Future, 1903. (Courtesy of Chautauqua Institution Archives.) 


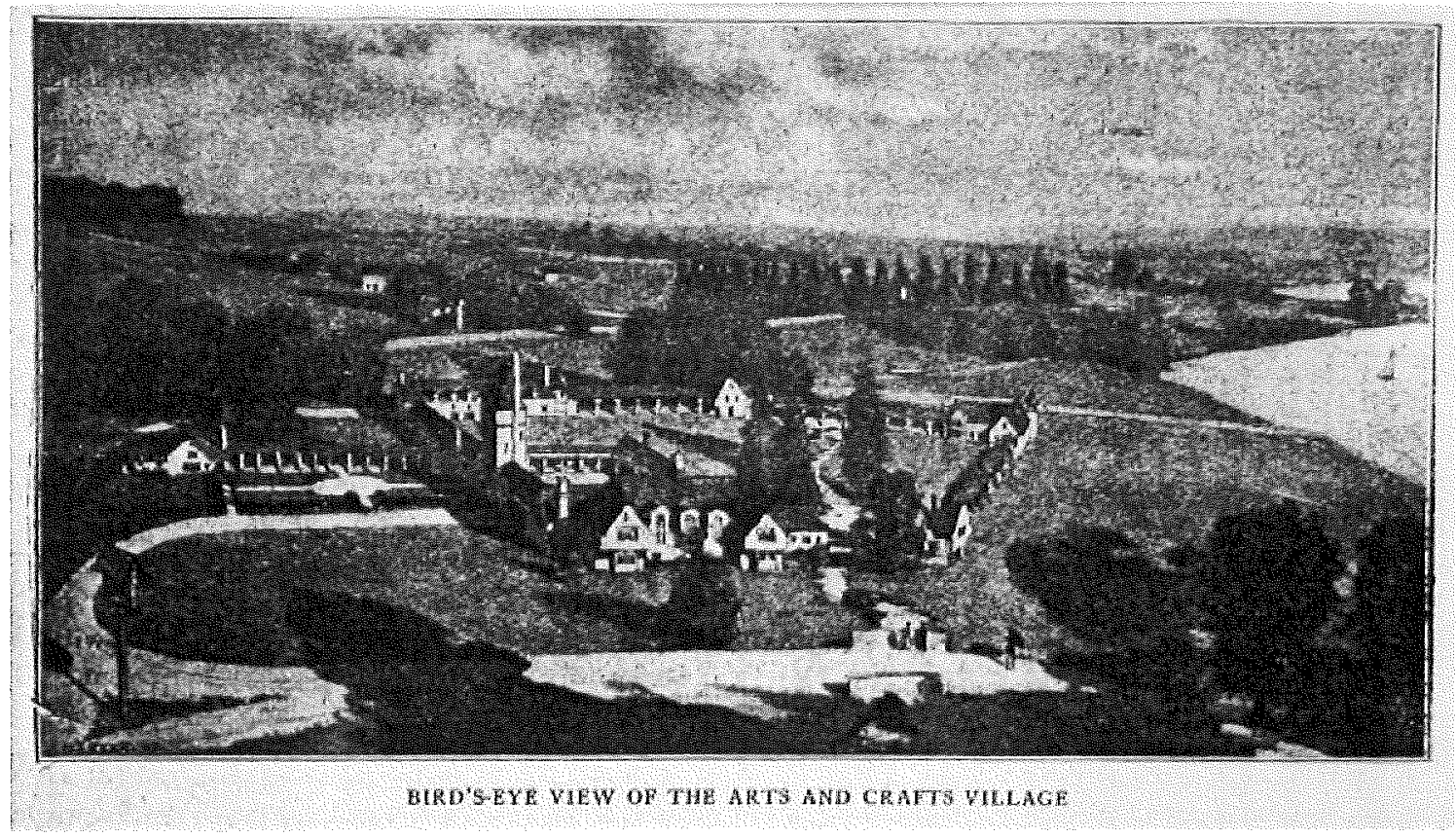

Figure 6.4

Albert Kelsey. Bird's-Eye View of Arts and Crafts Village, 1903. (Courtesy of Chautauqua Institution Archives.) 


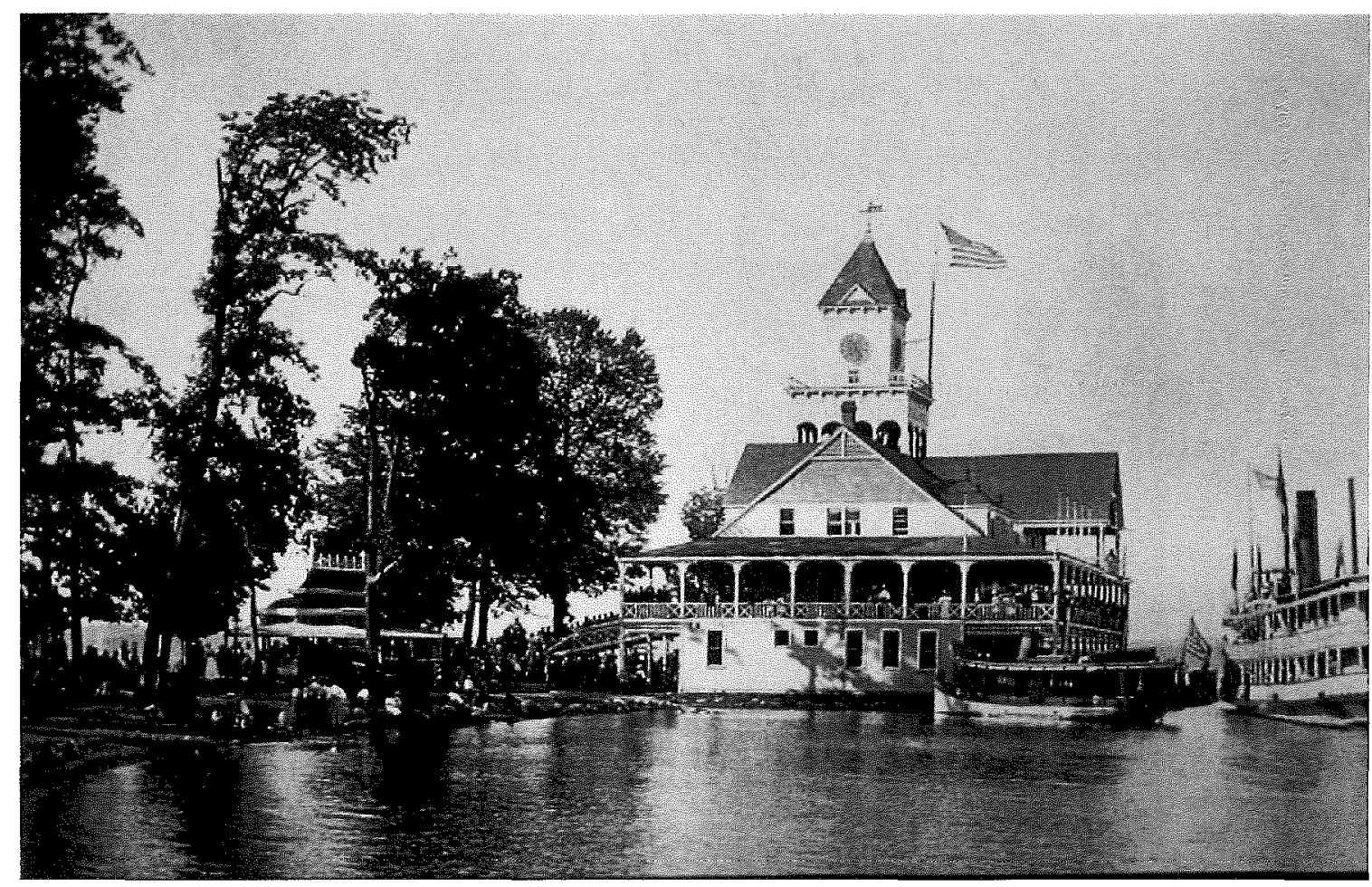

Figure 6.5

Chautauqua Pier, c. 1890. (Courtesy of Chautauqua Institution Archives.) 


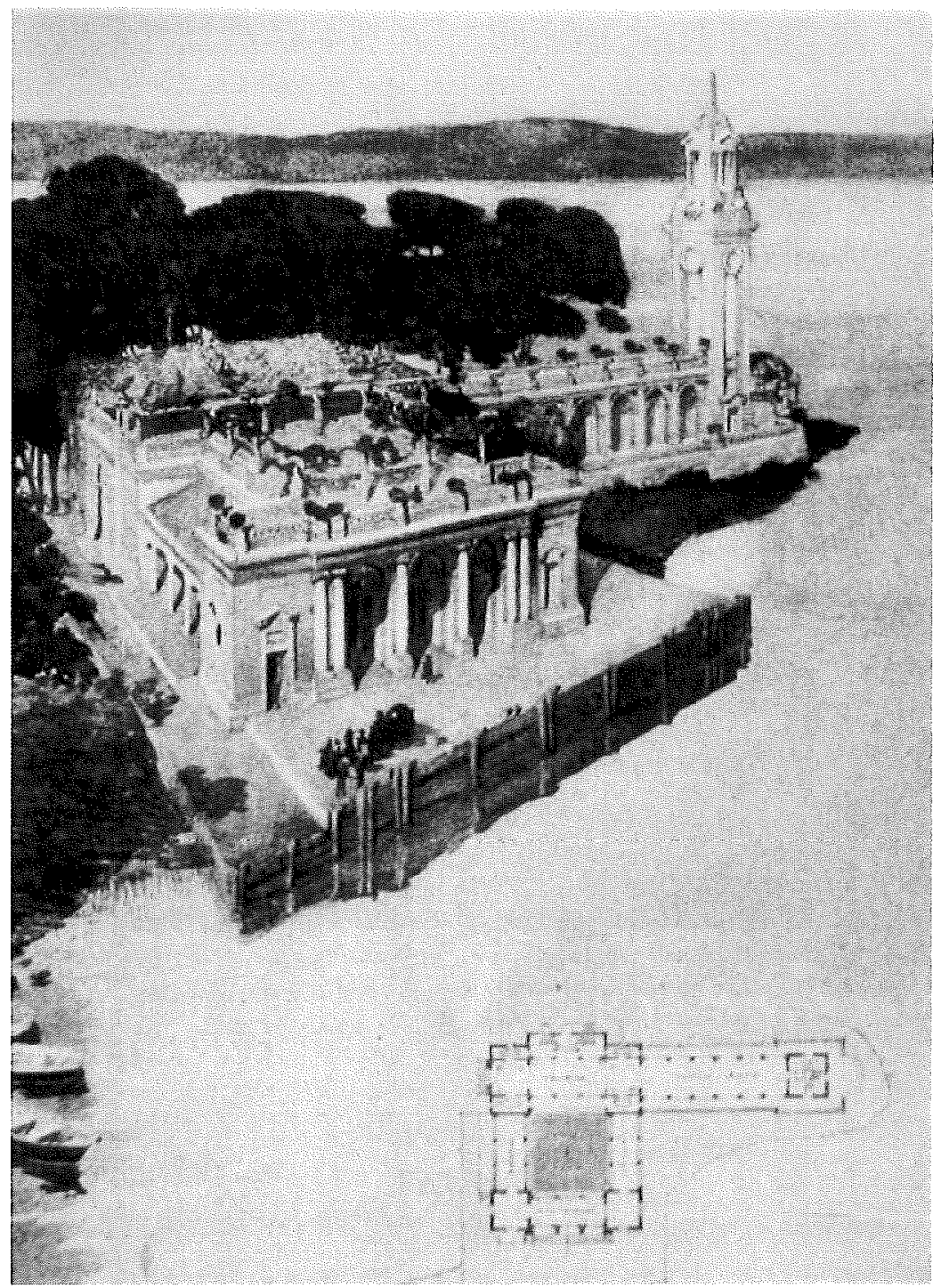

Figure 6.6

Albert Kelsey. Proposal for Chautauqua Pier Replacement, 1903. (Courtesy of Chautauqua Institution Archives.) 


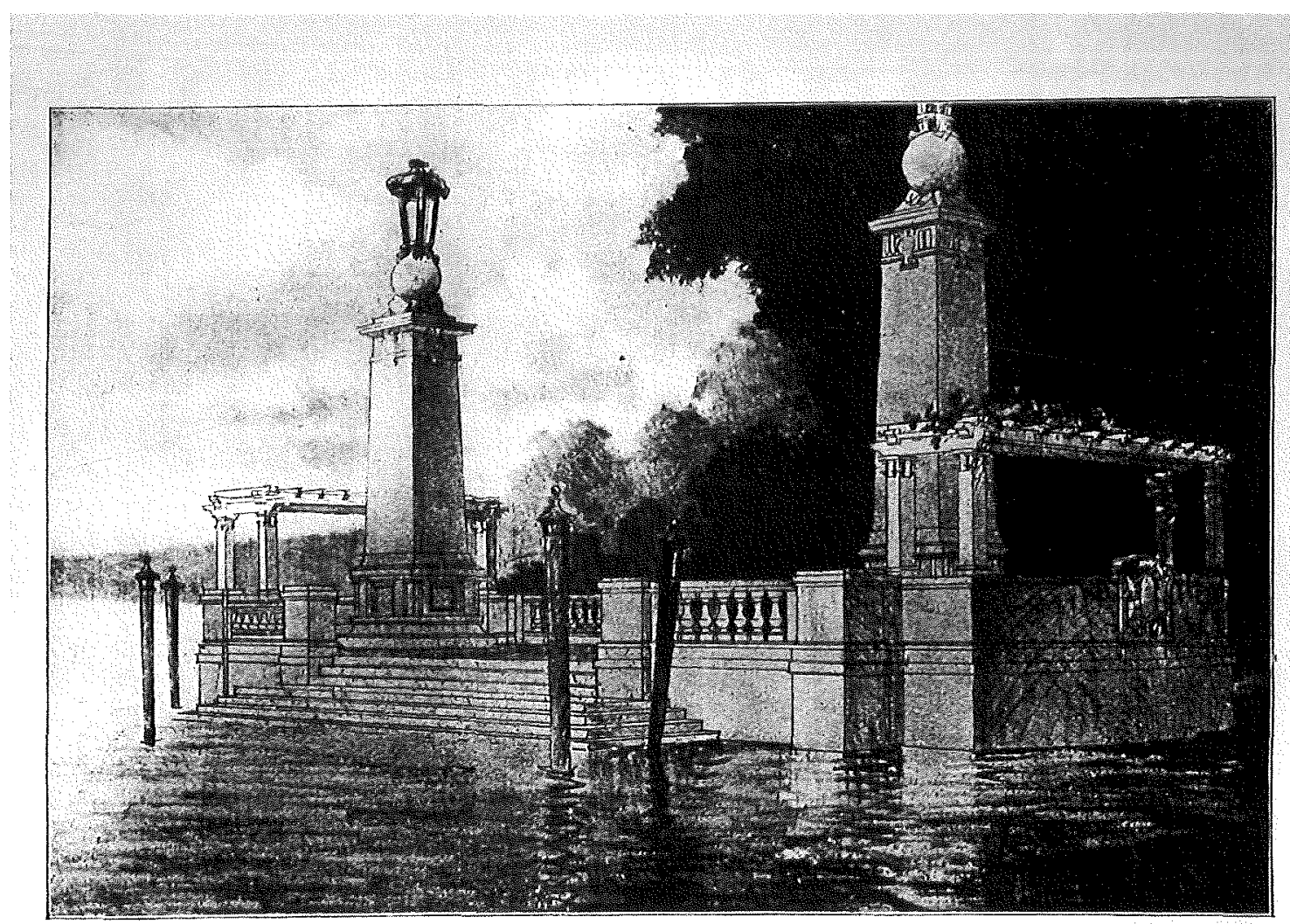

PROPOSED WATER APPROAGH TO THE HALL OF PHILOSOPHY

Figure 6.7

Albert Kelsey. Proposed Water Approach to the Hall of Philosophy. (Courtesy of Chautauqua Institution Archives.) 


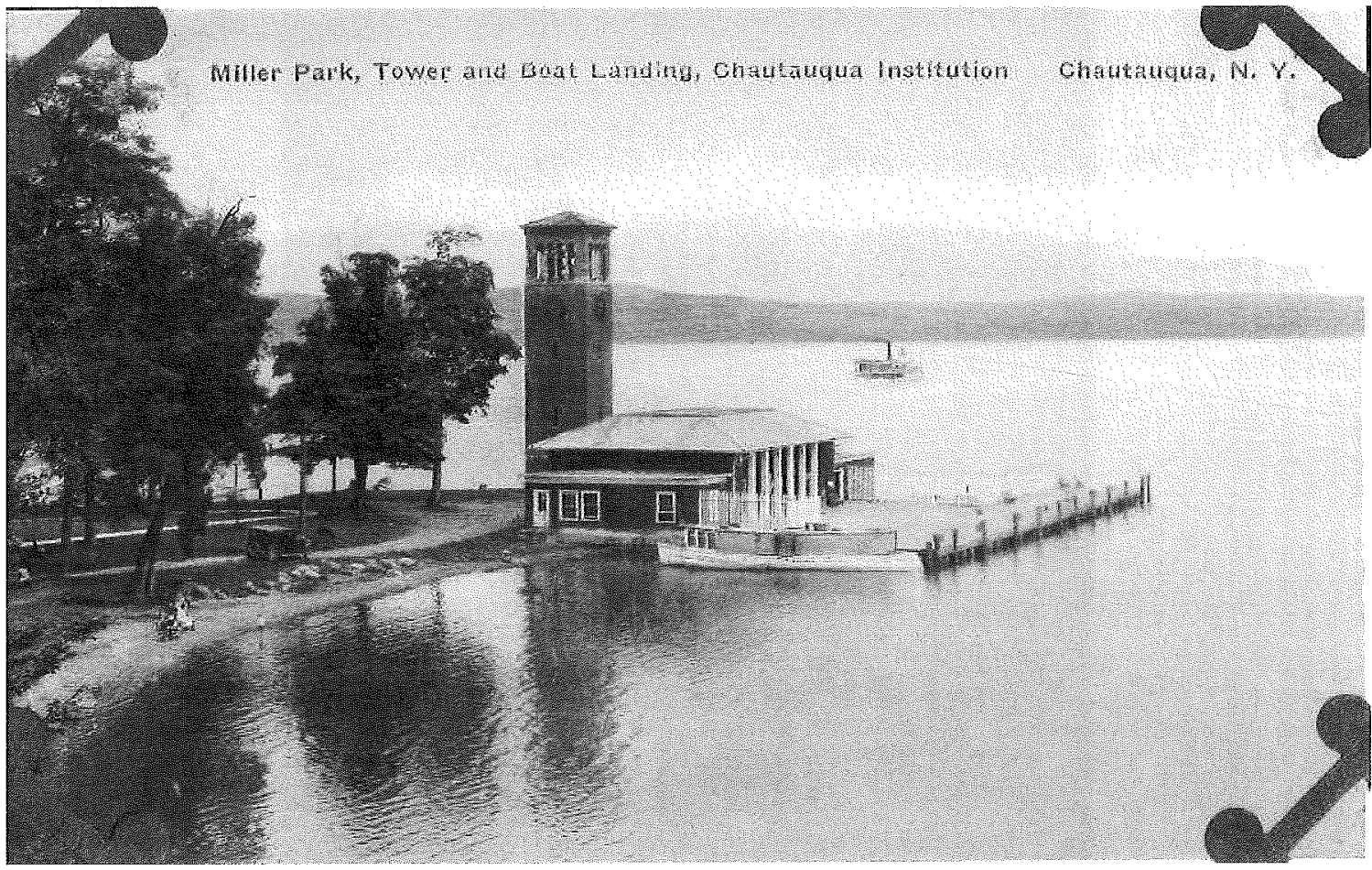

Figure 6.8

E. B. Green, Sr. Miller Park, Tower and Boat Landing, 1911, postcard. (Courtesy of Chautauqua Institution Archives.) 

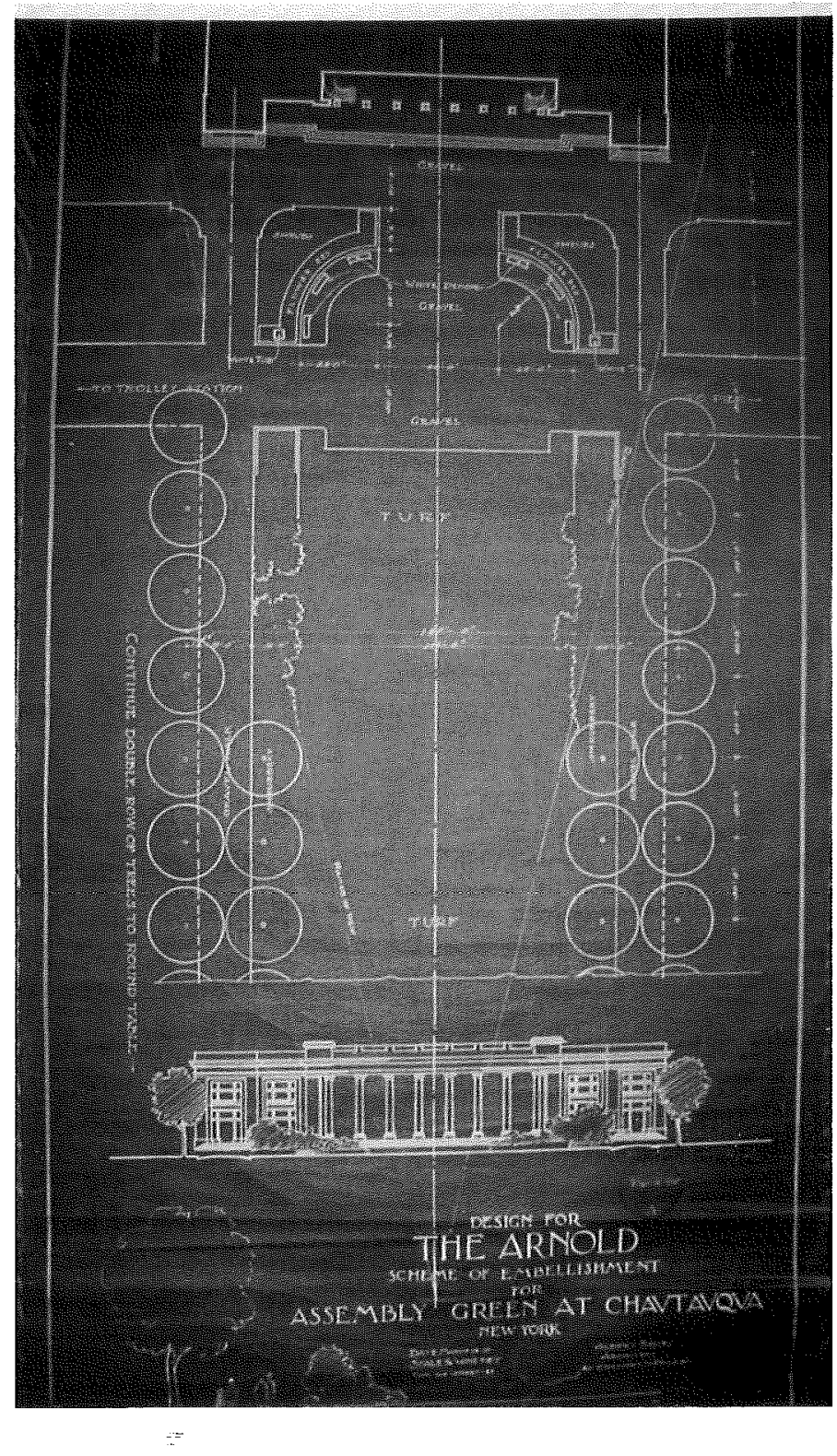

Figure 6.9

Albert Kelsey. The Arnold, 1906. (Courtesy of Chautauqua Institution Archives.) 


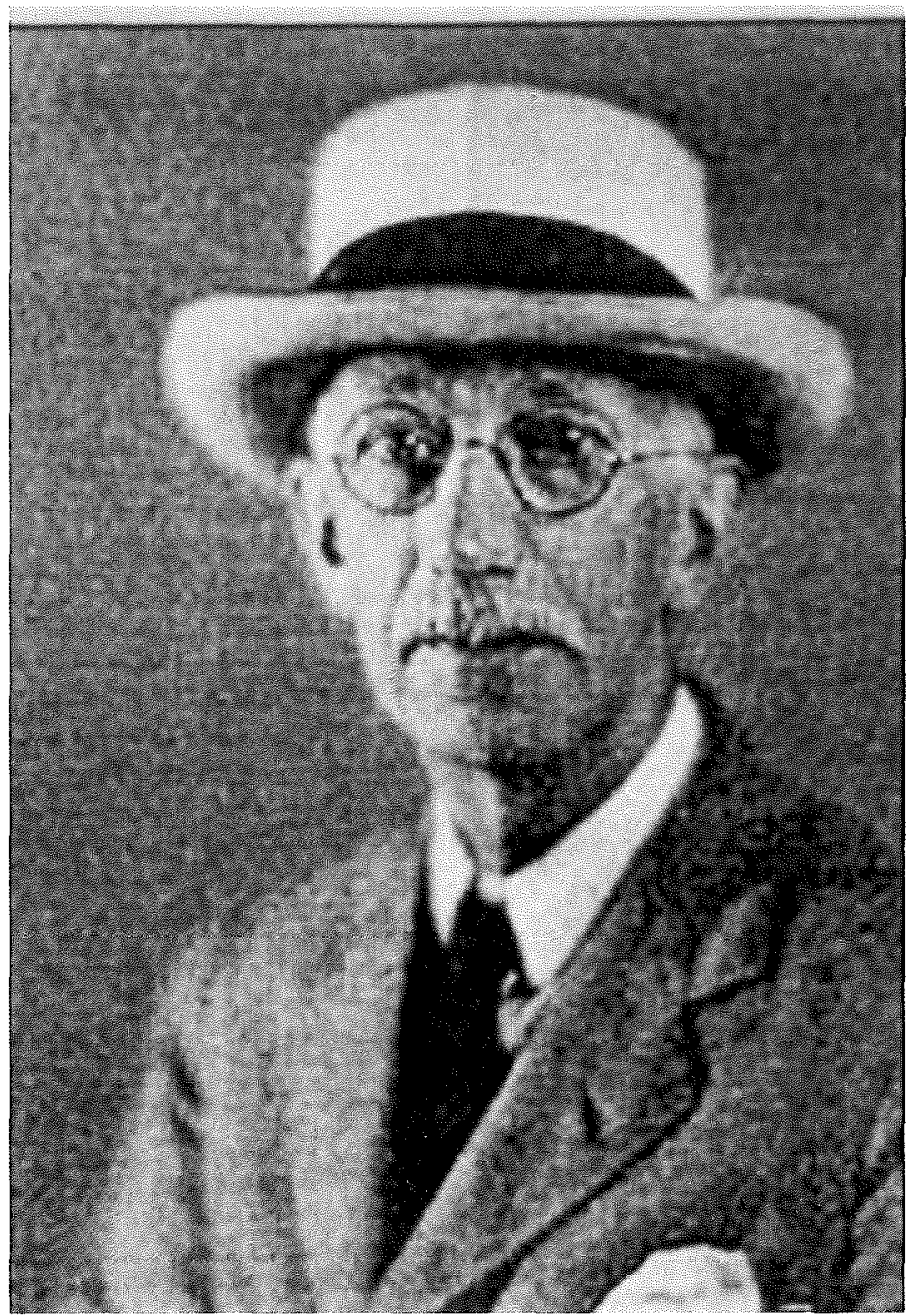

Figure 6.10

Edward B. Green. (Buffalo as an Architectural Museum. Web.) 


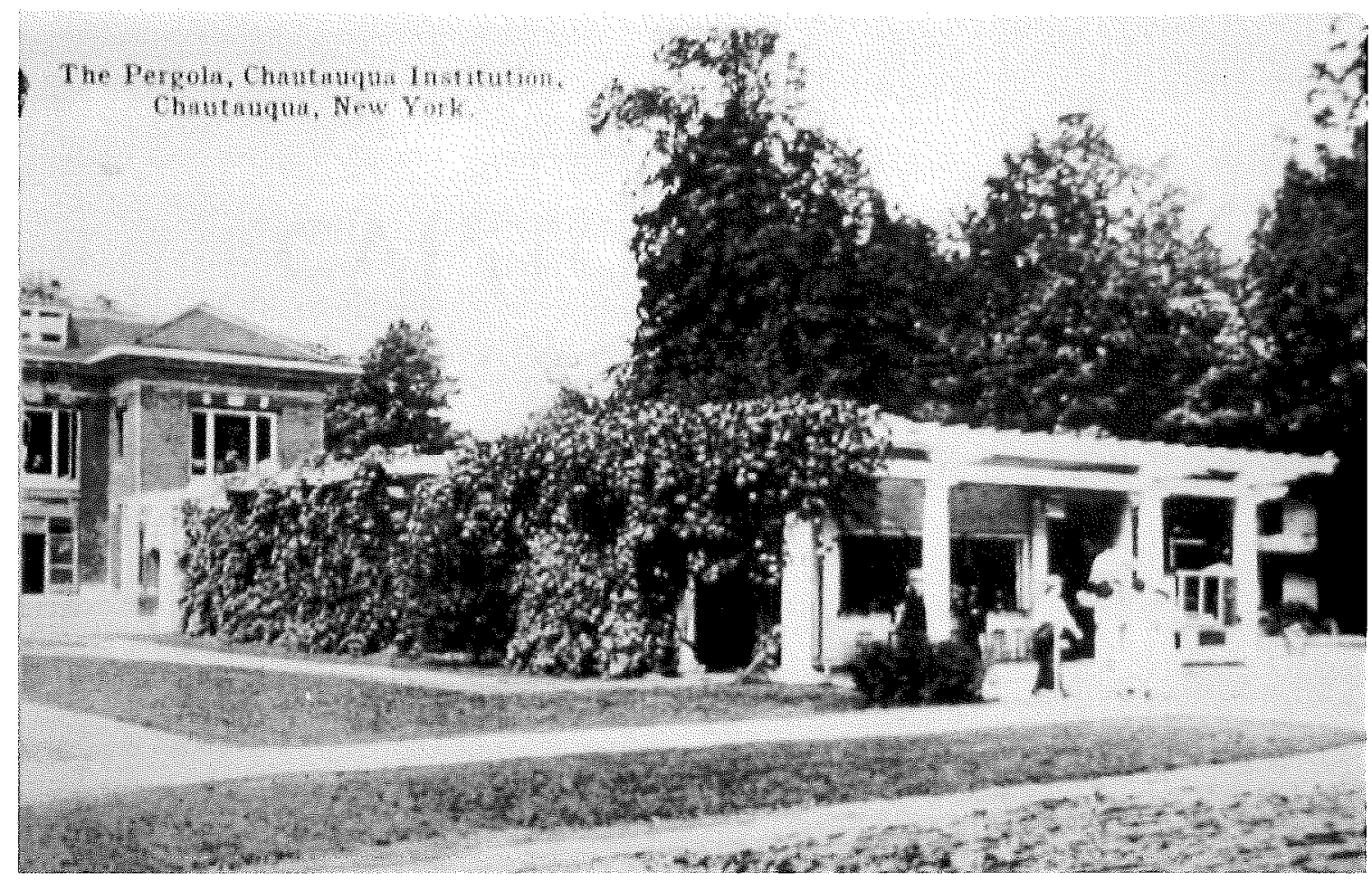

Figure 6.11

Edward B. Green. The Pergola, 1908, postcard, c. 1915. (Courtesy collection of John Cofield.) 


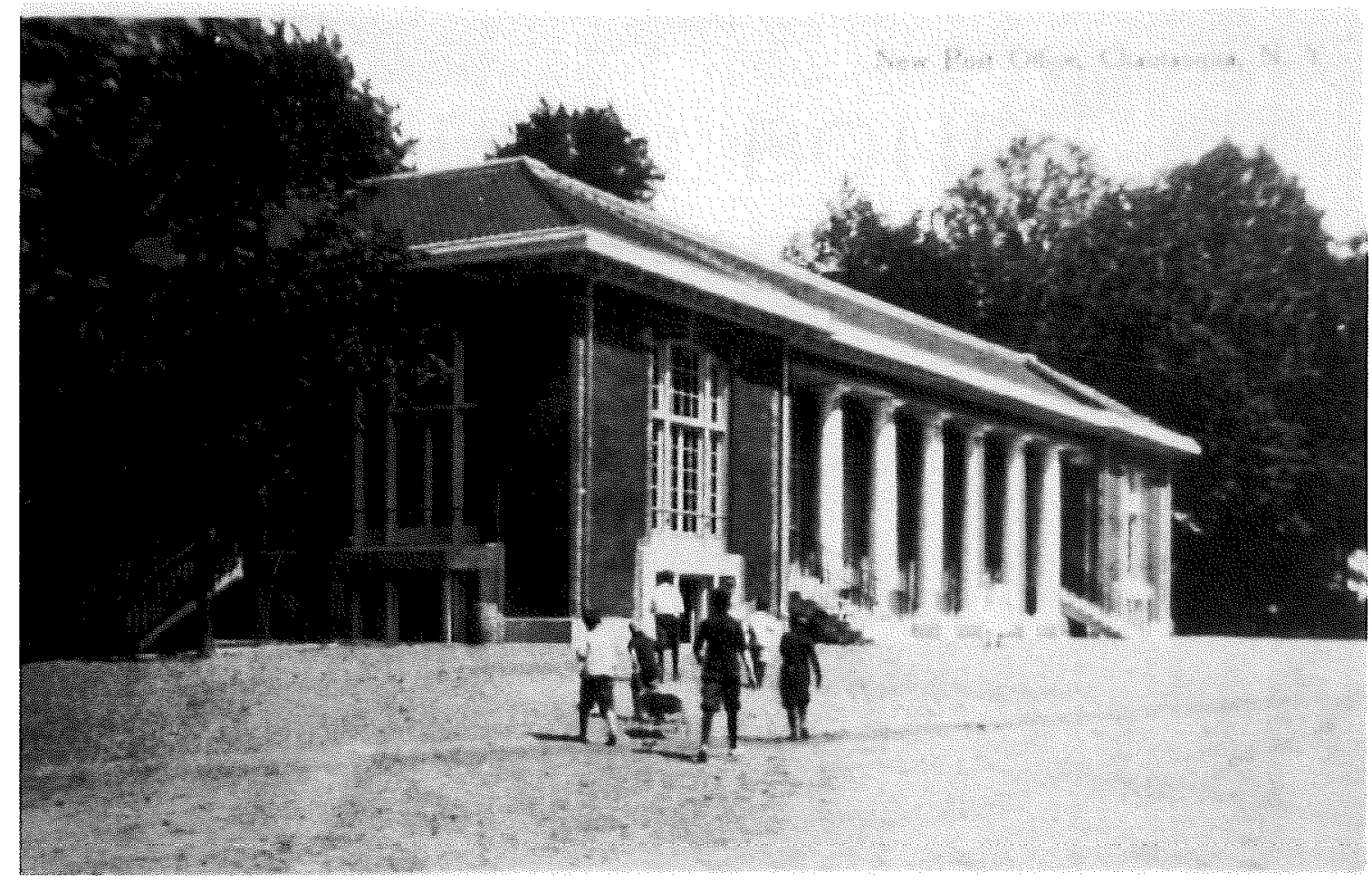

Figure 6.12

Edward B. Green. New Post Office, 1909, postcard, c. 1910. (Courtesy collection of John Cofield.) 


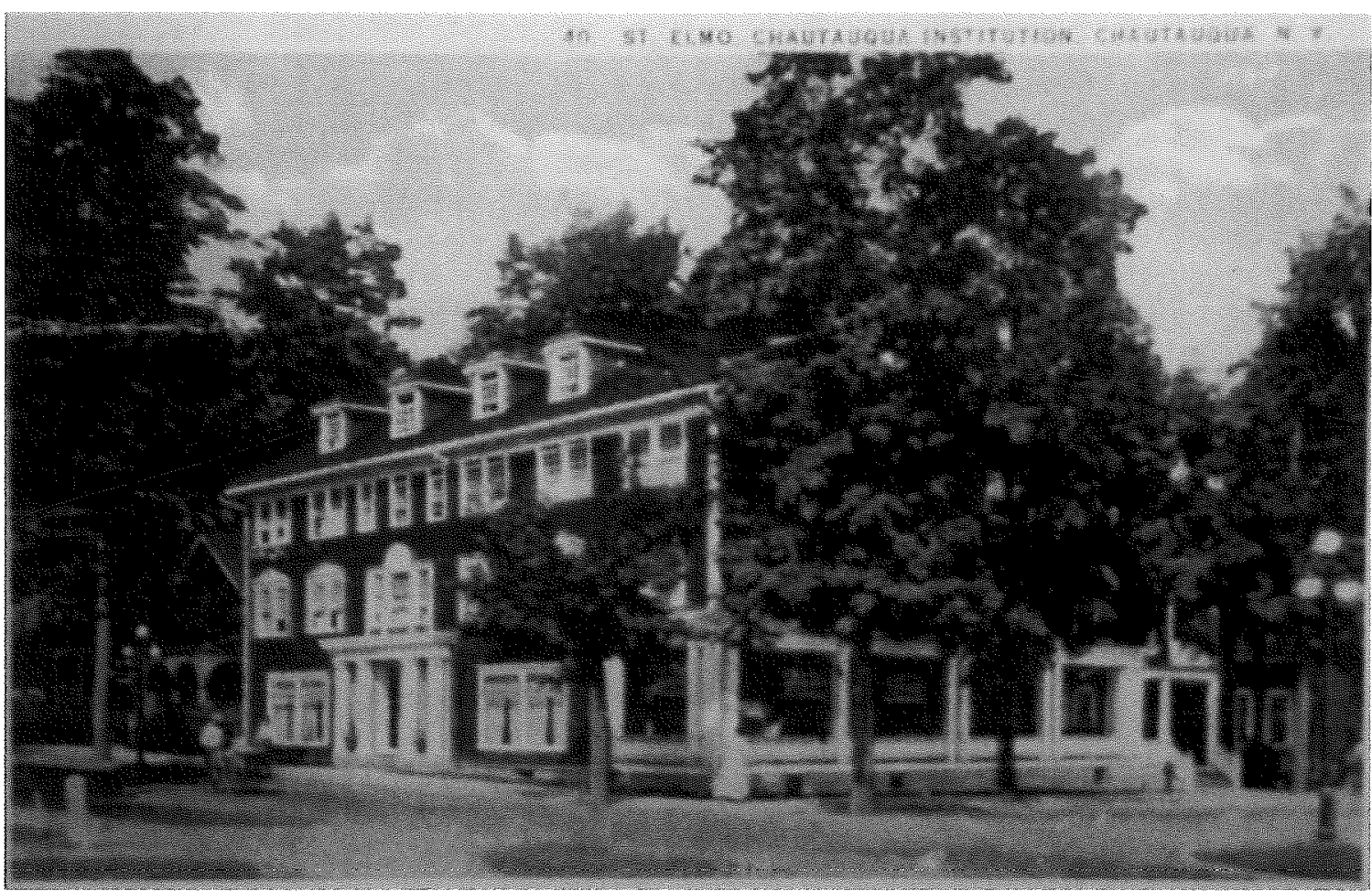

Figure 6.13

St. Elmo Hotel, postcard, c. 1910. (Courtesy collection of John Cofield.) 


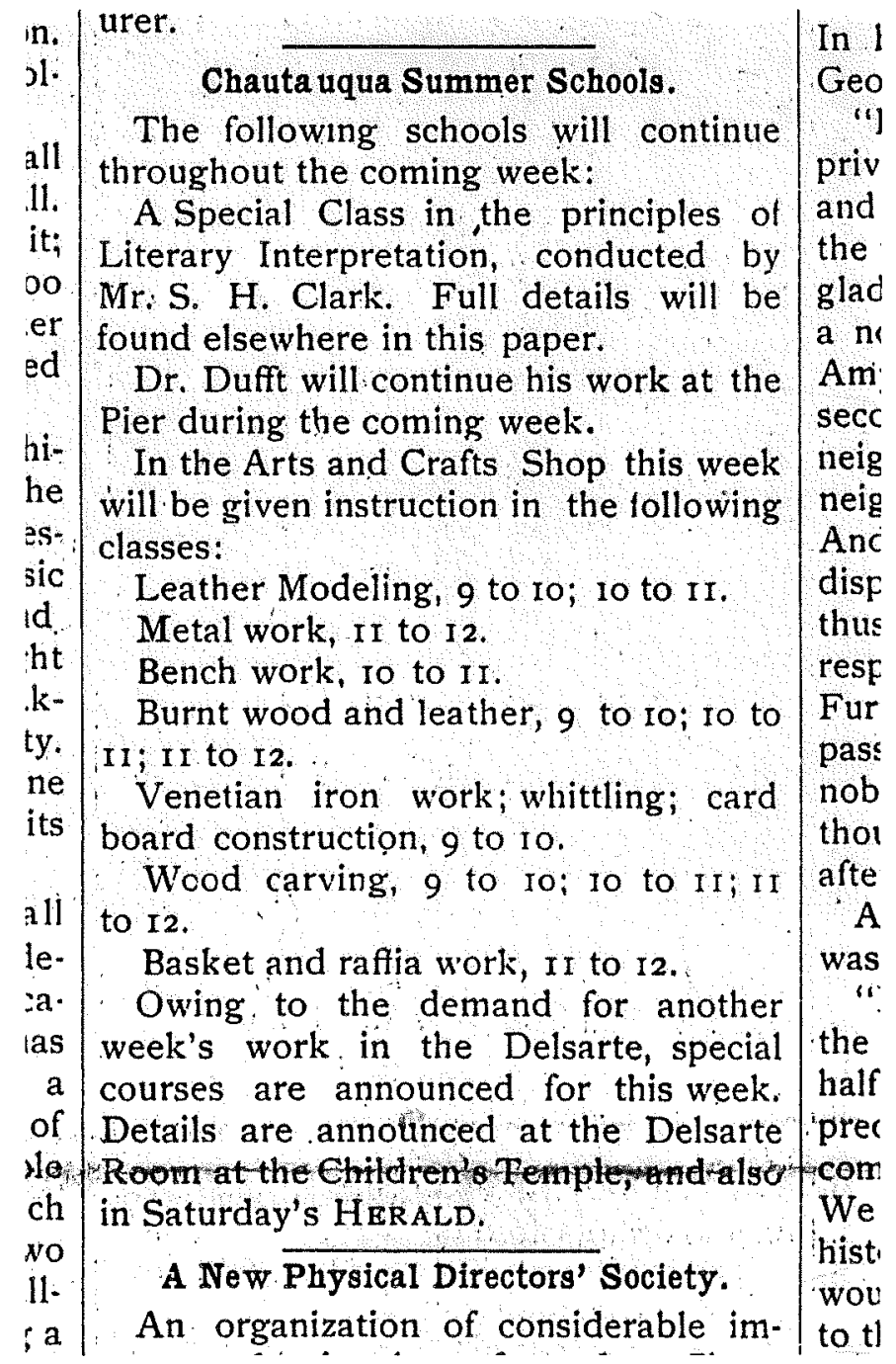

Figure 6.14

Arts and Crafts Course Listing. (Chautauqua Assembly Herald 18 Aug. 1902: 1.) 


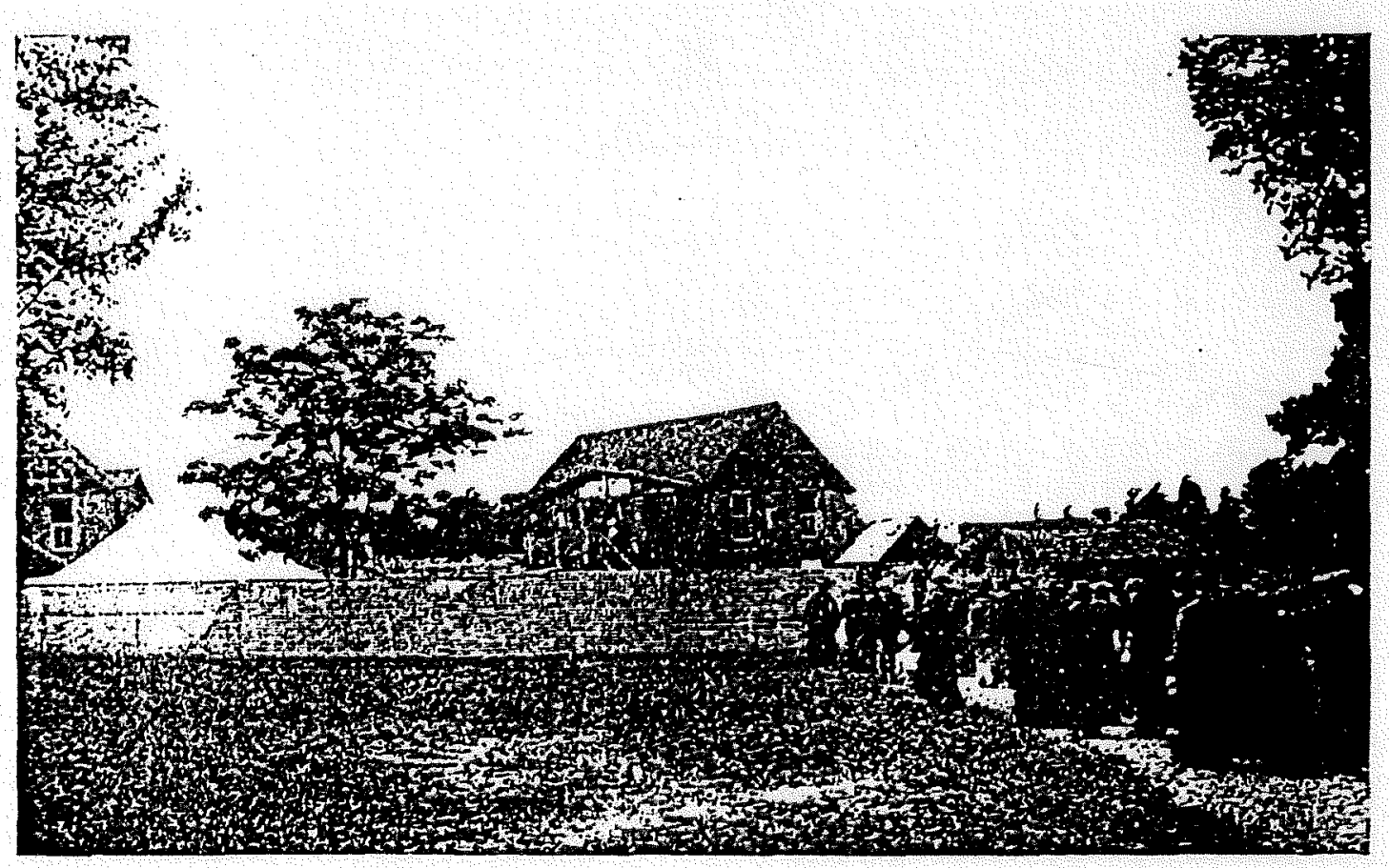

Arts AND CRAftS Vlllace

Figure 6.15

Arts and Crafts Village, c. 1902. (Frank Chapin Bray. A Reading Journey Through Chautauqua, 39.) 


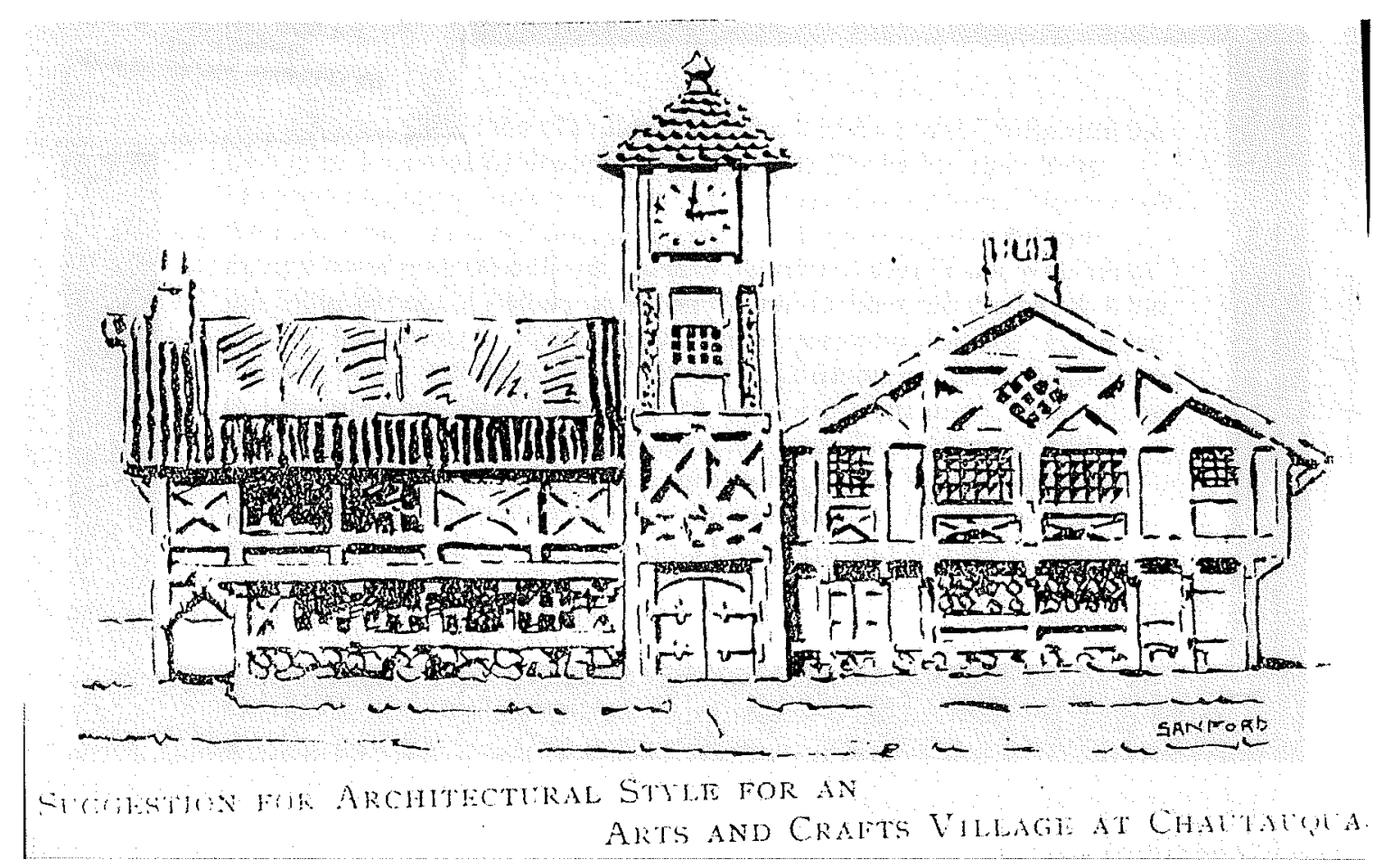

Figure 6.16

Frank G. Sanford. Suggestion for Architectural Style for an Arts and Crafts Village at Chautauqua. (Chautauqua Assembly Herald 20 Aug. 1902: 1.) 


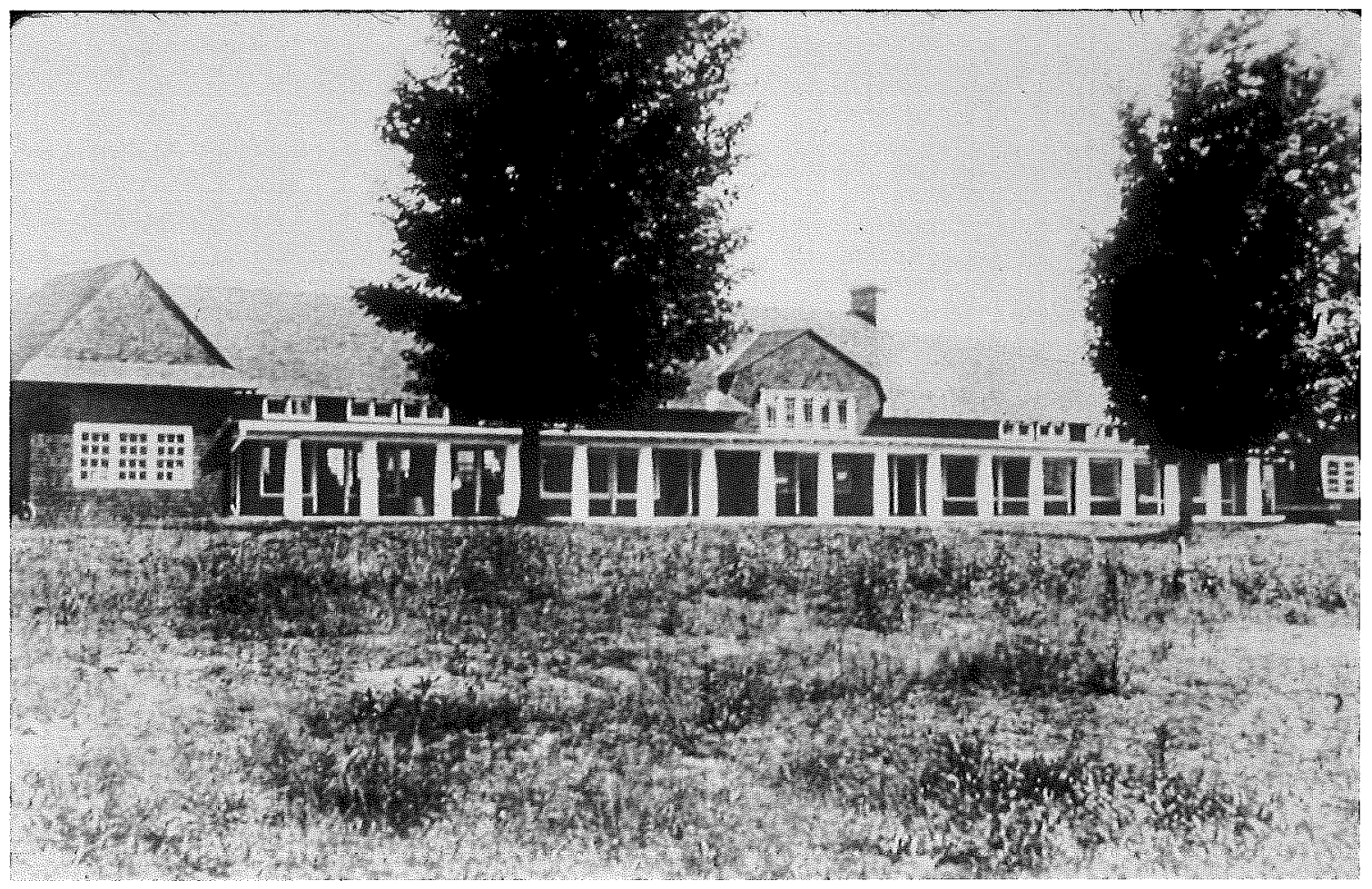

Figure 6.17

Edward B. Green. Arts and Crafts Quadrangle, 1909, original section. (Courtesy of Chautauqua Institution Archives.) 


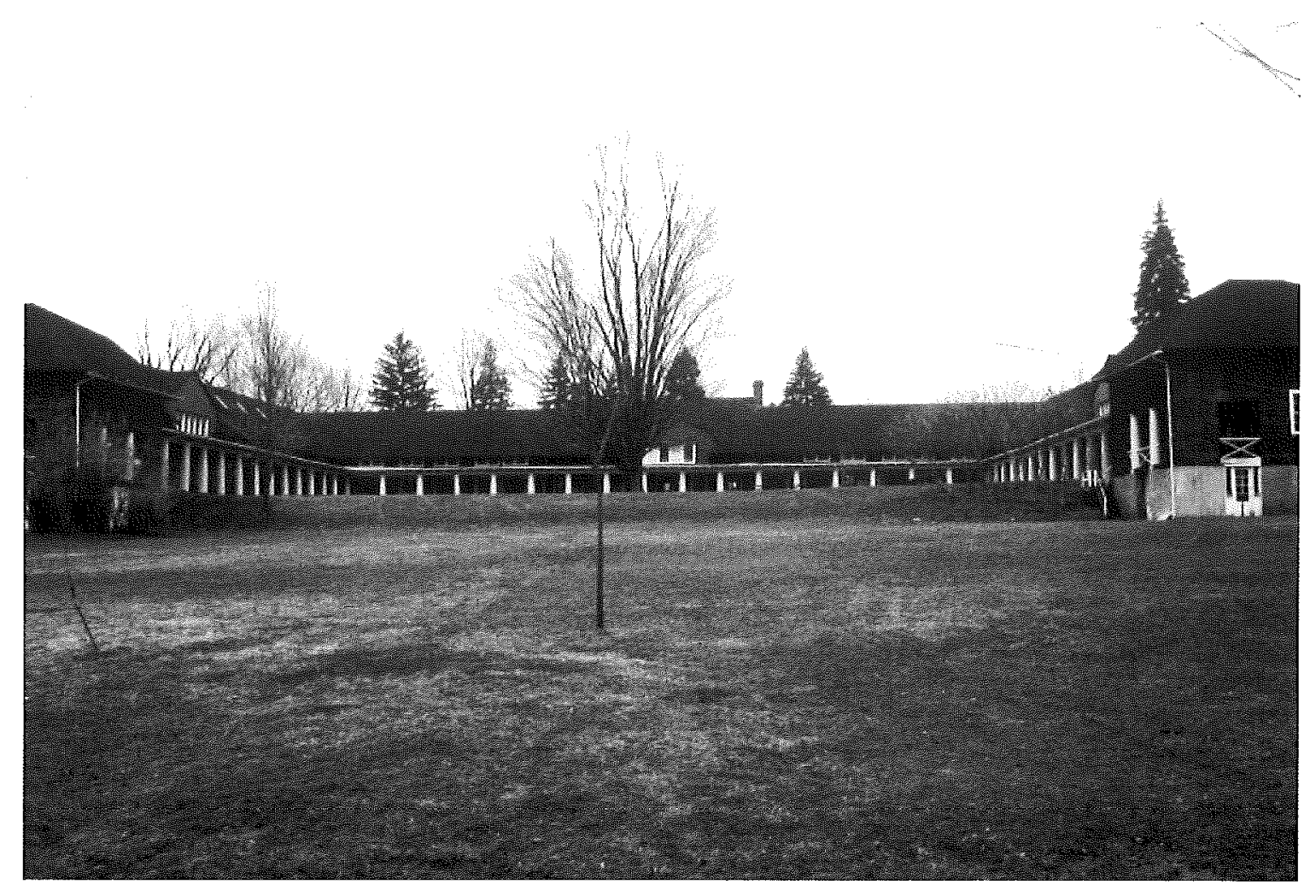

Figure 6.18

Edward B. Green. Arts and Crafts Quadrangle, 1909-1917. (Author's photograph, 2000.) 


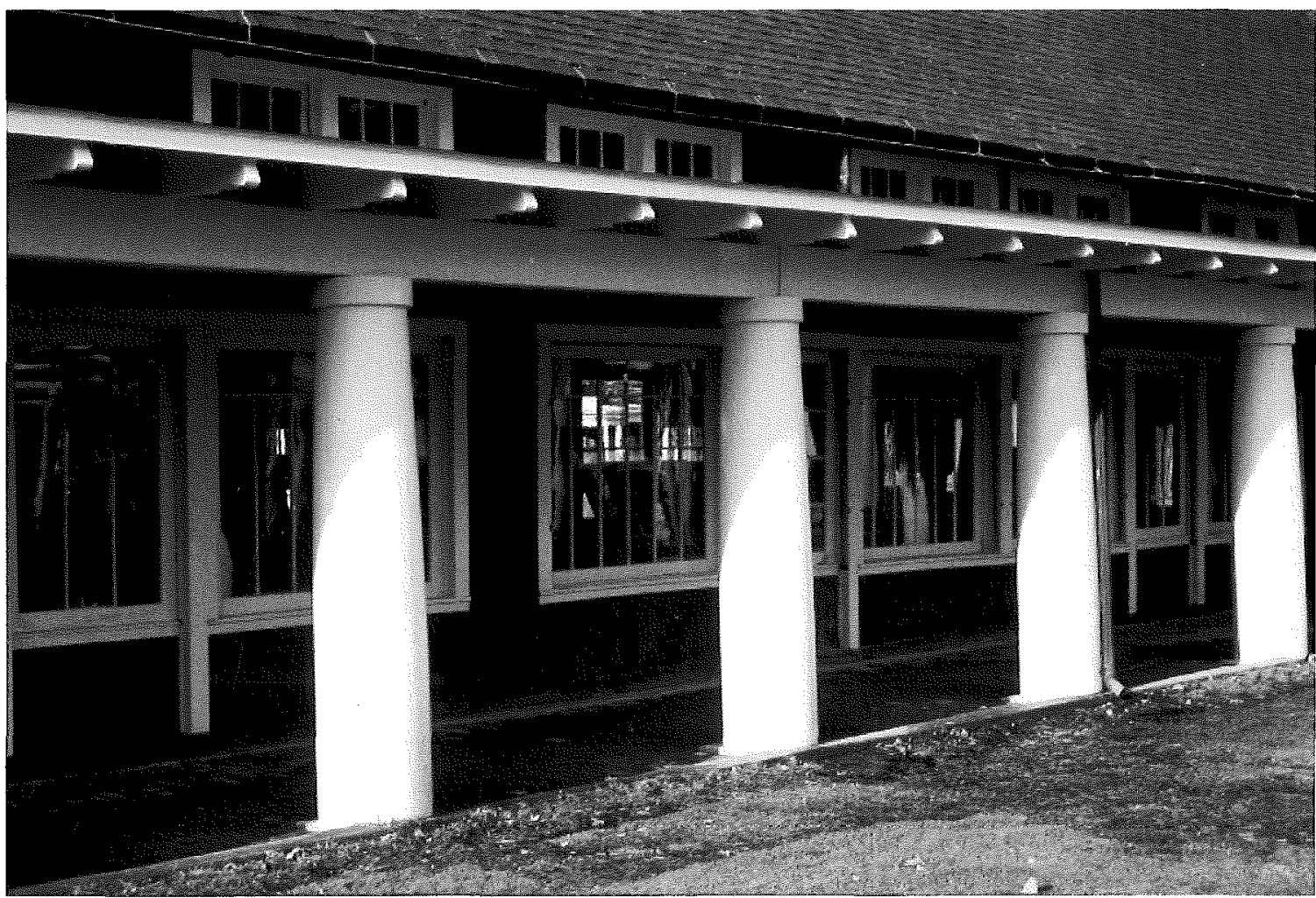

Figure 6.19

Edward B. Green. Arts and Crafts Quadrangle, 1909-1917, colonnade detail. (Author's photograph, 2000.) 


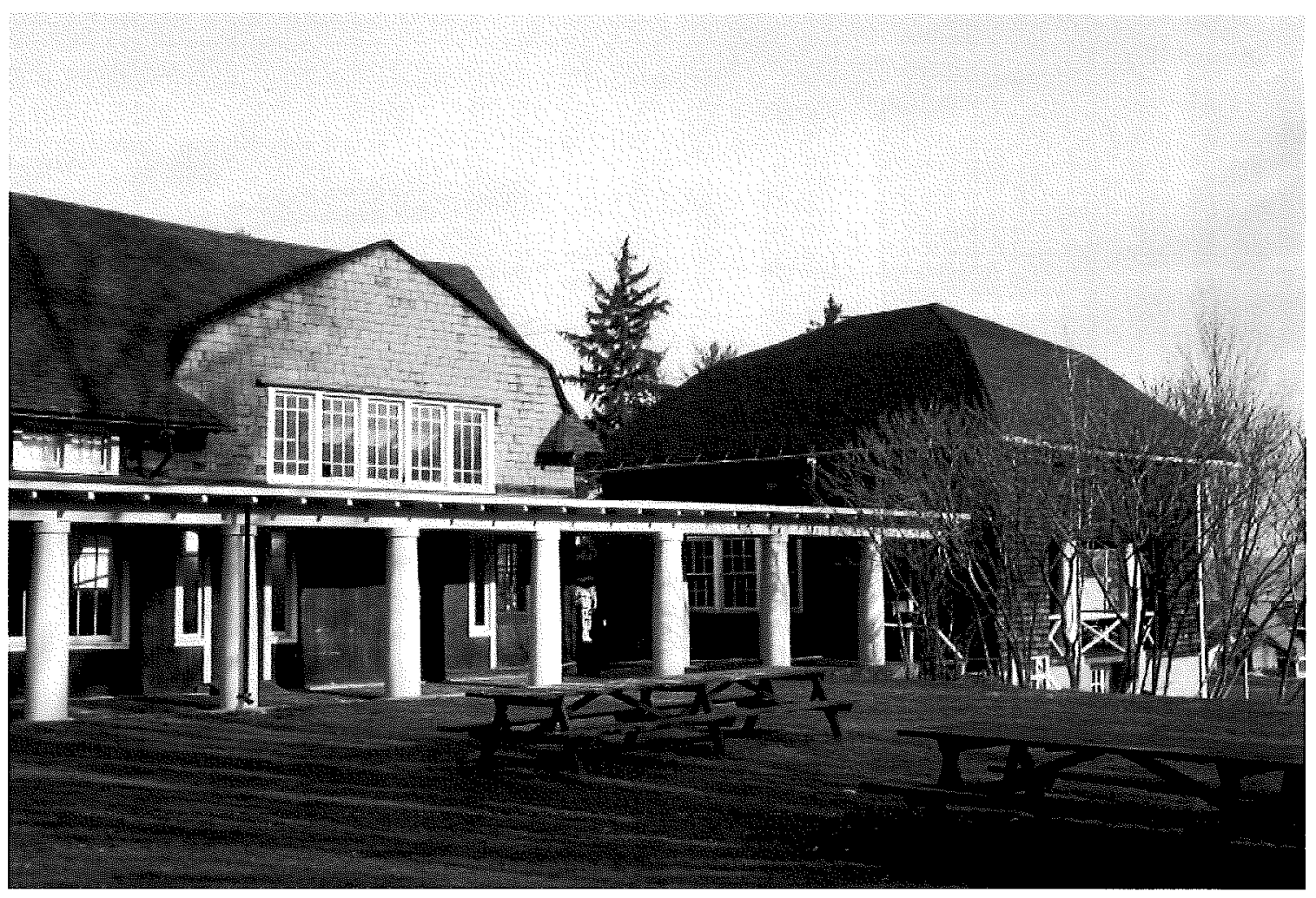

Figure 6.20

Edward B. Green. Arts and Crafts Quadrangle, c. 1917, pavilion detail. (Author's photograph, 2000.) 

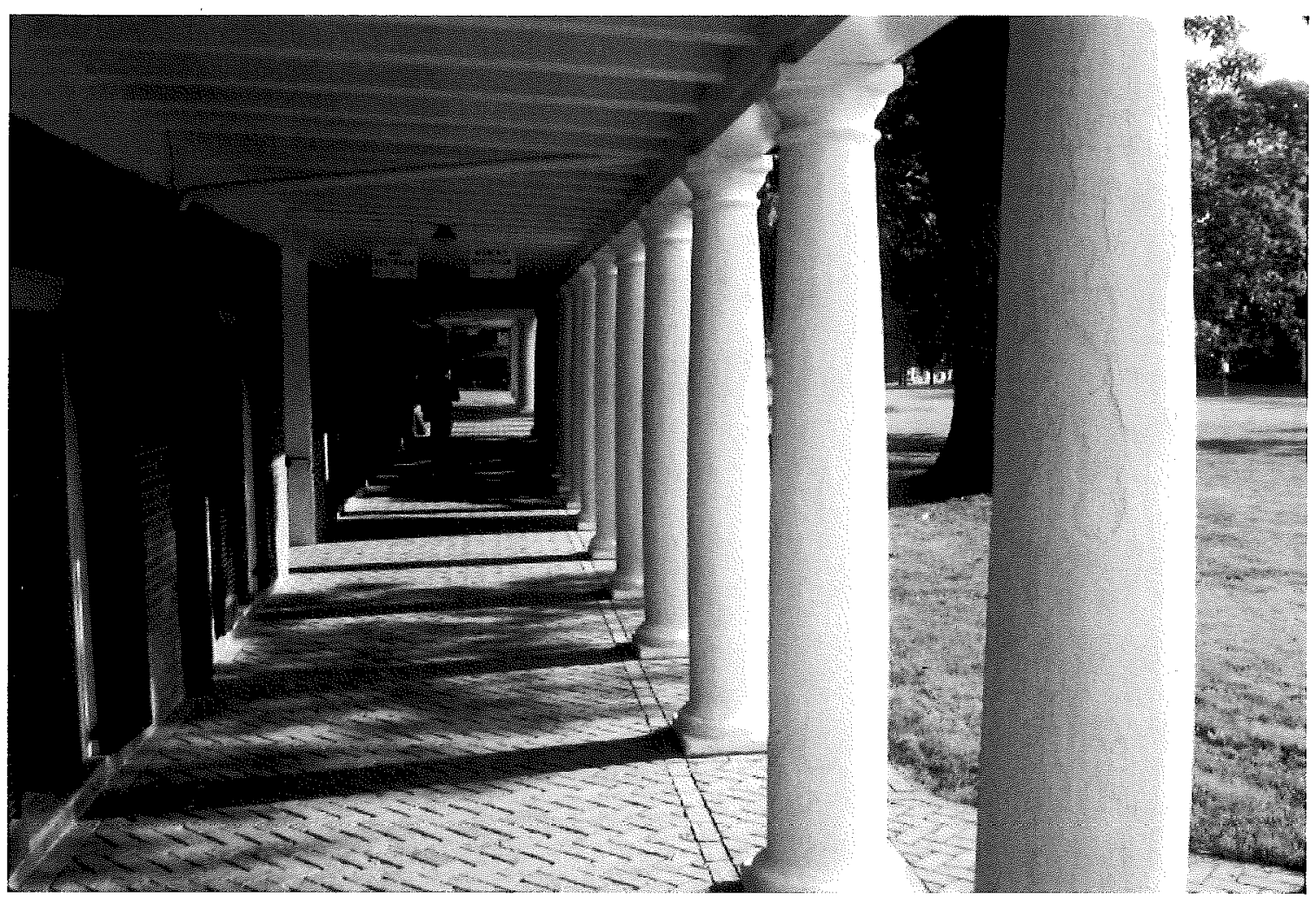

Figure 6.21

Thomas Jefferson. The Lawn, University of Virginia, 1817-1826, colonnade detail. (Author's photograph, 2000.) 


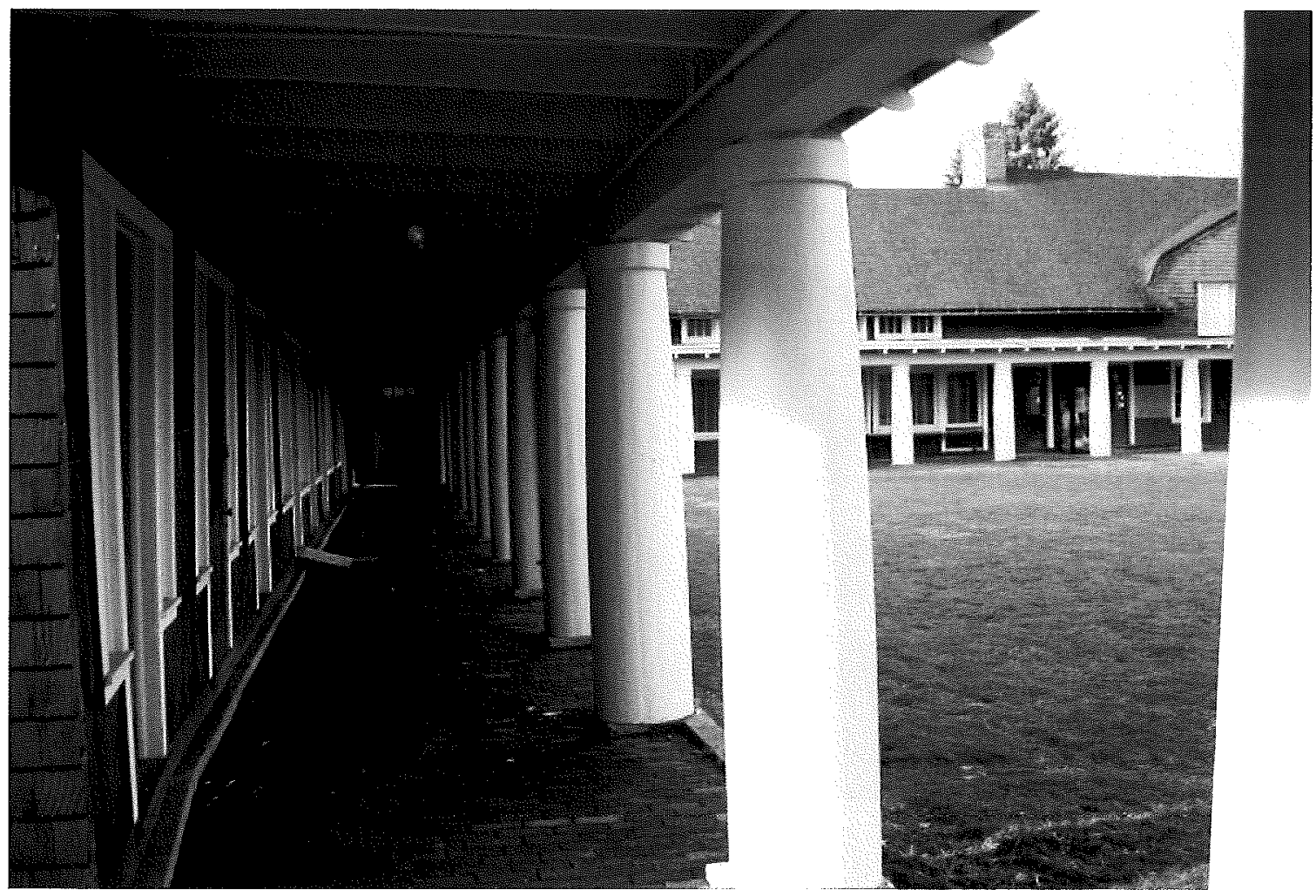

Figure 6.22

Edward B. Green. Arts and Crafts Quadrangle, 1909-1917, colonnade detail. (Author's photograph, 2000.) 


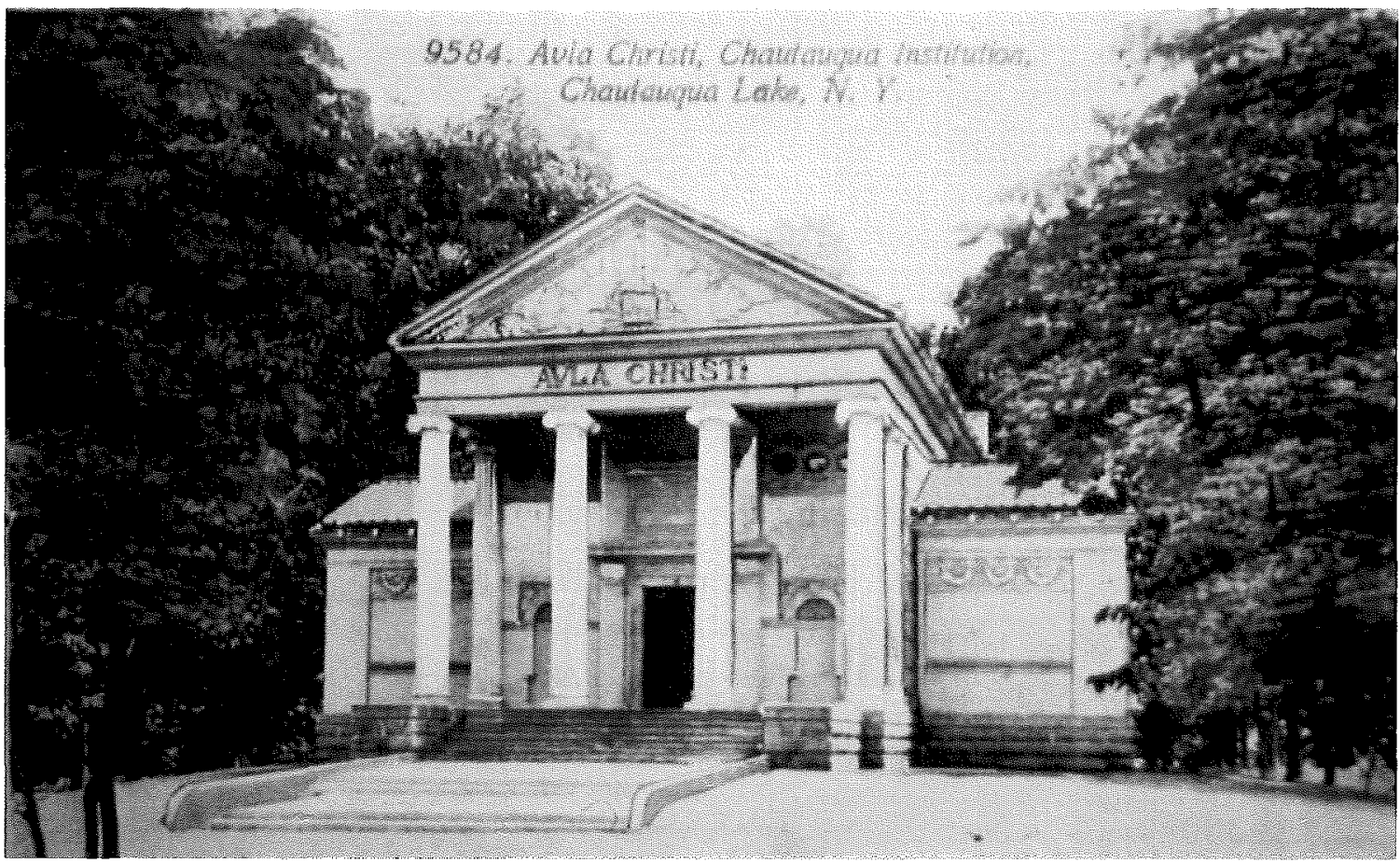

Figure 6.23

Paul Pelz. Aula Christi (Hall of Christ), 1909, postcard. (Courtesy collection of John Cofield.) 


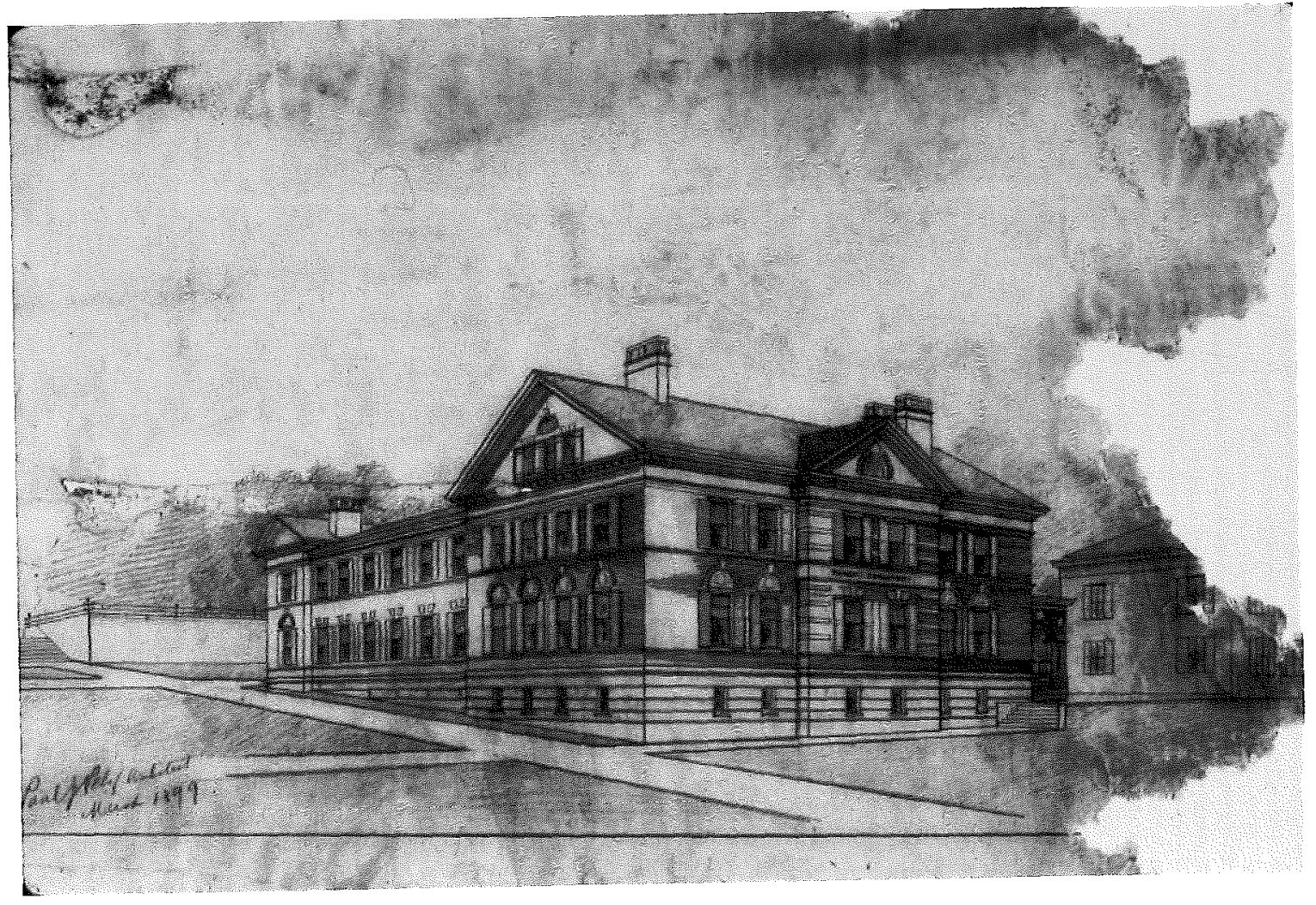

Figure 6.24

Paul Pelz. Randall Hall, University of Virginia, 1899. (Courtesy of University of Virginia slide library.) 


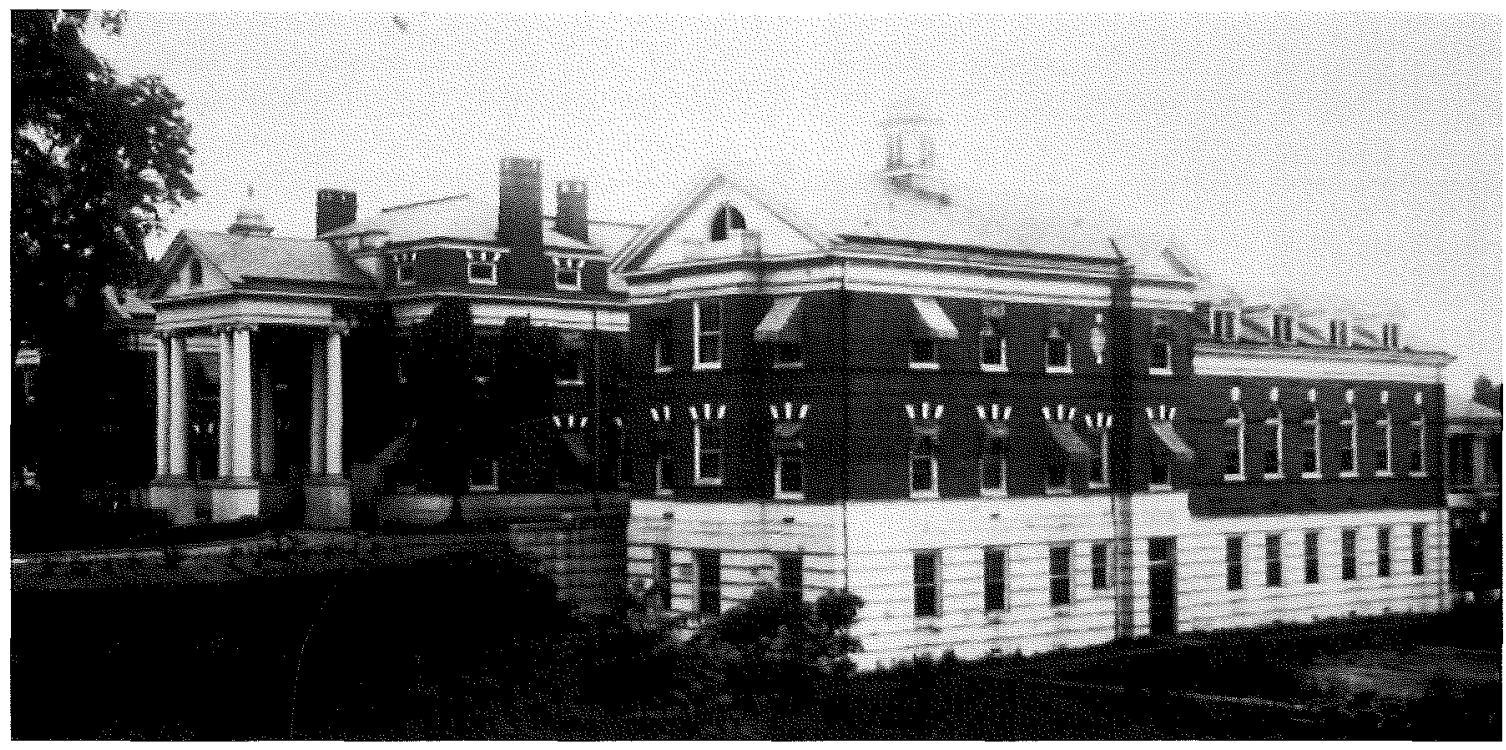

Figure 6.25

Paul Pelz. Medical School, University of Virginia, 1901-04. (Courtesy of University of Virginia slide library.) 


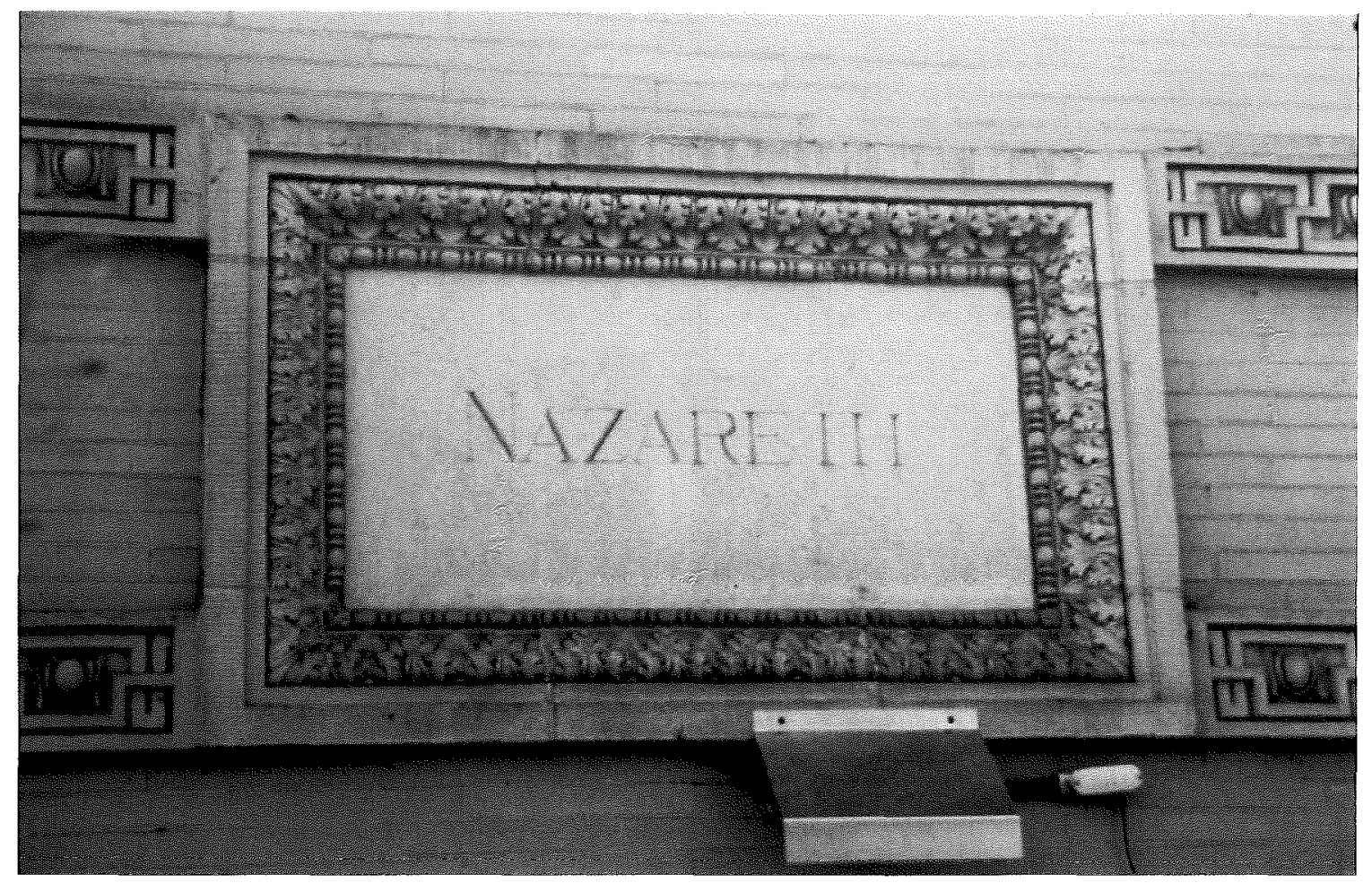

Figure 6.26

Paul Pelz. "Nazareth," Hall of Christ, 1909. (Author's photograph, 2000.) 


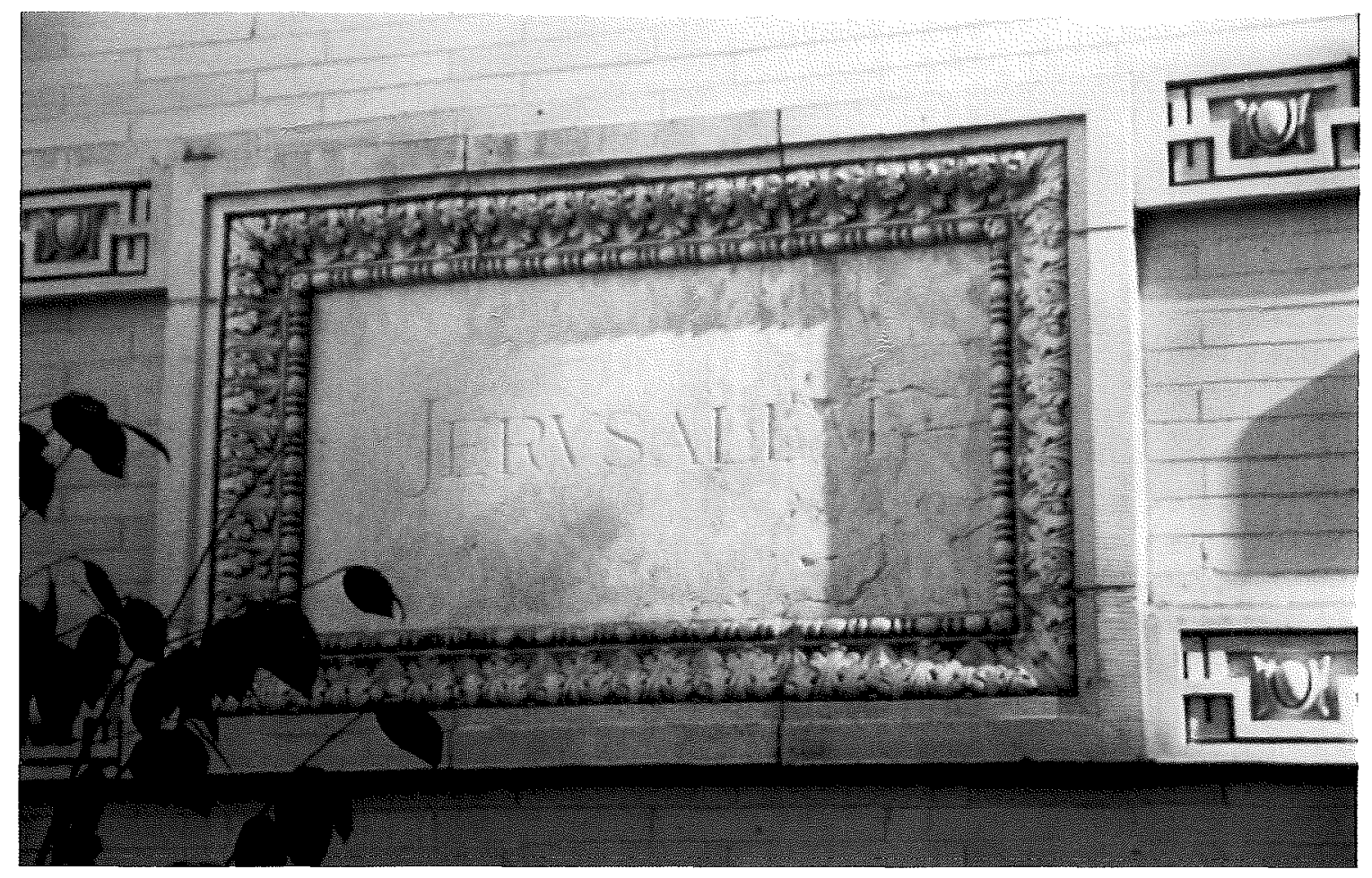

Figure 6.27

Paul Pelz. "Jerusalem," Hall of Christ, 1909. (Author's photograph, 2000.) 


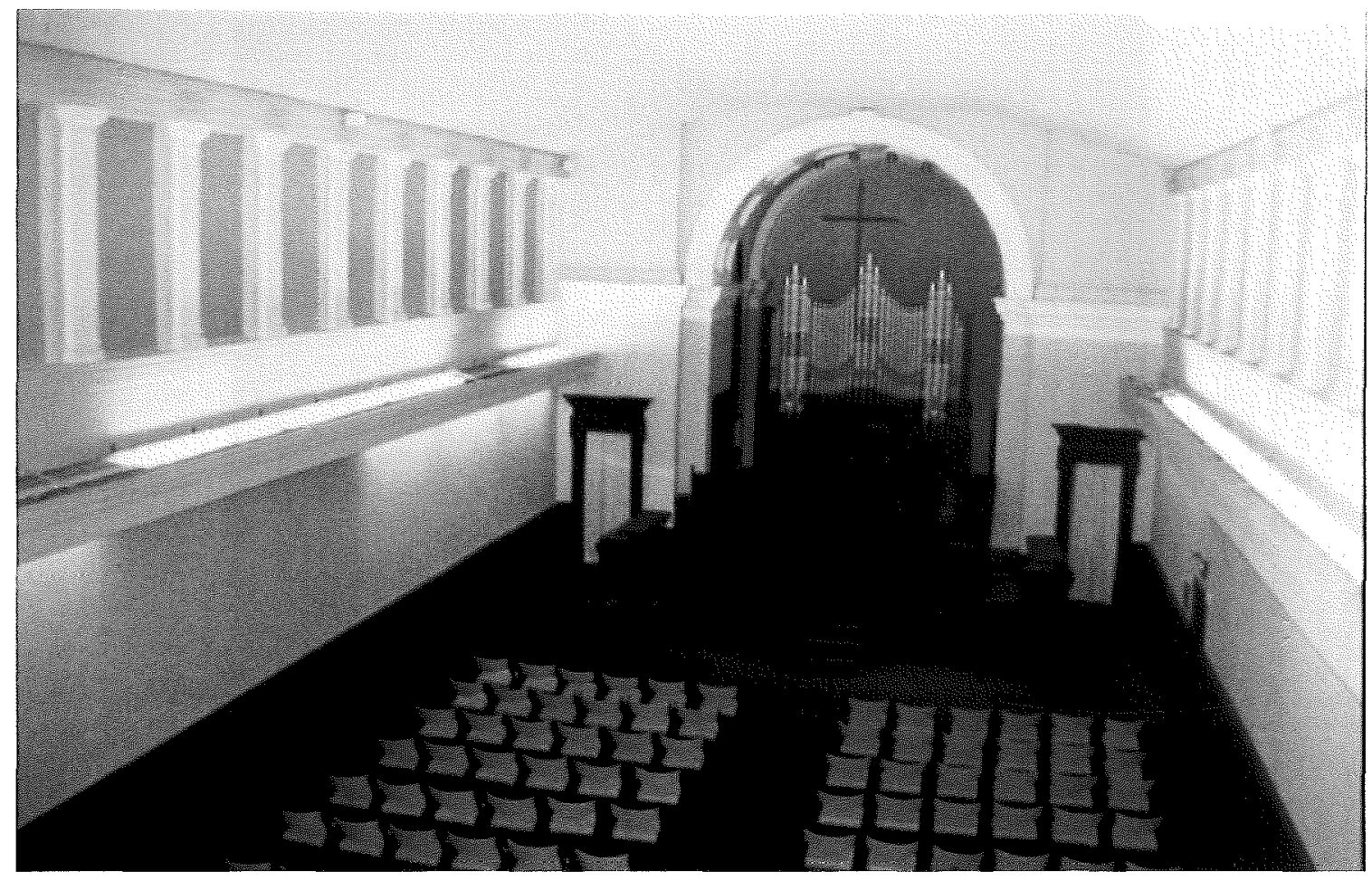

Figure 6.28

Paul Pelz. Hall of Christ, 1909, interior. (Author's photograph, 2000.) 


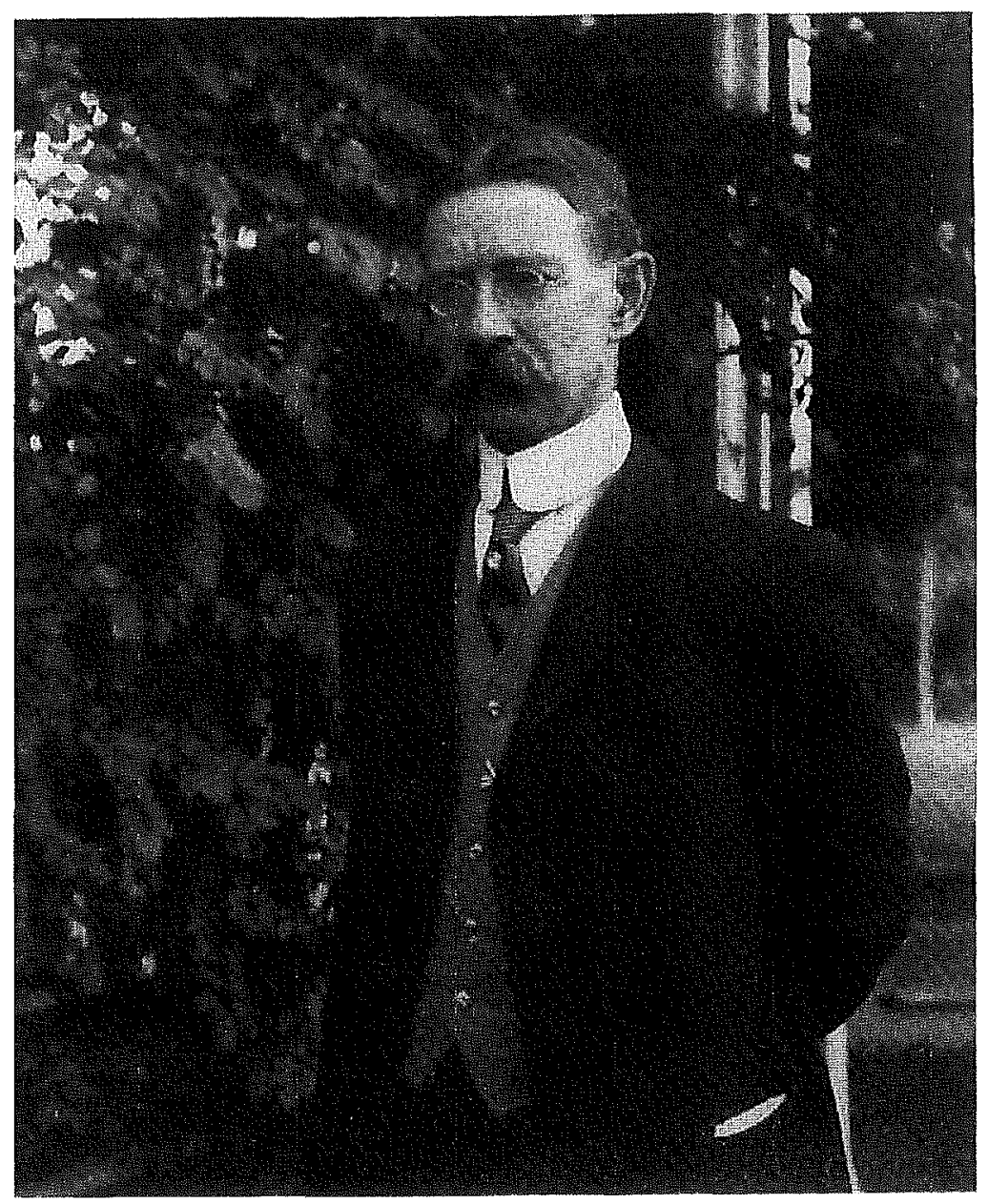

Figure c.1

J. Horace McFarland (1859-1948). (Ernest Morrison. J. Horace McFarland, A Thorn for Beauty, n. pag.) 


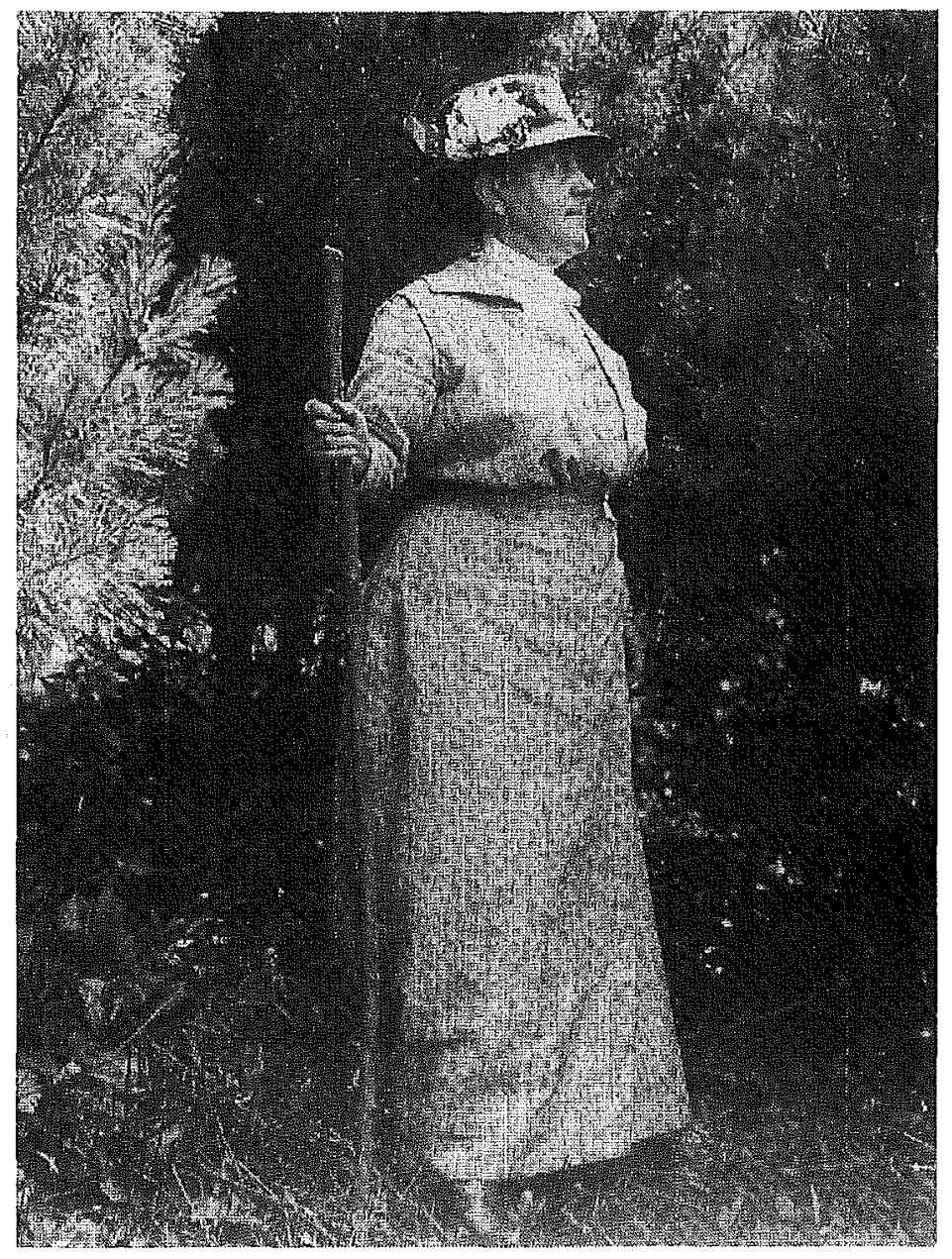

Figure c.2

Mira Lloyd Dock (1853-1945). (Ernest Morrison. J. Horace McFarland, A Thorn for Beauty, n. pag.) 


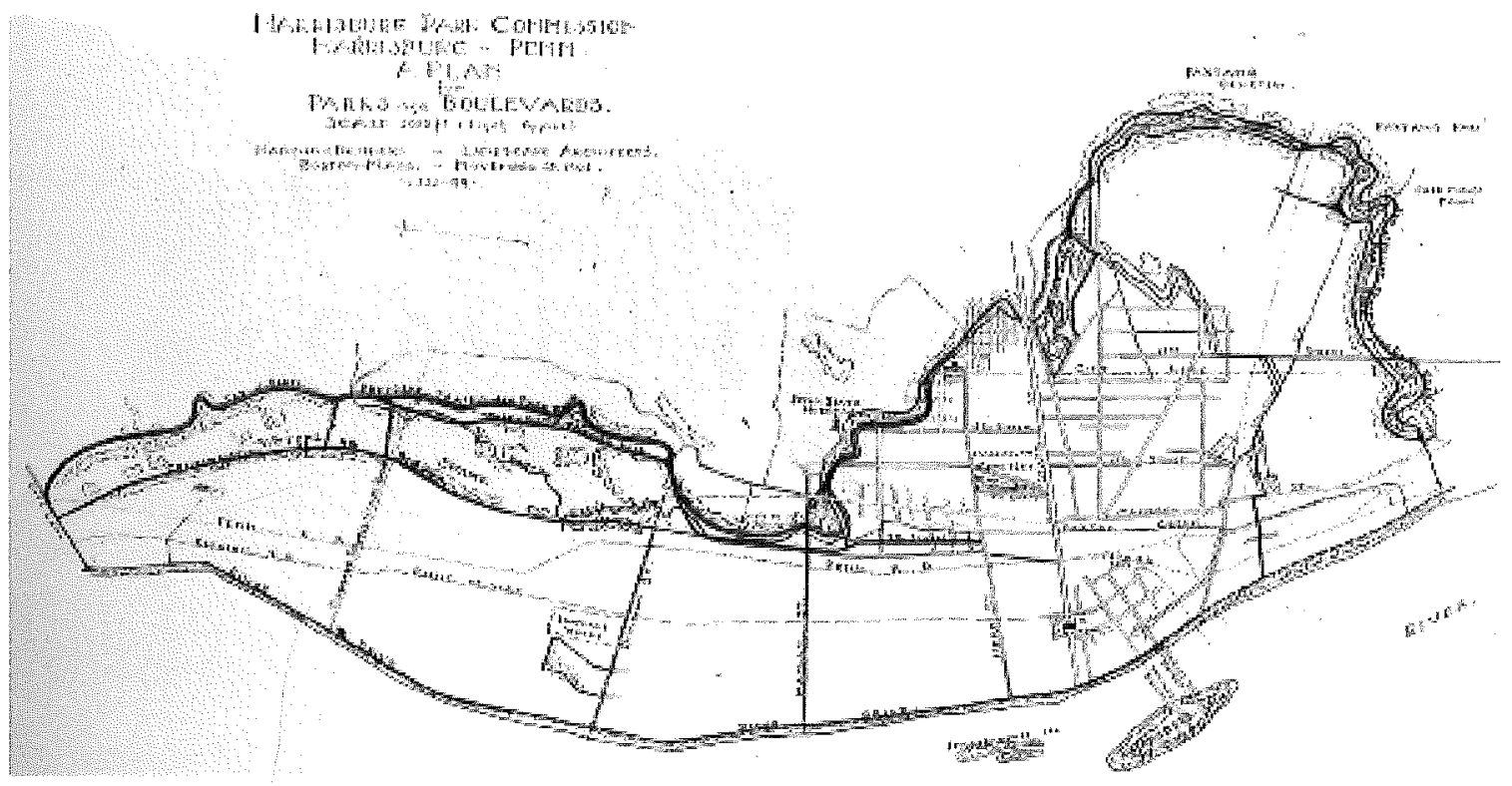

Figure c.3

Warren Manning. Plan for Harrisburg, PA., 1903. (Robin Karson. A Genius For Place: American Landscapes of the Country Place Era, 37.) 


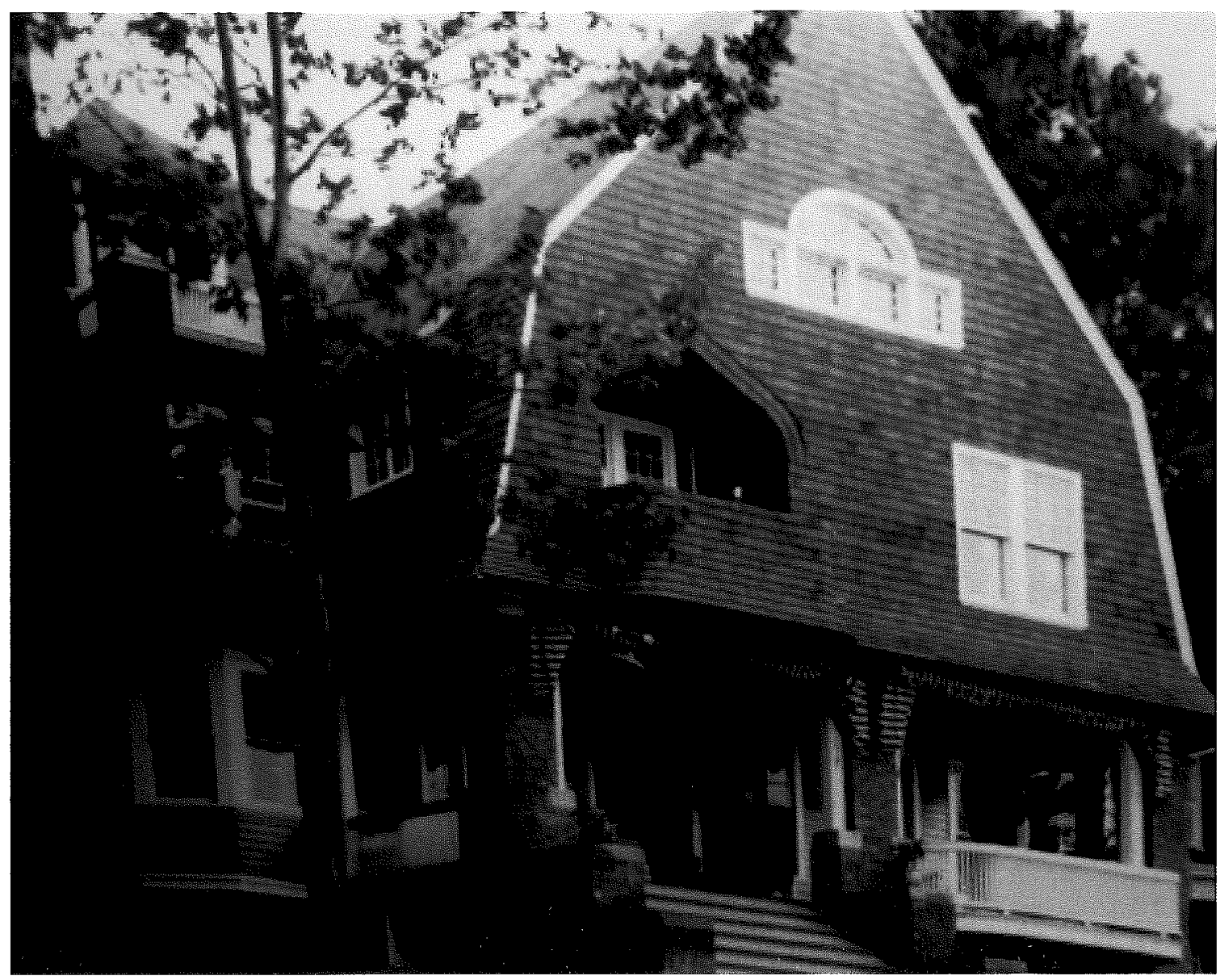

Figure c. 4

Clement Studebaker, Jr. Cottage. 39 North Lake Drive, Chautauqua, NY. (Courtesy Chautauqua Institution Archives.) 


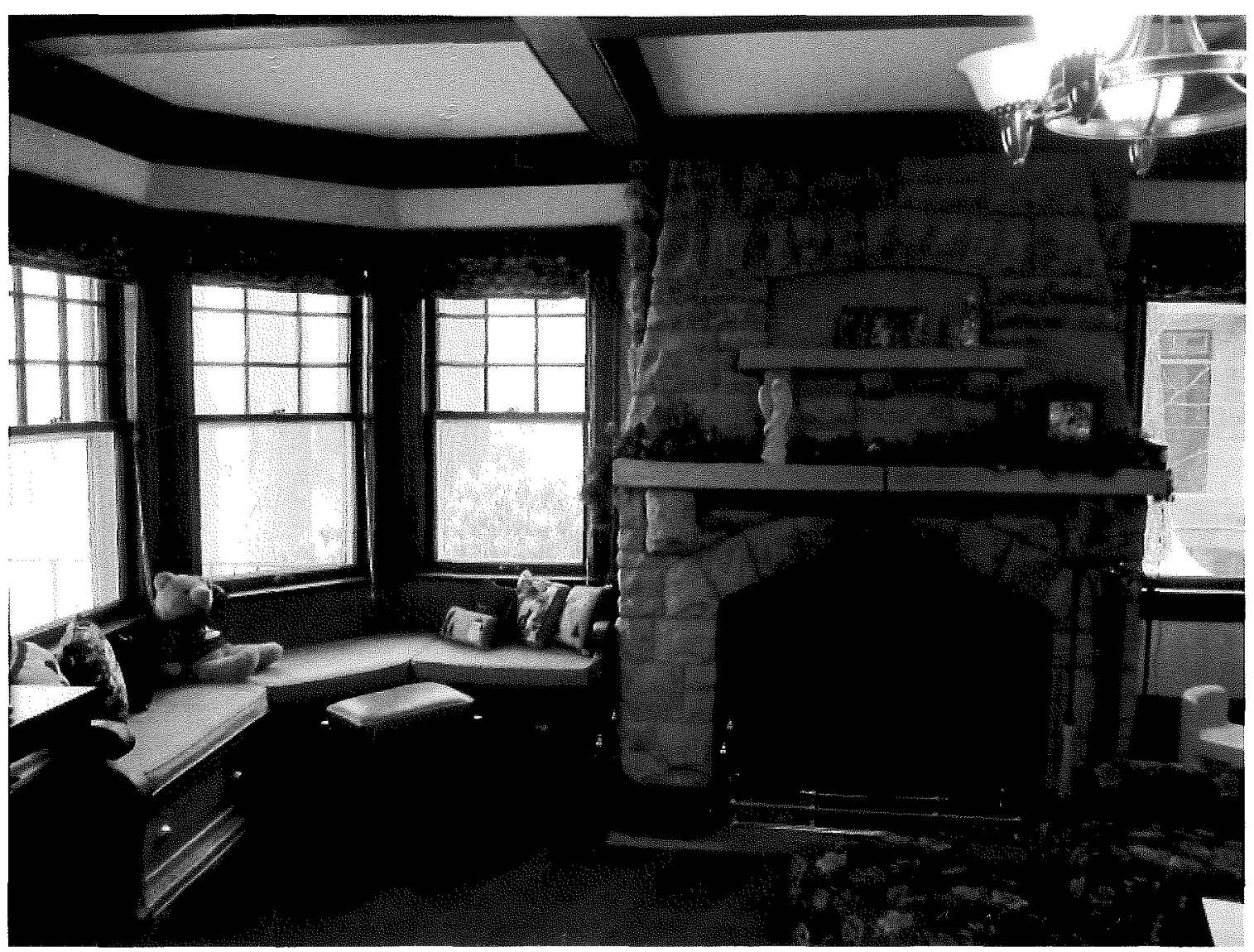

Figure c.5

Clement Studebaker, Jr. Cottage, interior: living room. 39 North Lake Drive, Chautauqua, NY. (Author's Photograph, 2011.) 


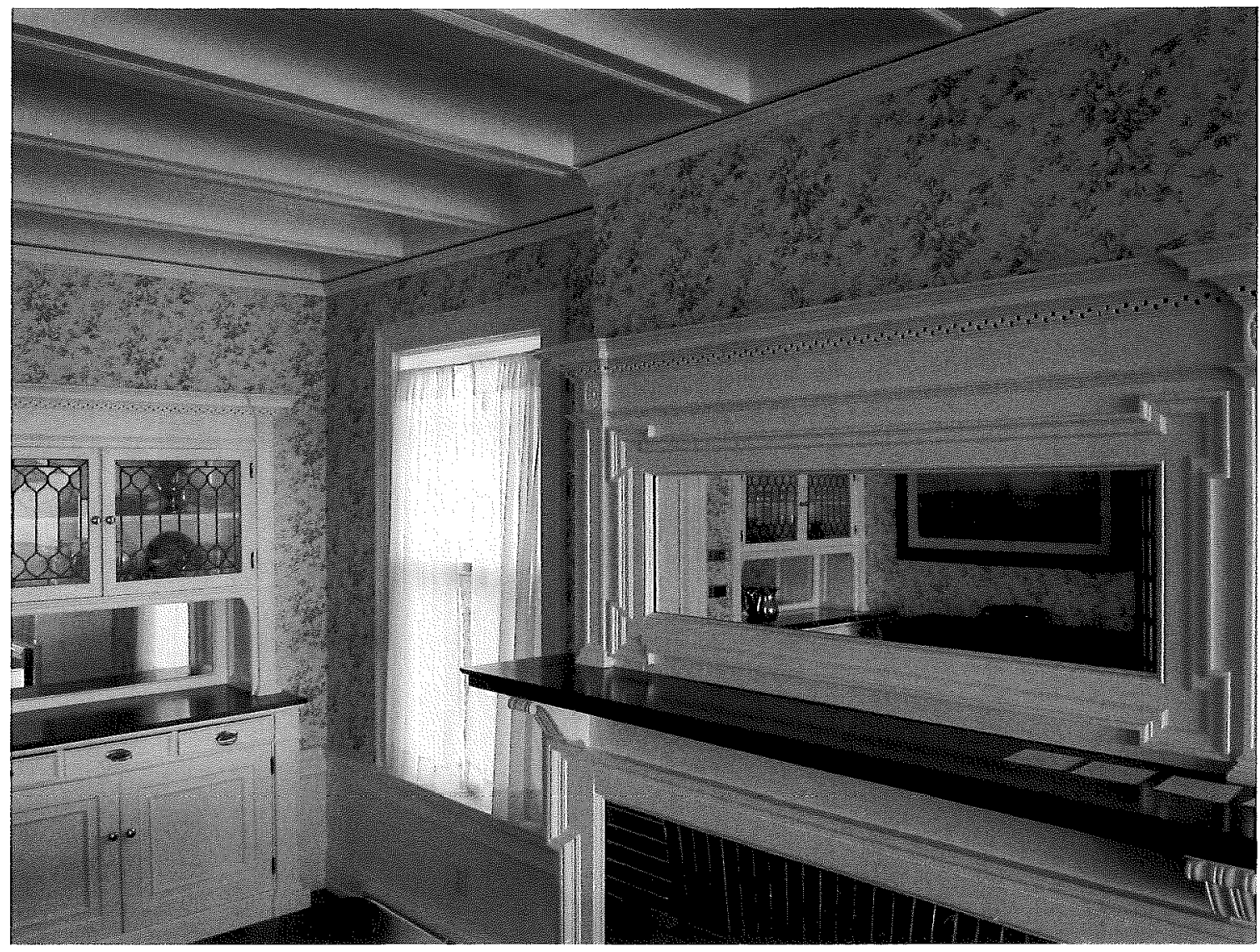

Figure c. 6

Clement Studebaker, Jr. Cottage, interior: dining room. 39 North Lake Drive, Chautauqua, NY. (Author's Photograph, 2011.) 


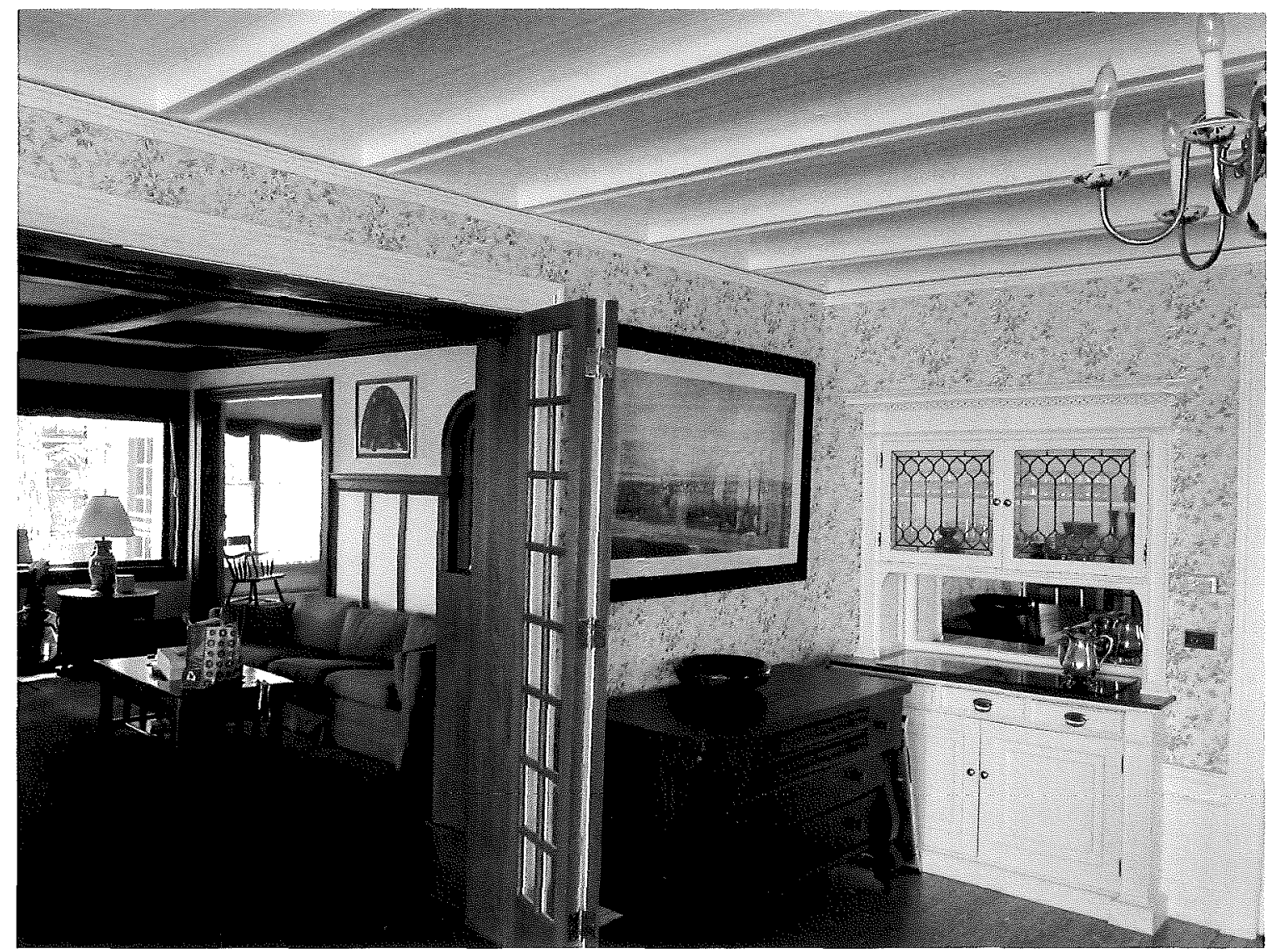

Figure c.7

Clement Studebaker, Jr. Cottage, interior: view from dining room. 39 North Lake Drive, Chautauqua, NY. (Author's Photograph, 2011.) 